$$
\begin{aligned}
& \text { UNIVERSIDADE DE SÃO PAULO } \\
& \text { INSTITUTO DE GEOCIÊNCIAS }
\end{aligned}
$$

\title{
GEOCRONOLOGIA E EVOLUÇÃO TECTÔNICA PALEO-MESOPROTEROZOICA DO ORIENTE BOLIVIANO - REGIÃO SUDOESTE DO CRATON AMAZÔNICO
}

\author{
Gerardo Ramiro Matos Salinas
}

Orientador: Prof. Dr. Wilson Teixeira

TESE DE DOUTORAMENTO

Programa de Pós-Graduação em Geoquímica e Geotectônica 
Ficha catalográfica preparada pelo Serviço de Biblioteca e Documentação do Instituto de Geociências da Universidade de são Paulo

Matos Salinas, Gerardo Ramiro

Geocronologia e evolução tectônica paleomesoproterozoica do oriente boliviano - região sudoeste do craton amazônico / Gerardo Ramiro Matos Salinas. - São Paulo, 2010. 52 p. + 1 mapa.

Tese (doutorado):IGc / USP

Orient.: Teixeira, Wilson

1. Bolívia: Geocronologia 2. Bolívia: Evolução tectônica 3. Bolívia: Proterozóico 4. Provincia Rondoniana - San Ignacio I. Título 


\section{SUMÁRIO}

Resumo

Abstract

Agradecimentos

1. Introdução

01

1.1 Apresentação 01

2. Objetivos 05

3. Localização da área de estudo 06

4. Revisão histórica da Geologia do Oriente de Bolívia 08

5. Metodologia $\quad 19$

5.1 Trabalhos de campo 19

5.2 Trabalhos experimentais 23

5.2.1 Petrografia 23

5.3. Geoquímica 24

5.4 Geocronologia 24

6. Producao científica comentada 26

6.1 Santos, J. O. S., Rizzotto, G.J., Mcnaughton, N. J., Matos, R., Hartmann, L. A., Chemale Jr., F., Potter, P. E., Quadros, M.L.E.S, 2008. Age and autochthonous evolution of the Sunsás Orogen in West Amazon Craton based on mapping and U-Pb geochronology. Precambrian Research, 165, 120-152.

6.2 Matos, R., Teixeira, W., Geraldes, M. C., 2008. El granito diamantina: evidencia isotópica y química de magmatismo de arco em el Complejo Pensamiento, Provincia Rondoniana-San Ignacio, Precámbrico de Bolivia oriental. Revista del institutode Investigaciones Geológicas y del Medio Ambiente. Ano 2, Diciembre de 2008, p. 5-11.

6.3 Matos, R., Teixeira, W., Geraldes, M. C., Bettencourt, J. S., 2009. Geochemistry and $\mathrm{Nd}$-Sr Isotopic Signatures of the Pensamiento Granitoid Complex, Rondonian-San Ignacio Province, Eastern Precambrian Shield of Bolivia: Petrogenetic Constraints for a Mesoproterozoic Magmatic Arc Setting. Geologia USP, Série Científica 9, 2, 89-117.

6.4 Bettencourt J.S., Leite Jr. W.B., Ruiz, A. S., Matos R., Payola B.L., Tosdal R.M., 2010. The Rondonian- San Ignacio Province in the SW Amazonian Craton: An overview. Journal of South American Earth Sciences, 29, 28-46.

6.5 Teixeira, W., Geraldes, M. C., Matos R., Ruiz, A. S., Saes, G., Vargas-Mattos, G., 2010. A review of the tectonic evolution of the sunsás belt. SW Amazonian Craton. Journal of South American Earth Sciences, 29, 47-60.

6.6 Comentários sobre o estado de arte do Pré-Cambriano Boliviano 31

6.6.1. Granito Correreca 32

6.6.2. Suíte Yarituses 32

Granito La Cruz

Granito Refugio

Granito San Pablo

6.6.3. Suite Orogênica San Ignacio 36

6.6.4. Evolução crustal Paleo a Mesoproterozoica 41

Orogênese Sunsas

6.6.5 Considerações finais 45

7. Referencias 48 


\section{FIGURAS}

$\begin{array}{ll}\text { 3.1 Mapa de localização } & 07\end{array}$

3.2 Mapa da geofísica aerotransportada $\quad 16$

6.1 Diagrama Concordia Suite Yarituses 35

6.2 Diagrama Concordia Suite San Ignacio 39

6.3 Distribuição geográfica dos plútons mesoproterozoicos e das principais estruturas da área de estudo.

\section{TABELAS}

5.1 Etapas de campo realizadas

5.2 Discriminação das analises e metodologias utilizadas

\section{APÉNDICES}

A- Descrição sintética dos afloramentos com respectiva localização.

B- Dados experimentais.

B1.Geoquímica

B2.Resultados analíticos U-Pb SHRIMP

B3. Resultados analíticos TIMS

B4.Resultados analíticos LA-ICP-MS

B5.Resultados analíticos $\mathrm{Sm}-\mathrm{Nd}, \mathrm{Rb}-\mathrm{Sr}$

C- Mapa geológico

D- Artigos publicados (5), um (1) em preparação e artigos apresentados em simpósios 


\section{AGRADECIMENTOS}

Gostaria de expressar meus agradecimentos às diversas pessoas e instituições que contribuíram e tornaram viável em grande parte a realização desta pesquisa.

No primeiro lugar o meu Pai Celestial, quem me acompanha sempre.

Ao orientador, Prof. Dr. Wilson Teixeira, pela oportunidade de executar esta pesquisa no Programa de Pós-Graduação em Geoquímica e Geotectônica do Instituto de Geociências da Universidade de São Paulo, pelas sugestões, ajudas e apoio deste trabalho.

\section{Como surgiu esta tese?}

Um reencontro em Cuiabá, durante o Simpósio do Centro Oeste em 2003, na excursão realizada à Bolívia na qual o postulante foi o guia. O contato, 20 anos esperado pelo autor para iniciar um doutorado iniciou-se com o Prof. Dr. Teixeira.

Ao Instituto de Geociências (IGc) da Universidade de São Paulo (USP) pela oportunidade de desenvolver em suas dependências as diferentes etapas da pesquisa deste trabalho aonde encontrei vários amigos professores, funcionários e alunos. Agradeço particularmente também aos professores com os quais falei em muitas oportunidades, e são tantos que tenho medo esquecer alguém. Sempre encontrei palavras de amizade e acolhimento. Ao recorrer aos corredores sempre me senti como na minha própria casa. Confesso que a biblioteca exerceu um grande fascínio e além de tudo é um lugar muito convidativo.

Ao Centro de Pesquisas Geocronológicas (CP-Geo) do IGc/USP pela utilização de seu Laboratório de Geologia Isotópica e aos técnicos deste centro pelo apoio prestado durante os trabalhos analíticos.

A todos os professores do Curso de Pós-Graduação do IGc/USP, os amigos da Pós, jovens alegres, simpáticos sempre dispostos a oferecer amizade e ajuda durante a minha estadia no Brasil. Aos companheiros da sala um especial carinho. Aos colegas geólogos de outras universidades no Brasil e aos funcionários do IGc muito obrigado.

A Prof. Luiz Machado Filho, pela ajuda, amizade, amigo para sempre.

Aos irmãos da igreja de Jesus Cristo dos Santos dos Últimos Dias pela acolhida carinhosa. Aos colegas geólogos, autoridades e funcionários da Universidade Mayor de San Andrés na Cadeira de Geologia, obrigado pelo apoio.

Aos meus queridos irmãos Lourdes, Rosário(+), Jose, Raúl, Lila(+) e Vlady pelo apoio e carinho. 


\section{DEDICATÓRIA}

Ao Mestre dos mestres, Jesus.

A minha esposa Helga e a meus filhos Mara, Sabrina e Javier.

A minha pátria Bolívia, meu povo, o meu amado país, a minha gente.

A meu pai de quem herdei o amor pelas rochas.

A minha mãe de quem aprendi o amor ao trabalho.

A Cordilheira Oriental dos Andes, minha terra natal, lugar que me deu os primeiros conhecimentos geológicos. 
Qualquer princípio de inteligência que alcançarmos nesta vida surgirá conosco na ressurreição.

DOUTRINA E CONVENIOS 130:18 


\section{RESUMO}

Este trabalho caracteriza a evolucao tectónica, identificando a cronologia dos principais eventos tectono-magmáticos do Pré-Cambriano Boliviano. A complexa evolucao geológica do Oriente da Bolívia se estende desde o Paleo a Mesoproterozoico compreendendo as provincias Rio Negro Juruena, Rondoniana San Ignacio e Sunsás na regiao conhecida como Bloco Paragua. Diversos métodos de estudo foram adotados na pesquisa tendo em vista tratar-se de um terreno com evolução policíclica e incluiram, alem do mapeamento geológico e petrografía dos principais tipos de rocha, a metodologia U-Pb para determinação da idade de corpos graníticos e a metodologia $\mathrm{Sm}-\mathrm{Nd}$ na estimativa de idade das fontes destes corpos plutônicos e inferências de ordem petrogenética, bem como dados geoquímicos obtidos para detalhamento das interpretações petrogenéticas. Nas interpretações houve ainda a avaliação critica da literatura recente, a integração de dados de campo, aeromagnéticos e aero-radiométricos, inclusive embasadas na experiência profissional do autor. Os dados obtidos na última década modificaram substancialmente a concepcao do Pré-Cambriano Boliviano, tendo sido caracterizados tres conjuntos litológicos temporalmente distintos antecedendo a orogenia San Ignacio. O granito Correreca na parte meridional da area possui idade ${ }^{207} \mathrm{~Pb}^{206} \mathrm{~Pb}$ de 1,92 - 1,89 Ga, com modelo de idades $\mathrm{T}_{\mathrm{DM}}$ de 2,8 a 2,9 Ga e valores de $\varepsilon_{N d(t)}$ de -8,5 e -9,4. A Suite Yarituses composta pelos granitos La Cruz, Refugio e San Pablo possui quimismo calcio-alcalino. Os dados U-Pb SHRIMP, TIMS e abrasão por laser-ICPMS indicam a formação desta suíte no lapso temporal entre 1673 a $1621 \mathrm{Ma}$. A idade de cristalização U-Pb SHRIMP do granito La Cruz é de $1673 \pm 21 \mathrm{Ma}$, idade modelo $\mathrm{T}_{\mathrm{DM}}$ de 1,83 Ga e valor de $\varepsilon_{\mathrm{Nd}(\mathrm{t})}$ de +2.1 indicativo de derivação mantélica. O granito Refugio tem idade U-Pb TIMS de $1673 \pm 25$ Ma e o pluton San Pablo idade ICPMS por laser ablasion de $1621 \pm 80 \mathrm{Ma}$ (idade $\mathrm{T}_{\mathrm{DM}}$ de 1,7 $\mathrm{Ga}$ e valor de $\varepsilon_{\mathrm{Nd}(t)}$ de $\left.+3,5\right)$. Este conjunto de dados sugere uma derivação mantelica principal para a suite Yarituses. $O$ granodiorito San Ramón possui uma idade de cristalização de $1429 \pm 4 \mathrm{Ma}$ (SHRIMP), $\mathrm{T}_{\mathrm{DM}}$ de $1,7 \mathrm{Ga}$, e $\varepsilon_{H f(t)}$ entre $+3,49$ e $+5,47$ e representa um evento de geração da crosta, a partir de material juvenil. $O$ magmatismo, deformação e metamorfismo da orogênese San Ignácio constitui o principal evento representado na área de estudo, cujo maior representante é o Complexo Granitoide Pensamiento com seus plutons sin a tardi-cinemáticos e tardi a 
pos-cinemáticos. Os granitos San Martín, La Junta e Diamantina possuem idades de cristalizacao de 1373- $1340 \mathrm{Ma}$, idades modelo $\mathrm{T}_{\mathrm{DM}}$ de 1,6 a 2,0 $\mathrm{Ga}$, com valores de $\varepsilon_{\mathrm{Nd}(t)}$ de +2.0 ate $-4,0$. Os granitos Las Maras, Talcoso, Limonal e San Andrés produziram idades de cristalização de 1347 a $1275 \mathrm{Ma}$. As idades $\mathrm{T}_{\mathrm{DM}}$ dos granitos Limonal e San Andrés correspondem a 1,9 e 1,8 e $\varepsilon_{\text {Nd(t) }}$ de $-1,4$ e 1,6 respectivamente. A geoquímica em rocha total indica uma composição compatível com arco magmático, corroborando a assinatura acima dos parâmetros petrogeneticos. Em suma, a orogênese San Ignácio representa um arco acrescionário de natureza continental que construiu a arquitetura final da província Rondoniana-San Ignacio pela colisão entre o Bloco Paraguá e a província Rio Negro-Juruena. A evolução mesoproterozoica finaliza com a formação da faixa colisional Sunsás. Esta orogênese produziu plutonismo sin a tardi cinematico e tardi a cinemático marcando o limite com o bloco Paragua. A natureza alóctone e colisional do orogeno Sunsás como o evento mais jovem do Cráton Amazônico é marcada por frentes tectônicos, bem definidos de sentido sinistral, convergentes para o Bloco Paragua. 


\section{ABSTRACT}

This work characterizes the tectonic and magmatic evolution of the Precambrian shield of Bolivia. The complex geological evolution of the eastern Bolivia extends from the Paleo- to Mesoproterozoic, and can be related with the magmatic and metamorphic events that are ascribed to the Rio Negro - Juruena (1.78-1.60 Ga), Rondonian - San Ignacio (1.56-1.30 Ga) and Sunsás - Aguapei (1.25-1.00 Ga) provinces, known in Bolivia as the Paragua block. Several methods of study were adopted in the research with the scope that this is a land with polycyclic evolution. As such our study included, besides the geological mapping and petrography of major rock types, the $\mathrm{U}-\mathrm{Pb}$ age determinations of granitoid rocks, Sm-Nd and $\mathrm{Rb}-\mathrm{Sr}$ isotopic analyses, as well as geochemical data. At the interpretation there was the critical evaluation of recent papers, the integration of field data, aeromagnetic and aero-radiometric, including the field experience of the author. The data obtained in the last decade have substantially changed the geology of the Bolivian Precambrian shield. It has been characterized three temporally distinct granite suites preceding the San Ignacio orogeny $(1.37-1.30 \mathrm{Ga})$ : the Correreca granite in the southern part of the area has ${ }^{207} \mathrm{~Pb} /{ }^{206} \mathrm{~Pb}$ age from 1.92 to $1.89 \mathrm{Ga}$, with $\mathrm{T}_{\mathrm{DM}}$ model ages of 2.8 to 2.9 Ga and values of $\varepsilon_{\mathrm{Nd}(\mathrm{t})}$ of -8.5 and -9.4; the Yarituses suite (La Cruz, Refugio and San Pablo granites) shows calc-alkaline signature. Data U-Pb SHRIMP, TIMS and ICPMS laser ablation indicate the formation of this suite between 1673 to $1621 \mathrm{Ma}$. The $\mathrm{U}-\mathrm{Pb}$ SHRIMP crystallization age of La Cruz granite is $1673 \pm 21 \mathrm{Ma}, \mathrm{T}_{\mathrm{DM}}$ model age of $1.83 \mathrm{Ga}$ and $\varepsilon_{\mathrm{Nd}(\mathrm{t})}$ of +2.1 indicative of a predominantly mantle source. The Refugio granite has U-Pb TIMS age of $1673 \pm 25 \mathrm{Ma}$ and the San Pablo pluton yields a ICPMS Laser ablation age of $1621 \pm 80 \mathrm{Ma}\left(\mathrm{T}_{\mathrm{DM}}\right.$ age of $1.7 \mathrm{Ga}$ and $\left.\varepsilon_{\mathrm{Nd}(\mathrm{t})}+3.5\right)$. These data suggest again a mantle source for the Yarituses suite. The San Ramon granodiorite event has a crystallization age of $1429 \pm 4 \mathrm{Ma}$ (SHRIMP), $\mathrm{T}_{\mathrm{DM}}$ of $1.7 \mathrm{Ga}$, and $\varepsilon_{H f(t)}$ between +3.49 and +5.47 and represents a juvenile accreted episode. The magmatism, deformation and metamorphism of San Ignacio orogeny is the main event of the study area, represented by the Pensamiento Granitoid Complex with sin to late-kinematic and late to post-kinematic plutons. The San Martín, La Junta and Diamantina granites have crystallization ages of 1373 - $1340 \mathrm{Ma}, \mathrm{T}_{\mathrm{DM}}$ model ages from 1.6 to $2.0 \mathrm{Ga}$, with values of $\varepsilon_{\mathrm{Nd}(\mathrm{t})}$ from 2.0 up to -4.0. The Las Maras, Talcoso, Limonal and San Andrés granites yielded crystallization ages of 1347-1275 Ma. The 
$\mathrm{T}_{\mathrm{DM}}$ ages of Limonal and San Andrés granites are between 1.9 and $1.8 \mathrm{Ga}$ and the $\varepsilon_{\mathrm{Nd}(\mathrm{t})}$ values of -1.4 and +1.6 respectively. The whole rock geochemistry of these granites indicates a composition consistent with the magmatic arc. Thus the San Ignacio orogeny represents a continental accretionary arc that built the final architecture of the Rondonian-San Ignacio province (1.56-1.30 Ga) by the collision between the Paragua block and the Rio Negro -Juruena province (1.78-1.60 $\mathrm{Ga})$. The Mesoproterozoic evolution of the SW margin of the Amazonian craton ends with the formation of the Sunsás collisional belt that produced sin to-late and late topost-kinematic plutonism. The allochthonous and collisional nature of the Sunsás orogeny is marked by tectonic fronts, with well-defined sinistral sense, converging towards the Paragua block. 


\section{INTRODUÇÃO}

\subsection{Apresentação}

Esta tese aborda a evolução crustal da porção SW do Cráton Amazônico, com base em investigações geológicas, apoiadas por dados petrográficos, geoquímicos e geocronológicos. Os estudos abrangem áreas-chave do Pré-Cambriano boliviano com vistas às correlações tectônicas com terrenos policíclicos proterozoicos na contraparte brasileira, nos estados de Rondônia e Mato Grosso. O tema também é relevante para reconstruções paleotectônicas, uma vez que o SW da Amazônia é correlacionável com partes da Laurentia e Báltica, conforme simbolizado pelo Supercontinente Rodínia, edificado entre 1,2 - 1,0 Ga.

Para cumprimento dos estudos, este projeto de doutoramento beneficiou-se da colaboração de pesquisadores de universidades brasileiras (USP, UERJ, UFMT, UFPa), sob os auspícios do Conselho Nacional de Desenvolvimento Científico e TecnológicoCNPq (processos 304300/2003-9; 470373/2004-0 coordenados pelo orientador da Tese), bem como do Centro de Pesquisas Geocronológicas (CPGeo) do Instituto de Geociências da USP (IGc/USP Brasil). Vale destacar que as atividades do projeto incluíram a formação de recursos humanos em diferentes níveis (Dr., Ms., IC), valorizando ainda mais o esforço da cooperação científica no fomento ao conhecimento da geologia e geotectônica do Pré-Cambriano boliviano.

As atividades conjuntas realizadas na última década propiciaram avanços científicos de impacto no conhecimento geológico do Pré-Cambriano boliviano, divulgado em congressos e em periódicos indexados, cujos principais resultados serão aqui sintetizados, com destaque para a produção científica pessoal decorrente desta presente pesquisa. O autor desta tese, docente da Universidade Mayor de San Andrés (Bolívia), usufruiu de bolsa de Doutorado da Coordenação de Aperfeiçoamento de Pessoal de Nível Superior - CAPES, por meio do projeto "Evolução tectônica dos terrenos pré-cambrianos do oriente de Bolívia durante o Mesoproterozoico - na região sudoeste do Craton Amazônico". O autor também contou com recursos eventuais do Programa de Pós-Graduação de Geoquímica e Geotectônica do IGc-USP e do CPGeo para sua participação em Congressos (regionais, nacionais e internacionais), que 
tiveram por intuito a divulgação e discussão dos resultados parciais da Pesquisa. Sem estes apoios financeiros e a integração científica com os pesquisadores brasileiros, os estudos no Pré-Cambriano boliviano teriam sido inviabilizados, face à complexa logística para acesso à região de selva para os perfis geológicos e coleta de amostras, bem como para fazer frente ao apoio de análises para a pesquisa, especialmente isotópicos e geoquímicos.

Algumas décadas se passaram antes que o tema do Pré-Cambriano boliviano fosse incluído entre as prioridades de cooperação científica entre o Brasil e Bolívia. Como conseqüência novas visões foram alcançadas acerca do conhecimento cronoestratigráfico de uma região remota e de difícil acesso, em função da realização de estudos sistemáticos geocronológicos, isotópicos e geoquímicos, havendo ênfase nas rochas granitóides regionais. Com isso interrompeu-se o baixo interesse sobre 0 conhecimento geológico Pré-cambriano desde a finalização do clássico projeto angloboliviano por meio de um convênio de cooperação entre o Serviço Geológico da Bolívia (GEOBOL) e o Serviço Geológico Britânico (IGS- BGS) desenvolvido na Bolívia (e.g., Litherland, 1981; Report on geological discussions in São Paulo. Rep. East. Bolivia Miner. Expl. Project, Santa Cruz, ML 33; Litherland et al., 1986).

A colaboração profícua de pesquisadores interessados na evolução primitiva permitiu a divulgação dos primeiros avanços dos trabalhos conjuntos em congressos no Brasil e Bolívia (nos anos 2004, 2006), e no International Geological Congress, ocorrido no Rio de Janeiro (ano 2000) e Oslo (2008). O interesse do autor em desenvolver este projeto de doutoramento decorre do fato de ter atuado na década de 1990 no mapeamento do Pré-cambriano boliviano continuando o trabalho do "Proyecto Precámbrico" GEOBOL - projeto Anglo-Boliviano pioneiro que produziu o primeiro mapa geológico na escala 1:1.000.000 do Oriente boliviano. A oportunidade de retomar este tipo de estudo, surgiu a partir de uma viagem dos professores da Universidade Federal de Mato Grosso, às universidades regionais da Bolívia, do Chile e do Peru, com o propósito de promover um primeiro relacionamento entre as instituições de ensino superior do Centro Oeste Sul-Americano. Deu-se início uma cooperação científica informal, visando realizar trabalhos conjuntos, de cunho técnico/científico, estágios de professores e estudantes, como suporte da Cooperação Internacional e à Integração 
Regional. Em conseqüência desta iniciativa, este autor foi convidado a proferir palestra sobre a geologia pré-cambriana da fronteira Brasil-Bolívia no IX Simpósio de Geologia do Centro Oeste realizado em Cuiabá em julho de 2003, no qual coordenou, a convite, uma pioneira excursão científica ao Pré-Cambriano Boliviano. Naquela oportunidade veio conhecer o então Diretor do Instituto de Geociências (IGc) - USP, Prof. Dr Wilson Teixeira, contato este que conduziu posteriormente à decisão pessoal de se matricular no Programa de Pós-Graduação da USP, em 2005 - devidamente referendada pela Universidade Mayor de San Andres.

O presente documento está estruturado sob a forma de 5 artigos científicos o que requer uma estruturação e comentários distintos do modelo tradicional. O primeiro capítulo, introdutório da Tese, apresenta o tema estudado com ênfase na importância desta pesquisa para a compreensão da evolução geológica do Précambriano boliviano e a sua relação ao Craton Amazônico, bem como o porquê da iniciativa pessoal de realizá-lo. O segundo capítulo propõe o objetivo principal desta pesquisa e os objetivos específicos em razão da área eleita para os estudos acadêmicos, ao passo que o terceiro capítulo apresenta a localização da área onde se concentraram os trabalhos propostos. O quarto capítulo apresenta um histórico do avanço do conhecimento geológico (e bibliografia pertinente), além de uma reflexão do estado da arte do Pré-Cambriano do oriente boliviano, a partir das descobertas fundamentadas principalmente nos dados geocronológicos mais recentemente obtidos por terceiros. O quinto capítulo sintetiza os métodos de trabalho e estrategias aplicadas na Tese, as quais incluiram: a compilação de dados e publicações, com base no acesso a acervos de acesso restrito da GEOBOL (agora SERGEOTECMIN; em La Paz e Santa Cruz) em cadernetas, relatórios internos, mapas do "Proyecto Precámbrico"; mapas geofísicos digitalizados a partir da base de GEOBOL na década dos 90, imagens Google Earth de acesso franco na internet, assim como dos trabalhos de campo e de gabinete realizados na elaboração de mapas digitalizados, na escala 1:250.000 e 1:1.000.000.

O capítulo sexto, está representado pelos comentários e criticas pertinentes aos cinco artigos científicos publicados em periódicos nacionais (01 artigo em Brasil e 01 em Bolivia) e internacionais (03 artigos), devidamente anexados, havendo ênfase nos 
comentários integrados em relação ao bloco Paraguá e suas implicações para o SW do Craton Amazônico. O capítulo final (sétimo) apresenta as referências bibliográficas 


\section{OBJETIVOS}

Como objetivo principal pretende-se obter uma visão mais abrangente possível acerca da natureza e cronologia dos principais eventos tectono-magmáticos que afetaram a região SW do Craton Amazônico, com ênfase nos terrenos da Bolívia, e realce nas rochas que edificaram a chamada província Rondoniana-San Ignácio (1.56$1.30 \mathrm{Ga}$; e.g, Cordani and Teixeira, 2007).

Os objetivos específicos são:

i) A aplicação da metodologia U-Pb para determinação da idade de corpos graníticos (métodos SHRIMP, ICP-MS, TIMS) e de eventos metamórficos, fazendo uso de populações de zircão previamente analisadas por catodoluminescência, sempre que possível;

ii) A aplicação da metodologia Sm-Nd na estimativa de idade das fontes destes corpos plutônicos e inferências de ordem petrogenética e tectônica. Esta ferramenta é complementada com a metodologia $\mathrm{Rb}-\mathrm{Sr}$ através de diagramas $\mathrm{Nd}-\mathrm{Sr}$.

iii) A obtenção de dados geoquímicos de elementos maiores, traços e terras raras obtidos para detalhamento das interpretações petrogenéticas em rochas granitóides especialmente.

iv) A execução de perfis geológicos em áreas chave para fins de amostragem e análises geoquímicas, petrográficas e geocronológicas.

v) Integração de dados de campo, aeromagnéticos e aero-radiométricos de GEOBOL, imagens satelitais, para refinamento da cartografia para determinadas unidades. 


\section{LOCALIZAÇÃO DA ÁREA DE ESTUDO}

A região de estudo está localizada no oriente de Bolívia compreendendo parte leste do departamento Santa Cruz e o sul do departamento Beni, abrangendo parte das folhas 1: 250.000 de Concepción, Monte Verde, Perseverancia, Puerto Villazón, Huanchaca, Manomó, San Ignácio de Velasco, San José de Chiquitos, Roboré-Santo Corazón y Las Petas (Figura 3.1). Estas áreas em sua maior parte são desconhecidas geologicamente. O principal acesso por rodovia compreende Santa Cruz- San Ramón, San Javier, Concepción e San Ignácio de Velasco na Chiquitania. Outra via por sua vez está situada na porção meridional a partir de Santa Cruz até San José e Robore paralela á ferrovia. Partindo-se dos referidos pontos os acessos vicinais são estradas de terra, de difícil acesso em época de chuvas.

O Pré-Cambriano boliviano é uma área remota com estradas precárias e de acesso difícil. Em épocas secas o acesso aos afloramentos não apresenta dificuldades. Em época de chuvas as estradas ficam fechadas ao tráfego de veículos. A logística usual de campo no Pré-Cambriano boliviano necessita de aluguel do carro $(4 \times 4$ tracionado) disponíveis em Santa Cruz, a cidade com melhor estrutura logística para os trabalhos de campo. Cada campanha demanda um percurso de 1500 ate $2000 \mathrm{~km}$, inclusive com uso de tanques reserva de combustível e contratação de "materos" para corte de eventuais troncos de árvore que vez por outra interrompem as trilhas de acesso aos afloramentos. Uma viagem de campo foi realizada junto a candidata Gabriela Vargas, então doutoranda na Universidade Estadual do Rio de Janeiro. Para executar o trabalho foram alugadas duas motos com os seus respectivos motoristas, o que dá idéia das dificuldades de acesso por caminhos muitas vezes pouco usuais. 

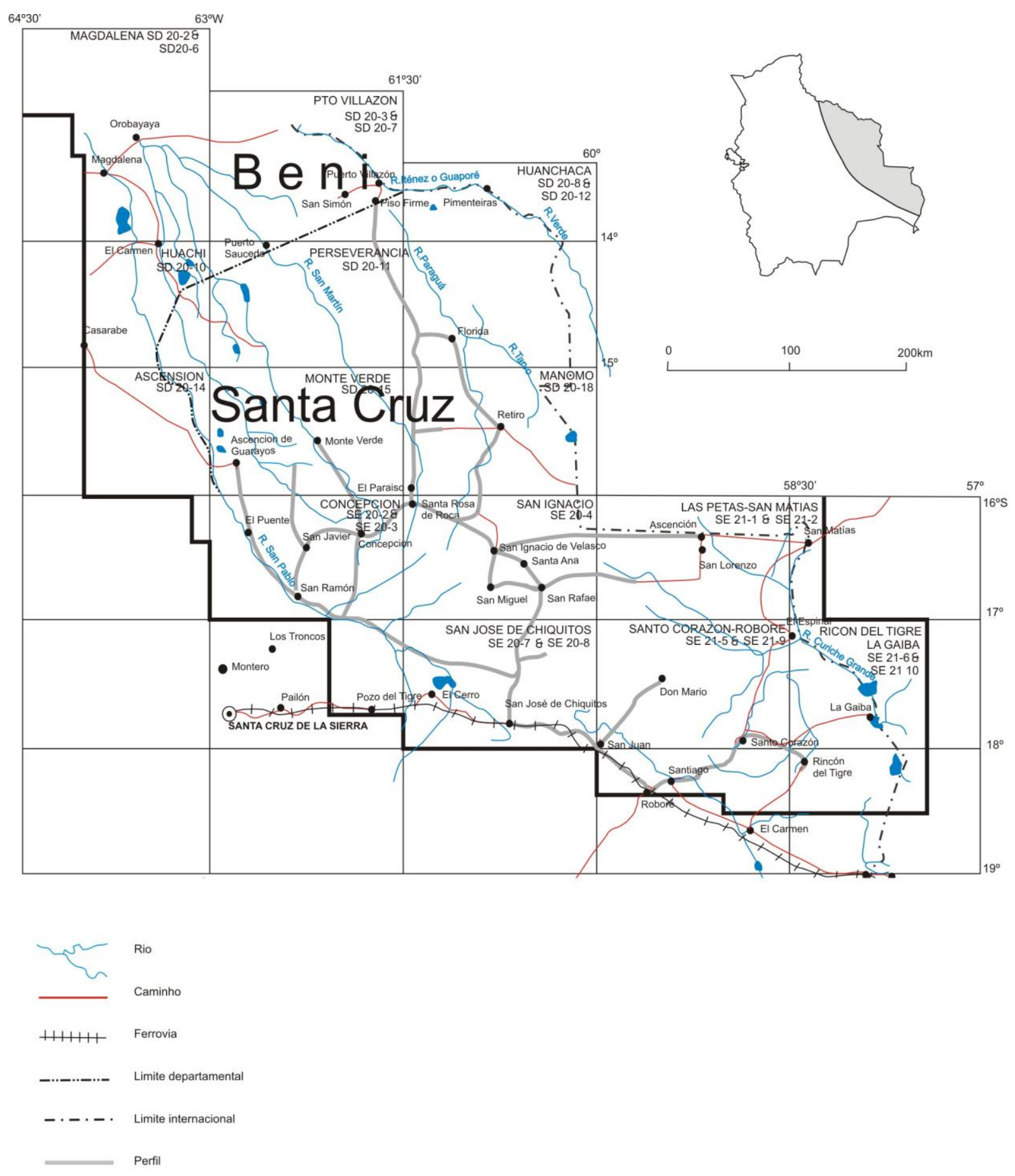

Figura 3.1 Mapa de localização da área de estudo. 


\section{REVISÃO HISTÓRICA DA GEOLOGIA DO ORIENTE DE BOLÍVIA}

Em termos históricos, cabe ao cientista Alcides d'Orbigny a fama de ser o pai de pesquisa geológica na Bolívia. Este naturalista francês em sua viagem pela América do Sul entre 1826 e 1832, visitou uma grande parte do território da Bolívia. Em sua grande obra apresentada em onze volumes "Voyage dans l'Amérique Meridionale" que apareceu em Paris, em 1835-1847, a mais importante para o presente tema são os três volumes que descrevem suas viagens. O volume Geologia que traz observações precisas sobre as planícies de Moxos (departamento Beni) em particular, é digno de ser lido ainda hoje, acima de tudo pela apresentação cuidadosa dos seus desenhos. Seus méritos, dedicados à pesquisa geológica pioneira na Bolívia, devem ser sempre reconhecidos (Ahlfeld, 1946).

F. Ahlfeld chegou à Bolívia em 1923 e até 1928 dedicou-se a investigações técnicas de mineração e depósitos minerais. Em 1935, assumiu a Divisão Geológica da Direcção Geral de Minas e Petróleo de La Paz. Nesta função viajou por boa parte do território boliviano a fim de coletar dados para um mapa geológico do país. Sua pesquisa geológica foi publicada pela primeira vez no ano de 1954, juntamente com o primeiro mapa geológico da região andina da Bolívia. Contudo, desde as viagens de d’Orbigny na Bolívia oriental, as investigações geológicas no Pré-cambriano foram totalmente negligenciadas. Em 1908 a área das serranias de Huanchaca foi visitada pelo explorador inglês Col. P. H. Fawcet, cujas descrições foram base para o livro de Arthur Conan Doyle "El mundo perdido".

Com relação ao potencial metalogenético das rochas intrusivas precambrianas da Bolivia F. Peiser, um geólogo de campo na Dirección General de Minas de La Paz, realizou estudos geológicos nos anos de 1939-1944 em grande parte do Distrito San Ramón. Este autor publicou um mapa e comentários sobre os pegmatitos micáceos da região de San Javier Concepcion e San Antonio de Lomerío (Peiser, 1944a); em um artigo subseqüente Peiser (1944b), destacou os veios de quartzo-aurífero relacionados que ocorrem no Distrito San Ramón. 
Já Kempff e Peiser (1945) descreveram os depósitos minerais pegmatíticos de Santa Ana, perto de San Ignacio. Já a Serrania San Simón, localizada ao sul do departamento Beni tem sido explorada de forma intermitente desde que o ouro foi descoberto pelos jesuítas na segunda metade do século 17. Rochas pegmatíticas também foram descritas na Bolívia em San Agustín, lado sudeste de San Ramón. Estes pegmatitos foram examinados em maior detalhe por tanto por Peiser (1944a) como Ahlfeld (1954), uma vez que neles foram observados veios de quartzo auríferos. Cabe também citar os estudos geológicos de F. Ahlfeld ao longo da ferrovia de Corumbá a Santa Cruz, publicados pela primeira vez no livro Geologia de Bolívia (Ahlfeld, 1954) que reporta também as observações de Peiser.

Quanto ao estado da investigação geológica na Bolívia para a época (sendo que até agora houve pouca mudança) são poucos os trabalhos publicados. Em função disso, a Bolívia é um país geologicamente muito pouco conhecido. Todos os esforços concentravam-se na parte andina, por exemplo no Cerro Rico de Potosí, as minas de Siglo XX e Huanuni, com jazidas ricas em Ag, Sn, W, Pb e $\mathrm{Zn}$ de classe mundial em veios de 0,1 ate $5 \mathrm{~m}$ chamados "tipo boliviano. O Cerro Rico de Potosí foi descoberto em 1545 e em 1611 já tinha a volta de 150.000 habitantes, a maior depois de Paris (Arce- Burgoa, 2007).

Até os anos da década dos 50 a área de San Ignácio de Velasco tinha sido pouco pesquisada geologicamente desde os estudos iniciais de d'Orbigny. Devido a essa lacuna de conhecimento as colinas que fazem fronteira com a região das cabeceiras do Itenez (Guaporé), Rio Verde e Rio Tarbo são geologicamente terras ainda virgens, também na zona fronteiriça entre Bolívia e Brasil, ao longo do Rio Itenez (Figura 3.1).

Segundo Ahlfeld (1946), o leste da Bolívia fazia parte do Escudo Brasileiro, que era considerado um maciço antigo representado principalmente pelo embasamento cristalino. Numa divisão geológica tentativa regional, Ahlfeld propôs a presença de rochas primitivas (arcaicas) e rochas algonquianas (Proterozoico), além de rochas magmáticas pré-paleozoicas. Com respeito às rochas primitivas foram distinguidas duas áreas principais: A primeira é uma faixa no departamento de Beni, perto de Guayaramerín onde o embasamento cristalino aflora nas cachoeiras do Rio Madera. As 
rochas descritas originalmente em 1906 por Evans (apud Ahlfeld, 1946) são as seguintes, envolvendo domínios geográficos contíguos no Brasil e Bolivia: gnaisse granulítico com microclínio e micropertita no salto Teotonio no Brasil, gnaisse granitóide (Villa Bella), gnaisses e anfibolitos. A segunda área compreende o bloco Chiquitano (Bolivia) que se estende desde Guarayos e San Miguel até Santo Corazón (Figura 3.1). Os tipos de rocha principais são os ortognaisses, paragnaisses, migmatitos, leptinitos, arteritos, micaxistos ou folhelhos, quartzitos e anfibolitos. Essas rochas primitivas apresentam-se altamente metamorfizadas, correspondendo à catazona.

A série Algonquiana, segundo Ahlfeld (1946), está representada no leste da Bolívia, nas colinas a leste das montanhas de Sunsás. Quanto à província Nuflo de Chavez, presume-se que determinados folhelhos que afloram na parte ocidental do vale do rio Quiser, norte de Santa Rosa de la Mina e San Javier sul, alternando com filito piritoso, também interpretado como pertencente ao Algonquiano.

As rochas magmáticas pré-paleozoicas descritas originalmente por Ahlfeld compreendiam intrusões graníticas que, segundo o conhecimento da época, não tinham um posicionamento cronológico definitivo. De acordo com Evans (citado em Ahlfeld, 1946), que estudou a geologia das corredeiras do rio Madera no extremo noroeste da Bolívia, no limite com o estado de Rondônia (Brasil), a geologia local era complexa, pois ocorriam rochas ígneas intrusivas como granitos com $74 \%$ de sílica (e.g., Cachoeira San Antonio), adamelitos (granitos com piroxênio, granitos porfiríticos com 69,6\% SiO2), sienitos biotíticos (Salto Teotônio), granitos anfibólicos (Porto Velho e Três Irmãos) granitos porfiríticos atravessados por diques de pegmatitos, aplitos, e ainda granitos a duas micas. Assim, Ahlfeld (1946) descreveu uma faixa de veios de quarzto praticamente contínua, limitada regionalmente em ambos os lados por intrusões pegmatíticas, que continua para o norte de San Javier. Na província de Velasco para oeste de Santa Ana d'Orbigny descreve veios de quartzo, com ametista e cristal de rocha. Já no ano de 1944, também embasados nas observações de Peiser, houve vários pedidos relativos à exploração de mineração de cristal de rocha no Santo Corazón. Geólogos da Comibol (Corporación Minera de Bolívia) fizeram em 1970 uma visita de reconhecimento a San Simon, ao sul do departamento Beni (Figura 3.1) para fazer uma primeira avaliação integrada das ocorrências mineralizadas. Em 1973, 
geólogos da COBOEN (Comissão Boliviana de Energia Nuclear) realizaram uma avaliação das reservas de ouro ali existente.

De outra parte, devido ao interesse da Bolívia Gulf Oil Company (posteriormente YPFB - Yacimientos Petrolíferos Fiscales Bolivianos) foram iniciados os estudos em rochas sedimentares que recobrem o Pré-cambriano e que ocorrem entre Santiago e Santo Corazón (Hess, 1960). Também com foco na prospecção de petróleo, rochas sedimentares precambrianas de grau metamórfico incipiente foram agrupadas na Série Sunsás por Oviedo e Justiniano (1968), em uma seção tipo ao longo do Rio Santo Corazón, que drena a Serranía Sunsás perto de Santo Corazón. Coube a estes dois geólogos estimar pela primeira vez a espessura de mais de $5000 \mathrm{~m}$ desta unidade clássica da Bolívia, com uma divisão tripartite em arenito quartzítico micáceo de cor branco na base, seguido por semi-pelitos e arenitos quartzíticos de cor rosa. Mais tarde, Castillo e outros (1971) reconheceram a existência de um conglomerado basal na Série Sunsás.

Entre os anos 1976 e 1983 a Bolívia foi palco de um dos maiores projetos de mapeamento sistemático da América do Sul, realizado por meio de um convênio de cooperação entre GEOBOL (Serviço Geológico da Bolívia) e o Serviço Geológico Britânico (IGS- BGS), cujos resultados principais estão sintetizados em Berrangé e Litherland (1982) e Litherland et al (1986).

Este trabalho envolveu duas fases:

Fase I. Compreendeu a coleção dos principais tipos de rocha para ser estudados em laboratório, e identificar as características estruturais nas imagens de satélite LANDSAT. Isso ajudou a identificar as condições de campo e fornecer informações úteis para a logística. Para algumas áreas inacessíveis um helicóptero foi utilizado.

Foram mapeadas duas folhas 1:100.000 em 1976 como parte do treinamento para o pessoal boliviano. As brigadas foram formadas por um geólogo do IGS, um ou dois geólogos de GEOBOL e pessoal de apoio. O mapeamento foi realizado usando folhas topográficas $1: 50.000$ do Instituto Geográfico Militar, fotografias aéreas convencionais e imagens Landsat para o controle regional. Coletaram-se sedimentos de corrente e solo para a prospecção geoquímica de reconhecimento. Foi ainda realizado 
mapeamento e amostragem geoquímica na escala 1:100.000 de algumas áreas de interesse econômico como a Província Alcalina de Velasco por elementos de terras raras e o Complexo Ígneo Rincón del Tigre por $\mathrm{Cu}, \mathrm{Ni}, \mathrm{Mn}, \mathrm{Cr}$, Co.

Fase II. A região norte do Projeto na época não tinha mapa topográfico, então foi preparado um mapa base 1:500.000 baseado em um mosaico de imagem LANDSAT, contendo todas as informações geológicas e geográficas disponíveis. Esta Fase II foi planejada e dividida em duas subfases. A primeira delas envolveu um acompanhamento detalhado acima de anomalias geoquímicas e mineralizações descobertas de terras raras durante a Fase I, tais como as do Cerro Manomó, San José de Chiquitos pelo $\mathrm{Cu}$, o Complexo Ígneo Rincón del Tigre, os pegmatitos de Concepción e San Ignacio, a Serranía San Simon pelo ouro e Ascensión de Guarayos pelo Sn (Litherland et al., 1986). A segunda subfase foi dedicada ao mapeamento e a geoquímica da zona norte do Pré-cambriano boliviano .

O período de mapeamento das folhas 1:250.000 demandou 3 anos com a participação de um ou dois geólogos para cada uma delas. O mapeamento e amostragem geoquímica foram orientados por meio de fotografias aéreas convencionais e imagens Landsat (bandas 6 e 7, escala 1:250.000 e 1:100.000) com plotagem em mapas topográficos 1:250.000. Devido às especificidades da região, com densa floresta, utilizaram-se várias formas de transporte, incluindo-se bois e cavalos, canoas de alumínio e troncos da árvore impulsionados por remos ou botes com motor, aeronaves de asa fixa, incluindo aviões mono-motores, um DC-3 e helicópteros. A base do Projeto em Santa Cruz tinha rádio-transmissores em contato permanente com as brigadas.

Como resultado deste esforço governamental importante avanço no conhecimento geológico do Pré-cambriano foi atingido, propiciando novos rumos para o progresso científico da Bolívia. Foram elaborados aproximadamente 280 relatórios internos, acompanhados de mapas para uso exclusivo da GEOBOL (situação permanece atualmente). Para uso público, foram elaborados 57 mapas geológicos em escala 1:100.000 com relatórios bilíngües que cobrem quadrículas de 20'x 30' na Zona Sul. Estes mapas cobrem uma área maior sobre a fronteira com o Brasil, como Las 
Petas-San Matías e incluem a localização das amostras geoquímicas e de rochas coletadas. Em adição foram elaborados 14 mapas geológicos e relatórios na escala 1:250.000, cobrindo uma folha topográfica de $1^{\circ} 00^{\prime \prime} \times 1^{\circ} 30^{\prime}$ ', incluindo uma extensão até a borda da fronteira com o Brasil. Cada folha-mapa contém um relatório sobre sua geologia e o potencial mineral, exceto casos em que um único relatório abrange duas folhas. As folhas individuais são mostradas na Figura 3.1. Estas folhas contém um relatório de acompanhamento.

O Proyecto Precámbrico contou ainda com um programa de determinação de idade realizadas na unidade de isótopos da BGS (British Geological Survey), tendo sido produzidas 89 determinações pelo método K-Ar e 81 pelo método Rb-Sr. Darbyshire (1979) elaborou um relatório especial com a interpretação das determinações de idade, juntamente com um mapa 1:1.000.000 que indica locais amostrados. Por exemplo, o artigo de Litherland \& Bloomfield (1981) sintetizou os resultados do mapeamento de cerca de $100.000 \mathrm{~km}^{2}$ do setor oriental da Bolívia. Os dados geocronológicos permitiram delinear o arcabouço evolutivo regional, com os Granulitos Lomas Manechis e o Complexo Gnáissico Chiquitania representando as unidades basais formadas durante o Ciclo Orogênico Transamazônico ( $\pm 2.000 \mathrm{Ma}$ ), ao passo que dois ciclos orogênicos posteriores foram identificados: San Ignacio ( \pm 2000-1300 Ma) e Sunsás (<1300-950 Ma). O Ciclo San Ignacio incluiu a deposição dos Xistos San Ignácio (com soleiras básicas / ultrabásicas) e sua posterior mobilização junto com o substrato primitivo dentro de uma faixa de rumo norte acompanhada de fases graníticas. Segundo estes autores o Ciclo Sunsás iniciou-se com a deposição do Grupo Sunsás seguido da formação de um cinturão orogênico marginal ao antepaís. Este Ciclo foi acompanhado por fases graníticas e uma atividade principal de rochas básicas-ultrabásicas. $O$ encerramento da orogenia Sunsás marcou a cratonização do escudo boliviano em torno de $950 \mathrm{Ma}$

A integração dos resultados gerais do projeto está sintetizada na obra clássica de Litherland et al. (1986) que até hoje é referência para os que têm interesse em conhecer a geologia boliviana e suas correlações com unidades geológicas do SW do Craton Amazônico. Entre outras publicações importantes destacam-se as primeiras teorias evolutivas propostas para a geologia regional e modelagem tectônica (e.g., 
Klinck e Litherland, 1982; Litherland et al., 1985; Litherland et al., 1989). Estes dois últimos trabalhos, um deles publicado na Nature, apresentam pela primeira vez as modelos paleotectônicos para os cinturões móveis mesoproterozocos então identificados na Bolívia. O artigo de Litherland et al. (1985) defende o modelo de faixas móveis paralelas pré-cambrianas do Craton Amazônico que exibem a mesma orientação andina, ressaltando que esta cadeia inclui restos de embasamento précambriano, que em alguns casos é mais antigo que 2000 Ma como é o caso do cerro Uyarani, na Cordilheira Ocidental (Worner et al 2000), muito embora a relação entre estas rochas e o Cráton Amazônico sejam desconhecidas, devido à grande extensão da cobertura sedimentar cenozóica. Na interpretação dos autores os dois domínios estão ligados na forma de cinco faixas móveis com uma largura combinada de $1.000 \mathrm{~km}$, progressivamente mais jovens, com idades variando de $1300 \mathrm{Ma}$ até o presente. Neste trabalho, como protólito dos granulitos é considerada uma seqüência sedimentar e uma série plutônica calcioalcalina. Ressalta-se também neste artigo o caráter litoestratigráfico do Grupo Sunsás que como tal representa um nível estratigráfico guía, bem como indica-se o sentido sinistral das zonas de cisalhamento Sunsás e que o metamorfismo atinge a zona de granada nas rochas desta sequência supracrustal.

Outros produtos importantes foram gerados na oportunidade do projeto, a exemplo dos mapas do subprojeto GEOBOL-SGAB (Serviço Geológico Sueco) "Avaliação dos recursos minerais do Precámbrico", como parte de um projeto estratégico, visando reabilitar o setor de mineração boliviano, com apoio financeiro do Banco Mundial, da Agência Sueca de Cooperação para o Desenvolvimento Internacional (SIDA) e do próprio Governo de Bolívia (representado pelo Serviço Geológico de Bolívia, GEOBOL). Nesse particular, o doutorando foi co-autor de dois boletins produzidos neste subprojeto. O primeiro deles, baseado em sensoriamento remoto com apoio geofísico, descreveu a seqüência vulcano-sedimentar que forma o Grupo Naranjal na área de San Ramón (Witschard et al., 1993).O segundo é um trabalho de mapeamento geológico no Distrito San Ramon e sua principal contribuição é a descrição pormenorizada da seqüência vulcano-sedimentar do Grupo Naranjal que forma um cinturão de rochas verdes ao qual associa-se mineralização de ouro. Produziu-se um mapa temático para a área de San Ramon, com a combinação de 
dados radiométricos e magnéticos, dando um importante subsidio à interpretação das estruturas mapeadas no terreno (Adamek et al., 1996). O doutorando foi também responsável por uma das brigadas que atuaram no mapeamento da região de San Diablo e Cerro El Encanto (escalas 1:250.000 e 1:100.000 ) em 1991-1995; projeto este apoiado por levantamento aerogeofísico com suporte financeiro do Banco Mundial SERGEOMIN (ex GEOBOL) com a publicação dos respectivos mapas. Este levantamento aerogeofísico, utilizando pela primeira vez os métodos magnetômetria, radiometria e VLF (Witschard et al., 1993), incluiu uma região mais extensa desde San Ramon até a região de San Javier, Concepción e Ascensión de Guarayos. Posteriormente, a Sanders Geophysics Limited em 1994 continuou o levantamento geofísico em seis setores Huachi, Las Petas-San Matias, Santo Corazón, San Ignacio e San Simon (Figura 3.2).

Mais recentemente, no âmbito do Programa de Promoção do Investimento em Mineração, realizado pelo Departamento de Cooperação Técnica para o Desenvolvimento (DCTD), do PNUD (Nações Unidas) e o Serviço geológico da Bolívia (GEOBOL), foram elaborados modelos geológicos sobre áreas com potencial mineral de metais preciosos para fins de promoção de projetos de exploração mineral. Nesse sentido Lopez e Bernasconi (1988) reconheceram a faixa de "xistos verdes" (Grupo San Ignacio), no Distrito San Ramón como potencialmente favorável para concentrações econômicas de ouro. Esta faixa de baixo grau metamórfico tem um comprimento superior a 150 km e uma largura de 50-60 km, e uma orientação NNW.

Por fim, posteriormente ao Projeto Precámbrico, alguns trabalhos de exploração em San Simon incluíram mapeamento geológico, com apoio de dados geofísicos (VLF$\mathrm{EM}$ e IP), para melhor definir as zonas de cisalhamento mapeadas regionalmente. $\mathrm{Na}$ oportunidade destes trabalhos foram realizadas amostragem geoquímica de solo, rocha e laterita, bem como escavado um túnel de 700 metros cortando as estruturas de mineralização de ouro e ainda perfurados cerca de 39.000 metros para interpretação das estruturas (Ticlla-Colque, 2000; Moisy e Ticlla-Colque, 2002, Arce Burgoa, 2007). 

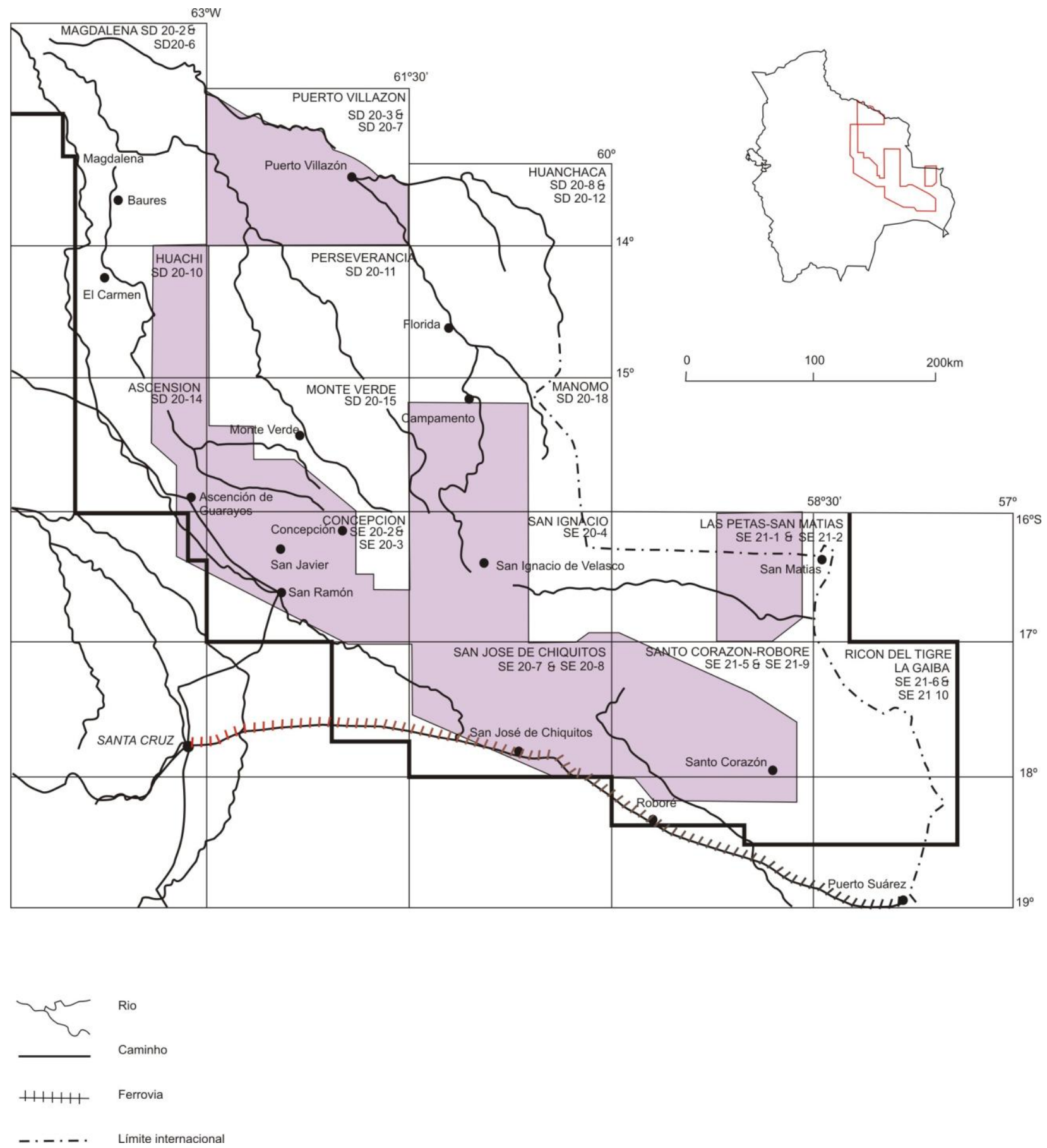

Figura 3.2 Mapa da geofísica aerotransportada 
$\mathrm{Na}$ década de 2000 foram retomados os trabalhos científicos na Bolivia, agora contando com as primeiras determinações de idade U-Pb SHRIMP (Boger et al, 2005), de modo a melhor definir os eventos acrescionários anteriormente delineados com base nos $\mathrm{Rb} / \mathrm{Sr}$ e K/Ar. Neste trabalho são apresentadas implicações tectônicas em relação ao chamado Craton Paraguá e aos eventos San Ignacio e Sunsás tendo por base comparações com a Laurentia. Boger et al, (2005) estabelecem claramente que o Complexo de Gnaisse Chiquitania e o Grupo de Xistos San Ignacio são derivados de fontes de $1765 \mathrm{Ma}$ e que não foram depositados antes de $1690 \mathrm{Ma}$. Consideram a colocação da Suíte Lomas Manechis entre 1690 - 1660 Ma e fizeram um giro na cronoestratigrafia considerando a Suíte Lomas Manechis mais jovem do que as duas unidades anteriores. Com os dados $\mathrm{U}-\mathrm{Pb}$ em zircão magmático e metamórfico restringem a orogenia San Ignacio no período 1340 - 1320 Ma. Interpretam as dobras na área de San Ignacio formadas durante a idade Sunsás, no entanto Litherland et al. (1986) estabeleceram este tipo de estruturas dentro do Complexo de Gnaisse Chiquitania.

O embasamento do Bloco Paragua não tem equivalentes em tempo em Rondônia e Mato Grosso. Para estes autores o Bloco Paraguá e o Bloco Arequipa Antofalla acrecionaram-se ao Cráton Amazônico durante a orogenia Sunsás. No entanto são propostos modelos distintos, por exemplo, Cordani e Teixeira (2007) como apresentado por Boger et al. (2005, cf. Figura 6), consideram que a colisão do bloco Paraguá (nosso terreno intra-oceânico de acresção Pensamiento-Rio Alegre), com a parte sul da província RNJ já cratonizada originou a orogenia Rondoniana-San Ignacio. Para estes autores o rifting dos grupos Aguapeí e Nova Brasilândia correspondem ao colapso orogênico final dentro da província RSI. A ativação posterior deles poderia ser um reflexo da colisões sucessivas, que produziu a faixa Sunsás. A sutura final seria, mais propriamente, entre a Amazônia e Laurentia, com o Sunsás como parte da faixa Grenville. Nos últimos 4 anos novas contribuições científicas foram publicadas, refinando o conhecimento geológico dos terrenos pré-cambrianos do Oriente Boliviano [Santos et al. (2008), Matos et al. (2009), Bettencourt et al. (2010), Teixeira et al. (2010)]. Estes quatro trabalhos são decorrência direta do 
desenvolvimento do projeto de Doutorado do presente autor e, como tal, serão objeto de comentários pertinentes no Capítulo 6. 


\section{METODOLOGIA}

Para esta etapa foram consultados os relatórios acompanhados de mapas do projeto GEOBOL-BGS (British Geological Survey) "Proyecto Precámbrico" que foram apenas para uso interno do pessoal de GEOBOL e não para publicação. Foram compilados os 21 relatórios e mapas de levantamento geológico em escala 1: 250.000 e o relatório das determinações de idade (Darbyshire, 1979). Também foram estudados os artigos produzidos pela contraparte britânica sobre vários aspectos da geologia da região (Berrangé, 1982; Litherland e Bloomfield, 1981). Entre os relatórios internos mais importantes foram consultados os trabalhos acerca das complexas teorias e principais modelos tectônicos estabelecidos durante o levantamento cartográfico (Klinck e Litherland, 1982) e Litherland e Klinck (1982). Foram consultados as cadernetas e os dois trabalhos do Projeto "Avaliação de Recursos Minerais do Pré-Cambriano" que fazia parte do Projecto de Reabilitação do Setor de Mineração, apoiados pelo Banco Mundial e a assistência técnica do Serviço Geológico da Bolívia, GEOBOL e o SGAB (Sweden Geological Survey). Também foram revistos os trabalhos do Programa de Promoção de Investimentos e Mineração realizado pelo Departamento de Cooperação Técnica para o Desenvolvimento (DCTD), do PNUD e do Serviço Geológico da Bolívia (GEOBOL), que prepararam informações de modelos geológicos de áreas potenciais para a mineração de metais preciosos para ser promovido como possíveis alvos para investimento em projetos exploração mineral (Lopez e Bernasconi 1988). Finalmente foi feita a interpretação de imagens de satélite de livre disponibilidade na internet. Neste caso, o Google Earth foi de grande importância para o estudo das feições estruturais e a comprensão da geologia da área estudada, uma vez que as técnicas de interpretação foram baseadas na experiência do autor da tese em áreas de pouca floresta como são os Andes bolivianos.

\subsection{Trabalhos de campo}

A partir dos perfis geológicos realizados e amostragens, os trabalhos experimentais enfatizaram os diferentes sistemas granitóides (unidades 
litoestratigráficas regionais) previamente estabelecidos na literatura (Fletcher, 1979; Litherland et al., 1986; adamek et al., 1996), com o intuito de definir suas respectivas idades e estudar as características geoquímicas e isotópicas. Em paralelo, foram realizadas comparações com dados publicados em unidades paleo- e mesoproterozoicas em Mato Grosso e Rondônia para subsidiar as interpretações sobre a evolução geológica regional. Em adição, a aplicação de aspectos estruturais, com ênfase no entendimento da cinemática regional do Pré-Cambriano Boliviano, foi útil na interpretação de mapas aeromagnéticos e aero-radiométricos.

Várias foram as visitas efetuadas à ex-GEOBOL, Santa Cruz com o intuito de pesquisar as amostras do Proyecto Precámbrico. Contudo, infelizmente esta Instituição pioneira da geologia na Bolívia não tem recursos e apoio do governo para realizar trabalhos de cartografia geológica.

A respeito dos trabalhos de campo, as amostras do Complexo Granitóide Pensamiento (21 amostras) foram enviadas a São Paulo desde a fronteira San Matias (Bolívia) - Curicha (Brasil). O veículo usado nesta campanha foi de SERGEOMIN, Santa Cruz (ex GEOBOL). A quilometragem total atingiu 2.362 desde Santa Cruz, Santa Rosa de Roca, Piso Firme, San Ignacio de Velasco, San Matias e Santa Cruz. O transporte desde Curicha (Brasil) até no IGc da USP foi em ônibus comercial. Com uma carta do Diretor do IGc-USP dirigida às autoridades aduaneras de Bolívia e Brasil que indicava o objetivo de pesquisa destas rochas o despacho desde este sítio foi muito simples. Um dos objetivos de uma das campanhas foi amostrar os granitos Sunsás na região entre San Javier e Casa de Piedra feito numa época de chuvas. O aluguel de duas motocicletas conduzidas por pessoal de San Javier permitiu a amostragem; o percurso foi de $80 \mathrm{~km}$ por dia.

A logística de campo no Pré-Cambriano Boliviano precisou de aluguel do carro em Santa Cruz. Cada campanha demanda um percurso de 1500 ate $2000 \mathrm{~km}$. As amostras da campanha de dezembro de 2005, totalizando 500 quilos de 44 amostras aproximadamente ficaram em aguardo no SERGEOMIN, Santa Cruz para ser despachadas a São Paulo. Foi necessária a participação pessoal do doutorante para fazer o envio por trem Santa Cruz até Quijarro no extremo este de Bolívia, fronteira com Corumbá no estado de Mato Grosso do Sul. O expediente de passar a fronteira na 
Aduana foi complicado pelo intenso tráfego. O envio desde Corumbá até a Terminal de Tiete foi em ônibus. Nesta terminal contratou-se um táxi e levou-se as amostras até o IGc, na USP.

O trabalho de campo constou do mapeamento dos terrenos do Pré-Cambriano do oriente da Bolívia baseadas nos trabalhos anteriores do autor da tese na cartografia realizada com GEOBOL e as empresas de exploração por minérios na década dos años 90. A maior atenção foi dedicada às folhas Huanchaca, Monte Verde, Puerto Villazón, Perseverancia (Figura 3.1) onde afloram as unidades do Complexo Granitóide Pensamiento. Nesta área remota, a logística viu-se dificultada pela coberta de vegetação e o acesso difícil. Os trabalhos de campo ao sul do Complexo Granitóide Pensamiento foram concentrados nas folhas geológicas 1: 250.000 Concepción, San José de Chiquitos, Santo Corazón-Roboré tendo sido obtidos exemplares representativos das suítes granitóides, fazendo particular ênfase à orogenia San Ignácio.

As amostras de rocha estão localizadas em Coordenadas com GPS utilizando-se o Sistema Geodésico de Referencia South American Datum- SAD 56 (ver Apêndice A). Os afloramentos descritos contém um registro fotográfico centrado na composição mineral, estrutura, magmatismo, metamorfismo e deformação. Em adição, foi percorrida a seqüência mais pesquisada no Pré-Cambriano boliviano, o Grupo Naranjal (rochas metavulcano-sedimentares), na região de San Ramón-Guarayos (Biste e Gourley, 2000). Ali ocorrem mineralizações auríferas associadas a BIF e cherts de origem exhalativo, posteriormente afetadas por zonas de cisalhamento e cujo depósito é Puquio Norte que produzia ao fiml da década de 90 aproximadamente 250.000 onças de ouro (R. Saenz Paz, comunicação verbal). A amostragem desta sequência volcanosedimentar será direcionada para geocronologia em zircão detrítico pelo método ICPMS-LA.

Finalmente, foram também amostrados granitos intrusivos (e.g., San Pablo, Tauca e Santo Corazón) associados à Zona de Cisalhamento San Diablo (área de San José de Chiquitos). Ali também ocorrem mineralizações auríferas associadas como o depósito de Cu-Au de Don Mario, originado a partir de soluções hidrotermais provenientes de 
uma fonte granítica, depositadas sob controle litológico-estructural e posteriormente afetadas por zonas de cisalhamento.

Tabela 1. Etapas de campo realizadas no Pré-Cambriano Boliviano.

\begin{tabular}{|c|c|c|c|c|c|c|c|}
\hline $\mathbf{N}^{\circ}$ & Data & Folha & Dias & Am. & Percurso & $\begin{array}{l}\text { Unidades } \\
\text { amostradas }\end{array}$ & Part. \\
\hline 1 & $\begin{array}{l}\mathrm{De} \\
31 / 07 / 04 \\
\text { até } \\
11 / 08 / 04\end{array}$ & $\begin{array}{l}\text { Concepción, } \\
\text { San Ignacio }\end{array}$ & 12 & 20 & $\begin{array}{lr}\text { Santa } & \text { Cruz, } \\
\text { Concepción, } & \text { San } \\
\text { Javier, } & \text { San } \\
\text { Ignacio } & \end{array}$ & $\begin{array}{l}\text { San Ramón,San Javier, } \\
\text { Refugio,San Rafael }\end{array}$ & $\mathrm{RM}$ \\
\hline 2 & $\begin{array}{l}\mathrm{De} \\
20 / 07 / 05 \\
\text { até } \\
30 / 07 / 05\end{array}$ & Concepción & 11 & 15 & $\begin{array}{l}\text { Santa Cruz, San } \\
\text { Javier, } \\
\text { Concepción, Piso } \\
\text { Firme }\end{array}$ & $\begin{array}{l}\text { CGP: La Junta, San Martín, } \\
\text { Porvenir, Diamantina }\end{array}$ & $\mathrm{RM}$ \\
\hline 3 & $\begin{array}{l}\mathrm{De} \\
\text { 10/12/05 } \\
\text { até } \\
17 / 12 / 05\end{array}$ & $\begin{array}{l}\text { Concepción } \\
\text { Monte Verde }\end{array}$ & 8 & 44 & $\begin{array}{l}\text { Santa } \quad \text { Cruz, } \\
\text { Concepción, San } \\
\text { Javier, Comunidad } \\
\text { Turunapé, } \\
\text { Lomerío, } \\
\text { Guarayos }\end{array}$ & $\begin{array}{l}\text { Lomas Manechis, } \\
\text { Chiquitanía, Limonal, La } \\
\text { Cruz, Guarayos }\end{array}$ & $\begin{array}{l}\text { WT, } \\
\text { MCG, } \\
\text { RM, } \\
\text { GVM }\end{array}$ \\
\hline 4 & $\begin{array}{l}\mathrm{De} \\
\text { 10/10/06 } \\
\text { até } \\
17 / 10 / 06\end{array}$ & $\begin{array}{l}\text { Huanchaca, San } \\
\text { José de } \\
\text { Chiquitos }\end{array}$ & 8 & 10 & $\begin{array}{lr}\text { Santa } & \text { Cruz, San } \\
\text { Javier, } & \text { Santa } \\
\text { Rosa de } & \text { Roca } \\
\text { Florida, } & \text { San } \\
\text { Diablo, } & \text { San Pablo }\end{array}$ & $\begin{array}{l}\text { S. Diablo, S. Pablo, El } \\
\text { Carmen, Chiquitania }\end{array}$ & $\begin{array}{c}\text { JSB, } \\
\text { MCG, } \\
\text { BLP, RM, } \\
\text { GVM, } \\
\text { VM, TR }\end{array}$ \\
\hline 5 & $\begin{array}{l}\mathrm{De} \\
12 / 10 / 07 \\
\text { até } \\
21 / 10 / 07\end{array}$ & $\begin{array}{l}\text { Huanchaca } \\
\text { San Ignacio }\end{array}$ & 10 & 5 & $\begin{array}{l}\text { Santa Cruz, San } \\
\text { Javier, } \\
\text { Rosa de Ranta } \\
\text { Florida, } \\
\text { Campamento }\end{array}$ & $\begin{array}{l}\text { Granito Discordancia, Sill } \\
\text { Huanchaca, Campamento }\end{array}$ & $\begin{array}{l}\text { RM, } \\
\text { VM, PB }\end{array}$ \\
\hline 6 & $\begin{array}{l}\mathrm{De} \\
08 / 02 / 08 \\
\text { até } \\
14 / 02 / 08\end{array}$ & $\begin{array}{l}\text { Concepción } \\
\text { Monte Verde }\end{array}$ & 7 & 10 & $\begin{array}{l}\text { Santa Cruz, San } \\
\text { Javier, Rio Blanco }\end{array}$ & $\begin{array}{l}\text { Las Maras, Santa Rosa, } \\
\text { Cachuela Suarez, Turunapé } \\
\text { e Atadijo }\end{array}$ & $\begin{array}{l}\text { RM, } \\
\text { GVM }\end{array}$ \\
\hline 7 & $\begin{array}{l}\text { De } \\
11 / 10 / 08 \\
\text { até } \\
20 / 10 / 08\end{array}$ & $\begin{array}{l}\text { San José de } \\
\text { Chiquitos e } \\
\text { Santo Corazón }\end{array}$ & 10 & 36 & $\begin{array}{l}\text { Santa Cruz, San } \\
\text { José, Roboré, } \\
\text { Santo Corazón }\end{array}$ & $\begin{array}{l}\text { Taseoro, } \\
\text { S. Diablo, S. Pablo, S. Juan, } \\
\text { Tauca, Chaquipoc, } \\
\text { Bocamina, Murciélago, } \\
\text { Boquí, Correreca, Sto. } \\
\text { Corazón, Rincon Del Tigre e } \\
\text { Don Mario }\end{array}$ & $\begin{array}{c}\text { RM } \\
\text { MCG } \\
\text { GVM, RF }\end{array}$ \\
\hline 8 & $\begin{array}{l}\mathrm{De} \\
27 / 01 / 10 \\
\text { até } \\
30 / 01 / 10\end{array}$ & $\begin{array}{l}\text { Concepción, } \\
\text { San Ignacio }\end{array}$ & 4 & 11 & $\begin{array}{l}\text { Santa Cruz, San } \\
\text { Javier, Moscú, } \\
\text { San } \quad \text { Ignacio, } \\
\text { Lomas Maneches }\end{array}$ & $\begin{array}{lr}\text { Moscu, } & \text { Cachuela, } \\
\text { Chiquitanía, } & \text { Lomas } \\
\text { Maneches } & \end{array}$ & $\begin{array}{l}\text { CCGT, } \\
\text { JM, AM, } \\
\text { RM }\end{array}$ \\
\hline
\end{tabular}

No total, mais de sete mil quilômetros foram percorridos no projeto de Tese, abrangendo praticamente todas as unidades do Pré-cambriano Boliviano, inclusive em áreas remotas de acesso restrito (parques nacionais tombados). Trata-se, portanto, de uma amostragem única e valiosa que deverá continuar a subsidiar inúmeros trabalhos 
acadêmicos nos próximos anos, e servirão de base duradoura para colaborações acadêmicas em benefício do progresso geológico da Amazônia.

\subsection{Trabalhos experimentais}

O desenvolvimento desta tese trouxe importantes benefícios para a comunidade científica interessada no conhecimento geológico do SW do Craton Amazônico pois permitiu a formação de um grupo de pesquisadores desenvolvendo atividades de campo e laboratoriais. Com isso foi possivel caracterizar as principais unidades geológicas e boa parte dos plútons granitóides relacionados às orogêneses San Ignácio e Sunsás. Uma volumosa coleção de rochas foi amostrada, visando os estudos laboratoriais (geoquímicos e isotópicos) os quais são apresentados no Apêndice -A.

A par das apresentações dos resultados preliminares obtidos em congressos e eventos, uma tese de Doutorado, (Gabriela Vargas-Mattos) foi defendida no mês de março de 2010 no Instituto de Geociências da UERJ. Do mesmo modo dois bolsistas IC (IGc-USP) foram incorporados no projeto notadamente na geocronologia de corpos granitóides (e.g., granitos Casa de Piedra, Refugio, Las Maras, Limonal, etc.) do Précambriano boliviano.

A aplicação das modernas metodologias e a obtenção de dados geoquímicos foram paralelos a trabalhos complementares duma equipe de pesquisa que definiram a estratégia abrangendo uma enorme área em branco de datações, a qual a través do tempo permitiu um refinamento da área com as mais modernas metodologias $(\mathrm{U}-\mathrm{Pb}$, $\mathrm{Sm}-\mathrm{Nd}$ ) que derivou na elaboração do mapa geológicos mais precisos.

\section{Petrografia}

As amostras coletadas nas diferentes etapas de campo representam as unidades do Complexo Lomas Manechis, Complexo Gnáissico da Chiquitania, Grupo de Esquistos San Ignácio, os granitóides da Suíte Granítica San Ignacio que formam o Complexo Granítico Pensamiento na zona setentrional e os granitos dispersos ao sul deste complexo. As amostras foram analisadas ao microscópio óptico com a 
finalidade de observar texturas, estruturas e associações minerais diagnósticas dos eventos ígneos e metamórficos regionais que permitiram a interpretação da geoquímica e geocronologia. As amostras de gnaisses e granitos (38 lâminas) foram cortadas en fatias de $1-2 \mathrm{~cm}$ de espessura e submetidas à coloração para distinção dos feldespatos sódicos e cálcicos. Posteriormente, realizou-se as estimativas modais que permitiram a classificação no diagrama QAP de Streckeisen.

\section{Geoquímica (Elementos maiores, menores e terras raras)}

As amostras representativas das unidades granitóides coletadas nas etapas de campo foram separadas em dois grupos: as rochas do Complexo Granitóide Pensamiento e as rochas granitóides aflorantes ao sul deste Complexo. Foram obtidas análises de elementos maiores, traços e terras raras; os elementos maiores analisados (em óxidos) foram: $\mathrm{SiO} 2, \mathrm{Al} 2 \mathrm{O} 3, \mathrm{MnO}, \mathrm{MgO}, \mathrm{CaO}, \mathrm{Na} 2 \mathrm{O}, \mathrm{K} 2 \mathrm{O}, \mathrm{TiO} 2, \mathrm{P} 2 \mathrm{O} 5$, e Fe2O3; os elementos traços analisados foram $\mathrm{Ba}, \mathrm{Ce}, \mathrm{Ga}, \mathrm{Nb}, \mathrm{Nd}, \mathrm{Pb}, \mathrm{Rb}, \mathrm{Sr}, \mathrm{Th}, \mathrm{U}, \mathrm{V}$, Zr. As técnicas analíticas empregadas incluíram fluorescência de raios $X$ no Laboratório de Química do IGc-USP. Os elementos terras raras foram analisados com espectrômetro de plasma ARL 3410 sequencial, os elementos analisados foram $\mathrm{La}, \mathrm{Ce}, \mathrm{Nd}, \mathrm{Sm}$, Eu, $\mathrm{Gd}$, Dy, Ho, Er, Yb, Lu. Os dados de química mineral foram tratados com o auxilio do programa para processamento de dados petrológicos Microsoft Excel e no programa Minpet (Richard 1995), e apresentados em diagramas clasificatórios e discriminantes e de ambiência tectônica binários.

\section{Geocronologia}

Foram empregados três métodos geocronológicos para os estudos das rochas do Pré-cambriano boliviano: U-Pb, Sm-Nd e Rb-Sr. Para a sistemática U-Pb em cristais de zircão foram utilizadas diferentes técnicas: SHRIMP, TIMS e LA-MC-ICP-MS, sendo que os grãos de zircão foram separados usando técnicas convencionais. 
Os granitos La Junta (amostra LJ20512), San Martín (CA0509), Diamantina (CP30507), La Cruz (LC0558) e San Andrés (SA0404) foram datadas por U-Pb SHRIMP. Os zircões foram documentados com imagens de luz transmitida e refletida, bem como catodoluminescência $(C L)$ com o intuito de revelar as suas estruturas internas e externas. Os granitos Refugio (amostra SR83) e Las Maras (amostra LM81) foram analisados pelo método U-Pb TIMS, ao passo que os granitos San Pablo (amostra SP0601), Talcoso (amostra BO418) e Limonal (amostra MT544) foram analizadas por U-Pb LA-MC-ICP-MS. A Tabela 2 a seguir é um resumo das análises do projeto no IGc da USP, como parte de doutorado do aluno Ramiro Matos.

Tabela 5.2 Resumo das analises e metodologias utilizadas na area de estudo.

\begin{tabular}{|c|c|c|c|c|c|c|c|c|c|}
\hline $\begin{array}{l}\text { Afloramen } \\
\text { tos } \\
\text { descritos }\end{array}$ & $\begin{array}{l}\text { Amos- } \\
\text { tras }\end{array}$ & $\begin{array}{l}\text { Petrogra- } \\
\text { fia }\end{array}$ & $\begin{array}{l}\text { Coloração de } \\
\text { feldspatos }\end{array}$ & $\begin{array}{l}\text { Análises } \\
\text { químicas }\end{array}$ & $\begin{array}{l}\text { U-Pb } \\
\text { SHRIMP } \\
\text { zircao }\end{array}$ & $\begin{array}{l}\text { U-Pb } \\
\text { TIMS }\end{array}$ & $\begin{array}{l}\text { U-Pb } \\
\text { ICP- } \\
\text { MS- } \\
\text { LA }\end{array}$ & $\begin{array}{l}\text { Rb-Sr } \\
\text { RTO }\end{array}$ & $\begin{array}{l}\text { Sm-Nd } \\
\text { RTO }\end{array}$ \\
\hline \multirow[t]{2}{*}{120} & 89 & 43 & 38 & 42 & 7 & & & 32 & 40 \\
\hline & & $\begin{array}{l}401,403, \\
404,406, \\
407,408, \\
412 \\
501,502, \\
503,504, \\
505,506, \\
507,508, \\
509,510, \\
511,512, \\
513,514, \\
515,516 \\
518,524, \\
531,532, \\
533,535, \\
537,538, \\
546,549, \\
550,551 \\
552, \\
553 A, \\
553 B \\
554,556, \\
558, \\
\text { PNK71, } \\
\text { PNK72 }\end{array}$ & $\begin{array}{l}401,403,404, \\
406,408,412 \\
501,502,503, \\
504,505,506, \\
507,508,509, \\
510,511,512, \\
513,514,515, \\
518,524, \\
531,532,533, \\
534,535,538, \\
545,546,549, \\
550,551552, \\
553 A, 553 B 558,\end{array}$ & $\begin{array}{l}401,403, \\
404,406, \\
407,408, \\
412 \\
501,502, \\
503,504, \\
505,506, \\
507,508, \\
509,510, \\
511,512, \\
513,514, \\
515,516 \\
518,524, \\
531,532, \\
533,535, \\
537,538, \\
546,549, \\
550, \\
551552, \\
553 A, \\
553 B, 554, \\
556,558, \\
\text { PNK71, } \\
\text { PNK72 }\end{array}$ & $\begin{array}{l}507,509, \\
512,558, \\
404, \\
534, \\
518\end{array}$ & $\begin{array}{l}413, \\
\text { LM81, } \\
\text { SR83 }\end{array}$ & $\begin{array}{l}544 \\
418 \\
601\end{array}$ & $\begin{array}{l}403,404, \\
406,408,501, \\
502, \\
503,504, \\
505,506, \\
507,508, \\
509,510, \\
511,512, \\
513,514, \\
515,516 \\
531,532, \\
533,534, \\
535,546 \\
547,550, \\
552,553 A \\
553 B, 558\end{array}$ & $\begin{array}{l}401,403, \\
404,406, \\
408,412 \\
501,502, \\
503,504, \\
505,506, \\
507,508, \\
509,510, \\
511,512, \\
513,514, \\
515,516 \\
518,528, \\
531,532, \\
533,534, \\
535,538, \\
546,547, \\
549,550, \\
551552, \\
553 A, 553 B, \\
554,558\end{array}$ \\
\hline
\end{tabular}




\section{PRODUÇÃO CIENTÍFICA COMENTADA}

Neste capitulo faremos uma breve reflexão acerca do conteúdo de 5 artigos publicados em periódicos nos quais houve a participação do doutorando como autor e co-autor. Também apresentamos uma proposta do cenário evolutivo com base no avanço do conhecimento e na caracterização de novas unidades geológicas précambrianas no Oriente Boliviano. Também são anexados outros produtos gerados (resumos apresentados) bem um manuscrito em preparação a ser submetido a um periódico internacional, este último apresentando a visão atual do autor sobre a evolução mesoproterozoica da área de estudo e implicações paleocontinentais.

Com o inicio do projeto de doutorado do autor, no ano de 2005, foi possível articular uma série de cooperações com pesquisadores e instituições brasileiros, possibilitando avançar no conhecimento geológico do Pré-Cambriano da Bolívia Oriental. Estas atividades, em parte apoiadas financeiramente pelo Conselho Nacional de Desenvolvimento Científico e Tecnológico (CNPq), culminaram com novos e importantes dados geológicos, geocronológicos e geoquímicos que foram examinados nesta Tese. Ressalte-se que parte desta nova etapa de conhecimento resultou do esforço pessoal do autor por meio da divulgação sistemática do conhecimento geológico e geocronológico da Bolívia em Simpósios Regionais no Brasil e no exterior, a partir de 2003, através de conferências convidadas, trabalhos orais e painéis: 5SSAGI; 7ํㅗㅇósio da Geologia da Amazônia; 33ํ IGC; Congreso Geológico da Bolivia; 45 Anos de Geocronologia (Matos et al., 2006; Matos et al., 2008; Matos et al., 2009; Matos et al., 2010).

Em várias oportunidades, associadas aos eventos científicos, foram organizadas e lideradas pelo autor excursões para reconhecimento das unidades geológicas regionais aos participantes destes eventos. Em adição foram incrementadas pesquisas conjuntas em diferentes segmentos do território boliviano, atividades que permanecem até hoje com colegas da UFMT, UERJ e USP. Esta estratégia de ação conduziu a uma efetiva integração da geologia do Pré-Cambriano nos projetos de pesquisadores brasileiros, resultando no incremento de dados analíticos essenciais para o avanço do conhecimento da área de estudo objeto do Doutorado. 
A seguir, são apresentados comentários e críticas pertinentes aos trabalhos completos publicados, a partir de 2008.

6.1 Santos, J. O. S., Rizzotto, G.J., McNaughton, N. J., Matos, R., Hartmann, L. A., Chemale Jr., F., Potter, P. E., Quadros, M.L.E.S, 2008. Age and autochthonous evolution of the Sunsás Orogen in West Amazon Craton based on mapping and U-Pb geochronology. Precambrian Research, 165, 120-152. (Apêndice D)

A amostragem das rochas do Pré-Cambriano da Bolívia reportada neste trabalho foi realizada por João Orestes Santos durante a primeira excursão à área, organizada pelo doutorando, na ocasião do Simpósio Geologia do Centro-Oeste ocorrido em Cuiabá de 2003. Nesta publicação os primeiros dados U-Pb e Sm/Nd obtidos na Austrália (Perth) foram compartimentados em duas províncias: províncias RondôniaJuruena (1,84-1,54 Ga) e Sunsás (1,46-1.11.Ga).

Para a província Sunsás, em um cenário integrado com a contraparte brasileira do SW do Craton Amazônico, foram propostas quatro orogenias, com base nas idades U-Pb SHRIMP e correlações geológicas: Santa Helena (1,46-1,42 Ga), Candeias (1,371,32 Ga), San Andrés (c. 1,27 Ga) (pelo povoado San Andrés, a oeste de Concepción) e Nova Brasilândia (1,18-1,11 Ga). No entanto, este modelo proposto não concorda com o cenário clássico das províncias Rio Negro Juruena, Rondoniana-San Ignacio e Sunsás Aguapeí (e.g., Cordani e Teixeira, 2007), cada um delas caracterizada por uma etapa de crescimento crustal e cratonização subseqüentes. Cabe também notar que Litherland et al. (1986) postulou um período estável de $300 \mathrm{Ma}$ separando as orogenias San Ignacio e Sunsás descritas na Bolívia, fato também registrado claramente pela ocorrência de rochas sedimentares não deformadas de idade Sunsás (serrania Huanchaca), depositadas discordantemente sobre o embasamento, como descrito por Litherland e Power (1989). Estas considerações sugerem que a proposta de uma orogênese alóctone "Sunsas" com duração de 400 milhões de anos, conforme a defendida, não se sustenta com base nos dados disponíveis no caso do território boliviano.

De outra parte, o granodiorito San Ramón, datado originalmente por Santos et al (2008) representa um novo evento acrescionário identificado pela primeira vez no 
escudo Pré-Cambriano da Bolívia. Trata-se de um corpo intrusivo de c. $35 \mathrm{~km}^{2}$, mesocrático, inequigranular, pertencente à série de alto potássio, com caráter peraluminoso. A rocha está levemente foliada e hospeda zonas de cisalhamento na direção NNW. Para o plúton San Ramon foram obtidas idades SHRIMP U- Pb similares em zircão e titanita de $1429 \pm 4 \mathrm{Ma}$, com idade $\mathrm{T}_{\mathrm{DM}}$ de 1,7 Ga, estabelecendo, portanto, um episódio distinto e anterior ao Complexo Granitóide Pensamiento (a ser comentado adiante) que tem grande extensão territorial no chamado Craton Paraguá. Os parâmetros petrogenéticos $\left(\varepsilon_{H f(t)}\right.$ entre $+3,49$ e $\left.+5,47\right)$ do plúton San Ramon implicam num evento magmático juvenil, porém sua dimensão geográfica ainda depende de estudos adicionais embasados em geocronologia $\mathrm{U}-\mathrm{Pb}$.

6.2 Matos, R., Teixeira, W., Geraldes, M. C., 2008. El granito diamantina: evidencia isotópica y química de magmatismo de arco em el Complejo Pensamiento, Provincia Rondoniana-San Ignacio, Precámbrico de Bolivia oriental. Revista del institutode Investigaciones Geológicas y del Medio Ambiente. Ano 2, Diciembre de 2008, p. 5-11.

Neste trabalho foi enfatizado o Granito Diamantina como exemplo de uma intrusão pos-cinemática do Complexo Granitóide Pensamiento. Quatro amostras do granito apresentam conteudo de $\mathrm{SiO}_{2}$ de 72 a $75 \mathrm{wt} \%$, indicando carater calcioalcalino, e composição peraluminosa. No diagrama de multielementos as amostras apresentam anomalias negativas de $\mathrm{Sr}, \mathrm{P}$ e $\mathrm{Ti}$ e interpretam-se devido á fracionação da mica, feldspato, apatita e titanita. Uma datação U-Pb SHRIMP do granito Diamantina produz uma idade de $1340 \pm 20$ Ma. O Granito Diamantina apresenta 4 idades modelo $T_{D M}$ variáveis entre 1.6 e $1.9 \mathrm{Ga}$ (três razoes $f_{\mathrm{Sm} / \mathrm{Nd}}$ entre -0.50 e -0.42 e uma razão de $0,25)$, e $\varepsilon_{\mathrm{Nd}(1.33 \mathrm{Ga})}$ de +0.4 a -1.2 , que indicam mistura de material derivado do manto e material crustal.

6.3 Matos, R., Teixeira, W., Geraldes, M. C., Bettencourt, J. S., 2009. Geochemistry and Nd-Sr Isotopic Signatures of the Pensamiento Granitoid Complex, Rondonian-San Ignacio Province, Eastern Precambrian Shield of Bolivia: Petrogenetic Constraints for a Mesoproterozoic Magmatic Arc Setting. Geologia USP, Série Científica 9, 2, 89-117. 
Este trabalho sintetiza os estudos realizados durante uma etapa intermediaria da Tese no Complexo Granitoide Pensamiento. Este ocorre na porção norte do PréCambriano Boliviano, estando tectonicamente associado à evolução da província Rondoniana San Ignacio (1,56-1,30 Ga) (Bettencourt et al. 2010). Suas rochas são classificadas em dois conjuntos: plutons sin- a tardi-cinemáticos e tardi- a póscinemáticos, com base nas inferências geológica, geocronológicas e características geoquímicas. Os plutons considerados sin- a tardi-cinemáticos representam uma maior área no complexo e mostran idades entre $1373-1347 \mathrm{Ma}$, os valores de $\varepsilon_{\mathrm{Nd}(\mathrm{t})} \mathrm{de}+1,8 \mathrm{e}$ 4,3 mostra mistura de material juvenil com crustal. No entanto os tardi- a póscinemáticos com valores de $\varepsilon_{\mathrm{Nd}(\mathrm{t})}$ em geral positivos mostram uma maior participação mantélica. Estes granitos foram estudados devido a que eles são os mais representativos do Complexo. Os resultados obtidos interpretados em conjunto com os dados geológicos de unidades contemporâneas na contraparte brasileira reforçam a existência de um arco magmático de idade mesoproterozoica que finalizou a evolução acrescionária da provincia Rondoniana-San Ignacio.

6.4 Bettencourt, J.S., Leite Jr., W.B., Ruiz, A. S., Matos, R., Payola, B.L., Tosdal, R.M., 2010. The Rondonian- San Ignacio Province in the SW Amazonian Craton: An overview. Journal of South American Earth Sciences, 29, 28-46.

Esta síntese reúne, pela primeira vez, as concepções tectônicas consensuais de pesquisadores brasileiros e do doutorando, embasados na correlação detalhada dos dados geológicos e geocronológicos do SW do Craton Amazônico, incluindo a ambiência tectônica. A revisão da evolução tectônica é apoiada pela definição de limites entre os terrenos, considerando que o terreno Paraguá separou-se da província Rio Negro-Juruena no lapso temporal 1,50-1,40 Ga. Fica implícito que o embasamento metamórfico consiste do Complexo Granulítico Lomas Manechis, o Complexo de Gnaisse Chiquitania e o Grupo de Xistos San ignacio. Divide-se a evolução da província Rondoniana- San Ignacio em dois períodos: 1560 - 1370 e 1370 - 1300 Ma. O primeiro intervalo temporal está caracterizado por eventos diacrônicos no tempo e espaço; o segundo período corresponde à subducção de litosfera oceânica (orógeno San Ignacio) devido à colisão de um microcontinente, o terreno Paraguá contra um continente 
(Craton proto-Amazônico). A colisão entre o Bloco Paragua e o Cráton Amazônico construiu a província Rondoniana-São Ignácio, resultando na formação do orógeno Rondoniano San Ignacio (1,56-1,30 Ga). Particularmente a duracao temporal proposta por Bettencourt et al. (2010) para o orógeno San Ignácio (1370-1320 Ma) desenvolveuse ate 1275 Ma uma vez que o granito San Andrés tem esta idade, apresentando-se porem obliterado pela deformação Sunsás. Por outro lado, defendemos que o termo Complexo Pensamiento seja restrito à parte setentrional do terreno Paragua, uma vez que se trata de um domínio preservado da deformação Sunsas, ao contrario do conjunto que aflora mais ao sul, apesar da toponímia local San Ignacio.

Em relação ao terreno Paraguá, o autor prefere empregar o termo "bloco Paragua" (cf. Boger et al. 2005) devido ao fato que este termo é mais apropriado para simbolizar o seu comportamento alóctone durante o Paleo e Mesoproterozoico, quando atuou como substrato dos granitóides da suíte San Ignacio. A cratonização deste bloco (e da província Rondoniana-San Ignácio) ocorreu entre 1,30-1,25 Ga, conforme sugerem os dados $\mathrm{Rb} / \mathrm{Sr}$ e K/Ar regionais e evidências geológicas.

6.5 Teixeira, W., Geraldes, M. C., Matos R., Ruiz, A. S., Saes, G., Vargas-Mattos, G., 2010. A review of the tectonic evolution of the sunsás belt. SW Amazonian Craton. Journal of South American Earth Sciences, 29, 47-60.

Este trabalho, tratando da evolução terminal do Craton Amazônico, enfatiza a natureza alóctone e colisional do orógeno Sunsás (1100-900 Ma) (concepção clássica). A faixa dobrada Sunsás com base nos dados geocronológicos mais recentes produziu plutonismo importante no período entre 1100 e $910 \mathrm{Ma}$. No território boliviano está marcada por frentes tectônicas bem definidas (sentido sinistral) demonstradas em três escalas de observação (micro, meso e macroescala) com idade aproximada de 1080 1050 Ma. As intrusivas plutônicas associadas ao evento Sunsás são agrupadas tentativamente em magmatismo sin- a tardi tectônico. Os primeiros estão relacionados com as zonas de cisalhamento e os segundos cortam a foliação típica de idade Sunsás.

No entanto os valores K-Ar em uma muscovita nos xistos Cristal do frente San Diablo, uma muscovita de um pegmatito que corta o granito El Carmen (972 \pm 21 ) e uma biotita no granito San Pedro com $968 \pm 21 \mathrm{Ma}$ (Litherland et al.1986) sugerem a 
época de resfriamento para a orogenia Sunsás. O modelo de deformação regional de Teixeira e colaboradores propõe que a colisão Sunsás deu-se de WSW para ENE contra o Bloco Paraguá, com a estabilidade tectônica final ocorrendo em torno de 950 Ma. Neste artigo os autores não destacaram o significato tectônico das intrusões básicas-ultrabasicas, como o complexo Rincón del Tigre que, em nossa opinião representa um magmatismo associado a etapa final da evolução Sunsas. Na verdade a idade reportada para este complexo (cerca $992 \mathrm{Ma}$ ), portanto mais jovem que os pulso felsico (1100-1070 Ma) e uma idade mínima referencial.

Em termos paleotectônicos, a faixa dobrada Sunsás representa eventos extensivos e compressivos que constituem excelentes testemunhas dos estágios mais jovens da evolução geológica entre a a Amazônia e a Laurentia (ver comentários adicionais adiante).

\subsection{COMENTÁRIOS SOBRE O ESTADO DE ARTE DO PRÉ-CAMBRIANO BOLIVIANO}

A crosta pré-cambriana na possui evolução tectônica perfeitamente comparável com os terrenos policíclicos pertencentes às províncias Rio Negro-Juruena e Rondoniana-San Ignacio, nos estados de Rondônia (Bettencourt et al., 1999; Payolla et al., 2002; Rizzotto \& Quadros, 2007) e Mato Grosso (Geraldes et al., 2001), embora o nível de conhecimento geológico e geocronológico regional seja muito heterogêneo e algumas vezes incipiente. Em função disso, ainda persistem muitas lacunas no tocante ao quadro litoestratigráfico, em especial em relação às seqüências supracrustais e suítes intrusivas. Do mesmo modo há dúvidas no tocante à caracterização espaçotemporal dos diferentes eventos tectonomagmáticos, o que dificulta o estabelecimento de modelos evolutivos. Nesse sentido o mapa geológico integrado (Apêndice C) apresenta modificações na cartografia dos corpos graníticos das orogeneses San Ignácio e Sunsas, em especial na regiao de San Ramon. Em adição foram realizadas modificações na cartografia na região sul do front tectônico San Diablo, com destaque para as estruturas que refletem a tectônica transcorrente geral. Estas questões encontram-se ilustradas na Figura 6.3 (no caso da cartografia dos granitos), no mapa 
do Apêndice $\mathrm{C}$ e no texto adiante quando se comenta a tectônica dúctil da orogenese Sunsas no front San Diablo.

Isto posto, os estudos desenvolvidos nesta Tese permitiram importantes avanços em termos do conhecimento evolutivo, ilustrados pela caracterização de novas unidades geológicas, conforme sintetizado abaixo e no mapa do Apêndice C.

\subsubsection{Granito Correreca}

Recentemente no $7^{\circ}$ SSAGI em Brasília foram apresentados os dados isotópicos deste plúton, que ocorre na área oeste de Rincón del Tigre e Santo Corazón. A imagem de satélite apresenta um terreno baixo com uma tênue foliação NNW, extensamente coberto por floresta. Segundo Mitchell (1979) o corpo está sobreposto ao norte pelos sedimentos do Grupo Sunsás, a oeste pelo Grupo Boquí e ao sul pelo Grupo Murciélago. A leste o plúton faz contato de falha com o Complexo Granitóide Santo Corazón. A geoquímica mostra uma afinidade peraluminosa, de médio potássio, compatível com ambiente tectônico de arco.

Duas amostras do granito Correreca forneceram idades ${ }^{207} \mathrm{~Pb}-{ }^{206} \mathrm{~Pb}$ (evaporação) de $1925 \pm 32$ Ma e $1894 \pm 13$ Ma que são comparaveis dentro do erro (Vargas Mattos, 2010), sendo que as idades $T_{D M}$ correspondem a 2,81 e 2,90 Ga (valores de $\varepsilon_{\text {Ndt }}$ de $-8,5$ e -9,4). A idade de cristalização é significativamente mais antiga que o valor U-Pb de 1818 Ma para o protólito (núcleo de zircão) do Complexo Granulítico Lomas Manechis (Santos et al., 2008), e revelam a presença pela primeira vez de crosta paleoproterozoica em um trato territorial da Bolívia (região de Santo Corazon). Esta idade paleoproterozoica indicaria que a area sul da Zona de Cisalhamento San Diablo, denominada terreno San Pablo por Saes et al. (1992), seria um terreno alóctone com uma história geológica distinta.

\subsubsection{Suíte Yarituses}

Os dados geocronológicos U-Pb SHRIMP, TIMS e ablasão por laser-ICPMS obtidos indicam a formação desta suíte granítica (segundo a tribo Yarituses que ocupa 
a área de San Javier, onde estes corpos afloram) no lapso temporal entre 1673 a 1621 $\mathrm{Ma}$, portanto comparáveis as idades $\mathrm{U}-\mathrm{Pb}$ reportadas para a suíte granítica Lomas Maneches de Boger et al. (2005). Os dados de campo e imagem de satélite mostram que os granitos desta suíte não são apenas sills, como mencionado por Boger et al. (2005), (ver mapa do Apêndice C). Este fato induziu o presente autor a introduzir o termo Suite Yarituses como uma nova unidade regional, distinguindo-a da clássica suíte Lomas Manechis. Ao mesmo tempo, mantem-se aqui a denominação Complexo Granulítico Lomas Manechis de Litherland et al. (1986), como uma unidade distinta mais antiga com base na idade magmática $\mathrm{U} / \mathrm{Pb}$ para um gnaisse granulítico de $1818 \pm$ 13 Ma na área de San Matias (Santos et al., 2008). Ressalta-se, porém, que o granito Correreca (idades $\mathrm{Pb}-\mathrm{Pb}$ em zircão de 1925-1894) é a rocha mais antiga dentro do Pré-cambriano Boliviano(ver acima).

Em resumo, a suite Yarituses compreenderia, com base no conhecimento atual, os granitos La Cruz, Refugio e San Pablo que foram identificados geocronologicamente nesta tese.

\section{Granito La Cruz}

Este corpo aflora $15 \mathrm{~km}$ ao nordeste de San Ramón, e constitui dois corpos de forma aproximadamente sigmoidal devido à deformação Sunsás, estando intrudidos no Grupo de Xistos San Ignacio. O granito La Cruz (amostra LC0558) é um sienogranito leucocrático, de cor rosa pálido, com escassa biotita como o mineral máfico. A textura dominante é alotriomórfica granular com o feldspato potássico pertítico caraterizado pelo padrão trançado. Geoquimicamente, a rocha é peraluminosa, calcioalcalina de alto potássio e de caráter intraplaca. Da análise U-Pb SHRIMP de oito grãos de zircão, cinco núcleos plotam sobre o diagrama Concórdia com idade ${ }^{207} \mathrm{~Pb} /{ }^{206} \mathrm{~Pb}$ de $1673 \pm 21$ Ma $(M S W D=1,6)$ (Figura 6.1a), considerada como a idade de cristalização. Esta idade compara-se dentro do erro com duas idades obtidas por Boger et al.(2005) e uma por Santos et al.(2008) para as rochas no intervalo de 1689 to $1663 \mathrm{Ma}$. A idade modelo $\mathrm{T}_{\mathrm{DM}}$ é de $1,83 \mathrm{Ga}$ (razão $f_{\mathrm{Sm} / \mathrm{Nd}}$ de -0.42 ), com $0 \varepsilon_{\mathrm{Ndt}}$ de +2.1 que indica derivação mantélica. 


\section{Granito Refugio}

O plúton Refugio distribui-se no lado norte da estrada de San Javier Concepción (Apêndice C). Santos et al. (2008) reportaram as primeiras idades SHRIMP U-Pb em zircão, monazita e titanita do granito Refugio. Os núcleos de zircões produziram uma idade de ${ }^{207} \mathrm{~Pb} /{ }^{206} \mathrm{~Pb}$ de $1641 \pm 4 \mathrm{Ma}$; a idade modelo $\mathrm{T}_{\mathrm{DM}}$ de $1.66 \mathrm{Ga}$, e $\varepsilon_{\mathrm{Nd}(\mathrm{t})}+4.06$ assinalando sua derivação mantélica e portanto a cristalização da rocha. Para esta Tese, este corpo foi amostrado em dois lugares. A primeira amostra SR83 localiza-se a $8 \mathrm{~km}$ leste de San Javier. A rocha é um leucogranito, cor esbranquiçada, sendo que o mineral máfico é a biotita. Os dados isotópicos U-Pb TIMS da amostra SR83 de quatro frações produz três pontos concordantes e um discordante, com uma idade ${ }^{207} \mathrm{~Pb} /{ }^{206} \mathrm{~Pb}$ de $1673 \pm 25 \mathrm{Ma}$, um MSWD = 36, idade esta comparável à obtida anteriormente para a cristalização do pluton (Figura 6.1b). A segunda amostra RF0408 foi coletada $17 \mathrm{~km}$ ao leste de San Javier, na estrada para Concepción. Trata-se de um sienogranito, fracamente foliado, com textura granular hipidiomórfica, cor rosa pálido, afinidade peraluminosa, de alto potássio, e ambiência tectônica de arco vulcânico. A idade modelo $T_{\mathrm{DM}}$ é de $1.9 \mathrm{Ga}$ (razão $f_{\mathrm{Sm} / \mathrm{Nd}}$ de -0.49 ), com valor de $\varepsilon_{\mathrm{Ndt}}$ de $+0,18$. Comparativamente ao dado de Santos et al. (2008), isto indica a presença de diferentes componentes na petrogênese deste plutonismo, neste ultimo caso.

\section{Granito San Pablo}

Este granito forma um corpo de $11 \mathrm{~km}$ de comprimento por $4 \mathrm{~km}$ de largura, exposto $25 \mathrm{~km}$ sul de San Antonio de Lomerío (Apêndice $\mathrm{C}$ ). O pluton é paralelo à Frente San Diablo de orientação WNW, conseqüentemente, o granito está afetado pelo cisalhamento. A rocha é um quartzo monzonito a biotita de cor rosa, e de granulação fina a média. $O$ índice de saturação de alumina mostra uma afinidade peraluminosa, de médio K e ambiente de intraplaca (Vargas Mattos, 2010). Em lâmina delgada apresenta uma textura granular anedral. 


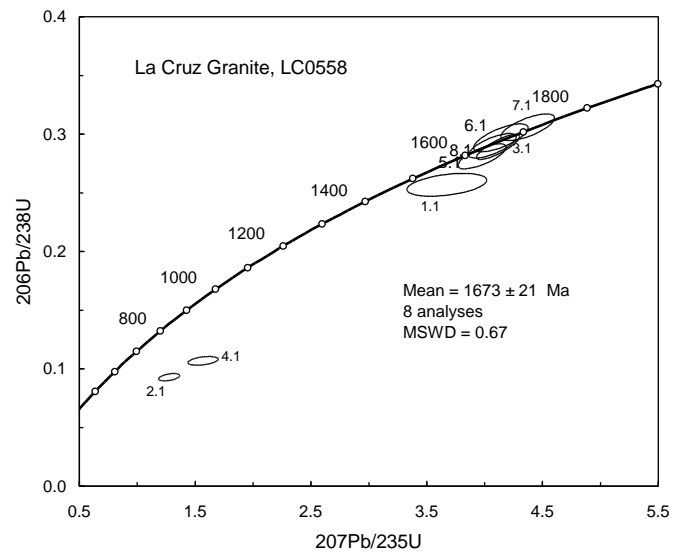

a

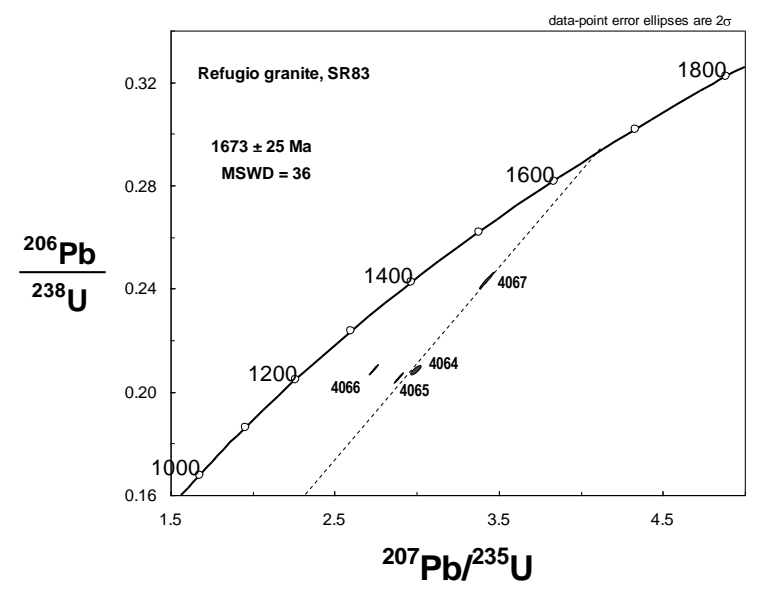

b

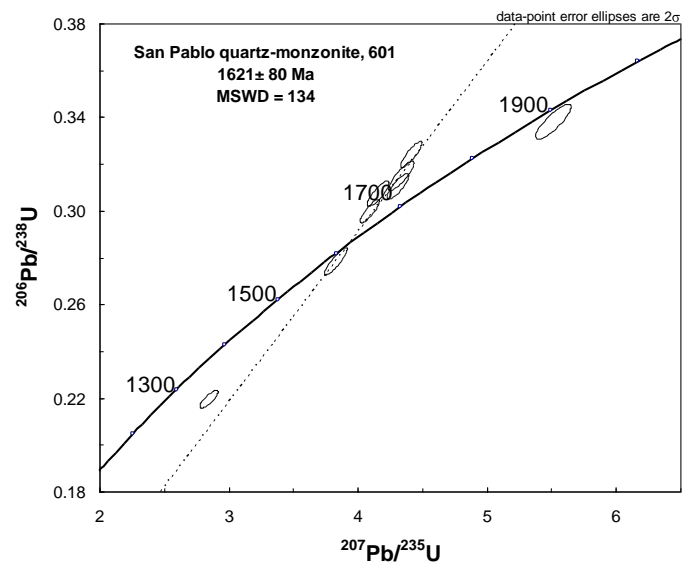

C

Figura 6.1. (a). Diagrama Concórdia: análises U-Pb SHRIMP do granito La Cruz. (b). Diagrama Concórdia: análises U-Pb TIMS do granito Refugio. (c). Diagrama Concórdia: análises U-Pb LA ICP MS do granito San Pablo. 
Os zircões do quartzo monzonito San Pablo (amostra SP0601) são prismáticos e na imagem MEV apresentam forma subarredondada. Os resultados U-Pb plotados em

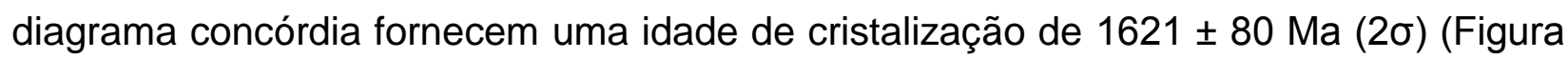
6.1c). A idade modelo $T_{\mathrm{DM}}$ corresponde a $1,7 \mathrm{Ga}$ (razão $f_{\mathrm{Sm} / \mathrm{Nd}}$ de -0.38 ), com valor de $\varepsilon_{\text {Ndt }}$ de $+3,5$ indicando significativa contribuição mantélica na origem da rocha.

\subsubsection{Suite Orogênica San Ignacio}

Representa a propria orogênese San Ignácio, cujos processos magmáticos, deformacionais e metamórficos estão amplamente representados no Pré-Cambriano da Bolívia, tanto no Complexo Granitóide Pensamiento como ao sul dele, embora parcialmente obliterados pela orogênese Sunsás (e.g., Boger et al., 2005; Bettencourt et al., 2010; Teixeira et al., 2010).

O termo Complexo Granitóide Pensamiento (Litherland et al., 1986) compreende um conjunto de rochas granitóides no setor norte do Pré-Cambriano boliviano (ou Bloco Paraguá) que não foi afetado pela orogenia Sunsás. Com base em evidências geológicas e isotópicas (ver abaixo), as rochas deste Complexo devem ser separadas dos granitóides do setor sul que ocorrem de modo disperso dentro do embasamento. $\mathrm{O}$ plutonismo orogenético é composto de volumosas massas graníticas, que acompanharam processos metamórficos com fusões localizadas de rochas do Complexo Lomas Manechis e gnaisses Chiquitania. A geoquímica em rocha total indica uma composição em geral peraluminosa, subalcalina de alto $\mathrm{K}$, compatível com ambiente de arco magmático.

Datações SHRIMP em zircão dos plútons San Martín e La Junta considerados sin a tardi-cinemáticos, situados na parte setentrional do bloco Paragua, produziram $1373 \pm 20 \mathrm{Ma}$ e $1347 \pm 21 \mathrm{Ma}$ respectivamente, com idades modelo $\mathrm{T}_{\mathrm{DM}}$ entre 1,7 e 2,0 $\mathrm{Ga}$, (La Junta quatro razoes $f_{\mathrm{Sm} / \mathrm{Nd}}$ entre -0.50 e -0.42 e San Martín uma razão de -0,28) e valores de $\varepsilon_{\text {Ndt }}$ entre $+1,8$ e -4,3. Assim também os plutons Porvenir, San Cristobal e Piso Firme, que são considerados tardi a pos-cinemáticos, têm idades $T_{\mathrm{DM}}$ entre 1,6 e $1,7 \mathrm{Ga}$ (razoes $f_{\mathrm{Sm} / \mathrm{Nd}}$ entre $-0,31$ e $-0,25$ ) e valores de $\varepsilon_{\mathrm{Ndt}}$ entre $+2,7$ e $+1,5$, o que corrobora uma origem em arco magmático. O pluton Diamantina, de natureza tardi- a 
pos-cinemático, possui uma datação SHRIMP em zircão de $1340 \pm 20 \mathrm{Ma}$, tem idades $\mathrm{T}_{\mathrm{DM}}$ entre 1,6 e 1,9 $\mathrm{Ga}$ e valores de $\varepsilon_{\mathrm{Ndt}}$ entre $+0,4$ e -1,2. Isto ratifica a existência de um arco magmático juvenil mesoproterozoico durante a sua gênese, conforme reportado recentemente por Matos et al. (2009).

A respeito dos granitoides do setor sul (plútons Las Maras, San Rafael, Talcoso Limonal, Cachuela e San Andrés), nove datações SHRIMP, TIMS e de abrasão por laser (Boger et al., 2005; Santos et al., 2008; Vargas-Mattos, 2010 e Matos et al, em preparação), em zircões produziram idades entre 1347 e 1275 Ma (Figura 6.2), idades modelo $T_{D M}$ entre 1,7 e 2,0 Ga, e valores de $\varepsilon_{N d t}$ entre +4 e -4 . Essa composição isotópica de $\mathrm{Nd}$ indica que o magma é derivado de uma mistura de fusão de um manto empobrecido com fusão de fonte crustal mais antiga. Por extrapolação as idades $\mathrm{T}_{\mathrm{DM}}$ mais antigas corroboram com a idéia de uma crosta pretérita com idade assemelhada ao evento Correreca. Por outro lado, as análises geoquímicas deste conjunto de rochas granitoides indicam uma composição predominantemente peraluminosa a metaluminosa, subalcalina de alto K e natureza tectônica de intraplaca e arco volcânico.

As informações disponíveis sugerem que a orogênese San Ignácio representa um arco acrescionário que construiu a arquitetura final da província homônima, pela colisão entre o Craton Paraguá e o antepaís ao norte - evolução essa que foi precedida pelo desenvolvimento de arcos magmáticos juvenis e continentais (Bettencourt et al., 2010; Teixeira et al., 2010).

Os representantes coevos da evolução do arco San Ignácio, expostos na contraparte brasileira, são os Complexos Colorado e Mamoré (Rizzotto e Quadros, 2007; Teixeira et al., 2006; Bettencourt et al., 2009). Na Bolívia este evento acrescionário afetou heterogeneamente todas as unidades pré-existentes, incluindo fusões localizadas dos paragnaisses Chiquitania e granulitos Lomas Manechis, conforme apontam muitas idades U/Pb SHRIMP obtidas em bordas recristalizadas de zircões (Santos et al., 2008; Matos et al., em preparação). 


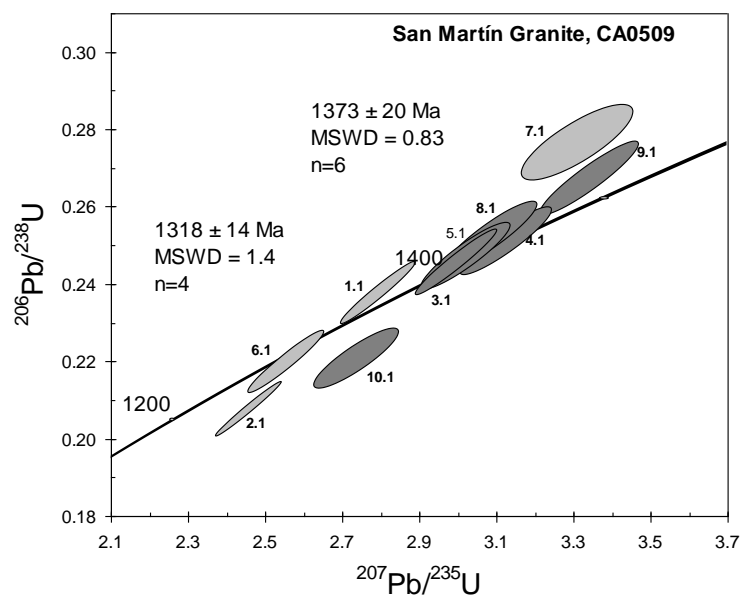

(a)

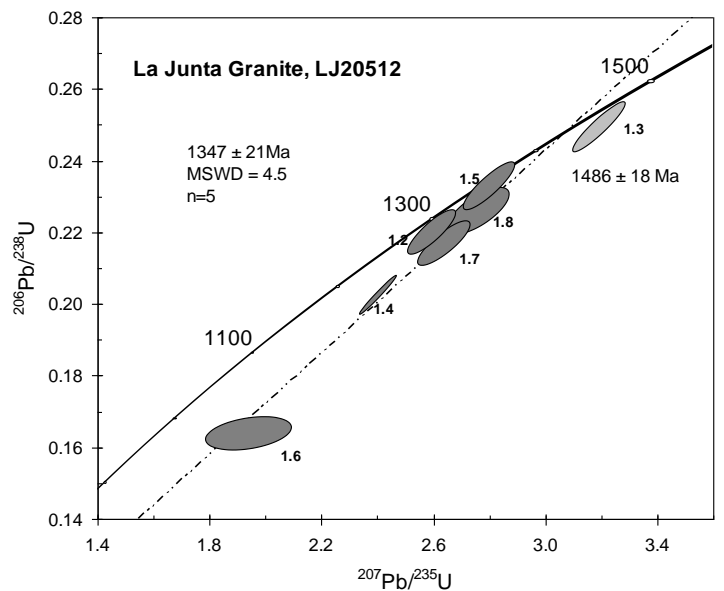

(b)

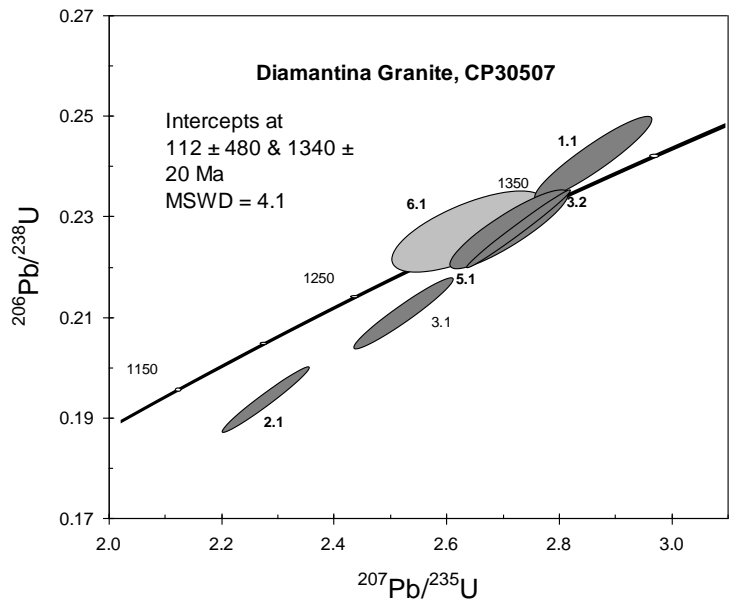

(c) 


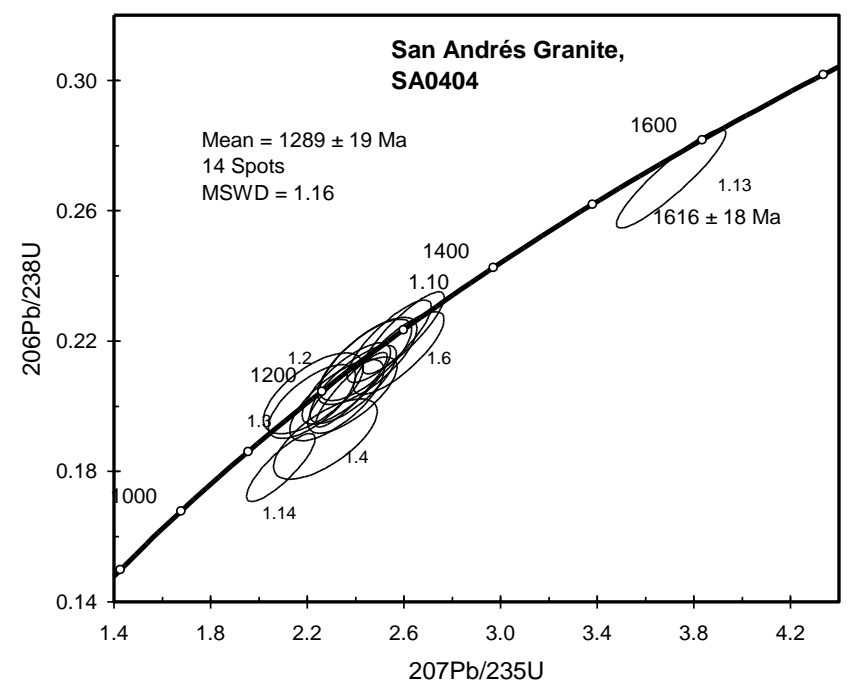

(d)

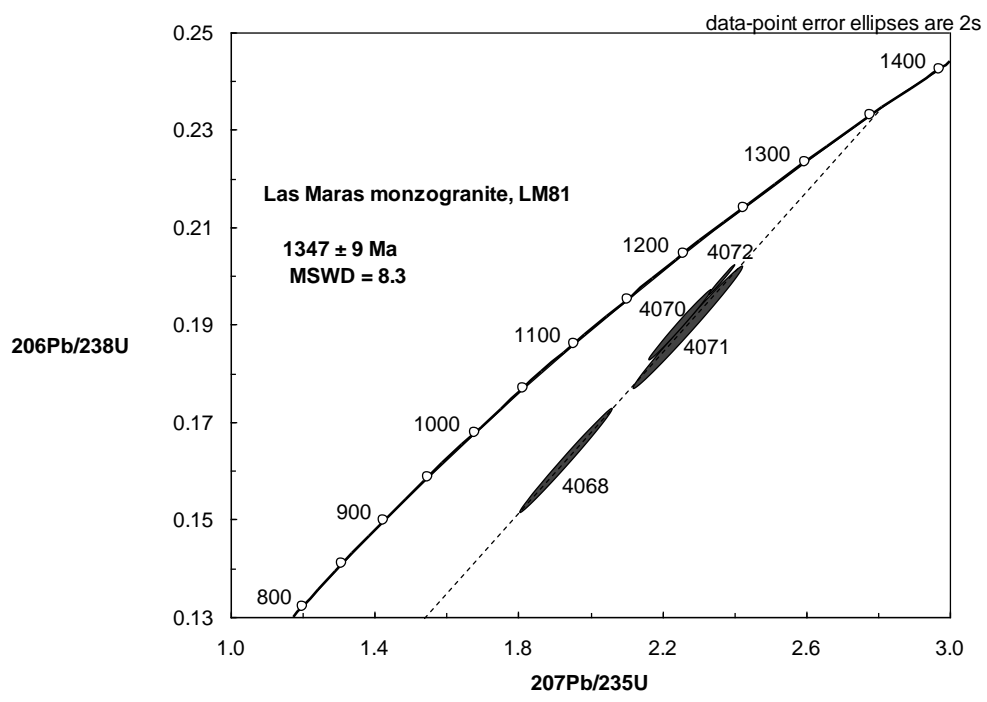

(e) 


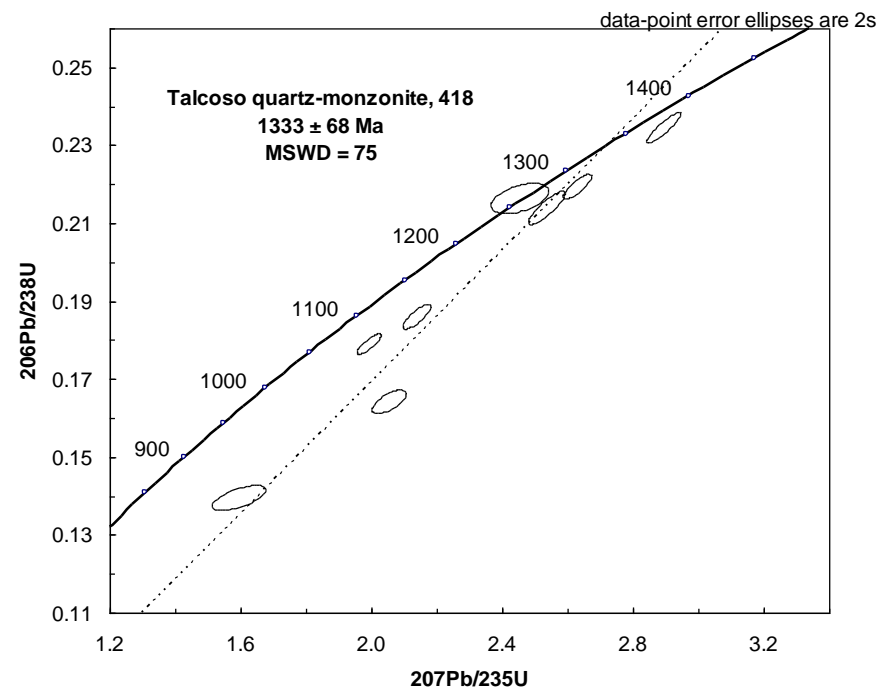

(f)

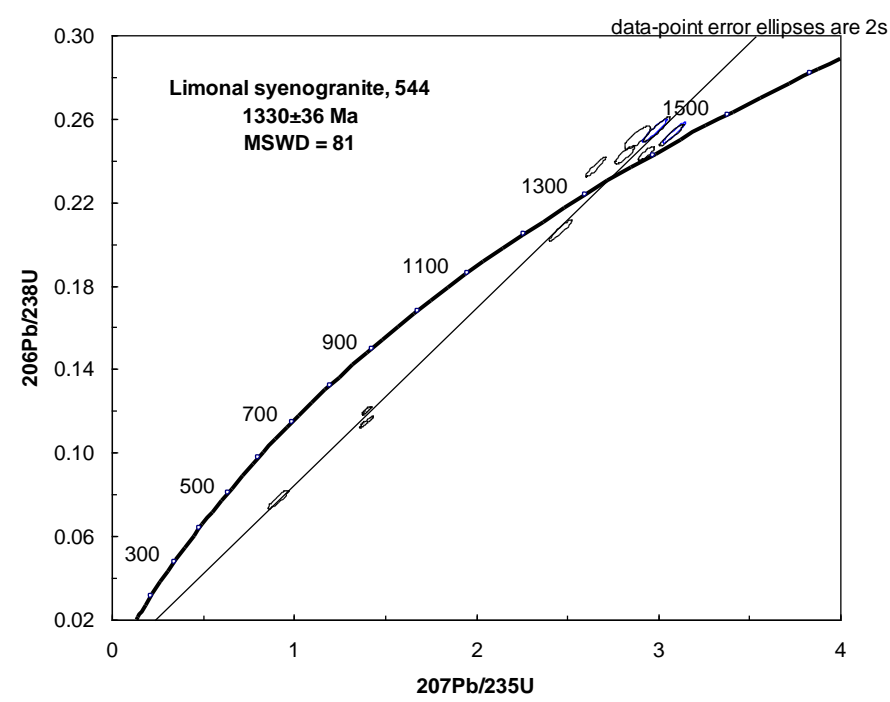

(g)

Figura 6.2 Diagrama Concordia Suite San Ignacio (a) Granito San Martín; (b) Granito La Junta; (c) Granito Diamantina, (d) Granito San Andrés, (e) Granito LasMaras; (f) Granito Talcoso; (g) Granito Limonal. 
Finalmente, uma avaliação integrada dos dados disponíveis para as suítes Yarituses e San Ramon no contexto evolutivo mesoproterozoico estão sendo interpretados em um manuscrito em preparação (Matos et al; em preparação Apêndice D), o qual apresenta também correlações com o SW do craton Amazônico .

\subsubsection{Evolução crustal Paleo a Mesoproterozoica}

A avaliação integrada dos dados geocronológicos, geoquímicos e geologicos, obtidos nesta tese ou compilados em publicações recentes, devidamente embasada na revisão da geologia regional permite estabelecer algumas considerações quanto ao arcabouço tectônico do Pré-Cambriano do Oriente Boliviano. Não obstante, embora o quadro evolutivo mesoproterozoico esteja delineado, diversas das intrusivas granitóides previamente interpretadas como de idade San Ignacio e/ou Sunsás, com base em relações geológicas e dados estruturais (e.g., Litherland et al., 1986; Boger et al., 2005), não foram confirmadas pelas datações $\mathrm{U} / \mathrm{Pb}$ realizadas no projeto de doutorado (ou publicações recentes), exigindo com isso o respectivo re-enquadramento cronoestratigráfico. Esta situação também se extrapola para as rochas encaixantes, exemplificadas pelo Complexo Lomas Manechis e, especialmente, pelas unidades paraderivadas como o Complexo Chiquitania e o Grupo San Ignacio.

Em síntese, o embasamento Pré-Cambriano na Bolívia Oriental é composto pelos complexos Lomas Manechis e Chiquitania, e o Grupo de Xistos San Ignácio, e ainda pelo granito Correreca recentemente caracterizado (ver acima). O complexo Lomas Manechis, considerada a unidade de mais alto grau metamórfico do Precambriano, ocorre na Serrania Lomas Maneches, Carmen de Ruiz e Espíritu- Las Rengas (Mapa geológico - Apêndice C). O conjunto está composto de granulitos charnockíticos, enderbíticos, básicos e gnaisses bandados quartzo-feldspáticos segundo Litherland et al. (1986), além dos sills de rochas granitóides (de acordo com Boger et al., 2005) com idade SHRIMP U-Pb de 1690-1630 Ma. Esta unidade metamórfica está caracterizada pela heterogeneidade litológica, estrutural e provavelmente geocronológica, foi datada por Santos et al., 2008 em Las Rengas, na proximidade do Posto Fortuna. Possui núcleos de zircões com idades U-Pb SHRIMP ${ }^{207} \mathrm{~Pb} /{ }^{206} \mathrm{~Pb}$ de $1818 \pm 13 \mathrm{Ma}$, ao passo que as bordas recristalizadas de monazita 
indicam idades $1339 \pm 4 \mathrm{Ma}$, indicando a remobilização por conta da orogênese San Ignacio. $A$ idade $T_{D M}(2.07 \mathrm{Ga})$ e valor de $\varepsilon_{\text {Ndt }}(+0.53)$ admitem um protolito com curta residência crustal.

O Complexo Chiquitania é constituído principalmente por paragnaisses que exhibem cor variando de cinza claro a escuro, granulação fina a media e textura granolepidoblástica. Apresentam marcante bandamento composicional metamórfico, definido pela alternância de bandas félsicas de constituição quartzo-feldespática e níveis máficos em general de constituição biotítica, parcialmente migmatizados que é o litotipo predominante. Estas rochas possuem muita representatividade na zona central e sul da área de estudo, definem uma foliação $S_{1}$ orientada segundo direção NW-SE e estão afetadas pelo metamorfismo da fácies anfibolito. Análises U-Pb (SHRIMP) em zircões detritícos desta unidade $20 \mathrm{~km}$ a leste de San Rafael indicam idades entre1830 Ma e 1690 Ma para seus protólitos (e.g., Boger et al., 2005). No entanto grãos de zircão levemente discordantes acusaram uma idade ${ }^{207} \mathrm{~Pb} /{ }^{206} \mathrm{~Pb}$ de $1333 \pm 6 \mathrm{Ma}$ interpretado como relativo a época da fusão parcial associada á orogênese San Ignácio. Portanto o Complexo Chiquitania depositou-se após $1690 \mathrm{Ma}$, conforme proposto por Boger et al. (2005). Idades semelhantes foram reportadas por Santos et al. (2005) para um paragnaisse a granada, localizado a $25 \mathrm{~km}$ a leste de Concepción. A principal população de zircones detríticos apresenta idades ${ }^{207} \mathrm{~Pb} /{ }^{206} \mathrm{~Pb}$ entre $1690-1630 \mathrm{Ma}$.

Santos et al. (2008) apresentam análises U-Pb SHRIMP do ortognaisse Rio Fortuna localizado $28 \mathrm{~km}$ a oeste de Ascensión. Ocorrem duas populações, uma delas assinalada pela presença de núcleos e herança em zircões, com idade entre $1772 \mathrm{e}$ $1734 \mathrm{Ma}$. A segunda população de zircões magmáticos e bordas recristalizadas agrupam-se na concórdia com idade ${ }^{207} \mathrm{~Pb} /{ }^{206} \mathrm{~Pb}$ de $1333 \pm 3 \mathrm{Ma}$. Com base nesta idade e no caráter ígneo da rocha datada há duas possibilidades: 1) Complexo Chiquitania agrega unidades orto e para-derivadas; 2) o ortognaisse Rio Fortuna é uma unidade precedente ao complexo Chiquitania. $\mathrm{Na}$ verdade preferimos a segunda opção correlacionando esta rocha as do Complexo Lomas Maneches.

O Grupo de Xistos San Ignácio caracteriza-se pela distribuição em faixas estreitas, contendo rochas metavulcano-sedimentares que incluem vulcânicas bimodais (basaltos toleiíticos e vulcânicas cálcio-alcalinas), rochas metassedimentares clásticas e 
químicas (arenitos, xistos, BIF, chert). O grupo está circundado por gnaisses e granitos e está superposto em discordancia pelos conglomerados e arenitos do Grupo Sunsás. Os estudos feitos pelo autor neste Grupo abrangem a sequência metavulcanosedimentar Naranjal (em fase de datação) que forma uma extensa faixa NS na porção sudoeste da área de estudo. Boger et al. (2005) coletaram grãos de zircão detrítico de uma amostra entre San Ignácio e San Rafael; que forneceram: uma idade ${ }^{207} \mathrm{~Pb} /{ }^{206} \mathrm{~Pb}$ de $1764 \pm 6 \mathrm{Ma} ; 3$ grãos entre 1840-1910 Ma; 14 grãos produziram aproximadamente 1690 Ma e 4 grãos entre 1690-1760 Ma. Com base nestes dados, os Xistos San Ignácio não foram depositados antes de $1690 \mathrm{Ma}$.

Este embasamento Pré-cambriano heterogeneo foi afetado por eventos magmáticos associados a orogêneses mesoproterozoicas, que geraram a suíte juvenil Yarituses, o plúton San Ramon) e o Complexo Granitoide Pensamiento (já sumarizados nesta Tese) e o magmatismo Sunsás (orogênese homônima).

\section{Orogênese Sunsas}

Este evento orogenético desenvolveu-se ao sul do Craton Paraguá, e representa o evento tectonomagmático mais jovem do Mesoproterozóico Boliviano, sendo contemporâneo à evolução do cinturão Nova Brasilândia em Rondônia (e.g, Tohver et al, 2006; Cordani e Teixeira, 2007; Rizzotto e Quadros, 2007). Conforme concebido por Litherland et al. (1986), a orogênese Sunsás originou-se a partir da deposição dos sedimentos do Grupo Sunsás e Vibosi em uma margem passiva, enquanto que evento contemporâneo no antepaís deu origem à bacia intracratônica Huanchaca-Aguapeí, conforme correlações geológicas apoiadas por idades $\mathrm{U} / \mathrm{Pb}$ em zircão detrítico (Santos et al., 2005; Saes et al., 2006; Teixeira et al., 2010). A inversão desta margem passiva em ativa provocou a deformação dos sedimentos Sunsás e Vibosi no âmbito do domínio orogênico. Ao mesmo tempo o espessamento crustal decorrente com geração de importante plutonismo intrusivo nos estratos sedimentares dobrados, como resultado da evolução de um cinturão colisional no período de 1,20 a 0,95 Ga (Teixeira et al., 2010). As rochas granitóides da Orogenia Sunsás como os plutons Naranjito, El Carmen, Casa 
de Piedra Taperas, e Primavera foram estudados em detalhe na tese de Doutorado de Vargas-Mattos (2010).

A geofísica aérea realizada na área de San Diablo (Landivar e Gonzalez, 1997) e os trabalhos de pesquisa mineira (Billiton, RTZ) definiram diversas frentes tectônicas ou zonas de cisalhamento, vinculadas à dinâmica colisional da faixa Sunsás, a saber: San Diablo, El Encanto, Don Mario, Surutú e Bahia Las Tojas. A característica principal destas frentes é o padrão anastomosado, envolvendo núcleos lenticulares de rocha pouco milonitizada (Apêndice $\mathrm{C}$ ). $\mathrm{O}$ grau de metamorfismo das rochas corresponde às fácies anfibolito inferior a médio dentro de uma zona de deformação dúctil. Como rochas do embasamento reconheceram-se gnaisse migmatito, augen gnaisse, paragnaisse granoblástico e gnaisse leucocrático relacionados ao Complexo Chiquitania. Uma banda estreita de orientação este-oeste é constituída por xisto a muscovita, meta-arenito e rocha calco-silicática. Dentro da seqüência de xistos, existem afloramentos de um metaconglomerado oligomíctico com clastos de quartzo cor cinza, branco e translúcido, de $9 \times 2 \mathrm{~cm}$ em tamanho, formando tectonitos $\mathrm{L}$ ou prolatos dentro de uma matriz rica em muscovita e quartzo. Em outros afloramentos, os clastos do metaconglomerado são achatados ou oblatos, ou tectonitos $\mathrm{S}$. Ao sudoeste do Cerro EI Encanto o metaconglomerado Sunsás recobre o Complexo Chiquitania em discordância; os clastos de quartzo mostram forte achatamento característico dos tectonitos S (Mitchell, 1979).

O Distrito San Ramon (Figura 6.3) é caracterizado por um estilo de tectônica oblíqua com estruturas S-C, sub-grãos gerados por fraturas de cisalhamento e deslocados e rotação de porfiroblastos ocorrida durante a orogenia Sunsás. Estas estruturas afetaram o embasamento e as rochas da suíte Yarituses, o granito San Ramón, a suíte granitóide San Ignácio e os granitóides Sunsás, sendo semelhantes à dinâmica deformacional sinistral da faixa metavulcano-ssedimentar de Nova Brasilândia e a Zona de Cisalhamento Ji-Paraná (Tohver et al., 2005).

$\mathrm{Na}$ Bolivia o sentido sinistral de cisalhamento é observado no campo e na geofísica aerotransportada (Adamek et al. 1996, Matos 2009), estando possivelmente relacionadas em sua maior ordem, com a colisão entre a Amazonia e Laurentia durante a orogenia Grenville. Isto implica em uma continuidade das estruturas de Rondônia até 
a Bolívia. A maioria dos milonitos nos frentes de cisalhamento mostra uma foliação milonítica (denominada $S$ ), que está geralmente com um ângulo inferior a $45^{\circ}$ nos limites da zona de cisalhamento. A foliação paralela à borda da zona de cisalhamento é denominada C. As estruturas S-C podem ser identificadas como exemplos de escalas regionais nas imagens de satélite, constituindo indicadores cinemáticos para determinar o sentido de cisalhamento, neste caso exibindo movimento lateral sinistral como é o caso do Distrito San Ramón.

\subsubsection{Considerações finais}

Com a integração de dados de campo obtidos da bibliografia e a vivencia do autor no oriente boliviano, agregado a os perfis geológicos em áreas chave, os dados litoquímicos, a aplicação da metodologia U-Pb, Sm-Nd, Rb-Sr permitiu obter uma visão atual da natureza e cronologia dos principais eventos tectono-magmáticos que afetaram a região SW do Craton Amazônico em particular para o Pré- cambriano da Bolívia.

Estos datos permiten destacar alguns pontos de grande importância relacionado á evolução geológica.

1. Um evento magmático representado pelo granito Correreca 1925 a $1894 \mathrm{Ma}$ revela a presença pela primeira vez de crosta paleoproterozoica no Pré-Cambriano de Bolívia, na região meridional da faixa Sunsás, que indicaria que a área sul da Zona de

Cisalhamento San Diablo, denominada terreno San Pablo por Saes et al. (1992), seria um terreno alóctone com uma história geológica distinta.

2. No bloco Paraguá o embasamento está constituído pelo Complexo Granulítico Lomas Manechis, o Complexo Gnáissico Chiquitania e o Grupo de Xistos San Ignácio representando as unidades basais com idades de 1810-1690 Ma.

3. As datações geocronológicas U-Pb SHRIMP, TIMS e ablasão por laser-ICPMS obtidos indicam a formação da Suíte Granítica Yarituses no lapso de tempo entre 1673 a $1621 \mathrm{Ma}$, as idades modelo $\mathrm{T}_{\mathrm{DM}}$ de $1,7-1,9 \mathrm{Ga}\left(\mathrm{f}_{\mathrm{Sm} / \mathrm{Nd}}\right.$ de 0.38 a 0,42$)$, com o $\varepsilon_{\mathrm{Nd}(\mathrm{t})}$ de $+0,2 \mathrm{a}+2.1$ que indica derivação mantélica.

4. O granodiorito San Ramón constitui um novo evento magmático no escudo Pré-Cambriano da Bolívia. Este plúton produziu uma idad SHRIMP U- Pb de $1429 \mathrm{Ma}$, com idade $\mathrm{T}_{\mathrm{DM}}$ de $1,7 \mathrm{Ga}$, com parâmetros petrogenéticos $\left(\varepsilon_{H f(t)}\right.$ entre $+3,49$ e $\left.+5,47\right)$ 
que implicam um evento juvenil. Este pluton seria o coevo com as suítes Santa Helena e Agua Clara (1,48-1,42 Ga), Pindaituba $(1,46-1,42 \mathrm{Ga})$ e a suíte Rio Branco de natureza anorogénica (1,42 Ga) (Bettencourt, et al., 2010).

5. Já os a suite orogênica San Ignacio está representada no Pré-Cambriano da Bolívia, tanto pelo Complexo Granitóide Pensamiento como ao sul dele, neste último caso parcialmente obliterados pela orogênese Sunsás. Datações SHRIMP em zircão dos plútons sin a tardi-cinemáticos San Martín e La Junta produziram idades de 1373 a 1347, idades modelo $\mathrm{T}_{\mathrm{DM}}$ entre 1,7 e 2,0 Ga. O pluton Diamantina, de natureza tardi- a pos-cinemática, possui uma datação SHRIMP em zircão de 1340, tem idades $T_{D M}$ entre 1,6 e $1,9 \mathrm{Ga}$ e valores de $\varepsilon_{\text {Ndt }}$ entre $+0,4$ e -1,2. A respeito dos granitoides do setor sul, nove datações SHRIMP, TIMS e de abrasão por laser em zircões produziram idades entre 1347 e $1275 \mathrm{Ma}$, idades modelo $\mathrm{T}_{\mathrm{DM}}$ entre 1,7 e 2,0 $\mathrm{Ga}$, e valores de $\varepsilon_{\mathrm{Ndt}}$ entre +4 e -4, indicando que o magma derivou de uma mistura de fusão de manto com fusão de fonte crustal mais antiga. A orogênese San Ignácio representa um arco acrescionário que construiu a arquitetura pela colisão entre o Craton Paraguá e a Província Rio Negro-Juruena. As evidencias da colisão poderiam se explicar pela ocorrência de rochas sedimentares não deformadas de idade Sunsás (serrania Huanchaca), depositadas discordantemente sobre o embasamento na area de San Simon e a Serrania Dalriada, como descrito por Litherland e Power (1989).

Os representantes coevos da evolução do arco San Ignácio, expostos em Rondônia são os Complexos Colorado e Mamoré.

6. O Distrito San Ramon na parte meridional da faixa Sunsás é caracterizado por um estilo de tectônica oblíqua com estruturas S-C, afetando o embasamento e as rochas das suíte Yarituses, o granito San Ramón, a suíte orogênica San Ignácio e os granitóides Sunsás, sendo a dinâmica deformacional sinistral semelhante a Nova Brasilândia e a Zona de Cisalhamento Ji-Paraná (Tohver et al., 2005).

7. O mapeamento realizado na área sul de San Diablo definiram diversas frentes tectônicas ou zonas de cisalhamento, vinculadas à dinâmica colisional da faixa Sunsás. A característica principal destas frentes é o padrão anastomosado, envolvendo núcleos lenticulares de rocha pouco milonitizada. 


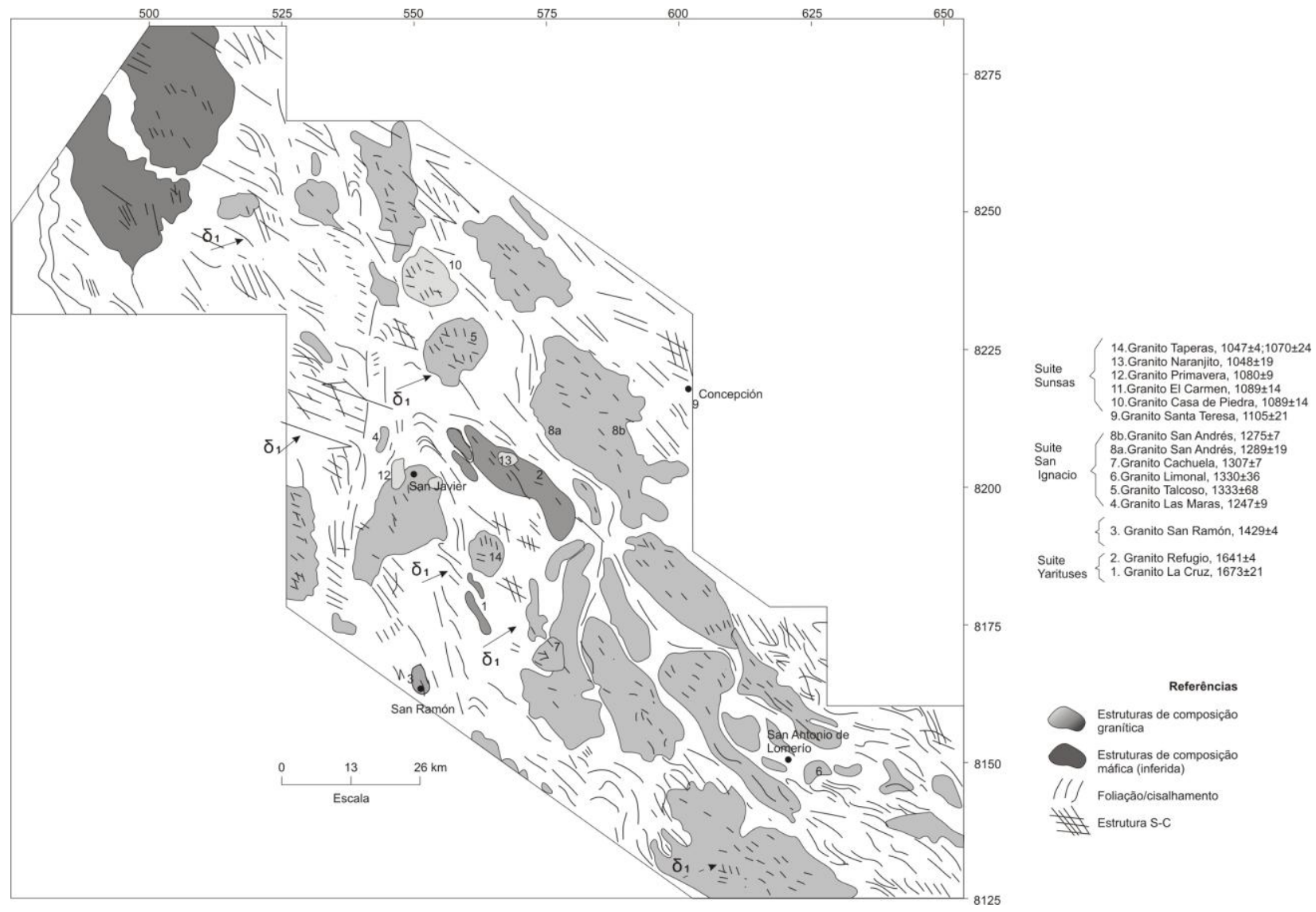

Figura 6.3 Distribuição geográfica dos plútons mesoproterozoicos e das principais estruturas da área de estudo. 


\section{REFERENCIAS}

Adamek, P. M.; Troeng, B.; Landívar, G.; Llanos, A.; Matos, R. 1996. Evaluación del los recursos minerales del Distrito San Ramón. - Boletín del Servicio Geológico de Bolivia, n.10, 77 p., La Paz.

Ahlfeld, F. 1946. Geología de Bolivia. Revista del Museo de La Plata (NS), 3 (19), 370p.

Ahlfeld, F. 1954. Los Yacimientos Minerales de Bolivia. Impr. Industr.S.A., Bilbao, España, 277 p. + Mapa.

Arce-Burgoa, O. R. 2007. Guía a los yacimientos metalíferos de Bolivia. SPC Impresores S.A. La Paz, $245 \mathrm{p}$.

Berrangé, J. P. 1982. The eastern Bolivia mineral exploration project "Proyecto Precámbrico". Episodes, 4, 3-8.

Bettencourt, J.S.; Leite, W.B.; Ruiz, A. S.; Matos, R.; Payolla, B.L.; Tosdal, R.M. 2010. The Rondonian- San Ignacio Province in the SW Amazonian Craton: An overview. Journal of South American Earth Sciences, 29, 28-46.

Biste M.,; Gourley A. 2000. Geology and Setting of the Miguela A-zone, Guarayos Greenstone Belt, Eastern Bolivia. VMS Deposits of Latin America, Geol Assoc of Canadá, Min Dep Div, Spec Publ № 2, p. 359- 374.

Boger, S.D.; Raetz, M.; Giles, D.; Etchart, E.; Fanning, M.C. 2005. U-Pb age data from the Sunsas region of Eastern Bolivia, evidence for the allochtonous origin of the Paragua Block. Precambrian Research, 139, 121-146.

Castillo, J. M. del; Marinez, C.; Tomasi, P.; Subieta, T., 1971. Perfil geológico realizado entre las localidades de Roboré y Santo Corazón. Serv. Geol. Bolivia, 15, 16-21.

Cordani, U. G.; Teixeira, W. 2007. Proterozoic accretionary belts of the Amazonian Craton. In: Hatcher, R.D. Jr., Carlson, M. P., McBride, J. H., and Martinez Catalán, J. R. (Org.). The 4D Framework of Continental Crust. GSA Memoir. Boulder, Colorado: Geological Society of America Book Editors 200, p. 297-320.

Darbyshire, D. P. F., 1979. Resultados del programa de determinación de edades. Informe interno del Instituto de Ciencias Geológicas, División de Ultramar-Servicio Geológico de Bolivia. La Paz.

$103 p$. 
Fletcher, C. J. N. 1979. La geología y potencial de minerales del área de Concepción (Cuadrante SE 20 - 3 con parte de SE 20 - 2). Informe inédito British Geological Survey Servicio Geológico de Bolivia. (1 mapa). Santa Cruz de la Sierra, 72 p.

Geraldes, M. C.; Van Schmus, W. R.; Condie, K. C.; Bell, S.; Teixeira, W.; Babinski, M. 2001. Proterozoic geologic evolution of SW part of the Amazonian craton in Mato Grosso State, Brazil. Precamb. Res. 111, 91-128.

Hess, W. A. 1960. Resume of the geology of the Santiago - Santo Corazón area, Chiquitos (Bolivia).- Informe interno BOGOC, (GR-02.39).

Kempff-Mercado, N.; Peiser, F. 1945. Geología del cantón Santa Ana (prov.de Velasco). Minería Boliviana, 2 (20) : 11-15. La Paz.

Klinck, B.A.; Litherland, M. 1982 A model for the proterozoic structural history of eastern Bolivia. Rep East. Bolivia Miner. Expl. Proj., Santa Cruz, BAK/15 (Unpublished).

Landivar, G.; Gonzales, R. 1997. Mapa Geológico del Área Serranías San José- San Diablo. Servicio Nacional de Geología y Minería, escala 1:250.000.

Litherland M.; Bloomfield, K. 1981. The Proterozoic history of Eastern Bolivia. Precambrian Res., 15:157-179.

Litherland., M.; Klinck, B. A. 1982. Introducing the terms "Paragua Craton" and "The Pensamiento Granitoid Complex" for use in sheet reports. Rep. East. Bolivia Miner. Expl. Proj., Santa Cruz (unpublished).

Litherland, M.; Power, G. 1989. The geologic and geomorphologic evolution of Serranía Huanchaca, eastern Bolivia: the legendary "Lost World". Journal of South American Earth Sciences, 2 (1), 1-17.

Litherland, M. ; Klinck, B.A.; O'Connor, E.A.; Pitfield. P.E.J. 1985. Andean-trending mobile belts in the Brazilian Shield. Nature, $314,345$.

Litherland, M.; Annells, R.N.; Appleton, J.D.; Berrrangé, J.P.; Bloomnfield, K.; Burton, C.C.J.; Darbyshire, D.P.F.; Fletcher, C.J.N.; Hawkins, M.P.; Klinck, B.A.; Llanos, A.; Mitchell, W.I.; O'Connor, E.A.; Pitfield, P.E.J.; Power, G.; Webb, B.C. 1986. The Geology and Mineral Resources of the Bolivian Precambrian Shield. British Geological Survey, Overseas Memoir 9, Keyworth, 153 p.

Litherland. M.; Annells, R.N.; Darbyshire, D.P.F.; Fletcher, C.J.N.; Hawkins, M.P.; Klinck, B.A.; Mitchell, W.I.; O'Connor, E.A.; Pitfield, P.E.J.; Power, G.; Webb, B.C. 1989. The Proterozoic of Eastem Bolivia and its relationship to the Andean mobile belt. Precambrian Res. 43, 157-174. 
López-Montaño, R.; Bernasconi, A. 1988. El cinturón de rocas verdes en la hoja Concepción, Precámbrico de Bolivia Oriental: Geología, mineralización y prospección aurífera. GEOBOL-PNUD, La Paz, Informe interno, 43 p.

Matos, R.; Teixeira, W.; Sato, K; Geraldes, M. C. 2006. Sm-Nd characteristics of the Diamantina granitoid, Rondonian-San Ignacio province- Bolivian Precambrian Shield. VSSAGI, Punta del Este, Uruguay, pag. 403-405, April 2006.

Matos, R.; Teixeira, W.; Geraldes, M. C.; Cordani, G.; Sato,K. 2008. Geochemistry and Nd isotopic evidence of the Pensamiento Granitoid Complex, Rondonian-San Ignacio province- Eastern Bolivian: Petrogenetic constraints for a plutonic model. 33IGC, Oslo, Noruega, CD Room.

Matos, R. 2009. Estilos tectónicos frontal y oblicuo en la evolución del Meso-Neoproterozoico de la Provincia Sunsás del Precámbrico Boliviano. XVIII Congreso Geológico Boliviano, Potosí, Bolivia, 2009 (Memorias), p. 120-123.

Matos, R.; Teixeira, W.; Geraldes, M. C.; Bettencourt, J. S. 2009. Geochemistry and Nd-Sr Isotopic Signatures of the Pensamiento Granitoid Complex, Rondonian-San Ignacio Province, Eastern Precambrian Shield of Bolivia: Petrogenetic Constraints for a Mesoproterozoic Magmatic Arc Setting. Geologia USP, Série Científica 9, 2, 89-117.

Matos, R.; Teixeira, W.; Geraldes, M. C.; Bettencourt, J. S.; Cordani, U.G. 2009. Proterozoic crustal evolution in the Eastern Bolivia Shield: SHRIMP, TIMS and LA-MC-ICP-MS U-Pb zircon geochronology and $\mathrm{Nd}-\mathrm{Sm}$ evidences (in preparation).

Mitchell, W. I., 1979. La geología y potencial de minerales del área de Santo Corazón - Rincón del Tigre (Cuadrantes SE 21-5, con parte de SE 21-9 y SE 21-6 con parte de SE 21-10). Informe inédito, British Geological Survey - Servicio Geológico de Bolivia. (1 mapa). Santa Cruz de la Sierra, $131 \mathrm{p}$.

Moisy, M.; Ticlla-Colque, L. 2002. Distrito aurífero de San Simón, Beni- Bolivia.- (Memorias del XV Congreso Geológico Boliviano, Santa Cruz). Revista Técnica de YPFB, 20: 297-302.

Oviedo, C.; Justiniano, I. 1967. Geología sobre la región del Complejo Cristalino Chiquitano, Prov.Velasco, Santa Cruz. Informe interno YPFB (GXG-1226).

Payolla, B.L.; Bettencourt, J.S.; Kozuch, M.; Leite Jr, W.B.; Fetter, A.H.; Van Schmus, W.R. 2002. Geological evolution of the basement rocks in the east-central part of the Rondônia Tin Province, SW Amazonian craton, Brazil: U-Pb and Sm-Nd isotopic constraints. Precambrian Research, 119, 141-169. 
Peiser, F. 1944a. Las pegmatitas de la Provincia Ñuflo de Chavez y la exploración de mica. Minería Boliviana, 1 (10): 9-14, La Paz.

Peiser, F. 1944b. Los yacimientos auríferos de la provincia Ñuflo de Chavez. Minería Boliviana, 1 (12): 21-30, La Paz.

Rizzotto, G.J.; Quadros, M.L.E.S. 2007. Margem Passiva e granitos Orogênicos do Ectasiano em Rondônia, X Simpósio de Geologia da Amazônia, Porto Velho, Rondônia, (CD Room).

Saes, G.S.; Leite, J.A.D.; Alvarenga, C.J.S. 1992. Evolução tectono-sedimentar do Grupo Aguapeí, Proterozoico Médio na porcao meridional do Craton Amazônico: Mato Grosso e Oriente Boliviano. Revista Brasileira de Geociências 23 (1), 31-37.

Saes, G.S;; Leite, J.A.D.; Fragoso Cesar, A.R.S. 2006. Seqüências deposicionais mesoproterozoicas do sudoeste do Craton Amazônico. In: Fernandes C.J., Riveiro R.V. (Eds), Coletánea Geológica de Mato Grosso, EDUFMT, pp. 149-164.

Santos, J. O. S.; McNaughton, N. J.; Hartmann, L. A.; Fletcher, I. R. ; Matos, R.S. 2005. The age of deposition of the Aguapeí Group, western Amazon Craton, based on U-Pb study of diagenetic xenotime and detrital zircon. In: 12th Congreso Latinoamericano de Geologia, Quito, Ecuador, Actas.

Santos, J. O. S.; Rizzotto, G.J.; Mcnaughton, N. J.; Matos, R.; Hartmann, L. A.; Chemale Jr., F.; Potter, P. E.; Quadros, M.L.E.S. 2008. Age and autochthonous evolution of the Sunsás Orogen in West Amazon Craton based on mapping and U-Pb geochronology. Precambrian Research, 165, 120-152.

Teixeira, W.; Geraldes, M. C.; Matos, R.; Ruiz, A. S.; Saes, G.; Vargas-Mattos, G. 2010. A review of the tectonic evolution of the sunsás belt. SW Amazonian Craton. Journal of South American Earth Sciences, 29, 47-60.

Ticlla-Colque, L. 2000. Prospección de los depósitos auríferos de Paitití-Burití en la Serranía de San Simón, Provincia Iténez, Beni, Bolivia. Memorias del XIV Congreso Geológico Boliviano, 448-454, La Paz.

Tohver, E.; van der Pluijm, B.A.; Scandolara, J.E.; Essene, E. 2005. Late Mesoproterozoic Deformation of SW Amazonia (Rondônia, Brazil): Geochronological and Structural Evidence for Collision with Southern Laurentia. Journal of Geology, 113, 309-324.

Tohver, E.; Teixeira, W.; van der Pluijm, B. A.; Geraldes, M. C.; Bettencourt, J. S.; Rizzotto, G. 2006. Restored transect across the exhumed Grenville orogen of Laurentia and Amazonia, with implications for crustal architecture. Geology, 34, 669-672. 
Vargas-Mattos, G.; Geraldes, M. C.; Matos, R.; Teixeira, W. 2006. Estudio petrográfico y geoquímico de los granitoides de la Orogenia Sunsás, SW del Cratón Amazônico. XVII Congreso Geológico de Bolivia,. Sucre, 2006., Memorias, p. 130-133.

Vargas-Mattos, G. 2010. Caracterização geocronológica e geoquímica dos granitos Proterozóicos: Implicação para a evolução crustal da borda SW do Cráton Amazônico na Bolívia. Doctoral thesis, Universidade do Estado do Rio de Janeiro, Rio de Janeiro-RJ, Brasil, 164p.

Witschard, F.; Matos, R.; Nilsson, L. 1993. Airborne Geophysical Survey and Interpretations of remote sensing in the San Ramón area. Boletin del Servicio Geológico de Bolivia, № 2 (Especial), La Paz, 55p.

Wömer, O.; Lezaun, J.; Beck, A.; Heber, V.; Lucassen, F.; Zinngrebe, E.; Rössling, R.; Wilke, H.G.; 2000. Preeambrian and Early Palaeozoic evolution of the Andean basement at Belen (northern Chile) and Cerro Uyarani (western Bolivia Altiplano). J. South Am. Earth Sci. 13, 717-737. 


\title{
Age and autochthonous evolution of the Sunsás Orogen in West Amazon Craton based on mapping and $\mathrm{U}-\mathrm{Pb}$ geochronology
}

\author{
J.O.S. Santos ${ }^{\text {a,b,* }}$, G.J. Rizzotto ${ }^{c}$, P.E. Potter ${ }^{\mathrm{d}}$, N.J. McNaughton ${ }^{\mathrm{e}}$, R.S. Matos ${ }^{\mathrm{f}}$, \\ L.A. Hartmann' ${ }^{g}$, F. Chemale Jr. ${ }^{g}$, M.E.S. Quadros ${ }^{c}$ \\ ${ }^{a}$ Redstone Resources, Suite 3 - 110 East Parade, East Perth, WA, 6004, Australia \\ ${ }^{\mathrm{b}}$ University of Western Australia, Centre for Exploration Targeting, Crawley, WA, 6009, Australia \\ c CPRM - Geological Survey of Brazil, Av. Lauro Sodré 2.561, CEP 78904-300, Porto Velho, Rondônia, Brazil \\ d Geology Department, University of Cincinnati, OH 45221-0013, USA \\ e Curtin University of Technology, GPO Box U1987, Bentley, WA, 6845, Australia \\ ${ }^{\mathrm{f}}$ Instituto de Geologia Económica y del Medio Ambiente, Universidad Mayor de San Andrés, Calle 27, Pabellón Geologia, La Paz, Bolivia \\ g Instituto de Geociências, Universidade Federal do Rio Grande do Sul, Avenida Bento Gonçalves, 9500; 91501-970 Porto Alegre, Rio Grande do Sul, Brazil
}

\section{A R T I C L E I N F O}

\section{Article history:}

Received 11 January 2008

Received in revised form 4 June 2008

Accepted 6 June 2008

\section{Keywords:}

Sunsás Orogen

Grenville Orogen

Amazon Craton

$\mathrm{U}-\mathrm{Pb}$ geochronology

\begin{abstract}
A B S T R A C T
The West Amazon Craton consists of rocks of the Sunsás Orogen and the Rondônia-Juruena Province. The Sunsás Orogen comprises the western part of the Amazon Craton in South America and is best exposed in eastern Bolivia and western Rondônia and Mato Grosso states of Brazil. The integration of available maps and isotopic data together with new $\mathrm{U}-\mathrm{Pb}$ and $\mathrm{Sm}-\mathrm{Nd}$ analyses from 20 samples (plus 55 earlier dates), establish the timing of geologic events in the West Amazon Craton from 1840 to $1110 \mathrm{Ma}$. To unravel the complex geologic history of the study area, we primarily sampled granitoids and gneisses to develop a better stratigraphy and secondarily to narrow the age gaps between known discordances. Four periods of orogenic activity are identified within the Sunsás Orogen: 1465-1427 Ma (Santa Helena orogeny), 1371-1319 Ma (Candeias orogeny), ca. $1275 \mathrm{Ma}$ (San Andrés orogeny), and 1180-1110 Ma (Nova Brasilândia orogeny). Notable is the absence of an Ottawan orogeny (1080-1020 Ma) equivalent. In the Rondônia-Juruena Province three main orogenies are recognized: the Juruena (1840-1780 Ma), the Jamari (1760-1740 Ma) and the Quatro Cachoeiras (1670-1630 Ma). Post-Sunsás rocks include Rondônia tin granites, Palmeiral sandstones, Nova Floresta basalt, and alkalic pipes.

All inherited U-Pb ages of zircon and all exposed pre-Sunsás rocks in Bolivia have ages that correlate well to the neighbouring Rondônia-Juruena Province. This fact, together with the absence of fragments of older, Archean and Trans-Amazonian crust, suggests that the Sunsás Orogen is autochthonous and evolved over a continental margin formed dominantly by rocks of the Jamari (1760-1740 Ma) and Quatro Cachoeiras (1670-1630 Ma) orogenies plus rocks of the post-tectonic Serra Providência Suite (1560-1540 Ma). Almost all granulites known in Eastern Bolivia and in neighbouring area in Brazil are not basement rocks, but were formed during the Mesoproterozoic and are mainly associated with the Candeias orogeny (1371-1319 Ma). Dated samples of the Chiquitania and Lomas Manechi Complexes in Bolivia revealed a variety of ages and types of ages (metamorphic, magmatic, and inherited) indicating that those two units require more study. There is no evidence for the existence of a Paraguá Craton or Paraguá Block, which is almost totally composed of arc-related granites also formed during the Candeias orogeny.

The main difference between the Sunsás Orogen and the Grenville Orogen of Laurentia is the absence in Amazonia of an Ottawan-equivalent orogeny (1080-1020 Ma). The existence of age-equivalents of the Candeias and Santa Helena orogenies in Laurentia (Pinwarian orogeny and rocks of the Eastern GraniteRhyolite Province and the Composite Arc Belt) indicates that the connection of the two continents may have started from about $1450 \mathrm{Ma}$. In addition, the two belts may not have been directly juxtaposed, but instead, that one may have been the extension of the other during the Mesoproterozoic. The possibility that Amazonia joined the southwestern part of Laurentia also provides a good fit for the Hudson-Tapajós and
\end{abstract}

\footnotetext{
* Corresponding author. Tel.: +61 8 93282552; fax: +61 893282660.

E-mail address: orestes.santos@bigpond.com (J.O.S. Santos).
} 
Mazatzal-Yapavai-Rondônia-Juruena Provinces. This possible link to Laurentia may have started during the formation of the Trans-Hudson Orogen and its correlative Rondônia-Juruena and Tapajós provinces from about $1900 \mathrm{Ma}$.

(c) 2008 Elsevier B.V. All rights reserved.

\section{Introduction}

This study has multiple objectives: to improve the Proterozoic stratigraphic correlations between western Brazil and eastern Bolivia; to develop better constraints about the duration of the Sunsás Orogenic cycle and the ages of its main orogenies; to test the relationship of the Sunsás Province to its neighbour, the RondôniaJuruena Province; to assess the evidence for the existence of the Paraguá Craton (Boger et al., 2005; Tohver et al., 2004); to update comparison to the Grenville Orogen of Laurentia; and to provide new clues about Mesoproterozoic paleogeography of the region. This lead to an integrated chronological table (see Section 5).

The Sunsás Orogen was formed along the western margin of the Amazon Craton during the Mesoproterozoic (1450-1100 Ma). It was partially consumed by the Andes Orogen to the west and locally by the Brasiliano Orogen (Neoproterozoic) to the southeast (Fig. 1). Much later, it was largely buried by Phanerozoic deposits derived from the erosion of the Andes Orogen to the west (Schenk et al., 2000; Roddaz et al., 2006). The original belt may have been $6000 \mathrm{~km}$ long, extending from northeast Argentina and Paraguay into eastern Venezuela, but today the Sunsás Belt is best exposed along the Brazil-Bolivia border, in an area of about $350,000 \mathrm{~km}^{2}$, where only regional geological maps are available.

The presence of tin granites dated at about $980 \pm 21 \mathrm{Ma}$ by $\mathrm{Rb}-\mathrm{Sr}$ whole-rock isochron led Priem et al. $(1966,1971)$ to first pro- pose correlation to the Grenville Orogen of Laurentia. Only three decades later did Sadowski and Bettencourt (1996) and Bettencourt et al. (1999) confirm the Late Mesoproterozoic-Early Neoproterozoic age of the post-orogenic (post-Sunsás) Rondônia tin granites using U-Pb TIMS geochronology. However, the first Grenvillian $\mathrm{U}-\mathrm{Pb}$ age of orogenic rocks within the Sunsás Belt came only in 1999, when Rizzotto et al. (1999) dated S-type granite derived from the partial melt of metapelites of the Nova Brasilândia Group at $1100 \pm 10 \mathrm{Ma}$.

The Sunsás Orogen is interpreted as part of the Mesoproterozoic Supercontinent named Rodinia (Dalziel, 1991; Hoffman, 1991; Karlstrom et al., 2001; Li et al., 2008). The connection of the West Amazon Craton to Laurentia within the Rodinia supercontinent is now a broadly accepted idea (Dalziel, 1991; Hoffman, 1991; Santos et al., 2002; Tohver et al., 2002; Boger et al., 2005; Fuck et al., 2008). The Sunsás Belt has been correlated to different areas of Laurentia: the southwestern Llanos segment (Tohver et al., 2002); the Grenville Province of Ontario (Sadowski and Bettencourt, 1996; Santos et al., 2002); and the southern and central Appalachians (Loewy et al., 2003; Tohver et al., 2004). The paleo-reconstruction of the Amazonia-Laurentia connection at the end of the Mesoproterozoic (at ca. $1.0 \mathrm{Ga}$ ) is, however, uncertain for two main reasons: only a limited zone of the Sunsás Belt of about $1100 \mathrm{~km}$ is exposed within one that potentially was longer than $6000 \mathrm{~km}$. In addition, large areas remain unmapped, poorly known or buried.

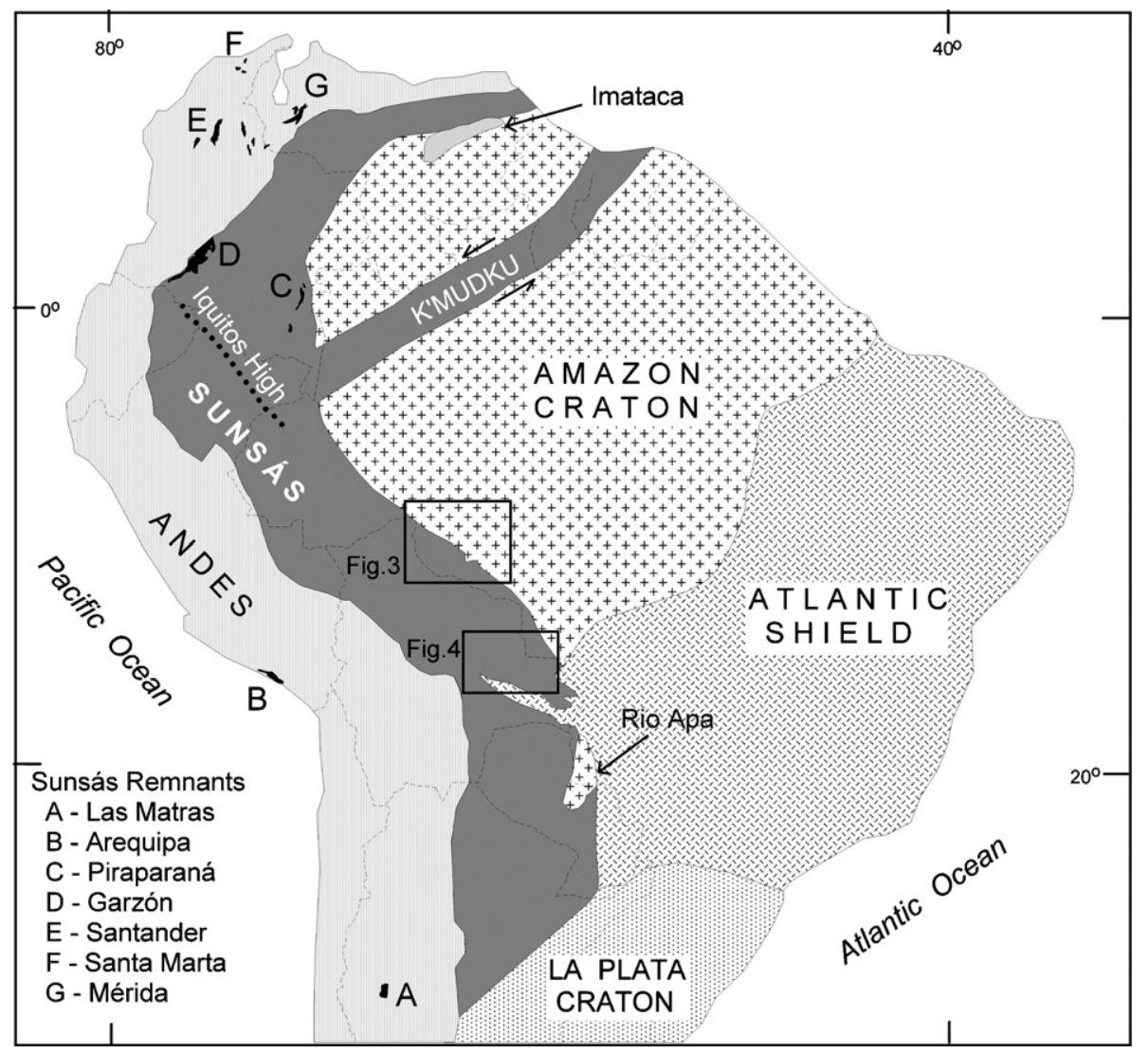

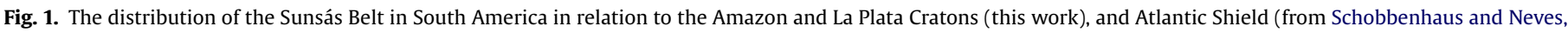
2003). Also shown are other Mesoproterozoic remnants within the Andes Belt, and location of Figs. 3 and 4. 
The time interval of the Sunsás Orogen and the main orogenies within the orogen started to be defined in 1999, when $\mathrm{U}-\mathrm{Pb}$ geochronology became available (Rizzotto et al., 1999; Bettencourt et al., 1999; Santos et al., 2000). Santos et al. (2002) proposed a duration of about 350 m.y. to build the orogen (1450-1100 Ma); they recognized three main orogenies or peaks of orogenic activity at 1465-1420 Ma (Santa Helena), 1370-1320 Ma (Candeias), and 1180-1100 Ma (Nova Brasilândia).

According to Santos et al. (2002), the first orogeny (Santa Helena, Geraldes et al., 2001) corresponds in age to the Pinwarian orogeny of the Grenville Orogen (Wasteneys et al., 1997) and to part of the Eastern Granite-Rhyolite Province of Laurentia (McBride et al., 2001). The rocks of the Candeias orogeny (Santos et al., 2000; 1350-1320 Ma) are equivalent in age to the Mount Holly Complex of Vermont (Ratcliffe et al., 1991). The Nova Brasilândia orogeny (Rizzotto et al., 1999; 1180-1100 Ma) is chronologically comparable to the Shawinigan Pulse (1190-1140 Ma) post-dating the Elzevirian orogeny of the Grenville Orogen (Rivers, 1997; Streepey, 2003; Davidson, 2008).

The main difference between the Grenville and Sunsás Orogens is that the Sunsás Orogen is lacking an equivalent to the youngest orogeny of Laurentia, the Ottawan orogeny (Santos et al., 2002, 2004a,b). During Ottawan time (1080-980 Ma; including the Rigolet Pulse, Rivers, 1997; Davidson, 2008), the West Amazon Craton was stabilized as shown by A-type tin granites (Rondônia Suite, 980 Ma; Bettencourt et al., 1999; Sparremberger et al., 2002), the presence of little deformed foreland basins (Caiabis, Palmeiral, <1030 Ma), rift-related basalts (Nova Floresta Formation, $1062 \pm 3$ Ma; Tohver et al., 2002), and alkalic pipes (Teotônio and Guariba; Teixeira, 1978).

Recent studies (Boger et al., 2005; Tohver et al., 2004, 2005) consider an allochthonous evolution of the Sunsás Belt and that its evolution is associated with the existence of a craton between the orogenic belt and the Amazon Craton: the Paraguá Craton in eastern Bolivia (Litherland et al., 1986, 1989). Because the relationship of the Sunsás Orogen to the craton margin (the Juruena Orogen, 1810-1550 Ma; Santos, 2003) since approximately $1460 \mathrm{Ma}$ is poorly known, there is no strong evidence for an allochtonous evolution. Further, the Paraguá Craton has not been defined and its presence is yet to be confirmed.

The present stratigraphy of the Precambrian rocks of Bolivia is based on $\mathrm{Rb}-\mathrm{Sr}$ geochronology and on a scheme associated to the metamorphic grade (strato-metamorphism; Litherland et al., 1986). By this stratigraphy, the higher the metamorphic grade the older the rock. This methodology is tested and compared to the neighbouring stratigraphy in Rondônia and Mato Grosso States of Brazil.

The present study combines a large dataset of 20 new $\mathrm{U}-\mathrm{Pb}$ and $\mathrm{Sm}-\mathrm{Nd}$ data with previous $\mathrm{U}-\mathrm{Pb}$ data, and integrates both with the new geological maps of Brazil (Schobbenhaus et al., 2004).

\section{Regional geology}

\subsection{Overview of Amazon Craton provinces}

Until 1974, the architecture of the Amazon Craton was interpreted as composed of two shields or blocks limited by E-W contact coincident to the axis of the Phanerozoic Amazon Basin. The northern part was named the Guyana Shield and the southern part the Brasil-Central or Guaporé Shield. Based on $\mathrm{K}-\mathrm{Ar}$ and secondarily on Rb-Sr data, Amaral (1974) demonstrated that the major internal limits of the craton are not E-W but NNW-SSE and that the western part (Western Province) of the craton is younger (Mesoproterozoic) than the central and eastern provinces, which are older (Archean and Paleoproterozoic). The model proposed by Amaral (1974) for the Amazon Craton evolution was followed by a model based on Rb-Sr isotopes (Cordani et al., 1979; Teixeira et al., 1989; Tassinari et al., 1996; Tassinari and Macambira, 1999). The present study uses a model based on U-Pb data of Santos et al. (2000) and Santos (2003) also includes two recent updates based on the work of Vasquez et al. (2008) on the Bacajá Domain plus that of Ruiz (2006) and Cordani et al. (2008) on the Rio Apa Domain (Fig. 1). According to Santos et al. (2003) the Sunsás Province (1450-1100 Ma) evolved against the Rondônia-Juruena Province (1820-1550 Ma) and the Rio Negro Province (1830-1480 Ma) - Fig. 2. During the evolution of the Sunsás Orogen extensive sinistral shear zones were produced inside the craton resulting from oblique compression from the northnorthwest ( $\sigma 1$ of Fig. 1) against the Amazon Craton (Santos et al., 2006). These shear zones are concentrated in a $1200 \mathrm{~km}$ long and $\pm 120 \mathrm{~km}$ wide belt, which affects all pré-Sunsás provinces in north and northwest parts of the craton: the Rio Negro, the TransAmazon and the Tapajós-Parima. This shearing event has been known since 1966 and is named the K'Mudku Mylonite episode (Barron, 1966).

\subsection{Previous work}

Only regional geological maps are available within the Sunsás Belt area. In Bolivia there is no significant geological work since the "Proyecto Precámbrico", a British-Bolivian bilateral program starting in 1976 and concluded in 1986 (Litherland et al., 1986, British Geological Survey, Overseas Memoir 9). A summary of the results of the project was published in Precambrian Research (Litherland et al., 1989). On the Brazilian side of the belt the most recent maps are the collection of digital maps at 1:1,000,000 scale published in 2004 (Schobbenhaus et al., 2004), which incorporate results of local maps at $1: 250,000$ and $1: 100,000$ scales. The lithostratigraphic names used in this work follow the nomenclature used by the geological surveys of Brazil (Santos, 2003; Rizzotto et al., 2004) and Bolivia (Litherland et al., 1986). Altogether over 80 stratigraphic units are recognized in the study area.

The geographic extension and the temporal evolution of the Sunsás Province were addressed using U-Pb SHRIMP (Santos et al., 2000, 2001, 2005, 2006; Boger et al., 2005; Bettencourt et al., 2006), U-Pb TIMS (Geraldes et al., 2000, 2001; Tohver et al., 2004; Ruiz, 2006), and Ar-Ar (Fernandes et al., 2005; Tohver et al., 2002, 2004, 2005) geochronology.

\subsection{Geology of the Rondônia-Juruena Province}

The geology of the western Rondônia-Juruena Province is summarized in Fig. 3, which is based on Santos (2003) and Rizzotto et al. (2004) and includes sample locations. The province was formed during approximately $300 \mathrm{~m} . \mathrm{y}$. (1840-1540 Ma) and has three main domains: Juruena (eastern), Jamari (western), and Alto Jauru (extreme south). The basement of the Juruena Domain (1848-1793 Ma) is about 80-40 m.y. older than the western basement, the Jamari Complex (1760-1740 Ma). The Juruena basement is composed of the Juruena Granodiorite (1848-1823 Ma), the Paranaíta Suite (1819-1793 Ma), the Cristalino Syenite (1806 Ma), the undated São Marcelo Group, and the undated Bacaeri Complex (JICA, 2000; Lacerda Filho et al., 2001; Santos, 2003). Volcanoplutonic continental arcs (Andean-type) formed between 1790 and $1770 \mathrm{Ma}$ in the Juruena Domain; these include the Colíder Group (1786-1781 Ma), Vitória Suite (1785-1775 Ma), São Romão Granite (1770 Ma), Monte Verde Complex (1774Ma), and São Pedro Granite (1784 Ma). The Jamari Domain started at 1760 Ma (oldest rocks of the Jamari Complex, this paper) with the formation of an island arc association of metatonalites and metabasalts in central-north Rondônia. These metatonalites and metabasalts are 


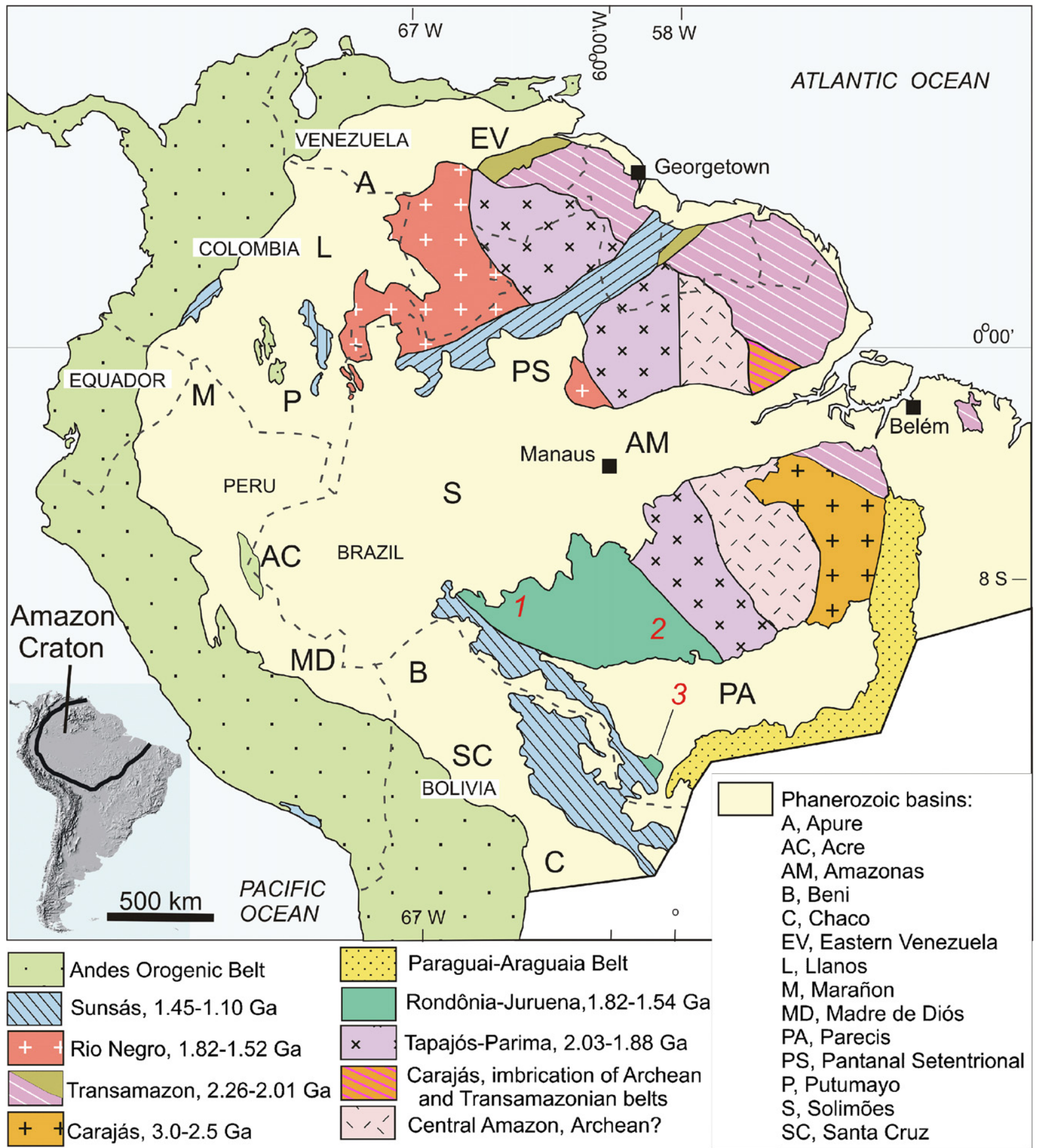

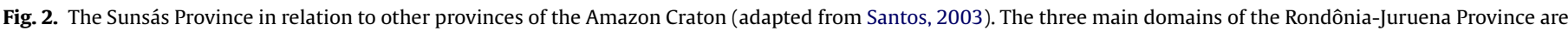
marked by red numbers: 1 (Jamari Domain), 2 (Juruena Domain), and 3 (Alto Jauru Domain). The location of several basins covering the Sunsás Province also is indicated.

contemporaneous to the volcano-plutonic association of the Aripuanã River region (northeast of Fig. 3); for example the Maçaranduba Dacite (1762 $\pm 6 \mathrm{Ma})$ and the Paraibão Granite (1755 $\pm 5 \mathrm{Ma}$; Neder et al., 2002). During the formation of the Jamari Complex in the western part of the Rondônia-Juruena Province and in the Maçaranduba-Paraibão association in the centre of the province, extensive A-type granite generation occurred in the eastern domain (Juruena) forming the Teles Pires Suite (1757 \pm 16 Ma;
Santos, 2003). Study by Pinho et al. (2001) revealed that the widespread volcanic rocks underlying the Beneficente Group in northwestern Mato Grosso are equivalent in age to those of the Colíder Group (ca. $1780 \mathrm{Ma}$ ); they also demonstrated the existence of a regional metamorphic event at ca. $1669 \mathrm{Ma}$.

Volcano-sedimentary (Roosevelt Group, 1740 Ma; Santos et al., 2000) and sedimentary (Beneficente Group, <1730 Ma; Leite and Saes, 2003) units occur throughout the two main domains of the 


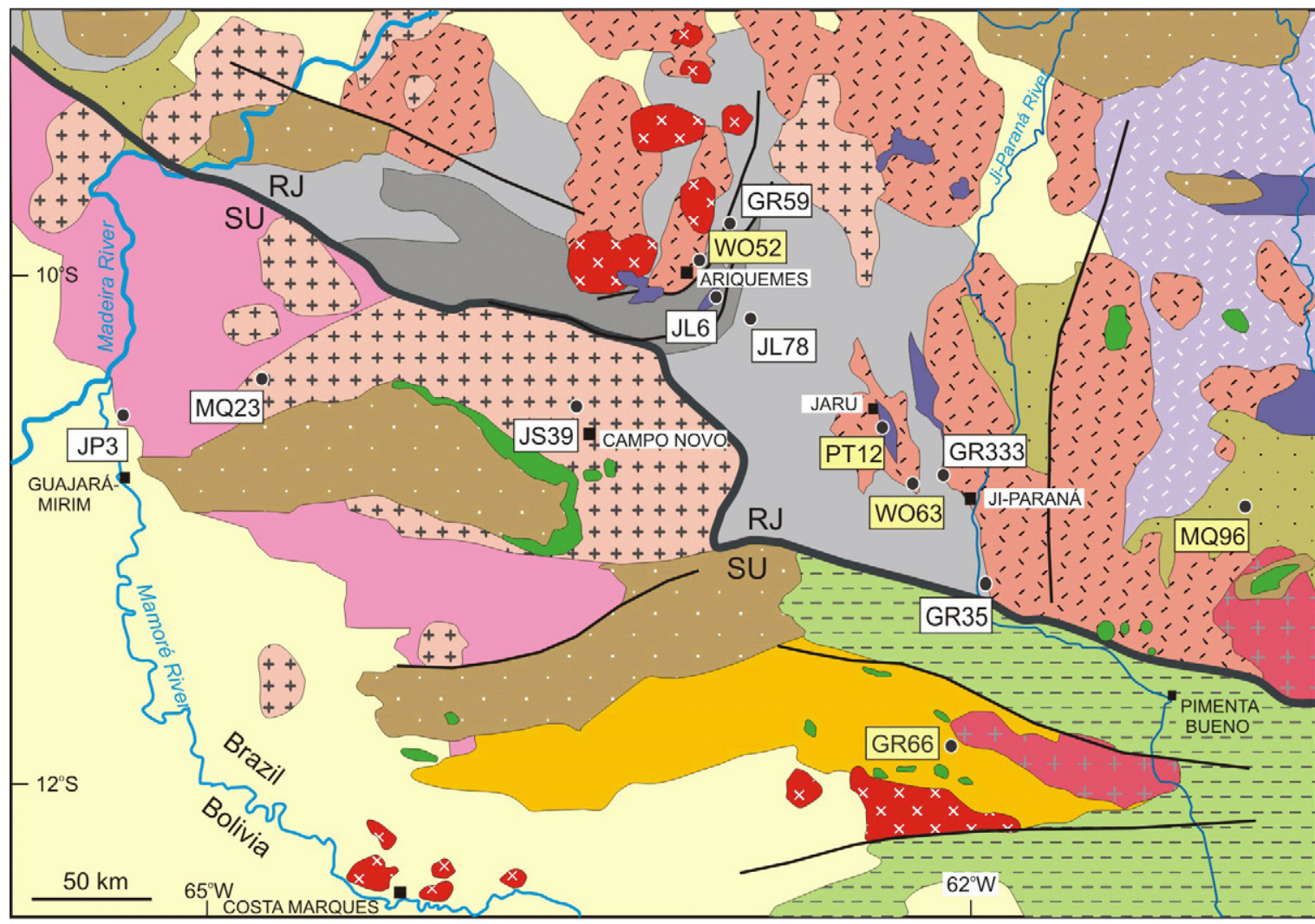

\begin{tabular}{|c|c|c|c|c|}
\hline \multicolumn{2}{|c|}{ Post-orogenic units } & \multicolumn{2}{|c|}{ Sunsás Province } & Rondônia-Juruena Province \\
\hline & Cenozoic cover & & Rio Pardo S-type suite, $1110 \mathrm{Ma}$ & $\because \because \quad \begin{array}{r}\text { S.Providência Suite, } \\
1560-1540 \mathrm{Ma}\end{array}$ \\
\hline & $\begin{array}{r}\text { Parecis basin, Devonian- } \\
\text { Cretaceous }\end{array}$ & & Nova Brasilândia Group, 1110 Ma & $\begin{array}{r}\text { Quatro Cachoeiras Gr., } \\
1670-1630 \mathrm{Ma}\end{array}$ \\
\hline & $\begin{array}{r}\text { Palmeiral Formation, } \\
<1.030 \mathrm{Ma}\end{array}$ & $\begin{array}{l}++++ \\
++++\end{array}$ & $\begin{array}{r}\text { Alto Candeias I-type suite, } \\
1370-1320 \mathrm{Ma}\end{array}$ & $\begin{array}{r}\text { Beneficente Group, } \\
1740-1670 \mathrm{Ma}\end{array}$ \\
\hline$x^{x} x^{x}>$ & $\begin{array}{r}\text { Rondônia Intrusive Suite, } \\
1040-980 \mathrm{Ma}\end{array}$ & & Rio Crespo gneiss, $1350-1320 \mathrm{Ma}$ & Jamari Complex, $1760 \mathrm{Ma}$ \\
\hline & & & Mamoré Complex, $1450-1320 \mathrm{Ma}$ & $\begin{array}{r}\text { Juruena basement, } \\
1820-1780 \mathrm{Ma}\end{array}$ \\
\hline
\end{tabular}

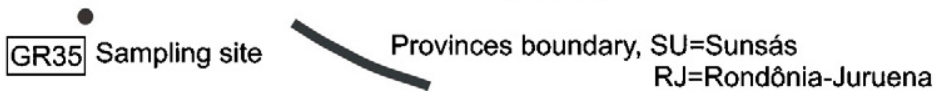

Mesoproterozoic mafic intrusions

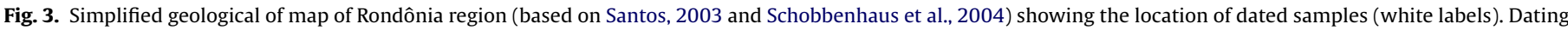
from Santos et al. (2000) are cream labels. The regional location of this map is indicated also in Fig. 1.

province (1 and 2 in Fig. 2). Continental collision occurred during $1670-1630 \mathrm{Ma}$ with movement from the south. This produced an E-W overprint in the older rocks, as is clearly seen in the Beneficente and Roosevelt Groups. Most of the paragneisses of Rondônia-Juruena Province were formed during this collisional orogeny, named Quatro Cachoeiras (Rizzotto et al., 2004) in reference to the paragneiss belt of the Jamari Domain (Schobbenhaus et al., 2004). This orogeny also metamorphosed the Monte Verde Group of the Juruena Domain (1654 Ma; Lacerda Filho et al., 2001) and the Colniza Granodiorite of the Aripuanã River region (1669 \pm 13 Ma; Pinho et al., 2003). After a period of about 80 m.y., apparently without any important geological activity, the Serra Providência Suite (1560-1530 Ma; Bettencourt et al., 1999; Santos, 2003) was formed in the Jamari Domain. This suite comprises an assemblage of A-type rapakivi granites and charnockitic rocks. The
Aripuanã Granite (1542 \pm 2 Ma; Silva et al., 2002) to the east is contemporaneous with the Serra Providência Suite.

The Rondônia-Juruena Province extends to the south under the Parecis Basin (Fig. 2), where the Alto Jauru Domain (also termed the Cachoerinha Domain by Ruiz et al., 2005a) is exposed (Pinho et al., 1997; Geraldes et al., 2001). The basement under the Parecis Basin is composed of volcano-sedimentary rocks (Cabaçal and Quatro Meninas Groups) and orthogneisses (Cabaçal, Santa Fé, and Aliança), dated by U-Pb ID-TIMS at 1790-1745 Ma (Geraldes et al., 2000). Here there is also an intrusive suite of granitoids, named the Cachoeirinha (Geraldes et al., 2000) or Santa Cruz Suite (Ruiz et al., 2005a) that has ages of $1562 \pm 36,1549 \pm 10$, and $1546 \pm 15 \mathrm{Ma}$ (Ruiz, 2006) equivalent to that of the Serra Providência Suite of the Jamari Domain. The Cachoeirinha Suite is interpreted as an orogenic arc (Geraldes et al., 2000; Ruiz, 2006), contrasting with 


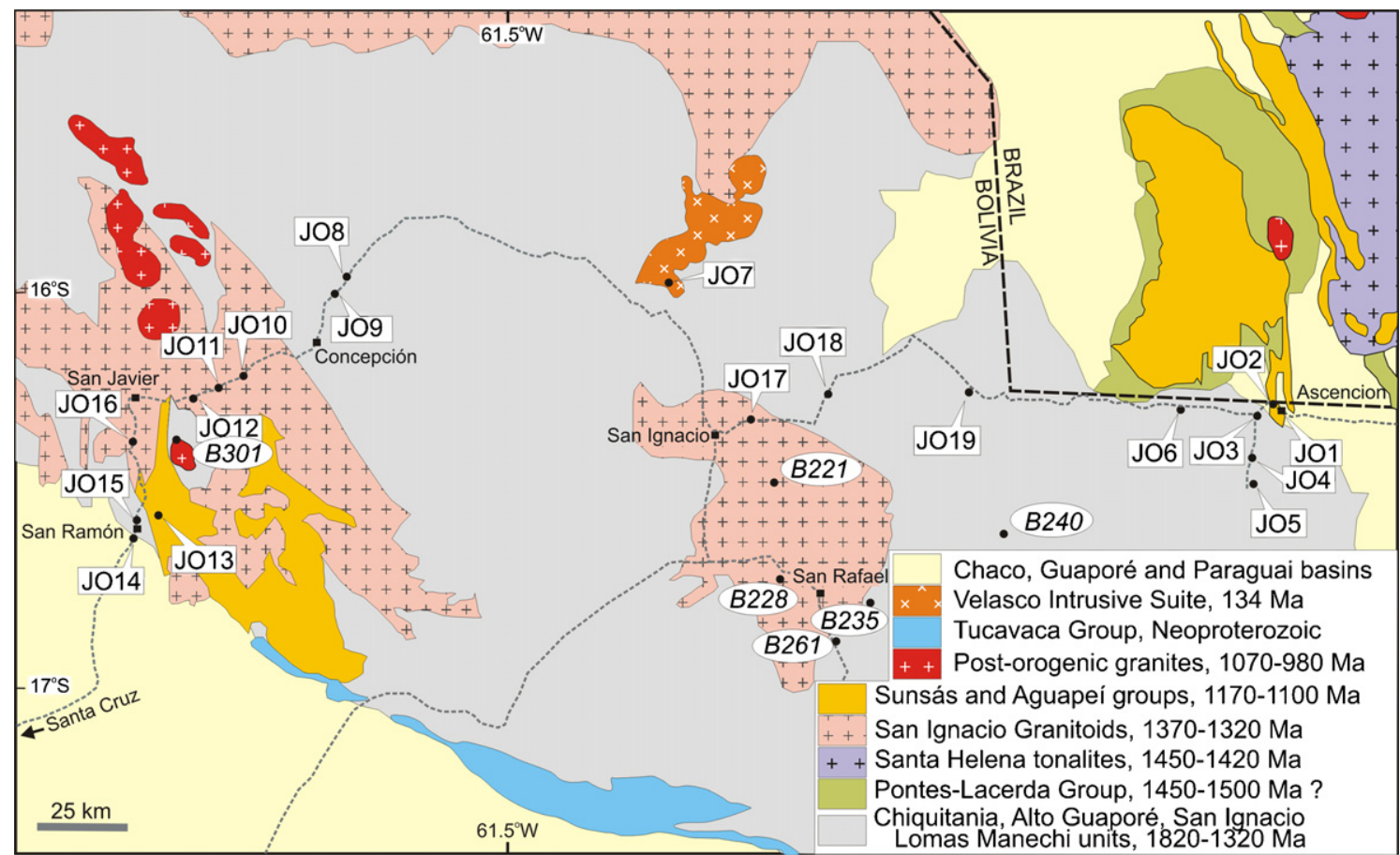

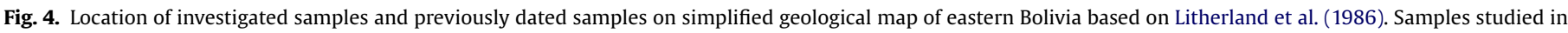

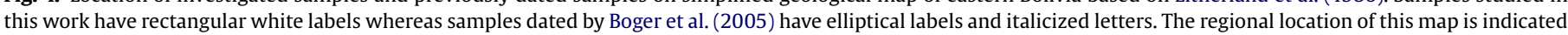
in Fig. 1.

the intracratonic rifting of the Serra Providência to the north (Bettencourt et al., 1999).

\subsection{Geology of the Sunsás Province}

The Sunsás Orogenic cycle was proposed by Litherland et al. $(1986,1989)$ to encompass orogenic rocks formed between 1280 and $980 \mathrm{Ma}$ and is represented by the meta-sedimentary Sunsás and Vibosi Groups, granite bodies, and mafic intrusions. As known today, the Sunsás Province covers an exposed area of about $350,000 \mathrm{~km}^{2}$ in adjacent Brazil and Bolivia between latitudes $8-18^{\circ}$ south and longitudes $58-67^{\circ}$ west. Santos et al. $(2000,2003)$ used the range of 1450-1100 Ma for the Sunsás Orogenic Cycle to include three main orogenies separated by intervals of less orogenic activity: Santa Helena (1450-1420 Ma), Candeias (1350-1320 Ma) and Nova Brasilândia (1200-1100 Ma). The older rocks of the Sunsás Orogen (Santa Helena Batholith) are located in the southeastern part of the belt in Mato Grosso and described by Geraldes et al. (2001) as representing a primitive magmatic arc. The second orogeny (Candeias) has two main components: an Andean-type magmatic arc (Candeias granitoids in Rondônia and Pensamiento Complex in Bolivia; Santos et al., 2003; Matos et al., 2006) and also some high-grade collisional metamorphic rocks (Colorado and Rio Crespo metamorphic suites; Payolla et al., 2001; Rizzotto et al., 2002; Bettencourt et al., 2006). Meta-sedimentary rocks and small bodies of S-type granite (Rizzotto et al., 1999) mainly compose the Nova Brasilândia orogeny. The meta-sedimentary rocks are more pelitic to the north (Nova Brasilândia Group) and more psammitic to the south (Aguapeí and Sunsás Groups). Quartz-arenites and subordinated arkose, subarkose, siltite and conglomerate are the main rocks within the Sunsás and Vibosi Groups. These rocks have undergone very low or low-grade metamorphism (Litherland et al., 1986, p. 60).

The age of the Sunsás orogeny was restricted by Litherland et al. (1986) to $1000-950 \mathrm{Ma}$ and included rocks dated in the
1143-730 Ma range ( $\mathrm{Rb}-\mathrm{Sr}$ and $\mathrm{K}-\mathrm{Ar}$ ). The Sunsás Group is called the Aguapeí Group (Saes and Leite, 1993) in Mato Grosso and the correlation of the two units is made since Litherland et al. (1986) because some meta-sedimentary belts (Huanchaca, Aguapeí, and Ascención) occur continuously on both sides of Brazil-Bolivia border as, for example, in the Ascención region (Fig. 4). The Sunsás orogenic front was restricted to the western part of the Bolivian Precambrian (Litherland et al., 1986, 1989; Tassinari et al., 1996, 1999). However, Santos et al. (2000) demonstrated that the Sunsás orogenic front is located about $400 \mathrm{~km}$ to the east in central Rondônia (Figs. 2 and 3) and that most of the granites previously interpreted as formed by the Sunsás orogeny in Bolivia may not orogenic, but are in fact post-orogenic and correlative to the Rondônia Suite of Brazil (980 Ma; Bettencourt et al., 1999). Rizzotto et al. (1999), using $\mathrm{U}-\mathrm{Pb}$ geochronology, found that the orogenic paroxysm occurred at $1110 \mathrm{Ma}$ and that the metamorphic grade reached the upper amphibolite facies (sillimanite zone) or even locally the granulite facies (Tohver et al., 2004). Another metamorphic event is detected by Tohver et al. (2005) in the age range of $1155-1187 \mathrm{Ma}$ using $\mathrm{Ar}-\mathrm{Ar}$ in hornblende. This metamorphism (lower amphibolite facies?) reached temperatures of $450-550^{\circ} \mathrm{C}$ (Tohver et al., 2005), which are not enough to recrystallize zircon (undetected by $\mathrm{U}-\mathrm{Pb}$ geochronology). The U-Pb data of Rizzotto et al. (1999) have also shown that the latest orogeny within the Sunsás Orogen is about 130 m.y. older (paroxysm at $1110 \mathrm{Ma}$ instead of $980 \mathrm{Ma}$ ) than previously established by $\mathrm{Rb}-\mathrm{Sr}$ and $\mathrm{K}-\mathrm{Ar}$ dating (Litherland et al., 1986).

The poorly known basement in western Rondônia (Fig. 3) is represented by the Mamoré Complex. This complex is thought to have been formed during 1450-1320 Ma and includes rocks formed during the Candeias and Santa Helena orogenies of Santos et al. (2002).

Santos et al. (2002) recognized three main orogenies within the Sunsás Orogen (Santa Helena, Candeias, and Nova Brasilândia) and established a preliminary correlation with the Grenville Orogen of Laurentia. The Santa Helena orogeny (1465-1420 Ma; Geraldes et 
al., 2001; Ruiz, 2006) is comparable in age to the Pinwarian orogeny and the Eastern Granite-Rhyolite Province of Laurentia (McBride et al., 2001); the Candeias orogeny (1370-1320 Ma) to the Composite Arc Belt (Carr et al., 2000) or Mount Holly Complex (Ratcliffe et al., 1991); and the Nova Brasilândia orogeny (1180-1110 Ma) is contemporaneous to the late Elzevirian orogeny of Grenville Orogen (Rivers, 1997). The most important distinction between the Sunsás and Grenville Orogens is that the Amazon Craton apparently lacks orogenic rocks younger than $1100 \mathrm{Ma}$ : there is no exposed equivalent to the Ottawan orogeny (Carr et al., 2000).

\section{Sample strategy and analytical methods}

The 20 rocks for isotopic investigation were selected from many rock samples collected by the authors (J.O.S. Santos, G.J. Rizzotto, P.E. Potter, and M.L.E.S. Quadros) during the field seasons of 2000 and 2003 and from the rock library of CPRM (Brazilian Geological Survey) in its Porto Velho office. Our sampling covers most stratigraphic units present in the Precambrian of Bolivia and Rondônia. Locations of sampling sites are shown in Figs. 3 and 4. General data for each sample (coordinates, rock name, stratigraphic unit, mineral dated by $\mathrm{U}-\mathrm{Pb}$, number of analyses per sample, references for names) are summarized in Table 1 and ordered from older to younger. All rocks were investigated in thin section and most of them have chemical analyses plus Sm-Nd data. The principal mineral used for $\mathrm{U}-\mathrm{Pb}$ geochronology is zircon, although titanite and monazite are also used in two samples. During the analysis of zircon both cores and rims where dated. The rims provided either the ages of younger metamorphic or magmatic crystallization.

\subsection{U-Pb SHRIMP methodology}

Rock samples were crushed, milled and sieved at 60 mesh and the heavy minerals were separated using heavy liquid (TBEtetra-bromo-ethane) and magnetic separation techniques. The final separation of the minerals was by hand picking the grains. These were mounted on epoxy discs with fragments of standards, ground and polished until nearly half of each grain was removed, photomicrographed in transmitted and reflected light, and imaged (backscattered electrons) for their internal morphology, using a scanning electron microscope at the Centre for Microscopy and Microanalysis at the University of Western Australia. The epoxy mounts were then cleaned and gold-coated to have a uniform electrical conductivity during the SHRIMP analyses. The zircon standards used were Sri Lanka CZ3 zircon (564 Ma; ${ }^{206} \mathrm{~Pb} /{ }^{238} \mathrm{U}$ ratio $\left.=0.0914 ; 551 \mathrm{ppm} \mathrm{U}\right)$ and BR266 zircon (559 Ma, $903 \mathrm{ppm} U$ ). Titanite standard is Namibia Khan ( $518 \mathrm{Ma} ;{ }^{206} \mathrm{~Pb} /{ }^{238} \mathrm{U}$ ratio $=0.083671 ; 700 \mathrm{ppm} \mathrm{U})$, and monazite standards are French, QMa and PD95 (Rasmussen et al., 2007). The isotopic composition of the minerals was determined using SHRIMP II (De Laeter and Kennedy, 1998), using methods based on those of Compston et al. (1992). For zircon and titanite, a primary ion beam of $\sim 4 \mathrm{nA}$, $10 \mathrm{kV} \mathrm{O}_{2}{ }^{2-}$ with a diameter of $\sim 25 \mu \mathrm{m}$ was focused onto the mineral. Monazite was analysed using a reduced spot size $(10-15 \mu \mathrm{m})$ and weaker primary beam $(\sim 1.2 \mathrm{nA})$ to prevent the $\mathrm{ThO}^{2+}$ signal exceeding that tolerated by the ion counter. Corrections for common $\mathrm{Pb}$ were made using the measured ${ }^{204} \mathrm{~Pb}$ and the $\mathrm{Pb}$ isotopic composition of Broken Hill galena. For each spot analysis, initial 60-90 s were used for pre-sputtering to remove the gold, avoiding the analysis of common $\mathrm{Pb}$ from the coatings. Results with more than $0.50 \%$ common lead correction are presented but not used in age calculations. Zircons and titanite data are reduced using SQUID (Ludwig, 2002), and Krill (P.D. Kinny, Curtin University) was used for monazite. Data were plotted on concordia diagrams using ISOPLOT/Ex software (Ludwig, 1999), which error ellipses on concordia plots are shown at the $95 \%$ confidence level $(2 \sigma)$. All ages given in text are weighted mean ${ }^{207} \mathrm{~Pb} /{ }^{206} \mathrm{~Pb}$ ages. Details of $\mathrm{U}-\mathrm{Pb}$ data are presented in Table 2, where samples follow the same order of Table 1 and the descriptions of Section 4.1.

\subsection{Sm-Nd methodology}

Whole-rock powders were spiked with mixed ${ }^{149} \mathrm{Sm}-{ }^{150} \mathrm{Nd}$ tracer and dissolved in a Teflon vial using an $\mathrm{HF}-\mathrm{HNO}_{3}$ mixture and $6 \mathrm{~N} \mathrm{HCl}$ until complete material dissolution. Column procedures used cationic AG-50W-X8 (200-400 mesh) resin in order

Table 1

Summary of the rock samples dated in this work ${ }^{\mathrm{a}}$

\begin{tabular}{|c|c|c|c|c|c|c|c|c|}
\hline Ample & Rock & Unit & Easting ${ }^{b}$ & Northing ${ }^{\mathrm{b}}$ & Mineral & $n$ & $\mathrm{Sm}-\mathrm{Nd}^{\mathrm{c}}$ & References $^{\mathrm{d}}$ \\
\hline JO3M & Granulitic gneiss & Lomas Manechi Complex & -59.478924 & -16.341479 & $\mathrm{z}-\mathrm{m}$ & $12-6$ & $\mathrm{x}$ & Litherland et al. (1986) \\
\hline GR35 & Quartz-diorite & Jamari Complex & -61.897222 & -11.205527 & $\mathrm{z}$ & 10 & $\mathrm{x}$ & Isotta et al. (1978) \\
\hline GR59 & Tonalite & Jamari Complex & -62.903889 & -9.7956110 & $\mathrm{z}$ & 13 & $\mathrm{x}$ & Isotta et al. (1978) \\
\hline JL78 & Tonalite & Jamari Complex & -62.833889 & -10.160944 & $\mathrm{z}$ & 16 & $\mathrm{x}$ & Isotta et al. (1978) \\
\hline J012 & Orthogneiss & Refugio Orthogneiss & -62.330851 & -16.274368 & $\mathrm{z}$ & 12 & $\mathrm{x}$ & This work \\
\hline GR333 & Meta-granite & Serra Providência Suite & -62.069333 & -10.779444 & $\mathrm{z}$ & 12 & $\mathrm{x}$ & Leal et al. (1978) \\
\hline J014 & Tonalite & San Ramón & -62.507128 & -16.615514 & $z-t$ & $9-4$ & $\mathrm{x}$ & This work \\
\hline JS39 & Monzogranite & Alto Candeias Granite & -63.521555 & -10.506500 & $\mathrm{z}$ & 7 & & Souza et al. (1975) \\
\hline JL6 & S-type granite & Unnamed & -62.973472 & -10.078778 & $\mathrm{z}$ & 6 & & This work \\
\hline J09 & Gneiss & Las Madres Gneiss & -61.969680 & -16.004839 & & & $\mathrm{x}$ & Litherland et al. (1986) \\
\hline J016 & Gneiss & Rio Branco Gneiss & -62.505284 & -16.381691 & & & $\mathrm{x}$ & Litherland et al. (1986) \\
\hline J06 & Orthogneiss & Rio Fortuna Gneiss & -59.733488 & -16.314850 & $\mathrm{z}$ & 17 & $\mathrm{x}$ & Litherland et al. (1986) \\
\hline JO5 & Gneiss & Lomas Manechi Complex & -59.520732 & -16.495433 & $\mathrm{z}$ & 6 & $\mathrm{x}$ & Litherland et al. (1986) \\
\hline J018 & Orthogneiss & Santa Rita Gneiss & -60.652397 & -16.265587 & $\mathrm{z}$ & 10 & $\mathrm{x}$ & Litherland et al. (1986) \\
\hline J010 & Granite & San Andrés Granite & -62.210490 & -16.215077 & $\mathrm{z}$ & 10 & $\mathrm{x}$ & Litherland et al. (1986) \\
\hline MQ23 & S-type granite & Laje Granite & -64.766948 & -10.397774 & $\mathrm{z}$ & 21 & & Rizzotto et al. (2004) \\
\hline JP3 & Sillimanite gneiss & Nova Brasilândia Group & -65.322834 & -10.538490 & $\mathrm{z}$ & 7 & & Rizzotto et al. (1999) \\
\hline JO13 & Rhyolite & Puquio Rhyolite & -62.431190 & -16.578660 & $\mathrm{z}$ & & $\mathrm{x}$ & This work \\
\hline $\mathrm{JO} 8$ & Garnet gneiss & Sunsás Group & -61.928064 & -15.964474 & $\mathrm{z}$ & 16 & $\mathrm{x}$ & Litherland et al. (1986) \\
\hline JO11 & Mica schist & Dolorida (Sunsás Group) & -62.271984 & -16.249407 & $\mathrm{mu}$ & & & This work \\
\hline JO7 & Alkali granite & Velasco Alkaline Complex & -61.083286 & -15.981384 & $\mathrm{z}$ & 6 & $\mathrm{x}$ & Litherland et al. (1986) \\
\hline
\end{tabular}

a Ordered from the older (JO3) to the younger (JO7) rock.

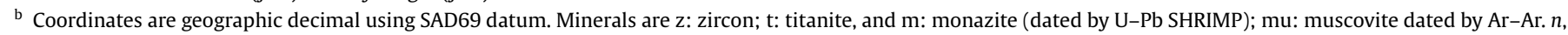
number of $\mathrm{U}-\mathrm{Pb}$ analyses per sample.

c Sm-Nd analyses are whole rock.

d References are exclusive for stratigraphic names. 
Table 2

$\mathrm{U}-\mathrm{Pb}$ SHRIMP isotopic data ordered from the older to the younger rock

\begin{tabular}{|c|c|c|c|c|c|c|c|c|c|c|c|c|}
\hline \multirow[t]{2}{*}{ Grain spot } & \multirow[t]{2}{*}{$\mathrm{U}(\mathrm{ppm})$} & \multirow[t]{2}{*}{ Th (ppm) } & \multirow[t]{2}{*}{ Th U } & \multirow[t]{2}{*}{$4 \mathrm{f} 206(\%)$} & \multicolumn{5}{|l|}{ Isotopic ratios } & \multicolumn{2}{|l|}{ Ages } & \multirow[t]{2}{*}{ Disc. \% } \\
\hline & & & & & ${ }^{207} \mathrm{~Pb} /{ }^{206} \mathrm{~Pb}$ & ${ }^{208} \mathrm{~Pb} /{ }^{206} \mathrm{~Pb}$ & ${ }^{206} \mathrm{~Pb} /{ }^{238} \mathrm{U}$ & ${ }^{207} \mathrm{~Pb} /{ }^{235} \mathrm{U}$ & ${ }^{208} \mathrm{~Pb} /{ }^{232} \mathrm{Th}$ & ${ }^{207} \mathrm{~Pb} /{ }^{206} \mathrm{~Pb}$ & ${ }^{206} \mathrm{~Pb} /{ }^{238} \mathrm{U}$ & \\
\hline \multicolumn{13}{|c|}{ J03, Lomas Manechi granulitic gneiss, zircon (UWA mount 04-76) } \\
\hline i.1-1 & 99 & 103 & 1.07 & 0.30 & $0.11466 \pm 0.97$ & $0.3090 \pm 0.96$ & $0.3441 \pm 0.91$ & $5.4426 \pm 1.33$ & $0.0978 \pm 1.35$ & $1876 \pm 17$ & $1906 \pm 15$ & -1.6 \\
\hline i.1-2 & 645 & 10 & 0.02 & 0.50 & $0.08493 \pm 0.92$ & $0.0112 \pm 7.60$ & $0.3441 \pm 0.91$ & $2.7456 \pm 0.70$ & - \pm- & $1359 \pm 11$ & $1330 \pm 5$ & 0.2 \\
\hline i.2-1 & 234 & 95 & 0.42 & 0.00 & $0.11459 \pm 0.63$ & $0.1205 \pm 0.98$ & $0.3418 \pm 0.71$ & $5.4007 \pm 0.95$ & $0.0989 \pm 1.21$ & $1873 \pm 11$ & $1895 \pm 12$ & -1.2 \\
\hline i.3-1 & 105 & 94 & 0.93 & 0.02 & $0.11060 \pm 0.92$ & $0.2676 \pm 1.00$ & $0.3258 \pm 1.21$ & $4.9682 \pm 1.51$ & $0.0941 \pm 1.64$ & $1809 \pm 17$ & $1818 \pm 19$ & -0.5 \\
\hline i.4-1 & 492 & 12 & 0.03 & 0.26 & $0.08753 \pm 0.76$ & $0.0138 \pm 2.04$ & $0.2304 \pm 0.41$ & $2.7829 \pm 0.68$ & - \pm- & $1374 \pm 10$ & $1334 \pm 5$ & 2.7 \\
\hline i.5-1 & 288 & 172 & 0.62 & 0.34 & $0.11015 \pm 0.77$ & $0.1827 \pm 0.67$ & $0.3283 \pm 0.51$ & $4.9863 \pm 0.93$ & $0.0935 \pm 1.27$ & $1802 \pm 14$ & $1830 \pm 8$ & -1.6 \\
\hline i.8-1 & 179 & 112 & 0.65 & 0.10 & $0.11188 \pm 0.76$ & $0.1842 \pm 0.87$ & $0.3308 \pm 0.67$ & $5.1031 \pm 1.01$ & $0.0929 \pm 1.20$ & $1830 \pm 14$ & $1842 \pm 11$ & -0.7 \\
\hline i.9-1 & 702 & 7 & 0.01 & 0.50 & $0.08560 \pm 0.82$ & $0.0139 \pm 4.29$ & $0.2360 \pm 0.41$ & $2.8109 \pm 0.61$ & - \pm- & $1346 \pm 9$ & $1363 \pm 5$ & -1.2 \\
\hline i.11-1 & 342 & 255 & 0.77 & 0.24 & $0.11107 \pm 0.76$ & $0.2212 \pm 0.97$ & $0.3315 \pm 0.58$ & $5.0791 \pm 0.94$ & $0.0932 \pm 1.35$ & $1818 \pm 14$ & $1846 \pm 9$ & -1.5 \\
\hline i.12-1 & 330 & 275 & 0.86 & 0.02 & $0.11144 \pm 0.53$ & $0.2464 \pm 0.57$ & $0.3279 \pm 0.92$ & $5.0381 \pm 1.06$ & $0.0937 \pm 1.10$ & $1823 \pm 10$ & $1828 \pm 15$ & -0.3 \\
\hline i.13-1 & 700 & 21 & 0.03 & 0.31 & $0.08563 \pm 0.74$ & $0.0130 \pm 2.37$ & $0.2402 \pm 0.43$ & $2.8781 \pm 0.66$ & - \pm- & $1358 \pm 9$ & $1387 \pm 5$ & -2.0 \\
\hline i.14-1 & 659 & 6 & 0.01 & 0.27 & $0.08914 \pm 0.92$ & $0.0086 \pm 19.1$ & $0.2364 \pm 0.44$ & $2.9116 \pm 0.78$ & - \pm- & $1411 \pm 12$ & $1368 \pm 5$ & 2.9 \\
\hline \multicolumn{13}{|c|}{ J03, Lomas Manechi granulitic gneiss, monazite (UWA mount 04-76) } \\
\hline b.15-1 & 7631 & 52813 & 6.92 & 0.015 & $0.08597 \pm 0.16$ & $1.8585 \pm 0.14$ & $0.2310 \pm 1.48$ & $2.7383 \pm 1.52$ & $0.0670 \pm 2.61$ & $1338 \pm 3$ & $1330 \pm 18$ & 0.1 \\
\hline b.16-1 & 3105 & 49200 & 15.85 & 0.038 & $0.08600 \pm 0.25$ & $4.1633 \pm 0.17$ & $0.2355 \pm 1.50$ & $2.7922 \pm 1.55$ & $0.0699 \pm 1.86$ & $1338 \pm 5$ & $1348 \pm 18$ & -1.9 \\
\hline b.16-2 & 6090 & 41577 & 6.83 & 0.000 & $0.08628 \pm 0.22$ & $1.8419 \pm 0.16$ & $0.2371 \pm 1.50$ & $2.8204 \pm 1.52$ & $0.0690 \pm 1.59$ & $1344 \pm 4$ & $1352 \pm 18$ & -2.0 \\
\hline b.17-1 & 5291 & 66607 & 12.59 & 0.007 & $0.08589 \pm 0.20$ & $3.3957 \pm 0.10$ & $0.2330 \pm 1.46$ & $2.7594 \pm 1.51$ & $0.0772 \pm 6.99$ & $1336 \pm 4$ & $1350 \pm 18$ & -1.0 \\
\hline b.19-1 & 4189 & 56442 & 13.47 & 0.015 & $0.08615 \pm 0.21$ & $3.4972 \pm 0.13$ & $0.2373 \pm 1.47$ & $2.8187 \pm 1.53$ & $0.1605 \pm 5.68$ & $1341 \pm 4$ & $1373 \pm 18$ & -2.0 \\
\hline b. $20-1$ & 8611 & 47438 & 5.51 & 0.007 & $0.08620 \pm 0.15$ & $1.4803 \pm 0.28$ & $0.2317 \pm 1.47$ & $2.7534 \pm 1.50$ & $0.1684 \pm 0.93$ & $1343 \pm 3$ & $1343 \pm 18$ & 0.0 \\
\hline \multicolumn{13}{|c|}{ GR35, Jamari Complex quartz-diorite, zircon (UWA mount B51) } \\
\hline d.1-1 & 155 & 50 & 0.33 & 0.05 & $0.10800 \pm 0.61$ & $0.1077 \pm 0.95$ & $0.3221 \pm 0.92$ & $4.7963 \pm 1.10$ & $0.0936 \pm 1.41$ & $1766 \pm 11$ & $1800 \pm 14$ & -1.9 \\
\hline d.2-1 & 1079 & 12 & 0.01 & 0.16 & $0.10135 \pm 0.25$ & $0.0978 \pm 0.98$ & $0.2982 \pm 0.98$ & $4.1683 \pm 1.01$ & - \pm- & $1649 \pm 5$ & $1682 \pm 14$ & -2.0 \\
\hline d.2-2 & 233 & 82 & 0.36 & 0.09 & $0.10845 \pm 0.55$ & $0.0047 \pm 1.78$ & $0.3136 \pm 0.86$ & $4.6889 \pm 1.02$ & $0.0917 \pm 1.47$ & $1773 \pm 10$ & $1758 \pm 13$ & 0.9 \\
\hline d.5-1 & 176 & 68 & 0.40 & 0.02 & $0.10686 \pm 0.59$ & $0.0282 \pm 1.32$ & $0.3121 \pm 0.90$ & $4.5987 \pm 1.07$ & $0.0891 \pm 1.32$ & $1747 \pm 11$ & $1751 \pm 14$ & -0.3 \\
\hline d. $8-1$ & 142 & 50 & 0.36 & 0.05 & $0.10763 \pm 0.69$ & $0.0629 \pm 1.20$ & $0.3186 \pm 0.94$ & $4.7282 \pm 1.17$ & $0.0942 \pm 1.54$ & $1760 \pm 13$ & $1783 \pm 15$ & -1.3 \\
\hline d.9-1 & 160 & 46 & 0.30 & 0.04 & $0.10845 \pm 0.77$ & $0.0847 \pm 1.29$ & $0.3135 \pm 0.92$ & $4.6875 \pm 1.20$ & $0.0889 \pm 1.87$ & $1774 \pm 14$ & $1758 \pm 14$ & 0.9 \\
\hline d.11-1 & 325 & 147 & 0.47 & 0.09 & $0.10708 \pm 0.45$ & $0.1357 \pm 0.59$ & $0.3125 \pm 0.82$ & $4.6132 \pm 0.94$ & $0.0894 \pm 1.08$ & $1750 \pm 8$ & $1753 \pm 13$ & -0.1 \\
\hline d.12-1 & 145 & 52 & 0.37 & 0.10 & $0.10633 \pm 0.75$ & $0.1064 \pm 1.01$ & $0.3097 \pm 0.94$ & $4.5401 \pm 1.20$ & $0.0875 \pm 1.73$ & $1737 \pm 14$ & $1739 \pm 14$ & -0.1 \\
\hline d.17-1 & 157 & 33 & 0.22 & 0.06 & $0.10820 \pm 0.66$ & $0.1137 \pm 0.86$ & $0.3156 \pm 0.92$ & $4.7079 \pm 1.13$ & $0.0900 \pm 2.00$ & $1769 \pm 12$ & $1768 \pm 14$ & 0.1 \\
\hline d.17-2 & 382 & 33 & 0.09 & 0.02 & $0.10610 \pm 0.49$ & $0.1089 \pm 1.00$ & $0.3010 \pm 0.81$ & $4.4037 \pm 0.95$ & $0.0936 \pm 2.68$ & $1733 \pm 9$ & $1696 \pm 12$ & 2.1 \\
\hline \multicolumn{13}{|c|}{ GR59, Jamari Complex tonalite, zircon (UWA mount B75) } \\
\hline k.1-1 & 84 & 32 & 0.40 & 0.00 & $0.10760 \pm 1.20$ & $0.1208 \pm 1.81$ & $0.3135 \pm 1.24$ & $4.6513 \pm 1.73$ & $0.0957 \pm 2.19$ & $1759 \pm 22$ & $1758 \pm 19$ & 0.1 \\
\hline k.2-1 & 202 & 108 & 0.55 & 0.07 & $0.10705 \pm 0.86$ & $0.1651 \pm 1.05$ & $0.3115 \pm 0.82$ & $4.5973 \pm 1.19$ & $0.0922 \pm 1.43$ & $1750 \pm 16$ & $1748 \pm 13$ & 0.1 \\
\hline k.3-1 & 199 & 82 & 0.43 & 0.20 & $0.10309 \pm 1.19$ & $0.1297 \pm 1.36$ & $0.3052 \pm 0.95$ & $4.3380 \pm 1.52$ & $0.0895 \pm 2.24$ & $1680 \pm 22$ & $1717 \pm 14$ & -2.2 \\
\hline k.4-1 & 242 & 109 & 0.46 & 0.01 & $0.10513 \pm 0.76$ & $0.1403 \pm 1.16$ & $0.3005 \pm 0.74$ & $4.3618 \pm 1.06$ & $0.0908 \pm 1.40$ & $1719 \pm 14$ & $1694 \pm 11$ & 1.5 \\
\hline k.5-1 & 205 & 131 & 0.66 & 0.13 & $0.10704 \pm 0.69$ & $0.1999 \pm 3.80$ & $0.2866 \pm 0.64$ & $4.2306 \pm 0.94$ & $0.0857 \pm 3.89$ & $1750 \pm 13$ & $1625 \pm 9$ & 7.1 \\
\hline k.5-2 & 138 & 50 & 0.38 & 0.10 & $0.10284 \pm 0.95$ & $0.1133 \pm 1.19$ & $0.2982 \pm 0.66$ & $4.2287 \pm 1.15$ & $0.0881 \pm 1.86$ & $1676 \pm 17$ & $1682 \pm 10$ & -0.4 \\
\hline k.5-3 & 213 & 69 & 0.34 & 0.09 & $0.10208 \pm 0.82$ & $0.1010 \pm 1.18$ & $0.2987 \pm 0.73$ & $4.2033 \pm 1.10$ & $0.0883 \pm 1.66$ & $1662 \pm 15$ & $1685 \pm 11$ & -1.3 \\
\hline k.7-1 & 174 & 61 & 0.36 & 0.17 & $0.10668 \pm 0.85$ & $0.1316 \pm 1.06$ & $0.2926 \pm 0.60$ & $4.1560 \pm 1.04$ & $0.0850 \pm 1.71$ & $1679 \pm 16$ & $1655 \pm 9$ & 1.4 \\
\hline k.8-1 & 165 & 73 & 0.45 & 0.06 & $0.10344 \pm 0.88$ & $0.1215 \pm 1.00$ & $0.3095 \pm 0.85$ & $4.4939 \pm 1.22$ & $0.0881 \pm 1.57$ & $1720 \pm 16$ & $1738 \pm 13$ & -1.1 \\
\hline k.9-1 & 214 & 85 & 0.41 & 0.06 & $0.10300 \pm 0.62$ & $0.1091 \pm 1.10$ & $0.2935 \pm 0.57$ & $4.2343 \pm 0.84$ & $0.0856 \pm 1.13$ & $1708 \pm 11$ & $1659 \pm 8$ & 2.9 \\
\hline k.10-1 & 168 & 67 & 0.41 & 0.01 & $0.10762 \pm 0.70$ & $0.1186 \pm 1.29$ & $0.3072 \pm 0.57$ & $4.5592 \pm 0.90$ & $0.0880 \pm 1.44$ & $1760 \pm 13$ & $1727 \pm 9$ & 1.8 \\
\hline k.11-1 & 197 & 84 & 0.44 & 0.19 & $0.10354 \pm 1.15$ & $0.1305 \pm 1.32$ & $0.3149 \pm 0.95$ & $4.3021 \pm 1.48$ & $0.0870 \pm 2.16$ & $1688 \pm 21$ & $1698 \pm 14$ & -0.6 \\
\hline k.12-1 & 140 & 53 & 0.39 & 0.00 & $0.10710 \pm 0.91$ & $0.1210 \pm 1.37$ & $0.3132 \pm 1.24$ & $4.6508 \pm 1.32$ & $0.0966 \pm 1.67$ & $1751 \pm 17$ & $1765 \pm 15$ & -0.8 \\
\hline \multicolumn{13}{|c|}{ JL78, Jamari Complex tonalite, zircon (UWA mount B76) } \\
\hline h.1-1 & 560 & 199 & 0.37 & 0.03 & $0.08622 \pm 0.75$ & $0.1837 \pm 0.99$ & $0.1838 \pm 0.99$ & $2.1851 \pm 1.24$ & $0.0502 \pm 1.53$ & $1343 \pm 14$ & $1088 \pm 10$ & 19.0 \\
\hline h.2-1 & 157 & 70 & 0.46 & 0.03 & $0.10659 \pm 0.79$ & $0.1270 \pm 1.13$ & $0.2375 \pm 2.34$ & $3.4906 \pm 2.47$ & $0.0662 \pm 2.63$ & $1742 \pm 14$ & $1374 \pm 29$ & 21.1 \\
\hline h.3-1 & 137 & 52 & 0.40 & 0.00 & $0.10617 \pm 0.62$ & $0.1150 \pm 2.30$ & $0.2903 \pm 0.87$ & $4.2497 \pm 1.05$ & $0.0858 \pm 2.53$ & $1735 \pm 11$ & $1643 \pm 13$ & 2.5 \\
\hline h.3-2 & 573 & 52 & 0.09 & 0.03 & $0.08579 \pm 0.30$ & $0.0297 \pm 0.84$ & $0.2322 \pm 1.14$ & $2.7472 \pm 1.17$ & - \pm- & $1334 \pm 5$ & $1346 \pm 14$ & -1.5 \\
\hline h.4-1 & 1123 & 183 & 0.17 & 0.01 & $0.08589 \pm 0.19$ & $0.0499 \pm 0.62$ & $0.2291 \pm 0.64$ & $2.7170 \pm 0.67$ & $0.0641 \pm 1.15$ & $1338 \pm 4$ & $1330 \pm 8$ & 0.6 \\
\hline h. $4-2$ & 984 & 156 & 0.16 & 0.02 & $0.08609 \pm 0.20$ & $0.2279 \pm 0.96$ & $0.2277 \pm 0.65$ & $2.7037 \pm 0.68$ & $0.0641 \pm 1.15$ & $1341 \pm 4$ & $1322 \pm 8$ & 1.4 \\
\hline
\end{tabular}


Table 2 (Continued)

\begin{tabular}{|c|c|c|c|c|c|c|c|c|c|c|c|c|}
\hline \multirow[t]{2}{*}{ Grain spot } & \multirow[t]{2}{*}{$\mathrm{U}(\mathrm{ppm})$} & \multirow[t]{2}{*}{ Th (ppm) } & \multirow[t]{2}{*}{ Th U } & \multirow[t]{2}{*}{$4 \mathrm{f} 206(\%)$} & \multicolumn{5}{|l|}{ Isotopic ratios } & \multicolumn{2}{|l|}{ Ages } & \multirow[t]{2}{*}{ Disc. \% } \\
\hline & & & & & ${ }^{207} \mathrm{~Pb} /{ }^{206} \mathrm{~Pb}$ & ${ }^{208} \mathrm{~Pb} /{ }^{206} \mathrm{~Pb}$ & ${ }^{206} \mathrm{~Pb} /{ }^{238} \mathrm{U}$ & ${ }^{207} \mathrm{~Pb} /{ }^{235} \mathrm{U}$ & ${ }^{208} \mathrm{~Pb} /{ }^{232} \mathrm{Th}$ & ${ }^{207} \mathrm{~Pb} /{ }^{206} \mathrm{~Pb}$ & ${ }^{206} \mathrm{~Pb} /{ }^{238} \mathrm{U}$ & \\
\hline h.4-3 & 1165 & 106 & 0.09 & 0.01 & $0.08616 \pm 0.33$ & $0.0279 \pm 0.94$ & $0.2261 \pm 0.34$ & $2.6861 \pm 0.48$ & $0.0662 \pm 1.05$ & $1342 \pm 6$ & $1314 \pm 4$ & 2.1 \\
\hline h.5-1 & 151 & 78 & 0.54 & 0.12 & $0.10604 \pm 0.82$ & $0.1550 \pm 1.21$ & $0.3041 \pm 1.16$ & $4.4465 \pm 1.41$ & $0.0866 \pm 1.80$ & $1732 \pm 15$ & $1712 \pm 17$ & 1.2 \\
\hline h.6-1 & 160 & 55 & 0.36 & 0.10 & $0.10704 \pm 1.32$ & $0.2559 \pm 2.01$ & $0.2557 \pm 2.01$ & $3.7736 \pm 2.41$ & $0.0744 \pm 3.50$ & $1750 \pm 24$ & $1468 \pm 26$ & 16.1 \\
\hline h.7-1 & 373 & 153 & 0.42 & 0.11 & $0.08538 \pm 0.46$ & $0.0854 \pm 0.64$ & $0.2278 \pm 0.91$ & $2.6820 \pm 1.11$ & $0.0654 \pm 1.35$ & $1324 \pm 12$ & $1323 \pm 11$ & 0.1 \\
\hline h.8-1 & 149 & 67 & 0.46 & 0.01 & $0.10662 \pm 0.46$ & $0.1242 \pm 0.79$ & $0.3036 \pm 0.74$ & $4.4622 \pm 0.88$ & $0.0889 \pm 1.35$ & $1742 \pm 8$ & $1709 \pm 11$ & 2.2 \\
\hline h.9-1 & 910 & 171 & 0.20 & 0.02 & $0.08613 \pm 0.46$ & $0.0588 \pm 1.61$ & $0.2252 \pm 0.82$ & $2.6746 \pm 0.93$ & $0.0663 \pm 1.54$ & $1341 \pm 9$ & $1309 \pm 10$ & 2.4 \\
\hline h.10-1 & 97 & 45 & 0.48 & 0.04 & $0.10769 \pm 0.61$ & $0.1385 \pm 0.86$ & $0.3127 \pm 1.15$ & $4.6563 \pm 1.30$ & $0.0902 \pm 1.60$ & $1766 \pm 11$ & $1754 \pm 18$ & 0.7 \\
\hline h.11-1 & 450 & 169 & 0.39 & 0.00 & $0.08572 \pm 0.62$ & $0.1140 \pm 0.92$ & $0.2203 \pm 1.45$ & $2.6039 \pm 1.46$ & $0.0651 \pm 1.58$ & $1332 \pm 12$ & $1284 \pm 15$ & 3.6 \\
\hline h.15-1 & 120 & 65 & 0.56 & 0.12 & $0.10688 \pm 0.82$ & $0.1620 \pm 1.22$ & $0.3136 \pm 1.32$ & $4.6216 \pm 1.72$ & $0.0901 \pm 2.12$ & $1747 \pm 20$ & $1758 \pm 20$ & 3.6 \\
\hline h. $17-1$ & 96 & 42 & 0.45 & 0.00 & $0.10577 \pm 1.02$ & $0.1270 \pm 1.52$ & $0.3041 \pm 1.15$ & $4.4325 \pm 1.41$ & $0.0861 \pm 2.11$ & $1732 \pm 15$ & $1711 \pm 17$ & -0.7 \\
\hline \multicolumn{13}{|c|}{ J012, Refugio Orthogneiss, zircon (UWA mount 04-118) } \\
\hline c. $1-2$ & 106 & 65 & 0.63 & 0.13 & $0.10100 \pm 1.95$ & $0.1809 \pm 1.10$ & $0.2923 \pm 0.86$ & $4.0698 \pm 2.13$ & $0.0828 \pm 2.61$ & $1643 \pm 36$ & $1653 \pm 13$ & -0.6 \\
\hline c.1-5 & 142 & 70 & 0.51 & 0.00 & $0.10110 \pm 0.89$ & $0.1339 \pm 1.25$ & $0.2915 \pm 2.14$ & $4.0652 \pm 2.32$ & $0.0765 \pm 2.47$ & $1645 \pm 17$ & $1649 \pm 31$ & 0.0 \\
\hline c. $2-1$ & 344 & 226 & 0.68 & 0.02 & $0.10096 \pm 0.55$ & $0.1995 \pm 0.66$ & $0.2965 \pm 0.54$ & $4.1281 \pm 0.77$ & $0.0871 \pm 0.85$ & $1642 \pm 10$ & $1674 \pm 8$ & -2.0 \\
\hline c. $2-2$ & 493 & 268 & 0.56 & 0.05 & $0.10246 \pm 0.44$ & $0.1627 \pm 0.53$ & $0.3011 \pm 0.36$ & $4.2544 \pm 0.57$ & $0.0867 \pm 0.70$ & $1669 \pm 8$ & $1697 \pm 5$ & -1.7 \\
\hline c. $2-3$ & 215 & 152 & 0.73 & 0.04 & $0.10098 \pm 0.60$ & $0.2084 \pm 0.69$ & $0.2992 \pm 0.52$ & $4.1663 \pm 0.79$ & $0.0853 \pm 0.87$ & $1642 \pm 11$ & $1688 \pm 8$ & -2.8 \\
\hline c. $2-5$ & 463 & 255 & 0.57 & 0.00 & $0.10059 \pm 0.43$ & $0.1546 \pm 0.87$ & $0.2891 \pm 0.50$ & $4.0092 \pm 0.66$ & $0.0786 \pm 0.76$ & $1635 \pm 8$ & $1637 \pm 7$ & -0.1 \\
\hline c. $2-6$ & 158 & 100 & 0.65 & 0.01 & $0.10079 \pm 0.71$ & $0.1803 \pm 0.85$ & $0.2799 \pm 0.64$ & $3.8892 \pm 0.95$ & $0.0774 \pm 1.07$ & $1639 \pm 13$ & $1591 \pm 9$ & 2.9 \\
\hline c. $4-1$ & 378 & 203 & 0.55 & 0.10 & $0.10198 \pm 0.59$ & $0.1607 \pm 0.59$ & $0.3054 \pm 0.41$ & $4.2947 \pm 0.72$ & $0.0876 \pm 1.00$ & $1660 \pm 11$ & $1718 \pm 6$ & -3.5 \\
\hline c. $4-2$ & 350 & 178 & 0.53 & 0.03 & $0.10114 \pm 0.42$ & $0.1433 \pm 0.54$ & $0.2948 \pm 0.38$ & $4.1117 \pm 0.56$ & $0.0800 \pm 0.70$ & $1645 \pm 8$ & $1666 \pm 6$ & -1.2 \\
\hline c.7-1 & 278 & 186 & 0.69 & 0.07 & $0.10224 \pm 0.82$ & $0.1869 \pm 0.65$ & $0.3044 \pm 0.52$ & $4.2914 \pm 0.97$ & $0.0828 \pm 1.20$ & $1665 \pm 15$ & $1713 \pm 8$ & -2.9 \\
\hline c. $8-1$ & 107 & 59 & 0.57 & 0.02 & $0.10260 \pm 0.99$ & $0.1546 \pm 1.32$ & $0.2774 \pm 1.13$ & $3.9238 \pm 1.50$ & $0.0749 \pm 1.74$ & $1672 \pm 18$ & $1578 \pm 16$ & 5.6 \\
\hline c.13-1 & 119 & 97 & 0.84 & 0.09 & $0.10123 \pm 0.88$ & $0.2313 \pm 0.91$ & $0.2812 \pm 0.76$ & $3.9254 \pm 1.16$ & $0.0769 \pm 1.24$ & $1647 \pm 16$ & $1598 \pm 11$ & 3.0 \\
\hline \multicolumn{13}{|c|}{ GR333, Serra Providência Meta-granite, zircon (UWA mount B76) } \\
\hline b.4-2 & 73 & 47 & 0.66 & 0.38 & $0.09451 \pm 1.57$ & $0.1931 \pm 1.32$ & $0.2717 \pm 1.75$ & $3.4190 \pm 2.35$ & $0.0763 \pm 2.59$ & $1452 \pm 30$ & $1524 \pm 24$ & -6.7 \\
\hline b.8-1 & 395 & 2 & 0.01 & 0.12 & $0.08591 \pm 0.42$ & $0.0019 \pm 5.93$ & $0.2173 \pm 1.06$ & $2.5789 \pm 1.15$ & - \pm- & $1339 \pm 8$ & $1268 \pm 12$ & 5.3 \\
\hline b.9-1 & 111 & 82 & 0.77 & 0.01 & $0.09437 \pm 0.57$ & $0.2254 \pm 0.57$ & $0.2640 \pm 0.84$ & $3.4348 \pm 1.02$ & $0.0769 \pm 1.37$ & $1516 \pm 11$ & $1510 \pm 14$ & 0.4 \\
\hline b.9-2 & 386 & 163 & 0.44 & 0.00 & $0.09420 \pm 0.30$ & $0.1296 \pm 0.40$ & $0.2658 \pm 1.07$ & $3.4492 \pm 1.11$ & $0.0787 \pm 1.14$ & $1510 \pm 6$ & $1519 \pm 14$ & -0.6 \\
\hline b.9-3 & 415 & 6 & 0.01 & 0.13 & $0.08605 \pm 0.42$ & $0.0071 \pm 1.73$ & $0.2154 \pm 0.70$ & $2.5615 \pm 0.77$ & - \pm- & $1344 \pm 6$ & $1258 \pm 8$ & 5.4 \\
\hline b. $12-1$ & 540 & 174 & 0.33 & 0.00 & $0.09334 \pm 1.07$ & $0.0982 \pm 2.17$ & $0.2317 \pm 0.78$ & $2.9814 \pm 1.33$ & $0.0678 \pm 2.43$ & $1495 \pm 20$ & $1343 \pm 10$ & 10.1 \\
\hline b. $14-1$ & 256 & 166 & 0.67 & 0.00 & $0.09543 \pm 0.65$ & $0.1954 \pm 0.72$ & $0.2654 \pm 1.35$ & $3.4922 \pm 1.50$ & $0.0779 \pm 1.56$ & $1537 \pm 12$ & $1517 \pm 18$ & 1.3 \\
\hline b. $15-1$ & 406 & 194 & 0.49 & 0.00 & $0.09382 \pm 0.70$ & $0.1389 \pm 1.68$ & $0.2118 \pm 0.83$ & $2.7398 \pm 1.09$ & $0.0605 \pm 2.04$ & $1504 \pm 13$ & $1238 \pm 9$ & 18.0 \\
\hline b. $19-1$ & 45 & 30 & 0.70 & 0.00 & $0.09601 \pm 1.23$ & $0.2099 \pm 0.99$ & $0.2671 \pm 1.07$ & $3.5355 \pm 1.63$ & $0.0813 \pm 1.94$ & $1548 \pm 23$ & $1526 \pm 15$ & 1.0 \\
\hline b.19-2 & 559 & 5 & 0.01 & 0.08 & $0.08697 \pm 0.27$ & $0.0070 \pm 1.75$ & $0.2136 \pm 0.68$ & $2.5500 \pm 0.73$ & - \pm- & $1351 \pm 5$ & $1248 \pm 8$ & 7.6 \\
\hline b. $20-1$ & 290 & 164 & 0.59 & 0.00 & $0.09438 \pm 0.34$ & $0.1713 \pm 0.41$ & $0.2668 \pm 1.07$ & $3.4561 \pm 0.84$ & $0.0776 \pm 0.94$ & $1516 \pm 6$ & $1518 \pm 11$ & -0.1 \\
\hline b.20-2 & 99 & 95 & 0.99 & 0.04 & $0.09588 \pm 0.65$ & $0.2932 \pm 0.61$ & $0.2662 \pm 0.85$ & $3.5198 \pm 1.08$ & $0.0786 \pm 1.16$ & $1546 \pm 12$ & $1528 \pm 16$ & 1.1 \\
\hline \multicolumn{13}{|c|}{ J014, San Ramón Tonalite, zircon (UWA mount 04-72) } \\
\hline b.1-1 & 242 & 16 & 0.07 & 0.05 & $0.09084 \pm 0.89$ & $0.0200 \pm 2.40$ & $0.2453 \pm 0.58$ & $3.0728 \pm 1.06$ & $0.0762 \pm 4.70$ & $1443 \pm 17$ & $1414 \pm 7$ & 2.0 \\
\hline b. $2-1$ & 271 & 35 & 0.13 & 0.00 & $0.08967 \pm 0.71$ & $0.0398 \pm 1.67$ & $0.2460 \pm 0.48$ & $3.0417 \pm 0.86$ & $0.0744 \pm 1.74$ & $1418 \pm 14$ & $1418 \pm 6$ & 0.0 \\
\hline b.3-1 & 645 & 179 & 0.29 & 0.11 & $0.09051 \pm 0.74$ & $0.0853 \pm 0.85$ & $0.2474 \pm 0.47$ & $3.0877 \pm 0.87$ & $0.0718 \pm 1.88$ & $1436 \pm 14$ & $1425 \pm 6$ & 0.8 \\
\hline b.6-1 & 504 & 97 & 0.20 & 0.01 & $0.09026 \pm 0.50$ & $0.0580 \pm 1.33$ & $0.2455 \pm 0.76$ & $3.0550 \pm 0.91$ & $0.0716 \pm 1.55$ & $1431 \pm 10$ & $1415 \pm 10$ & 1.1 \\
\hline b.8-1 & 449 & 61 & 0.14 & 0.03 & $0.09040 \pm 0.55$ & $0.0412 \pm 1.31$ & $0.2437 \pm 0.62$ & $3.0381 \pm 0.83$ & $0.0711 \pm 1.72$ & $1434 \pm 11$ & $1406 \pm 8$ & 1.9 \\
\hline b.9-1 & 420 & 204 & 0.50 & 0.03 & $0.09045 \pm 0.57$ & $0.1460 \pm 0.75$ & $0.2505 \pm 0.40$ & $3.1240 \pm 0.69$ & $0.0725 \pm 0.86$ & $1435 \pm 11$ & $1441 \pm 5$ & -0.4 \\
\hline b. $10-1$ & 186 & 16 & 0.09 & 0.09 & $0.09060 \pm 0.97$ & $0.0278 \pm 2.26$ & $0.2504 \pm 0.66$ & $3.1286 \pm 1.17$ & $0.0723 \pm 5.40$ & $1438 \pm 18$ & $1441 \pm 8$ & -0.2 \\
\hline b. $12-1$ & 397 & 52 & 0.14 & 0.06 & $0.08985 \pm 0.74$ & $0.0408 \pm 1.53$ & $0.2517 \pm 0.66$ & $3.1182 \pm 1.00$ & $0.0732 \pm 2.60$ & $1422 \pm 14$ & $1447 \pm 9$ & -1.7 \\
\hline b.13-1 & 425 & 102 & 0.25 & 0.00 & $0.08996 \pm 0.64$ & $0.0726 \pm 1.11$ & $0.2501 \pm 0.55$ & $3.1027 \pm 0.85$ & $0.0735 \pm 1.32$ & $1425 \pm 12$ & $1439 \pm 7$ & -1.0 \\
\hline \multicolumn{13}{|c|}{ n Tonalite, titanite (UWA mount 04-72) } \\
\hline a.1-1 & 248 & 219 & 0.91 & 1.23 & $0.08973 \pm 1.39$ & $0.9512 \pm 0.38$ & $0.2470 \pm 0.35$ & $3.0563 \pm 1.43$ & $0.1214 \pm 3.72$ & $1420 \pm 26$ & $1423 \pm 4$ & -0.2 \\
\hline a. $1-2$ & 280 & 252 & 0.93 & 1.05 & $0.08996 \pm 1.28$ & $0.8863 \pm 0.57$ & $0.2486 \pm 0.34$ & $3.0831 \pm 1.33$ & $0.1466 \pm 3.70$ & $1425 \pm 24$ & $1431 \pm 4$ & -0.4 \\
\hline a.1-3 & 251 & 233 & 0.96 & 1.17 & $0.08913 \pm 1.53$ & $0.8170 \pm 4.38$ & $0.2394 \pm 0.45$ & $2.9415 \pm 1.59$ & $0.1346 \pm 3.67$ & $1407 \pm 29$ & $1383 \pm 6$ & 1.7 \\
\hline a.1-4 & 264 & 246 & 0.96 & 1.07 & $0.08992 \pm 1.36$ & $0.7734 \pm 1.66$ & $0.2409 \pm 0.42$ & $2.9868 \pm 1.43$ & $0.0930 \pm 3.59$ & $1424 \pm 26$ & $1391 \pm 5$ & 2.3 \\
\hline \multicolumn{13}{|c|}{ JS39, Alto Candeias Monzogranite, zircon (UWA mount B63) } \\
\hline e.1-1 & 131 & 41 & 0.32 & 0.03 & $0.08598 \pm 0.66$ & $0.0985 \pm 0.98$ & $0.2345 \pm 0.51$ & $2.7762 \pm 0.85$ & $0.0724 \pm 1.17$ & $1359 \pm 13$ & $1358 \pm 6$ & 0.1 \\
\hline e.2-1 & 263 & 87 & 0.34 & 0.01 & $0.08532 \pm 0.47$ & $0.1022 \pm 0.69$ & $0.2256 \pm 0.56$ & $2.6537 \pm 0.73$ & $0.0673 \pm 0.90$ & $1320 \pm 10$ & $1311 \pm 7$ & 0.7 \\
\hline e.4-1 & 113 & 38 & 0.35 & 0.03 & $0.08618 \pm 0.71$ & $0.1065 \pm 2.08$ & $0.2200 \pm 1.02$ & $2.6145 \pm 1.24$ & $0.0668 \pm 2.35$ & $1344 \pm 17$ & $1282 \pm 12$ & 4.6 \\
\hline e.5-1 & 536 & 135 & 0.26 & 0.02 & $0.08599 \pm 0.32$ & $0.0784 \pm 0.54$ & $0.2331 \pm 0.35$ & $2.7637 \pm 0.47$ & $0.0698 \pm 0.70$ & $1342 \pm 7$ & $1351 \pm 4$ & -0.7 \\
\hline e.7-1 & 374 & 102 & 0.28 & 0.03 & $0.08656 \pm 0.38$ & $0.0829 \pm 0.83$ & $0.2263 \pm 0.32$ & $2.7012 \pm 0.50$ & $0.0662 \pm 1.00$ & $1336 \pm 9$ & $1314 \pm 4$ & 1.6 \\
\hline
\end{tabular}




\begin{tabular}{|c|c|c|c|c|c|c|c|c|c|c|c|c|}
\hline e.8-1 & 105 & 30 & 0.29 & 0.18 & $0.08590 \pm 0.73$ & $0.0892 \pm 1.15$ & $0.2254 \pm 0.58$ & $2.6696 \pm 0.93$ & $0.0655 \pm 1.75$ & $1303 \pm 19$ & $1308 \pm 7$ & -0.4 \\
\hline e.9-1 & 398 & 122 & 0.32 & 0.03 & $0.08610 \pm 0.38$ & $0.0960 \pm 0.58$ & $0.2264 \pm 0.71$ & $2.6872 \pm 0.80$ & $0.0678 \pm 0.99$ & $1343 \pm 9$ & $1316 \pm 8$ & 2.0 \\
\hline \multicolumn{13}{|c|}{ JL6, Unnamed S-type granite, zircon (UWA mount B76) } \\
\hline f. $2-1$ & 1278 & 27 & 0.02 & 0.03 & $0.08569 \pm 0.32$ & $0.0985 \pm 0.98$ & $0.2254 \pm 0.80$ & $2.6637 \pm 0.86$ & $0.0606 \pm 3.23$ & $1331 \pm 6$ & $1311 \pm 9$ & 1.6 \\
\hline f.3-1 & 953 & 18 & 0.02 & 0.03 & $0.08560 \pm 0.40$ & $0.1022 \pm 0.69$ & $0.2255 \pm 0.81$ & $2.6620 \pm 0.91$ & $0.0587 \pm 8.27$ & $1329 \pm 8$ & $1311 \pm 10$ & 1.4 \\
\hline f.5-1 & 1449 & 36 & 0.03 & 0.02 & $0.08594 \pm 0.31$ & $0.1065 \pm 2.08$ & $0.2283 \pm 0.79$ & $2.7052 \pm 0.85$ & $0.0640 \pm 4.52$ & $1337 \pm 6$ & $1326 \pm 10$ & 0.8 \\
\hline f.5-2 & 830 & 17 & 0.02 & 0.04 & $0.08582 \pm 0.40$ & $0.0784 \pm 0.54$ & $0.2252 \pm 0.82$ & $2.6652 \pm 0.92$ & $0.0571 \pm 3.98$ & $1334 \pm 8$ & $1309 \pm 10$ & 1.9 \\
\hline f.6-1 & 980 & 18 & 0.02 & 0.03 & $0.08589 \pm 0.40$ & $0.0829 \pm 0.83$ & $0.2268 \pm 0.83$ & $2.6864 \pm 0.92$ & $0.0609 \pm 8.08$ & $1336 \pm 8$ & $1318 \pm 10$ & 1.3 \\
\hline f. $8-1$ & 1013 & 18 & 0.02 & 0.04 & $0.08557 \pm 0.39$ & $0.0892 \pm 1.15$ & $0.2267 \pm 0.81$ & $2.6743 \pm 0.90$ & $0.0541 \pm 9.72$ & $1329 \pm 8$ & $1317 \pm 10$ & 0.9 \\
\hline \multicolumn{13}{|c|}{ JO6, Rio Fortuna Orthogneiss, zircon (UWA mount 04-76) } \\
\hline b.1-1 & 1391 & 227 & 0.17 & 0.03 & $0.10646 \pm 0.36$ & $0.0482 \pm 0.91$ & $0.3152 \pm 0.31$ & $4.6273 \pm 0.47$ & $0.0890 \pm 1.12$ & $1740 \pm 7$ & $1766 \pm 5$ & -1.5 \\
\hline b.2-1 & 357 & 68 & 0.20 & 0.00 & $0.0851 \pm 0.60$ & $0.0578 \pm 1.16$ & $0.2312 \pm 0.47$ & $2.7140 \pm 0.77$ & $0.0681 \pm 1.26$ & $1319 \pm 12$ & $1341 \pm 6$ & -1.7 \\
\hline b.3-1 & 554 & 48 & 0.09 & 0.00 & $0.08614 \pm 0.52$ & $0.0267 \pm 1.35$ & $0.2289 \pm 0.43$ & $2.7187 \pm 0.67$ & $0.0658 \pm 2.26$ & $1341 \pm 10$ & $1329 \pm 5$ & 0.9 \\
\hline b.4-1 & 179 & 49 & 0.28 & 0.03 & $0.10689 \pm 0.97$ & $0.0823 \pm 1.45$ & $0.3090 \pm 0.62$ & $4.5546 \pm 1.16$ & $0.0893 \pm 2.74$ & $1747 \pm 18$ & $1736 \pm 10$ & 0.6 \\
\hline b.5-1 & 266 & 54 & 0.21 & 0.22 & $0.08195 \pm 2.38$ & $0.0520 \pm 1.63$ & $0.2231 \pm 0.98$ & $2.5222 \pm 2.56$ & $0.0499 \pm 4.84$ & $1245 \pm 46$ & $1298 \pm 12$ & -4.2 \\
\hline b. $5-1 \mathrm{~b}$ & 286 & 51 & 0.18 & 0.04 & $0.08638 \pm 0.81$ & $0.0544 \pm 1.42$ & $0.2273 \pm 0.55$ & $2.7076 \pm 0.98$ & $0.0659 \pm 2.20$ & $1347 \pm 16$ & $1320 \pm 7$ & 2.0 \\
\hline b.5-2 & 238 & 83 & 0.36 & 0.21 & $0.10274 \pm 0.91$ & $0.1038 \pm 1.02$ & $0.2953 \pm 0.67$ & $4.1848 \pm 1.12$ & $0.0818 \pm 1.94$ & $1675 \pm 17$ & $1668 \pm 10$ & 0.4 \\
\hline b.5-3 & 293 & 53 & 0.19 & 0.22 & $0.10642 \pm 1.16$ & $0.0519 \pm 1.26$ & $0.2908 \pm 0.55$ & $4.2678 \pm 1.26$ & $0.0739 \pm 6.11$ & $1740 \pm 21$ & $1645 \pm 8$ & 5.4 \\
\hline b.7-1 & 310 & 75 & 0.25 & 0.16 & $0.10650 \pm 0.70$ & $0.0569 \pm 1.87$ & $0.3086 \pm 0.53$ & $4.5323 \pm 0.88$ & $0.0664 \pm 2.89$ & $1741 \pm 13$ & $1734 \pm 8$ & 0.4 \\
\hline b.8-1 & 734 & 58 & 0.08 & 0.02 & $0.09154 \pm 0.48$ & $0.0243 \pm 1.21$ & $0.2493 \pm 0.34$ & $3.1463 \pm 0.59$ & $0.0711 \pm 2.86$ & $1458 \pm 9$ & $1435 \pm 4$ & 1.6 \\
\hline b.8-2 & 470 & 77 & 0.17 & 0.00 & $0.10842 \pm 1.13$ & $0.0486 \pm 1.26$ & $0.3276 \pm 0.56$ & $4.8967 \pm 1.26$ & $0.0926 \pm 2.02$ & $1773 \pm 21$ & $1827 \pm 9$ & -3.0 \\
\hline b. $8-3$ & 621 & 69 & 0.11 & 0.00 & $0.08854 \pm 0.53$ & $0.0288 \pm 1.48$ & $0.2417 \pm 0.37$ & $2.9508 \pm 0.64$ & $0.0576 \pm 2.73$ & $1394 \pm 10$ & $1396 \pm 5$ & -0.1 \\
\hline b.11-1 & 315 & 88 & 0.29 & 0.07 & $0.10748 \pm 0.67$ & $0.0830 \pm 1.00$ & $0.3086 \pm 0.53$ & $4.5745 \pm 0.85$ & $0.0870 \pm 1.60$ & $1757 \pm 12$ & $1734 \pm 8$ & 1.3 \\
\hline b.11-2 & 610 & 70 & 0.12 & 0.01 & $0.08602 \pm 0.57$ & $0.0345 \pm 1.24$ & $0.2338 \pm 0.40$ & $2.7734 \pm 0.69$ & $0.0675 \pm 2.18$ & $1339 \pm 11$ & $1354 \pm 5$ & -1.2 \\
\hline b.13-1 & 218 & 60 & 0.29 & 0.05 & $0.10777 \pm 0.83$ & $0.0800 \pm 1.19$ & $0.3126 \pm 0.62$ & $4.6463 \pm 1.03$ & $0.0863 \pm 2.26$ & $1762 \pm 15$ & $1754 \pm 9$ & 0.5 \\
\hline b.14-1 & 236 & 49 & 0.21 & 0.18 & $0.10722 \pm 0.86$ & $0.0617 \pm 1.29$ & $0.3123 \pm 0.67$ & $4.6189 \pm 1.08$ & $0.0847 \pm 3.16$ & $1753 \pm 16$ & $1752 \pm 10$ & 0.1 \\
\hline b.15-1 & 249 & 64 & 0.26 & 0.00 & $0.10791 \pm 0.84$ & $0.0759 \pm 1.06$ & $0.3163 \pm 0.55$ & $4.7067 \pm 1.00$ & $0.0890 \pm 1.62$ & $1764 \pm 15$ & $1772 \pm 8$ & -0.4 \\
\hline \multicolumn{13}{|c|}{ J05, Lomas Manechi gneiss, zircon (UWA mount 04-78) } \\
\hline f.1-1 & 1489 & 164 & 0.11 & 0.04 & $0.08566 \pm 0.32$ & $0.0336 \pm 0.75$ & $0.2274 \pm 0.28$ & $2.6858 \pm 0.42$ & $0.0656 \pm 1.07$ & $1331 \pm 6$ & $1321 \pm 3$ & 0.7 \\
\hline f.1-2 & 1370 & 136 & 0.10 & 0.04 & $0.08561 \pm 0.34$ & $0.0300 \pm 0.81$ & $0.2285 \pm 0.29$ & $2.6970 \pm 0.44$ & $0.0647 \pm 1.36$ & $1330 \pm 6$ & $1326 \pm 3$ & 0.2 \\
\hline f.1-3 & 1353 & 148 & 0.11 & 0.02 & $0.08613 \pm 0.37$ & $0.0330 \pm 0.90$ & $0.2278 \pm 0.34$ & $2.7050 \pm 0.50$ & $0.0658 \pm 1.16$ & $1341 \pm 7$ & $1323 \pm 4$ & 1.4 \\
\hline f. $2-1$ & 3963 & 217 & 0.06 & 0.00 & $0.08581 \pm 0.20$ & $0.0170 \pm 0.66$ & $0.2299 \pm 0.20$ & $2.7202 \pm 0.28$ & $0.0686 \pm 0.99$ & $1334 \pm 4$ & $1334 \pm 2$ & 0.0 \\
\hline f.2-2 & 166 & 67 & 0.42 & 0.06 & $0.08505 \pm 1.03$ & $0.1213 \pm 1.18$ & $0.2249 \pm 0.63$ & $2.6521 \pm 1.05$ & $0.0644 \pm 1.73$ & $1317 \pm 20$ & $1310 \pm 8$ & 0.5 \\
\hline f.4-1 & 1569 & 91 & 0.06 & 0.01 & $0.08588 \pm 0.30$ & $0.0179 \pm 0.99$ & $0.2266 \pm 0.25$ & $2.6838 \pm 0.39$ & $0.0665 \pm 1.25$ & $1336 \pm 6$ & $1317 \pm 3$ & 1.4 \\
\hline \multicolumn{13}{|c|}{ J018, Santa Rita Orthogneiss, zircon (UWA mount 04-78) } \\
\hline h.1-1 & 95 & 258 & 2.80 & 0.15 & $0.08453 \pm 1.62$ & $0.8139 \pm 0.80$ & $0.2306 \pm 0.91$ & $2.6877 \pm 1.86$ & $0.0668 \pm 1.24$ & $1305 \pm 31$ & $1338 \pm 11$ & -2.5 \\
\hline h.1-2 & 49 & 70 & 1.49 & 0.12 & $0.08759 \pm 1.73$ & $0.4397 \pm 1.44$ & $0.2246 \pm 1.31$ & $2.7118 \pm 2.17$ & $0.0658 \pm 2.43$ & $1320 \pm 65$ & $1302 \pm 16$ & 1.4 \\
\hline h. $2-1$ & 325 & 360 & 1.15 & 0.04 & $0.08512 \pm 0.73$ & $0.3381 \pm 0.59$ & $0.2246 \pm 0.50$ & $2.6364 \pm 0.88$ & $0.0662 \pm 0.80$ & $1318 \pm 14$ & $1306 \pm 6$ & 0.9 \\
\hline h.3-1 & 448 & 187 & 0.43 & 0.00 & $0.08530 \pm 0.54$ & $0.1256 \pm 0.73$ & $0.2287 \pm 0.48$ & $2.6895 \pm 0.72$ & $0.0666 \pm 0.88$ & $1322 \pm 11$ & $1328 \pm 6$ & -0.4 \\
\hline h.3-2 & 410 & 182 & 0.46 & 0.06 & $0.08434 \pm 0.85$ & $0.1331 \pm 0.77$ & $0.2263 \pm 0.45$ & $2.6321 \pm 0.96$ & $0.0651 \pm 1.01$ & $1300 \pm 17$ & $1315 \pm 5$ & -1.2 \\
\hline h. $3-3$ & 299 & 110 & 0.38 & 0.09 & $0.08626 \pm 0.71$ & $0.1130 \pm 1.01$ & $0.2300 \pm 0.54$ & $2.7350 \pm 0.89$ & $0.0673 \pm 1.59$ & $1330 \pm 17$ & $1333 \pm 7$ & -0.2 \\
\hline h.4-1 & 131 & 108 & 0.86 & 0.13 & $0.08486 \pm 1.49$ & $0.2583 \pm 1.02$ & $0.2244 \pm 1.07$ & $2.6269 \pm 1.82$ & $0.0671 \pm 1.69$ & $1313 \pm 29$ & $1305 \pm 13$ & 0.6 \\
\hline h. $5-1$ & 394 & 59 & 0.15 & 0.06 & $0.10536 \pm 0.53$ & $0.0433 \pm 1.58$ & $0.3033 \pm 0.44$ & $4.4060 \pm 0.68$ & $0.0828 \pm 2.28$ & $1746 \pm 21$ & $1708 \pm 7$ & 0.8 \\
\hline h.6-1 & 129 & 132 & 1.06 & 0.76 & $0.08958 \pm 1.06$ & $0.3138 \pm 1.22$ & $0.2241 \pm 0.82$ & $2.7685 \pm 1.34$ & $0.0627 \pm 2.22$ & $1261 \pm 49$ & $1293 \pm 10$ & -2.5 \\
\hline h. $8-1$ & 148 & 218 & 1.53 & 0.13 & $0.08567 \pm 1.25$ & $0.4476 \pm 0.78$ & $0.2196 \pm 0.82$ & $2.5949 \pm 1.48$ & $0.0641 \pm 1.19$ & $1331 \pm 24$ & $1280 \pm 9$ & 3.9 \\
\hline \multicolumn{13}{|c|}{ J010, San Andrés Granite, zircon (UWA mount 04-118) } \\
\hline g.2-1 & 241 & 97 & 0.42 & 0.06 & $0.08360 \pm 0.74$ & $0.1225 \pm 0.97$ & $0.2275 \pm 0.51$ & $2.6886 \pm 0.90$ & $0.0674 \pm 1.19$ & $1332 \pm 14$ & $1321 \pm 6$ & 0.8 \\
\hline g.3-1 & 259 & 210 & 0.84 & 0.24 & $0.08543 \pm 1.56$ & $0.2467 \pm 0.70$ & $0.2254 \pm 0.52$ & $2.6549 \pm 1.64$ & $0.0675 \pm 1.59$ & $1325 \pm 30$ & $1310 \pm 6$ & 1.1 \\
\hline g.5-1 & 372 & 205 & 0.57 & 0.01 & $0.08285 \pm 0.78$ & $0.1703 \pm 0.72$ & $0.2253 \pm 0.62$ & $2.5738 \pm 0.99$ & $0.0671 \pm 1.15$ & $1266 \pm 15$ & $1310 \pm 7$ & -3.5 \\
\hline g.5-2 & 324 & 133 & 0.42 & 0.05 & $0.08333 \pm 0.69$ & $0.1210 \pm 0.91$ & $0.2240 \pm 0.49$ & $2.5734 \pm 0.84$ & $0.0647 \pm 1.09$ & $1277 \pm 13$ & $1303 \pm 6$ & -2.0 \\
\hline g.6-1 & 139 & 126 & 0.94 & 0.02 & $0.08368 \pm 1.01$ & $0.2796 \pm 1.07$ & $0.2231 \pm 0.80$ & $2.5744 \pm 1.29$ & $0.0665 \pm 1.34$ & $1285 \pm 20$ & $1298 \pm 9$ & -1.0 \\
\hline
\end{tabular}




\begin{tabular}{|c|c|c|c|c|c|c|c|c|c|c|c|c|}
\hline \multirow[t]{2}{*}{ Grain spot } & \multirow[t]{2}{*}{$\mathrm{U}(\mathrm{ppm})$} & \multirow[t]{2}{*}{ Th (ppm) } & \multirow[t]{2}{*}{ Th U } & \multirow[t]{2}{*}{$4 \mathrm{f} 206(\%)$} & \multicolumn{5}{|l|}{ Isotopic ratios } & \multicolumn{2}{|l|}{ Ages } & \multirow[t]{2}{*}{ Disc. \% } \\
\hline & & & & & ${ }^{207} \mathrm{~Pb} / 206 \mathrm{~Pb}$ & ${ }^{208} \mathrm{~Pb} / 206 \mathrm{~Pb}$ & ${ }^{206} \mathrm{~Pb} /{ }^{238} \mathrm{U}$ & ${ }^{207} \mathrm{~Pb} /{ }^{235} \mathrm{U}$ & ${ }^{208} \mathrm{~Pb} /{ }^{232} \mathrm{Th}$ & ${ }^{207} \mathrm{~Pb} / 206 \mathrm{~Pb}$ & ${ }^{206} \mathrm{~Pb} /{ }^{238} \mathrm{U}$ & \\
\hline g.7-1 & 95 & 61 & 0.66 & 0.03 & $0.08380 \pm 1.24$ & $0.1944 \pm 1.35$ & $0.2200 \pm 0.86$ & $2.5420 \pm 1.51$ & $0.0646 \pm 1.63$ & $1288 \pm 24$ & $1282 \pm 10$ & 0.5 \\
\hline g.10-1 & 116 & 81 & 0.73 & 0.09 & $0.08349 \pm 1.84$ & $0.2120 \pm 1.15$ & $0.2343 \pm 0.89$ & $2.6978 \pm 2.04$ & $0.0679 \pm 1.85$ & $1281 \pm 36$ & $1357 \pm 11$ & -6.0 \\
\hline g.11-1 & 352 & 139 & 0.41 & 0.02 & $0.08274 \pm 0.87$ & $0.1227 \pm 0.79$ & $0.2218 \pm 0.43$ & $2.5299 \pm 0.97$ & $0.0672 \pm 0.96$ & $1263 \pm 17$ & $1291 \pm 5$ & -2.2 \\
\hline g.12-1 & 309 & 144 & 0.48 & 0.12 & $0.08366 \pm 1.15$ & $0.1418 \pm 0.80$ & $0.2270 \pm 0.47$ & $2.6182 \pm 1.24$ & $0.0656 \pm 1.85$ & $1285 \pm 22$ & $1319 \pm 6$ & -2.6 \\
\hline g.16-1 & 121 & 81 & 0.69 & 0.20 & $0.08395 \pm 2.70$ & $0.2062 \pm 1.14$ & $0.2194 \pm 0.90$ & $2.5415 \pm 2.85$ & $0.0640 \pm 3.20$ & $1293 \pm 53$ & $1279 \pm 10$ & 1.1 \\
\hline \multicolumn{13}{|c|}{ MQ23, Laje S-type granite, zircon (UWA mount 05-60) } \\
\hline d.1-1 & 138 & 86 & 0.65 & 0.00 & $0.09523 \pm 0.91$ & $0.1926 \pm 1.04$ & $0.2658 \pm 0.97$ & $3.4896 \pm 1.33$ & $0.0794 \pm 1.45$ & $1533 \pm 17$ & $1519 \pm 13$ & 0.9 \\
\hline d. $2-1$ & 303 & 118 & 0.40 & 0.00 & $0.08614 \pm 0.67$ & $0.1169 \pm 0.94$ & $0.2299 \pm 0.78$ & $2.7311 \pm 1.03$ & $0.0670 \pm 1.22$ & $1341 \pm 13$ & $1334 \pm 9$ & 0.5 \\
\hline d. $2-2$ & 147 & 59 & 0.42 & 0.00 & $0.09731 \pm 1.08$ & $0.1249 \pm 1.35$ & $0.2716 \pm 0.88$ & $3.6438 \pm 1.39$ & $0.0815 \pm 1.72$ & $1573 \pm 20$ & $1549 \pm 12$ & 1.6 \\
\hline d. $3-1$ & 521 & 207 & 0.41 & 0.02 & $0.09710 \pm 0.45$ & $0.1189 \pm 0.64$ & $0.2744 \pm 0.68$ & $3.6739 \pm 0.82$ & $0.0795 \pm 0.96$ & $1569 \pm 8$ & $1563 \pm 9$ & 0.4 \\
\hline d. $4-1$ & 181 & 91 & 0.52 & 0.03 & $0.09589 \pm 0.80$ & $0.1517 \pm 1.00$ & $0.2764 \pm 0.89$ & $3.6546 \pm 1.19$ & $0.0805 \pm 1.38$ & $1546 \pm 15$ & $1573 \pm 12$ & -1.8 \\
\hline d. $4-2$ & 100 & 65 & 0.68 & 0.07 & $0.09624 \pm 1.19$ & $0.2027 \pm 1.27$ & $0.2629 \pm 1.13$ & $3.4892 \pm 1.64$ & $0.0782 \pm 1.78$ & $1552 \pm 22$ & $1505 \pm 15$ & 3.1 \\
\hline d.5-1 & 84 & 39 & 0.48 & 0.00 & $0.09433 \pm 1.11$ & $0.1459 \pm 1.47$ & $0.2729 \pm 1.16$ & $3.5497 \pm 1.61$ & $0.0839 \pm 1.87$ & $1515 \pm 21$ & $1556 \pm 16$ & -2.7 \\
\hline d.5-1 & 86 & 40 & 0.48 & 0.00 & $0.09572 \pm 1.56$ & $0.1450 \pm 1.70$ & $0.2715 \pm 1.30$ & $3.5836 \pm 2.03$ & $0.0846 \pm 2.63$ & $1542 \pm 29$ & $1549 \pm 18$ & -0.4 \\
\hline d.5-2 & 860 & 282 & 0.34 & 0.01 & $0.09512 \pm 0.39$ & $0.1031 \pm 0.59$ & $0.2809 \pm 0.37$ & $3.6834 \pm 0.53$ & $0.0855 \pm 0.70$ & $1530 \pm 7$ & $1596 \pm 5$ & -4.3 \\
\hline d.7-1 & 163 & 63 & 0.40 & 0.15 & $0.09513 \pm 1.13$ & $0.1235 \pm 1.30$ & $0.2723 \pm 0.84$ & $3.5716 \pm 1.41$ & $0.0819 \pm 1.99$ & $1531 \pm 21$ & $1552 \pm 12$ & -1.4 \\
\hline d.10-1 & 1168 & 14 & 0.01 & 0.02 & $0.08680 \pm 0.36$ & $0.0039 \pm 2.63$ & $0.2268 \pm 0.62$ & $2.7140 \pm 0.71$ & - \pm- & $1354 \pm 7$ & $1317 \pm 7$ & 2.7 \\
\hline d.11-1 & 1674 & 59 & 0.04 & 0.00 & $0.08635 \pm 0.28$ & $0.0107 \pm 1.23$ & $0.2280 \pm 0.61$ & $2.7151 \pm 0.67$ & - \pm- & $1345 \pm 5$ & $1324 \pm 7$ & 1.6 \\
\hline d.11-2 & 182 & 72 & 0.41 & 0.00 & $0.09584 \pm 0.83$ & $0.1223 \pm 1.09$ & $0.2658 \pm 0.88$ & $3.5121 \pm 1.21$ & $0.0800 \pm 1.55$ & $1545 \pm 16$ & $1519 \pm 12$ & 1.6 \\
\hline d.12-1 & 1862 & 39 & 0.02 & 0.03 & $0.08629 \pm 0.29$ & $0.0068 \pm 1.60$ & $0.2441 \pm 0.25$ & $2.9045 \pm 0.38$ & - \pm- & $1342 \pm 6$ & $1408 \pm 3$ & -4.9 \\
\hline d.14-1 & 134 & 42 & 0.32 & 0.00 & $0.08585 \pm 1.00$ & $0.0946 \pm 1.54$ & $0.2328 \pm 1.00$ & $2.7554 \pm 1.41$ & $0.0685 \pm 1.83$ & $1335 \pm 19$ & $1349 \pm 12$ & 0.1 \\
\hline d.15-1 & 322 & 155 & 0.50 & 0.02 & $0.13806 \pm 0.43$ & $0.1450 \pm 0.64$ & $0.3952 \pm 0.75$ & $7.5229 \pm 0.86$ & $0.1152 \pm 1.01$ & $2203 \pm 7$ & $2147 \pm 14$ & 0.7 \\
\hline d.16-1 & 1069 & 6 & 0.01 & 0.25 & $0.08729 \pm 0.37$ & $0.0066 \pm 2.49$ & $0.2212 \pm 0.62$ & $2.6621 \pm 0.73$ & - \pm- & $1356 \pm 10$ & $1288 \pm 7$ & 5.0 \\
\hline d.17-1 & 655 & 254 & 0.40 & 0.03 & $0.11165 \pm 0.36$ & $0.1146 \pm 0.54$ & $0.3263 \pm 0.65$ & $5.0239 \pm 0.74$ & $0.0928 \pm 0.87$ & $1826 \pm 6$ & $1821 \pm 10$ & 0.3 \\
\hline d.19-1 & 187 & 78 & 0.43 & 0.08 & $0.10406 \pm 0.71$ & $0.1269 \pm 1.05$ & $0.3066 \pm 0.87$ & $4.3985 \pm 1.12$ & $0.0896 \pm 1.41$ & $1698 \pm 13$ & $1724 \pm 13$ & -1.5 \\
\hline d.19-2 & 263 & 174 & 0.68 & 0.15 & $0.10662 \pm 0.75$ & $0.2044 \pm 0.77$ & $0.3149 \pm 0.66$ & $4.6288 \pm 1.00$ & $0.0929 \pm 1.14$ & $1742 \pm 14$ & $1765 \pm 10$ & -1.3 \\
\hline d.21-1 & 607 & 117 & 0.20 & 0.15 & $0.08586 \pm 0.78$ & $0.0763 \pm 0.95$ & $0.2020 \pm 0.53$ & $2.3918 \pm 0.94$ & $0.0743 \pm 1.97$ & $1335 \pm 15$ & $1186 \pm 6$ & 11.1 \\
\hline \multicolumn{13}{|c|}{ JP3, lata sillimanite gneiss, zircon (UWA mounts B68 and B75) } \\
\hline a.1-1 & 100 & 123 & 1.27 & 0.00 & $0.09041 \pm 1.55$ & $0.0036 \pm 26.1$ & $0.2210 \pm 2.53$ & $2.7529 \pm 2.96$ & $0.0020 \pm 36.4$ & $1433 \pm 29$ & $1287 \pm 29$ & 10.2 \\
\hline a.2-1 & 79 & 34 & 0.44 & 0.05 & $0.08541 \pm 0.94$ & $0.1350 \pm 1.5$ & $0.2220 \pm 0.65$ & $2.6150 \pm 1.14$ & $0.0673 \pm 1.8$ & $1325 \pm 18$ & $1293 \pm 8$ & 2.5 \\
\hline a.4-1 & 125 & 147 & 1.21 & 0.00 & $0.09527 \pm 2.38$ & $0.0132 \pm 7.1$ & $0.4316 \pm 3.38$ & $5.6624 \pm 4.11$ & $0.0105 \pm 19.5$ & $1531 \pm 44$ & $2313 \pm 66$ & -51.1 \\
\hline a.7-2 & 137 & 62 & 0.47 & 0.10 & $0.09550 \pm 1.09$ & $0.1337 \pm 1.48$ & $0.2591 \pm 0.99$ & $3.4111 \pm 1.47$ & $0.0729 \pm 1.71$ & $1537 \pm 21$ & $1485 \pm 13$ & 3.4 \\
\hline j.2-1 & 379 & 21 & 0.06 & 0.01 & $0.08494 \pm 0.64$ & $0.0164 \pm 2.0$ & $0.2315 \pm 0.46$ & $2.7121 \pm 0.79$ & $0.0662 \pm 2.3$ & $1314 \pm 12$ & $1343 \pm 6$ & -2.1 \\
\hline j.3-1 & 34 & 14 & 0.43 & 0.41 & $0.08051 \pm 3.70$ & $0.1272 \pm 2.7$ & $0.2225 \pm 1.49$ & $2.4734 \pm 3.92$ & $0.0613 \pm 6.1$ & $1212 \pm 71$ & $1295 \pm 17$ & -6.8 \\
\hline j. $8-1$ & 209 & 74 & 0.36 & 0.17 & $0.09585 \pm 0.89$ & $0.1077 \pm 1.4$ & $0.2703 \pm 0.67$ & $3.5736 \pm 1.11$ & $0.0774 \pm 2.0$ & $1546 \pm 17$ & $1542 \pm 9$ & 0.2 \\
\hline \multicolumn{13}{|c|}{ J08, Las Madres garnet gneiss, Chiquitania Complex, zircon (UWA mount 04-78) } \\
\hline g.1-1 & 330 & 157 & 0.49 & 0.00 & $0.10339 \pm 0.59$ & $0.1399 \pm 0.73$ & $0.2997 \pm 0.49$ & $4.2726 \pm 0.77$ & $0.0852 \pm 0.90$ & $1686 \pm 11$ & $1690 \pm 7$ & -0.2 \\
\hline g.2-1 & 887 & 254 & 0.30 & 0.02 & $0.10081 \pm 0.33$ & $0.0869 \pm 0.55$ & $0.2898 \pm 0.27$ & $4.0287 \pm 0.43$ & $0.0849 \pm 0.66$ & $1639 \pm 6$ & $1641 \pm 4$ & -0.1 \\
\hline g.3-1 & 377 & 167 & 0.46 & 0.01 & $0.10325 \pm 0.49$ & $0.1324 \pm 0.65$ & $0.3061 \pm 0.49$ & $4.3578 \pm 0.69$ & $0.0889 \pm 0.90$ & $1683 \pm 9$ & $1721 \pm 7$ & -2.3 \\
\hline g.4-1 & 231 & 95 & 0.42 & 0.03 & $0.10379 \pm 0.76$ & $0.1217 \pm 1.00$ & $0.2915 \pm 0.60$ & $4.1720 \pm 0.96$ & $0.0835 \pm 1.39$ & $1693 \pm 14$ & $1649 \pm 9$ & 2.6 \\
\hline g.4-2 & 842 & 418 & 0.51 & 0.00 & $0.10271 \pm 0.34$ & $0.1460 \pm 0.46$ & $0.2980 \pm 0.33$ & $4.2208 \pm 0.47$ & $0.0848 \pm 0.57$ & $1674 \pm 6$ & $1682 \pm 5$ & -0.5 \\
\hline g.5-1 & 372 & 11 & 0.03 & 0.04 & $0.07689 \pm 0.72$ & $0.0100 \pm 3.60$ & $0.1921 \pm 0.58$ & $2.0347 \pm 0.93$ & - \pm- & $1118 \pm 15$ & $1133 \pm 6$ & -1.3 \\
\hline g.5-2 & 86 & 37 & 0.45 & 0.42 & $0.09980 \pm 1.53$ & $0.1283 \pm 1.57$ & $0.3002 \pm 1.16$ & $4.1313 \pm 1.91$ & $0.0803 \pm 2.99$ & $1620 \pm 28$ & $1692 \pm 17$ & -4.5 \\
\hline g.6-1 & 902 & 466 & 0.53 & 0.02 & $0.10347 \pm 0.37$ & $0.1578 \pm 0.48$ & $0.2974 \pm 0.30$ & $4.2422 \pm 0.47$ & $0.0875 \pm 0.57$ & $1687 \pm 7$ & $1678 \pm 4$ & 0.5 \\
\hline g.7-1 & 683 & 150 & 0.23 & 0.00 & $0.09612 \pm 0.43$ & $0.0695 \pm 0.80$ & $0.2774 \pm 0.37$ & $3.6759 \pm 0.57$ & $0.0846 \pm 0.99$ & $1550 \pm 8$ & $1578 \pm 5$ & -1.8 \\
\hline g.8-1 & 456 & 41 & 0.09 & 0.08 & $0.08654 \pm 0.56$ & $0.0295 \pm 1.49$ & $0.2316 \pm 0.49$ & $2.7631 \pm 0.74$ & - \pm- & $1350 \pm 11$ & $1343 \pm 6$ & 0.6 \\
\hline g.8-2 & 113 & 47 & 0.43 & 0.09 & $0.10317 \pm 1.11$ & $0.1287 \pm 1.43$ & $0.2884 \pm 0.85$ & $4.1037 \pm 1.39$ & $0.0848 \pm 2.04$ & $1682 \pm 20$ & $1634 \pm 12$ & 2.9 \\
\hline g.9-1 & 46 & 26 & 0.59 & 0.31 & $0.10471 \pm 2.28$ & $0.1689 \pm 2.22$ & $0.3163 \pm 1.41$ & $4.5667 \pm 2.68$ & $0.0945 \pm 3.93$ & $1709 \pm 42$ & $1772 \pm 22$ & -3.6 \\
\hline g.10-1 & 183 & 94 & 0.53 & 0.14 & $0.10215 \pm 0.69$ & $0.1529 \pm 0.89$ & $0.3048 \pm 0.69$ & $4.2925 \pm 0.98$ & $0.0863 \pm 1.20$ & $1664 \pm 13$ & $1715 \pm 10$ & -3.1 \\
\hline g.11-1 & 181 & 115 & 0.65 & 0.15 & $0.10192 \pm 0.88$ & $0.1931 \pm 0.92$ & $0.2926 \pm 0.93$ & $4.1119 \pm 1.29$ & $0.0850 \pm 1.45$ & $1659 \pm 16$ & $1655 \pm 14$ & 0.3 \\
\hline g.12-1 & 560 & 42 & 0.08 & 0.01 & $0.08502 \pm 0.51$ & $0.0229 \pm 1.55$ & $0.2187 \pm 0.44$ & $2.5642 \pm 0.68$ & - \pm- & $1317 \pm 10$ & $1275 \pm 5$ & 3.1 \\
\hline g.12-2 & 301 & 116 & 0.40 & 0.07 & $0.10156 \pm 0.68$ & $0.1147 \pm 0.85$ & $0.2924 \pm 0.52$ & $4.0947 \pm 0.85$ & $0.0829 \pm 1.33$ & $1653 \pm 13$ & $1653 \pm 8$ & 0.0 \\
\hline
\end{tabular}


to separate REE, followed by Sm and Nd separation using anionic poly-Teflon HDEHP LN-B50-A (100-200 mesh) resin according to Patchett and Ruiz (1987). Each sample was dried to a solid and then loaded with $0.25 \mathrm{~N} \mathrm{H}_{3} \mathrm{PO} 4$ on an appropriated filament (single Ta for $\mathrm{Sm}$ and triple $\mathrm{Ta}-\mathrm{Re}-\mathrm{Ta}$ for $\mathrm{Nd}$ ). Isotopic ratios were measured in static mode with a VG Sector 54 multi-collector mass spectrometer at the Laboratório de Geologia Isotópica of the Universidade Federal do Rio Grande do Sul (Brazil). We normally collected $100-120$ ratios with a $1-\mathrm{V} 88 \mathrm{Sr}$ beam and a $0.5-1-\mathrm{V}{ }^{144} \mathrm{Nd}$ beam. $\mathrm{Nd}$ ratios were normalized to ${ }^{146} \mathrm{Nd} /{ }^{144} \mathrm{Nd}=0.7219$. All analyses were adjusted for instrumental bias due to periodic adjustment of collector positions as monitored by measurements of our internal standards. Measurements for the Nd Spex ${ }^{143} \mathrm{Nd} /{ }^{144} \mathrm{Nd}=0.511130( \pm 0.000010)$. Total blanks average were $<100 \mathrm{pg}$ for $\mathrm{Sm}$ and $<500 \mathrm{pg}$ for Nd. Correction for blank was insignificant for $\mathrm{Nd}$ isotopic compositions and generally insignificant for $\mathrm{Sm} / \mathrm{Nd}$ ratios. Neodymium crustal residence ages $\left(T_{\mathrm{DM}}\right)$ were calculated following the depleted mantle model of De Paolo (1981). $\mathrm{Nd}_{\mathrm{t}}$ values were calculated using the $\mathrm{U}-\mathrm{Pb}$ SHRIMP or U-Pb TIMS ages from this work and from the literature. For three samples lacking U-Pb data the assumed ages are based on stratigraphic correlation (Table 3 ).

\section{Geochronological results and discussion}

\section{1. $U-P b$ SHRIMP}

Analytical results are grouped into two provinces (RondôniaJuruena and Sunsás) and described in chronological order, from the oldest to the youngest samples, following the order of Table 1. This table also shows the geographic coordinates and the dated minerals for each sample. The $\mathrm{U}-\mathrm{Pb}$ data are presented in Table 2 and a summary of the results in Table 3.

\subsubsection{Rondônia-Juruena Province}

4.1.1.1. Lomas Manechi granulitic gneiss (JO3). The outcrop is located $7 \mathrm{~km}$ west of Ascención in eastern Bolivia, Santa Cruz Department (Fig. 4). The rock is dark grey displaying an irregular foliation (nebulitic) and has pyroxene. Zircon grains (120-250 $\mu \mathrm{m}$ in diameter) are short prisms and rounded grains; all have metamorphic rims, some large enough to be analysed by SHRIMP. The cores are euhedrally zoned and truncated by the metamorphic rims. The zoned magmatic population of zircon has a ${ }^{207} \mathrm{~Pb} /{ }^{206} \mathrm{~Pb}$ age of $1818 \pm 13 \mathrm{Ma}$ (MSWD $=2.6 ; n=6$ ) whereas the metamorphic rims have the weighted mean age of $1338 \pm 21$ Ma (Table 2; Fig. 5). Because this rim age has low precision, monazite from the same sample was also dated (Fig. 5) providing a more precise age of $1339 \pm 4 \mathrm{Ma}$ (MSWD $=1.15 ; n=6)$, which is taken as a better estimate of the metamorphic peak. Monazite grains (100-200 $\mu \mathrm{m})$ are yellowish, clear, rounded, with irregular internal zoning. Because both zircon (partially) and monazite (fully) recrystallized or overgrew existing grains, the metamorphic grade is high and is interpreted as formed during the Candeias collisional orogeny. Its magmatic age of $1818 \mathrm{Ma}$ is the oldest age in Bolivia and is comparable to the basement ages within the Juruena region in northern Mato Grosso, particularly the Juruena Granodiorite (1817-1848 Ma; JICAMMAJ, 2000). The rock also has two inherited grains with ages at ca. $1874 \mathrm{Ma}$. These ages are equivalent to the ages of late-Tapajós volcano-plutonism (Iriri Group and Maloquinha Suite; Santos et al., 2004a,b). Sample JO3 could be a fragment of Juruena-type crust within the Sunsás Orogen in Bolivia.

4.1.1.2. Jamari Complex quartz-diorite (GR35). This sample comes from an outcrop located $5 \mathrm{~km}$ to the south of Presidente Médici (Fig. 3) along BR364 highway in Rondônia. The rock is fine to medium-grained, foliated, with plagioclase porphyroclasts in a 
Table 3

Summary of the U-Pb ages and Sm-Nd model ages discussed in text

\begin{tabular}{|c|c|c|c|c|c|c|c|c|}
\hline \multirow[t]{2}{*}{ Sample } & \multirow[t]{2}{*}{ Rock } & \multirow[t]{2}{*}{ Unit } & \multicolumn{3}{|l|}{ Ages } & \multirow[t]{2}{*}{$T_{\mathrm{DM}(\mathrm{t})}$} & \multirow[t]{2}{*}{$\varepsilon_{\mathrm{Nd}}$} & \multirow[t]{2}{*}{ Ref } \\
\hline & & & Metamorphic & Magmatic & Detrital/inherited & & & \\
\hline JO3 & Granulitic gneiss & Lomas Manechi & $1339 \pm 4$ & $1818 \pm 13$ & & 2.07 & +0.53 & 1 \\
\hline GR35 & Quartz-diorite & Jamari & $1649 \pm 5$ & $1758 \pm 7$ & & 2.00 & +1.57 & 1 \\
\hline GR59 & Tonalite & Jamari & $1677 \pm 6$ & $1753 \pm 9$ & & 1.90 & +1.95 & 1 \\
\hline JL78 & Tonalite & Jamari & $1334 \pm 7$ & $1738 \pm 6$ & & 1.95 & +1.04 & 1 \\
\hline MQ96 & Dacite & Roosevelt & & $1740 \pm 8$ & & 1.72 & +3.81 & 2 \\
\hline PT12 & Paragneiss & Ouro Preto & $1657 \pm 12$ & & & & & 2 \\
\hline $\mathrm{JO} 12$ & Orthogneiss & Refugio & & $1641 \pm 4$ & & 1.66 & +4.06 & 1 \\
\hline GR333 & Meta-granite & S. Providência & $1348 \pm 4$ & $1515 \pm 8$ & & 2.00 & -0.95 & 1 \\
\hline J014 & Tonalite & San Ramón & & $1429 \pm 4$ & & 1.57 & +2.32 & 1 \\
\hline JS39 & Monzogranite & Alto Candeias & & $1339 \pm 7$ & & & & 1 \\
\hline JL6 & S-type granite & Unnamed & $1339 \pm 3$ & & & & & 1 \\
\hline J09 & Gneiss & Las Madres & & 1330 & & 1.74 & -0.61 & 1 \\
\hline JO16 & Gneiss & Rio Branco & & 1330 & & 1.58 & +0.94 & 1 \\
\hline JO6 & Orthogneiss & Rio Fortuna & $1336 \pm 3$ & $1349 \pm 6$ & $1674,1772-1734$ & 2.06 & -3.83 & 1 \\
\hline $\mathrm{JO5}$ & Gneiss & Lomas Manechi & $1334 \pm 3$ & $1334 \pm 3$ & & 2.06 & -3.97 & 1 \\
\hline JO18 & Orthogneiss & Santa Rita & & $1319 \pm 6$ & 1746 & 1.96 & -2.57 & 1 \\
\hline J010 & Granite & San Andrés & & $1275 \pm 7$ & $1331 \pm 13$ & 1.68 & -0.15 & 1 \\
\hline GR66 & Paragneiss & N. Brasilândia & & & $<1160 \pm 14,1210,1290,1427,1753$ & & & 2 \\
\hline MQ23 & S-type granite & Laje & & $1110(?)$ & $1334 \pm 9,1356 \pm 10,1545,1826,2203$ & & & 1 \\
\hline JP3 & Sillimanite gneiss & Iata & & & $1210,1325,1433,1531,1546$ & & & 1 \\
\hline MT1 & Quartzite & Aguapeí & & & $<1171,1278,1447,1617,1660$ & & & 3 \\
\hline J013 & Rhyolite & Puquio & & $<1110$ & & 1.54 & $<-1.46$ & 1 \\
\hline JO8 & Garnet gneiss & Las Madres & $1118 \pm 15$ & & $1678,1640,1551,1351,1318$ & 1.86 & -4.88 & 1 \\
\hline $\mathrm{JO7}$ & Alkali granite & Velasco & & $136 \pm 2$ & & 0.74 & -2.37 & 1 \\
\hline
\end{tabular}

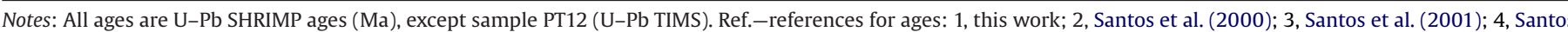
(2003). The ages in italic on "magmatic" column are ages estimated by correlation (see text). $T_{\mathrm{DM}(\mathrm{t})}$ model ages in Ga.

granoblastic matrix composed of quartz, plagioclase, epidote and amphibole. Mylonitic foliation averages $\mathrm{N} 15^{\circ} \mathrm{E}$, dipping is $60^{\circ} \mathrm{SE}$, and lineation plunges $55^{\circ} ; \mathrm{S} 70^{\circ} \mathrm{E}$. Local partial melting produced thin $(2-10 \mathrm{~cm}$ thick) quartz-K-feldspar veins with garnet. The quartz-diorite has a single population of zircon with crystals that are $50-200 \mu \mathrm{m}$ long, prismatic (aspect ratio 1:3), finely zoned, with no evidence of older cores. Two grains have metamorphic rims or metamorphic zones. The age of the magmatic population is $1758 \pm 7 \mathrm{Ma}$ (MSWD = 1.9; $n=8$; Fig. 6 ), a typical age of the Jamari Complex (Santos, 2003; Schobbenhaus et al., 2004). The metamorphic rims are younger: $1724 \pm 8 \mathrm{Ma}$ (rim d.17-2) and $1649 \pm 5 \mathrm{Ma}$ (rim d.2-1) and display very low Th/U ratios of 0.09 and 0.01
(Table 2) typical of metamorphic growth. The age of $1649 \mathrm{Ma}$ is identified as coeval with the Quatro Cachoeiras collision. Because no regional event is recognized at $1724 \mathrm{Ma}$ this U-Pb SHRIMP age is likely to be the result of spot analyses overlapping both the rim and the magmatic core.

4.1.1.3. Jamari Complex tonalite (GR59). This tonalite was collected about $21 \mathrm{~km} \mathrm{NW}$ of Ariquemes (Fig. 3) in the Madalena River Basin in Rondônia. It is a medium-grained tonalitic orthogneiss with regular, centimetric banding and folded quartz-K-feldspar veins. Texture is porphyroclastic and plagioclase porphyroclasts are enveloped by biotite-hornblende concentrates. The mylonitic

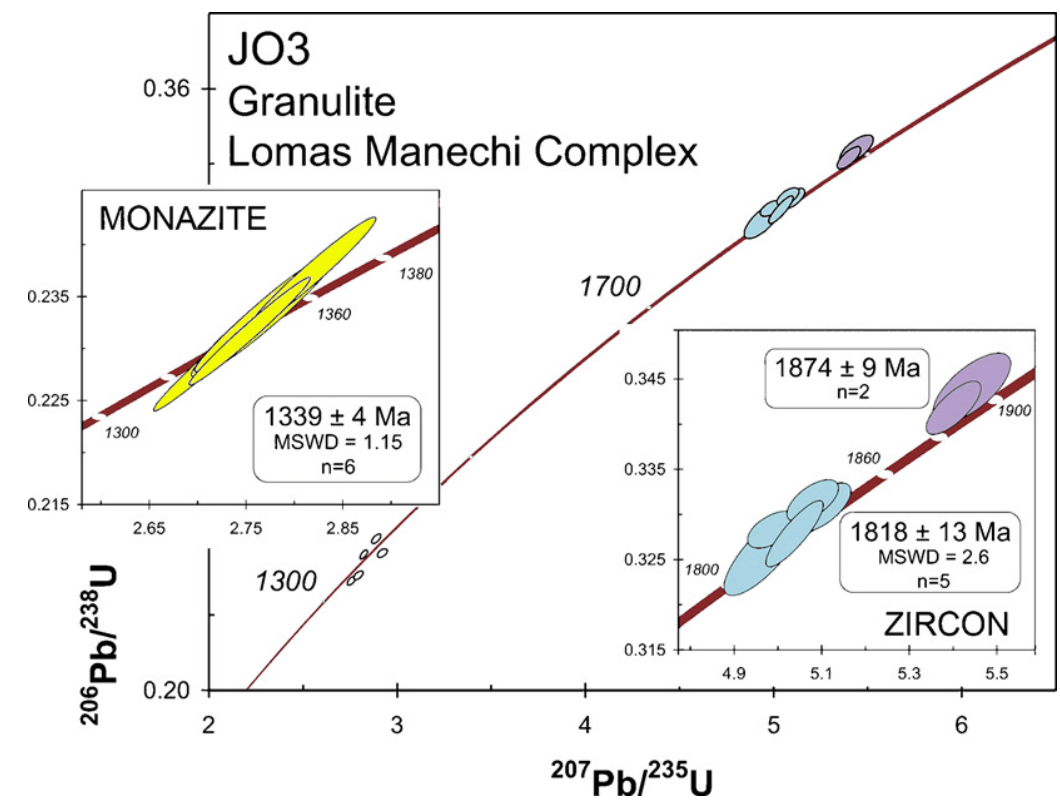

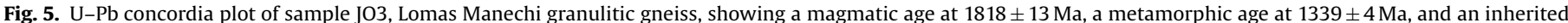
age at $1874 \pm 9 \mathrm{Ma}$. 


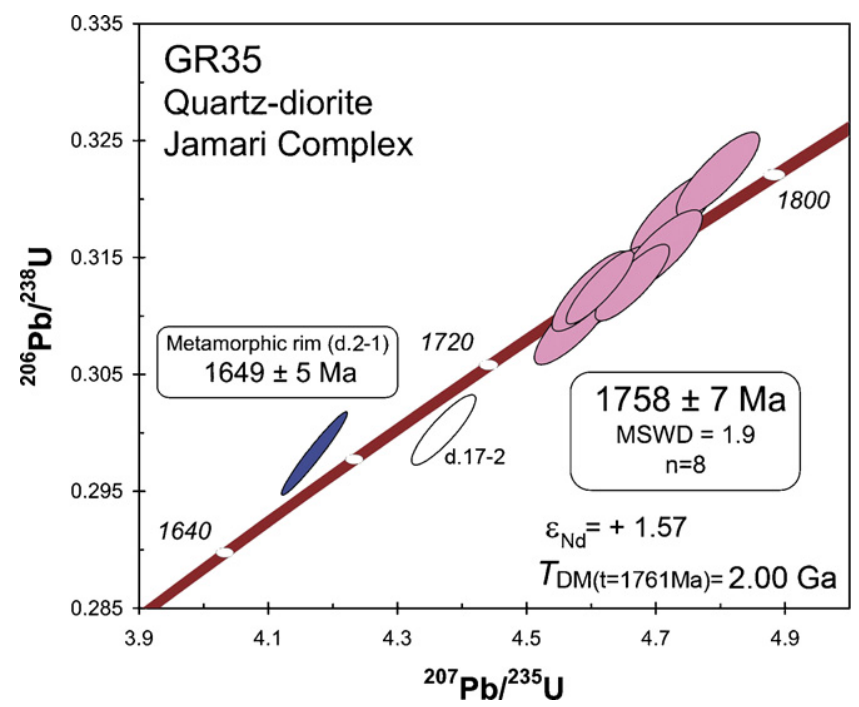

Fig. 6. Concordant ${ }^{207} \mathrm{~Pb} /{ }^{206} \mathrm{~Pb}$ age of GR35 quartz-diorite at $1758 \pm 7 \mathrm{Ma}$, an example of Jamari Complex. The age of metamorphic rim at $1649 \pm 5 \mathrm{Ma}$ (rim d.2-1) is also shown (see Table 2). Blank ellipse corresponds to a mixed age of $1724 \pm 8 \mathrm{Ma}$.

foliation is sigmoidal trending $\mathrm{N} 30^{\circ} \mathrm{E} ; 80^{\circ} \mathrm{NW}$. The tonalite has metric lenses of calc-silicate gneiss. Finely zoned zircon grains are prismatic (1:2-1:5) and 50-350 $\mu \mathrm{m}$ long. They have rounded edges and euhedral apatite inclusions are common. The $\mathrm{Th} / \mathrm{U}$ ratios are between 0.34 and 0.66 . The rock has two ages - one at $1753 \pm 8 \mathrm{Ma}$ and the other at $1677 \pm 6 \mathrm{Ma}, 2 \sigma$ (Figs. 7 and 8 ). The younger and magmatic age occurs both in single crystals and in recrystallized rims developed over older cores. Grain k.5 has a core with $1750 \pm 13 \mathrm{Ma}$ and magmatic rim with $1676 \pm 17 \mathrm{Ma}$ (Table 2 and Fig. 8). The older inherited age of $1753 \pm 8 \mathrm{Ma}(\mathrm{MSWD}=0.43$; $n=6$ ) is correlated with the Jamari Complex. The tonalite GR59 is interpreted to have been deformed and re-melted about 74 m.y. later during the Quatro Cachoeiras orogeny.

4.1.1.4. Jamari Complex tonalite (JL78). This tonalite was sampled about $1.5 \mathrm{~km}$ to the south of BR364 highway between Ariquemes and Jaru in Rondônia. The gneiss is medium-grained and has centimetric bands of mafic (biotite and rare amphibole) and felsic (quartz and plagioclase, with minor biotite and magnetite) zones.

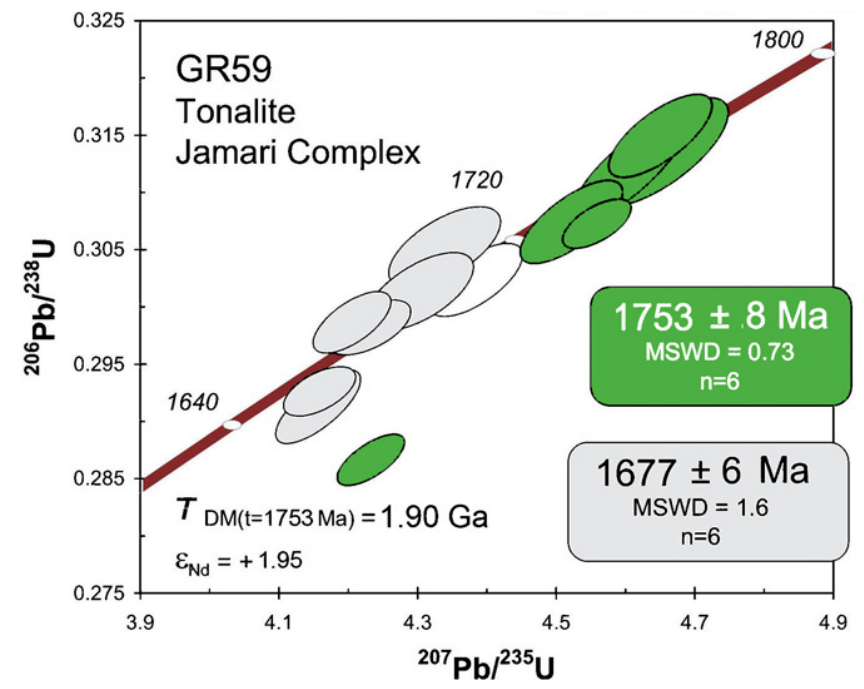

Fig. 7. Concordia plot of sample GR59, Jamari Complex tonalite displaying two ages at $1753 \pm 8$ and $1677 \pm 6 \mathrm{Ma}$.

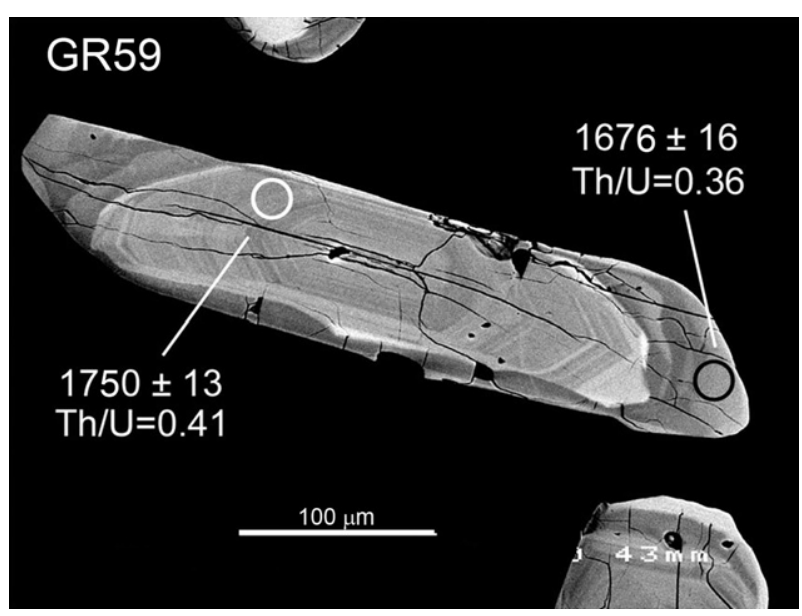

Fig. 8. BSE image of grain k.5 of sample GR59 (Jamari Complex tonalite) displaying two magmatic ages at $1750 \pm 13 \mathrm{Ma}$ and $1676 \pm 16 \mathrm{Ma}$ (Table 2). The younger age reflects the partial melting of the rock during the Quatro Cachoeiras orogeny.

Orthoamphibolite lenses are common and their mylonitic foliation trends $\mathrm{N} 5^{\circ} \mathrm{W}$. Lineations are marked by ribbon quartz striking $\mathrm{N} 70^{\circ} ; \mathrm{N} 55^{\circ} \mathrm{E}$. About two thirds of the zircon grains from JL78 are equidimensional, elliptical to circular in plane section, due to metamorphic re-crystallization and the other third are prismatic (about $180-250 \mu \mathrm{m}$ long). All grains show bright rims in BSE (black in $\mathrm{CL}$ ) over magmatic zoned cores (Fig. 9). The age of the cores is $1738 \pm 6$ Ma (MSWD $=2.6 ; n=7$ out of 8 ; Fig. 10) slightly younger than the other ages of the Jamari Complex (i.e. 1761 and $1753 \mathrm{Ma}$, GR59 and GR35). Metamorphic rims have an age of $1334 \pm 7 \mathrm{Ma}$ (MSWD $=4.9 ; n=7 ;$ Fig. 10 ), and are interpreted as high-grade metamorphic zircon formed during the Candeias collision.

4.1.1.5. Refugio Orthogneiss (JO12). This gneiss crops out $12 \mathrm{~km}$ to the east of San Javier along the San Javier-Concepción road in Eastern Bolivia, Department of Santa Cruz (Fig. 4). The gneiss is leucocratic, well banded $\left(\mathrm{N} 30^{\circ} \mathrm{W}\right)$ and has the composition of syeno- to monzogranite granite whit biotite as its main mafic mineral. Banding is sinuous and probably of magmatic origin. On the $1: 250,000$ Concepción sheet of Bolivia (Litherland et al., 1986) this rock is

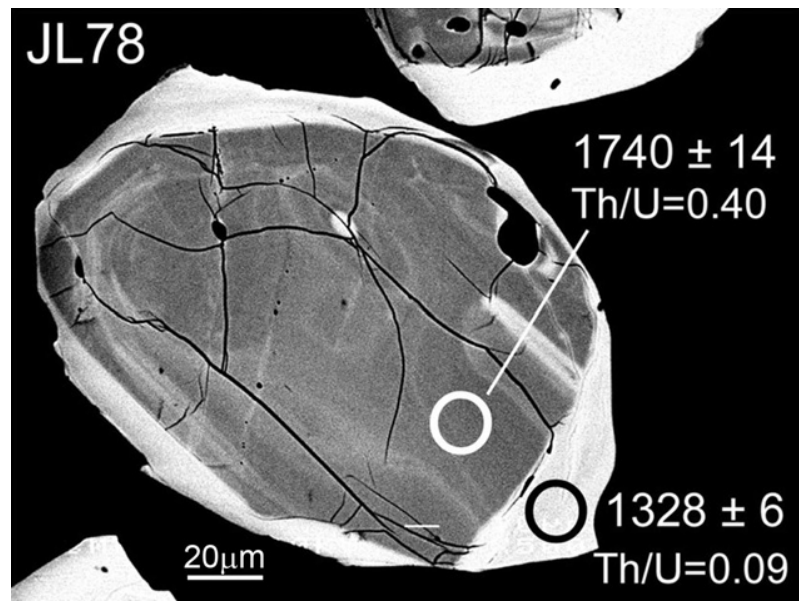

Fig. 9. BSE image of zircon h.3 of sample JL78. Most zircons of this sample have metamorphic rims and magmatic cores such as grain h.3. This grain has a zoned magmatic core with normal Th/U ratios at 0.40 and a BSE bright metamorphic rim with very low $\mathrm{Th} / \mathrm{U}$ ratio of 0.09 (Table 2 ). The rock was formed during the Jamari orogeny (1743 $\pm 9 \mathrm{Ma}$ ) and metamorphosed about $400 \mathrm{~m}$.y. later during the Candeias orogeny (1334 \pm 6 Ma) - see Fig. 10. 


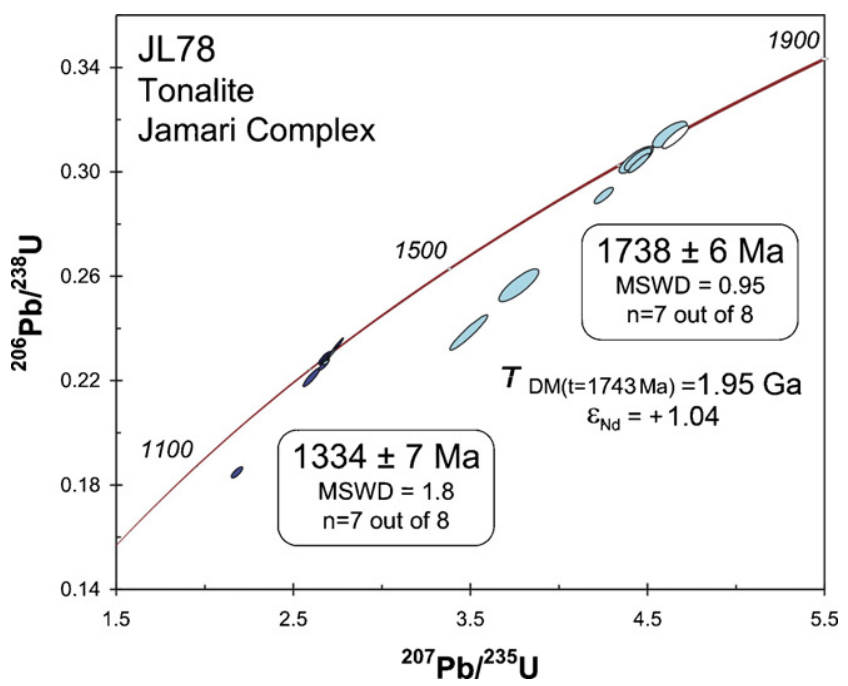

Fig. 10. Concordia plot of sample JL78 (Jamari Complex tonalite) displaying magmatic population of zircon (cores) at $1738 \pm 6 \mathrm{Ma}$ and metamorphic population (rims) at $1334 \pm 6 \mathrm{Ma}$.

mapped as the Refugio Granite. This gneiss has two populations of zircon none with visible metamorphic rims and older cores. Zircon is zoned and prismatic (aspect ratio $1: 1.5$ to $1: 3$ ), $100-240 \mu \mathrm{m}$ long, with $\mathrm{Th} / \mathrm{U}$ ratios from 0.53 to 0.73 (Table 2 ). The magmatic population has the pooled ${ }^{207} \mathrm{~Pb} /{ }^{206} \mathrm{~Pb}$ age $(n=8)$ of $1641 \pm 4 \mathrm{Ma}$ $(\mathrm{MSWD}=0.66)$ and correlates to the Quatro Cachoeiras orogeny (Fig. 11). The inherited grains are slightly older and apparently represent only one inherited population formed at $1668 \pm 8 \mathrm{Ma}$ $(\mathrm{MSWD}=0.64 ; n=4)$. The Refugio orthogneiss is much older than the San Andrés Granite (sample J010, $1275 \mathrm{Ma}$ ) and may represent a fragment of the Rondônia-Juruena Province which survived within the Sunsás Orogen in Bolivia. Additional support for this hypothesis comes from the similar inherited ages of $1663 \pm 13 \mathrm{Ma}$ and $1686 \pm 16$ Ma detected by Boger et al. (2005) in zircon from the Lomas Manechi charnockite (sample 240) and San Rafael Granite (228). The Sm-Nd model age (depleted mantle) is $1.66 \mathrm{Ga}$ (Table 1) and the $\varepsilon_{\mathrm{Nd}}$ (at $1641 \mathrm{Ma}$ ) is +4.06 . This suggests that the melt which generated the Refugio Orthogneiss was derived from a source which was dominantly juvenile with little or no crustal contamination.

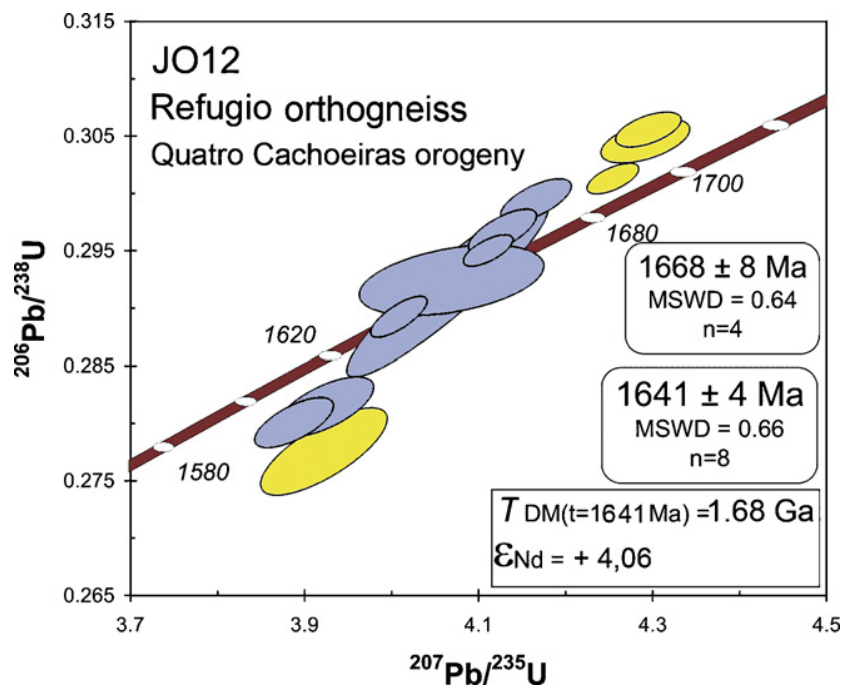

Fig. 11. U-Pb concordia plot of sample JO12, Refugio Orthogneiss showing magmatic age at $1641 \pm 4 \mathrm{Ma}(n=8)$ and an inherited population at $1668 \pm 8 \mathrm{Ma}(n=4)$.

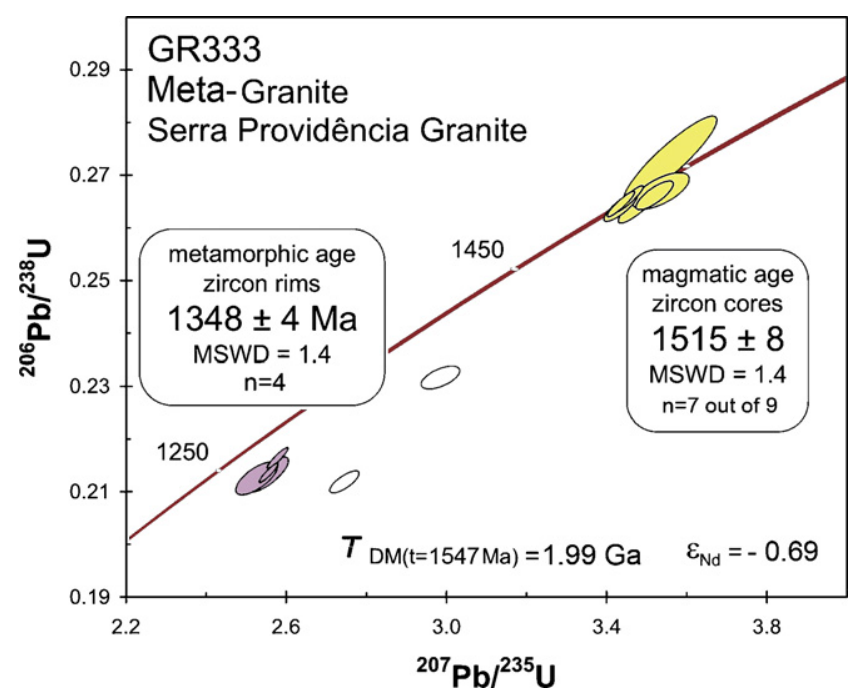

Fig. 12. U-Pb concordia plot of sample GR333, Serra Providência Meta-granite. The rock crystallized at $1515 \pm 8 \mathrm{Ma}$ and was metamorphosed at $1348 \pm 4 \mathrm{Ma}$ (ages of metamorphic rims). Most discordant analyses (10\% and 16\%; white ellipses) are not used.

The inherited zircon ( $1668 \pm 8 \mathrm{Ma})$ may be derived from such a juvenile source of ca. $1665 \mathrm{Ma}$.

4.1.1.6. Serra Providência Meta-granite (GR333). This meta-granite comes from $15 \mathrm{~km}$ to the NW of Ji-Paraná town near the western border of Serra Providência Batholith (type-locality) in Rondônia (Fig. 3). It is a pinkish to greyish, coarse-grained monzogranite with mylonitic structure and irregular banding. Rapakivi texture is partially preserved and its mafic bands are mainly composed of biotite, plagioclase and hornblende, and felsic bands of quartz and K-feldspar. Banding strikes $\mathrm{N} 60^{\circ} \mathrm{W} ; 65^{\circ} \mathrm{SW}$ with lineation trending $\mathrm{N} 20^{\circ} ; \mathrm{N} 55^{\circ} \mathrm{W}$. Where deformation is more intense the gneiss is finer grained and the banding is more regular. Average composition is oligoclase (33\%), microcline (28\%), quartz (26\%), biotite $(8 \%)$, hornblende $(4 \%)$, titanite $(1 \%)$, allanite, zircon, apatite and fluorite $(<1 \%)$. Metamorphic re-crystallization occurred at middle amphibolite facies temperatures. Zircon crystals are prismatic, with aspect ratios $1: 2$ to $1: 4$, poorly zoned, and $\mathrm{Th} / \mathrm{U}$ ratios vary from 0.43 to 0.99 (Table 2). Metamorphic areas are present, particularly at the pyramidal terminations, but do not form complete rims as in sample JL78. Metamorphic areas are extremely low in Th/U ratios (as low as 0.004 , as in grain b.8-1), bright in BSE and dull in CL images. The magmatic age is $1515 \pm 8 \mathrm{Ma}(\mathrm{MSWD}=1.4 ; n=5$; Fig. 12$)$, which was obtained from the most concordant data (i.e. $>98 \%$ ), excluding grains b.12-1 and b.15-1 (Table 2). This age is in agreement with previous dating of the Serra Providência Batholith (Bettencourt et al., 1999). The metamorphic age of the Serra Providência Granite is additional evidence of mylonitization associated with the Candeias collision at $1348 \pm 4 \mathrm{Ma}(\mathrm{MSWD}=1.4 ; n=4$; Fig. 12). This age is slightly older than the age of the metamorphism of the Rio Crespo Suite in Rondônia (1331 \pm 9 Ma; Bettencourt et al., 2006).

\subsubsection{Sunsás Province}

4.1.2.1. San Ramón Tonalite (JO14). This sample was collected $2 \mathrm{~km}$ south of San Ramón on the road to Santa Cruz de La Sierra in Bolivia (Fig. 4). It is composed of plagioclase, hornblende and quartz with minor biotite and is cut by trondhjemite veins, $2-8 \mathrm{~cm}$ thick. No foliation is visible nor is there evidence of metamorphism. Zircon grains are clear and relatively large $(200-600 \mu \mathrm{m})$. Only two grains show re-crystallization zones of metamorphic zircon (b.1-1 and b.21). Titanite is abundant as brown-reddish chips of $500 \mu \mathrm{m}$ to $1 \mathrm{~mm}$ 


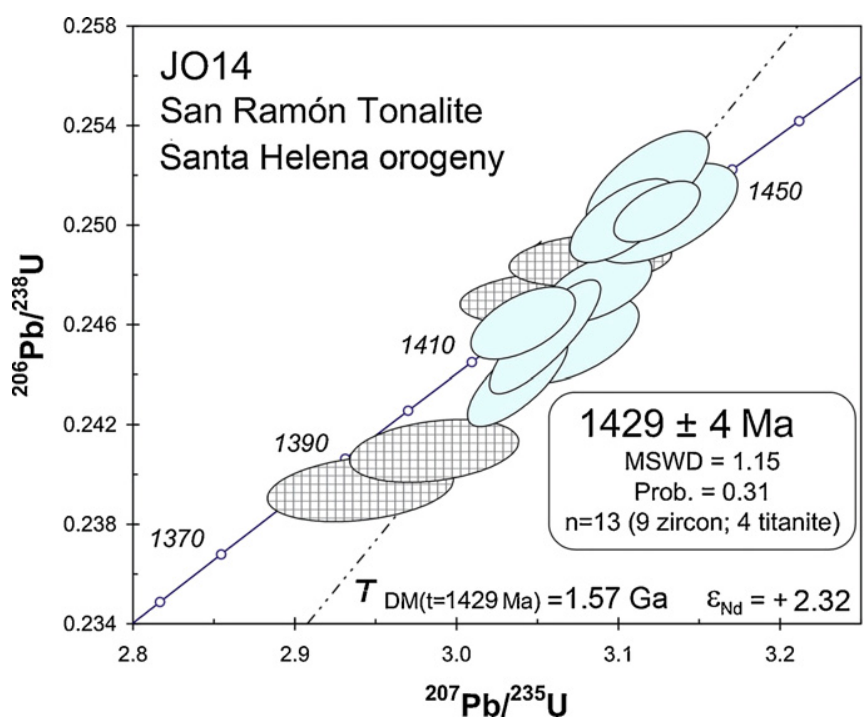

Fig. 13. Concordia diagram of the San Ramón Tonalite where U-Pb ratios of titanite (hatched) and zircon group at the age of $1429 \pm 4$ Ma.

in diameter. Titanite has darker and lighter zones in BSE and analyses were concentrated in the brighter zones, which have higher U content (240-280 ppm; Table 2). All ${ }^{207} \mathrm{~Pb} /{ }^{206} \mathrm{~Pb}$ ages of zircon and titanite form a pooled age of $1429 \pm 4 \mathrm{Ma}(\mathrm{MSWD}=1.15 ; n=13$; Fig. 13). The age of the titanite is undistinguishable from the zircon age (within error). The Sm-Nd model age (Table 1) is $1.57 \mathrm{Ga}$ and the $\varepsilon_{\mathrm{Nd}}$ (at $1429 \mathrm{Ma}$ ) is +2.3 , which demonstrates the dominantly juvenile origin of the rock. The age of the San Ramón tonalite is similar to the age of the juvenile Santa Helena Tonalite (Geraldes et al., 2001) and of the Pindaituba Suite (Ruiz, 2006) in western Mato Grosso in the southern part of the Sunsás Belt. All units are interpreted as juvenile and derived from the upper mantle (Geraldes et al., 2001; Santos et al., 2002; Ruiz, 2006) and as remnants of the first magmatic arc accreted to the craton during the beginning of the Sunsás Orogen evolution. The orogeny is named Santa Helena (Geraldes et al., 2001; Santos et al., 2002; Santos, 2003; Ruiz, 2006) and is best known in Mato Grosso (Geraldes et al., 2001; Ruiz, 2006). The apparent scarcity of preserved granitoids formed during the Santa Helena orogeny within the Sunsás Belt in Bolivia and Rondônia may result from lack of both mapping and robust geochronology. Intense magmatic activity during $1450-1420$ Ma is suggested by the strong presence of detrital zircons with this age within the late and post-Sunsás sedimentary rocks (Santos et al., 2002).

4.1.2.2. Alto Candeias Granite (JS39). This rock is a monzogranite cropping out $6 \mathrm{~km}$ to the northeast of Campo Novo in Rondônia (Fig. 3) at the centre of the Candeias Batholith. There are two facies, one equigranular and the other porphyritic. The porphyritic facies has a medium to coarse-grained matrix containing elliptic and tabular crystals of perthitic orthoclase $(2-6 \mathrm{~mm})$ mantled by plagioclase. The phaneritic matrix is composed of quartz, albite, amphibole, biotite and opaques. Mesoperthites (albite in orthoclase) are common. The equigranular facies is a biotite monzogranite with magmatic flux foliation and common angular xenoliths, which are mainly paragneisses. Discrete ductile shears are present in the core of the batholith. The rock has only one population of magmatic zircon and metamorphic rims or zones were not detected. Zircon is prismatic (aspect ratio 4:1), zoned with $U$ contents ranging from 105 to $503 \mathrm{ppm}$ (Table 2). The age is $1339 \pm 7 \mathrm{Ma}(\mathrm{MSWD}=1.7 ; n=6$; Fig. 14), which represents the age of the Candeias Batholith in its type-locality and is comparable to the U-Pb ages of the components in the Pensamiento Granite Com-

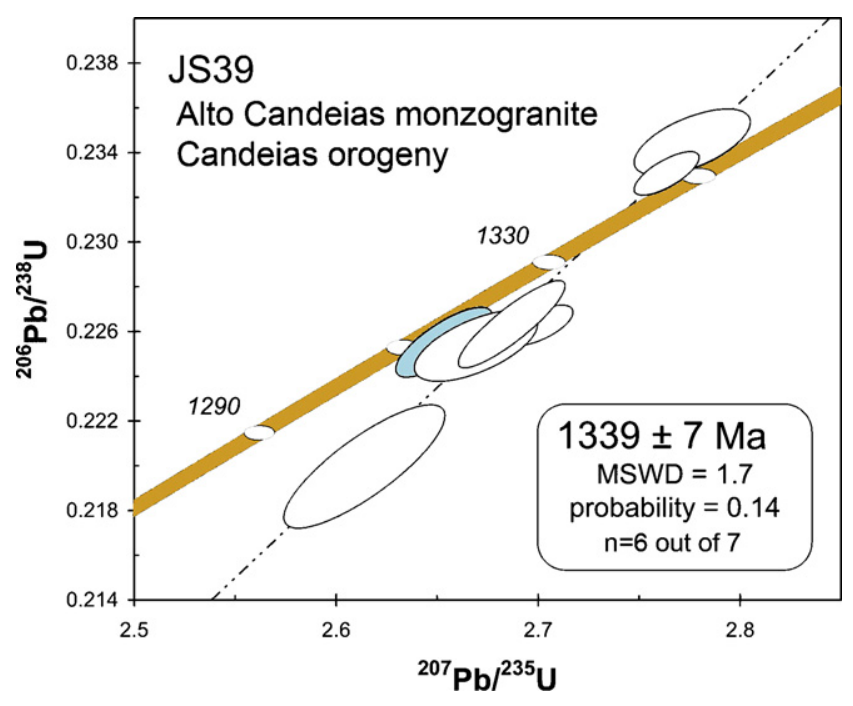

Fig. 14. U-Pb concordia plot of zircon of sample JS39, a monzogranite of Alto Candeias Batholith in its central region. The magmatic ${ }^{207} \mathrm{~Pb} /{ }^{206} \mathrm{~Pb}$ age is $1339 \pm 7 \mathrm{Ma}$. The gray ellipse is from an outlier not used in age calculation.

plex in Bolivia: the San Rafael (1334 \pm 12 Ma, Boger et al., 2005), La Junta ( $1347 \pm 21 \mathrm{Ma})$ and Diamantina $(1340 \pm 20 \mathrm{Ma})$ granites (ages recalculated from Matos et al., 2006).

4.1.2.3. Un-named S-type granite (JL6). This rock comes from an outcrop of paragneiss southwest of Ariquemes in Rondônia (Fig. 3). The gneiss has dark bands composed mainly of biotite and garnet layered with felsic quartz-feldspathic bands. Biotite is iron-rich and partially altered to chlorite and epidote. Veins and pods of garnet leucogranite derived of partial melt are common and one of these was sampled (JL6). Most of these veins are parallel to the banding $\left(\mathrm{N} 10^{\circ} \mathrm{E} ; 80^{\circ} \mathrm{SE}\right.$ and mineral lineation at $35^{\circ}$; $\mathrm{S} 10^{\circ} \mathrm{E}$ ). The asymmetry of pressure shadows on garnet crystals indicates sinistral movement. Zircon tends to be equidimensional (120-200 $\mu \mathrm{m})$, multifaceted, appearing rounded. No zoning is visible and all crystals are bright in BSE. All grains are metamorphic, U-rich (830-1449 ppm) and Th-poor (17-36 ppm). Small nuclei $(10-20 \mu \mathrm{m})$ are present in most of grains but impossible to be dated because they are small, fractured and metamict. Th/U ratios are very low (0.018-0.022), indicative of a metamorphic origin. The age is $1339 \pm 3 \mathrm{Ma}(\mathrm{MSWD}=0.61 ; n=6-$ Fig. 15$)$ and suggests that the rock was metamorphosed during the Candeias collision. Most rocks of Jamari Complex and Serra Providência Suite of central-north Rondônia were strongly and variably metamorphosed during 1350-1320 Ma. It is uncertain whether the S-type melt derives from paragneiss associated with the Quatro Cachoeiras metamorphic suite (ca. 1650 Ma; Rizzotto et al., 2004) or with the Rio Crespo metamorphic suite ( $1331 \pm 9 \mathrm{Ma}$; Bettencourt et al., 2006).

4.1.2.4. Rio Fortuna Orthogneiss (JO6). This rock was sampled $28 \mathrm{~km}$ to the west of Ascención and $2 \mathrm{~km}$ south of Brazil-Bolivia border in Santa Cruz Department (Fig. 4) in the area of the Rio Fortuna Gneiss (Litherland et al., 1986). It is a dark grey orthogneiss with granodioritic to tonalitic composition and has conspicuous and coarse metamorphic banding (layers of $2-12 \mathrm{~cm}$ thick trending $\mathrm{N} 40^{\circ} \mathrm{W}$ ). Zircon (200-400 $\mu \mathrm{m})$ is dominantly prismatic and most grains have well-defined core and rim structures (grains b.5, b.8, and b.11). There are two main populations of zircon: zoned magmatic zircon and rims both formed at $1336 \pm 3 \mathrm{Ma}(\mathrm{MSWD}=0.07 ; n=4$; Fig. 16) and inherited grains and cores in the age range of 1772-1734 Ma. One core (b.5-2) has the age of $1674 \mathrm{Ma}$, which correlates to the 


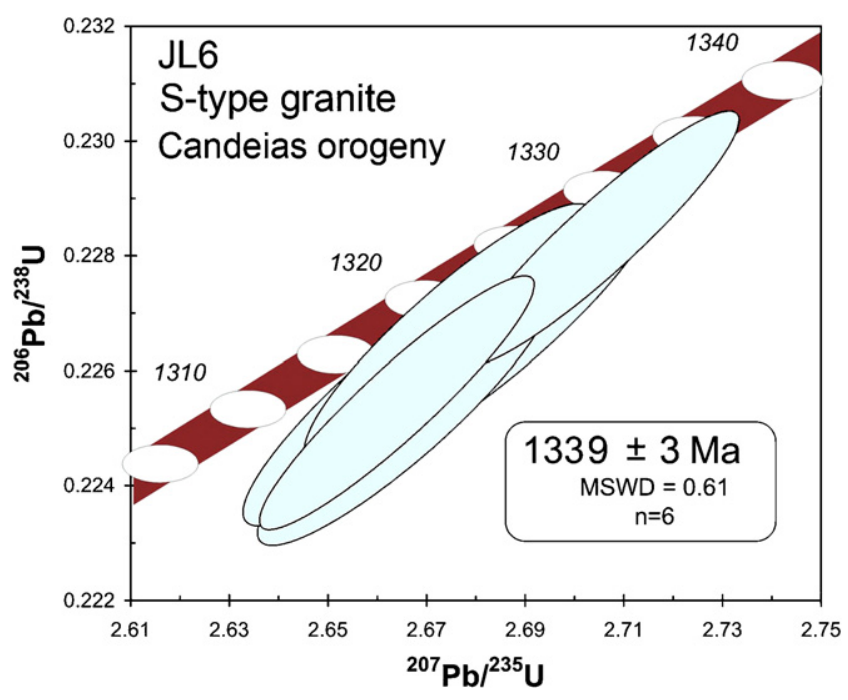

Fig. 15. U-Pb concordia plot of zircons from sample JL6, an unnamed S-type granite. The $1339 \pm 3 \mathrm{Ma}$ age is remarkably similar to the age of granulite metamorphism in Bolivia (sample JO5, Fig. 17)

Quatro Cachoeiras orogeny. The two contrasting populations of zircon - magmatic and young (1336 Ma) versus inherited and old (1772-1734 Ma and 1674 Ma) - indicate that the rock was formed during the Candeias collisional orogeny and that the rock is derived from the older Jamari Complex and the Quatro Cachoeiras metamorphic suite.

4.1.2.5. Lomas Manechi gneiss (JO5). This is a well foliated (N50 $\left.{ }^{\circ} \mathrm{W}\right)$ gneiss of granodioritic composition (plagioclase, quartz, biotite, and microcline) collected about $30 \mathrm{~km}$ to the south of Ascención and $35 \mathrm{~km}$ to the south of Brazil-Bolivia border in an area mapped as Lomas Manechi Complex (Litherland et al., 1986) - Fig. 4. The foliation shows mylonitic stretching of quartz and plagioclase. Most zircon grains are large $(200-500 \mu \mathrm{m})$ and rounded and some are short prisms with rounded edges. Zircons are U-rich (up to $3950 \mathrm{ppm}$; Table 2) and have a consistent concordant ${ }^{207} \mathrm{~Pb} /{ }^{206} \mathrm{~Pb}$ age at $1334 \pm 2 \mathrm{Ma}(\mathrm{MSWD}=1.6 ; n=6$; Fig. 17). Five analyses are on

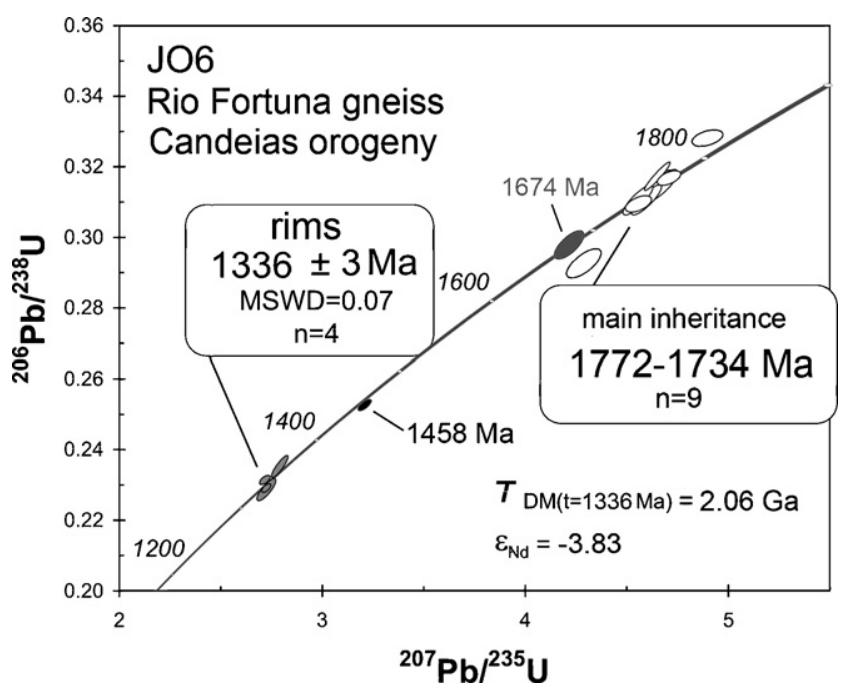

Fig. 16. U-Pb concordia plot of zircon of the Rio Fortuna Gneiss (JO6). The rock has two main ages: the age of $1336 \pm 3$ Ma groups ages of magmatic zircon and metamorphic rims and the 1772-1734 Ma range represents inherited zircon cores, possibly derived from Jamari-type crust.

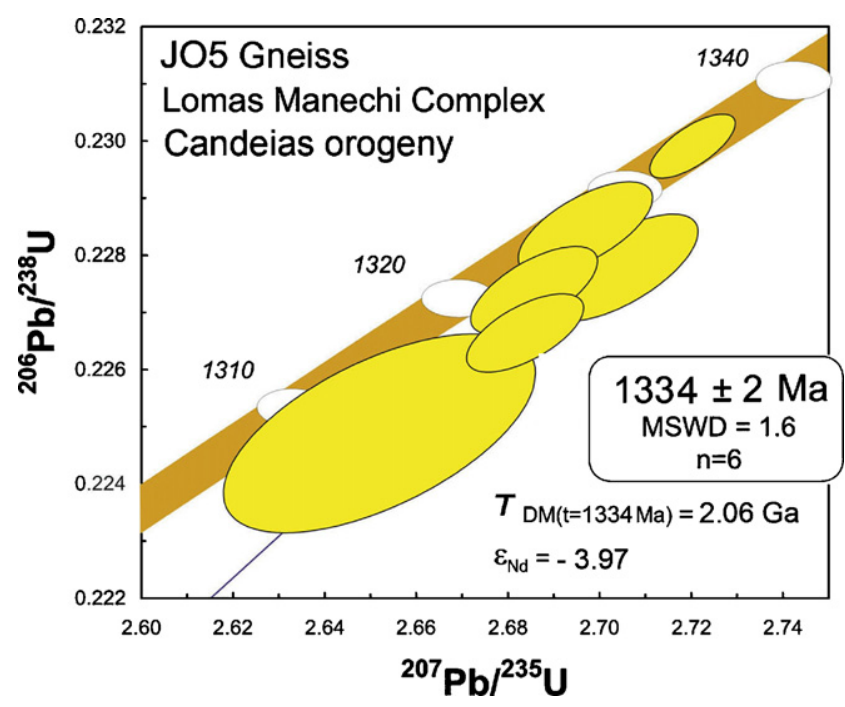

Fig. 17. U-Pb concordia plot of zircons from sample JO5, a gneiss from the Lomas Manechi Complex. The age of $1334 \pm 2$ Ma is from magmatic and metamorphic zircons. This is an example of granulite facies metamorphism associated to the Candeias orogeny in Bolivia.

metamorphic zircon grains (unzoned and very low Th/U ratios of 0.06-0.11) or rims and one analysis is from a magmatic area (zoned and $\mathrm{Th} / \mathrm{U}$ ratio of 0.46 ). Both magmatic and metamorphic ages are within error. The age correlates with the Candeias orogeny and not with the basement. In fact most of high-grade metamorphism in Eastern Bolivia and Western Brazil was produced during the Candeias orogeny and even some during the Nova Brasilândia orogeny (JO8). Within the whole exposed Sunsás Orogen, granulitic metamorphism is typical of the Mesoproterozoic but not of basement rocks.

4.1.2.6. Santa Rita Orthogneiss (JO18). This rock was collected from $34 \mathrm{~km}$ to the east of San Ignacio town in Bolivia, Santa Cruz Department (Fig. 4). It is an orthogneiss of granodiorite composition, with flat and parallel banding. Individual gneissic bands range from 2 to $30 \mathrm{~cm}$ in thickness and are cut by a few, irregular and thin quartz-Kfeldspar veins. Zircon is prismatic (1:1.5 to 1:4), zoned and unzoned, with irregular edges and no evidence of either metamorphic rims or zones and older cores. Most of the zircon grains have the same age at $1319 \pm 6 \mathrm{Ma}(\mathrm{MSWD}=1.3 ; n=8$; Fig. 18) and only one grain is inherited $(1729 \pm 9 \mathrm{Ma})$. This indicates that the Santa Rita Gneiss is younger than the Chiquitania Complex (older than $1400 \mathrm{Ma}$; Litherland et al., 1986) and that it was formed during the late stages of Candeias orogeny. The inherited zircon has an age comparable to the age of felsic volcanic rocks of Rondônia-Juruena Province such as the Roosevelt Group dacite (MQ96, $1740 \pm 8$ Ma; Santos et al., 2000) and to the rocks of Jamari Complex (1760-1740 Ma, this work).

4.1.2.7. San Andrés Granite (JO10). This sample was collected $24 \mathrm{~km}$ SW of Concepción along the road between San Javier and Concepción in Santa Cruz Province, Bolivia (Fig. 4). It is a coarse-grained leucocratic, biotite granite with discrete foliation trending $\mathrm{N} 20^{\circ} \mathrm{W}$. Zircon grains are clear, prismatic (aspect ratio 1:1.5 to 1:3), weakly zoned, $80-150 \mu \mathrm{m}$ long, and contain intermediate amounts of $U$ (95-372 ppm); Th/U ratios range between 0.41 and 0.94 (Table 2). Some crystals (g.5-2 and g.10-1) have areas interpreted as metamorphic, which are too small to be dated $(<10 \mu \mathrm{m})$. All ${ }^{207} \mathrm{~Pb} /{ }^{206} \mathrm{~Pb}$ ages form one population at $1275 \pm 7 \mathrm{Ma}(\mathrm{MSWD}=1.16 ; n=7$, Fig. 19). Two grains (g.2-1 and g.3-1) are inherited and correlated to the rocks of the Candeias orogeny. The age of $1275 \mathrm{Ma}$ is younger than 


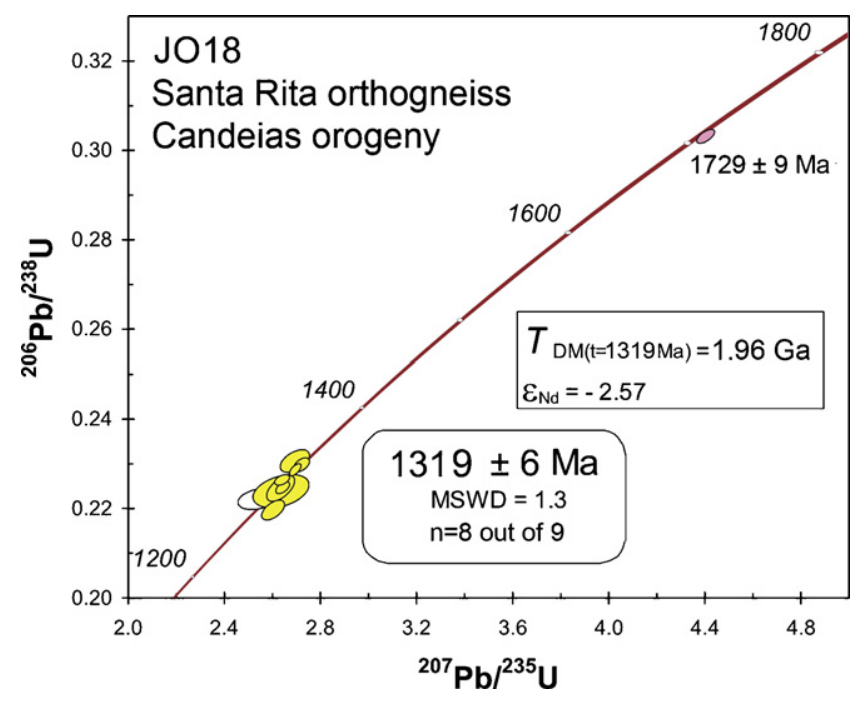

Fig. 18. Concordia plot of Santa Rita Orthogneiss of Chiquitania Complex (JO18). The age at $1319 \pm 6 \mathrm{Ma}$ demonstrates that the rock is younger than the Chiquitania Complex (supposed to be older than $1400 \mathrm{Ma}$; Litherland et al., 1986) and that it was formed during the Candeias orogeny. The inherited age of $1729 \pm 9$ Ma may represent participation of Jamari-type crust in the melt which generated rock J018.

the rocks generated during the Candeias orogeny, but older than the age of the Nova Brasilândia orogeny. The age of $1275 \pm 7 \mathrm{Ma}$ may represent granite formation during another, perhaps discrete, magmatic arc here named the San Andrés. Litherland et al. (1986) mention several plutons formed at about this time, such as Orobayaya Granite $(1283 \pm 33 \mathrm{Ma})$, El Tigre Nordmarkite $(1286 \pm 96 \mathrm{Ma})$, and San Javier Granite (1291 $\pm 49 \mathrm{Ma})$. However, the nature of the dating ( $\mathrm{Rb}-\mathrm{Sr}$ whole-rock isochrons) and their large uncertainties (33-6 m.y.) make the correlation of those three intrusions with the San Andrés orogeny uncertain. The San Rafael Granite may be another intrusion produced during the San Andrés orogeny because sample 228 of Boger et al. (2005) has grain 12.1 formed at $1259 \pm 13 \mathrm{Ma}(\mathrm{U}-\mathrm{Pb})$. The Candelária Granite is other granite formed during the San Andrés orogeny according to the $\mathrm{U}-\mathrm{Pb}$ age of $1285 \pm 16 \mathrm{Ma}$ (Ramiro Matos, unpublished).

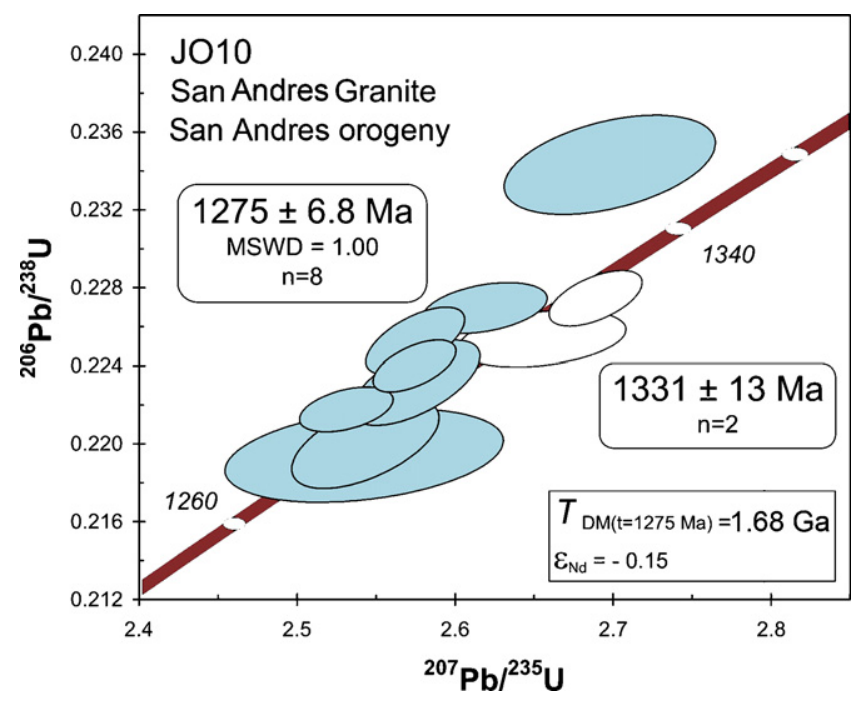

Fig. 19. Concordia plot of zircon U-Pb ages of the San Andrés Granite, sample JO10. The age at $1275 \pm 7$ Ma may represent the existence of an orogeny between the Candeias and Nova Brasilândia herein named the San Andrés. The age of $1331 \pm 13 \mathrm{Ma}$ represents inheritance from the Candeias orogey.

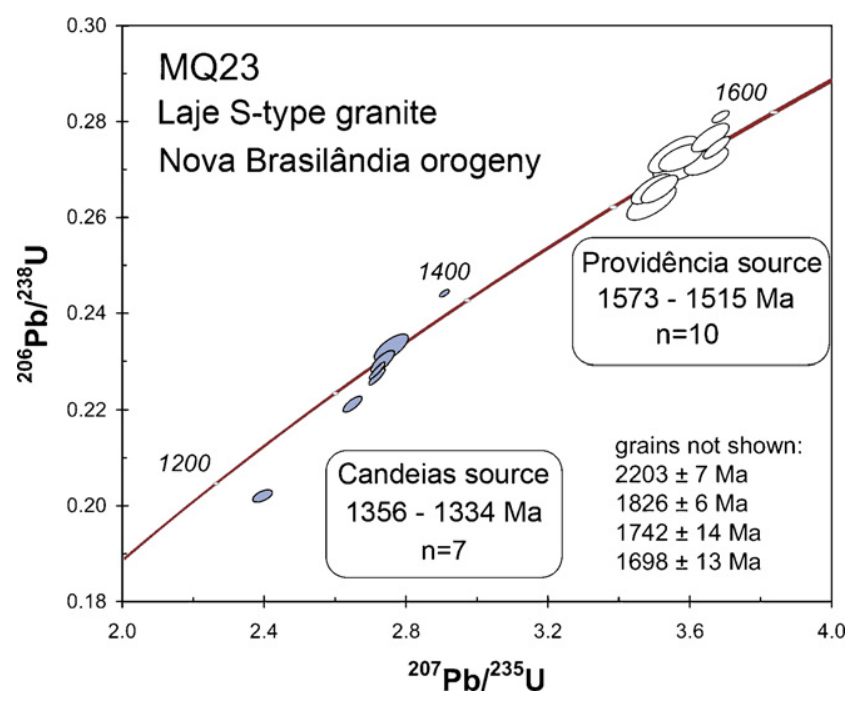

Fig. 20. Concordia plot showing the two main populations of zircon in sample MQ23 (Laje S-type Granite). The interpretation is that the cluster at 1573-1515 $14 \mathrm{Ma}$ is derived from Serra Providência-like rocks, whereas the population at 1356-1334 Ma is derived from felsic rocks and paragneisses generated during the Candeias orogeny. The Laje Granite is interpreted as post-Candeias and is tentatively correlated to the Nova Brasilândia orogeny.

4.1.2.8. Laje S-type Granite (MQ23). This sample was collected in the west Candeias Batholith region (Fig. 3). It is a fine-grained equigranular granite, slightly foliated (magmatic flux), pink to grey, containing discontinuous and irregular quartz veins usually parallel to the foliation of the host rock (paragneiss). Garnet porphyroblasts $( \pm 1 \mathrm{~cm})$ are abundant in quartz-rich aggregates. Essential mineralogy is K-feldspar, oligoclase, quartz, biotite and garnet. These granites are small bodies, intrusive into paragneisses (metapelites) and are believed to have been derived from them. Magmatic foliation is concordant to the paragneiss banding (N45 ${ }^{\circ} \mathrm{E} ; 30^{\circ} \mathrm{SE}$ with mineral lineation at $20^{\circ} ; \mathrm{N} 90^{\circ} \mathrm{E}$ ). As expected in S-type granites, this rock has a complex population of zircon including several shapes and ages. Twenty-one dated grains have ages from 2203 to $1334 \mathrm{Ma}$ (Table 2). Older grains may be inherited from the Juruena basement (1826 $\pm 6 \mathrm{Ma}$, grain d.17-1) and the Jamari Complex (1742 $\pm 14 \mathrm{Ma}$, grain d.19-2). The two main populations of zircon have the ages of 1573-1515 Ma and 1356-1334 Ma - Fig. 20. The ages of the first cluster are similar to the ages of samples of the Serra Providência Suite (Bettencourt et al., 1999; Payolla et al., 2002; Santos, 2003). This suggests that there was a strong component of the Serra Providência Suite in the source from which the Laje Granite (MQ23) originated. The ages of 1356-1334 Ma include metamorphic and magmatic zircon based on Th/U ratios and BSE images and the maximum possible age of the granite is $1334 \mathrm{Ma}$. This suggests that the sedimentary rocks which were melted to form the Laje Granite have at least two main components: one derived from rocks of the Candeias orogeny and the other from the Serra Providência Suite. Granites of this suite are common to the northwest, north, northeast and east of the sampling site. The existence of several intrusions of Candeiasage to the west-southwest of MQ23 outcrop is a potential source of the magmatic-detrital zircon found in the sample. The widespread metamorphic rocks (paragneisses) to the west of the MQ23 outcrop (Rio Mamoré Complex, Fig. 3), seems to be the most likely source for the metamorphic-detrital grains. Because the metamorphic grains are detrital, it seems that the Laje S-type granite postdates the Candeias orogeny. Because the generation of S-type melts is common at \pm 1110 Ma during the paroxysm of the Nova Brasilândia orogeny (Rio Pardo Granite; Rizzotto et al., 1999; Santos, 2003) the more probable correlation for sample MQ23 is with the Nova Brasilândia orogeny. 
4.1.2.9. Iata sillimanite gneiss (JP3). The outcrop of this sample is known in Rondônia as the "lata outcrop", located $30 \mathrm{~km}$ to the north of Guajará-Mirim in Brazil (Fig. 3). The rock is steeply folded and isofolds trend E-W and extend to the Bolivia territory. The sample is very poor in zircon and rich in quartz, sillimanite and pyrite. Processing three samples yielded only 14 grains of zircon all of which are highly fractured and, in addition, four are metamict. Thus only seven reliable U-Pb SHRIMP analyses could be made (Table 2). Three of the seven grains (mean average of $1541 \pm 12 \mathrm{Ma}$ ) may be derived from the Serra Providência Suite; one grain (1433 Ma) has an age within the range of the Santa Helena orogeny; two grains (1325 and $1314 \mathrm{Ma}$ ) are possibly derived from the Candeias-type granites; the youngest grain of 1212 Ma establishes the maximum age of the sillimanite gneiss (post-San Andrés orogeny), which is tentatively correlated to the Nova Brasilândia Group. This interpretation extends the distribution of the rocks formed during the youngest Nova Brasilândia orogeny to the west probably reaching the Bolivian territory to the west of the Mamoré River (Fig. 3).

4.1.2.10. Las Madres paragneiss (JO8). This sample is a garnet-rich leucocratic paragneiss cropping out $25 \mathrm{~km}$ northeast of Concepción in the area mapped as Las Madres Gneiss of Chiquitania Complex by Litherland et al. (1986) in Bolivia (Fig. 4). Its zircons are relatively large (200-400 $\mu \mathrm{m})$, have rounded edges and variable shapes and colour and are all detrital. The main population $(n=12)$ has ages in the 1690-1630 Ma range (Fig. 21) and is interpreted as derived from rocks of the Quatro Cachoeiras orogeny, such as the Refugio Orthogneiss (JO12) to the west of Concepción. One grain has an age of $1550 \pm 8 \mathrm{Ma}$ and possibly is derived from rocks correlated to the Serra Providência Suite. Three grains (g.12, g.8, and g.5) have younger, low Th/U (0.03-0.09), metamorphic cores ( $1317 \pm 10$, $1350 \pm 11$, and $1118 \pm 15 \mathrm{Ma}$ ) inside older rims having ages of $1653 \pm 8,1682 \pm 20$, and $1620 \pm 28 \mathrm{Ma}$ (Fig. 22). The formation of metamorphic nucleus and patches results from metamorphic fluids migrating along fractures within the zircon (Hartmann et al., 1997). One scenario is that the high-grade Candeias-type metamorphism of source-rock (1317 and $1350 \mathrm{Ma}$ ) preceded the erosion and sedimentation of the pelitic rock, which subsequently was metamorphosed into a paragneiss. The latest metamorphic recrystallization of zircon g.5 at $1118 \mathrm{Ma}$ reflects the age of the paragneiss formation during the Nova Brasilândia orogeny; the age

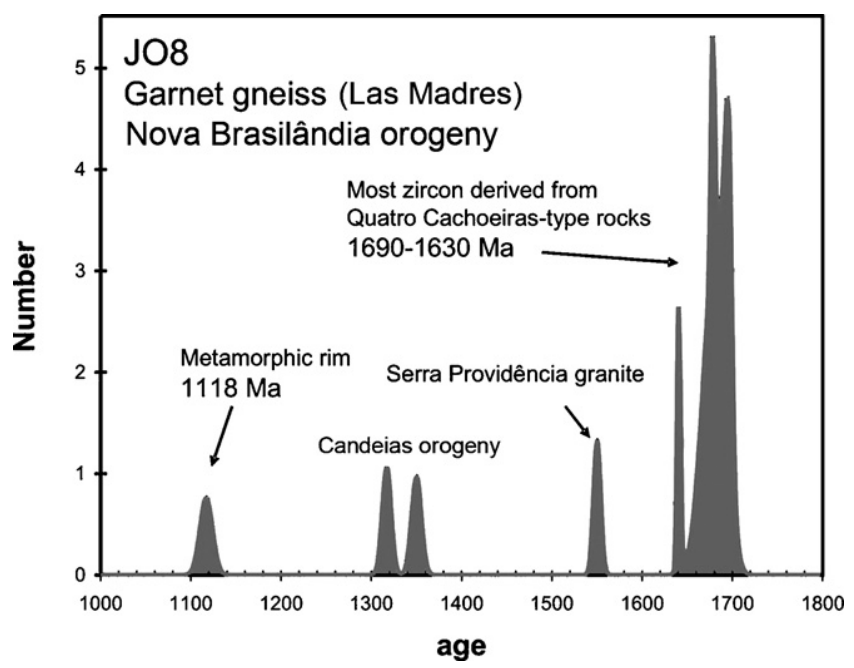

Fig. 21. Relative probability plot of zircon ages from sample J08, the Las Madres garnet gneiss. The main detrital population has its main age peak at $1690-1630 \mathrm{Ma}$, which is evidence for a dominant derivation from Quatro Cachoeiras-type rocks. A metamorphic rim at $1118 \mathrm{Ma}$ shows, however, that the rock was metamorphosed during the Nova Brasilândia orogeny.

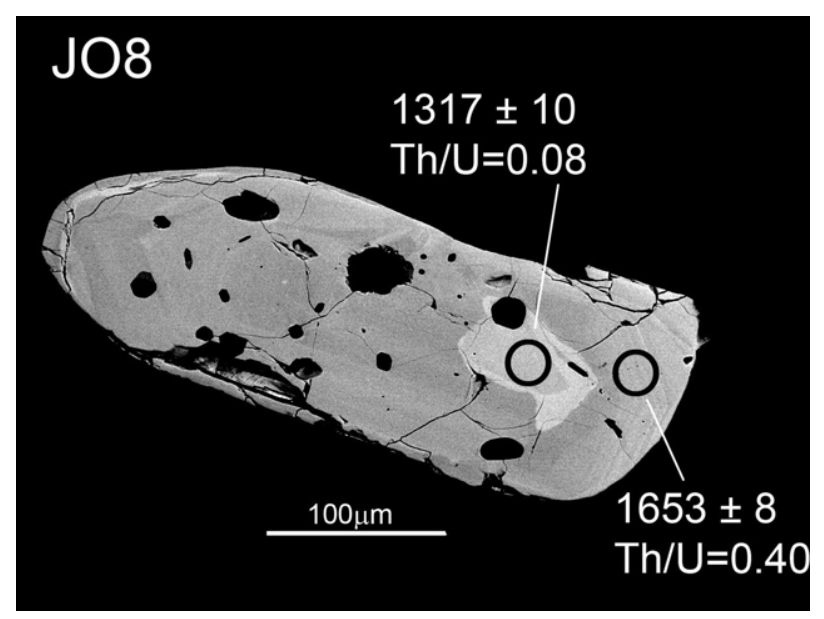

Fig. 22. BSE image showing unusual inverse relation between rim and core in zircon. Grain g.12 of sample JO8 (Las Madres paragneiss) has a younger metamorphic core $(1317 \pm 10 \mathrm{Ma})$ inside an older magmatic grain $(1653 \pm 8 \mathrm{Ma})$.

of $1110 \pm 10 \mathrm{Ma}$ is considered the age of the metamorphic climax of the Nova Brasilândia orogeny (Rizzotto et al., 1999; Santos, 2003; Tohver et al., 2004).

4.1.2.11. Puquio Norte Rhyolite (J013). The Puquio Norte gold deposit is hosted by undated low-grade, foliated meta-sedimentary rocks, which are cut by a sub-vertical felsic dike or sill parallel to foliation. The meta-sedimentary unit is part of the San Ignacio Group, whose age was estimated in the 2000-1400 Ma range by Litherland et al. (1986). Most of the rocks of this group have many analogies to the younger meta-sedimentary Aguapeí and Sunsás Groups, including the Ar-Ar age at $990 \mathrm{Ma}$ and the style of its gold mineralization. The dike would provide the minimum age for the unit, but the dike is very poor in zircon and of the five zircon grains extracted from the sample, all are inherited, as indicated by the variable shape and colour and the corroded edges of the crystals. Each grain has different ${ }^{207} \mathrm{~Pb} /{ }^{206} \mathrm{~Pb}$ ratios in the $0.1050-0.950$ range corresponding to ages of $1700-1500 \mathrm{Ma}$. The ratios are from analyses with only one scan. The Sm-Nd model age is $1.54 \mathrm{Ga}$, which is a lower limit for the rhyolite age. The rhyolite age may be anything younger than $1.54 \mathrm{Ga}$. However, because of the interpreted correlation of the Puquio meta-sedimentary rocks to the Sunsás Group based on mapping and Ar-Ar dating of $990 \pm 3 \mathrm{Ma}$ (sample J011; Santos, unpublished) the rhyolite dike is probably younger than $1100 \mathrm{Ma}$.

\subsubsection{Andes Province}

4.1.3.1. Tanomonia Granite (JO7). Mesozoic intrusions related to the Andes evolution are present within the Sunsás Province where Litherland et al. (1986) identified three complexes of alkaline affinities: the Cerro Manomó Carbonatite, the Candelária Complex (nordmarkite, trachyte, foyaite, pulaskite), and the Velasco Complex (biotite granite, pulaskite, nordmarkite, quartz-syenite). Two samples of Velasco Complex were dated by $\mathrm{Rb}-\mathrm{Sr}$ isochrons at $144 \pm 4 \mathrm{Ma}$ (Bambá pluton) and $141 \pm 5 \mathrm{Ma}$ (Cabeza de Toro pluton), Litherland et al. (1986). We investigated the southernmost intrusion, the Tanomonia pluton by U-Pb and $\mathrm{Sm}-\mathrm{Nd}$ to compare its age to the $\mathrm{Rb}-\mathrm{Sr}$ age and to investigate the contamination of the magma with rocks of the Sunsás Orogen. Sample JO7 is orthoclase granite with large, U-rich (up to $3700 \mathrm{ppm}$ ) and Th-rich (up to $3000 \mathrm{ppm}$ ) zircon crystals. The $\mathrm{U}-\mathrm{Pb}$ age is $135.9 \pm 1.8 \mathrm{Ma}(\mathrm{MSWD}=1.03 ; n=5$; Fig. 23) or Early Cretaceous (Valanginian-Hauterivian according to the time scale of Gradstein et al., 2005), which is about 5\% younger than the Rb-Sr ages. The Nd model age is $0.74 \mathrm{Ga}$ (Table 4) and may 


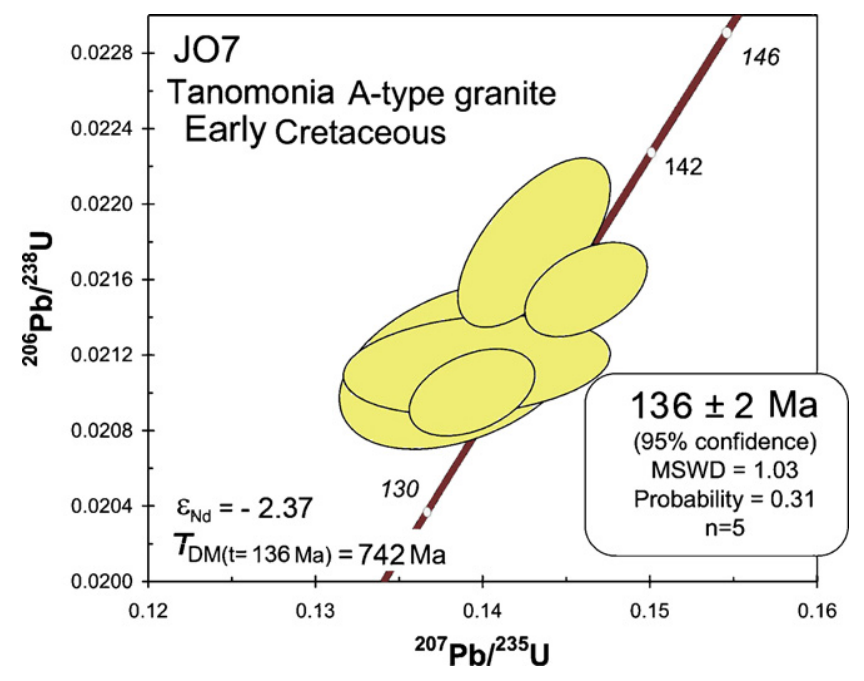

Fig. 23. Concordia plot of zircon from the Tanomonia Granite ( $135.9 \pm 1.8 \mathrm{Ma})$ corresponding to an Early Cretaceous age (Valanginian-Hauterivian; Gradstein et al., 2005).

indicate derivation from the Neoproterozoic rocks of the Brasiliano Orogen, whose front is present about $150 \mathrm{~km}$ to the south and southwest of the Velasco Complex. Another interpretation is that the model age may result from a mixture of Mesozoic juvenile material with Sunsás-age crust. At least three magmatic events took place at the craton margin during the Mesozoic: the formation of the Anari basalt (Marzolli et al., 1999); the Early Cretaceous Velasco alkali-granites; and the Upper Cretaceous Juína and Pimenta Bueno kimberlites (Rizzotto et al., 2004).

\section{2. $S m-N d$ results}

Santos et al. (2000) integrated the available Sm-Nd data for the SW Amazon Craton and demonstrated that the Nd model ages (depleted mantle model) of the Sunsás Province are in the range of $1.06-1.93 \mathrm{Ga}$. This fact precludes significant participation of old continental crust in the evolution of the Sunsás Province, i.e. Archean and Trans-Amazonian rocks were not incorporated in reasonable amounts during magma generation along the orogen. Some of the Nd model ages of 1.50-1.20 Ga suggest generation of juvenile crust and little or no participation of older crust. The other group of model ages are in the $1.50-1.90 \mathrm{Ga}$ range, and is interpreted as evidence of the recycling of Rondônia-Juruena crust. The Sm-Nd data of Tables 1 and 3 show only one sample (JO14, San Ramon tonalite) with a short crustal residence time: the rock was formed at $1431 \mathrm{Ma}$ and its model age is $1.56 \mathrm{Ga}\left(\varepsilon_{\mathrm{Nd}}=+2.32\right)$. The other analysed samples reveal model ages from 2.06 to $1.68 \mathrm{Ga}$, suggesting again the participation of the nearby Rondônia-Juruena crust in some of the melts produced during the Sunsás evolution and perhaps some contribution of rocks from the Tapajós-Parima Province (model ages older than $1.90 \mathrm{Ga}$ ).

The Sm-Nd data of Santos et al. (2000) for the Rondônia-Juruena Province correspond to model ages in the 2.19-1.68 Ga range. These values combine rocks with a strong juvenile source-component (model ages between 1.90 and $1.60 \mathrm{Ga}$ ) and rocks with evidence of participation of rocks from the neighbouring province: the TapajósParima (values older than $1.90 \mathrm{Ga}$ ). The Sm-Nd data (Table 4) show similarity to the Santos et al. (2000) data. The model ages are 1.99-1.67 Ga and some of the rocks represent new crust formed during the orogen, such as the Lomas Manechi granulite, JO3 (crystallization at $1818 \mathrm{Ma}$, model age at $1.86 \mathrm{Ga} ; \varepsilon_{\mathrm{Nd}}=+3.36$ ) and the Refugio Orthogneiss, JO12 (crystallization at $1641 \mathrm{Ma}$, model age at $\left.1.66 \mathrm{Ga} ; \varepsilon_{\mathrm{Nd}}=+4.06\right)$.

\section{Discussion}

\subsection{Synthesis of Sunsás Belt evolution, age and nomenclature}

The integration of both previous and new $\mathrm{U}-\mathrm{Pb}$ and $\mathrm{Sm}-\mathrm{Nd}$ data makes possible a synthesis (Table 5) of the main events of the Rondônia-Juruena and Sunsás Provinces (see discussion below for full details).

A compilation of the 71 available $\mathrm{U}-\mathrm{Pb}$ ages for the West Amazon Craton is shown in Table 6. There are four clusters of ages each representing periods of continuous magmatic and tectonic activity (orogeny) separated by periods of much lesser activity or orogenic interval. These four main orogenies are summarised below:

(a) The Santa Helena orogeny, $1465-1427 \mathrm{Ma}$, is exposed in two separate areas: a southern area (Mato Grosso: Santa Helena Batholith, Pindaituba Suite, Vila Oeste Gneiss; Ruiz, 2006) and

Table 4

Sm-Nd data (whole-rock) for studied samples of West Amazon Craton

\begin{tabular}{|c|c|c|c|c|c|c|c|c|c|c|c|}
\hline Sample & Rock & Unit & $\mathrm{Sm}(\mathrm{ppm})$ & $\mathrm{Nd}(\mathrm{ppm})$ & ${ }^{147} \mathrm{Sm} /{ }^{144} \mathrm{Nd}$ & ${ }^{143} \mathrm{Nd} /{ }^{144} \mathrm{Nd}$ & Error $1 \sigma$ & $\varepsilon_{\mathrm{Nd}(0)}$ & $\operatorname{Age}^{a}(\mathrm{Ma})$ & $\varepsilon_{\mathrm{Nd}(\mathrm{t})}$ & $T_{\mathrm{DM}^{\mathrm{b}}}^{\mathrm{b}}(\mathrm{Ga})$ \\
\hline JO3 & Granulitic gneiss & Lomas Manechi & 3.94 & 21.94 & 0.108572 & 0.511625 & 21 & -20.09 & 1818 & +0.53 & 2.07 \\
\hline GR35 & Quartz-diorite & Jamari & 2.05 & 8.80 & 0.13455 & 0.512016 & 45 & -12.46 & 1761 & +1.57 & 2.00 \\
\hline GR59 & Tonalite & Jamari & 8.41 & 45.38 & 0.10736 & 0.511725 & 10 & -18.14 & 1753 & +1.95 & 1.90 \\
\hline JL78 & Tonalite & Jamari & 8.51 & 48.15 & 0.10690 & 0.511669 & 23 & $-18,90$ & 1738 & +1.04 & 1.95 \\
\hline MQ96 & Dacite & Roosevelt & 6.31 & 39.10 & 0.111464 & 0.511902 & 10 & -14.69 & 1740 & +4.35 & 1.72 \\
\hline JO12 & Orthogneiss & Refugio & 3.4 & 23.5 & 0.087878 & 0.511678 & 13 & -19.06 & 1641 & +4.06 & 1.67 \\
\hline GR333 & Meta-granite & Providência & 7.48 & 35.21 & 0.12800 & 0.511916 & 25 & -14.42 & 1515 & -0.95 & 2.00 \\
\hline JO14 & Tonalite & San Ramón & 7.66 & 57.86 & 0.080035 & 0.511677 & 12 & -19.08 & 1429 & +2.32 & 1.57 \\
\hline J09 & Gneiss & Las Madres & 10.4 & 57.2 & 0.110000 & 0.511867 & 12 & -15.37 & 1330 & -0.61 & 1.74 \\
\hline JO16 & Gneiss & Rio Branco & 2.1 & 14.7 & 0.087557 & 0.511747 & 15 & -17.71 & 1330 & +0.94 & 1.58 \\
\hline JO6 & Gneiss & Rio Fortuna & 8.78 & 45.03 & 0.117849 & 0.511761 & 20 & -17.44 & 1349 & -3.83 & 2.06 \\
\hline JO5 & Gneiss & Lomas Manechi & 9.73 & 49.78 & 0.118118 & 0.511764 & 12 & -17.38 & 1334 & -3.97 & 2.06 \\
\hline J018 & Orthogneiss & Santa Rita & 28.90 & 142.38 & 0.122721 & 0.511883 & 24 & -15.06 & 1319 & -2.57 & 1.96 \\
\hline JO10 & Granite & San Andrés & 14.8 & 77.9 & 0.114947 & 0.511963 & 24 & -13.50 & 1275 & -0.15 & 1.68 \\
\hline JO13 & Rhyodacite & Puquio & 3.84 & 25.79 & 0.090071 & 0.511804 & 15 & -16.60 & 1110 & -1.46 & 1.54 \\
\hline J08 & Garnet gneiss & Las Madres & 16.02 & 91.03 & 0.106375 & 0.511743 & 13 & -17.79 & 1118 & -4.88 & 1.86 \\
\hline $\mathrm{JO7}$ & Alkali granite & Velasco & 47.5 & 343.2 & 0.083756 & 0.512434 & 13 & -4.31 & 135 & -2.37 & 0.74 \\
\hline
\end{tabular}

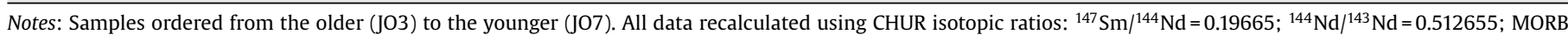
isotopic ratios: ${ }^{147} \mathrm{Sm} /{ }^{144} \mathrm{Nd}=0.21353 ;{ }^{144} \mathrm{Nd} /{ }^{143} \mathrm{Nd}=0.513168$.

a $\mathrm{U}-\mathrm{Pb}$ ages. Ages in italic are assumed by correlation.

b Depleted mantle model (DePaolo, 1981). $T_{\mathrm{DM}(\mathrm{t})}$ model ages in Ga. 
Table 5

Chronology and correlation of main events/units of Sunsás and Rondônia-Juruena Provinces

\begin{tabular}{|c|c|c|c|c|c|c|c|}
\hline & \multicolumn{6}{|l|}{ Province } & \multirow[t]{3}{*}{ Age (Ma) } \\
\hline & \multicolumn{3}{|l|}{ Rondônia-Juruena } & \multicolumn{3}{|l|}{ Sunsás } & \\
\hline & Juruena $^{\mathrm{a}}$ & Jamari $^{a}$ & Alto Jauru $^{a}$ & Bolivia $^{\mathrm{b}}$ & Rondônia $^{b}$ & W Mato Grosso ${ }^{b}$ & \\
\hline $\begin{array}{l}\text { Post-Sunsás } \\
\text { Foreland basins } \\
\text { A-type granites }\end{array}$ & Apiacás, Dardanelos & $\begin{array}{l}\text { Palmeiral, Prainha } \\
\text { Rondônia Suite }\end{array}$ & & Huanchaca & $\begin{array}{l}\text { Palmeiral, Pacaás } \\
\text { Rondônia Suite }\end{array}$ & Rio Branco Suite & $\begin{array}{l}<980 \\
1060-980\end{array}$ \\
\hline $\begin{array}{l}\text { Sunsás } \\
\text { Nova Brasilândia orogeny }\end{array}$ & & & & $\begin{array}{l}\text { Sunsás, Vibosi, and } \\
\text { Aguapeí Groups; Sunsás } \\
\text { paragneiss }\end{array}$ & $\begin{array}{l}\text { Nova Brasilândia Group, } \\
\text { S-type granites }\end{array}$ & Aguapei Group & $1180-1100$ \\
\hline San Andrés orogeny & & & & $\begin{array}{l}\text { San Andrés, San Rafael, } \\
\text { Orobayaya Granites }\end{array}$ & $\begin{array}{l}\text { Detrital zircon in Nova } \\
\text { Brasilândia samples }\end{array}$ & & 1275 \\
\hline Candeias orogeny & & $\begin{array}{l}\text { Jamari Complex } \\
\text { metamorphism, Serra } \\
\text { Providência } \\
\text { metamorphism }\end{array}$ & & $\begin{array}{l}\text { Pensamiento Complex, } \\
\text { Lomas Manechi } \\
\text { metamorphism, Rio } \\
\text { Fortuna Gneiss (JO6), } \\
\text { Santa Rita Gneiss (JO18) }\end{array}$ & $\begin{array}{l}\text { Candeias Granite, Rio } \\
\text { Crespo Group }\end{array}$ & Indiavai Granite & 1371-1319 \\
\hline Santa Helena orogeny & & & & San Ramón Tonalite & $\begin{array}{l}\text { Mamoré Complex (?), } \\
\text { detrital zircon in Nova } \\
\text { Brasilândia samples }\end{array}$ & $\begin{array}{l}\text { Santa Helena Tonalite, } \\
\text { Pindaituba Suite }\end{array}$ & $1465-1427$ \\
\hline \multicolumn{8}{|l|}{ Pre-Sunsás } \\
\hline Post-tectonic granites & Aripuanã Granite & Serra Providência Suite & $\begin{array}{l}\text { Cachoeirinha and Santa } \\
\text { Cruz suites }\end{array}$ & & & & $1560-1530$ \\
\hline Quatro Cachoeiras orogeny & $\begin{array}{l}\text { Monte Verde } \\
\text { metamorphism, } \\
\text { Colniza Granodiorite }\end{array}$ & $\begin{array}{l}\text { Quatro Cachoeiras } \\
\text { Group, Jamari Complex } \\
\text { metamorphism }\end{array}$ & Vila Oeste Gneiss & $\begin{array}{l}\text { Refugio Orthogneiss, } \\
\text { detrital zircon in Las } \\
\text { Madres Paragneiss (JO8) }\end{array}$ & & & $1670-1630$ \\
\hline Beneficente Basin & Beneficente Group & Beneficente Group & & \multirow{3}{*}{$\begin{array}{l}\text { Detrital zircon in sample } \\
\text { JO6, Rio Fortuna Gneiss }\end{array}$} & & & $1740-1700$ \\
\hline \multirow[b]{2}{*}{ Magmatic Arc 3} & $\begin{array}{l}\text { Roosevelt Group, } \\
\text { Paraibão Granite, } \\
\text { Maçaranduba Dacite, } \\
\text { Teles Pires Suite }\end{array}$ & Jamari Complex & $\begin{array}{l}\text { Cabaçal and Quatro } \\
\text { Meninas Groups; Santa } \\
\text { Fé and Aliança } \\
\text { Gneisses }\end{array}$ & & & & $1760-1740$ \\
\hline & $\begin{array}{l}\text { Colíder Group, Vitória } \\
\text { Suite, Monte Verde } \\
\text { Complex, São Pedro } \\
\text { Granite, São Romão } \\
\text { Granite }\end{array}$ & & Santa Fé orogeny & & & & $1786-1770$ \\
\hline Magmatic Arc 2 & $\begin{array}{l}\text { Paranaita Suite, } \\
\text { Cristalino Syenite, }\end{array}$ & & & $\begin{array}{l}\text { Lomas Manechi protolith } \\
\text { (JO3) }\end{array}$ & & & $1819-1793$ \\
\hline Magmatic Arc 1 & Juruena Granodiorite & & & & & & $1848-1823$ \\
\hline
\end{tabular}

Notes: Details of ages and references are in Tables 6 and 7. The dashed lines are marking periods (30-60 m.y.) of much less magmatic and tectonic activity (hiatus). aDomain; ${ }^{\text {b Region. }}$

a southwestern area (San Ramon Tonalite) of the Sunsás Orogen and consists mostly of island-arc-type rocks (Geraldes et al., 2001; Santos et al., 2002; Ruiz, 2006). Other occurrences not yet identified are anticipated, because detrital zircons with ages in the 1465-1417 Ma range are present in sandstones and quartzites from a broad geographic distribution, such as in Nova Brasilândia: JP8 $(n=1)$, JP3 $(n=1)$, GR66 $(n=2)$; Aguapeí: J01 $(n=1)$, JP10 $(n=3)$, MT1 $(n=10)$; Palmeiral: JP2 $(n=1)$, JP6 $(n=4)$; Pacaás-Novos: pac $(n=2)$ : Prosperança: VP2 $(n=1)$, studied by Santos et al. (2008).

(b) The Candeias orogeny, 1371-1319 Ma, has two main components: (1) An Andean-type magmatic arc with I-type (eastern Candeias Batholith), high-K( $\mathrm{A}_{2}$-type; central Candeias Batholith and Ariquemes Granite) and some S-type granites (sample JL6); and (2) metamorphic rocks reaching to the granulite facies (Rio Crespo and Colorado suites; Bettencourt et al., 2006; Rizzotto et al., 2002). More than $60 \%$ of the exposed Sunsás Orogen is formed by rocks of this orogeny. The name San Ignacio is not used to avoid confusion: the San Ignacio Supergroup was deposited between 2000 and 1400 Ma (Litherland et al., 1986), but the same name was also used for a younger orogeny (1400-1280 Ma).

(c) The San Andrés orogeny, upper and lower age limits unknown, is represented by the San Andrés Granite formed at 1275 Ma. Detrital zircons in late-Sunsás and post-Sunsás basins (Santos et al., 2002) indicate important felsic magmatic activity at 1220-1280 Ma that may be associated with the San Andrés orogeny. Santos et al. (2008), studying the ages of detrital zircon in five samples of post-Sunsás sandstones detected two important peaks of magmatic activity at 1285 and 1240 Ma. This orogeny may include the following granites: San Andrés, San Rafael, Orobayaya, El Tigre, San Javier, and Candelaria. (d) The Nova Brasilândia orogeny, 1180-1110 Ma, is dominated by meta-sedimentary belts such as Nova Brasilândia, Aguapeí, and Sunsás. The most common metamorphic grades are medium to high (upper amphibolite) in the northern part of the belt in Rondônia (Iata, Colorado, and Nova Brasilândia units) and low to medium grade (green schist to lower amphibolite facies) in the southern zone in Bolivia and Mato Grosso (Aguapeí and Sunsás Groups). Granulite facies is locally present as described by Tohver et al. (2004) and as identified in sample JO8 (Las Madres garnet gneiss). The meta-sedimentary basins are more pelitic to the north (Rondônia) and more psammitic to the south (Bolivia and Mato Grosso). Small bodies of S-type granites represent another characteristic rock produced during the Nova Brasilândia orogeny.

These orogenies are not necessarily manifested throughout the entire Sunsás Orogen, they may also be diachronous. They were formed during Mid- to Late Mesoproterozoic resulting of northeastdirected crustal contraction.

The Candeias Batholith was originally mapped as orogenic and heterogeneous (Souza et al., 1975). Some following models proposed an anorogenic or intraplate tectonic setting focusing in the A-type composition and lack of deformation in some facies (Isotta et al., 1978). Bettencourt et al. (1999) proposed an extensional regime related to the orogenic cycle or to the opening of Grenvillian Ocean. However, the K-rich facies predominates only in the central zone, whereas the western zone is composed by dominant S-type facies (sample MQ23, this work) and the eastern part is composed by I-type monzogranite and granodiorite (mapping by the senior author during 1970, unpublished data; Souza et al., 1975). The Atype composition is not direct evidence for anorogenic or intraplate setting because part of the A-type granites - the $A_{2}$-type - forms in 
Table 6

$\mathrm{U}-\mathrm{Pb}$ ages of orogenic rocks in the Sunsás and Rondônia-Juruena Provinces

\begin{tabular}{|c|c|c|c|c|c|c|c|c|c|}
\hline Sample & Rock & Unit & Tectonic unit & $\mathrm{U}-\mathrm{Pb}$ age & $\mathrm{m}^{1}$ & Type & $T_{\mathrm{DM}(\mathrm{t})^{\mathrm{a}}}$ & $\varepsilon_{\mathrm{Nd}}$ & Reference \\
\hline 134 & Paragneiss & Nova Brasilândia & & $1097 \pm 5$ & $\mathrm{~m}$ & Metamorphic & & & Tohver et al. (2004) \\
\hline GR20 & Leucogranite & Rio Pardo & $\begin{array}{l}\text { 4th orogeny Nova } \\
\text { Brasilândia }\end{array}$ & $1110 \pm 8$ & $\mathrm{z}$ & Magmatic & & & $\begin{array}{l}\text { Rizzotto et al. } \\
\text { (1999) }\end{array}$ \\
\hline $\mathrm{JO} 2$ & Conglomerate & Aguapeí & & 1165-1149 & $\mathrm{z}-\mathrm{x}$ & Detrital & 1.63 & -1.14 & Santos et al. (2005) \\
\hline J013 & Rhyodacite & Puquio Norte & & $1700-1500$ & $\mathrm{z}$ & Inherited & 1.54 & -1.46 & This work \\
\hline JO8 & Garnet gneiss & Las Madres & & $1118 \pm 15$ & $\mathrm{z}$ & Metamorphic & 1.86 & -4.88 & This work \\
\hline MT1 & Quartzite & Aguapeí & & $<1171$ & $\mathrm{z}$ & Detrital & & & Santos et al. (2001) \\
\hline JP3 & Sillimanite gneiss & lata & & $<1210$ & $\mathrm{z}$ & Detrital & & & This work \\
\hline GR66 & Quartzite & N. Brasilândia & & $1160 \pm 14$ & $\mathrm{z}$ & Detrital & & & Santos et al. (2000) \\
\hline GR66 & Quartzite & N. Brasilândia & $\begin{array}{l}\text { 3rd orogeny San } \\
\text { Andrés }\end{array}$ & $1226 \pm 13$ & $\mathrm{z}$ & Detrital & & & Santos et al. (2000) \\
\hline 228 & 2 mica granite & San Rafael & & $1259 \pm 13$ & $\mathrm{z}$ & Magmatic & & & Boger et al. (2005)* \\
\hline J010 & Granite & San Andrés & & $1275 \pm 7$ & $\mathrm{z}$ & Magmatic & 1.68 & -0.15 & This work \\
\hline GR66 & Quartzite & N. Brasilândia & & $1289 \pm 16$ & $\mathrm{z}$ & Detrital & & & Santos et al. (2000) \\
\hline J018 & Orthogneiss & Santa Rita & $\begin{array}{l}\text { 2nd orogeny } \\
\text { Candeias }\end{array}$ & $1319 \pm 6$ & & Magmatic & 1.96 & -2.57 & This work \\
\hline 240 & Charnockite & Lomas Manechi & & $1320 \pm 10$ & $\mathrm{z}$ & Magmatic & & & Boger et al. (2005) \\
\hline WB44A & Augen gneiss & Jaru & & $1326 \pm 2$ & $\mathrm{z}$ & Metamorphic & 1.84 & +0.50 & Payolla et al. (2002) \\
\hline RO8 & Kinzigite & Rio Crespo & & $1331 \pm 8$ & $\mathrm{z}$ & Metamorphic & & & $\begin{array}{l}\text { Tassinari et al. } \\
\text { (1999) }\end{array}$ \\
\hline WB51 & Orthogneiss & Rio Crespo & & $1331 \pm 9$ & $\mathrm{z}$ & Metamorphic & 1.75 & +1.20 & $\begin{array}{l}\text { Bettencourt et al. } \\
\text { (2006) }\end{array}$ \\
\hline J010 & Granite & San Andrés & & $1331 \pm 13$ & $\mathrm{z}$ & Inherited & & & This work \\
\hline JO5 & Gneiss & Lomas Manechi & & $1334 \pm 3$ & $\mathrm{z}$ & Metamorphic & 2.06 & -3.97 & This work \\
\hline 228 & 2 mica granite & San Rafael & & $1339 \pm 6$ & $\mathrm{z}$ & Inherited & & & Boger et al. (2005)* \\
\hline APQ11 & Monzogranite & Indiavaí & & $1334 \pm 14$ & $\mathrm{z}$ & Magmatic & & & Ruiz (2006) \\
\hline JL78 & Tonalite & Jamari & & $1334 \pm 7$ & $\mathrm{z}$ & Metamorphic & 1.95 & +1.04 & This work \\
\hline JO6 & Orthogneiss & Rio Fortuna & & $1336 \pm 3$ & $\mathrm{z}$ & Magmatic & 2.06 & -3.83 & This work \\
\hline $235 \mathrm{~A} 1$ & Paragneiss & Chiquitania & & $1336 \pm 6$ & $\mathrm{z}$ & Metamorphic & & & Boger et al. (2005) \\
\hline JL6 & S-type granite & Unnamed & & $1339 \pm 3$ & $\mathrm{z}$ & Metamorphic & & & This work \\
\hline JO3M & Granulitic gneiss & Lomas Manechi & & $1339 \pm 4$ & $\mathrm{~m}$ & Metamorphic & & & This work \\
\hline JS39 & Monzogranite & Alto Candeias & & $1339 \pm 7$ & $\mathrm{z}$ & Magmatic & & & This work \\
\hline MQ23 & S-type Granite & Laje & & $1334 \pm 9$ & $\mathrm{z}$ & Magmatic & & & This work \\
\hline J09 & Gneiss & Las Madres & & & & & 1.74 & -0.61 & This work \\
\hline J016 & Gneiss & Rio Branco & & & & & 1.58 & +0.94 & This work \\
\hline GR333 & Meta-granite & S. Providência & & $1348 \pm 4$ & $\mathrm{z}$ & Metamorphic & 2.00 & -0.95 & This work \\
\hline R010 & Leucogabbro & Colorado & & $1352 \pm 6$ & $\mathrm{z}$ & Magmatic & & & $\begin{array}{l}\text { Rizzotto et al. } \\
(2002)\end{array}$ \\
\hline W052 & Granite & Ariquemes & & $1352 \pm 8$ & $\mathrm{z}$ & Magmatic & & & Santos et al. (2000) \\
\hline $235 \mathrm{~A}$ & Paragneiss & Chiquitania & & $1371 \pm 14$ & $\mathrm{z}$ & Metamorphic & & & Boger et al. (2005) \\
\hline LR42 & Monzogranite & Santa Clara & & $1426 \pm 27$ & $\mathrm{z}$ & Magmatic & & & Ruiz (2006) \\
\hline GR66 & Quartzite & N. Brasilândia & $\begin{array}{l}\text { 1st orogeny Santa } \\
\text { Helena }\end{array}$ & $1427 \pm 11$ & $\mathrm{z}$ & Detrital & & & Santos et al. (2000) \\
\hline JO14 & Tonalite & San Ramón & & $1429 \pm 4$ & $z-t$ & Magmatic & 1.57 & +2.32 & This work \\
\hline LR20 & Monzogranite & Anhangüera & & $1437 \pm 28$ & $\mathrm{z}$ & Magmatic & 1.70 & +1.51 & Ruiz (2006) \\
\hline RP24 & Monzogranite & Pindaituba & & $1437 \pm 45$ & $\mathrm{z}$ & Magmatic & 1.69 & +1.02 & Ruiz (2006) \\
\hline MT1 & Quartzite & Aguapeí & & $1447 \pm 7$ & $\mathrm{z}$ & Detrital & & & Santos et al. (2001) \\
\hline RN23 & Orhtogneiss & Vila Oeste & & $1447 \pm 18$ & $\mathrm{z}$ & Magmatic & & & Ruiz (2006) \\
\hline RN22 & Granodiorite & Mineiros & & $1455 \pm 12$ & $\mathrm{z}$ & Magmatic & 1.70 & +1.92 & Ruiz (2006) \\
\hline CARD & Granite & Cardoso & & $1455 \pm 20$ & $\mathrm{z}$ & Magmatic & 1.61 & & Condie et al. (2005) \\
\hline RP15 & Monzogranite & Sapé & & $1462 \pm 9$ & $\mathrm{z}$ & Magmatic & 1.83 & +0.03 & Ruiz (2006) \\
\hline RN151 & Tonalite & Nova Lacerda & & $1464 \pm 12$ & $\mathrm{z}$ & Magmatic & 1.68 & +2.33 & Ruiz (2006) \\
\hline JWB3a & Garnet gneiss & Ouro Preto & Quatro Cachoeiras & $1634 \pm 8$ & $\mathrm{z}$ & Metamorphic & & & $\begin{array}{l}\text { Bettencourt et al. } \\
\text { (2001) }\end{array}$ \\
\hline J012 & Othogneiss & Refugio & & $1641 \pm 4$ & $\mathrm{z}$ & Magmatic & 1.66 & +4.06 & This work \\
\hline GR35 & Quartz-diorite & Jamari & & $1649 \pm 5$ & $\mathrm{z}$ & Metamorphic & 2.00 & +1.57 & This work \\
\hline PS171 & Amphibolite & Monte Verde & & $1653 \pm 42$ & $\mathrm{z}$ & Metamorphic & 2.00 & +0.1 & $\begin{array}{l}\text { M. Pimentel } \\
\text { (personal } \\
\text { communication) }\end{array}$ \\
\hline JWB10 & Granulitic gneiss & Ouro Preto & & $1655 \pm 11$ & $\mathrm{z}$ & Metamorphic & & & $\begin{array}{l}\text { Bettencourt et al. } \\
\text { (2001) }\end{array}$ \\
\hline PT12 & Paragneiss & Ouro Preto & & $1657 \pm 12$ & $\mathrm{z}$ & Metamorphic & & & Santos et al. (2000) \\
\hline RN23 & Orthogneiss & Vila Oeste & & $1657 \pm 31$ & $\mathrm{Z}$ & Inherited & & & Ruiz (2006) \\
\hline JS15 & Gneiss & Quatro Cachoeiras & & $1661 \pm 11$ & $\mathrm{z}$ & Magmatic & & & Silva et al. (2002) \\
\hline 240 & Charnockite & Lomas Manechi & & $1663 \pm 13$ & $\mathrm{z}$ & Inherited & & & Boger et al. (2005) \\
\hline P18 & Meta-granodiorite & Colniza & & $1669 \pm 13$ & $\mathrm{z}$ & Metamorphic & 2.16 & -0.30 & Pinho et al. (2003) \\
\hline GR59 & Tonalite & Jamari & & $1677 \pm 6$ & $\mathrm{z}$ & Magmatic & 1.90 & +1.95 & This work \\
\hline WB152 & Paragneiss & Machadinho & & $1677 \pm 5^{*}$ & $\mathrm{z}$ & Metamorphic & 2.13 & -1.19 & Payolla et al. (2002) \\
\hline J08 & Garnet gneiss & Concepción & & $1678 \pm 11$ & $\mathrm{z}$ & Detrital & 1.86 & -4.88 & This work \\
\hline 228 & 2 mica granite & San Rafael & & $1686 \pm 16$ & $\mathrm{z}$ & Inherited & & & Boger et al. (2005) \\
\hline 261 & Orthogneiss & Lomas Manechi & & $1689 \pm 5$ & $\mathrm{z}$ & Magmatic & & & Boger et al. (2005) \\
\hline
\end{tabular}


Table 6 (Continued)

\begin{tabular}{|c|c|c|c|c|c|c|c|c|c|}
\hline Sample & Rock & Unit & Tectonic unit & U-Pb age & $\mathrm{m}^{1}$ & Type & $T_{\mathrm{DM}(\mathrm{t})}{ }^{\mathrm{a}}$ & $\varepsilon_{\mathrm{Nd}}$ & Reference \\
\hline JL78 & Tonalitic gneiss & Jamari & Jamari & $1738 \pm 6$ & $\mathrm{z}$ & Magmatic & 1.95 & +1.04 & This work \\
\hline J018 & Orthogneiss & Santa Rita & & $1746 \pm 21$ & $\mathrm{z}$ & Inherited & 1.96 & -2.57 & This work \\
\hline B335 & Tonalite & Jamari & & $1750 \pm 24$ & $\mathrm{z}$ & Magmatic & 2.22 & -1.84 & $\begin{array}{l}\text { Tassinari et al. } \\
\text { (1996) }\end{array}$ \\
\hline J06 & Foliated granite & Rio Fortuna & & $1753 \pm 10$ & $\mathrm{z}$ & Inherited & 2.06 & -3.83 & This work \\
\hline A338a & Tonalitic gneiss & Jamari & & $1756 \pm 38$ & $\mathrm{z}$ & Magmatic & 2.20 & -1.50 & $\begin{array}{l}\text { Tassinari et al. } \\
\text { (1996) }\end{array}$ \\
\hline GR66 & Quartzite & N. Brasilândia & & $1753 \pm 18$ & $\mathrm{z}$ & Detrital & & & Santos et al. (2000) \\
\hline GR59 & Tonalite & Jamari & & $1753 \pm 8$ & $\mathrm{z}$ & Magmatic & 1.90 & +1.95 & This work \\
\hline GR35 & Quartz-diorite & Jamari & & $1758 \pm 7$ & $\mathrm{z}$ & Magmatic & 1.99 & +1.57 & This work \\
\hline WB152 & Paragneiss & Machadinho & & $1762 \pm 4$ & $\mathrm{z}$ & Inherited & 2.13 & -1.19 & Payolla et al. (2002) \\
\hline 221d & Paragneiss & San Ignacio Gr. & & $1764 \pm 6$ & $\mathrm{z}$ & Detrital & & & Boger et al. (2005) \\
\hline $235 a$ & Gneiss & Chiquitania & & $1764 \pm 12$ & $\mathrm{z}$ & Inherited & & & Boger et al. (2005) \\
\hline JO3 & Granulitic gneiss & Lomas Manechi & Juruena & $1818 \pm 13$ & $\mathrm{z}$ & Magmatic & 2.07 & +0.53 & This work \\
\hline
\end{tabular}

Notes: Samples of this work located in Figs. 3 and 4. m1-mineral: z, zircon; x, xenotime; t, titanite; m, monazite.

* Ages recalculated from Boger et al. (2005).

a Nd model ages from whole-rock (Ga), except sample CARD, where the model age is from Hf isotopes in zircon.

orogenic environment. According to Eby (1992), the A 2 -type granites are generated from magmas derived from continental crust or underplated crust that has been through a cycle of continentcontinent collision. More recent models for the Candeias Batholith (Santos et al., 2000; Schobbenhaus et al., 2004; Rizzotto et al., 2004) suggest derivation from continental crust in orogenic environment, which agrees with the paleogeography of the western margin of the Amazon Craton at $1370-1320$ Ma. Such paleogeography suggests that intraplate magmatism is unlikely and there is no evidence for a mantle plume underneath the Sunsás Orogen at 1370-1320 Ma to generate intraplate-like granites.

\subsection{Distribution of Sunsás Orogen}

The distribution of the Sunsás Orogen in South America is not well defined and all available information is derived from less than $15 \%$ of the belt. At least $85 \%$ of the belt is covered by Phanerozoic deposits, mostly modern molasse deposited in foreland basins derived from the erosion of the Andes. These basins are named Apure and East Venezuela (Venezuela), Llanos and Putumayo (Colombia), Marañon (Ecuador and Peru), Acre and Solimões (Brazil), Madre de Diós (Peru), Beni and Santa Cruz (Bolivia), and Chaco (Paraguay and Argentina) basins (Fig. 2).

There is strong evidence to extend the Sunsás Orogen from the Brazil-Bolivia (type-area) to the north and to the south forming a belt about $6000 \mathrm{~km}$ long from northern Argentina-Paraguay to East Venezuela. Because these northern and southern extensions are largely covered by Phanerozoic foreland deposits, evidence for such a belt is indirect.

To the north of parallel $36^{\circ} \mathrm{S}$, there are several crustal fragments of Sunsás-age preserved within the Andean Belt. These are known as the Arequipa Complex (Quilca and Mollendo) in Peru (Wasteneys et al., 1995; Martignole and Martelat, 2003; Casquet et al., 2006), the Las Matras Trondhjemite in northwest Argentina (Sato et al., 2004), Garzon, Santander, and Santa Marta Complexes in Colombia (Priem et al., 1982; Pace et al., 1997), and the Merida Complex in Venezuela (Pace et al., 1997; Lopez et al., 2001).

The presence of large crustal fragments of age correlate to the Sunsás Orogen combined with the absence of older, Archean to Paleoproterozoic crust within the Andes Orogen (to the north of parallel $36^{\circ} \mathrm{S}$ ) is direct evidence that the central and northern Andes was built on a continental margin formed by the Sunsás Province (Litherland et al., 1985). Although these fragments have been suggested as independent and isolated microcratons (Casquet et al., 2006), allochtonous (Suarez, 1990), or interpreted as exotic terranes (Wasteneys et al., 1995), we argue that they were all part of the larger and continuous Sunsás Orogen during the Mesoproterozoic (Santos et al., 2000; Li et al., 2008; Fuck et al., 2008).

\subsubsection{Extension to the north}

The Iquitos High in Peru-Brazil border is a buried topographic high (paleo-arch) in the West Amazon that is parallel to the Sunsás front as mapped in Rondônia (Fig. 1). The Iquitos ridge is evident as a NNW elongate gravity high (Fig. 6 of Roddaz et al., 2005) and that may have been produced during one of the two major Sunsás collisions - either the Candeias, $1350-1320$ Ma or the Nova Brasilândia, 1180-1100 Ma. In Colombia, there are three main exposed areas of age comparable to the age of the Sunsás Orogen: the Santa Marta Complex in the northern Andes (Priem et al., 1982), the Garzon Complex (Kroonemberg, 1982; Pace et al., 1997) at the Amazon Craton-Andes boundary and the Piraparaná and Yaca-yaca formations (Priem et al., 1989) near the Brazilian border (Fig. 1). In Venezuela, the presence of the Sunsás Orogen is interpreted in a region totally covered by the Llanos or Eastern Venezuela Basin to the north of the Imataca Complex and north of the Orinoco River. Here the existence of the K'Mudku event has been reported since Bellizzia (1974) and named the Orinoquensis event. Onstott et al. (1989), investigating the Paleoproterozoic Imataca Complex (Santos et al., 2005, 2006) and using Ar-Ar dating, published 11 Mesoproterozoic plateau ages in the 1439-1112 Ma range. This strong metamorphic overprint is an indication that the northern craton margin in Venezuela is not far from the Sunsás orogenic front. Other evidence derives from the study by Goldstein et al. (1997) using detrital zircon. The main population $(n=17)$ of detrital zircon in a sample of modern sand collected from the lower Orinoco River near Ciudad Bolivar has ages correlating to the Sunsás Orogen (1449-1016 Ma). Those zircons may come from the Mesoproterozoic Merida fragment at the headwaters of the Apure River in the Andes (Western Venezuela, Fig. 1). However, this potential source is about $1200 \mathrm{~km}$ to the west and represents less than $1 \%$ of the area of the Orinoco River Basin. Further, the presence of only six Paleozoic-Mesozoic zircon grains in that sample suggests that the contribution of detritus from the Andes (recycled or not) to the Orinoco system is small. The suggested and more probable source of those zircons are actually hidden Sunsás rocks to the north and west of Orinoco River, which eroded mainly before the deposition of the Llanos, Apure and East Venezuela basins (Schenk et al., 2000).

\subsubsection{Extension to the south}

Recent work by Ruiz et al. (2005b) and Ruiz (2006) recorded the Mesoproterozoic age of the Rio Apa "terrane" along the BrazilParaguay border. The Rio Apa Belt appears to be structurally 
concordant with the Sunsás Orogen and is now interpreted as an extension of the Amazon Craton to about $240 \mathrm{~km}$ to the south. Recent U-Pb data from Cordani et al. (2008) on Rio Apa samples revealed an orthogneiss formed at ca. $1350 \mathrm{Ma}$ (sample 95) and Cordani and Teixeira (2007) detected a strong metamorphic imprint at about $1300 \mathrm{Ma}$. The basement rocks have ages of $1829 \mathrm{Ma}$ (similar to the age of Juruena Granodiorite, Table 5), and within 1763-1720 Ma (mainly comparable to the ages of the Jamari Complex). All these are evidences that the Rio Apa region is related to the Amazon Craton.

The prolongation of the Rio Apa Belt farther to the south is unknown, because it lies under the Paraná Basin. In central-north Argentina, the Sierras Pampeanas show a provenance from Sunsásage lithosphere as indicated by Hf isotopes (Chernicoff et al., 2008). The Sunsás connection is present in Sierras de Córdoba where Schwartz and Gromet (2004) proposed a link to the Amazon Craton and to the Sunsás Belt. Steenken et al. (2004) proposed that the basement rocks of the Sierras San Luis in Argentina have age comparable to the Grenvillian Orogen. Another fragment comparable in age to the Sunsás Orogen occurs to the south in Argentina: there where the Las Matras tonalite-trondhjemite forms the basement of the Cuyania terrane (Chernicoff et al., 2008), which according to Sato et al. $(2000,2004)$, was formed at $1244 \pm 42 \mathrm{Ma}$.

\subsection{Age of the Lomas Manechi Complex}

The age of the Lomas Manechi ${ }^{1}$ Complex is considered older than $1961 \mathrm{Ma}$ based on a Rb-Sr isochron plot of Litherland et al. $(1986,1989)$. This isochron combines isotopic ratios from six different groups of rocks (charnockites, gneisses of Chiquitania Complex, Ascención Schists of San Ignacio Group, granulites, leptites, and mafic rocks). The heterogeneity of the plot reflects the very high MSWD value of 286, evidence for a mixture of several populations of ages. The Lomas Manechi Complex was defined as a granulite complex and all its granulites dated by $\mathrm{U}-\mathrm{Pb}$ were formed during the Candeias orogeny. There is no evidence for older, pre-Candeias, granulite metamorphism within the Sunsás and Rondônia-Juruena Provinces. We recommend keeping the Lomas Manechi name for the granulitic rocks in Bolivia as these represent the high-grade metamorphic component of the Candeias orogeny as detected previously in the Rondônia region of Brazil (Santos et al., 2002). The youngest age for metamorphic zircons is $1319 \pm 6 \mathrm{Ma}$ (JO18) and the oldest metamorphic zircon population has an age of $1353 \pm 11 \mathrm{Ma}$ (JO3); this constrains the high-grade metamorphic event to the 1319-1353 Ma period. Another problem is that charnockitic igneous rocks are associated with the Lomas Manechi Complex (supposed basement) together with granulites. Charnockitic rocks are regionally known as post-tectonic (in relation to the orogenies of Rondônia-Juruena Province) intrusions contemporaneous to the Serra Providência Suite and formed during 1570-1530 Ma (Payolla et al., 2002; Santos et al., 2000). Unfortunately, the charnockites of Eastern Bolivia remain undated by U-Pb so we cannot test properly their correlation to the Serra Providência Suite. The only possible test was made using $\mathrm{Rb}-\mathrm{Sr}$ data. Combining the charnockites of Litherland et al. (1989) Rb-Sr plot to the charnockites of Rondônia (Santos et al., 2000) in a single isochron plot (Fig. 24) shows that they all plot on the same regression line at $1587 \pm 86 \mathrm{Ma}$ (MSWD $=2.9 ; n=10$ ). This is the first indication of the existence of charnockitic rocks equivalent in age to the Serra Providência Suite (including the Ouro Preto charnockites) in eastern Bolivia.

\footnotetext{
1 Lomas Manechi, instead of Lomas Maneches. Manechi is the Bolivian name for several species of monkeys of the genus Alouatta as for example Alouatta seniculus. Manechi is equivalent to guariba in Brazil.
}

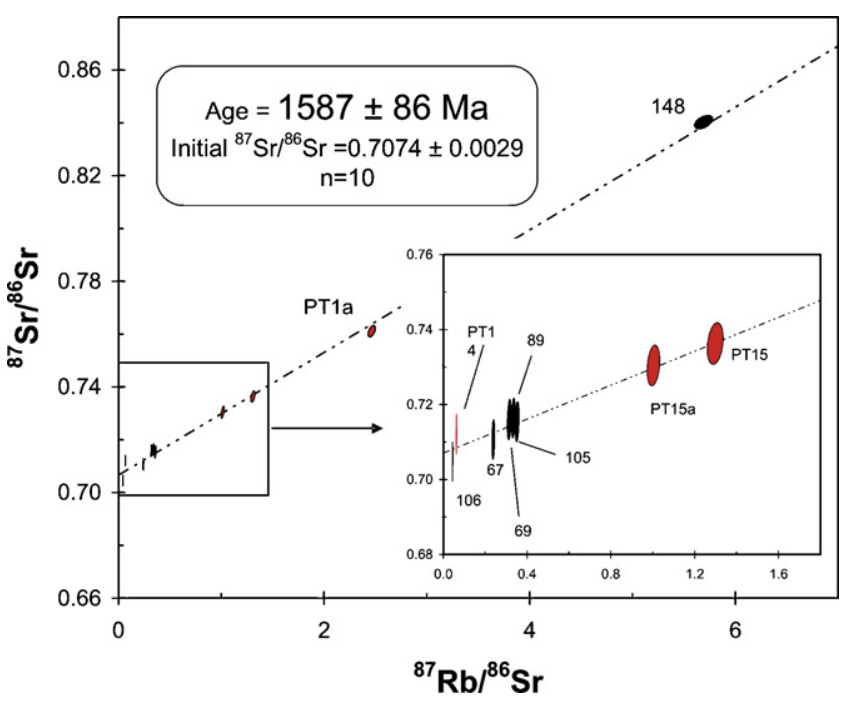

Fig. 24. Integration of $\mathrm{Rb}-\mathrm{Sr}$ isotopic data (whole-rock analyses) of Ouro Preto charnockites from Rondônia (samples PT1, PT1a, PT15, and PT15a; Santos et al., 2000) with mafic granulites and charnockitic granulites of the Lomas Manechi Complex in Bolivia (samples 4, 67, 69, 89, 106, and 148; Litherland et al., 1986, appendix 5). All data are shown on the same regression line at $1587 \pm 86 \mathrm{Ma}$.

\subsection{The problem of the Paraguá Craton}

Litherland et al. (1986) were the first to publish the existence of a craton of about $124,000 \mathrm{~km}^{2}$ in northern Bolivian Precambrian and named it the Paraguá Craton following the unpublished report of Klinck and Litherland (1982). Since then, this craton is recognized on most maps and tectonic models proposed for the evolution of the southwestern part of the Amazon Craton (Tassinari and Macambira, 1999; Geraldes et al., 2001; Boger et al., 2005; Tohver et al., 2002, 2005; Fernandes et al., 2005). One problem is that such a craton is essentially composed (at least about 72\%) of the rocks of the "Orogenic Pensamiento Granitoid Complex" (Litherland et al., 1986, 1989) and the ages of this complex are too young (in relation to the ages of the basement) to be a Precambrian craton. Litherland et al. (1989) recognized two main groups of granitoids within the Pensamiento Complex: syn- to late-kinematic (1350 Ma) and late- to post-kinematic granitoids (1300 Ma). These ages are much younger than the ages of several units in the Bolivian Precambrian, such as the San Ignacio Supergroup, Chiquitania Complex, and Lomas Manechi Complex, both of which formed between 2000 and 1400 Ma according to Litherland et al. (1986, 1989). The Paraguá Craton would be only older than the Sunsás and Aguapeí Belts (Fig. 51 of Litherland et al., 1986), which establishes its minimum age at $>1180-1100 \mathrm{Ma}$ according to the U-Pb ages available for both units (Santos et al., 2005; D'Agrella-Filho et al., 2008). The ages of 1350 and $1300 \mathrm{Ma}$ are $\mathrm{Rb}-\mathrm{Sr}$ whole-rock isochrons and may reflect reset ages in older rocks (i.e. the effect of the Candeias orogeny on older basement). The Pensamiento Complex is composed of an expanded series, including monzogranites, granodiorites, tonalites, trondhjemites and diorites. Litherland et al. (1986) also described hornblende-biotite gneiss and Matos et al. (2006) show that part of the complex has the geochemistry of a magmatic arc and syncollisional environment. Recently Matos et al. (2006) demonstrated that some granitoids and gneisses of the Pensamiento Complex were formed (and not recycled) during the Candeias orogeny. Three granite and gneiss bodies are dated using U-Pb SHRIMP (Matos et al., 2006): Diamantina Monzogranite, La Junta biotite-(hornblende) Orthogneiss, and San Martín hornblende Monzogranite. The ages of these granitoids are (recalculated here at $2 \sigma$ ): $1340 \pm 20 \mathrm{Ma}$, $1347 \pm 21 \mathrm{Ma}$, and $1373 \pm 20 \mathrm{Ma}$. These ages demonstrate that most, 


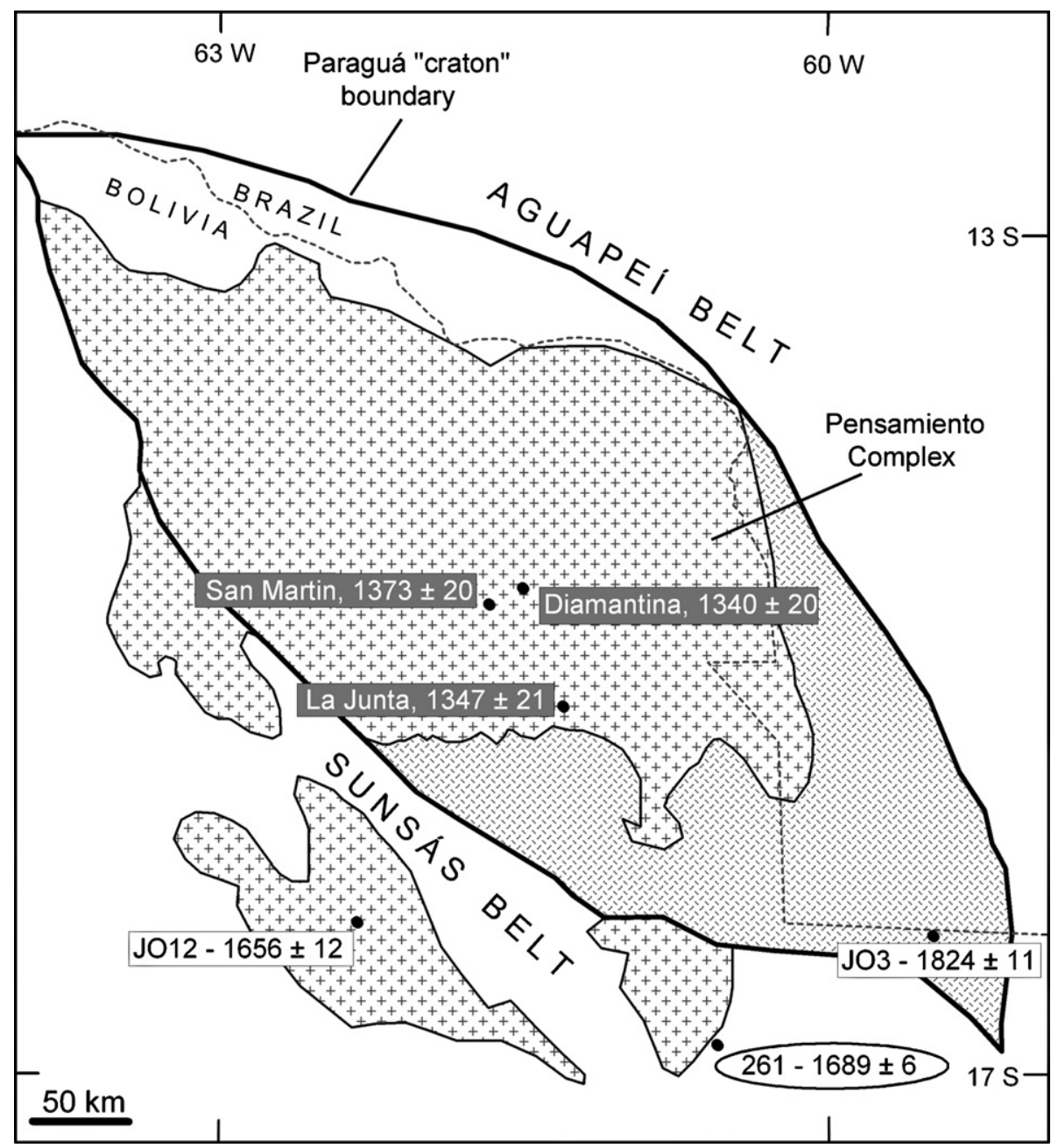

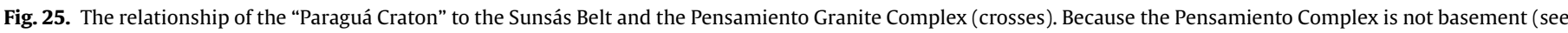

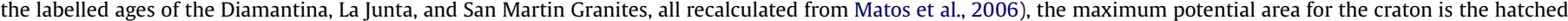
zone to the southeast. Location of Paraguá Craton, Pensamiento Complex, Sunsás Belt, and Aguapeí Belt following Litherland et al. (1986, 1989).

if not all of Pensamiento Complex was formed during the Candeias orogeny. There are many analogies (stratigraphic, petrological, and geochronological) between the Pensamiento granitoids and the Candeias Batholith in Rondônia. In light of the above evidence, we argue that the "Paraguá Craton" does not exist and that the Pensamiento Granitoid Complex is mainly composed of intrusions generated in a continental, Andean-type, orogenic arc produced during the Candeias orogeny.

Removing the area of the Pensamiento Complex from the area of the supposed craton (Figs. 25 and 46 of Litherland et al., 1986), the remaining area is only $34,600 \mathrm{~km}^{2}$. Boger et al. (2005) dated one sample (240) of the Lomas Manechi Complex in this area and reported an age of $1320 \pm 11 \mathrm{Ma}$. They also dated five samples of the Bolivian Precambrian and found only one rock formed before the Sunsás Orogen at $1689 \pm 11 \mathrm{Ma}$ (sample 261). This sample is located within the Sunsás Belt of Figure 51 in Litherland et al. (1986) and occurs outside the area of the supposed craton (Fig. 25).

Four samples from the Lomas Manechi and Chiquitania Complexes (JO3, JO5, JO6, and J018) were dated and three of them were formed during the Candeias orogeny. Only sample JO3 is older ( $1818 \mathrm{Ma}$ ), but was metamorphosed by the Candeias orogeny at $1339 \mathrm{Ma}$ (see Section 4.1.2). Another pre-Candeias rock among the seventeen dated by $\mathrm{U}-\mathrm{Pb}$ is the Refugio Orthogneiss (JO12, $1641 \pm 4 \mathrm{Ma}$ ), which is also outside the limits of the "Paraguá Cra- ton" (Fig. 25). The relatively young Sm-Nd model ages (1.58 and $1.74 \mathrm{Ga}$ ) of two undated gneisses from the Chiquitania Complex, the Las Madres (JO9) and Rio Branco (JO16) gneisses (Tables 1 and 5) are additional evidence that most of the complex was not formed from basement rocks.

None of the granulite rocks (type-rock of the Lomas Manechi unit) in eastern Bolivia and western Rondônia (Tassinari et al., 1999; this work) are basement rocks (pre-Sunsás Orogen), but orogenic rocks formed during the Candeias and Nova Brasilândia orogenies. The amount of older rocks ( 1818 and $1641 \mathrm{Ma}$, this work; 1686-1663 Ma, Boger et al., 2005) in the Bolivian Precambrian is very minor (one sample) and is restricted to the southern area of the supposed craton and beyond it (three samples). The size of these occurrences is unknown, but because they are surrounded by rocks formed during the Candeias orogeny, they are interpreted as small and discontinuous fragments which do not represent a craton or even a tectonic block. Because the evident temporal correlation, these fragments probably derive from the neighbouring Rondônia-Juruena Province. They represent small areas of the continental margin which survived the Candeias orogeny. Excluding the Pensamiento Complex and the younger part of the Lomas Manechi and Chiquitania Complexes of the proposed area for the "Paraguá Craton" (i.e. about 70-80\% of the area of the "craton"), its area would be reduced to only about less than $10,000 \mathrm{~km}^{2}$. 
This small crustal fragment that formed at about 1818-1630 Ma probably is not a craton and is interpreted as a discontinuous fragment of the Rondônia-Juruena Province, which survived the Sunsás evolution, particularly the collisional Candeias orogeny.

\subsection{Proterozoic stratigraphy of Eastern Bolivia}

The inferred stratigraphic succession of the Bolivian Precambrian is based on the metamorphic grade, where the older rocks or units that have the higher metamorphic grade (Litherland et al., 1986). Granulites (Lomas Manechi Complex) were considered the basement and the less-metamorphosed rocks were grouped as the youngest units (Sunsás and Vibosi Groups). Because the region evolved from several successive orogenies from ca. 1820 to $1110 \mathrm{Ma}$, the use of metamorphic grade to establish stratigraphy is not reliable. Each orogeny may have produced a variety of rocks under variable sedimentary, magmatic, and metamorphic environments. Almost all granulites known in Eastern Bolivia and in neighbouring areas in Brazil are not basement rocks, but were formed during the Mesoproterozoic and are related to the Candeias orogeny. However, the Nova Brasilândia orogeny - including the Sunsás and Aguapeí Groups - contrary consisting of only low metamorphic grade (Litherland et al., 1986), also produced anatexis, upper amphibolite metamorphism and re-crystallization of zircon. Dated samples of the Chiquitania and Lomas Manechi Complexes revealed a variety of ages and types of ages (metamorphic, magmatic, and inherited) indicating that those two units should be further subdivided. All are evidence that a broad reinterpretation of these two units is required as well as a review of available regional geological maps.

\subsection{U-Pb ages of the Rondônia-Juruena Province}

The available $\mathrm{U}-\mathrm{Pb}$ data including data from this work and from the literature are listed in Table 5 (orogenic rocks) and Table 6 (post-orogenic rocks). The $\mathrm{U}-\mathrm{Pb}$ ages are listed chronologically independently of their origin, be they magmatic, metamorphic, inherited or detrital. Twenty-six ages from the Rondônia-Juruena Province are organized into three groups of ages, at $1764-1746 \mathrm{Ma}$ (10 samples), 1689-1632 (12 samples), and $1818 \mathrm{Ma}$ (1 sample). The first group corresponds to ages of the Jamari Domain and the second to the collisional Quatro Cachoeiras orogeny. The older age at $1818 \mathrm{Ma}$ is comparable to ages of the Juruena Granodiorite of the Juruena Domain (Lacerda Filho et al., 2001; Santos, 2003). Most of the ages of Quatro Cachoeiras orogeny are metamorphic, reflecting the re-crystallization of zircon under high-grade conditions that resulted from an orogen with a strong collisional component. This type of component has not yet been detected within the Jamari orogeny as shown by the apparent absence of metamorphic zircons in the period of $1760-1740 \mathrm{Ma}$.

The Serra Providência Suite was formed during the Early Mesoproterozoic about 60-90 m.y. after the cessation of the Quatro Cachoeiras orogeny. There are $16 \mathrm{U}-\mathrm{Pb}$ ages of rapakivi granites, granites and charnockites formed during 1573-1532 Ma (Table 5). The Serra Providência Suite was restricted to the Jamari Domain (Santos et al., 2002), but there is an equivalent in the Juruena Domain, namely the Aripuanã Granite (MQ33, $1542 \pm 2 \mathrm{Ma}$; Rizzotto et al., 2002). The apparent scarcity of Serra Providência magmatism within the Juruena Domain possibly results from the paucity of mapping and dating. Part of the numerous granites interpreted as related to the Teles Pires Suite (1780-1760 Ma; Rizzotto et al., 2004) may be younger and equivalent to the Aripuanã Granite.

\subsection{Autochthonous evolution of the Sunsás Orogen}

All of our new $\mathrm{U}-\mathrm{Pb}$ data indicate that the exposed area of the Sunsás Orogen developed largely in situ. This is supported by two lines of evidence. First, on both sides of the border Sunsás rocks contain scattered fragments - from centimetres to kilometres - of Paleoproterozoic rocks with ages equivalent to those of the Rondônia-Juruena Province. Secondly, potentially exotic allochthonous rocks (either Archean or Trans-Amazonian in age) have yet to be found.

Table 7

$\mathrm{U}-\mathrm{Pb}$ and $\mathrm{Ar}-\mathrm{Ar}$ ages of post-orogenic rocks (post-Andean, post-Sunsás, and post-Quatro Cachoeiras)

\begin{tabular}{|c|c|c|c|c|c|c|c|c|}
\hline & Sample & Rock & Unit & $\mathrm{U}-\mathrm{Pb}$ & Method & $T_{\mathrm{DM}(\mathrm{t})}$ & $\varepsilon_{\mathrm{Nd}}$ & Reference \\
\hline Post-Andean & J07 & Alkali granite & Velasco & $136 \pm 2$ & $\mathrm{~S}$ & 749 & -2.31 & This work \\
\hline Post-Sunsás & $\begin{array}{l}\text { MGJB194 } \\
\text { AM52b } \\
\text { O2678 } \\
301 \\
\text { NF14e }\end{array}$ & $\begin{array}{l}\text { Syenogranite } \\
\text { Syenogranite } \\
\text { Alkali granite } \\
\text { Rapakivi granite } \\
\text { Basalt }\end{array}$ & $\begin{array}{l}\text { Maçangana } \\
\text { Santa Bárbara } \\
\text { Pedra Branca } \\
\text { Taperas } \\
\text { Nova Floresta }\end{array}$ & $\begin{array}{l}991 \pm 14 \\
993 \pm 5 \\
998 \pm 5 \\
1061 \pm 6^{*} \\
1062 \pm 3\end{array}$ & $\begin{array}{l}\mathrm{C} \\
\mathrm{Cm} \\
\mathrm{C} \\
\mathrm{S} \\
\mathrm{Aw}\end{array}$ & 1.73 & -3.21 & $\begin{array}{l}\text { Bettencourt et al. (1999) } \\
\text { Sparrenberger et al. (2002) } \\
\text { Bettencourt et al. (1999) } \\
\text { Boger et al. (2005) } \\
\text { Tohver at el. (2002) }\end{array}$ \\
\hline Post-Quatro Cachoeiras & $\begin{array}{l}\text { GR333 } \\
\text { WB36 } \\
\text { JS1 } \\
\text { MQ33 } \\
\text { MQ33 } \\
\text { AR3-1 } \\
\text { JS19 } \\
\text { MQ23 } \\
\text { J08 } \\
\text { JS16 } \\
\text { WB46c } \\
\text { WB46a } \\
\text { SPGR36 } \\
\text { SPGR39 } \\
\text { WO63 } \\
\text { MS6030 } \\
\text { SPGR21 }\end{array}$ & $\begin{array}{l}\text { Meta-granite } \\
\text { Quartz-syenite } \\
\text { Gneiss } \\
\text { Granite } \\
\text { Granite } \\
\text { Monzogranite } \\
\text { Leucogranite } \\
\text { S-type granite } \\
\text { Garnet gneiss } \\
\text { Granite } \\
\text { Gneiss } \\
\text { Monzogranite dyke } \\
\text { Charnockite } \\
\text { Syenogranite } \\
\text { Monzogranite } \\
\text { Mylonitic granite } \\
\text { Orthogneiss } \\
\text { Monzogranite }\end{array}$ & $\begin{array}{l}\text { Providência } \\
\text { União } \\
\text { Providência } \\
\text { Aripuanã } \\
\text { Aripuanã } \\
\text { Samuel } \\
\text { Providência } \\
\text { Laje } \\
\text { Las Madres } \\
\text { Samuel } \\
\text { Providência } \\
\text { Japonês } \\
\text { Japonês } \\
\text { Providência } \\
\text { Providência } \\
\text { Providência } \\
\text { Providência } \\
\text { Providência }\end{array}$ & $\begin{array}{l}1515 \pm 8 \\
1532 \pm 5 \\
1535 \pm 27 \\
1537 \pm 8 \\
1542 \pm 2 \\
1544 \pm 5 \\
1545 \pm 8 \\
1573-1515 \\
1550 \pm 8 \\
1550-1540 \\
1555 \pm 19 \\
1560 \\
1560 \\
1565 \pm 4 \\
1566 \pm 3 \\
1569 \pm 16 \\
1570 \pm 30 \\
1573 \pm 13\end{array}$ & $\begin{array}{l}S \\
C \\
S \\
S \\
C \\
C \\
S \\
S \\
S \\
C \\
S \\
C \\
C \\
C \\
C \\
S \\
C \\
C\end{array}$ & $\begin{array}{l}1.99 \\
1.88 \\
\\
\\
2.07 \\
\\
\\
1.86 \\
\\
\\
\\
1.86 \\
1.86 \\
\\
1.52 \\
2.22 \\
1.89\end{array}$ & $\begin{array}{l}-0.69 \\
+0.20 \\
\\
-0.20 \\
\\
-4.88 \\
\\
\\
-0.70 \\
+0.80 \\
-0.86 \\
-4.58 \\
+0.79\end{array}$ & $\begin{array}{l}\text { This work } \\
\text { Bettencourt at al. (1999) } \\
\text { Silva et al. (2002) } \\
\text { Silva et al. (2002) } \\
\text { Rizzotto et al. (2002) } \\
\text { Payolla et al. (2002) } \\
\text { Silva et al. (2002) } \\
\text { This work } \\
\text { This work } \\
\text { Payolla et al. (2002) } \\
\text { Silva et al. (2002) } \\
\text { Payolla et al. (2002) } \\
\text { Payolla et al. (2002) } \\
\text { Bettencourt at al. (1999) } \\
\text { Bettencourt at al. (1999) } \\
\text { Santos et al. (2000) } \\
\text { Tassinari et al. (1996) } \\
\text { Bettencourt at al. (1999) }\end{array}$ \\
\hline
\end{tabular}

Notes: S, SHRIMP; C, conventional (TIMS); A, Ar-Ar. All data from zircon except AM52b (m: monazite) and NF14e (w: whole-rock).

"Recalculated age. 
All inherited $\mathrm{U}-\mathrm{Pb}$ ages of zircon from granitoids and gneisses and all exposed pre-Sunsás rocks in Bolivia have ages well correlated to the neighbouring province, the Rondônia-Juruena Province. The pre-Sunsás $\mathrm{U}-\mathrm{Pb}$ ages obtained in Bolivia are undistinguishable from the ages of rocks from the Brazilian side (Table 6), strongly suggesting that the Sunsás Belt in both Bolivia and Brazil evolved over a continental margin formed dominantly of rocks of the Jamari and Quatro Cachoeiras orogenies and only secondarily of rocks of the Juruena Domain and Serra Providência Suite (1560-1540 Ma). The same conclusion was reached by Santos et al. (2002, 2005), using detrital zircon. These observations and the absence of any craton to the west (see Section 5.4) indicate that the Sunsás Orogen evolved as a direct (autochthonous) accretion to the western Amazon Craton margin in four periods of more intense orogenic activity as discussed above (Section 5.1). We infer the existence of a continent to the west and moving eastward as a driving force closing the Santa Helena Basin/Ocean and causing the Candeias collision. Direct evidence for such a continent has not yet been found (it may have been removed during Rodinia supercontinent breakup) but certainly should be looked for in future studies.

The fragments of pre-Sunsás rocks present within the Sunsás Province, despite been deformed or redeformed and metamorphosed during the latest orogeny (Nova Brasilândia), correlate with the rocks of the older province (Rondônia-Juruena) to the east and northeast of the Sunsás front. Such fragments may be almost in situ or may have been displaced short distances towards the Sunsás Front allowing terming the orogenic evolution as parautochthonous. A similar evolution is interpreted by Davidson (2008) for that part of the Grenville Province lying between the Grenville front and the Allochthonous Boundary Thrust (Rivers, 1997).

\subsection{Connection to Laurentia}

The inferred collision of Amazonia to Laurentia to form part of the Rodinia supercontinent has been considered to occurred at $\pm 1200 \mathrm{Ma}$ (Tohver et al., 2002), $1100 \mathrm{Ma}$ (metamorphism of Brasilândia and Aguapeí Groups; Fuck et al., 2008), or 1080-970 Ma (Li et al., 2008). However, there is no evidence in Amazonia for a continental collision of such magnitude at $1200 \mathrm{Ma}, 1100 \mathrm{Ma}$ or later. There is no record of magmatism, tectonism, and high-grade metamorphism at ca. $1200 \mathrm{Ma}$ in the West Amazon Craton, a period of orogenic quiescence. The metamorphism of Nova Brasilândia and Aguapeí meta-sedimentary belts is mainly greenschist facies and locally reached upper amphibolite conditions (Rizzotto et al., 1999). The volume of felsic magmatic activity during the Nova Brasilândia orogeny (1180-1110 Ma) is minor. The most feasible timing for the Amazonia-Laurentia amalgamation would be during the Candeias orogeny (1370-1320 Ma), when large volume of felsic magma was generated, and when widespread granulite metamorphism was produced not only within the Sunsás Orogen, but up to thousand of $\mathrm{km}$ inside the craton, such as the K'Mudku shear belt.

Amazonia-Laurentia correlations are mainly based on the comparison of orogenic rocks (Sunsás and Grenville Orogens) possibly because Neoproterozoic Post-Grenvillian magmatism (ca. $1000-800 \mathrm{Ma}$ ) is little reported in Laurentia. Volkert et al. (2005) described widespread small felsic intrusions within the Grenville terrane in the north-central Apallachians of New Jersey and New York. These intrusions are dated from $1020 \pm 4 \mathrm{Ma}$ to $965 \pm 10 \mathrm{Ma}$ providing a strong temporal correlation to the post-orogenic Rondônia Suite of Brazil and Bolivia (Table 8).

\subsubsection{Definition of units}

Some authors (Gower and Krogh, 2002) use the name "Grenville orogeny" for the latest orogeny at 1090-980 Ma, for which most authors in North America (Rivers, 1997; Carr et al., 2000; McLelland et al., 1996) prefer the name "Ottawan". The absence of orogenic rocks in the Sunsás Orogen that are equivalent in age to the Ottawan orogeny (1110-950 Ma; Carr et al., 2000) indicates that cratonization started earlier in the Amazon Craton than in Laurentia. The age limits of the Ottawan orogeny are controversial and may vary along the Grenville Belt: e.g. 1110-950 Ma (Carr et al., 2000), 1090-1030 (Volkert et al., 2005), or 1080-1020 Ma (Rivers, 1997). All these lower age-limits of the Ottawan orogeny $(1080,1090,1100 \mathrm{Ma})$ indicate that this orogeny only started at or after $1100 \mathrm{Ma}$, during post-Nova Brasilândia time (Table 8). The rocks in the western Amazon Craton with ages comparable to the Ottawan orogeny are not orogenic, but instead are cratogenic (rapakivi tin granites, continental rift deposits, alkali basalt, alkaline pipes, etc.) and extend into the interior of the craton, particularly inside the Rondônia-Juruena Province. The Nova Floresta basaltic flows (1062 Ma; Tohver et al., 2002) and associated dike swarms and sills (such as the Rincón Del Tigre in Bolivia) are related to an important period of crustal extension and mantle plume activity. These extensional intracratonic processes may be associated with continental break-up and suggest that separation of Amazonia from the Rodinia supercontinent may have started before 1000 Ma during the Late Mesoproterozoic and not during the Neoproterozoic.

The duration of the Elzevirian orogeny is also controversial: 1350-1185 Ma (McLelland et al., 1996); 1250-1190 Ma (Rivers, 1997); and 1230-1180 Ma (Gower and Krogh, 2002). The equivalent to the Elzevirian orogeny in Amazonia would be the discrete San Andrés orogeny (1275 Ma) and perhaps the early rocks formed during the Nova Brasilândia orogeny (1180-1110 Ma). During this orogeny, represented by the formation of inter-arc basins, upper amphibolite facies metamorphism, and generation of S-type granites, the Grenville Province was affected by intense magmatism (Adirondian magmatism, referred to by McLelland et al., 1996 as AMCG magmatism) at 1180-1080 Ma (McLelland et al., 1996; Kusky and Loring, 2001) - Table 8.

The Eastern Granite-Rhyolite Province (EGRP) is defined in United States by Bickford et al. (1986) as buried basement composed by granite-rhyolite rocks formed during 1500-1300 Ma. These rocks are cropping out in two areas: the Southern Granite Rhyolite Province (SGRP) and the Eastern Granite Rhyolite Province (Van Schmus et al., 1996). These were formed along the southern margin of Laurentia respectively at 1400-1340 Ma and 1500-1440 Ma, according to Slagstad et al. (2004a) based on Van Schmus et al. (1996) and Bickford (1988). More recently, Renee (2005) indicated that the age of the older eastern province is ca. $1470 \mathrm{Ma}$, whereas the age of the younger southern province is ca. 1370 Ma. Most Canadian workers do not use the term EGRP and correlate similar age rocks in the Grenville Province to the Eastern Granite-Rhyolite Province of the United States. Tollo et al. (2004; Fig. 1) presented a map of Laurentia where both the eastern and southern provinces are shown undivided and parallel to the Grenville Orogen. The two Granite-Rhyolite Provinces usually are not included in the evolution of the Grenville Province, probably because their rocks are not much deformed. Typical rocks and ages of this arc are the Britt pluton in Ontario (1456 $\pm 7 \mathrm{Ma}$; Van Breemen et al., 1986), the Shawanaga pluton (ca. $1460 \mathrm{Ma}$; Culshaw et al., 1994), and the basement of the Muskoka and Shawanaga Domains (1450 Ma; Slagstad et al., 2004b). The Eastern Granite-Rhyolite Province includes some rocks that may be younger than $1400 \mathrm{Ma}$, but most available younger ages have low precision (1346+69/-39 Ma; Van Breemen et al., 1986). The crystallization ages of granites and rhyolites of the SGRP are in the 1400-1340 Ma range (Renee, 2005). The above dates suggest a temporal correlation of the EGRP to the Santa Helena orogeny (1465-1427 Ma) and of the SGRP to the Candeias orogeny (1371-1319Ma) - see 
Table 8

Chronological comparison between Amazonia and Laurentia evolution from ca. 1840 to ca. $965 \mathrm{Ma}$

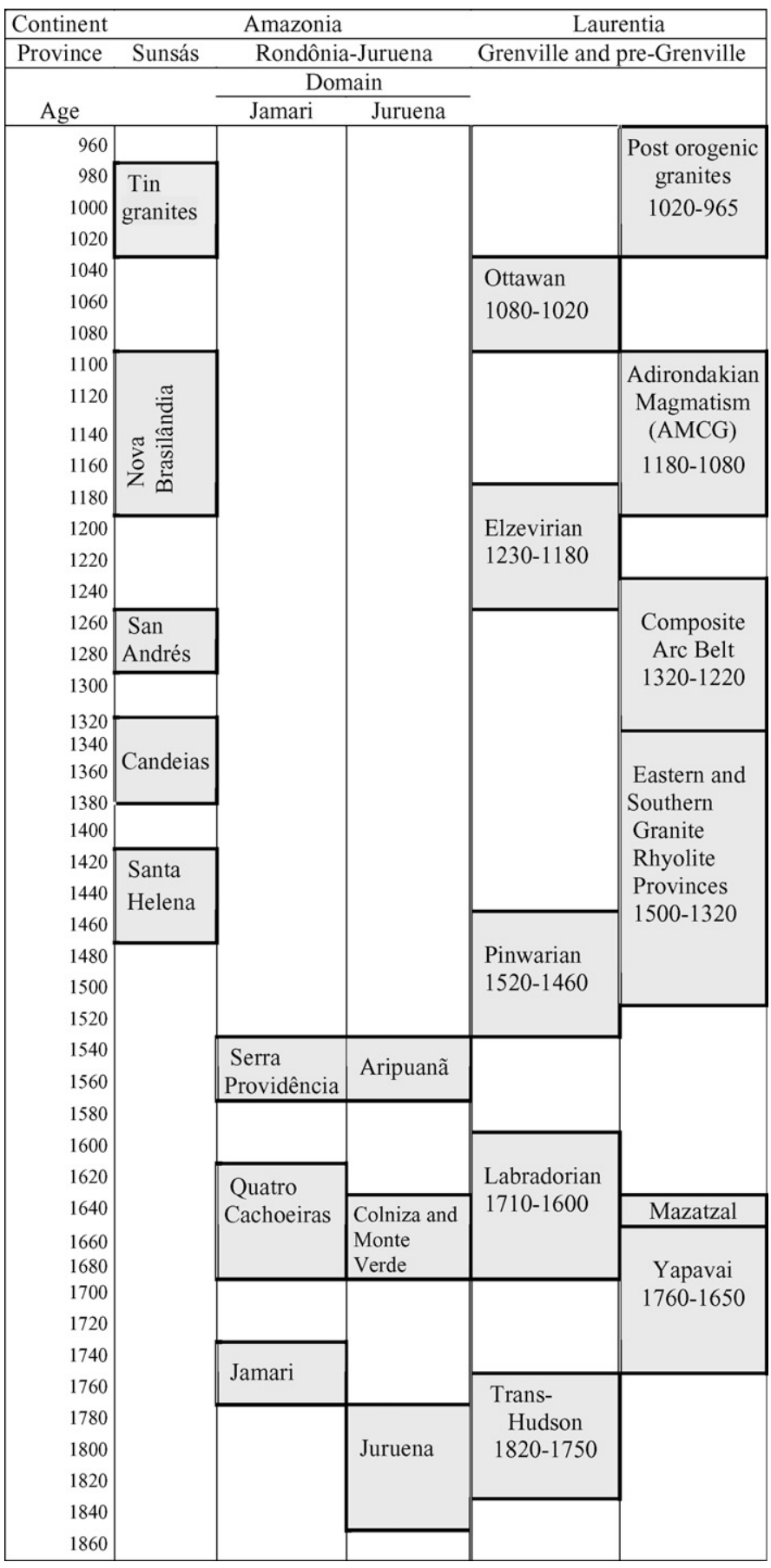

Ages of the Amazonia continent are from the text and Tables 1,2 and 4. Ages of Laurentia are taken from Rivers (1997), Schneider et al. (2001), Gower and Krogh (2002), Tollo et al. (2004), Schwerdtner et al. (2004), Cannon et al. (2005), Amato et al. (2006), Schneider et al. (2007), Gonzales and Van Schmus (2007)

Tables 5 and 8. According to Slagstad et al. (2004a), early models (Hoffman, 1989; Windley, 1993) suggested an anorogenic setting for both the ERGP and SGRP based on A-type composition of the granites and relative lack of deformation. Later models suggested orogenic setting and derivation from juvenile continental crust (Van Schmus et al., 1996). Could it be that the Eastern GraniteRhyolite Province may represent the early stages of the Grenville
Orogen in Laurentia? Another regional unit of Laurentia not considered to be part of the Grenville Orogen by several authors is the Composite Arc Belt (1320-1220 Ma, Schwerdtner et al., 2004), an assemblage of metamorphosed volcanic, sedimentary, and plutonic rocks. The oldest rocks of the Composite Arc Belt have an age equivalent to the youngest rocks of the Candeias orogeny of Amazonia (Table 8).

The West Amazon Craton seems to be much richer in intraplate plutons formed between 1580-1520 Ma (Serra Providência Suite, rapakivi granites and charnockites) when compared to Laurentia. Magmatism of that age is detected by Van Breemen and Corriveau (2005) in inherited zircon of Wakeham Group and nearby plutons (1610-1550 Ma).

The two main components of the Sunsás basement compare well in age to pre-Grenville units of Laurentia. The Quatro Cachoeiras orogeny (1689-1632 Ma) is broadly comparable to the Mazatzal Orogen of central-north United States (Van Schmus et al., 2007) both in timing and nature: both are essentially collisional orogenies which deformed neighbour orogen formed during geon 17 (Jamari in Amazonia and Yavapai in Laurentia). It is comparable in timing to the Labradorian rocks of Canada (1710-1600 Ma; Gower and Krogh, 2002) including the Labradorian Batholith (1650 Ma; Schärer and Gower, 1988) and plutonic rocks of AMCG affinity (1650-1630 Ma). The Jamari orogeny (1764-1746 Ma) is coeval to pre-Labradorian rocks (>1710 Ma; Gower and Krogh, 2002) in Canada and to the Yavapai accretion in central-north USA (ca. $1760 \mathrm{Ma}$; Holm et al., 2007). The older Juruena Domain (1840-1780 Ma) is partially contemporaneous to the Trans-Hudson Orogen in Canada (1820-1790 Ma; Schneider et al., 2007) and in Colorado (1800-1750 Ma; Gonzales and Van Schmus, 2007). The Yavapai Orogen in Iowa, Wisconsin and Minnesota was formed between 1760 and $1650 \mathrm{Ma}$ (Cannon et al., 2005; Holm et al., 2007), a period partially contemporaneous to the timing of Jamari Complex and Quatro Cachoeiras Group (Table 8). The Yavapai (geon 17) and Mazatzal (geon 16) terranes of Laurentia in the USA "probably also continue estward into Ontario, Canada and farther east into protolith of the Grenville Province" (Van Schmus et al., 2007). This is analogous to the Amazonia evolution, where the Jamari (geon 17) and Quatro Cachoeiras (geon 16) terranes are the main protoliths of the Sunsás Orogen.

\subsubsection{Alternative hypothesis}

How were the Amazonia and Laurentia continents connected, if at all, during the interval of 1465-1110 Ma?

The role of the Amazonia continent in the Rodinia supercontinent has been much debated since 1991 (Dalziel, 1991), and the timing of its amalgamation to Laurentia has been proposed as $1200 \mathrm{Ma}$ by Tohver et al. (2004). The late separation of Amazonia from Rodinia is yet to be chronologically established, but the general breakup of Rodinia is considered Neoproterozoic at about 780 Ma (Harlan et al., 2003) or 800 Ma (Weil et al., 1998). The fragmentation may have started earlier, before about $1000 \mathrm{Ma}$, as suggested by the absence of Ottawan rocks in Amazonia. The existence of age-equivalents of the Candeias and Santa Helena orogenies in Laurentia (Pinwarian orogeny and rocks of Eastern Granite-Rhyolite Province and of the Composite Arc Belt, Table 8) is an indication that the connection of the two continents may be older than $1200 \mathrm{Ma}$. It may have started as early as ca. $1450 \mathrm{Ma}$ as suggested by Santos et al. (2002) or even earlier (ca. 1820 Ma?), should the correlation of the Trans-Hudson Orogen to the Jamari and Juruena Domains be correct (Table 8).

The palaeogeography of the large combined Sunsás-Grenville Orogen in the Rodinia supercontinent at the end of the Mesoproterozoic is largely unresolved. Most paleo-reconstructions have interpreted the juxtaposition of Amazonia and Laurentia side-by- 


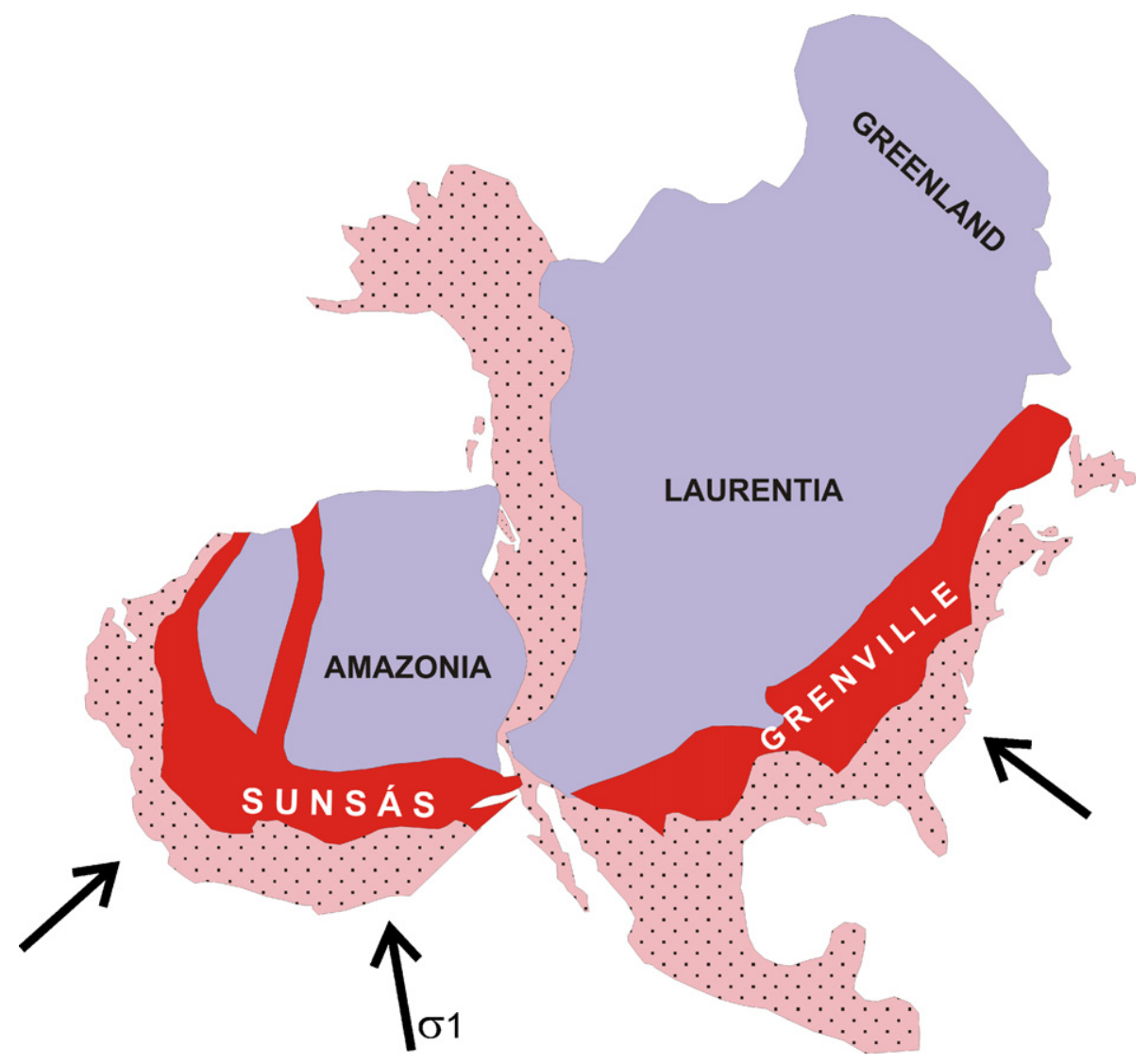

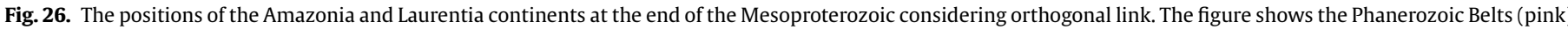

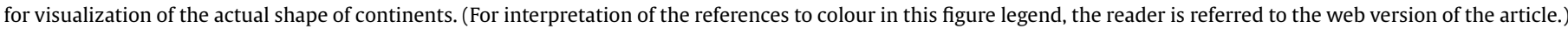

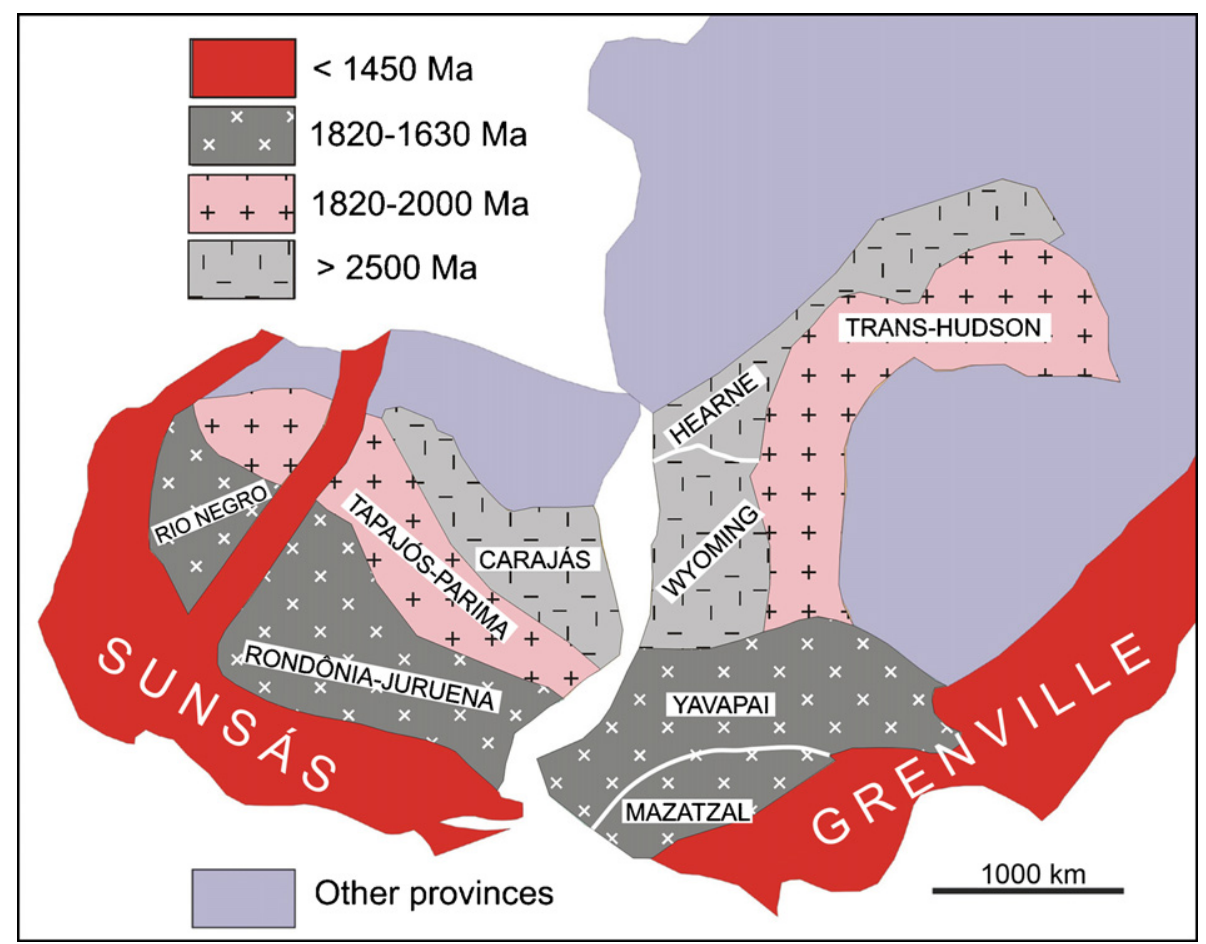

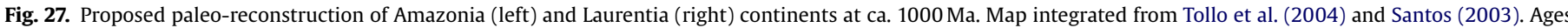

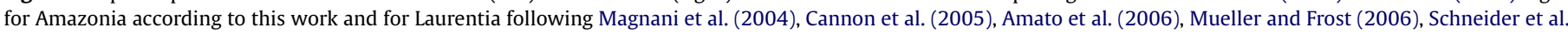
(2007), Holm et al. (2007). 
side (Weil et al., 1998; Keppie et al., 2001; Tohver et al., 2004; Cawood et al., 2007; Li et al., 2008) in the eastern part of Laurentia (the eastern connection). However, there is another possibility to consider in light of the new $\mathrm{U}-\mathrm{Pb}$ ages. This new possibility utilizes the polarity of subduction in both the Sunsás and Grenville Orogens and the broader geochronology of both Laurentia and Amazonia continents during the Mesoproterozoic. First, we note that the Grenville Orogen broadly developed from southeast to northwest, whereas the Sunsás Orogen evolved in the opposite sense from southwest to northeast. Because of the good correlations between most of Mesoproterozoic (Sunsás and Grenville) and Late Paleoproterozoic units, it seems likely that the two continents were once closely adjacent or even connected. If so, one was subsequently rotated in relation to the other to ensure the same polarity for the two orogens (Fig. 26).

The proposed western connection model also works well for the other pre-Grenville provinces on both continents. The TransHudson (Schneider et al., 2007) and Yavapai (Holm et al., 2007) orogens in Laurentia fit well with the Rio Negro, Rondônia-Juruena, and Tapajós-Parima provinces (Santos, 2003) in Amazonia (Fig. 27). The collision of the Mazatzal Province to the Yavapai Province in southwestern Laurentia (1680-1650 Ma, Magnani et al., 2004; $1650-1630 \mathrm{Ma}$, Holm et al., 2007) is remarkably contemporaneous to the Quatro Cachoeiras collisional orogeny in Amazonia. The main lineaments present in the Mazatzal-Yapavai (presently N60E Jemez lineament; Magnani et al., 2004) and in the RondôniaJuruena (actually E-W Quatro Cachoeiras lineament) provinces become parallel after reconstruction of Fig. 27. This fit supports the Amazonia-Laurentia connection as being pre-Grenvillian and part of the 1.9-1.8 Ga Paleoproterozoic Columbia supercontinent (Rogers and Santosh, 2003). A western connection also suggests that the amalgamation of the Archean Wyoming Province to the western Laurentia margin at 1.90-1.80 Ga (Mueller and Frost, 2006) was pushed from the west by Amazonia (see position of Wyoming Province in Fig. 27). Hopefully, future paleomagnetic studies can test this idea.

The crustal block or continent which drove the evolution of the combined Grenville-Sunsás into Amazonia-Laurentia continent to form the Rodinia supercontinent would had been positioned to the south, southeast and southwest of Amazonia-Laurentia continent as shown in Fig. 26. It seems likely that such a block was removed, probably during the Rodinia breakup.

\section{Conclusions}

Despite some advances achieved by this work, there is a gap on knowledge of the West Amazon Craton. Several problems remain unresolved and ongoing $\mathrm{U}-\mathrm{Pb}$ SHRIMP and $\mathrm{Hf}$ isotopes studies can contribute for their solution. The main improvements in the regional geology are listed below:

(1) New U-Pb and Sm-Nd data, together with the integration of previous geochronology, establish the chronological evolution of the Sunsás and Rondônia-Juruena Provinces; these new data also improve correlations between tectonic domains and geographic regions (Table 5).

(2) The Sunsás Orogen evolved in situ in the western margin of the Amazon Craton during about 360 m.y. (from 1465 to $1110 \mathrm{Ma}$ ). Four orogenies are defined: Santa Helena, Candeias, San Andrés, and Nova Brasilândia, each separated by long periods of quiescence.

(3) Use of metamorphic grade-based stratigraphy is not appropriate for a region with several successive orogenies. Some examples of stratigraphic reinterpretations based on new $\mathrm{U}-\mathrm{Pb}$ dating include the following:
- The granulitic rocks in Bolivia (Lomas Manechi Complex) and Rondônia are not the basement (the older regional rocks), but were formed by the Candeias orogeny at 13701320 Ma.

- The rocks generated by the youngest orogeny (the Nova Brasilândia; 1180-1110 Ma) are not restricted to the low metamorphic grade, but also include rocks of upper amphibolite facies and anatectic rocks.

- All the four Sunsás Orogenies and the basement rocks include orhogneisses, which are not restricted to the Chiquitania Complex.

(4) The predominance of detrital zircons with ages comparable to the age of the Sunsás Orogen in the lower Orinoco River sand is evidence for the extension of the Sunsás Belt into eastern Venezuela. The Mesoproterozoic age of part of the Rio Apa Complex in Paraguay and the Hf model ages in northeast Argentina are evidence for the presence of the Sunsás Orogen to the southeast of the type locality (Brazil-Bolivia border). These two extensions to northeast and southeast are mostly covered by Phanerozoic basins and together form a $6000 \mathrm{~km}$ long belt.

(5) There is no evidence for the existence of a microcraton - the Paraguá - between the Sunsás Orogen and the Amazon Craton.

(6) The apparent absence of the Ottawan orogeny in Amazonia shows that cratonization began earlier there than in Laurentia and also that the break-up of the Rodinia supercontinent may have started before $1.0 \mathrm{Ga}$.

(7) The polarity of subduction in Laurentia and Amazonia during the Mesoproterozoic suggests that the paleo-juxtaposition of the two continents along the Atlantic margin of Laurentia (the eastern connection) is unlikely. Instead, the docking of Amazonia seems to fit much with the west-southwest parts of Laurentia (the western connection).

\section{Acknowledgements}

The field work for this project was supported by the Brazilian Geological Survey during 2003 and 2004. Part of the study was conducted by J.O.S. Santos under a postdoctoral fellowship awarded by CAPES - Coordenação de Aperfeiçoamento de Pessoal de Nível Superior (grant BEX 2623/03-0). Part of U-Pb analyses was completed with the assistance of BHP Billiton, who provided financial support. SHRIMP II U-Pb analyses were performed at the John De Laetter Centre for Mass Spectrometry at Curtin University of Technology in Perth, Western Australia, which is operated jointly with the University of Western Australia and the Geological Survey of Western Australia with support from the Australian Research Council.

The authors would like to thank Eric Tohver who provided important suggestions. We greatly appreciate the insightful reviews of Dr. Reinhardt A. Fuck and Prof. R.W. Van Schmus. These comments were of considerable assistance in shaping the published version of this manuscript.

\section{References}

Amaral, G., 1974. Geologia Pré-Cambriana da Região Amazônica. Universidade de São Paulo, Tese de Livre Docência, São Paulo, 212 pp. (in Portuguese).

Amato, J.M., Boullion, A., Sanders, A., Gehrels, G., Andronicos, C., Heizler, M.T. Farmer, G.L., 2006. Magmatism, metamorphism, and deformation of Proterozoic Mazatzal Province crust: a comprehensive case study from the Burro Mountains, Southwestern New Mexico. Rocky Mountain Section-58th Annual Meeting, Geological Society of America Abstracts with Programs, vol. 38 (6), p. 4, paper $1-4$.

Barron, C.N., 1966. Notes on the stratigraphy of Central British Guyana. In: DNPM, Conferência Geológica Interguianas, vol. 6, Belém, 1966. Anais 41, pp. 121-126. 
Bellizzia, C.M., 1974. Paleotectonica del Escudo de Guayana. In: Conferencia Geológica Interguayanas 9, Puerto Ordaz, 1972, Venezuela, Memoria, Boletin de Geologia, Publicacion Especial 6, pp. 251-305.

Bettencourt, J.S., Tosdal, R.M., Leite, W.B., Payolla, B.L., 1999. Mesoproterozoic rapakivi granites of the Rondônia tin province, southwestern border of the Amazonian Craton, Brazil: Reconnaissance U-Pb geochronology and regional implications. Precambrian Research 95, 41-67.

Bettencourt, J.S., Payolla, B.L., Tosdal, R.M., Wooden, J.L., Leite, W.B., Sparremberger, I., 2006. Shrimp-RG U-Pb zircon geochronology of gneiss from the Rio Crespo Intrusive Suite, Sw Amazonian Craton, Rondônia, Brazil: New insight about protolith crystallization and metamorphic ages. In: 5th Symposium on South America Isotope Geology. Actas, Punta Del Este, Uruguay, pp. 49-52.

Bickford, M.E., 1988. The formation of continental crust, Part I: A review of some principles; Part 2: An application to the Proterozoic evolution of southern North America. Geological Society of America Bulletin 100, 1375-1391.

Bickford, M.E., Van Schmus, W.R., Zietz, I., 1986. Proterozoic history of the Midcontinent region of North America. Geology 14, 492-496.

Boger, S.D., Raetz, M., Giles, D., 2005. U-Pb age data from the Sunsas region of eastern Bolivia, evidence for the allochthonous origin of the Paragua Block. Precambrian Research 139 (3-4), 121-146.

Cannon, W.F., Schulz, K.J., Daniels, D.L., Anderson, R.R., Chandler, V.W., Holm, D.K., Schneider, D.A., Van Schmus, W.R., 2005. Geology of Precambrian basement rocks in Iowa and the southern parts of Wisconsin and Minnesota (abs.). In: 51 st annual Meeting of the Institute on Lake Superior Geology, Proceedings and Abstracts, pp. 10-11.

Carr, S.D., Easton, R.M., Jamieson, R.A., Culshaw, N.G., 2000. Geologic transect across the Grenville orogen of Ontario and New York. Canadian Journal of Earth Sciences 37, 193-216.

Casquet, C., Pankhurst, R.J., Fanning, M., Baldo, E., Galindo, C., Rapela, C.W., Casado, J.M.G., Dahlquist, J.A., 2006. U-Pb SHRIMP zircon dating of Grenvillian metamorphism in Western Sierras Pampeanas (Argentina): correlation with the Arequipa-Antofalla craton and constraints on the extent of the Precordillera Terrane. Gondwana Research 9 (4), 524-529.

Cawood, P.A., Nemchim, A.A., Strachan, R., Prave, T., Krabbendam, M., 2007. Sedimentary basin and detrital zircon record along East Laurentia and Baltica during assembly and breakup of Rodinia. Journal of the Geological Society 164 (2), 257-275.

Chernicoff, C.J., Zappettini, E.O., Santos, J.O.S., Griffin, W., McNaughton, N.J., 2008. Foreland basin deposits associated with Cuyania accretion in La Pampa Province, Argentina. Gondwana Research 13 (2), 189-203.

Compston, W., Williams, I.S., Kirschvink, J.L., Zichao, Z., Guogan, M., 1992. Zircon ages for the Early Cambrian timescale. Journal of Geological Society, London 149, 171-184.

Condie, K.C., Beyer, E., Belousova, E., Griffin, W.L., O'Reilly, S.Y., 2005. U-Pb isotopic ages and Hf isotopic composition of single zircons: the search for juvenile Precambrian continental crust. Precambrian Research 139, 42-100.

Cordani, U.G., Tassinari, C.G.C., Teixeira, W., Basei, M.A.S., Kawashita, K., 1979. Evolução tectônica da Amazônia com base nos dados geocronológicos. In: Congreso Geológico Chileno 2, Arica, Anais, pp. 137-138.

Cordani, U.G., Teixeira, W., 2007. Proterozoic accretionary belts in the Amazonian Craton. In: Hatcher Jr., R.D., Carlson, M.P., McBride, J.H., Martinez-Catalan, J.R. (Eds.), 4-D Framework of Continental Crust. Geological Society of America Memoir 200.

Cordani, U.G., Tassinari, C.C.G., Teixeira, W., Coutinho, J.M.V., 2008. U-Pb SHRIMP zircon ages for the Rio Apa cratonic fragment in Mato Grosso do Sul (Brazil) and northern Paraguay: Tectonic implications. In: VI South American Symposium on Isotope Geology, San Carlos de Bariloche, Argentina, article 63 on CD-ROM, $8 \mathrm{pp}$.

Culshaw, N.G., Ketchum, J.W.F., Wodicka, N., Wallace, P., 1994. Ductile extension following thrusting in the deep crust: evidence from the southern Britt Domain, southwest Grenville Province, Georgian Bay, Ontario. Canadian Journal of Earth Sciences 31, 160-175.

Dalziel, I.W.D., 1991. Pacific margins of Laurentia and East Antarctica-Australia as a conjugate rift pair: evidence and implications for an Eocambrian supercontinent. Geology 19, 598-601.

Davidson, A., 2008. Late Paleoproterozoic to mid-Neoproterozoic history of northern Laurentia: an overview of central Rodinia. Precambrian Research 160, 5-22.

D’Agrella-Filho, M.S., Tohver, E., Santos, J.O.S., Elming, S.Å., Trindade, R.I.F., Pacca, I.I.G., Geraldes, M.C., 2008. Direct dating of paleomagnetic results from Precambrian sediments in the Amazon craton: evidence for Grenvillian emplacement of exotic crust in SE Appalachians of North America. Earth and Planetary Science Letters 267, 188-199.

De Laeter, J.R., Kennedy, A.K., 1998. A double focusing mass spectrometer for geochronology. International Journal of Mass Spectrometry 178, 43-50.

De Paolo, D.J., 1981. A neodymium and strontium isotopic study of the Mesozoic calc-alkaline granitic batholiths of the Sierra Nevada and Peninsular Ranges, California. Journal of Geophysical Research 86, 10470-10488.

Eby, G.N., 1992. Chemical subdivision of the A-type granitoids: petrogenetic and tectonic implications. Geology 20 (7), 641-644.

Fernandes, C.J., Ruiz, A.S., Pinho, F.E.C., Kuyumjian, R.M., 2005. Compartimentação tectônica da deformação na faixa móvel Aguapeí, sudoeste do Cráton Amazônico, e as mineralizações auríferas associadas. Revista Brasileira de Geociências 35 (1), $1-12$.

Fuck, R.A., Neves, B.B.B., Schobbenhaus, C., 2008. Rodinia descendants in South America. Precambrian Research 160, 108-126.
Geraldes, M.C., Teixeira, W., Van Schmus, W.R., 2000. Isotopic and chemical evidence for three accretionary magmatic arcs (1.79-1.42 Ga) in the SW Amazon Craton, State of Mato Grosso, Brazil. Revista Brasileira de Geociências 30 (1), 99-101.

Geraldes, M.C., Van Schmus, W.R., Condie, K.C., Bell, S., Teixeira, W., Babinski, M. 2001. Proterozoic geologic evolution of the SW part of the Amazonian craton in Mato Grosso state, Brazil. Precambrian Research 111, 91-128.

Goldstein, S.L., Arndt, N.T., Stallard, R.F., 1997. The history of a continent from U-Pb ages of zircons from Orinoco River sand and Sm-Nd isotopes in Orinoco basin river sediments. Chemical Geology 139, 271-286.

Gonzales, D.A., Van Schmus, W.R., 2007. Proterozoic history and crustal evolution in southwestern Colorado: insight from $\mathrm{U} / \mathrm{Pb}$ and $\mathrm{Sm} / \mathrm{Nd}$ data. Precambrian Research 154 (1-2), 31-70.

Gower, C.F., Krogh, T.E., 2002. A U-Pb geochronological review of the Proterozoic history of the eastern Grenville Province. Canadian Journal of Earth Sciences 39 795-829.

Gradstein, F.M., Ogg, J.G., Smith, A.G., et al., 2005. A Geologic Time Scale 2004, Cambridge University Press, ISBN 0-521-78142 6, 610 pp.

Harlan, S.S., Heaman, L., LeCheminant, A.L., Premo, W.R., 2003. Gunbarrel mafic magmatic event: a key 780 Ma time marker for Rodinia plate reconstructions. Geology 31 (12), 1053-1056.

Hartmann, L.A. Takehara, L., Leite, J.A.D. McNaughton, N.J., Vasconcelos, M.A.Z 1997. Fracture sealing of zircon as evaluated by electron microprobe analyses, back-scattered electrons and cathodoluminescence images. Chemical Geology $141,67-72$

Hoffman, P.F., 1989. Precambrian geology and tectonic history of North America In: Bally, A.W., Palmer, A.R. (Eds.), The geology of North America: An overview. Geological Society of America, v. A, Boulder, Colorado, pp. 447-511.

Hoffman, P.F., 1991. Did the breakout of Laurentia turn Gondwana inside out? Science 252, 1409-1412.

Holm, D.K., Schneider, D.A., Rose, S., Mancuso, C., McKenzie, M., Foland, K.A., Hodges K.V., 2007. Proterozoic metamorphism and cooling in the southern Lake Superior region, North America and its bearing on crustal evolution. Precambrian Research 157 (1-4), 106-126.

Isotta, C.A.L., Carneiro, J.M., Kato, H.T., Barros, R.J.L., 1978. Projeto provincial Estanífera de Rondônia. Final Report, Porto Velho, Rondônia, Companhia de Pesquisa de Recursos Minerais, $12 \mathrm{v}$. (in Portuguese).

JICA (Japan International Cooperation Agency)-MMAJ (Metal Mining Agency of Japan, Japan International Cooperation Agency, 2000. Report on the mineral exploration in the Alta Floresta area, Federative Republic of Brazil (Phase II) Unpublished report.

Karlstrom, K.E., Åhäll, K.I., Harlan, S.S., Williams, M.L., McLelland, J., Geissman, J.W., 2001. Long-lived (1.8-1.0 Ga) convergent orogen in southern Laurentia, its extensions to Australia and Baltica, and implications for Rodinia. Precambrian Research 111, 5-30.

Keppie, J.D., Dostal, J., Gutiérrez, F.O., Lopez, R., 2001. A Grenvillian arc on the margin of Amazonia: evidence from the southern Oaxacan Complex, southern Mexico. Precambrian Research 112, 165-181.

Klinck, B.A., Litherland, M., 1982. A model for the Proterozoic structural history of eastern Bolivia. Report on Eastern Bolivia Mineral Exploration Project, Santa Cruz, number BAK/15 (unpublished).

Kroonemberg, S.B., 1982. A Grenvillian Granulite Belt in the Colombian Andes and its relation to the Guiana Shield. Geologie en Mijnbouw 61, 325-333.

Kusky, T.M., Loring, D.P., 2001. Structural and U/Pb chronology of superimposed folds, Adirondack Mountains: implications for the tectonic evolution of the Grenville Province. Journal of Geodynamics 32, 395-418.

Lacerda Filho, J.V., Souza, J.O., Pimentel, M.M., et al., 2001. Geocronologia U-Pb e SmNd da região de Alta Floresta, norte de Mato Grosso. In: Bettencourt, J.S., Teixeira, W., Pacca, I.G., Geraldes, M.C., Sparemberg, I. (Eds.), Workshop on Geology of the SW Amazonian Craton: state-of-the-art, São Paulo. Extended Abstracts, São Paulo, pp. 53-59.

Leal, J.W.L., Silva, G.H., Santos, D.B., Teixeira, W., Lima, M.I.C., Fernandes, C.A.C., Pinto, C., 1978. Projeto Radar na Amazônia. Levantamento de Recursos Naturais, vol. 16 Folha SC.20-Porto Velho, Geologia, Departamento Nacional da Produção Mineral, Brasília, Brazil, 184 pp. (in Portuguese).

Leite, J.A.D., Saes, G.S., 2003. Geocronologia Pb-Pb de zircões detríticos e análise estratigráfica das coberturas sedimentares proterozóicas do sudoeste do Cráton Amazonas. Revista do Instituto de Geociências da USP 3, pp. 113-127 (in Portuguese).

Li, Z.X., Bogdanova, S.V., Collins, A.S., Davidson, A., De Waele, B., Ernst, R.E., Fitzsimons, I.C.W., Fuck, R.A., Gladkochub, D.P., Jacobs, J., Karlstrom, K.E., Lul, S. Natapov, L.M., Pease, V., Pisarevsky, S.A., Thrane, K., Vernikovsky, V., 2008. Assembly, configuration, and break-up history of Rodinia: a synthesis. Precambrian Research 160, 179-210.

Litherland, M., Klinck, B.A., O’Connor, E.A., Pitfield, P.E.J., 1985. Andean-trending mobile belts in the Brazilian Shield. Nature 314, 345-348.

Litherland, M., Annels, R.N., Appleton, J.D., Berrangé, J.P., Bloomfield, K., Burton, C.C.J., Darbyshire, D.P.F., Fletcher, C.J.N., Hawkins, M.P., Klinck, B.A., Llanos, A., Mitchell, W.I., O'Connor, E.A., Pitfield, P.E.J., Power, G., Webb, B.C., 1986. The geology and mineral resources of the Bolivian Precambrian shield. British Geological Survey, Overseas Memoir, vol. 9, Keyworth, 153 pp.

Litherland, M., Annels, R.N., Darbyshire, D.P.F., Fletcher, C.J.N., Hawkins, M.P., Klinck, B.A., Mitchell, W.I., O'Connor, E.A., Pitfield, P.E.J., Power, G., Webb, B.C., 1989. The Proterozoic of Eastern Bolivia and its relationship to the Andean Mobile Belt Precambrian Research 43, 157-174. 
Loewy, S.L., Connelly, J.N., Dalziel, I.W.D., Gower, C.F., 2003. Eastern Laurentia in Rodinia: constraints from whole-rock $\mathrm{Pb}$ and $\mathrm{U} / \mathrm{Pb}$ geochronology. Tectonophysics 375, 169-197.

Lopez, R., Cameron, K.L., Jones, N.W., 2001. Evidence for Paleoproterozoic, Grenvillian, and Pan-African age Gondwanan crust beneath northeastern Mexico. Precambrian Research 107 (3/4), 195-214.

Ludwig, K.R., 1999. Using ISOPLOT/Ex, version 2: a geochronological toolkit for Microsoft Excel. Berkeley Geochronological Center Special Publication Ia, 47 pp.

Ludwig, K.R., 2002. Squid 1.02, a user's manual. Berkeley Geochronological Center Special Publication 2 (Berkeley, California, USA), 21 pp.

Magnani, M.B., Miller, K.C., Levander, A., Karlstrom, K., 2004. The Yavapai-Mazatzal boundary: a long-lived tectonic element in the lithosphere of southwestern North America. Geological Society of America Bulletin 116 (9/10), 1137-1142.

Martignole, J., Martelat, J.E., 2003. Regional-scale Grenvillian-age UHT metamorphism in the Mollendo-Camana block (basement of the Peruvian Andes). Journal of Metamorphic Geology 21, 99-120.

Marzolli, A., Renne, P.R., Picirillo, E.M., Ernesto, M., Bellieni, G., Min, A., 1999 Extensive 200-Million-year-old continental flood basalts of the Central Atlantic Magmatic Province. Science 284, 616-618.

Matos, R.S., Teixeira, W., Cordani, U.G., Sato, K., Geraldes, M.C., Mattos, G.V., Bohórquez, J.L., 2006. Caracteristicas Sm-Nd, U-Pb de los granitos del Complejo Pensamiento, Provincia Rondoniana-San Ignacio, Precambrico de Bolivia Oriental, Memorias del XVII Congreso Geologico Boliviano, Sucre, Bolivia, pp. $13-15$

McBride, J.H., Kolata, D.R., Hildebrand, T.G., 2001. New constraints on interpreting the origin of the Eastern Granite-Rhyolite Province beneath the Illinois Basin. GSA Annual Meeting, November 5-8, 2001 Session No. 36: The Proterozoic of the Eastern Midcontinent and Beyond, Paper No. 36-0.

McLelland, J., Daly, S., McLelland, J.M., 1996. The Grenville Orogenic Cycle (ca. 1350-1000 Ma): an Adirondak perpective. Tectonophysics 265 (1-2), $1-28$.

Mueller, P.A., Frost, C.D., 2006. The Wyoming Province: a distinctive Archean craton in Laurentian North America. Canadian Journal of Earth Sciences 43 (10) 1391-1397.

Neder, R.D., Leite, J.A.D., Figueiredo, B.R., McNaughton, N.J., 2002. 1.76 Ga volcanoplutonism in the southwestern Amazonian craton, Aripuanã-MT, Brazil: tectono-stratigraphic implications from SHRIMP U-Pb zircon data and rock geochemistry. Precambrian Research 119, 171-187.

Onstott, T.C., Hall, C.M., York, D., $1989 .{ }^{40} \mathrm{Ar} /{ }^{39} \mathrm{Ar}$ thermochronometry of the Imataca Complex, Venezuela. Precambrian Research 42 (3-4), 255-291.

Pace, P.A.R., Ruiz, J., Gehrels, G., Cosca, M., 1997. Geochronology and Nd isotopic data of Grenville-age rocks in the Colombian Andes: new constraints for Late Proterozoic-Early Paleozoic paleocontinental reconstructions of the Americas. Earth and Planetary Science Letters 150, 427-441.

Patchett, P.J., Ruiz, J., 1987. Nd isotopic ages of crust formation and metamorphism in the Precambrian of eastern and southern Mexico. Contributions to Mineralogy and Petrology 96, 523-528.

Payolla, B.L., Bettencourt, J.S., Kozuch, M., Leite Jr., W.B., Basei, M.A.S., 2001. The Rio Crespo Intrusive Suite: Geological U-Pb and Sm-Nd isotopic evidence for a major $1.43 \mathrm{Ga}$ arc-related magmatism in the Rondônia State, SW Amazonian Craton, Brazil. In: Bettencourt, J.S., Teixeira, W., Pacca, I.G., Geraldes, M.C., Sparremberg, I. (Eds.), Workshop on Geology of the SW Amazon Craton: State-of-the-art, São Paulo, Brazil, August 2001, Extended Abstracts Volume, 156 pp.

Payolla, B.L., Bettencourt, J.S., Kozuch, M., Leite Jr., W.B., Fetter, A., Van Schmus, W.R 2002. Geological evolution of the basement rocks in the east-central part of the Rondônia Tin Province, SW Amazonian Craton, Brazil: U-Pb and Sm-Nd isotopic constraints. Precambrian Research 119, 141-169.

Pinho, M.B., Fyfe, W.S., Pinho, M.A.S.B., 1997. Early Proterozoic evolution of the Alto Jauru greenstone belt, southern Amazonian craton, Brazil. International Geology Review 39, 220-229.

Pinho, M.A.S.B., Lima, E.F., Van Schmus, W.R., Fetter, A., Chemale Júnior, F., 2001. Caracterização petrográfica e dados geocronológicos preliminares das rochas vulcânicas da Formação Iriri, porção centro-sul do Cráton Amazônico, Aripuanã Mato Grosso. Revista Brasileira de Geociências 31 (1), 37-42.

Pinho, M.A.S.B., Chemale Júnior, F., Van Schmus, W.R., Pinho, F.E.C., 2003. U-Pb and Sm-Nd evidence for 1.76-1.77 Ga magmatism in the Moreru region, Mato Grosso, Brazil: implications for province boundaries in the SW Amazon Craton. Precambrian Research 126, 1-25.

Priem, H.N.A., Boelrijk, N.A.I.M., Hebeda, E.H., Verdumen, E.A.T., Verschure, R.H., Bon, E.H., 1966. Isotopic age of tin granites in Rondônia, N.W. Brazil. Geologie en Mijnbouw 45 (6), 191-192.

Priem, H.N.A., Boelrijk, N.A.I.M., Hebeda, E.H., Verdumen, E.A.T., Verschure, R.H., Bon, E.H., 1971. Granitic complexes and associated tin mineralization of Grenville age in Rondônia, western Brazil. Geological Society of America Bulletin 82 (4), 1095-1102.

Priem, H.N.A., Andriessen, P.A.M., Boelrijk, N.A.I.M., De Boorder, H., Hebeda, E.H., Huguett, A., Verdurmen, E.A.T., Verschure, R.H., 1982. Geochronology of the precambrian in the Amazonas region of southeastern Colombia (western Guiana Shield). Geologie en Mijnbouw 61, 229-242.

Priem, H.N.A., Kroonenberg, S.B., Boelrijk, N.A.I.M., Hebeda, E.H., 1989. Rb-Sr and KAr evidence for the presence of a $1.6 \mathrm{Ga}$ basement underlying the $1.2 \mathrm{Ga}$ GarzónSanta Marta granulite belt in the Colombian Andes. Precambrian Research 42 (3-4), 315-324.

Rasmussen, B., Fletcher, I.R., Muhling, J.R., 2007. In situ U-Pb dating and element mapping of three generations of monazite: unravelling cryptic tectonother- mal events in low-grade terranes. Geochimica et Cosmochimica Acta 71 (3), 670-690.

Ratcliffe, N.M., Aleinikoff, J.N., Burton, W.C., Karabinos, P., 1991. Trondhjemitic, 1.35-1.31 Ga gneisses of the Mount Holly Complex of Vermont: evidence for an Elzevirian event in the Grenville Basement of the United State Appalachians. Canadian Journal of Earth Sciences 28, 77-93.

Renee, R.C., 2005. Isotopic connections in the Granite and Rhyolite Provinces of the Southern Midcontinent. Geological Society of America Annual Meeting, 39th, South-Central Section, Paper 17-1.

Rivers, T., 1997. Lithotectonic elements of the Grenville Province: review and tectonic implications. Precambrian Research 86, 117-154.

Rizzotto, G.J., Chemale, F., Lima, E.F., Van Schmus, W.R., Fetter, A., 1999. Dados isotópicos Sm-Nd and U-Pb das rochas da sequência metavulcanossedimentar Nova Brasilândia (SMNB) - RO. In: Sociedade Brasileira de Geologia, Núcleo Norte, Simpósio de Geologia da Amazônia, vol. 6, Boletim de Resumos Expandidos, Companhia de Pesquisa de Recursos Minerais, Manaus, Amazonas, pp. 490-493 (in Portuguese).

Rizzotto, G.J., Bettencourt, J.S., Teixeira, W., Pacca, G.I.G., D’Agrella Filho, M.S., Vasconcelos, P., Basei, M.A.S., Onoe, A.T., Passarelli, C.R., 2002. Geologia e geocronologia da Suíte Metamórfica Colorado e suas encaixantes, SE de Rondônia: Implicações para a Evolução Mesoproterozóica do SW do Cráton Amazônico. Revista do Instituto de Geociências, Universidade de São Paulo, Série Científica 2, pp. 41-55 (in Portuguese)

Rizzotto, G.J., Quadros, M.L.E.S., Bahia, R.B.C., Ferreira, R.B.C., Lopes, R.C., Cordeiro, A.V., 2004. Folha SC.21-Juruena. In: Schobbenhaus, C., Gonçalves, J.H., Santos, J.O.S., Abram, M.B., Leão Neto, R., Matos, G.M.M., Vidotti, R.M., Ramos, M.A.B., Jesus, J.D.A. (Eds.), Carta Geológica do Brasil ao milionésimo, Sistema de Informações Geográficas, 46 folhas na escala 1:1.000.000. Programa Geologia do Brasil, Brasília, Companhia de Pesquisa de Recursos Minerais, 41 CD-ROM, ISBN 85-7499-099-4 (in Portuguese)

Roddaz, M., Baby, P., Brusset, S., Hermoza, W., Darrozes, J.M., 2005. Forebulge dynamics and environmental control in Western Amazonia: the case study of the Arch of Iquitos (Peru). Tectonophysics 399 (1-4), 87-108.

Roddaz, M., Viers, J., Brusset, S., Baby, P., Boucayrand, C., Hérail, G., 2006. Controls on weathering and provenance in the Amazonian foreland basin: insights from major and trace element geochemistry of Neogene Amazonian sediments. Chemical Geology 226 (1/2), 31-65.

Rogers, J.J.W., Santosh, M., 2003. Supercontinents in earth history. Gondwana Research 6 (3), 357-368.

Ruiz, A.S., 2006. Evolução geológica do Sudoeste do Cráton Amazônico, região limítrofe Brasil-Bolívia-Mato Grosso. Universidade Estadual Paulista, Instituto de Geociências e Ciências Exatas, Campus de Rio Claro, PhD thesis, 299 pp. (in Portuguese).

Ruiz, A.S., Simões, L.S.A., Godoy, A.M., Ruiz, L.M.B.A., Neves, B.B.B., 2005a. Rio Apa Massif: southern segment of Amazonian Craton. Academia Nacional de Ciencias, Gondwana 12, Mendoza 2005 - Abstracts, p. 315

Ruiz, A.S., Simões, L.S.A., Neves, B.B.B., 2005b. Maciço Rio Apa: extremo meridional do Cráton Amazônico. In: Simpósio de Estudos Tectônicos, 10th, Curitiba, Anais, pp. 301-304.

Sadowski, G.R., Bettencourt, J.S., 1996. Mesoproterozoic tectonic correlations between eastern Laurentia and the western border of Amazon craton. Precambrian Research 76, 213-227.

Saes, G.S., Leite, J.A.D., 1993. Evolução tectono-sedimentar do Grupo Aguapeí, Proterozóico Medio na porção meridional do Craton Amazonico: Mato Grosso e oriente boliviano. Revista Brasileira de Geociências 23, 31-38.

Santos, J.O.S., 2003. Geotectonics of the Guyana and Central-Brazil shields. In: Bizzi, L.A., Schobbenhaus, C., Vidotti, R.M., Gonçalves, J.H. (Eds.), Geology, Tectonics, and Mineral Resources of Brazil. Companhia de Pesquisa de Recursos Minerais, Brasília, ISBN 85-230-0790-3, pp. 169-226.

Santos, J.O.S., Hartmann, L.A., Gaudette, H.E., Groves, D.I., McNaughton, N., Fletcher, I.R., 2000. A new understanding of the provinces of the Amazon Craton based on integration of field mapping and U-Pb and Sm-Nd geochronology. Gondwana Research 3 (4), 453-488

Santos, J.O.S., Rizzotto, G.R., Hartmann, L.A., McNaughton, N.J., Fletcher, I.R., 2001 Ages of sedimentary basins related to the Sunsás and Juruena Orogenic cycles, southwestern Amazon Craton, established by zircon U-Pb geochronology. In: South American Symposium on Isotope Geology, vol. 3 Pucon, Chile, Comunicaciones.

Santos, J.O.S., Rizzotto, G., Easton, M.R., Potter, P.E., Hartmann, L.A., McNaughton, N.J., 2002. The Sunsás Orogen in Western Amazon Craton, South America and correlation with the Grenville Orogen of Laurentia, based on U-Pb isotopic study of detrital and igneous zircons. In: Geological Society of America, 2002 Denver Annual Meeting (October 27-30, 2002), Precambrian Geology, paper 122-8.

Santos, J.O.S., Rizzotto, G.J., Chemale, F., Hartmann, L.A., Quadros, M.L.E.S., McNaughton, N.J., 2003. Three distinctive collisional orogenies in the southwestern Amazon Craton: Constraints from U-Pb geochronology. South American Symposium on Isotope Geology, 4, Companhia Bahiana de Pesquisa Mineral, Salvador, Bahia, Short papers, vol. 1, pp. 282-285.

Santos, J.O.S., Breemen, O.B.V., Groves, D.I., Hartmann, L.A., Almeida, M.E., McNaughton, N.J., Fletcher, I.R., 2004a. Timing and evolution of multiple Paleoproterozoic magmatic arcs in the Tapajós Domain, Amazon Craton: constraints from SHRIMP and TIMS zircon, baddeleyite and titanite U-Pb geochronology. Precambrian Research 131 (1/2), 73-109. 
Santos, J.O.S., Rizzotto, G.J., Dietsch, C., Potter, P.E., Easton, R.M., 2004b. First inventory of Grenvillian rocks in South America. GSA Denver Annual Meeting (November 7-10, 2004), Paper 197-12.

Santos, J.O.S., McNaughton, N.J., Hartmann, L.A., Fletcher, I.R., Matos, R.S., 2005. The age of deposition of the Aguapeí Group, western Amazon Craton, based on U-Pb study of diagenetic xenotime and detrital zircon. In: 12th Congreso Latinoamericano de Geologia, Quito, Ecuador, Actas.

Santos, J.O.S., Faria, M.S.G., Riker, S.R.L., Souza, M.M., Hartmann, L.A., Almeida, M.E., McNaughton, N.J., Fletcher, I.R., 2006. A faixa colisional K'Mudku (Idade Grenvilleana) no norte do Cráton Amazonas: Reflexo intracontinental do Orógeno Sunsás na margem ocidental do cráton. 9th Simpósio de Geologia da Amazônia, Belém, Pará, Brazil. Sessão Temática III, 4 pp., CD-ROM.

Santos, J.O.S., Potter, P.E., Rizzotto,G.J., McNaughton, N.J., 2008. Evolution of the Sunsás Orogen, a Grenvillian equivalent in South America, based on detrital zircon U-Pb geochronology. VI South American Symposium on Isotope Geology, San Carlos de Bariloche - Argentina - 2008, Book of Abstracts, p. 36, extended abstract in CD-ROM.

Sato, A.M., Tickyj, H., Llambías, E.J., Sato, K., 2000. The Las Matras tonalitictrondhjemitic pluton, central Argentina: Grenvillian-age constraints, geochemical characteristics, and regional implications. Journal of South American Earth Sciences 13 (7), 587-610.

Sato, A.M., Tickyj, H., Llambías, E.J., Basei, M.A.S., González, P.D., 2004. Las Matras Block, Central Argentina $\left(37^{\circ} \mathrm{S}-67^{\circ} \mathrm{W}\right)$ : the southernmost Cuyania Terrane and its relationship with the Famatinian Orogeny. Gondwana Research 7 (4), 1077-1087.

Schenk, C.J., Roland, J., Viger, R.J., Anderson, C.P., 2000. Maps showing geology, oil and gas fields, and geologic provinces of the South America Region. U.S. Department of the Interior, USGS open-file report 97-470D.

Schärer, U., Gower, C.F., 1988. Crustal evolution in eastern Labrador; constraints from precise U-Pb ages. Precambrian Research 38, 405-421.

Schneider, D.A., Bickford, M.E., Heizler, M.T., Williams, M.L., Jercinovic, M.J., 2001. Monazite thermochronology of the Trans-Hudson Orogen, Canada: ID-TIMS U$\mathrm{Pb}$, EMP Total $\mathrm{Pb}$, and $\mathrm{Ar}-\mathrm{Ar}$ age comparisons. Geological Society of America Annual meeting, paper 179-0.

Schneider, D.A., Heizler, M.T., Bickford, M.E., Wortman, G.L., Condie, K.C., Perilli, S., 2007. Timing constraints of orogeny to cratonization: thermochronology of the Paleoproterozoic Trans-Hudson orogen, Manitoba and Saskatchewan, Canada. Precambrian Research 153 (1/2), 65-95.

Schobbenhaus, C., Neves, B.B.B., 2003. A Geologia do Brasil no contexto da Plataforma Sul-Americana. In: Bizi, L.A., Schobbenhaus, C., Vidotti, R.M., Gonçalves, J.H. (Orgs.), Geologia, Tectônica e Recursos Minerais do Brasil. Brasília-DF: Serviço Geológico do Brasil-CPRM, 2003, v. 1, pp. 1-54 (in Portuguese).

Schobbenhaus, C., Gonçalves, J.H., Santos, J.O.S., Abram, M.B., Leão Neto, R., Matos, G.M.M., Vidotti, R.M., Ramos, M.A.B., Jesus, J.D.A., 2004. Carta Geológica do Brasil ao milionésimo, Sistema de Informações Geográficas, 46 folhas na escala 1:1.000.000. Programa Geologia do Brasil, Brasília, Companhia de Pesquisa de Recursos Minerais, 41 CD-ROM, ISBN 85-7499-099-4

Schwartz, J.J., Gromet, L.P., 2004. Provenance of a late Proterozoic-early Cambrian basin, Sierras de Córdoba, Argentina. Precambrian Research 129 (1-2), 1-21.

Schwerdtner, W.M., Downey, M.W., Alexander, S.A., 2004. L-S shape fabrics in the Mazinaw domain and the issue of northwest-directed thrusting in the Composite Arc Belt, southeastern Ontario. In: Tollo, R.P., et al. (Eds.), Proterozoic tectonic evolution of the Grenville orogen in North America, vol. 197. Geological Society of America Memoir, Boulder, Colorado, pp. 183-207.

Silva, L.C., Armstrong, R., Pimentel, M.M., Scandolara, J.E., Ramgrab, G.E., Wildner, W., Angelim, L.A.A., Vasconcelos, A.M., Rizzoto, G.J., Quadros, M.L.E.S., Sander, A., Rosa, A.L.Z., 2002. Reavaliação da evolução geológica em terrenos pré-cambrianos brasileiros com base em novos dados U-Pb SHRIMP, Parte III: Províncias Borborema, Mantiqueira Meridional e Rio Negro-Juruena. Revista Brasileira de Geociências 32 (4), 529-544.

Slagstad, T., Culshaw, N.G., Jamieson, R.A., Ketchum, J.W.F., 2004a. Early Mesoproterozoic tectonic history of the southeastern Grenville Province, Ontario: constraints from geochemistry and geochronology of high-grade gneisses. In: Tollo, R.P., et al. (Eds.), Proterozoic Tectonic Evolution of the Grenville Orogen in North America, vol. 197. Geological Society of America Memoir, Boulder, Colorado, pp. 209-241.

Slagstad, T., Hamilton, M.A., Jamieson, R.A., Culshaw, N.G., 2004b. Timing and duration of melting in the mid orogenic crust: constraints from U-Pb (SHRIMP) data, Muskoka and Shawanaga domains, Grenville Province, Ontario. Canadian Journal of Earth Sciences 41 (11), 1339-1365.

Souza, E.C., Romanini, S.J., Adamy, A., Soeiro, R., 1975. Projeto Noroeste de Rondônia. Companhia de Pesquisa de Recursos Minerais-Departamento Nacional da Produção Mineral, Relatório Final, Porto Velho, Brazil, 6 v. (in Portuguese)

Sparrenberger, I., Bettencourt, J.S., Tosdal, R.M., Wooden, J.L., 2002. Datações U-Pb convencional versus SHRIMP do Maciço Estanífero Santa Bárbara, Suíte Granitos Últimos de Rondônia, Brasil. Revista do Instituto de Geociências, Universidade de São Paulo, Série Científica - Geologia 2, pp. 79-94 (in Portuguese).

Steenken, A., Werner, K., Luch, M.G.L., Siegesmund, S., Pawlig, S., 2004. Crustal provenance and cooling of the basement complexes of the Sierra de San Luis: an insight into the tectonic history of the Proto-Andean Margin of Gondwana. Gondwana Research 7 (4), 1171-1195.

Streepey, M.M., 2003. Multiple Proterozoic metamorphic events in the Grenville Province, northwestern New York State: evidence from ion microprobe (SHRIMP) analysis. GSA annual meeting, Seattle, November 2-5, 2003, paper 239-16.

Suarez, A.F., 1990. The basement of the Eastern Cordillera, Colombia: an allochthonous terrane in northwestern South America. Journal of South American Earth Sciences 3 (2-3), 141-151.

Tassinari, C.C.G., Cordani, U.G., Nutman, A.P., Schmus, W.R.V., Bettencourt, J.S., Taylor, P.N., 1996. Geochronological systematics on basement rocks from the Rio Negro-Juruena Province (Amazonian Craton) and tectonic implications. International Geology Reviews 38, 161-175.

Tassinari, C.C.G., Macambira, M.J.B., 1999. Geochronological provinces of the Amazonian Craton. Episodes 22 (3), 174-182.

Tassinari, C.C.G., Cordani, U.G., Correia, C.T., Nutman, A.P., Kinny, P., Dias Neto, C., 1999. Dating granulites by SHRIMP U-Pb systematics in Brazil: constraints for the age of the metamorphism of Proterozoic Orogenies. In: II Symposium on South America Isotope Geology, Actas, Cordoba, Argentina, IGRM-SGMA, pp. 234-238.

Teixeira, W., 1978. Significado tectônico do Magmatismo anorogênico PréCambriano básico e alcalino na região amazônica. In: Sociedade Brasileira de Geologia, Congresso Brasileiro de Geologia, vol. 30, Recife, Anais 1, pp. 491-511, in Portuguese.

Teixeira, W., Tassinari, C.C.G., Cordani, U.G., Kawashita, K., 1989. A review of the geochronology of the Amazonian Craton: tectonic implications. Precambrian Research 42, 213-227.

Tohver, E., Pluijm, B.A.V.D., Voo, R.V.D., Rizzotto, G.J., Scandolara, J.E., 2002. Paleogeography of the Amazon Craton at $1.2 \mathrm{Ga}$ : early Grenvillian collision with the Llano segment of Laurentia. Earth and Planetary Science Letters 199, 185-200.

Tohver, E., Pluijm, B.A.V.D., Mezger, K., Essene, E., Scandolara, J.E., Rizzotto, G.J., 2004 Significance of the Nova Brasilândia metasedimentary belt in Western Brazil: redefining the Mesoproterozoic boundary of the Amazon Craton. Tectonics 23, $1-20$.

Tohver, E., Pluijm, B.A.V.D., Scandolara, J.E., Essene, E., 2005. Late Mesoproterozoic deformation of SW Amazônia (Rondônia, Brazil): geochronological and structural evidence for collision with Southern Laurentia. Journal of Geology 113, 309-323.

Tollo, R.P., Corriveau, L., McLelland, J., Bartholomew, M.J., 2004. Proterozoic tectonic evolution of the Grenville orogen in North America: an introduction. Geological Society of America Memoir 197, 1-18.

Van Breemen, O., Davidson, A., Loweridge, W.D., Sullivan, R.W., 1986. U-Pb zircon geochronology of Grenville tectonites, granulites and igneous precursors, Parry Sound, Ontario. In: Moore, J.M., Davidson, A., Baer, A.J. (Eds.), The Grenville Province: St. John's, Newfoundland. Geological Association of Canada Specia Paper, vol. 31, pp. 192-207.

Van Breemen, O., Corriveau, L., 2005. U-Pb age constraints on arenaceous and volcanic rocks of the Wakeham Group, eastern Grenville Province. Canadian Journal of Earth Sciences 42 (10), 1677-1697.

Van Schmus, W.R., Bickford, M.E., Turek, A., 1996, Proterozoic geology of the eastcentral midcontinent basement. In: van der Pluijm, B.A., Catacosinos, P. (Eds.) Basement and basins of eastern North America. Geological Society of America Special Paper, vol. 308, pp. 7-32.

Van Schmus, W.R., Schneider, D.A., Holm, D.K., Dodson, S., Nelson, B.K., 2007. New insights into the southern margin of the Archean-Proterozoic boundary in the north-central United States based on U-Pb, Sm-Nd, and Ar-Ar geochronology. Precambrian Research 157, 80-105.

Vasquez, M.L., Macambira, M.J.B., Armstrong, R.A., 2008. Zircon geochronology of granitoids from the western Bacajá Domain, southeastern Amazonian Craton, Brazil: Neoarchean to Rhyacian evolution. Precambrian Research 161 (3-4), 279-302.

Volkert, R.A., Zartman, R.E., Moore, P.B., 2005. U-Pb zircon geochronology of Mesoproterozoic postorogenic rocks and implications for post-Ottawan magmatism and metallogenesis, New Jersey Highlands and contiguous areas, USA. Precambrian Research 139 (1/2), 1-19.

Wasteneys, H.A., Clark, A.H., Farrar, E., Langridge, R.J., 1995. Grenvillian granulitefacies metamorphism in the Arequipa Massif, Peru: a Laurentia-Gondwana link. Earth and Planetary Science Letters 132 (1-4), 63-73.

Wasteneys, H.A., Kamo, S.L., Moser, D., Krogh, T.E., Gower, C.F., Owen, J.V., 1997. U-Pb geochronological constraints on the geological evolution of the Pinware terrane and adjacent areas, Grenville Province, southeast Labrador, Canada. Precambrian Research 81 (1), 101-128.

Weil, A.B., Voo, R.V.D., Niocaill, C.M., Meert, J.G., 1998. The Proterozoic supercontinent Rodinia: paleomagnetically derived reconstructions for 1100 to $800 \mathrm{Ma}$. Earth and Planetary Science Letters 154, 13-24.

Windley, B.F., 1993. Proterozoic anorogenic magmatism and its orogenic connections. Journal of the Geological Society of London 150, 39-50. 


\title{
EL GRANITO DIAMANTINA: EVIDENCIA ISOTÓPICA Y QUIMICA DE MAGMATISMO DE ARCO EN EL COMPLEJO PENSAMIENTO, PROVINCIA RONDONIA- SAN IGNACIO, PRECAMBRICO DE BOLIVIA ORIENTAL
}

\author{
Matos, R. ${ }^{1,2}$, Teixeira, W. ${ }^{2}$, Geraldes, M.C. ${ }^{3}$ \\ 1 Instituto de Investigaciones Geológicas y del Medio Ambiente, Universidad Mayor de San Andrés, Calle27, Pabellón Geología, \\ Campus Universitario Cota Cota. La Paz, Bolivia. E-mail: rmatoss@yahoo.com \\ 2 Instituto de Geociências, Universidade de São Paulo, Rua do Lago 562, Cidade Universitária. 05508-080 Sao Paulo, SP, Brasil. \\ E-mail: rmatoss@igc.usp.br; wteixeir@usp.br \\ 3 Faculdade de Geologia, Universidade do Estado do Rio de Janeiro, Rua São Francisco Xavier 524, 20559-900 Rio de Janeiro, \\ RJ, Brasil. E-mail: geraldes@uerj.br
}

Palabras claves: Bolivia, Complejo Granítico Pensamiento, Granito Diamantina, Orogenia San Ignacio, sistemática Sm-Nd, Cratón Amazónico.

\begin{abstract}
RESUMEN
El Granito Diamantina es un plutón comprendido en el Complejo Granitoide Pensamiento (CGP), en el Precámbrico de Bolivia. EI CGP está asignado a la evolución de la Provincia Rondoniana- San Ignacio (1.50-1.30 Ga) del sudoeste del Cratón Amazónico. La evolución del Cratón en el Proterozoico resulta del desarrollo de fajas móviles de dirección NO-SE, que se tornan más jóvenes al sudoeste como es el caso de las orogenias Rondoniana-San Ignacio (1.36-1.30 Ga) y Sunsás (1.20-1.00 Ga) en Bolivia y Brasil. EI CGP aflora enteramente dentro del Cratón Paraguá y está parcialmente sobreimpreso por la orogenia Sunsás. EI CGP comprende granitos y términos subvolcánicos y subordinadamente sienitas, granodioritas, tonalitas, trondhjemitas y dioritas, tectónicamente caracterizadas como sin a tardicinemáticas y tardi a post cinemáticas. El granito Diamantina es un plutón tardi a post cinemática.
\end{abstract}

Cuatro muestras del Granito Diamantina analizadas en roca total por elementos mayores, traza y ETR indican carácter subalcalino, en el diagrama AFM caen en el campo calcoalcalino. El granito despliega contenido de $\mathrm{SiO}_{2}$ de 72 a $75 \mathrm{wt} \%$ y es peraluminoso en composición. . Esta roca muestra dos características diferentes en el diagrama REE: $I$ ) las muestras CP0505, CP20506 y CP30507 exhiben un comportamiento empinado. Esto se relacionaría con los altos contenidos de LREE y bajo contenido en HREE, probablemente reflejando la fraccionación de anfíbol y/o allanita. ii) la muestra ME0508 presenta forma de "ala de gaviota" con moderada anomalía negativa de Eu, típica de granitos diferenciados. En el diagrama de multielementos, los picos negativos de $\mathrm{Sr}, \mathrm{P}$ y $\mathrm{Ti}$ se interpretan como debido a la fraccionación de mica, feldespato, apatita, y fases de Ti. Una datación U-Pb SHRIMP produjo una de edad de $1340 \pm 20 \mathrm{Ma}$. El Granito Diamantina despliega edades modelo $\mathrm{T}_{\mathrm{DM}}$ variables entre 1.6 y $1.9 \mathrm{Ga}$ (razones $f_{\mathrm{Sm} / \mathrm{Nd}}$ entre -0.50 y -0.25$)$, y $\varepsilon_{\mathrm{Nd}(1.33 \mathrm{Ga})}$ de +0.4 a -1.2 . que indican una mezcla de material derivado del manto y material cortical Estos datos son consistentes con un ambiente de arco magmático

\section{INTRODUCCIÓN}

El Cratón Amazónico (Figura 1),de amplio desarrollo en Sudamérica, comprende las provincias geocronológicas Maroni-Itacaiunas (2.25-1.95 Ga), Ventuari-Tapajós (2.0-1.8 Ga), Río Negro-Juruena (1.78-1.55 Ga), Rondoniana-San Ignacio (1.50-1.30 Ga), y Sunsás (1.25-1.0 Ga), Teixeira et al., (1989); Tassinari et al., (2000). Los estudios de Sm-Nd (Cordani y Sato, 1999) confirmaron esta arquitectura cortical, respaldada por numerosos trabajos gecronológicos en isótopos de U-Pb y Rb-Sr en rocas granitoides. La Provincia Rondoniana-San Ignacio (PRSI) de amplia distribución en la región sudoeste del Cratón Amazónico (Brasil y Bolivia) fue estudiada por varios autores (Litherland et al., 1986; Sato y Tassinari, 1997; Van Schmus et al., 1998; Bettencourt et al., 1999; Geraldes et al., 2000, 2001, 2004; Leite y Saes, 2000; Payolla et al. 2002, Santos et al., 2000; Santos et al., 2005, 2006), sin embargo la edad, estructura, composición de las unidades rocosas y eventos orogénicos dentro del territorio boliviano aun son poco conocidos.

El Granito Diamantina, un plutón del CGP, constituye una elevación de orientación norte, de forma elíptica, de $53 \mathrm{~km}$ de largo (Klinck y O'Connor, 1982). Aflora como una "isla" en medio de la vegetación sobre el camino que une las localidades de Santa Rosa de la Roca y Piso Firme, departamentos de Santa Cruz y Beni (Figura 2). El tipo de roca dominante es un monzogranito biotítico, de color rosado pálido, sin foliación y considerado como tardío a postcinemático. Las rocas hospedantes del Granito 
Diamantina son los granitos San Martín y La Junta, considerados sincinemáticos a tardicinemáticos en edad, moderadamente foliados de acuerdo a la estructura regional del Complejo Granitoide Pensamiento.

Este trabajo, efectuado en el Instituto de Investigaciones Geológicas y del Medio Ambiente (IGEMA) de la UMSA y el Centro de Pesquisas Geocronológicas del Instituto de Geociencias de la Universidad de Sao Paulo, Brasil, presenta resultados de geoquímica y de isótopos de $\mathrm{Sm}-\mathrm{Nd}$ y U-Pb del Granito Diamantina y emplaza importantes definiciones isotópicas en los protolitos rocosos de la PRSI en territorio boliviano. Este estudio es parte de un proyecto de doctorado que el autor, docente e investigador de la UMSA realiza en la USP de Sao Paulo, Brasil. El propósito de la tesis es determinar la evolución tectónica del Precámbrico del oriente de Bolivia y su relación a la evolución de la región sudoeste del Cratón Amazónico en el Mesoproterozoico.

\section{GEOLOGÍA REGIONAL}

El Granito Diamantina, pertenece al Complejo Granitoide Pensamiento dentro del Cratón Paraguá y forma parte de la Provincia Rondoniana-San Ignacio en el Precámbrico de Bolivia (Litherland et al., 1986). Esta provincia es el resultado de la geodinámica durante el Mesoproterozoico (1600 a $1000 \mathrm{Ma}$ ) que produjo una serie de fajas acrecionadas culminando con una colisión continental contra la provincia Rió Negro-Juruena (1.78-1.55 Ga) (Cordani y Teixeira, 2007), El evento colisional está marcado por el metamorfismo de facies granulita (1.35-1.32 Ga) que produjo una sobreimpresión en la roca hospedante. Se debe resaltar que el conocimiento detallado del escenario tectónico de la Provincia Rondoniana-San Ignacio es una tarea difícil debido a la evolución cortical policíclica. La sobreimpresión más joven está asociada a la orogenia colisional Sunsás (1.2-1.0 Ga).

\section{GRANITO DIAMANTINA, GEOLOGÍA Y PETROGRAFÍA}

Las rocas del basamento metamórfico del Precámbrico boliviano están constituidas por el Complejo Granulítico Lomas Maneches, el Complejo Gnéisico de la Chiquitania y por el Grupo de Esquistos San Ignacio. Estas tres unidades fueron intruídas por los granitos del Complejo Pensamiento y por los granitos de la Zona Sur. El Complejo Granitoide Pensamiento es una unidad plutónica extensa con granitoides subvolcánicos subordinados. Este mar de gneisses y granitos consiste de sienitas, granodioritas, tonalitas, trondhjemitas y dioritas. Se reconocen dos eventos magmáticos intrusivos dentro del CGP, los granitos sin a tardi cinemáticos y los granitos tardi a post cinemáticos. El granito Diamantina es parte de ese segundo grupo.

El granito Diamantina está expuesto sobre el camino de Santa Rosa de Roca a Piso Firme. Es de grano fino y a veces de grano medio a grueso, con biotita como mineral máfico principal. Contiene xenolitos de litologías variadas (gneisses biotíticos, gneisses de granate-biotita y gneiss hornbléndico). Contiene venas y lentes de pegmatita (Klinck y O'Connor, 1982). El granito Diamantina en el presente trabajo fue muestreado en cuatro lugares (Figura 2). El tipo de roca dominante es un sienogranito biotítico rosado pálido, no foliado. Una muestra (ME0508; un cuarzo monzonito moderadamente foliado), se colectó en la estancia La Mechita y se asemeja a un gneiss del Complejo Chiquitanía. 
Tabla1. Descripción petrográfica de cuatro muestras del Granito Diamantina.

\begin{tabular}{|c|c|c|}
\hline Muestra & Plutón & Características principales \\
\hline СР0505 & Diamantina & $\begin{array}{l}\text { Sienogranito masivo a ligeramente porfirítico, de grano medio, de color blanco } \\
\text { rosado. La textura es equigranular anhedral a subhedral. Esporádicos parches } \\
\text { de intercrecimiento de plagioclasa con cuarzo vermicular. Algunos cristales de } \\
\text { plagioclasa (An26), contienen pajuelas de muscovita. El feldespato potásico es } \\
\text { micropertítico y muestra maclado en rejilla propio de la microclina. La biotita es el } \\
\text { principal mineral ferromagnesiano y está escasamente cloritizado y es de color } \\
\text { amarillo pajizo a verde olivo obscuro. La roca contiene masas irregulares de } \\
\text { minerales opacos, zircón euhedral, escasa apatita, a veces incluida en la biotita. }\end{array}$ \\
\hline CP20506 & Diamantina & $\begin{array}{l}\text { Sienogranito de grano medio, blanquecino, masivo a ligeramente porfirítico. } \\
\text { Textura equigranular subhedral a anhedral. Los cristales de plagioclasa (An28), } \\
\text { contienen una densa masa de muscovita de grano fino y minerales de arcilla, de } \\
\text { color pardo pálido procedentes de la alteración. El feldespato potásico muestra } \\
\text { maclado en enrejado característico de la microclina. La biotita está escasamente } \\
\text { cloritizada y es de color amarillo pajizo a verde olivo obscuro. El epidoto es de } \\
\text { origen secundario y aparece en pequeños cristales. Masas esqueléticas de } \\
\text { minerales opacos conteniendo apatita y epidoto. La apatíta aparece también } \\
\text { como inclusión en la biotita. El zircón y el apatito se presentan en cristales } \\
\text { euhedrales. }\end{array}$ \\
\hline CP30507 & Diamantina & $\begin{array}{l}\text { Sienogranito de grano medio, blanquecino, masivo a ligeramente porfirítico.. } \\
\text { Textura inequigranular anhedral. El feldespato potásico contiene un } \\
\text { intercrecimiento tipo micropertita. Parches de plagioclasa intercrecida con cuarzo } \\
\text { vermicular. La biotita es de color amarillo pajizo a verde olivo obscuro. Pajuelas } \\
\text { de muscovita en plagioclasa. Masas irregulares de minerales opacos asociados } \\
\text { a la biotita. Apatita euhedral. }\end{array}$ \\
\hline ME0508 & Diamantina & $\begin{array}{l}\text { Cuarzo monzonita de color rosado blanquecino. Grano medio a grueso. Textura } \\
\text { equigranular subhedral a anhedral. Algunos fenocristales de feldespato potásico, } \\
\text { con maclado tipo microclina. La plagioclasa contiene cristales de grano muy fino } \\
\text { de muscovita y arcillas de color pardo pálido. Abundante plagioclasa intercrecida } \\
\text { con cuarzo vermicular. Biotita de color amarillo pajizo a verde olivo obscuro. Muy } \\
\text { poco epidoto diminuto secundario. Zircón como inclusiones en la biotita. Apatita } \\
\text { euhedral. }\end{array}$ \\
\hline
\end{tabular}

\section{TÉCNICAS ANALÍTICAS}

Se seleccionaron cuatro muestras para el análisis químico de roca total para elementos mayores y menores $\left(\mathrm{SiO}_{2}, \mathrm{TiO}_{2}, \mathrm{Al}_{2} \mathrm{O}_{3}, \mathrm{Fe}_{2} \mathrm{O}_{3}\right.$ Tot, $\mathrm{MnO}, \mathrm{MgO}, \mathrm{CaO}, \mathrm{K}_{2} \mathrm{O}, \mathrm{Na}_{2} \mathrm{O}$ and $\left.\mathrm{P}_{2} \mathrm{O}_{5}\right)$ y elementos traza en el Laboratorio Químico del Instituto de Geociencias de la Universidad de São Paulo (IGc-USP), Brasil, siguiendo las técnicas formuladas por Navarro (2004). Asimismo, se analizaron cuatro muestras por Sm$\mathrm{Nd}$ en roca total en el Centro de Pesquisas Geocronológicas (CPGeo) del Instituto de Geociencias de la Universidad de Sao Paulo siguiendo la rutina descrita por Sato et al. (1995).

\section{RESULTADOS Y DISCUSIÓN}

El granito Diamantina muestra contenido de $\mathrm{SiO}_{2}$ de 72 a $75 \mathrm{wt} \%$, y pertenece al campo de alto $\mathrm{K}$ en el diagrama SiO2 versus K2O de Peccerillo y Taylor (1976), e indica una composición peraluminosa en el diagrama de Maniar y Piccoli (1989); la razón $\mathrm{K}_{2} \mathrm{O} / \mathrm{Na}_{2} \mathrm{O}$ varía de 1.5 a 1.8. Cuatro muestras del Granito Diamantina analizadas en roca total por elementos mayores, trazas y ETR indican carácter subalcalino; en el diagrama AFM de Irvine y Baragar se encuentran en el campo calcoalcalino. Este plutón muestra dos características diferentes en el diagrama REE (Figura 3): i) las muestras CP0505, CP20506 y CP30507 exhiben un comportamiento empinado. Esto se relacionaría con los altos contenidos de LREE y bajo contenido en HREE, probablemente reflejando la fraccionación de anfíbol y/o allanita. ii) la muestra ME0508 en el diagrama de ETR presenta forma de "ala de gaviota" con moderada anomalía negativa de Eu debido a la fraccionación de la plagioclasa, típica de granitos diferenciados; los valores más elevados en los ETRP indica fuente cortical para esta muestra. En el diagrama de multielementos (Figura 4), los picos negativos de Sr, $\mathrm{P}$ y Ti se interpreta como debido a la fraccionación de mica, plagioclasa, apatita, y fases de Ti en la magnetita.

Los parámetros isotópicos de $\mathrm{Nd}$ de las rocas investigadas se calcularon de acuerdo a la referencia proporcionada por la edad U/Pb SHRIMP en los bordes de zircones (1.33 Ga) del Granito San Rafael 
(Boger et al., 2005), interpretado como la edad de emplazamiento del plutón durante la orogenia San Ignacio. Adicionalmente edades zircón U-Pb SHRIMP se efectuaron (Matos, en preparación) en la muestra CP30507 del Granito Diamantina, permitiendo la interpretación de los procesos petrogenéticos del CGP.

El Granito Diamantina despliega edades modelo $\mathrm{T}_{\mathrm{DM}}$ variables entre 1.6 y $1.9 \mathrm{Ga}$ (razones $f_{\mathrm{Sm} / \mathrm{Nd}}$ entre 0.50 y -0.25$)$, y $\varepsilon_{\mathrm{Nd}(1.33 \mathrm{Ga})}$ de +0.4 a -1.2 . A partir de los datos anteriores el Granito Diamantina muestra valores de $\mathrm{Nd}$ compatibles con una mezcla de material derivado del manto con corta residencia cortical en el proceso petrogenético. El nuevo análisis U-Pb SHRIMP efectuado en el Granito Diamantina produjo una edad de $1340 \pm 20 \mathrm{Ma}$ (Matos, en preparación, 2008). El Granite Diamantina consiguientemente es contemporáneo con el Granito San Rafael (1.33 Ga), un plutón representativo de la Orogenia San Ignacio en Bolivia (Boger et al., 2005). Los datos adicionales de edad U-Pb SHRIMP en zircón en el rango de $1.34-1.32$ Ga para las unidades Lomas Maneches y Chiquitania (Boger et al., 2005; Santos et al., 2006; 2007), revela una sobreimpresión metamórfica asociada con esta orogenia que afectó no solo al escudo del Precámbrico Boliviano sino también la contraparte Brasilera.

\section{CONCLUSIONES}

Varios eventos orogénicos se reportaron en el SW del Cratón Amazónico, en el Estado de Mato Grosso, como ser Alto Jauru (1.79- $1.74 \mathrm{Ga})$, Cachoerinha (1.58-1.52 Ga) y Santa Helena (1.45-1.40 Ga), Geraldes et al., (2004); asimismo, se determinaron series graníticas rapakivi en el Estado de Rondonia como Serra da Providencia (1.66- $1.64 \mathrm{Ga}$ ), Santo Antonio y Teotonio (1406 Ma y $1387 \mathrm{Ma}$ respectivamente ), Alto Candeais (1338-1346 Ma) y San Lorenzo-Caripunas (1314-1309 Ma) estudiadas por Bettencourt et al., (1999). Las características isotópicas y geoquímicas presentadas en este trabajo concuerdan bien con un escenario de arcos magmáticos culminando con una colisión continental a los 1.33 Ga contra la provincia Rio Negro-Juruena, como recientemente fue propuesto para la evolución de la provincia Rondoniana-San Ignacio por Cordani y Teixeira (2007). Adicionalmente, las rocas granitoides del Precámbrico Boliviano presentan valores negativos de $\mathrm{Nb}, \mathrm{Sr}$ and $\mathrm{Ti}$, mientras que muestran valores de $\mathrm{Rb}$, Ba y Th enriquecidos respecto al Nb (Litherland et al., 1986). Este es un rasgo típico de magmas evolucionados en arcos magmáticos.

\section{AGRADECIMIENTOS}

Este trabajo forma parte de la tesis doctoral en preparación para ser presentada a la Universidad de São Paulo, Brasil y cuenta con el apoyo financiero de CAPES (Coordenação de Aperfeiçoamento de Pessoal de Nível Superior, Brasil. El estudio está financiado por el Conselho Nacional de Pesquisa Científica e Tecnológica, CNPq, de Brasil con el número 470373/2004-0.

El autor agradece al Director del IGEMA, Dr. J. Argollo por todo el esfuerzo desplegado para permitir esta publicación.

\section{REFERENCIAS}

BETTENCOURT, J. S.; TOSDAL, R. M.; LEITE, W. B. JR.; PAYOLLA, B. L., 1999. Mesoproterozoic rapakivi granites of the Rondônia Tin Province, southwestern border of the Amazonian craton, Brazil-I. Reconnaisance U-Pb geochronology and regional implications. Precambrian Research, 95, 1-2, p. 41-67.

BETTENCOURT, J. S.; PAYOLLA, B. L.; TOSDAL, R. M.; WOODEN, J. L.; LEITE, W. B. JR.; SPARRENBERGER, I., 2006. SHRIMP-RG U-Pb zircon geochronology of gneiss from the Rio Crespo Intrusive Suite, SW Amazonian craton, Rondônia, Brazil: New insight about protolith crystallization and metamorphic ages. In: Short Papers, SOUTH AMERICAN SYMPOSIUM ON ISOTOPE GEOLOGY, 5, Punta del Este, Uruguay, p. 49-52.

BETTENCOURT, J. S.; PAYOLLA, B. L.; TOSDAL, R. M.; WOODEN, J. L.; LEITE, W. B. JR.; SPARRENBERGER, I., 2006. Refining of the timing of orogenetic events in northern Rondônia, SWAmazonian craton, during geons 17-12: Implications for understanding the evolution of the Proterozoic lithosphere. In: ABSTRACTS VOLUME AND FIELD TRIPS GUIDE, SYMPOSIUM ON MAGMATISM, CRUSTAL EVOLUTION, AND METALLOGENESIS OF THE AMAZONIAN CRATON, Belem, Brazil, p. 14.

BOGER, S.D.; RAETZ, M.; GILES, D.; ETCHART, E.; FANNING, M.C., 2005. U-Pb age data from the Sunsas region of Eastern Bolivia, evidence for the allochtonous origin of the Paragua Block. Precambrian Research, 139, 121-146. 
CORDANI, U.G.; SATO, K., 1999. Crustal evolution of the South American Platform, based on Nd isotopic systematics on granitoid rocks. Episodes, 22, 3, 167-173.

CORDANI, U. G.; TEIXEIRA, W., 2007 Proterozoic accretionary belts of the Amazonian Craton. In: Hatcher, R.D. Jr., Carlson, M. P., McBride, J. H., and Martinez Catalán, J. R. (Org.). The 4D Framework of Continental Crust. GSA Memoir. Boulder, Colorado: Geological Society of America Book Editors, 200, p. 297-320.

CORDANI, U.G.; SATO, K.; TEIXEIRA, W.; TASSINARI, C. C. G.; BASEI, M. A. S., 2000. Crustal evolution of the South American Platform. In: $31^{\text {ST }}$ INTERNATIONAL GEOLOGIC CONGRESS, Rio de Janeiro, Brazil, p. 19-40.

GERALDES, M. C.; TEIXEIRA, W.; VAN SCHMUS, W. R., 2000. Isotopic and chemical evidence for three accretionary magmatic arcs (1.79- $1.42 \mathrm{Ga}$ ) in SW Amazon craton, Mato Grosso State, Brazil, Revista Brasileira de Geociências, 30, 99-101.

GERALDES, M. C.; VAN SCHMUS, W. R.; CONDIE, K. C.; BELL, S.; TEIXEIRA, W.; BABINSKI, M., 2001. Proterozoic geologic evolution of SW part of the Amazonian craton in Mato Grosso State, Brazil. Precambrian Research, 111, 91-128.

HAWKINS, M. P., 1982. The geology and mineral potential of the Manomó area (Part of quadrangle SD 20-16). Open File Report. Institute of Geological Sciences-Servicio Geológico de Bolivia. Santa Cruz. 105 p.

IRVINE, T. N. and BARAGAR, W. R. A., 1971.A guide to the chemical of the common volcanic rocks. Can J. Earth Sci., 8, 523-548.

KLINCK, B. A.; O'CONNOR, E. A., 1983. The geology and mineral potential of the Perseverancia and Monte Verde areas (Quadrangles SD 20-15 and SD 20-11). Open File Report. Institute of Geological Sciences-Servicio Geológico de Bolivia. Santa Cruz. 178 p.

LITHERLAND, M., 1982. The geology and mineral potential of the Huanchaca area (Parts of Quadrangles SD 20-15 and SD 20-11). Open File Report. Institute of Geological Sciences-Servicio Geológico de Bolivia. Santa Cruz. 173 p.

LITHERLAND, M.; BLOOMFIELD, K., 1981. The Proterozoic history of Eastern Bolivia.- Precambrian Research, $15: 157-179$.

LITHERLAND, M.; KLINCK. B. A.., 1982. Introducing the terms "Paragua Craton" and "The Pensamiento Granitoid Complex" for use in sheet reports. Rep. East. Bolivia Miner. Expl. Proj., Santa Cruz (unpublished).

LITHERLAND, M. ; ANNELLS, R. N.; APPLETON, J. D.; BERRRANGÉ, J.P.; BLOOMFIELD, K.; BURTON, C. C. I.; DARBYSHIRE, D. P. F.; FLETCHER, C. J. N.; HAWKINS. M.P.; KLINCK, B.A.; LLANOS, A.; MITCHELL, W. I.; O'CONNOR. E.A.; PITFIELD. P.E.J.; POWER, G.; WEBB, B.C., 1986. The geology and mineral resources of the Bolivian Precambrian Shield, British Geological Survey, Overseas Memoir 9. London. 153 p.

LITHERLAND. M.; ANNELLS, R. N.; DARBYSHIRE, D. P .F.; FLETCHER, C .J .N.; HAWKINS, M. P.; KLINCK, B. A.; MITCHELL, W. I.; O'CONNOR, E. A.; PITFIELD. P. E .J.; POWER, G.; WEBB, B. C., 1989. The Proterozoic of Eastern Bolivia and its relationship to the Andean mobile belt. Precambrian Research, 43,157-174.

MANIAR, P. D. and PICCOLI, P. M., 1989. Tectonic discrimination of granitoids. Geological Society of America Bulletin, Bolder, 101(5), 635-643.

MATOS, R.; TEIXEIRA, W.; GERALDES, M. C.; CORDANI, U.G.; BETTENCOURT, J. S. U-Pb and Sm$\mathrm{Nd}$ constraints to the evolution of Bolivian Precambrian terranes (in preparation).

NAVARRO, M. S., 2004. A implantação de rotina, e seu refinamento, para a determinação de elementos terras raras em materiais geológicos por ICP-OES e ICP-MS. Aplicação ao caso dos granitóides de Piedade-Ibiúna (SP) e Cunhaporanga (PR). Dissertação de mestrado, Instituto de Geociências, Universidade de São Paulo, 132p. 
PAYOLLA, B. L.; BETTENCOURT, J. S.; KOSUCH, M.; LEITE, W. B. JR.; FETTER, A. H.; VAN SCHMUS, W. R., 2002. Geological evolution of the basement rocks in the east-central part of the Rondônia Tin province, SW Amazonian craton, Brazil: U-Pb and Sm-Nd isotopic constraints. Precambrian Research, 119, 141-169.

PECCERILLO, R. and TAYLOR, S. R., 1976. Geochemistry of Eocene calc-alkaline volcanic rocks from Kastamonu area, northern Turkey. Contributions to Mineralogy and Petrology, Berlin, 58(1), 63-81.

SANTOS, J. O. S.; RIZZOTTO, G.J.; MCNAUGHTON, N. J.; MATOS, R.; HARTMANN, L. A.; POTTER, P. E.; FLETCHER, I. R., 2006. The Four Main Orogenies within the Autochthonous Mesoproterozoic Sunsas Province in SW Amazon Craton, XVII CONGRESO GEOLÓGICO DE BOLIVIA. Sucre, Bolívia, p. $1-4$.

SANTOS, J. O. S.; RIZZOTTO, G.J.; MCNAUGHTON, N. J.; MATOS, R.; HARTMANN, L. A.; CHEMALE Jr., F.; POTTER, P. E.; QUADROS, M.L.E.S, 2007. The age and autochthonous evolution of Sunsás Orogen in West Amazon Craton. Submitted to Precambrian Research.

SATO, K.; TASSINARI, C. C. G.; KAWASHITA, K.; PETRONHILO, L. O., 1995. Método GeocronológicoSm-Nd no IGc/USP e suas aplicações. Anais da Academia Brasileira das Ciências, 67, 313-336.

SATO, K.; TASSINARI, C. C. G., 1997. Principais eventos de acreçao continental no Cráton Amazonico baseados em idade modelo $\mathrm{Sm}-\mathrm{Nd}$, calculada em evoluçoes de estágio único e estágio duplo. In: Costa , M.L., Angelica, R.S., (Eds.), CONTRIBUÇOES À GEOLOGIA DA AMAZONIA, Belém, Sociedade Brasileira de Geologia, p. 91-142.

TASSINARI, C.C.G.; BETTENCOURT, J. S.; GERALDES, M. C.; MACAMBIRA, M. J. B.; LAFON, J.M., 2000. The Amazon craton. In: Cordani, U.; Milani, E.J.; Thomaz Filho, A., and Campos, D.A., (Eds.), Tectonic evolution of South America, $31^{\text {st }}$ INTERNATIONAL GEOLOGICAL CONGRESS, Rio de Janeiro, Brazil, p. 41-95.

TEIXEIRA, W.; TASSINARI, C. C. G.; CORDANI, U. G.; KAWASHITA, K., 1989. A review of the geochronology of the Amazonian Craton: Tectonic implications. Precambrian Research, 42, 213-227.

TEIXEIRA, W.; BETTENCOURT, J. S.; GIRARDI, V. A. V.; ONOE, A.; SATO, K.; RIZZOTTO, G. J., 2006. Mesoproterozoic mantle heterogeneity in the SW Amazonian Craton: ${ }^{40} \mathrm{Ar} /{ }^{39} \mathrm{Ar}$ and $\mathrm{Nd}-\mathrm{Sr}$ isotopic evidence from mafic- felsic rocks. In: HANSKI, E.; MERTANEN, S.; RÄMÖ, T; VUOLLO, J.(eds) Dyke swarms - Time Markers of Crustal Evolution. London, Taylor \& Francis Group, p. 113-130.

TEIXEIRA, W., CORDANI, U. G., 2008. Proterozoic evolution of the Amazonian Craton reviewed. Special volume of the Indian Conference on Global Scenario. World Scientific. (in press).

VAN SCHMUS, W.R.; GERALDES, M.C.; KOZUCH, M.; FETTER, A.H.; TASSINARI, C.C.G.; TEIXEIRA, W., 1998. U/Pb and Sm/Nd constraints on the age and origin of Proterozoic crust in southwestern Mato Grosso, Brazil: evidence for a $1450 \mathrm{Ma}$ magmatic arc in Sw Amazonia. International Symposium on Tectonics, Ouro Preto-MG, Brazil, Abstract Volume, pp. 121-125. 


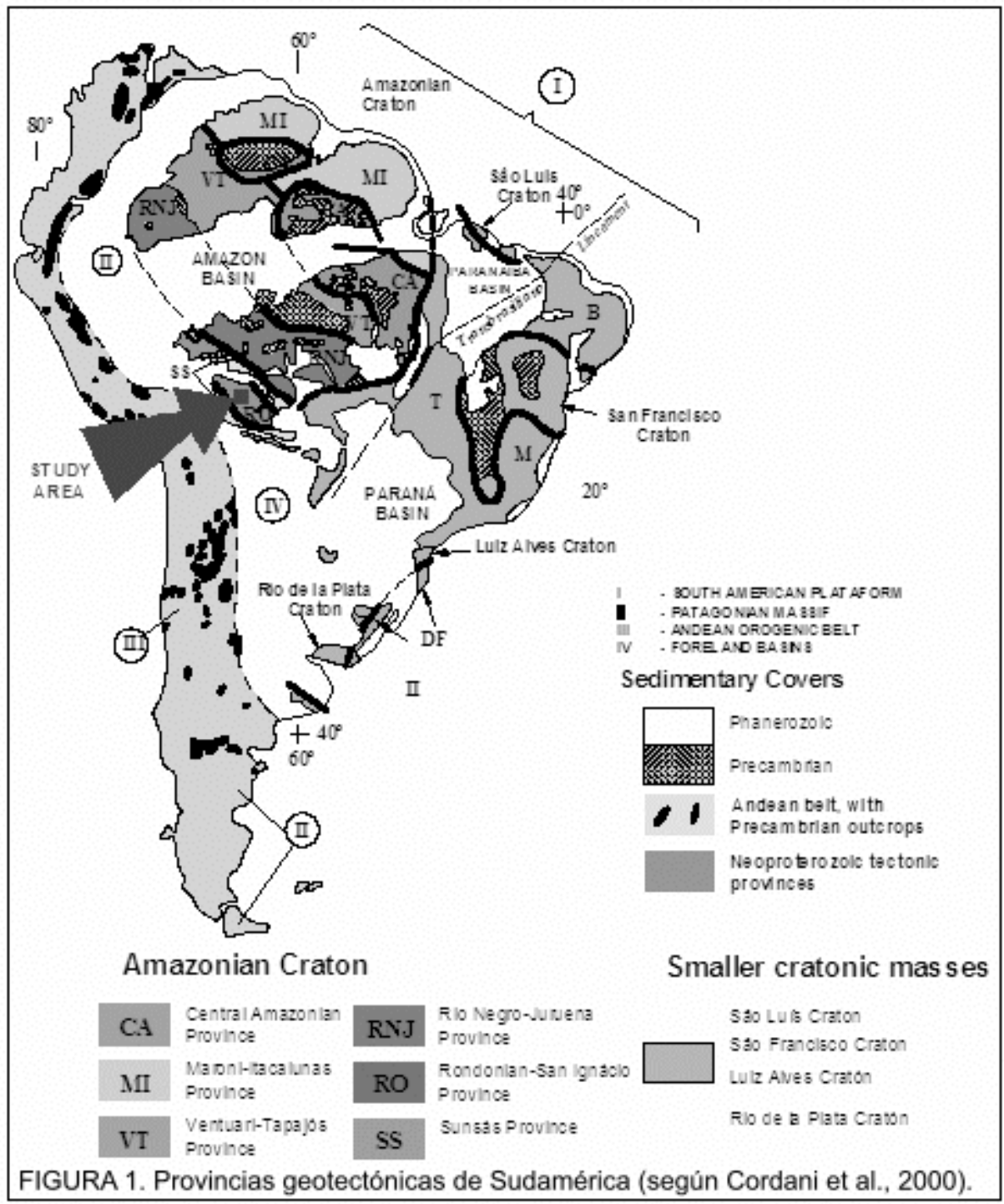




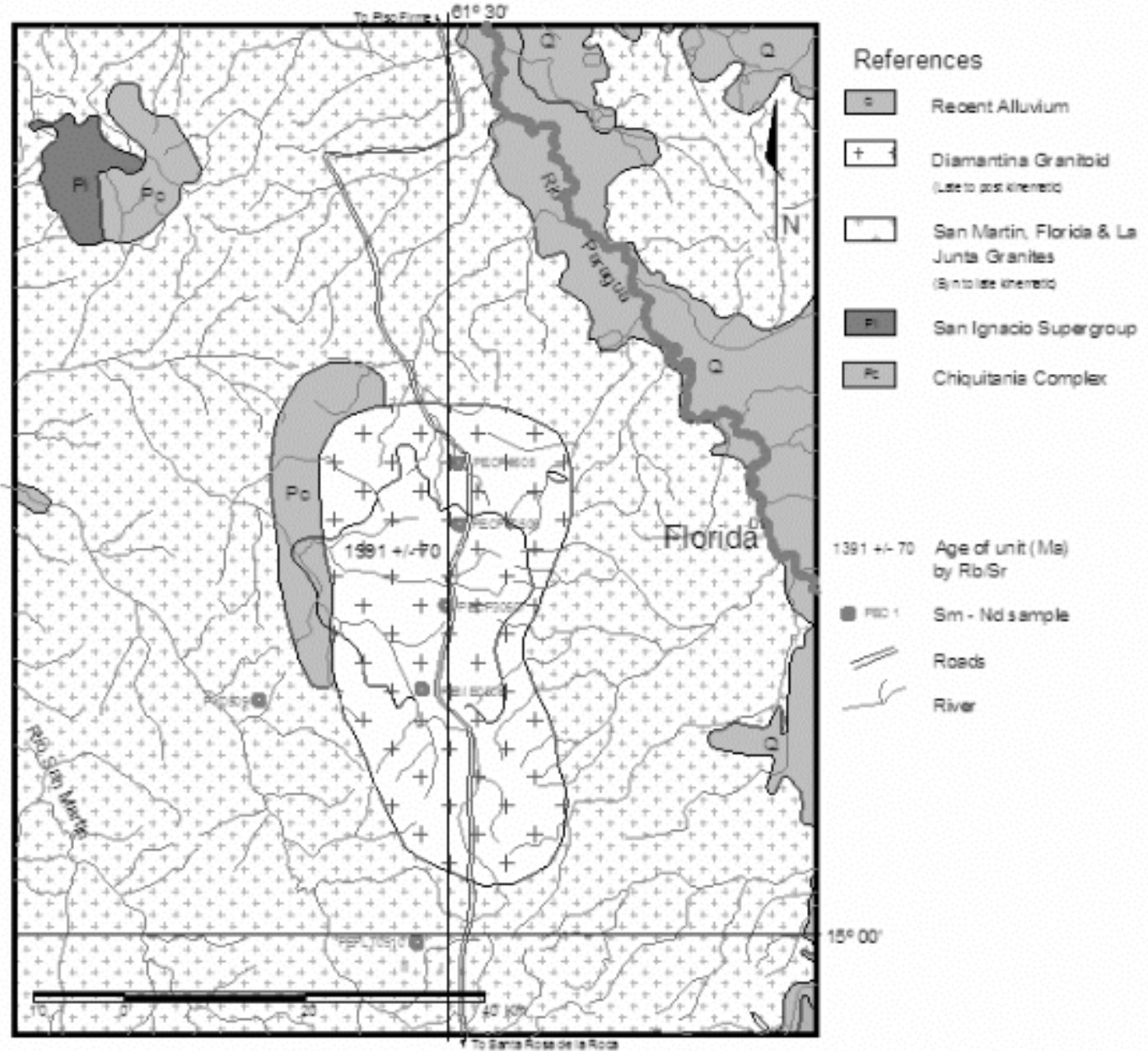

Figure 2. Geological map of Diamantina Granitoid (Modified from Litherland et al.,1982) 


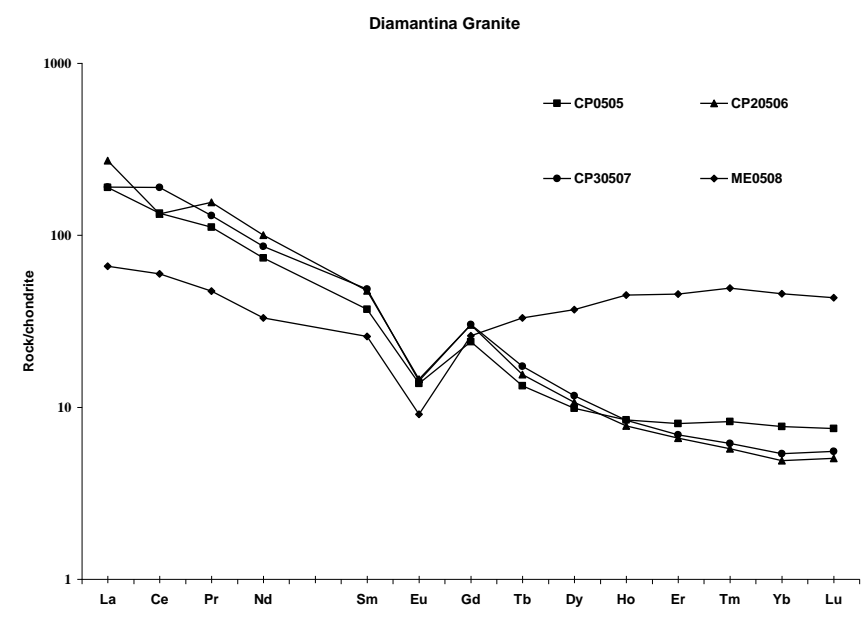

Figura 3. Diagrama REE, normalizado al condrito del Granito Diamantina.

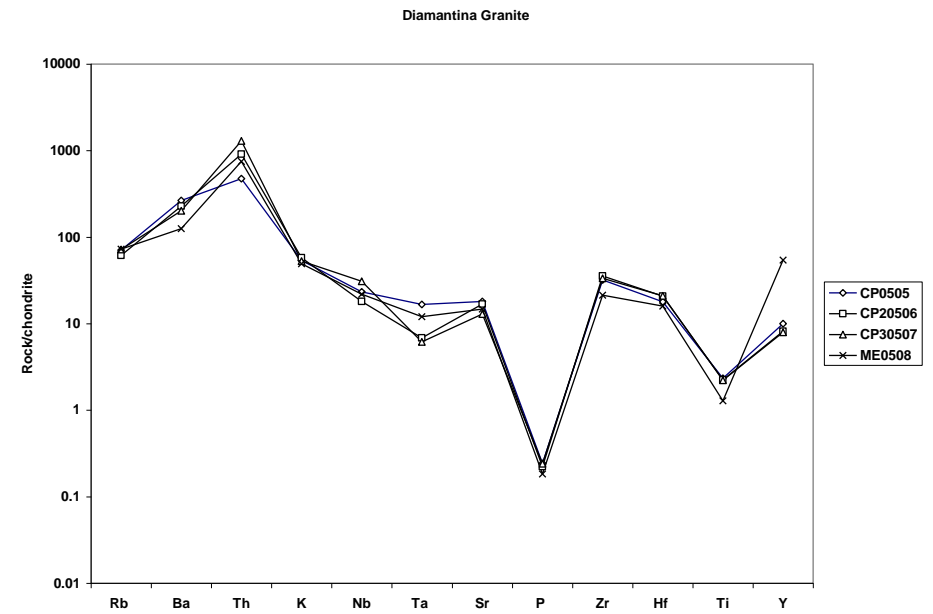

Figura 4. Diagrama de elementos traza normalizado al condrito del Granito Diamantina. 


\title{
Geochemistry and Nd-Sr Isotopic Signatures of the Pensamiento Granitoid Complex, Rondonian-San Ignacio Province, Eastern Precambrian Shield of Bolivia: Petrogenetic Constraints for a Mesoproterozoic Magmatic Arc Setting
}

\section{Geoquímica e Assinaturas Nd-Sr do Complexo Granitoide Pensamiento, Província Rondoniana-San Ignacio, Pré-Cambriano de Bolívia Oriental: Caracterização Petrogenética de um Arco Magmático no Mesoproterozoico}

\author{
Ramiro Matos ${ }^{1,3}$ (rmatoss@igc.usp.br),Wilson Teixeira' (wteixeir@usp.br), \\ Mauro Cesar Geraldes² (geraldes@ueri.br), Jorge Silva Bettencourt' (jsbetten@usp.br) \\ 'Departamento de Mineralogia e Geotectônica - Instituto de Geociências - USP \\ R. do Lago 562, CEP 05508-080, São Paulo, SP, BR \\ ${ }^{2}$ Faculdade de Geologia - UERJ, Rio de Janeiro, RJ, BR \\ ${ }^{3}$ Instituto de Investigaciones Geológicas y del Medio Ambiente - UMSA, La Paz, BO
}

Recebido em 04 de dezembro de 2008; aceito em 15 de maio de 2009

\begin{abstract}
The Pensamiento Granitoid Complex (PGC), located in the northern part of the eastern Precambrian shield of Bolivia, is tectonically assigned to the Rondonian-San Ignacio Province $(1.55-1.30 \mathrm{Ga})$ of the Amazonian Craton that is made up by Archean and Proterozoic provinces. The Proterozoic ones result from accretionary orogens that become successively younger southwestwards, such as the Rondonian/San Ignacio $(1.37-1.32 \mathrm{Ga})$ and the Sunsás orogenies $(1.20-1.00 \mathrm{Ga})$. The PGC crops out mainly on the "Paragua craton" bounded to the south by the Sunsás belt, and composed of granites and subvolcanic terms, and subordinately of syenites, granodiorites, tonalites, trondhjemites and diorites as orogenic representatives of the Rondonian/San Ignacio Orogeny, intrusive into the Lomas Maneches (ca. $1.68 \mathrm{Ga}$ ) and Chiquitania (ca. $1.7 \mathrm{Ga}$ ) complexes. Thirteen whole rock chemical analyses for major, trace and REE elements were performed for the La Junta, San Martin, Diamantina, Porvernir, San Cristobal, Piso Firme plutons of the PGC. The negative trends of $\mathrm{MgO}, \mathrm{Al}_{2} \mathrm{O}_{3}$ and $\mathrm{CaO}$ contents with increasing $\mathrm{SiO}_{2}$ suggest that fractional crystallization played an important role in the petrogenesis of the investigated rocks. The data also indicate a mainly peraluminous, sub-alkaline to high-K calc-alkaline composition, and fractionated LREE/ HREE patterns are consistent with a magmatic arc character for these plutons. SHRIMP U-Pb zircon ages of the La Junta and San Martin syn- to late-kinematic plutons are $1347 \pm 21 \mathrm{Ma}$ and $1373 \pm 20 \mathrm{Ma}$ respectively, and the Sm-Nd $\mathrm{T}_{\mathrm{DM}}$ model ages are between 1.9 to $2.0 \mathrm{Ga}$, while $\varepsilon_{\mathrm{Nd}(1330)}$ values range from +1.8 to -4.3 , respectively. In addition, the late- to post-kinematic Diamantina pluton yields SHRIMP U-Pb zircon age of $1340 \pm 20 \mathrm{Ma}$, and variable $\mathrm{Sm}-\mathrm{Nd} \mathrm{T}_{\mathrm{DM}}$ model ages (1.6 to $\left.1.9 \mathrm{Ga}\right)$ and $\varepsilon_{\mathrm{Nd}(1330)}$ values ( +0.4 to -1.2$)$ that are comparable with previous results found for other coeval plutons. The Porvenir, San Cristobal and Piso Firme plutons show $\varepsilon_{\mathrm{Nd}(1330)}$ signatures varying from +1.5 to +2.7 , in agreement with a plutonic arc setting as is suggested for the Diamantina pluton. Integrated interpretation of the geochemical and isotopic data coupled with new geologic correlations of the PGC with contemporary units in the Brazilian counterpart establishes one Mesoproterozoic magmatic arc in the evolution of the Rondonian-San Ignacio province.
\end{abstract}

Keywords: Bolivia; Pensamiento Granitoid Complex; Geochemistry; Nd-Sr isotopes; Rondonian-San Ignacio province; Amazonian Craton.

\section{RESUMO}

O Complexo Granitoide Pensamiento (CGP) ocorre na porção norte do Pré-Cambriano Boliviano, estando tectonicamente associado à evolução da província Rondoniana-San Ignacio (1.55 - $1.30 \mathrm{Ga})$ do Craton Amazônico, constituído por uma província central de idade arqueana e províncias proterozoicas marginais. A evolução proterozoica resulta do desen- 
volvimento de cinturões acrescionários sucessivamente mais jovens para sudoeste, a exemplo das orogenias Rondoniana-San Ignacio (1.37 - $1.32 \mathrm{Ga})$ e Sunsás (1.20 - $1.00 \mathrm{Ga}$ ). O CGP ocorre na parte setentrional do Pré-Cambriano Boliviano, ao norte do cinturão Sunsás, sendo constituído por granitos e termos subvulcânicos. Subordinadamente ocorrem sienitos, granodioritos, tonalitos, trondjemitos e dioritos. Em termos tectônicos, essas rochas são classificadas em dois conjuntos: plutons sin a tardicinemáticos e tardi a pós-cinemáticos. Treze análises químicas em rocha total para elementos maiores, traços e ETR foram realizadas em rochas granitoides orogênicas do CGP. Diagramas de correlação geoquímica indicam tendência negativa entre os conteúdos de $\mathrm{MgO}, \mathrm{Al}_{2} \mathrm{O}_{3}$ and $\mathrm{CaO}$ em função do aumento de $\mathrm{SiO}_{2}$, sugerindo processos de cristalização fracionada na petrogênese das rochas investigadas. Em adição os dados indicam uma composição principalmente peraluminosa, subalcalina de alto K, compatível com ambiente de arco magmático, para a geração dos plútons estudados, corroborado pelo padrão de fracionamento dos ETRL/ETRP. Datações SHRIMP em zircão dos plútons La Junta e San Martin (sin a tardicinemáticos; $1347 \pm 21$ e $1373 \pm 20$ Ma, respectivamente) em conjunto com idades modelo $\mathrm{T}_{\mathrm{DM}}$ entre 1,9 e 2,0 Ga e valores de $\varepsilon_{\mathrm{Nd}(1330)}$ entre $+1,8$ e $-4,3$ são semelhantes a resultados publicados em outros corpos coevos. Em adição, os plútons Porvenir, San Cristobal e Piso Firme (tardi a pós-cinemáticos) têm idades $\mathrm{T}_{\mathrm{DM}}$ modelo entre 1,6 e 1,7 Ga e valores de $\varepsilon_{\mathrm{Nd}(1330)}$ positivos entre $+2,7$ e $+1,5$, o que sugere uma origem em arco magmático intraoceânico. O plúton Diamantina (tardi a pós-cinemático; idade SHRIMP em zircão de $1340 \pm 20 \mathrm{Ma}$ ) tem idades $\mathrm{T}_{\mathrm{DM}}$ modelo entre 1,6 e 1,9 Ga com valores de $\varepsilon_{\mathrm{Nd}(1330)}$ entre $+0,4 \mathrm{e}-1,2$. Isto corrobora a hipótese de significativa contribuição de material juvenil mesoproterozoico durante a sua gênese. Os resultados aqui obtidos interpretados em conjunto com os dados geológicos de unidades contemporâneas na contraparte brasileira reforçam a existência de um arco magmático juvenil mesoproterozoico que finalizou a evolução acrescionária da província Rondoniana-San Ignacio.

Palavras-chave: Bolívia; Complexo Granitoide Pensamiento; Província Rondoniana-San Ignacio; Geoquímica; Isótopos Nd-Sr.

\section{INTRODUCTION}

The Pensamiento Granitoid Complex (PGC) constitutes a large volume of Mesoproterozoic gneisses and granitoid rocks that occur in the Bolivian departments of Santa Cruz and Beni. The PGC rocks are one of the major components that built up the Rondonian-San Ignacio Province (1.55 to $1.30 \mathrm{Ga}$; e.g., Cordani and Teixeira, 2007) of widespread extension along the SW part of the Amazonian Craton, Brazil (Rondônia and Mato Grosso states besides Bolivia). Tectonically the PGC (Figures 1 and 2) is attributed to the onset of the San Ignacio orogeny in Bolivia (1400 - $1280 \mathrm{Ga}$; Litherland et al., 1986), as part of the "Paraguá Craton" which bounds are subjected to Sunsás-age low grade metamorphic and shearing overprints (e.g., Litherland et al., 1989; Boger et al., 2005). The San Ignacio orogeny produced three fold generations overprinting Paraguá crystalline basement rocks, whereas the earliest stages of deformation established the observed metamorphic sequence at regional scale (Litherland et al., 1986, 1989; Boger et al., 2005). Field mapping of the PGC revealed that the plutonic rocks are syn- to late-kinematic with reference to Do3 deformational event (Litherland and Bloomfield, 1981) whilst the late- to postkinematic ones crosscut Do3.

We have carried out a reconnaissance geologic investigation along the road that connects Santa Rosa de la Roca and Piso Firme localities (Figure 2), covering a $330 \mathrm{~km}$ transverse along the PGC. From south to north, the studied units are: the syn- to late-kinematic La Junta and San Martin granites, and the late- to post-kinematic Diamantina, Porvenir and San Cristobal granites and the Piso Firme granophyre. However, further detailed geological studies are needed to better define the relationships among the granitoid rocks and with the crystalline basement. The present work is part of an ongoing $\mathrm{PhD}$ project (R. Matos) at the Institute of Geosciences of University of São Paulo, Brazil, aiming to delineate the petrogenetic evolution of the PGC and its tectonic significance. We present petrographic and geochemical data coupled with systematic Sr-Nd isotopic work of PGC rocks, supported by SHRIMP published and unpublished data. The integrated interpretation provides new insights on the nature the Granitoid Complex with implications for the Mesoproterozoic history of the SW part of the Amazonian Craton.

\section{GEOLOGIC FRAMEWORK}

The Rondonian-San Ignacio Province - RSIP (Figure 1) was formed by Mesoproterozoic accretionary belts whose dynamics included stacking of intra-oceanic and continental arcs, as well as intervening microcontinents. The accretionary/ agglutination processes culminated with collision against the already cratonized Rio Negro-Juruena Province $(1.78$ - $1.55 \mathrm{Ga})$, in the southwest part of the Amazonian Craton. Lithologically the RSIP consists predominantly of granite-gneiss and granitoid rocks, some of them with rapakivi structures, as well as tonalites and granulites. Isotopic studies on these rocks indicate positive to slightly negative $\varepsilon_{\mathrm{Nd}(t)}$ signatures, roughly between +4.0 and -2.0 , reinforcing the idea that juvenile events combined with reworking of the pre-existent crust played a major role during the long-lived plate convergence and collision against the tectonically stable foreland (see for review Tassinari et al., 2000; Cordani and Teixeira, 2007). 


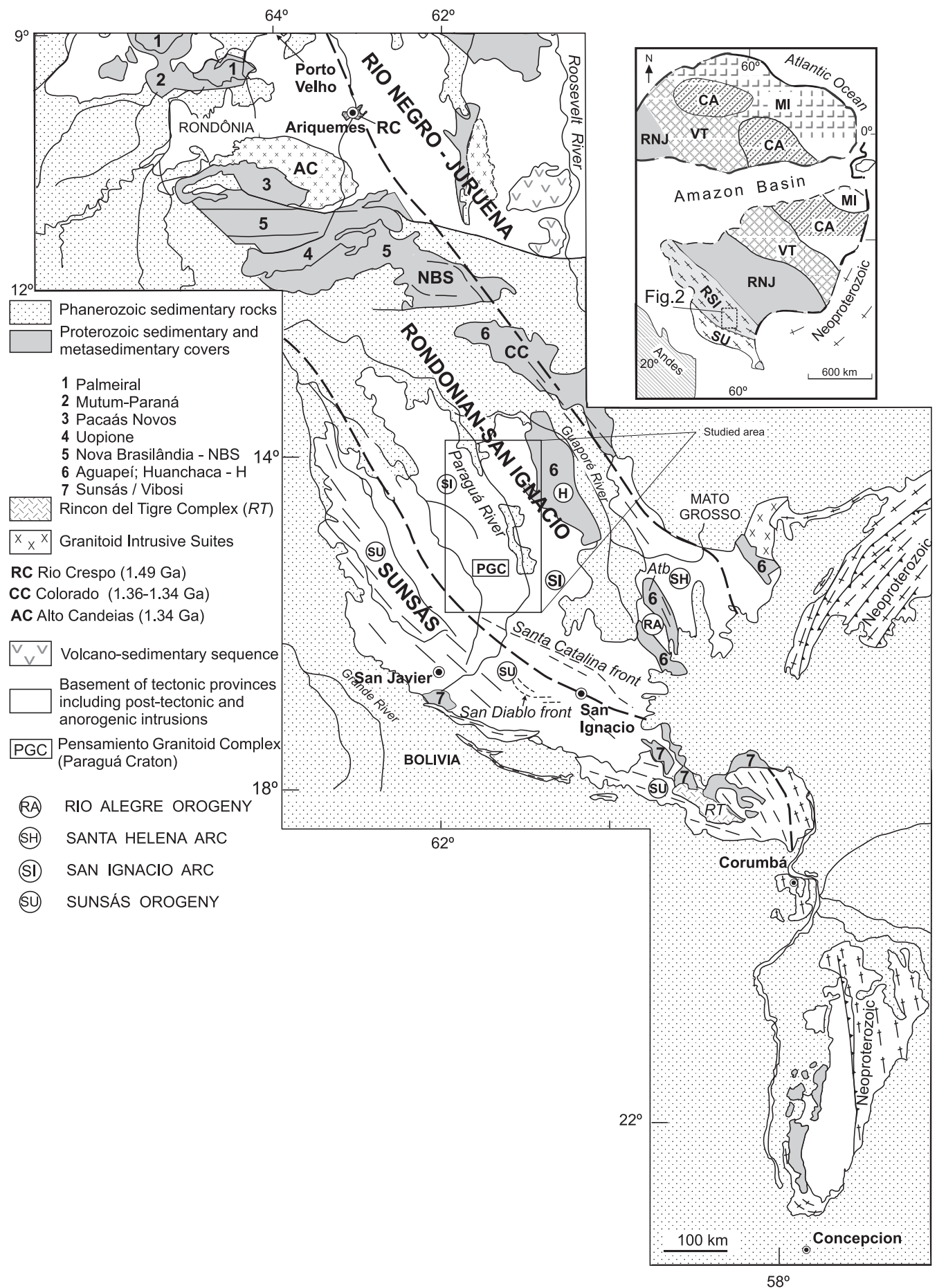

Figure 1. Geologic outline of the SW portion of the Amazonian Craton showing the main orogenic belts, the tectonically related intrusive magmatic suites and sedimentary covers and volcano-sedimentary sequences. The inferred boundaries between the Proterozoic provinces are also shown (adapted from Cordani and Teixeira, 2007). Keys: SP = Serra da Providência batholith, CMS = Colorado Metamorphic Sequence; NBS = Nova Brasilândia Sequence. Inset: geochronological provinces of the Amazonian Craton = Central Amazonian - CA (> 2.6 Ga); Maroni-Itacaiúnas - Ml (2.25 - 2.05 Ga); Ventuari-Tapajós - VT (1.98 - $1.81 \mathrm{Ga})$; Rio Negro-Juruena - RNJ (1.78 - 1.55 Ga); Rondonian-San Ignacio - RSI (1.55 - 1.30 Ga) and Sunsás - SU (1.25 - $0.97 \mathrm{Ga})$. See text for details. 


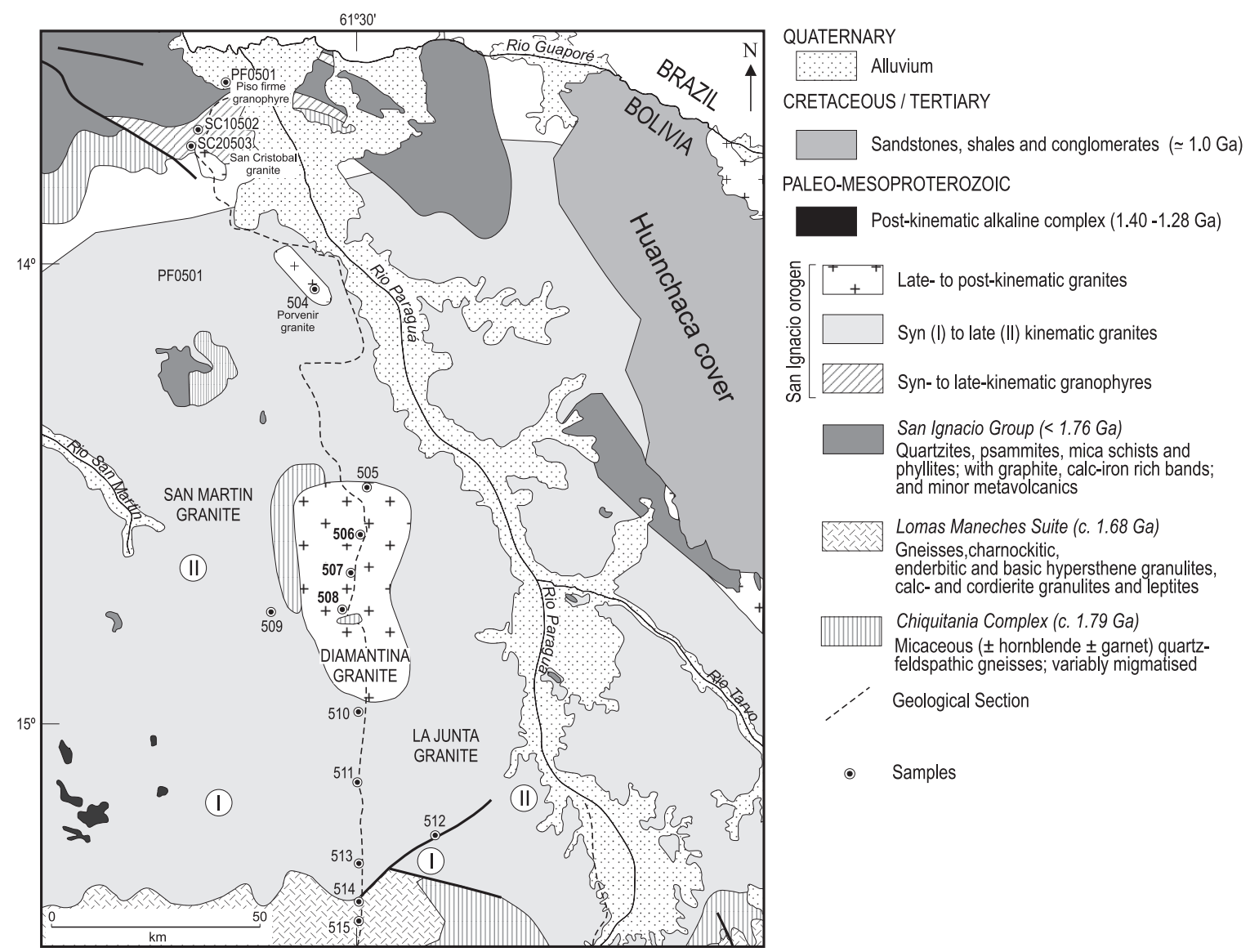

Figure 2. Geologic sketch of the studied area showing the regional occurrence of the Pensamiento Granitoid Complex (PGC) and the country rocks (modified from Litherland et al., 1986).

The collision features between the Rio Negro-Juruena and Rondonian-San Ignacio provinces are mirrored by faults, shear zones and fold-and-thrust belts (e.g., Tassinari et al., 2000), and associated to granulitic facies metamorphism $(1.35-1.32 \mathrm{Ga})$ that overprint the country rocks in some places of the state of Rondônia, Brazil (SHRIMP U/Pb ages of zircon overgrowths; Bettencourt et al., 1999; Payolla et al., 2002; Santos et al., 2005) - see Table 1 and Figure 1. Contemporarily, the Colorado Complex (1.35 Ga), a "mafic" to "chemical"-clastic assemblage of passive-margin setting of the RSIP, in Rondônia (e.g., Teixeira et al., 2006), was deformed and overprinted by recognized medium- to high grade metamorphism. During this phase syn- to late tectonic, high-K, calc-alkaline granitoid rocks (e.g., Igarapé Enganado and Alto Escondido suites; 1345 - $1336 \mathrm{Ma}$ ) were emplaced into the Colorado Complex (Rizzotto and Quadros, 2007), whereas coeval granitoid rocks intruded into the already cratonized Rio Negro-Juruena crust (e.g., Alto Candeias Intrusive Suite; $1.34 \mathrm{Ga}$ ) - see Figure 1. On the whole all of these magmatic and metamorphic events are representative of the Rondonian-San Ignacio orogeny of widespread occurrence in the SW corner of the Amazonian Craton (Cordani and Teixeira, 2007; Teixeira and Cordani, 2009).

The RSIP exhibits a polycyclic evolution, giving rise to several rock units (e.g., Rio Crespo, Santa Helena, Rio Alegre, Colorado, PCG; see Table 2) that show chemical and isotopic affinities of island arc and continental arc settings. These rock units were variably overprinted by the Sunsás orogeny $(1.2-1.0 \mathrm{Ga})$ at the same time that several coeval geologic features were formed in Rondônia and Bolivia, such as rift basins (e.g., Nova Brasilândia, Pacaás Novos, Palmeiral), platform covers (e.g., Huanchaca/Aguapeí; see Figure 2), shear zones and basic and felsic magmatism (Rizzotto et al., 2002; Litherland et al., 1986; Tohver et al., 2006). The emplacement of the Santa Bárbara and Santa Clara Intrusive Suites between 1.08 and $0.98 \mathrm{Ga}$ and of the Younger Granites of Rondônia (0.99 - $0.97 \mathrm{Ga})$ reveals the important role of extensional regimes over the cratonized crust during post-tectonic or anorogenic stages of the Sun- 
Table 1. Main characteristics of the Rondonian-San Ignacio and Sunsás provinces, SW Amazonian Craton. Keys: RSI = Rondonian-San Ignacio orogeny; SU = Sunsás orogeny.

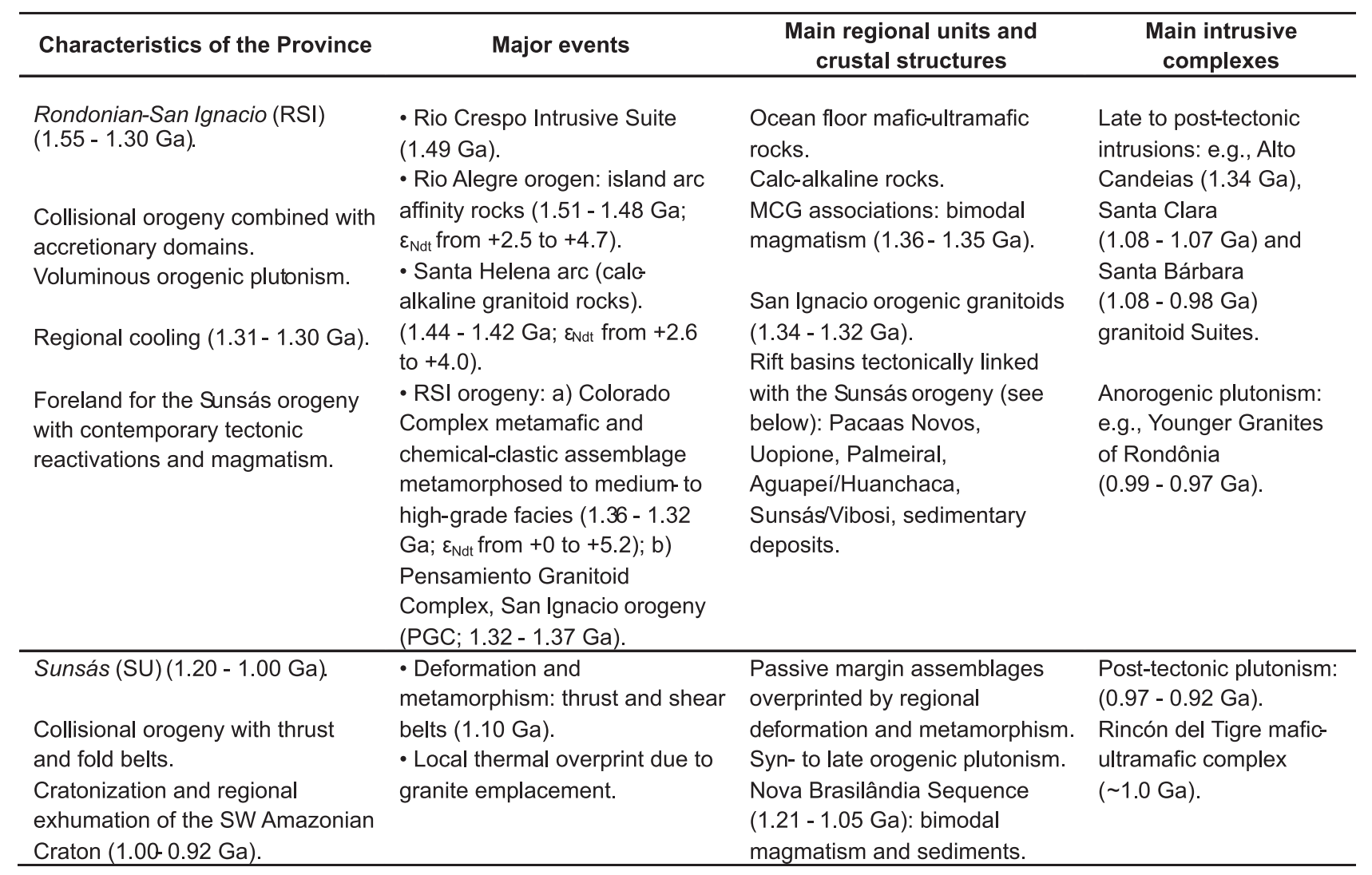

sás orogeny (e.g., Bettencourt et al., 1999; Payolla et al., 2002; Sparrenberger et al., 2002).

Litherland and Bloomfield (1981) originally defined the Sunsás orogeny as a cycle of sedimentation that took place in an extensional environment (e.g., Sunsás and Vibosi groups; Litherland et al., 1989). This was followed by erosion, deformation and metamorphism of the passive-margin sedimentary sequences, as well as of the PGC and the crystalline basement rocks named Paraguá Craton. Due to the Sunsás orogeny, brittle cataclastic deformation and mylonitization largely overprinted the country rocks giving rise to Rio Negro Front, the Santa Catalina Zone (Litherland et al., 1986; Klinck and O'Connor, 1983; Litherland and Klinck, 1982), the Blanco-Ibaiminí Line Shear Zone and the curvilinear San Diablo Front, in Bolivia (Figure 1). In addition, coeval reactivated structures over the RSIP developed northward (e.g., Aguapeí fold and thrust belt, Nova Brasilândia belt, in Brazil - Figure 2). As such, the boundary between the Rio Negro-Juruena and Sunsás provinces with the RSIP is a very complex one.
The RSIP has been studied by several authors by means of geologic mapping, structure, geochemistry, geochronology (e.g., Litherland et al., 1986; Teixeira et al., 1989; Sato and Tassinari, 1997; Bettencourt et al., 1999; Cordani et al., 2000; Tassinari et al., 2000; Geraldes et al., 2001; Payolla et al. 2002; Boger et al., 2005; Santos et al., 2006, 2008). These efforts have also led to paleotectonic reconstructions mainly using geologic correlations, paleomagnetism and age data from the granitoid systems and mafic magmatism (Sadowski and Bettencourt, 1996; Tassinari et al., 2000; Tohver et al., 2002, 2004a, 2004b, 2005a, 2005b). Table 2 presents SHRIMP U-Pb, Rb-Sr and K-Ar ages of selected geologic units of the Bolivian Precambrian shield, including the data available for the PGC rocks to be discussed afterward.

The geologic framework of Bolivian Precambrian Shield (Litherland et al., 1986, 1989) comprises mainly four lithostratigraphic units based on the geologic work performed by the British Geologic Survey - GEOBOL, supported by Rb/ Sr and K/Ar ages: 1. the Lomas Maneches Granulitic Complex; 2. the Chiquitania Gneissic Complex; 3. the San Ig- 
nacio Schist Group; 4. the PGC - see Table 2 and Figure 2. The Lomas Maneches Complex was originally considered as the oldest lithoestratigraphic unit of the shield, as suggested by $\mathrm{Rb} / \mathrm{Sr}$ regional model age, but this assumption have been discarded on the basis of more precise SHRIMP work recently reported (see below). It comprises bands of charnockitic, enderbitic, and basic hypersthene granulites, and gneisses that contain metamorphic hypersthene or cordierite. The Chiquitania Gneiss Complex, considered to be structurally over the Granulite Complex, consists of banded micaceous quartz-feldspathic gneisses, without hypersthene and/ or cordierite. These rocks in the "Paraguá craton" show K-Ar mineral ages in the range 1.34 - $1.32 \mathrm{Ga}$ that compare well with the age pattern of the granitoid rocks of the PGC (assigned as the San Ignacio orogeny). The San Ignacio Schist Group crops out as discrete NW belts that are surrounded by distinct gneisses and granitoid rocks of the Lomas Maneches and Chiquitania units. It is composed of quartzites, metapsamites, schists, phyllites and metavolcanics. This unit is overlaid by the flat-lying sediments of the Sunsás Group (e.g., Huanchaca Formation) in the "Paraguá craton" (Figures 1 and 2).

Subsequently Boger et al. (2005) performed additional geologic work with the add of SHRIMP U-Pb zircon geochronology in distinct rock units that crop out southward from the PGC (see Figure 2), thereby providing new

Table 2. Summary of SHRIMP U-Pb, Rb-Sr and K-Ar ages of selected rocks of Bolivian Precambrian shield. Keys: $\mathbf{z r}=$ zir$\mathbf{c o n} ; \mathbf{h b}=$ hornblende; $\mathbf{b i}=$ biotite; $\mathbf{w r}=$ whole rock isochron; Met. age = metamorphic age; Inh. $\mathbf{a g e}=$ inherited age; * K-Ar cooling age; ${ }^{* *}$ Isochron model age (spurious); ${ }^{\text {P }}$ Pensamiento Granitoid Complex. References: a. Boger et al. (2005); b. Santos et al. (2006; 2008); c. Litherland et al. (1986).

\begin{tabular}{|c|c|c|c|c|c|c|c|c|}
\hline Unit & Rock & Sample & $\begin{array}{l}\text { Age } \\
(\mathrm{Ma})\end{array}$ & $\begin{array}{c}\text { Met. age } \\
\text { (Ma) }\end{array}$ & $\begin{array}{c}\text { Inh. age } \\
\text { (Ma) }\end{array}$ & Method & Mat. & Ref. \\
\hline Chiquitania & gneiss & $235 \mathrm{~A} 1$ & & $1333 \pm 6$ & & $\mathrm{U}-\mathrm{Pb}$ & $\mathrm{zr}$ & a \\
\hline Chiquitania & gneiss & $235 A$ & $1764 \pm 12$ & & & U-Pb & $\mathrm{zr}$ & a \\
\hline Chiquitania & gneiss & 23 & $1336 \pm 33^{*}$ & & & $\mathrm{~K}-\mathrm{Ar}$ & $\mathrm{hb}$ & c \\
\hline Chiquitania & gneiss & 24 & $1323 \pm 33^{*}$ & & & $\mathrm{~K}-\mathrm{Ar}$ & $\mathrm{hb}$ & C \\
\hline Lomas Maneches & gneiss & 240 & $1663 \pm 13$ & $1320 \pm 11$ & & $\mathrm{U}-\mathrm{Pb}$ & $\mathrm{zr}$ & $b$ \\
\hline Lomas Maneches & granulite & - & $\sim 1960^{* *}$ & & & $\mathrm{Rb}-\mathrm{Sr}$ & $w r$ & c \\
\hline Lomas Maneches & gneiss & JO5 & & $1334 \pm 2$ & & $\mathrm{U}-\mathrm{Pb}$ & $z r$ & $b$ \\
\hline Lomas Maneches & granulite & JO3 & $1818 \pm 13$ & $1339 \pm 4^{\star *}$ & & U-Pb & $\mathrm{zr} ;{ }^{* *} \mathrm{mo}$ & $b$ \\
\hline Lomas Maneches & gneiss & 261 & $1689 \pm 5$ & & & U-Pb & $\mathrm{zr}$ & a \\
\hline Refugio & granite & JO12 & $1641 \pm 4$ & & $1668 \pm 8$ & U-Pb & $\mathrm{zr}$ & $b$ \\
\hline San Ramón & granite & JO14 & $1429 \pm 4$ & & & U-Pb & $z r-t i$ & $b$ \\
\hline San Rafael & granite & 228 & $1334 \pm 12$ & & $1686 \pm 16$ & U-Pb & $\mathrm{zr}$ & a \\
\hline Santa Rita & orthogneiss & JO18 & $1319 \pm 6$ & & $1746 \pm 21$ & U-Pb & $z r$ & $b$ \\
\hline Rio Fortuna & orthogneiss & JO6 & $1336 \pm 3$ & & $1753 \pm 10$ & U-Pb & $\mathrm{zr}$ & $b$ \\
\hline San Ignacio & paragneiss & 221D & $<1764 \pm 6$ & & & U-Pb & $\mathrm{zr}$ & a \\
\hline San lgnacio & schist & - & 1340 & & & $\mathrm{Rb}-\mathrm{Sr}$ & $w r$ & c \\
\hline Florida $^{P}$ & granite & 151 & $1244 \pm 27^{*}$ & & & $\mathrm{~K}-\mathrm{Ar}$ & bi & C \\
\hline Florida $^{P}$ & granite & 189 & $1380 \pm 19$ & & & $\mathrm{~K}-\mathrm{Ar}$ & bi & c \\
\hline Padre Eterno $^{P}$ & granite & 178 & $1326 \pm 19^{*}$ & & & $\mathrm{~K}-\mathrm{Ar}$ & bi & c \\
\hline Piso Firme ${ }^{P}$ & granophyre & - & $1325 \pm 45$ & & & $\mathrm{Rb}-\mathrm{Sr}$ & $w r$ & C \\
\hline La Junta ${ }^{P}$ & granite & - & $1375 \pm 80$ & & & $\mathrm{Rb}-\mathrm{Sr}$ & $w r$ & c \\
\hline Diamantina $^{P}$ & granite & - & $1391 \pm 70$ & & & $\mathrm{Rb}-\mathrm{Sr}$ & $w r$ & $\mathrm{C}$ \\
\hline San Andrés & granite & JO10 & $1275 \pm 7$ & & & U-Pb & $\mathrm{zr}$ & $b$ \\
\hline Orobayaya & granite & - & $1283 \pm 33$ & & & $\mathrm{Rb}-\mathrm{Sr}$ & $w r$ & $\mathrm{C}$ \\
\hline 日Tigre & alkaline & - & $1286 \pm 46$ & & & $\mathrm{Rb}-\mathrm{Sr}$ & $w r$ & c \\
\hline San Javier & granite & - & $1291 \pm 49$ & & & $\mathrm{Rb}-\mathrm{Sr}$ & $w r$ & C \\
\hline San Cristobal & granite & 153 & $1296^{\star} \pm 18$ & & & $\mathrm{~K}-\mathrm{Ar}$ & bi & C \\
\hline Cerro Grande & granophyre & - & $1176 \pm 100$ & & & $\mathrm{Rb}-\mathrm{Sr}$ & $w r$ & $\mathrm{c}$ \\
\hline
\end{tabular}


insights on the chronostratigraphy of Bolivian Precambrian shield. They interpreted the Lomas Maneches as a magmatic suite consisting of granitic sills that were emplaced after the deposition of the Chiquitania Complex, but previously to the deposition of the San Ignacio Group. The main results (Table 2) are summarized as follow:

1. one sample from the Lomas Maneches suite contains zircon core that yielded a weighted mean ${ }^{207} \mathrm{~Pb} /{ }^{206} \mathrm{~Pb}$ age of $1663 \pm 13 \mathrm{Ma}$, inferred as the rock's emplacement age. Additional analyses of the zircon rims yielded an age of $1320 \pm 11 \mathrm{Ma}$, interpreted as the time of partial melting;

2. another Lomas Maneches sample yielded a concordant ${ }^{207} \mathrm{~Pb} /{ }^{206} \mathrm{~Pb}$ zircon age of $1689 \pm 5 \mathrm{Ma}$;

3. two samples of the Chiquitania Complex showed zircon cores with inherited ages of $1788 \pm 16 \mathrm{Ma}, 1757 \pm$ $14 \mathrm{Ma}$ and $1764 \pm 12 \mathrm{Ma}$, whilst the zircon rims were interpreted as metamorphic $(1333 \pm 6 \mathrm{Ma})$;

4. one San Ignacio paragneiss yielded (29 detrital zircons) a concordant ${ }^{207} \mathrm{~Pb} /{ }^{206} \mathrm{~Pb}$ age of $1764 \pm 6 \mathrm{Ma}$;

5. five zircon cores from the syn-kinematic San Rafael Granite yielded an upper intercept age of $1686 \pm 16 \mathrm{Ma}$, suggesting its derivation from a Paleo- to Mesoproterozoic protolith - an idea that was already envisaged by the limited $\mathrm{Nd}$ isotopic evidence reported for selected PGC rocks (Darbyshire, 2000). Finally, the San Rafael pluton has zircon rim analyses that yielded an upper intercept ${ }^{207} \mathrm{~Pb} /{ }^{206} \mathrm{~Pb}$ age of $1334 \pm 12 \mathrm{Ma}$, indicating the tectonic relationship with the San Ignacio orogeny.

Santos et al. (2006, 2008) reported additional SHRIMP $\mathrm{U}-\mathrm{Pb}$ ages in zircon, monazite and titanite from granitoid rocks to the south of PGC. One sample of the Lomas Maneches granulitic gneiss has magmatic zircons with ${ }^{207} \mathrm{~Pb} /{ }^{206} \mathrm{~Pb}$ age of $1818 \pm 13 \mathrm{Ma}$, which is the oldest age identified in Bolivia up to present. The monazite from this rock gives a metamorphic age of $1342 \pm 3 \mathrm{Ma}$, in agreement with the age of another Lomas Maneches sample that has metamorphic zircons with $1334 \pm 2.4 \mathrm{Ma}$ (concordant ${ }^{207} \mathrm{~Pb} /{ }^{206} \mathrm{~Pb}$ age). On the other hand the Refugio granite has zircons with no metamorphic rim, and yields a ${ }^{207} \mathrm{~Pb} /{ }^{206} \mathrm{~Pb}$ age of $1641 \pm 4 \mathrm{Ma}$ and $\mathrm{T}_{\mathrm{DM}}$ model age of $1.7 \mathrm{Ga}\left(\varepsilon_{\mathrm{Nd}(\mathrm{t})}=\right.$ $+4.06)$. The San Ramon granite yields similar zircon and titanite ${ }^{207} \mathrm{~Pb} /{ }^{206} \mathrm{~Pb}$ ages of $1429 \pm 4 \mathrm{Ma}$. Its $\mathrm{Sm}-\mathrm{Nd} \mathrm{T}_{\mathrm{DM}}$ model age is $1.6 \mathrm{Ga}\left(\varepsilon_{\mathrm{Ndt}}=+2.3\right)$. Therefore both granites were mainly derived from Mesoproterozoic juvenile sources. The San Andrés granite yields a ${ }^{207} \mathrm{~Pb} / 206 \mathrm{~Pb}$ age of $1275 \pm 7 \mathrm{Ma}$, and may represent one of the syn-kinematic granites associated to Sunsás orogeny. On the other hand, the Rio Fortuna orthogneiss has two zircon populations: the first population (inherited core grains) between 1772 - 1734 Ma whereas the second one (magmatic zircon and rims) formed at $1336 \pm 3 \mathrm{Ma}$. Finally, the Santa Rita orthogneiss has magmatic zircons with ${ }^{207} \mathrm{~Pb} /{ }^{206} \mathrm{~Pb}$ age of $1319 \pm 6 \mathrm{Ma}$, although a single grain yields an inherited $\mathrm{U}-\mathrm{Pb}$ age of $1729 \pm 9 \mathrm{Ma}$ (see Table 2).

In summary, the U-Pb SHRIMP ages and Sm-Nd data, coupled with the more recent field information of the Precambrian rocks of Eastern Bolivia established the age and igneous nature of the Lomas Maneches suite (1.69 $1.66 \mathrm{Ga}$ ). Furthermore the U-Pb data evidenced some significantly older protholiths (up to $1.82 \mathrm{Ga}$ ) may have participated in the Proterozoic evolution. On the other hand, the San Ignacio orogeny, marked by syn- to late- kinematic plutonic pulses (PGC) and coeval metamorphism, took place in Bolivian territory between $1.37-1.32 \mathrm{Ga}$. This time interval correlates well with the ultimate tectonic and magmatic episodes assigned to the Rondonian-San Ignacio orogeny in the Brazilian counterpart, as proposed by Cordani and Teixeira (2007) and Teixeira and Cordani (2009).

\section{The Pensamiento Granitoid Complex}

The PGC consists of voluminous intrusive plutonic and subvolcanic granitic rocks, with subordinate syenites, granodiorites, tonalites, trondhjemites and diorites, which have been dated firstly by $\mathrm{Rb} / \mathrm{Sr}$ and $\mathrm{K} / \mathrm{Ar}$ methods that indicate ages between 1.39 to $1.24 \mathrm{Ga}$ (Litherland et al., 1986) (see Table 2). According to these authors the youngest $\mathrm{K}-\mathrm{Ar}$ ages refer to the uplift and regional cooling of the Paraguá craton. In addition, they distinguished two intrusive magmatic events within the PGC, on the basis of the structural work: the syn- to late-kinematic and the late- to post-kinematic granitoid rocks such as the San Martin and La Junta granites, and the Diamantina pluton, respectively. Moreover, they recognized two regional metamorphic episodes (Mol and Mo2) in association with the San Ignacio Orogeny, attributed to the Do1/Do2 and Do3 deformational phases, respectively, whereas the metamorphism varies from low grade to granulite facies. A high grade hypersthene zone was recognized to the west of the San Martin river, and decreases to medium grade on the both sides of it (Klinck and O'Connor, 1983). The Do3, the major penetrative event in the area, accompanies generation of the bulk syn-kinematic granitoid plutons. Some of the late to post-kinematic granitoid plutons postdate Do3 phase and were emplaced following a markedly NNW trend (Litherland et al., 1986).

Recent geologic mapping (R. Mattos, pers. information) has revealed that the La Junta pluton has sharp intrusive contacts with the 1.69 - 1.66 Ga Lomas Maneches suite. Moreover, the field information has indicated that the San Cristóbal, Porvenir, and Diamantina granites, besides the Piso Firme granophyre (Figure 2), are late- to 
post- kinematic, although Litherland et al. (1986) classified this granophyre as a syn- to late- tectonic intrusion. Furthermore, in the Brazilian counterpart (southeastern of Rondônia), contemporary orogenic and post-orogenic granites are intrusive into the $1.36-1.30 \mathrm{Ga}$ Colorado Complex (Rizzotto and Quadros, 2007), that is tectonically linked with the Rondonian-San Ignacio Orogeny, as proposed by Teixeira and Cordani (2009).

The syn- to late- kinematic Puerto Alegre/La Junta granites of PGC display comparable $\mathrm{T}_{\mathrm{DM}}$ model ages (2.0 and $2.1 \mathrm{Ga}$ ) and $\varepsilon_{\mathrm{Nd}(\mathrm{T})}$ values of -1.5 and -2.8 , respectively (Darbyshire, 2000; Darbyshire, pers. comm., 2007). In contrast, the $\sim 1.35$ Ga Piso Firme granophyre (Litherland et al., 1986) yields significant younger but comparable $\mathrm{T}_{\mathrm{DM}}$ model ages $(1.5$ and $1.6 \mathrm{Ga})$ and positive $\varepsilon_{\mathrm{Nd}(\mathrm{T})}$ values $(+3.3$ to +3.9$)$. In a similar way the contemporary Diamantina and Orobayaya granites yield positive $\varepsilon_{\mathrm{Nd}(\mathrm{T})}$ values $(+1.0$ to +1.4 ) and $\mathrm{T}_{\mathrm{DM}}$ model ages of $1.7 \mathrm{Ga}$ (see Table 1).

\section{ANALYTICAL TECHNIQUES}

Thirteen samples were selected for major and minor elements $\left(\mathrm{SiO}_{2}, \mathrm{TiO}_{2}, \mathrm{Al}_{2} \mathrm{O}_{3}, \mathrm{Fe}_{2} \mathrm{O}_{3 \text { Tot }}, \mathrm{MnO}, \mathrm{MgO}, \mathrm{CaO}\right.$, $\mathrm{K}_{2} \mathrm{O}, \mathrm{Na}_{2} \mathrm{O}$ and $\mathrm{P}_{2} \mathrm{O}_{5}$ ) and trace elements chemistry at Chemical Laboratory of Institute of Geosciences of the University of São Paulo (IGc/USP), Brazil (Table 3), and following the technical procedures for REE separation as reported by Navarro (2004). The samples were first powered to $<200$ mesh in an agate mill. The analytical routine for major elements and some trace elements comprises fusion using a mixture of $0.25 \mathrm{~g}$ of rock powder and $0.75 \mathrm{~g}$ flux (lithium tetra and metaborate). $\mathrm{HNO}_{3} 0.2 \mathrm{~N}$ solutions diluted to 1:1000 were analyzed in an ARL-3410 sequential spectrometer. The routine of the laboratory comprises: fluorescence X-ray spectrometry (Philips PW2400) for the analysis of the major and minor elements $\left(\mathrm{SiO}_{2}, \mathrm{TiO}_{2}\right.$, $\mathrm{Al}_{2} \mathrm{O}_{3}, \mathrm{FeO}_{\text {Tot }}, \mathrm{MnO}, \mathrm{MgO}, \mathrm{CaO}, \mathrm{K}_{2} \mathrm{O}, \mathrm{P}_{2} \mathrm{O}_{5}$ ); atomic absorption spectrometry, after dissolution with $\mathrm{HF}+\mathrm{HCLO}_{4}$ for $\mathrm{Na}_{2} \mathrm{O}$; decomposition with $\mathrm{HF}+\mathrm{H}_{2} \mathrm{SO}_{4}$ in platinum crucible buffered for $\mathrm{FeO}$, and $\mathrm{FeO}$ titullation with $\mathrm{KMnO}_{4}$; loss of ignition by calcination at $1000^{\circ} \mathrm{C}$ under constant weight; X-ray fluorescence spectrometry using pressed powder pellets for $\mathrm{Ba}, \mathrm{Rb}, \mathrm{Sr}, \mathrm{Zr}, \mathrm{Y}, \mathrm{Cu}, \mathrm{Pb}$ and $\mathrm{Zn}$.

The same thirteen samples were analyzed by $\mathrm{Sm}-\mathrm{Nd}$ whole-rock technique at the Geochronological Research Center (CPGeo) of the IGc-USP (Table 4). Approximately $0.1 \mathrm{mg}$ of powdered rock sample was dissolved in concentrated $\mathrm{HNO}_{3}, \mathrm{HF}$ and $\mathrm{HCl}$. The Sm and $\mathrm{Nd}$ concentrations were determined by isotope dilution with a combined spike tracer, using the two-column technique, as described by Sato et al. (1995). The isotope ratios were measured on VG-354 multi-collector mass spectrometer.
Laboratory blanks for the chemical procedure, during the period of analyses, yielded maximum values of $0.4 \mathrm{ng}$ for $\mathrm{Nd}$ and $0.7 \mathrm{ng}$ for Sm. The average ${ }^{143} \mathrm{Nd} /{ }^{144} \mathrm{Nd}$ for La Jolla standard was 0.511857 (46), with $2 \sigma$ standard deviations reported in parentheses. The $\mathrm{Sm}-\mathrm{Nd} \mathrm{T}_{\mathrm{DM}}$ model ages, were calculated using DePaolo (1981) model parameters: $\mathrm{a}=0.25, \mathrm{~b}=3, \mathrm{c}=8.5$ as well as ${ }^{143} \mathrm{Nd} /{ }^{144} \mathrm{Nd}=0.7219$ to normalize the isotope ratios $\left[{ }^{143} \mathrm{Nd} /{ }^{144} \mathrm{Nd}(\mathrm{CHUR})_{0}=\right.$ 0.512638 and $\left.{ }^{147} \mathrm{Sm} /{ }^{144} \mathrm{Nd}(\mathrm{CHUR})_{0}=0.1967\right]$. The $\varepsilon_{\mathrm{Nd}}$ values were calculated using the simplified equation $\varepsilon_{\mathrm{Nd}(\mathrm{T})}$ $=\varepsilon_{\mathrm{Nd}(0)}-\mathrm{Q}_{\mathrm{Nd}} \mathrm{f}_{\mathrm{Sm} / \mathrm{Nd}} \mathrm{T}$, with the (CHUR), values above and $\mathrm{Q}_{\mathrm{Nd}}=25.09$. The $\varepsilon_{\mathrm{Nd}}$ values for the PGC samples were recalculated for the $1.33 \mathrm{Ga}$ reference age (SHRIMP U-Pb, as reported by Boger et al., 2005).

In addition to the Sm-Nd work, thirteen samples were analyzed by $\mathrm{Rb}-\mathrm{Sr}$ using isotope dilution technique at the CPGeo (Table 5). The ${ }^{87} \mathrm{Sr} /{ }^{86} \mathrm{Sr}$ ratios are listed with absolute errors $(2 \sigma)$, and have been corrected to the mean value of the NBS-987 standard $[0.710254 \pm 0.000022(2 \sigma)]$. The overall blank for the chemical procedure was $4 \mathrm{ng}$ for $\mathrm{Sr}$. Isotope ratios were measured on VG-354 multicollector and single collector mass spectrometers, and the ${ }^{87} \mathrm{Sr} /{ }^{86} \mathrm{Sr}$ ratios were normalized to ${ }^{86} \mathrm{Sr} /{ }^{88} \mathrm{Sr}=0.1194$.

\section{RESULTS}

The investigated samples were previously studied by petrography (see Appendix A). The new isotopic and geochemical data were interpreted together with the published characteristics of PGC rocks (e.g., Litherland et al., 1986; Darbyshire, 2000), and taking into account the geochronologic background of the Bolivian Precambrian shield, particularly SHRIMP U-Pb zircon ages of distinct rock-units of Paraguá craton (Boger et al., 2005; Santos et al., 2006, 2008), including the unpublished ones (data from R. Matos).

\section{Field aspects and petrography}

Appendix A presents hand sample and petrographic descriptions with modal composition, textures and structures of the investigated PCG rocks (see Figure 2) whereas Appendix B summarizes the megascopic and microscopic petrography of this PGC after Klinck and O'Connor (1983); Hawkins (1982); Pitfield (1983) and Litherland (1982).

Modal composition for selected rocks of the PGC was determined using macro point counting method as described by Fitch (1959). Staining of rock slabs was necessary to distinguish between $\mathrm{K}$-feldspar and plagioclase and to determine their proportions (Table 6). The investigated syn- to late-kinematic rocks can be classified mostly as syenogranites, monzogranites and quartz monzonites whe- 
Table 3. Major and trace elements of the PGC. Keys: Porv. = Porvenir; Diam.= Diamantina.

\begin{tabular}{|c|c|c|c|c|c|c|c|c|c|c|c|c|c|}
\hline Sample & $\begin{array}{c}\text { PF } \\
0501 \\
\end{array}$ & $\begin{array}{c}\text { SC } \\
10502 \\
\end{array}$ & $\begin{array}{c}\text { SC } \\
20503 \\
\end{array}$ & $\begin{array}{l}\text { PRV } \\
0504 \\
\end{array}$ & $\begin{array}{c}C P \\
0505 \\
\end{array}$ & $\begin{array}{c}C P \\
20506 \\
\end{array}$ & $\begin{array}{c}\text { CP } \\
30507 \\
\end{array}$ & $\begin{array}{c}\text { ME } \\
0508 \\
\end{array}$ & $\begin{array}{c}\text { CA } \\
0509 \\
\end{array}$ & $\begin{array}{l}\text { FLT } \\
0510 \\
\end{array}$ & $\begin{array}{c}\text { LJ } \\
10511 \\
\end{array}$ & $\begin{array}{c}\text { LJ } \\
20512 \\
\end{array}$ & $\begin{array}{c}\text { LJ } \\
30513 \\
\end{array}$ \\
\hline Unit & $\begin{array}{l}\text { Piso } \\
\text { Firme }\end{array}$ & $\begin{array}{c}\text { San } \\
\text { Cristobal }\end{array}$ & $\begin{array}{c}\text { San } \\
\text { Cristobal }\end{array}$ & Porv. & Diam. & Diam. & Diam. & Diam. & $\begin{array}{c}\text { San } \\
\text { Martín }\end{array}$ & $\begin{array}{c}\text { La } \\
\text { Junta }\end{array}$ & $\begin{array}{c}\text { La } \\
\text { Junta }\end{array}$ & $\begin{array}{c}\text { La } \\
\text { Junta }\end{array}$ & $\begin{array}{c}\text { La } \\
\text { Junta }\end{array}$ \\
\hline Rock & QSy & $\mathrm{MzGrBi}$ & MzGrBi & SyGrHb & SyGrBi & SyGrBi & SyGrBi & $\mathrm{QMzBi}$ & SyGrHb & SyGr & $\mathrm{QMzBi}$ & MzGrBi & $\mathrm{MzGrHb}$ \\
\hline $\mathrm{SiO}_{2}$ & 76.07 & 76.08 & 74.12 & 74.26 & 72.33 & 72.14 & 73.53 & 74.84 & 76.76 & 69.27 & 71.26 & 74.19 & 68.63 \\
\hline $\mathrm{Al}_{2} \mathrm{O}_{3}$ & 12.44 & 12.46 & 13.02 & 13.75 & 14.39 & 14.47 & 13.49 & 13.43 & 11.51 & 14.83 & 14.48 & 14.16 & 15.46 \\
\hline $\mathrm{MnO}$ & 0.025 & 0.030 & 0.054 & 0.043 & 0.035 & 0.034 & 0.034 & 0.033 & 0.044 & 0.034 & 0.032 & 0.022 & 0.030 \\
\hline $\mathrm{MgO}$ & 0.06 & 0.08 & 0.22 & 0.22 & 0.30 & 0.29 & 0.28 & 0.19 & 0.09 & 0.75 & 0.43 & 0.24 & 0.59 \\
\hline $\mathrm{CaO}$ & 0.56 & 0.56 & 1.07 & 1.27 & 1.33 & 1.28 & 1.15 & 1.00 & 0.62 & 1.24 & 1.33 & 2.04 & 1.80 \\
\hline $\mathrm{Na}_{2} \mathrm{O}$ & 4.47 & 3.73 & 3.49 & 3.74 & 3.19 & 3.21 & 2.96 & 3.36 & 2.41 & 2.55 & 2.80 & 3.63 & 3.49 \\
\hline $\mathrm{K}_{2} \mathrm{O}$ & 4.07 & 4.88 & 4.86 & 4.53 & 5.52 & 5.94 & 5.44 & 5.07 & 5.63 & 6.52 & 6.30 & 3.96 & 4.98 \\
\hline $\mathrm{TiO}_{2}$ & 0.123 & 0.117 & 0.242 & 0.173 & 0.255 & 0.243 & 0.241 & 0.140 & 0.188 & 0.477 & 0.330 & 0.106 & 0.442 \\
\hline $\mathrm{P}_{2} \mathrm{O}_{5}$ & 0.017 & 0.017 & 0.048 & 0.047 & 0.068 & 0.062 & 0.067 & 0.051 & 0.025 & 0.148 & 0.120 & 0.044 & 0.156 \\
\hline $\mathrm{Fe}_{2} \mathrm{O}_{3}$ & 1.50 & 1.42 & 2.24 & 1.31 & 1.68 & 1.65 & 2.03 & 1.35 & 2.20 & 2.79 & 2.05 & 1.33 & 3.24 \\
\hline Loi & 0.67 & 0.38 & 0.21 & 0.39 & 0.38 & 0.20 & 0.34 & 0.40 & $<0.01$ & 0.82 & 0.40 & 0.19 & 0.67 \\
\hline Total & 100.01 & 99.75 & 99.57 & 99.73 & 99.48 & 99.52 & 99.56 & 99.86 & 99.48 & 99.43 & 99.53 & 99.91 & 99.49 \\
\hline ACNK & 0.97 & 1.00 & 1.00 & 1.03 & 1.05 & 1.03 & 1.05 & 1.05 & 1.03 & 1.10 & 1.04 & 1.01 & 1.07 \\
\hline $\mathrm{K}_{2} \mathrm{O} / \mathrm{Na}_{2} \mathrm{O}$ & 0.91 & 1.31 & 1.39 & 1.21 & 1.73 & 1.85 & 1.84 & 1.51 & 2.34 & 2.56 & 2.25 & 1.09 & 1.43 \\
\hline $\mathrm{Ba}$ & 811 & 336 & 614 & 822 & 902 & 776 & 690 & 429 & 721 & 1515 & 776 & 805 & 525 \\
\hline $\mathrm{Nb}$ & 11 & 10 & 8 & 22 & 9 & 7 & 12 & 8 & 7 & 13 & 12 & 4 & 20 \\
\hline $\mathrm{Pb}$ & 6 & 13 & 12 & 21 & 44 & 39 & 44 & 55 & 22 & 26 & 40 & 20 & 36 \\
\hline $\mathrm{Rb}$ & 100 & 157 & 158 & 179 & 245 & 212 & 249 & 251 & 144 & 165 & 224 & 141 & 223 \\
\hline $\mathrm{Sr}$ & 24 & 24 & 59 & 21 & 215 & 201 & 153 & 176 & 69 & 287 & 168 & 296 & 109 \\
\hline Th & 8 & 7 & 6 & 14 & 20 & 39 & 55 & 32 & 17 & 20 & 33 & 5 & 67 \\
\hline$U$ & 3 & 3 & 2 & 5 & 5 & 7 & 8 & 16 & 1 & 2 & 3 & 2 & 5 \\
\hline V & $<9$ & $<9$ & $<9$ & $<9$ & $<9$ & 18 & 14 & $<9$ & $<9$ & 26 & 14 & 16 & 37 \\
\hline$Y$ & 45 & 66 & 54 & 148 & 23 & 18 & 18 & 122 & 95 & 54 & 23 & 7 & 43 \\
\hline $\mathrm{Zr}$ & 215 & 142 & 197 & 360 & 178 & 197 & 185 & 118 & 292 & 206 & 216 & 110 & 314 \\
\hline La & 31.4 & 33.0 & 34.8 & 65.1 & 69.7 & 99.5 & 70.0 & 24.2 & 91.6 & 64.0 & 70.5 & 17.2 & 110 \\
\hline $\mathrm{Ce}$ & 60.1 & 61.7 & 55.9 & 179 & 128 & 128 & 182 & 56.9 & 212 & 130 & 148 & 31.8 & 220 \\
\hline $\mathrm{Pr}$ & 7.83 & 8.97 & 9.45 & 19.3 & 15.2 & 21.3 & 17.8 & 6.49 & 26.8 & 20.2 & 17.3 & 3.55 & 25.9 \\
\hline $\mathrm{Nd}$ & 29.2 & 35.1 & 36.4 & 76.0 & 52.4 & 71.1 & 61.2 & 23.5 & 106 & 76.1 & 60.5 & 11.6 & 91.0 \\
\hline $\mathrm{Sm}$ & 6.44 & 8.13 & 8.33 & 17.9 & 8.55 & 11.0 & 11.2 & 5.95 & 24.1 & 14.0 & 10.8 & 1.77 & 16.3 \\
\hline $\mathrm{Eu}$ & 0.64 & 0.44 & 1.12 & 1.88 & 1.20 & 1.27 & 1.24 & 0.79 & 2.70 & 1.95 & 1.10 & 0.59 & 1.15 \\
\hline $\mathrm{Gd}$ & 6.61 & 8.59 & 8.30 & 20.1 & 7.34 & 9.21 & 9.28 & 7.96 & 24.3 & 12.5 & 9.81 & 1.75 & 15.6 \\
\hline $\mathrm{Tb}$ & 1.13 & 1.52 & 1.48 & 3.57 & 0.77 & 0.90 & 1.00 & 1.92 & 3.88 & 1.71 & 1.08 & 0.21 & 1.86 \\
\hline Dy & 7.10 & 9.36 & 8.98 & 22.3 & 3.75 & 4.06 & 4.45 & 14.1 & 21.0 & 9.39 & 4.99 & 1.15 & 9.11 \\
\hline $\mathrm{Ho}$ & 1.69 & 2.23 & 2.07 & 5.26 & 0.72 & 0.66 & 0.72 & 3.82 & 4.16 & 1.90 & 0.85 & 0.25 & 1.56 \\
\hline Er & 4.80 & 6.24 & 5.86 & 14.9 & 2.00 & 1.65 & 1.72 & 11.3 & 10.1 & 5.00 & 1.99 & 0.75 & 3.39 \\
\hline $\mathrm{Tm}$ & 0.77 & 0.98 & 0.94 & 2.30 & 0.29 & 0.20 & 0.22 & 1.75 & 1.24 & 0.68 & 0.24 & 0.12 & 0.34 \\
\hline $\mathrm{Yb}$ & 5.33 & 6.67 & 6.41 & 15.4 & 1.92 & 1.21 & 1.33 & 11.3 & 7.03 & 3.98 & 1.31 & 0.89 & 1.69 \\
\hline $\mathrm{Lu}$ & 0.80 & 0.99 & 0.94 & 2.27 & 0.29 & 0.19 & 0.21 & 1.65 & 0.85 & 0.51 & 0.20 & 0.14 & 0.25 \\
\hline $\mathrm{Hf}$ & 7.00 & 6.13 & 6.15 & 12.6 & 5.51 & 6.43 & 6.45 & 4.93 & 11.0 & 5.86 & 7.33 & 4.45 & 10.0 \\
\hline $\mathrm{Ta}$ & 0.77 & 0.75 & 0.76 & 1.38 & 0.68 & 0.28 & 0.25 & 0.49 & 0.53 & 1.22 & 0.26 & 0.46 & 0.96 \\
\hline$(\mathrm{La} / \mathrm{Yb}) \mathrm{n}$ & 3.99 & 3.34 & 3.66 & 2.85 & 24.60 & 55.33 & 35.30 & 1.44 & 8.79 & 10.90 & 36.40 & 13.97 & 44.26 \\
\hline$(\mathrm{Eu}) \mathrm{n} / \mathrm{Eu}$ & 0.30 & 0.16 & 0.41 & 0.30 & 0.46 & 0.38 & 0.37 & 0.35 & 0.34 & 0.45 & 0.32 & 0.16 & 0.22 \\
\hline
\end{tabular}


Table 4. Sm-Nd isotopic data for rocks of the PGC. Keys: SyGr = Syenogranite; $\mathbf{M z G r}=$ Monzogranite; $Q M z=Q$ Quartz monzonite; QSy = Quartz syenite.

\begin{tabular}{|c|c|c|c|c|c|c|c|c|c|c|}
\hline Sample & Unit & Rock & Sm (ppm) & Nd (ppm) & ${ }^{147} \mathrm{Sm} /{ }^{144} \mathrm{Nd}$ & ${ }^{143} \mathrm{Nd} /{ }^{144} \mathrm{Nd}$ & $\varepsilon_{(0)}$ & $f_{S m / N d}$ & $\mathrm{~T}_{\mathrm{DM}}(\mathrm{Ga})$ & $\varepsilon_{(T 1)}$ \\
\hline PF0501 & Piso Firme & QSy & 6.830 & 30.375 & 0.1360 & 0.51223 & -7.99 & -0.31 & 1.59 & 2.32 \\
\hline SC10502 & San Cristobal & $\mathrm{MzGrBi}$ & 7.826 & 32.431 & 0.1459 & 0.51234 & -5.87 & -0.26 & 1.58 & 2.75 \\
\hline SC20503 & San Cristobal & $\mathrm{MzGrBi}$ & 9.647 & 40.460 & 0.1442 & 0.51232 & -6.28 & -0.27 & 1.59 & 2.63 \\
\hline PRV0504 & Porvenir & SyGrHb & 19.278 & 79.089 & 0.1474 & 0.51229 & -6.89 & -0.25 & 1.74 & 1.48 \\
\hline CP0505 & Diamantina & SyGrBi & 10.664 & 63.260 & 0.1019 & 0.51183 & -15.7 & -0.48 & 1.65 & 0.39 \\
\hline CP20506 & Diamantina & SyGrBi & 12.872 & 78.696 & 0.0989 & 0.51179 & -16.6 & -0.50 & 1.66 & 0.03 \\
\hline CP30507 & Diamantina & SyGrBi & 13.279 & 70.132 & 0.1145 & 0.51186 & -15.2 & -0.42 & 1.82 & -1.25 \\
\hline ME0508 & Diamantina & QMzBi & 5.738 & 23.615 & 0.1469 & 0.51220 & -8.51 & -0.25 & 1.92 & -0.06 \\
\hline CA0509 & San Martín & SyGrHb & 25.353 & 107.634 & 0.1424 & 0.51226 & -7.43 & -0.28 & 1.68 & 1.78 \\
\hline FLT0510 & La Junta & SyGr & 18.727 & 99.733 & 0.1135 & 0.51173 & -17.8 & -0.42 & 2.01 & -3.66 \\
\hline LJ10511 & La Junta & QMzBi & 14.692 & 80.734 & 0.1100 & 0.51172 & -17.9 & -0.44 & 1.95 & -3.21 \\
\hline LJ20512 & La Junta & $\mathrm{MzGrBi}$ & 3.599 & 22.018 & 0.0988 & 0.51164 & -19.6 & -0.50 & 1.87 & -2.94 \\
\hline LJ30513 & La Junta & $\mathrm{MzGrHb}$ & 18.697 & 100.573 & 0.1124 & 0.51169 & -18.6 & -0.43 & 2.04 & -4.29 \\
\hline
\end{tabular}

Table 5. Sr isotopic data for rocks of the PGC. Keys: SyGr = Syenogranite; $\mathbf{M z G r}=$ Monzogranite; $\mathbf{Q M z}=\mathrm{Quartz}$ monzonite; QSy = Quartz syenite. T(Ma)=1.33 Ga calculated according as a SHRIMP U/Pb age (Boger et al., 2005).

\begin{tabular}{|c|c|c|c|c|c|c|c|c|}
\hline Unit & Sample & Rock & $\begin{array}{c}\mathrm{Rb} \\
(\mathrm{ppm})\end{array}$ & $\begin{array}{c}\mathrm{Sr} \\
(\mathrm{ppm}) \\
\end{array}$ & $1 / \mathrm{Sr}$ & $\begin{array}{c}{ }^{87} \mathrm{Sr} /{ }^{86} \mathrm{Sr} \\
(\mathrm{Y})\end{array}$ & $\begin{array}{c}{ }^{87} \mathrm{Rb} /{ }^{86} \mathrm{Sr} \\
(\mathrm{X})\end{array}$ & $\begin{array}{c}\left({ }^{87} \mathrm{Sr} /{ }^{86} \mathrm{Sr}\right) \mathrm{t} \\
\mathrm{p} / \mathrm{T}(\mathrm{Ma})\end{array}$ \\
\hline Piso Firme & PF0501 & QSy & 111.59 & 27.68 & 0.0361 & 0.72473 & 11.687 & \\
\hline San Cristobal & SC10502 & $\mathrm{MzGrBi}$ & 157.45 & 27.69 & 0.0361 & 1.03027 & 16.979 & 0.70656 \\
\hline San Cristobal & SC20503 & $\mathrm{MzGrBi}$ & 170.66 & 71.97 & 0.0139 & 0.83417 & 6.949 & 0.70169 \\
\hline Porvenir & PRV0504 & SyGrHb & 183.36 & 21.98 & 0.0455 & 1.18192 & 25.278 & \\
\hline Diamantina & CP0505 & SyGrBi & 271.15 & 224.81 & 0.0044 & 0.76889 & 3.512 & 0.70194 \\
\hline Diamantina & CP20506 & SyGrBi & 228.71 & 207.95 & 0.0048 & 0.76477 & 3.201 & 0.70370 \\
\hline Diamantina & CP30507 & SyGrBi & 301.01 & 167.87 & 0.0060 & 0.79670 & 5.235 & \\
\hline Diamantina & ME0508 & QMzBi & 232.91 & 166.14 & 0.0060 & 0.78021 & 4.086 & 0.70230 \\
\hline San Martín & CA0509 & SyGrHb & 158.81 & 72.92 & 0.0137 & 0.82563 & 6.376 & 0.70407 \\
\hline La Junta & FLT0510 & SyGr & 169.30 & 287.44 & 0.0035 & 0.73645 & 1.710 & 0.70386 \\
\hline La Junta & LJ10511 & QMzBi & 242.15 & 187.28 & 0.0053 & 0.77713 & 3.768 & 0.70530 \\
\hline La Junta & LJ20512 & $\mathrm{MzGrBi}$ & 140.09 & 323.02 & 0.0031 & 0.73007 & 1.258 & 0.70609 \\
\hline La Junta & LJ30513 & $\mathrm{MzGrHb}$ & 245.65 & 119.90 & 0.0083 & 0.81792 & 5.994 & \\
\hline
\end{tabular}

reas the late- to post-kinematic ones plot mainly in the syenogranite, monzogranite, quartz monzonite and quartz syenite fields in the Streckeisen QAP diagram (see Figure 3).

Syn- to late- kinematic granitoid rocks

La Junta granite

This moderately to weakly foliated body occurs in the southern part of PGC. The colour composite satellite im- agery and the surface cover of the La Junta granite do not allow defining its size because the field relations with the other rock units are not exposed. In some places the granite becomes distinctly gneissic with a well developed planar fabric. The observed anatexis is syn- to late- Do3, but an early prograde metamorphism (pre- Do3) reached highgrade metamorphism in the country rocks located close to the pluton, as evidenced by prismatic sillimanite.

According to Hawkins (1982) the La Junta granite includes numerous xenoliths of hornblende-biotite gneiss 
Table 6. Modal analysis for rocks of the PGC. All samples have $\mathrm{Nd}$ and $\mathrm{Sr}$ analyses (this work). See text for details. Keys: SyGr = Syenogranite; MzGr = Monzogranite; $\mathbf{Q M z}=$ Quartz monzonite; $\mathbf{Q S y}=$ Quartz syenite; $\mathbf{Q z}=$ Quartz; K-feld = K-feldspar; Plag = Plagioclase; Biot = Biotite; Horn = Hornblende; Zr = Zircon; Sph = Sphene; Magn = Magnetite; Apat = Apatite; Allan = Allanite; Epid = Epidote; Chlor = Chlorite; PF = Piso Firme; SC = San Cristobal; $\mathbf{P}=$ Porvenir; $\mathbf{D}=$ Diamantina; LJ = La Junta; SM = San Martín. * Magnetite was determined using a pocket magnet.

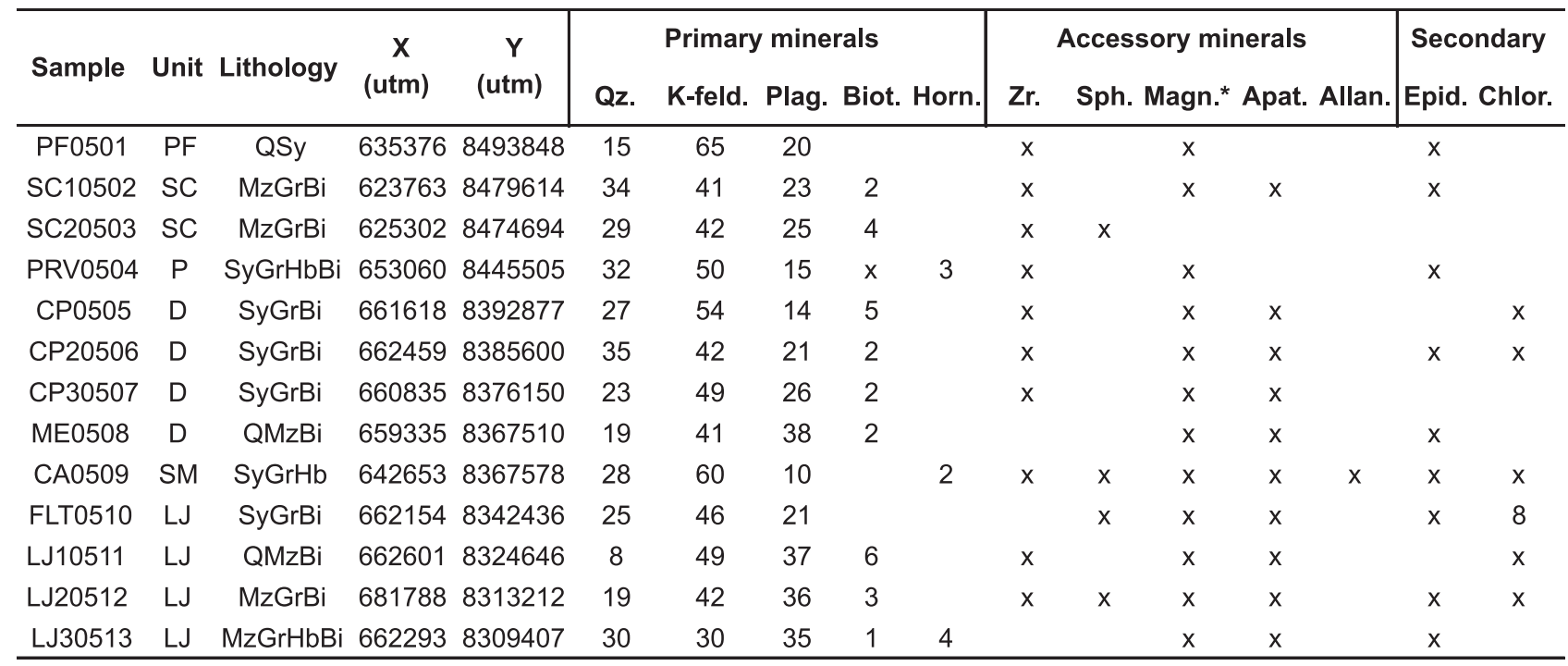

partly migmatitic, calc-silicate gneiss, quartzite and amphibolite. This author classified the La Junta granite as a porphyritic rock, medium-to coarse-grained with biotite and hornblende. In addition to our analyses (FLT0510, LJ10511, LJ20512, LJ30513), the QAP diagram includes data from Hawkins (1982) (dark gray field in Figure 3). The resulting feature indicates that the La Junta pluton is constituted by gneisses of monzogranitic to syenogranitic composition. Sample FLT0510 is a pinkish, coarse-grained syenogranite gneiss, and consists of K-feldspar and plagioclase surrounded by a irregularly streaky chlorite accompanied by epidote, also strongly replaced by sericite shreds that are pale gray in color and cloudy. Sample LJ10511, one biotite, quartz monzonitic gneiss, has apatite, whereas sample LJ20512, one medium leucocratic biotitic monzogranitic gneiss, has sphene as the principal accessory mineral. Sample LJ30513 is a hornblende monzogranite, white pinkish in color, medium to coarse grained, isotropic to moderately foliated and porphyritic.

\section{San Martin granite}

This pluton crops out extensively in the western side of PGC (Figure 2). It is a heterogeneous batholith, partly migmatitic, granitic gneiss of autochtonous character (Klinck and O'Connor, 1983). The investigated sample (CA0509) has a syenogranite composition in the QAP diagram (Figure 3). In the central part of the batholith banded

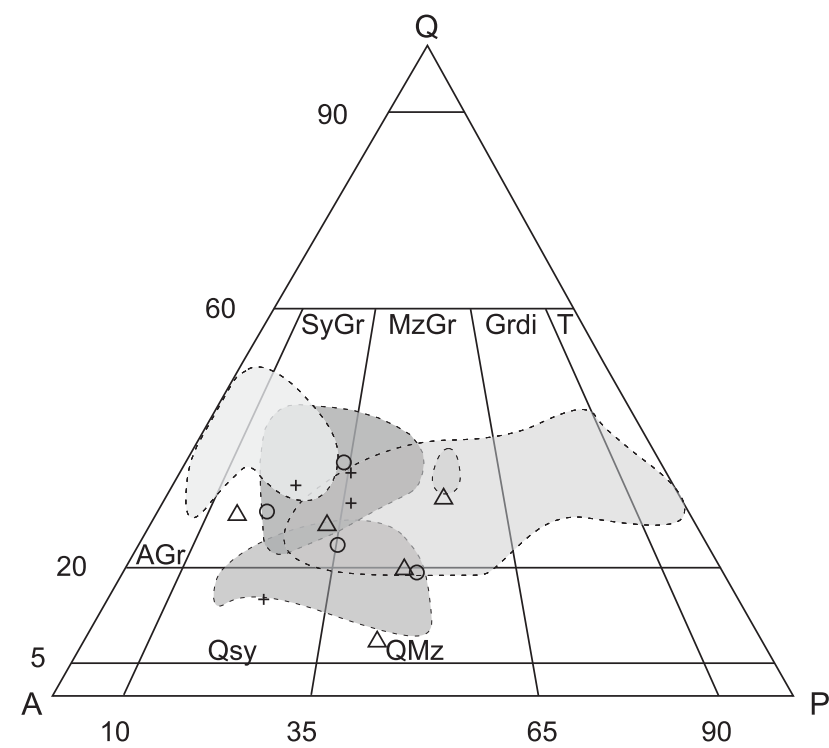

Figure 3. Streckeisen QAP diagram for selected samples of the PGC. $\mathbf{T}=$ Tonalite; $\mathbf{G r d i}=$ Granodiorite; $\mathbf{M z G r}=$ Monzogranite; SyGr = Syenogranite; $\mathbf{A G r}=$ Alkali-feldspar granite; $\mathbf{Q M z}=$ Quartz monzonite; $\mathbf{Q S y}=$ Quartz syenite. + = Lateto post-kinematic granites; $O=$ Diamantina granite; $\triangle$ = Synto late kinematic granites. All samples have $\mathrm{Nd}$ and $\mathrm{Sr}$ isotopic data (this work); see text for details. Keys: $\bigcirc$ - La Junta granite (modified from Hawkings, 1982); - Diamantina Granite (modified from Litherland, 1982); - Diamantina Granite (modified from Klink and $\mathrm{O}^{\prime}$ Connor, 1982); $\bigcirc$ - Piso Firme Granophyre (modified from Piffield, 1983); $\bigcirc$ - San Cristobal Metagranite (modified from Piffield, 1983). 
enclaves of migmatitic biotite gneiss show both concordant and discordant contacts with the granite injections. The biotite defines a weak foliation, but lens- or augentexture are observed in places. Along the western side of the batholith the distribution of the isogrades indicates medium grade metamorphic conditions. The most representative rock exhibits a granular texture and biotite flakes and prismatic hornblende. The K-feldspar form scattered phenocrysts from 1.5 to $3 \mathrm{~cm}$ long. In the southern part the San Martin pluton becomes melanocratic.

\section{Late- to post -kinematic granitoid rocks}

\section{Piso Firme granophyres}

This rock crops out nearby Piso Firme village in Beni department, in the vicinity of Paraguá river (PF samples; Figure 2) The colour composite satellite imagery shows this pluton as wooded hills with the principal fractures following E-W direction and subordinately NNW trend. The east-west long axis of the intrusion is $6 \mathrm{~km} v s .3 \mathrm{~km}$ wide along the NS direction.

The Piso Firme granophyre (Pitfield, 1983) comprises three distinctive lithologic facies from north to south: a) coarse to medium-grained potassic granophyre (sample PF0501 in the present work); b) medium to coarse-grained microespherulitic granophyre; c) spherulitic plagiophyric microgranophyre. One aegirine-riebeckite-bearing sodicpotassic granophyre crops out as a small hillrock that was previously described in the eastern side of Cerro Piso Firme (Pitfield, 1983). The QAP diagram includes the new data and those from Pitfield (1983) (light gray field; Figure 3). The investigated samples fall between the syenogranite and the alkali-feldspar granite fields.

\section{Porvenir granite}

This body, first characterized near the homonymous village, crops out as positive topographic feature, such as the Pica Pica hill (sample PRV0504; Table 6) located to the eastern side from the road to Piso Firme and Cerro Porvenir (Figure 2). On the color composite satellite imagery this intrusion forms a forested hill raising no more than 60 $100 \mathrm{~m}$ above the plain. It shows a roughly shape with fractures of joints following NW direction, sometimes gently curved (Klinck and O'Connor, 1983). Following its long NW oriented axis the outcrop is $10-12 \mathrm{~km}$ long, and the width of the intrusion in the NW direction is 2 to $5 \mathrm{~km}$. The investigated outcrop is an isotropic, medium-fine grained, massive hornblende syenogranite to weakly foliated monzogranite. These compositions are displayed by the samples plotted in the QAP diagram (Figure 3). The quartz appears as polygonal grained aggregates, and K-feldspar is partly replaced by sericite. Plagioclase is very subordinate. Hornblende forms irregular shaped grains commonly in aggregates. The observed granoblastic textures suggest a post-tectonic metamorphism, in agreement with the low grade metamorphism (actinolite+epidote+chlorite) reported by Klinck and O'Connor (1983) in rocks located $7.5 \mathrm{~km}$ to the SW of the Porvenir granite.

\section{San Cristobal granite}

This granite makes up the Leyton hill (samples SC10502 and SC20503; Figures 2, 3 and Table 6), among many other hills named Serranía San Cristobal - a NW oriented ridge which is clearly seen in the colour composite satellite imagery. In general, the rock in Leyton hill is a homogeneous, biotitic monzogranite that locally grades or is emplaced into concordant zones of the gneisses of the crystalline basement. Banded porphyroblastic gneiss and pegmatite are also present. From the above the San Cristobal granite can be classified as a moderately to smooth streaky granitic gneiss. Its N-NW foliation (Do3) is assigned to be tectonically related with the San Ignacio orogeny (e.g., Litherland et al., 1986). The rock is pinkish in hand sample, and in the thin section quartz is anhedral with undulose extinction, K-feldspar consists of irregular microcline twinning and plagioclase occurs as tabular crystals with fine and coarse twinning. In the QAP diagram (Figure 3) our data in conjunction with those from Pitfield (1983) plot in the monzogranite field.

\section{Diamantina granite}

This intrusion makes up a north trending hill, forming a large elliptical body about $53 \mathrm{~km}$ long (Klinck and O'Connor, 1983), that crops out as an "island" in the forest, close to the road to Piso Firme village (Figure 2). The northern and central parts of the Diamantina granite are made up by several outcrops that exhibit two clear systems of joints $\left(80^{\circ}\right.$ and $\left.170^{\circ}\right)$. In the southern part the outcrops appear as small sprinkled mottled aspect.

According to Klinck and O'Connor (1983) the Diamantina pluton was formed by distinct intrusive phases: first magmatic phase produced granodiorite and/or tonalite. After cooling of these rocks, a second phase (monzogranite) intruded the earlier granodiorite-tonalite, as shown by the typical xenoliths with spherical to tabular forms (50 $\mathrm{cm}$ to $43 \mathrm{~m}$ long). They are also fine-grained and sometimes medium and coarse grained and may contain biotite as the principal mafic mineral. Other xenoliths comprise exotic lithologies (biotite gneisses, garnet-biotite gneiss and hornblende gneisses) with irregular distri- 
bution. The northern side of the Diamantina granite is xenoliths free compared to the southern side. Some lenses and veins of pegmatites are present. The Diamantina granite represents either the last magmatic post-tectonic phase of the PGC (Klinck and O'Connor, 1983) or shortly succeeded Do3 episode (Litherland, 1982).

The Diamantina granite was sampled in four places (Figure 2). The dominant rock type is a pale pink and non foliated biotitic syenogranite. One sample (ME0508; moderately foliated biotitic quartz monzonite), collected at La Mechita farm was previously considered as belong to the Chiquitania Complex by Litherland 1:1.000.000 map. However, it was herein considered as representative of the Diamantina intrusion based in the field relationships of our work.

The QAP diagram (Figure 3; Table 6) shows our analyses and the published ones (Klinck and O'Connor, 1983) that were sampled in the western side of the Diamantine granite (medium gray field). The previous data indicate a transition from tonalite to syenogranite in composition, but the new analyses fall mainly within the monzogranite field. In addition, Figure 3 shows the data from Litherland (1982) (dark- medium gray field) referring to the samples from the eastern side of the body. This distinct samples show a transition from intermediate rocks of quartz monzonite to syeno-granite.

\section{Major and trace elements}

Table 3 presents the major and trace elements data of thirteen samples of PGC.

\section{Syn- to late-kinematic granitoid rocks}

Four samples of the La Junta granite (FLT0510, LJ10511, LJ20512, LJ30513) and one of the San Martin granite (CA0509) show $\mathrm{SiO}_{2}$ contents from 69 to 77 $w t \%$. Major oxides display regular trends of decreasing $\mathrm{Al}_{2} \mathrm{O}_{3}, \mathrm{MgO}, \mathrm{CaO}$ and $\mathrm{Fe}_{2} \mathrm{O}_{3 \mathrm{Tot}}$ with increasing $\mathrm{SiO}_{2}$ contents suggesting that fractional crystallization played an important role in the petrogenetic process (Figure 4). Figures $5 \mathrm{~A}$ to $5 \mathrm{C}$ present variation diagrams of $\mathrm{Zr}$, Ba and $\mathrm{Sr}$ against $\mathrm{SiO}_{2}$ showing roughly decreasing of the trace elements with increasing $\mathrm{SiO}_{2}$. This behavior is probably due to zircon, feldspar and plagioclase separation from the evolving melts. Figure 5D ( $\mathrm{Rb} / \mathrm{Sr}$ vs. $\mathrm{Sr} / \mathrm{Ba})$ shows linear trends for the samples, which suggests again the hypothesis of fractional crystallization. All the investigated samples, including those from syn- to late-kinematic plutons reported in the literature (Litherland et al., 1986), are subalkaline (Figures 6A and 6B), as indicated by the characteristic $\mathrm{Na}_{2} \mathrm{O}+\mathrm{K}_{2} \mathrm{O}$ values $<$ to $8.5 \mathrm{wt} \%$ (Table 3) (see, e.g., Nardi and Bonin, 1991). In addition the La Junta and San
Martin samples show mainly a high-K and calc-alkaline affinity with $\mathrm{SiO}_{2}$ content higher than $69 \mathrm{wt} \%$ (see Figures 7 and 8) suggesting they have an arc-related geochemical signature. The highest-K tendency of FLT0510 and LJ10511 samples is probably due to the feldspar and plagioclase alterations $\left(\mathrm{K}_{2} \mathrm{O} / \mathrm{Na}_{2} \mathrm{O}\right.$ ratio of 2.56 and 2.25 respectively; see Table 3 ), that originate sericite as cloudy masses and minute shreds. Therefore the whole rock compositions of these particular samples were modified toward apparent peraluminosity (Figure 8).

The REE patterns of the La Junta and San Martin granite samples (Figure 9) are moderately fractioned in terms of LREE/HREE with a slightly negative Eu anomaly. In the spider diagram the samples present steep patterns due to their high LILE contents which compare well with the typical pattern of Andean-type igneous rocks (segmented line in Figure 10). The observed negative peaks of Sr, P, and Ti suggest fractionation of feldspars, apatite, and titano-magnetite and sphene, respectively. Sample LJ20512 presents a contrasting signature with no negative Eu anomaly (Figure 9), suggesting either one depleted REE source, or fractionation with amphibole and/or allanite in the residue. The lower values of $\mathrm{Ta}$ and $\mathrm{Nb}$ in the sample LJ20512 may be ascribed to crustal contamination.

\section{Late- to post-kinematic granitoid rocks}

Major and trace elements data of four samples from Porvenir and San Cristobal granites and Piso Firme granophyre are given in Table 3. In the Harker's diagram (Figure 4), the samples display negative correlations for $\mathrm{Al}_{2} \mathrm{O}_{3}$, $\mathrm{MgO}, \mathrm{CaO}$ and $\mathrm{Fe}_{2} \mathrm{O}_{3 \mathrm{Tot}}$ with increasing $\mathrm{SiO}_{2}$ contents and a positive correlation to the $\mathrm{Na}_{2} \mathrm{O}$, suggesting the role of fractional crystallization process. The plots of $\mathrm{Zr}, \mathrm{Ba}$ and $\mathrm{Sr}$ against $\mathrm{SiO}_{2}$ show decreasing of the trace elements with the increasing contents of $\mathrm{SiO}_{2}$ (Figure 5) which is probably due to zircon, feldspar and plagioclase separation from the evolving melts. On the $\mathrm{Rb} / \mathrm{Sr}$ vs. $\mathrm{Sr} / \mathrm{Ba}$ diagram (Figure 5D), the studied samples show a linear trend, which is consistent again with fractional crystallization. All the samples are sub-alkaline (Figure 6), in agreement with their characteristic $\mathrm{Na}_{2} \mathrm{O}+\mathrm{K}_{2} \mathrm{O}$ values (Table 3 ).

The investigated late- to post -kinematic rocks have narrow range in the $\mathrm{SiO}_{2}$ contents (from 74 to $76 \mathrm{wt} \%$ ) and plot in the high-K field likewise most of the syn- to late-kinematic rocks (Figures $8 \mathrm{~A}$ and $8 \mathrm{~B}$ ). The Piso Firme granophyre and San Cristobal granite have metaluminous composition and the Porvenir granite (Figure 9), show a tendency to peraluminous character $(\mathrm{ACNK}=1.03)$. These three plutons have $\mathrm{K}_{2} \mathrm{O} / \mathrm{Na}_{2} \mathrm{O}$ ratios that range from 0.9 to 1.4 (see Table 2). Regarding the REE patterns, all the samples show low LREE fractionation, and subhorizontal tendency of HREE 

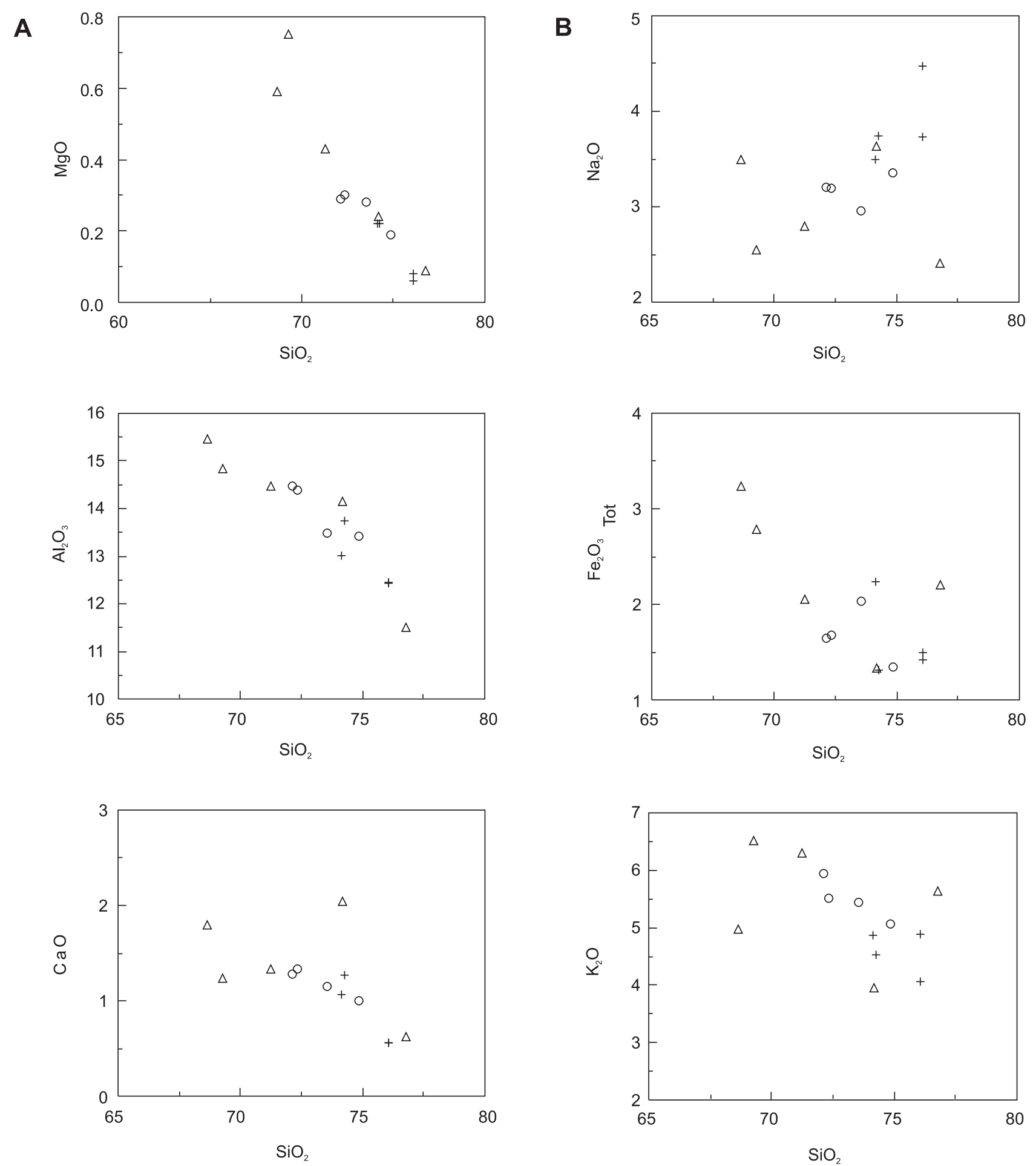

Figure 4. Variation diagrams of major elements for the PGC. Symbols as shown in Figure 3. 
A

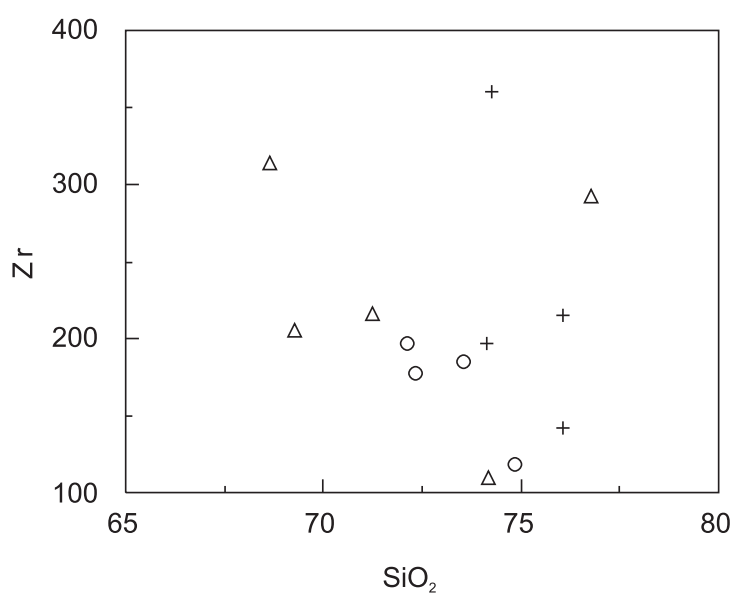

c

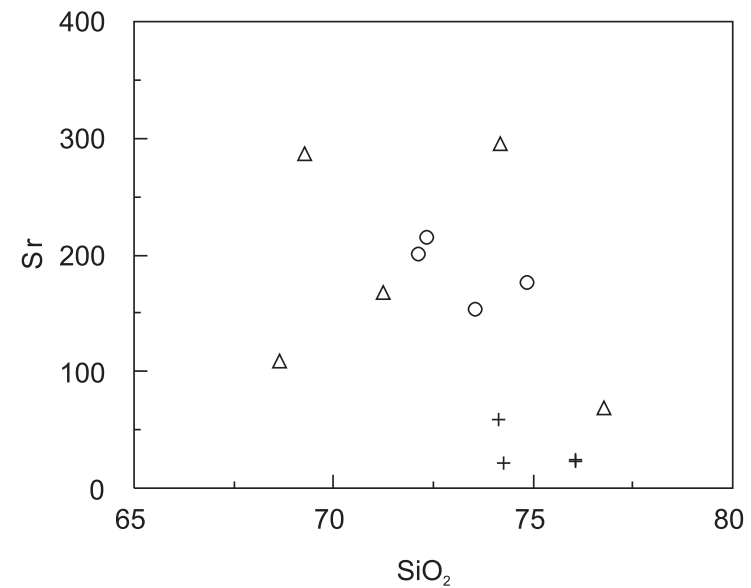

B

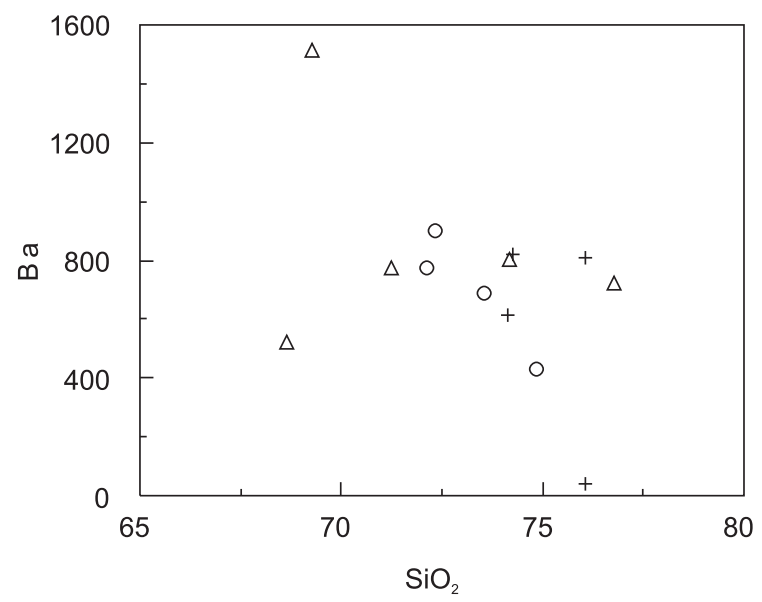

D

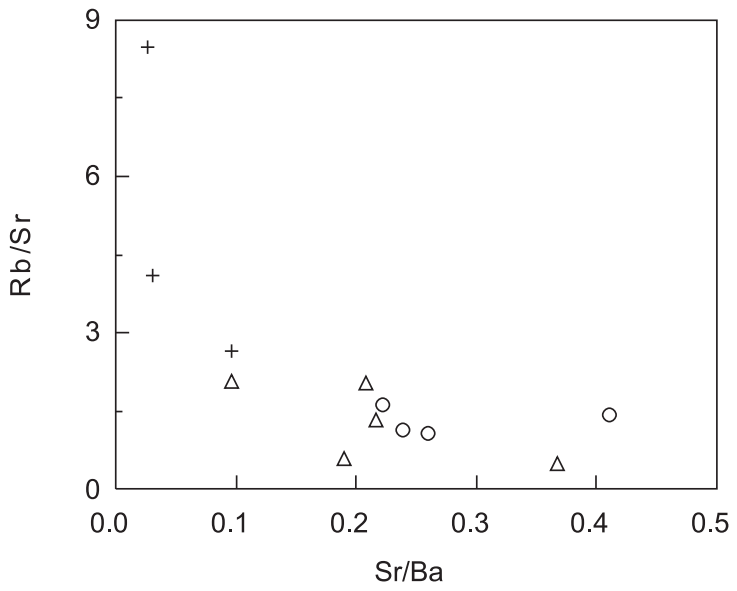

Figure 5. Variation diagrams of trace elements vs. $\mathrm{SiO}_{2}$ for $\mathrm{PGC}$ rocks. $5 \mathrm{~A}$. $\mathrm{Zr}$ vs. $\mathrm{SiO}_{2}$. 5b. Ba vs. 2. 5C. Sr vs. $\mathrm{SiO}_{2}$. 5D. $\mathrm{Rb} / \mathrm{Sr}$ vs. Sr/Ba. Symbols as shown in Figure 3. 
A

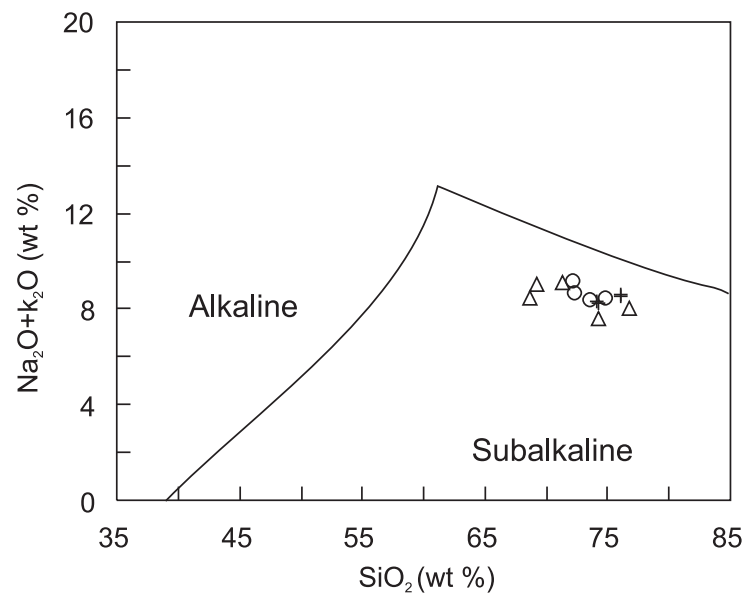

B

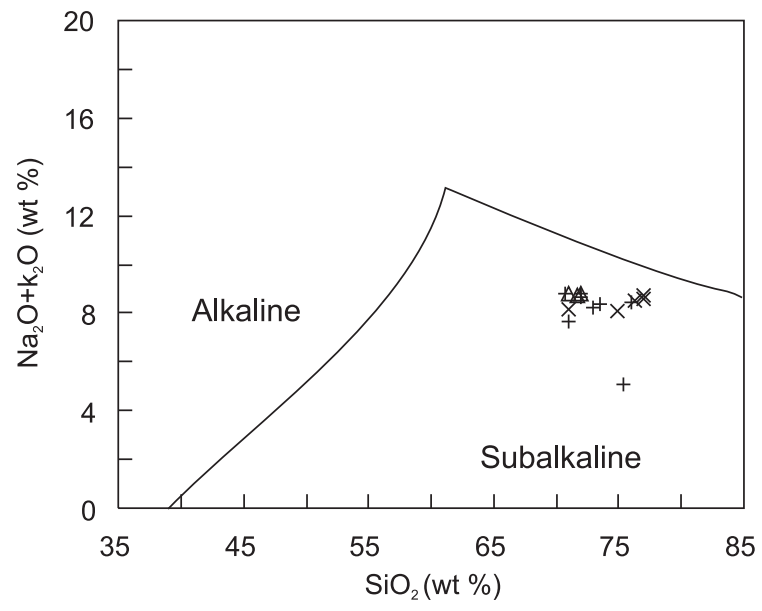

Figure 6. A. Plot of the PGC rocks (this work) in the total alkalis vs. silica diagram; modified from Middlemost (1985). Symbols as shown in Figure 3. B. Plot of PGC rocks from Litherland et al. (1986) in the total alkalis vs. silica diagram; modified from Middlemost (1985). with negative Eu anomaly. This probably reflects plagioclase and/or feldspar fractionation process (Figure 9B). They are slightly less enriched in LILE compared to the syn-to late-kinematic granitoid rocks, and also have deeper negative peaks of Sr, P and Ti reflecting once more the role of fractional crystallization (see Figure 11).

Four samples of the Diamantina granite show $\mathrm{SiO}_{2}$ content from 72 to $75 \mathrm{wt} \%$, and plot within the high-K field (Figure 7), with a peraluminous composition (Figure 8). The $\mathrm{K}_{2} \mathrm{O} / \mathrm{Na}_{2} \mathrm{O}$ ratio of the Diamantina samples varies from 1.5 to 1.8 , suggesting their pristine character. They show two different REE signatures (Figure 9): 1. samples CP0505, CP20506 and CP30507 exhibit steep patterns compared with the Piso Firme, San Cristobal and Porvenir granitoid rocks. This is related with the LREE high contents and depletion in HREE, probably reflecting amphibole fractionation and/or allanite; 2. sample ME0508 shows "gull wingshaped" REE pattern with moderate negative Eu anomaly, typical of differentiated granites (Figure 9C). In the multi-element diagrams, the samples show a pattern similar to the syn- to late-kinematic plutons (see Figure 10) with the negative peaks of $\mathrm{Sr}, \mathrm{P}$, and $\mathrm{Ti}$ which are interpreted as due to fractionation of mica, feldspar, apatite, and Ti phases (Figure 11C).

\section{$\mathrm{Nd}-\mathrm{Sr}$ isotopes}

The $\mathrm{Nd}$ and $\mathrm{Sr}$ isotopic parameters of the investigated PGC rocks were recalculated according as reference SHRIMP U/Pb age of $1.33 \mathrm{Ga}$ (zircon rims) reported for the San Rafael granite, and interpreted as the emplacement age (Boger et al., 2005).

The Sm-Nd whole rock analyses for the syn- to latekinematic granitoid rocks yielded "normal" crustal (plutonic rocks) $f_{\mathrm{Sm} / \mathrm{Nd}}$ ratios of -0.28 (San Martin) and -0.42 to -0.50 (La Junta). Their $\mathrm{T}_{\mathrm{DM}}$ model ages are $1.67 \mathrm{Ga}$ and in the range 1.87 to $2.04 \mathrm{Ga}$, respectively (Table 4). The $\varepsilon_{\mathrm{Nd}(133 \mathrm{Ga})}$ value for the San Martin granite is +1.8 whereas the La Junta samples show contrasting negative values between -2.9 to -4.3 (Table 4). The late- to post kinematic San Cristobal, Porvenir and Piso Firme plutons show roughly comparable $f_{\mathrm{Sm} / \mathrm{Nd}}$ ratios $(-0.31$ and -0.25$)$, similar $\mathrm{T}_{\mathrm{DM}}$ model ages $(1.6$ to $1.7 \mathrm{Ga})$ and positive $\varepsilon_{\mathrm{Nd}(1.33 \mathrm{Ga})}$ values of +2.7 to +1.5 (Table 4 ). In contrast, the Diamantina granite displays variable $\mathrm{T}_{\mathrm{DM}}$ model ages between 1.6 and $1.9 \mathrm{Ga}\left(f_{\mathrm{Sm} / \mathrm{Nd}}\right.$ ratios between -0.50 and -0.25$)$, and $\varepsilon_{\mathrm{Nd}(1.33 \mathrm{Ga})}$ values from +0.4 to -1.2 . As such, the $\varepsilon_{\mathrm{Nd}(1.33 \mathrm{Ga})}$ signatures are consistent with mixing of mantle derived and short crustal residence components (e.g., Paleoproterozoic) in the petrogenetic process. This idea agrees well with the variable $\mathrm{Nd}$ contents (22 to $100 \mathrm{ppm}$ ) of the studied samples (see Table 4). 
A

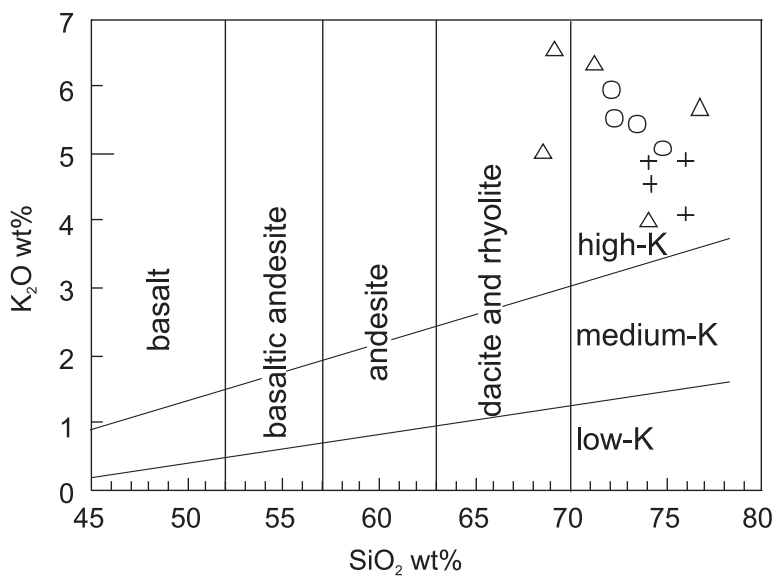

B

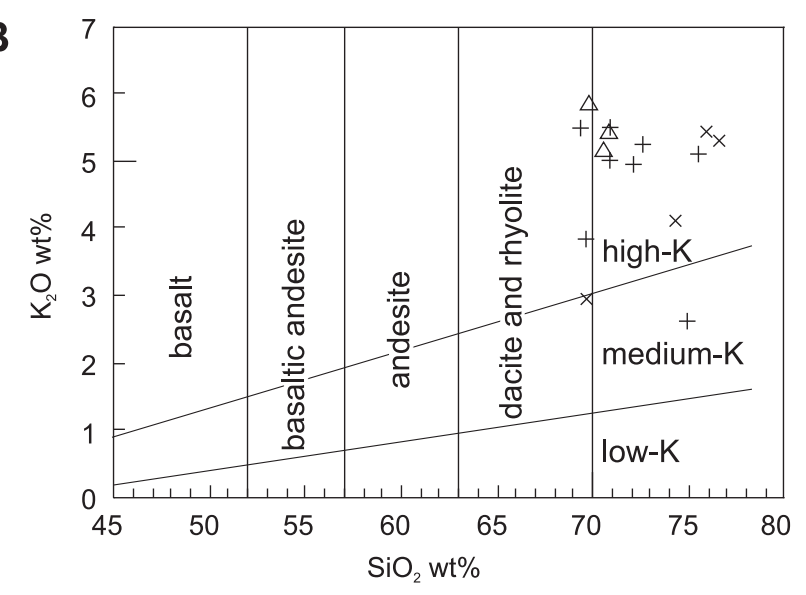

Figure 7. A. Plot of PGC rocks in the $\mathrm{K}_{2} \mathrm{O} w+\%$ vs. $\mathrm{SiO}_{2} \mathrm{wt} \%$ diagram of Le Maitre (2002). Symbols as shown in Figure 3. B. Plot of PGC rocks reported by Litherland et al. (1986) in the $\mathrm{K}_{2} \mathrm{O}$ wt\% vs. $\mathrm{SiO}_{2}$ wt\% diagram of Le Maitre (2002).
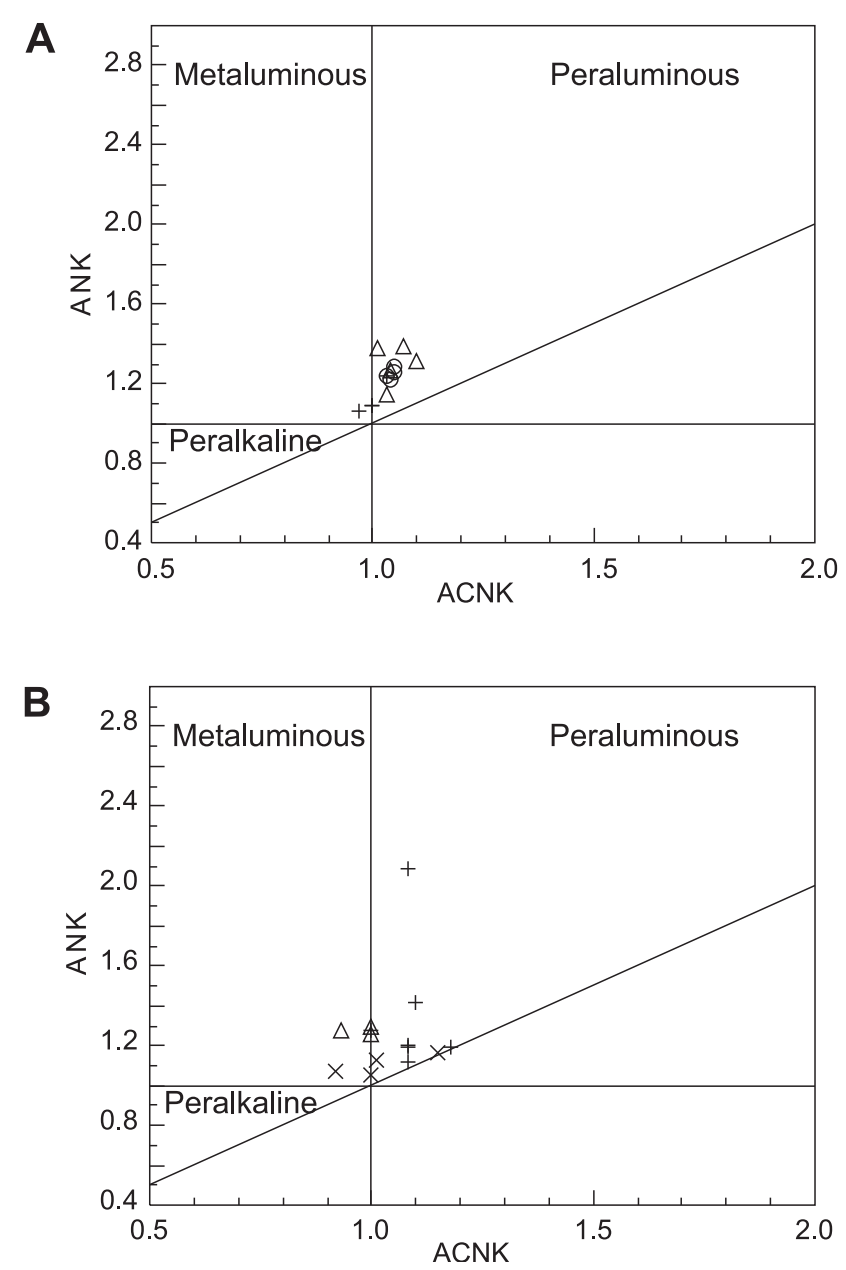

Figure 8. A. Alumina saturation diagram of Maniar and Piccoli (1989) for rocks of PGC. Symbols as shown in Figure 3. B. Alumina saturation diagram, after Maniar and Piccoli (1989) for PGC rocks (gray field), as reported by Litherland et al. (1986). 
A

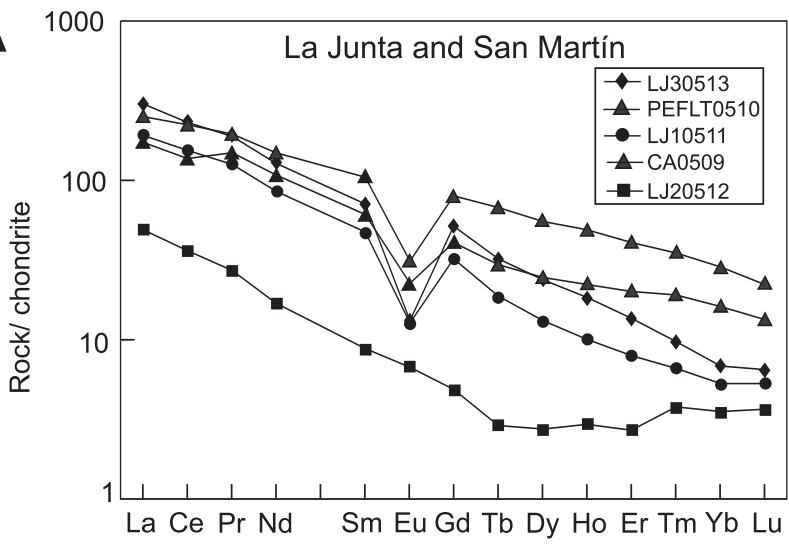

B

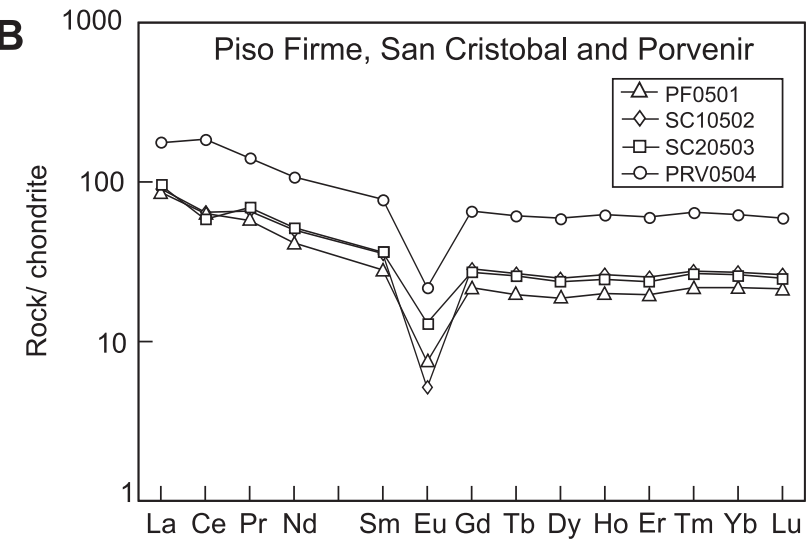

\section{C}

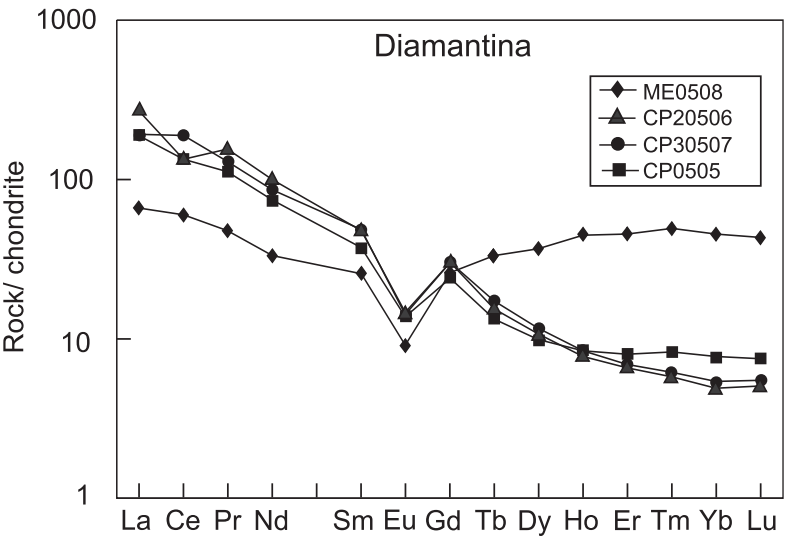

Figure 9. Chondrite-normalized REE paterns of the PGC. A. Syn- to late-kinematic granitoids (La Junta and San Martin). B. Late- to post-kinematic granitoids (San Cristobal and Porvenir and Diamantina granites and Piso Firme Granophyre). C. Diamantina Granite 10c. Normalized values are from Taylor and McLennan (1985).
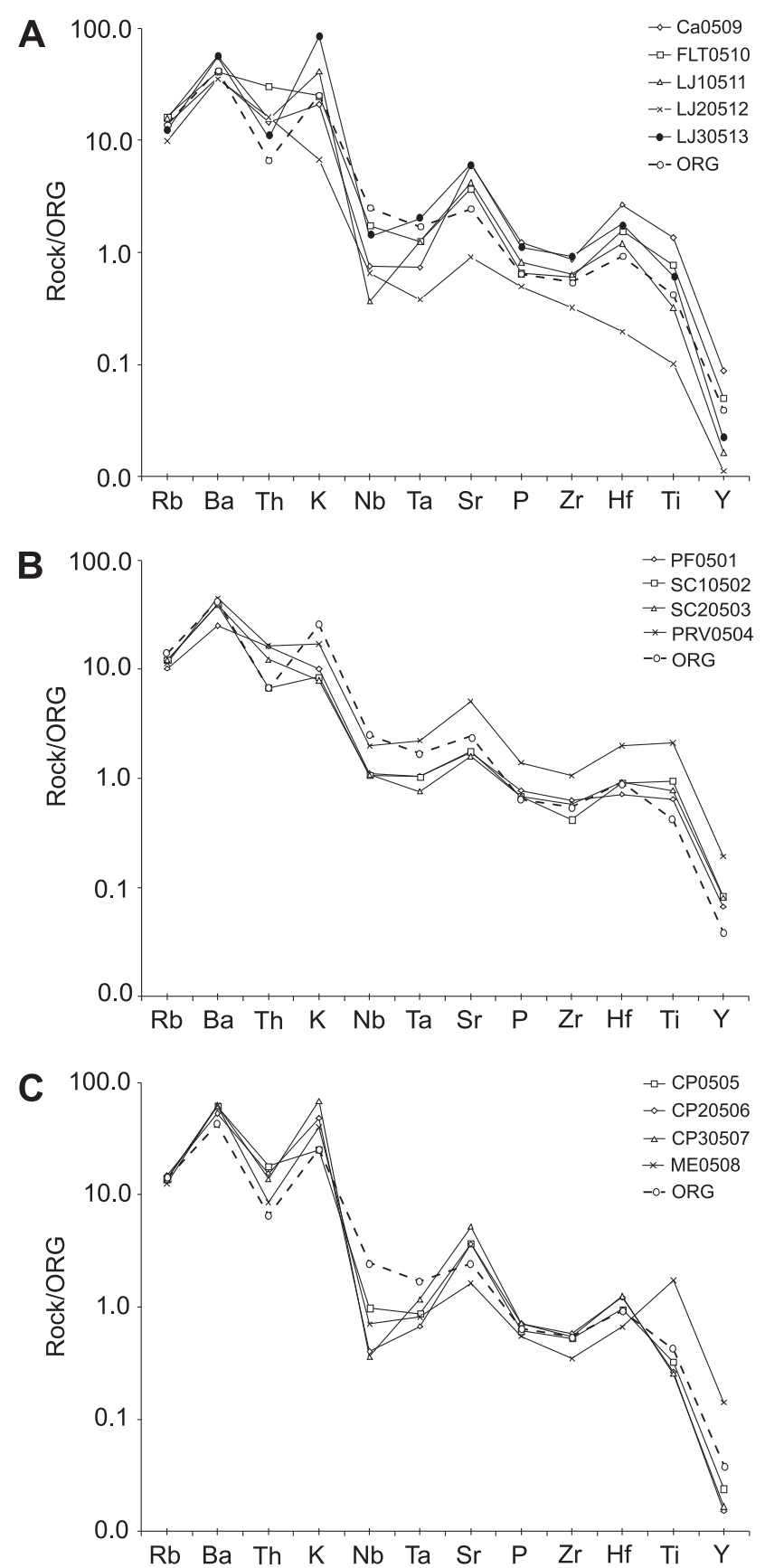

Figure 10. Trace element concentrations normalized to the ORG composition. A. Syn- to late-kinematic granitoids (La Junta and San Martin). B. Late- to post-kinematic granitoids (San Cristobal and Porvenir granites and Piso Firme granophyre). C. Late- to post-kinematic Diamantina granite. Normalizing values are from Pearce et al. (1984). 
A

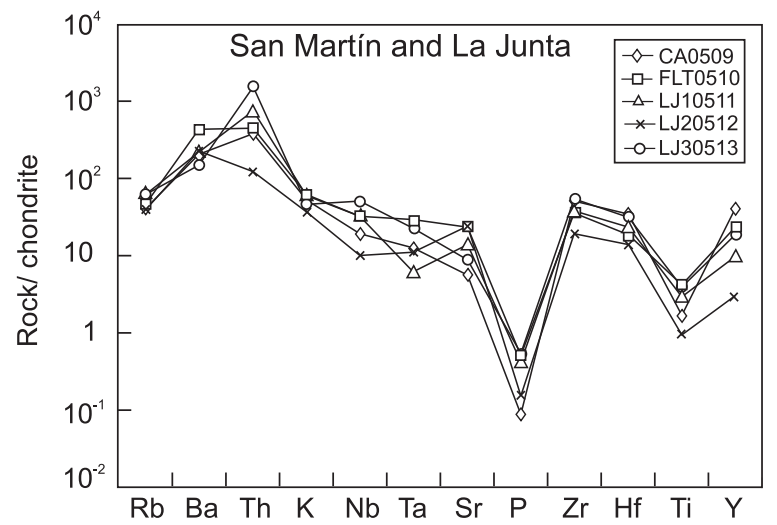

B

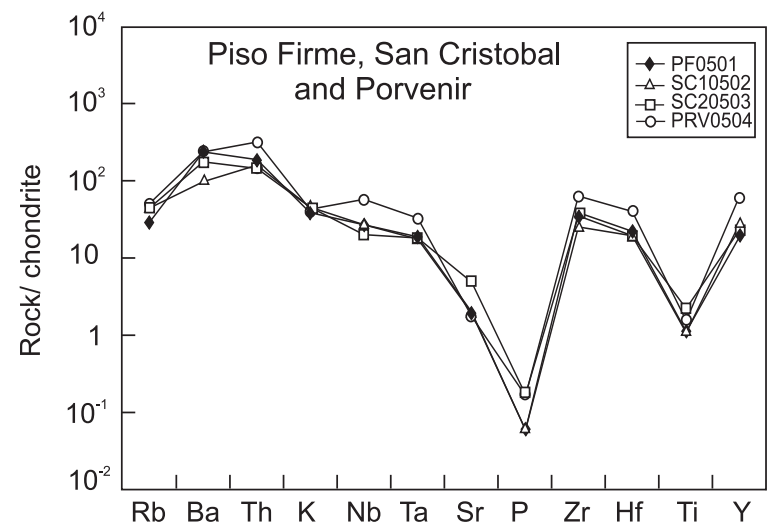

C

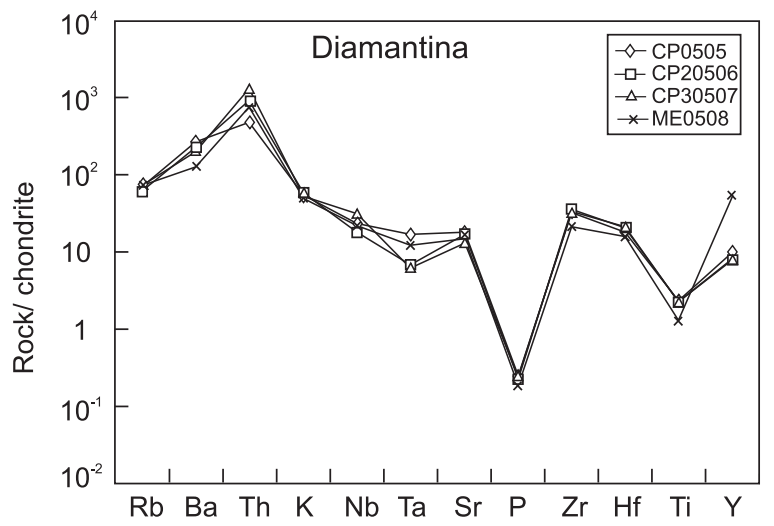

Figure 11. Trace element concentrations normalized to the composition of chondritic meteorites. The data are plotted from left to right according with the increasing compatibility to PGC samples. A. Syn- to late-kinematic granitoids (La Junta and San Martin). B. Late- to post-kinematic granitoids (San Cristobal and Porvenir granites and Piso Firme Granophyre). C. Diamantina Granite. Normalized values are from Taylor and McLennan (1985).
Figure 12 provides additional clues for the petrogenetic inferences of the PGC samples by recalculating the $\varepsilon_{\mathrm{Nd}(t)}$ value and ${ }^{87} \mathrm{Sr} /{ }^{86} \mathrm{Sr}$ ratios for the $1.33 \mathrm{Ga}$ reference age (see Table 5). However, some samples of the late- to posttectonic plutons (PF0501, PRV0504, CP30507) indicated spurious ${ }^{87} \mathrm{Sr} /{ }^{86} \mathrm{Sr}_{t}$ reference values $(<0.701)$ and were not further considered herein because the clear disturbance of their isotopic systems.

The correlation diagram discriminates different isotopic fields for the PCG rocks. The syn- to late-kinematic La Junta and San Martin samples yield ${ }^{87} \mathrm{Sr}^{86}{ }^{86} \mathrm{Sr}_{\mathrm{t}}$ ratios from 0.704 to 0.706 , show predominantly negative $\varepsilon_{\mathrm{Nd}(t)}$ values (up to -4.3), and plot close to Bulk Earth. This reinforces the role of heterogeneous sources in their origin in an arc setting. The late- to post-kinematic plutons show two distinct signatures, combined a larger variation in ${ }^{87} \mathrm{Sr}^{86}{ }^{86} \mathrm{Sr}_{\mathrm{t}}$ ratios (from 0.702 to 0.707 ). The first group exhibits ${ }^{87} \mathrm{Sr}^{\mathrm{t}}{ }^{86} \mathrm{Sr}_{\mathrm{t}}$ ratios from 0.702 to 0.707 and $\varepsilon_{\text {Nd(1.33Ga) }}$ values from +1.48 to +2.75 . The second group (Diamantina) shows ${ }^{87} \mathrm{Sr} r{ }^{86} \mathrm{Sr}_{\mathrm{t}}$ values from 0.702 to 0.704 , and $\varepsilon_{\text {Nd(1.33Ga) }}$ values from +0.39 to -1.25 (Figure 12, Tables 4 and 5). The San Cristobal and Diamantina (CP0505) samples preserve the most juvenile signatures among the investigated PGC rocks. The signature implies again to the important role of Mesoproterozoic mantle sources in the petrogenesis, in agreement with an intra-oceanic arc setting.

The fact that these late- to post-kinematic intrusions are sharply discordant in relation with the regional foliation of the country rocks, in conjunction with their distinct positive $\varepsilon_{\mathrm{Nd}(t)}$ values and youngest $\mathrm{T}_{\mathrm{DM}}$ model ages suggest that they are products from a juvenile magmatic arc. In contrast, the syn- to late-kinematic granitoid rocks (e.g., La Junta granite) have Nd isotopic signatures that are coherent with mixing sources, except for the San Martin pluton.

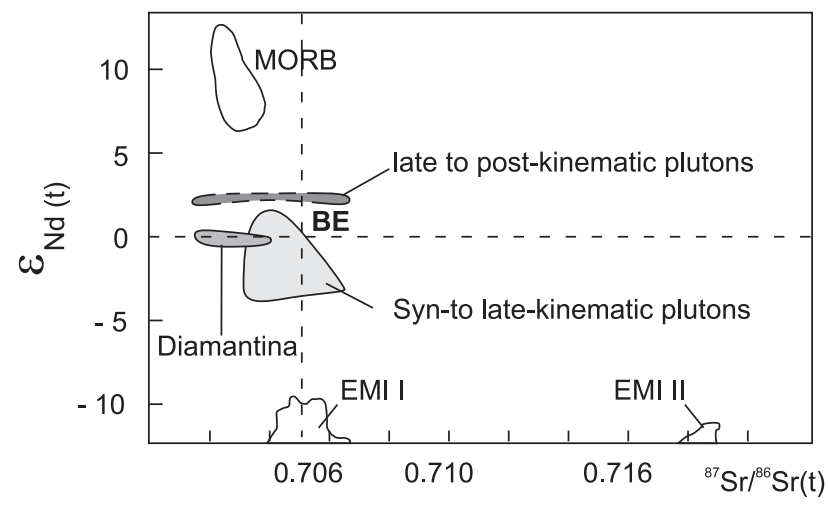

Figure 12. $\left({ }^{87} \mathrm{Sr} /{ }^{86} \mathrm{Sr}\right)_{(1.33 \mathrm{Ga})}$ vs. $\varepsilon_{\mathrm{Nd}(1.33 \mathrm{Ga})}$ correlation diagram for PGC samples. Symbols as shown in Figure 3. 


\section{DISCUSSION AND TECTONIC CORRELATION}

The PGC is formed by voluminous Mesoproterozoic syn- to late-kinematic and late- to post-kinematic granitoid events, dated between 1373 and $1340 \mathrm{Ma}$, as the SHRIMP $\mathrm{U}-\mathrm{Pb}$ evidence. Additional SHRIMP U-Pb zircon datings [Matos, in preparation (2009)] carried out in the La Junta and the Diamantina granites yielded comparable ages (1347 $\pm 21 \mathrm{Ma}$ and $1340 \pm 20 \mathrm{Ma}$, respectively), in agreement with a previous $\mathrm{Rb} / \mathrm{Sr}$ isochron age for the Diamantina pluton (Litherland et al., 1986) - whereas the San Martin Granite yielded a significantly older SHRIMP zircon age (1373 \pm $20 \mathrm{Ma}$ ). As such the geochronologic work provides new insights for the timing of the syn- to late tectonic phases of the San Ignacio Orogeny, in Bolivia. It is noteworthy that additional SHRIMP U-Pb zircon ages (Boger et al., 2005; Santos et al., 2006, 2008) for the basement rocks (Lomas Maneches and Chiquitania units) in the range $1.34-1.32 \mathrm{Ga}$ revealed metamorphic overprints associated with the San Ignacio Orogeny and also with coeval magmatic and deformational events in the Brazilian counterpart.

The PGC rocks display $\mathrm{Nd}-\mathrm{Sr}_{(\mathrm{t})}$ signatures that suggest that different sources contributed to the magma genesis of the plutonic pulses, in coherence with the trace element compositions that reflect magmatic differentiation processes combined with crustal contamination (see above). This scenario is consistent with the onset of successive magmatic arcs culminating with continental collision of the PGC (at ca. $1.33 \mathrm{Ga}$ ) against the Rio Negro-Juruena Province, as proposed for the Mesoproterozoic evolution of the SW Amazonian craton (e.g., Boger et al., 2005; Cordani and Teixeira, 2007).

The syn- to late-kinematic La Junta granite has ${ }^{87} \mathrm{Sr} /{ }^{86} \mathrm{Sr}_{t}$ ratios of 0.704 to 0.706 , the oldest $\mathrm{T}_{\mathrm{DM}}$ ages $(1.9-2.0 \mathrm{Ga})$ and negative $\varepsilon_{\mathrm{Ndt}}$ values (-2.9 to -4.3$)$, as previously delineated by Darbyshire (2000). Such isotopic features favor again the hypothesis of significant contribution of crustal material in the petrogenetic process, supported by the recognized negative $\mathrm{Nb}$ and $\mathrm{Ta}$ anomalies in the studied samples, as well as by the plot of the samples near the boundary "within plate-volcanic arc granite fields" in the Pearce' Diagram (Figure 13). Furthermore, the syn- to late-kinematic plutons are associated with gneisses and migmatites, but do not contain basic xenoliths (Hawkins, 1982; Litherland, 1981; this work). This suggests that they are products from partial melting of the lower crust, as discussed by Nardi and Bonin (1991) on the basis of petrogenetic inferences from Proterozoic granites in southern Brazil.

The late- to post-kinematic Porvenir, San Cristobal, Piso Firme intrusions displayed $\varepsilon_{\mathrm{Ndt}}$ values from +2.7 to $+1.5 ; \mathrm{T}_{\mathrm{DM}}$ ages from 1.6 to $1.7 \mathrm{Ga}$, and ${ }^{87} \mathrm{Sr} /{ }^{86} \mathrm{Sr}_{t}$ ratios between 0.702 and 0.706. In addition, Darbyshire (2000) reported signifi- cant positive $\varepsilon_{\mathrm{Ndt}}$ values of +3.3 and +3.9 for the Piso Firme granophyre with $\mathrm{T}_{\mathrm{DM}}$ ages of 1.5 and $1.6 \mathrm{Ga}$. The isotopic signatures agree well with the observed $\mathrm{Sr}, \mathrm{P}$ and Ti negative peaks that are characteristics of fractional crystallization. This process is similarly envisaged from the presence of intermediate compositions of the late- to post-kinematic rocks (quartz monzonites to quartz syenites and syenogranites). The lower alkaline contents $\left(\mathrm{Na}_{2} \mathrm{O}+\mathrm{K}_{2} \mathrm{O}<8.5\right)$ are otherwise commonly seen in mantle derived rocks of arc settings. In the Pearce' diagram (Figure 13) the late- to post-kinematic samples fall in the within plate field (Porvenir, San Cristobal, Piso Firme). In contrast the Diamantina samples plot mainly within the "volcanic arc field" whereas they show ${ }^{87} \mathrm{Sr} /{ }^{86} \mathrm{Sr}_{\mathrm{t}}(0.702$ to 0.704$)$ and $\varepsilon_{\mathrm{Ndt}}$ values $(+0.4$ to -1.2$)$ close to Bulk Earth (Figure 12). From the above signatures these plutons probably derived from mixtures among MORB-like magmas and isotopically homogeneous protholiths.

Petrogenetic models to explain the generation of felsic magmas, as the case of PGC, may be considered into two broad categories (Riley et al., 2001). The first assumption advocates that felsic magmas are derived from mafic parent magma by fractional crystallization or assimilation combined with fractional crystallization (AFC). This process is often suggested for small magma batches for generating large volumes of felsic magma, when unreasonably large amounts of basalt must be crystallized. Nevertheless, an alternative model, in which mafic magmas provide heat for the partial melting of crustal rocks, is considered more appropriate for large volume felsic magma bodies, likewise the case of the PGC.

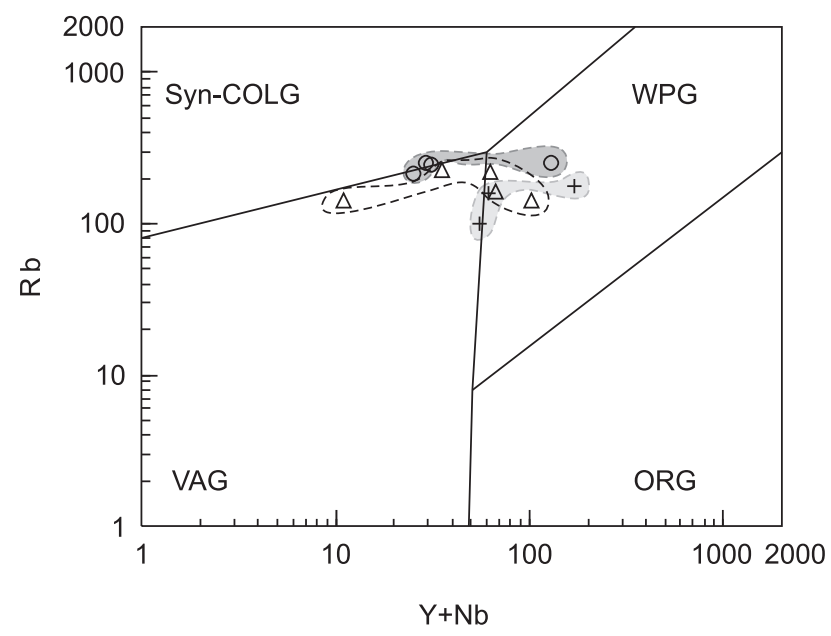

Figure 13. The $\mathrm{Rb}$ vs. $(\mathrm{Y}+\mathrm{Nb})$ discrimination diagram for PGC granites (after Pearce et al., 1984) showing the fields of syn-collisional granites (syn-COLG), within-plate granites (WPG), volcanic-arc granites (VAG) and ocean-ridge granites (ORG). Symbols as shown in Figure 3. 
From the above, the integrated geological, geochemical and isotopic data suggest that the La Junta plutons (syn- to late-kinematic) resemble I-Caledonian type granites (e.g., Pitcher, 1993; Cobbing, 1996; Barbarin, 1999; Roberts and Clemens, 1993), which are represented by batholiths related to infracrustal melts linked with subduction of oceanic lithosphere beneath the more stable foreland. In contrast, most of the investigated late- to post-kinematic rocks originated predominantly from juvenile sources as suggested by the $\mathrm{Nd} / \mathrm{Sr}_{(\mathrm{t})}$ signatures, geochemistry and the observed primary hornblende. According to Chappell and White (2001) I-type suites range from metaluminous, hornblende-bearing granites to very weakly peraluminous rocks that contain biotite as the only ferromagnesian mineral.

The rocks of the PGC display roughly similar geochemistry to the Colorado Complex that occurs in the Brazilian counterpart. Major and trace elements data in PGC samples (Litherland et al., 1986) display regular trends of decreasing $\mathrm{Al}_{2} \mathrm{O}_{3}, \mathrm{MgO}, \mathrm{CaO}$ and $\mathrm{Fe}_{2} \mathrm{O}_{3 \text { Tot }}$ with increasing $\mathrm{SiO}_{2}$ contents. They are similarly sub-alkaline to high-K calc-alkaline, and metaluminous to peraluminous in composition. A similar chemical tendency is displayed by the contemporary syn-kinematic Igarapé Enganado Intrusive Suite, and the post-kinematic Alto Escondido Intrusive Suite of the Colorado Complex, in Rondônia, Brazil (Rizzotto and Quadros, 2007). On the other hand, the Diamantina granite shows high LREE fractionation pattern, and subhorizontal tendency of HREE with negative Eu anomalies which is similarly seen again by the granitoid suites of the Colorado Complex.

The Nd isotopic features of the Colorado felsic-mafic intrusions (Teixeira et al., 2006; Rizzotto and Quadros, 2007) - $\mathrm{T}_{\mathrm{DM}}$ model ages between 1.5 to $1.6 \mathrm{Ga}$ and $\varepsilon_{\mathrm{Nd}(\mathrm{t})}=+2.3-$ compares well with that of the San Martin and Piso Firme plutons; they are distinct from the La Junta isotopic features (see above). However, such a petrogenetic complexity may be expected in accretionary belts, in agreement with the tectonic framework of SW Amazonian Craton. In this respect, the late- to post-kinematic granitoids, including the Diamantina granite indicate juvenile- and crustal-like $\mathrm{Nd}$ signatures and show chemical features that are suggestive of differentiation from tonalites to alkali-feldspar granites. This strongly supports once more a plutonic arc setting for the origin of the Diamantina pluton in which a "fertilized" mantle source would be envisaged. If this is correct, the Porvenir, San Cristobal, Diamantina and Piso Firme granitoid rocks would display the most "primitive" signatures of such plutonic episodes among the PGC rocks investigated here. Furthermore, these late- to post- kinematic granitoid are comparable in age with the Alto Candeias Intrusive Suite (U-Pb ages of $1346 \mathrm{Ma}$ and $1338 \mathrm{Ma}$ ) in Rondônia (Bettencourt et al., 1999; Payolla et al., 2002). Moreover, the PGC granitoid rocks present negative values of $\mathrm{Nb}, \mathrm{Sr}$ and $\mathrm{Ti}$ whereas they show $\mathrm{Rb}, \mathrm{Ba}$ and $\mathrm{Th}$ enriched relative to $\mathrm{Nb}$ (Litherland et al., 1986). This is again a typical feature of magmas evolved in magmatic arcs.

Finally, according with the scenario for collisional orogenies envisaged by Condie (1997) we suggest that the PGC resulted from island arc evolution with the intervening Paraguá Craton, and further collision with the Rio Negro-Juruena Province. If this is true, the PGC rocks together with coeval igneous suites (e.g., Colorado Complex, Alto Candeias Intrusive Suite) represents the onset of the ultimate stage of the Rondonian-San Ignacio orogeny (Cordani and Teixeira, 2007), considered here as the major magmatic and metamorphic event that gave rise to the Rondonian-San Ignacio province.

\section{ACKNOWLEDGEMENTS}

Ramiro Matos thanks to CAPES (Coordenação de Aperfeiçoamento de Pessoal de Nível Superior) for the financial support for his Phd project. Wilson Teixeira, Mauro C. Geraldes and Jorge S. Bettencourt greatly acknowledge the support of CNPq (Conselho Nacional de Desenvolvimento Científico e Tecnológico, Brazil; grant \# 470373/2004-0). We sincerely thank to the reviewers for their suggestions that greatly improved the early version of the manuscript.

\section{REFERENCES}

BARBARIN, B. A review of the relationships between granitoid types, their origins and their geodynamic environments. Lithos, v. 46, p. 605-626, 1999.

BETTENCOURT, J. S.; TOSDAL, R. M.; LEITE, W. B. JR.; PAYOLLA, B. L. Mesoproterozoic rapakivi granites of the Rondônia Tin Province, southwestern border of the Amazonian craton, Brazil-I. Reconnaisance U-Pb geochronology and regional implications. Precambrian Research, v. 95, n. 1-2, p. 41-67, 1999.

BOGER, S. D.; RAETZ, M.; GILES, D.; ETCHART, E.; FANNING, M. C. U-Pb age data from the Sunsás region of Eastern Bolivia, evidence for the allochtonous origin of the Paraguá Block. Precambrian Research, v. 139, p. 121-146, 2005.

COBBING, J. Granites- an overview. Episodes, v. 19, n. 4, p. 103-106, 1996.

CONDIE, K. C. Plate tectonics and crustal evolution. 4. th ed. Butterworth: Oxford. 1997. 282 p. 
CORDANI, U. G.; SATO, K.; TEIXEIRA, W.; TASSINARI, C. C. G.; BASEI, M. A. S. Crustal evolution of the South American Platform. In: INTERNATIONAL GEOLOGIC CONGRESS, 31., 2000. Rio de Janeiro. Tectonic evolution of South America... Rio de Janeiro, 2000. p. 19-40.

CORDANI, U. G.; TEIXEIRA, W. Proterozoic accretionary belts of the Amazonian Craton. In: HATCHER, R.D. Jr., CARLSON, M. P., MCBRIDE, J. H. ; MARTINEZ CATALÁN, J. R. (Org.). The 4D Framework of Continental Crust. Boulder, Colo.: Geological Society of America, 2007. p. 297-320. (Memoir. v. 200).

CHAPPELL, B.W.; WHITE, A.J.R. Two contrasting granite types: 25 years later. Australian Journal of Earth Sciences, v. 48, p. 489-499, 2001.

DARBYSHIRE, D. P. F. The Precambrian of Eastern Bolivia - a Sm-Nd isotope study. In: INTERNATIONAL GEOLOGIC CONGRESS, 31., 2000, Rio de Janeiro. Abstract Volume ...Rio de Janeiro: CPRM , 2000. 1 CD-ROM.

DEPAOLO, D. J. A neodymium and strontium isotopic study of Mesozoic calc-alkaline granitic batholiths of of the Sierra Nevada and Peninsular Ranges, California. Journal Geophysical Research, v. 86, n B11, p. 10470-10488, 1981.

FITCH, F. J. Macro point counting. The American Mineralogist, v. 44, p. 667-669, 1959.

GERALDES, M. C.; VAN SCHMUS, W. R.; CONDIE, K. C.; BELL, S.; TEIXEIRA, W.; BABINSKI, M. Proterozoic geologic evolution of SW part of the Amazonian craton in Mato Grosso State, Brazil. Precambrian Research, v. 111, p. 91-128, 2001.

HAWKINS, M. P. The geology and mineral potential of the Manomó area (Part of quadrangle SD 20-16). Santa Cruz de la Sierra: British Geological Survey/Servicio Geológico de Bolivia, 1982. 105 p. (Informe, 13).

KLINCK, B. A.; O'CONNOR, E. A. The geology and mineral potential of the Perseverancia and Monte Verde areas (Quadrangles SD 20-15 and SD 20-11). Santa Cruz de la Sierra: British Geological Survey/Servicio Geológico de Bolivia, 1983. 178 p. (Informe, 11).

LE MAITRE, R. W. (Ed.). Igneous rocks: a classification and glossary terms. 2. ed. Cambridge: Cambridge University Press., 2002. 236 p.
LITHERLAND, M. The geology and mineral potential of the Huanchaca area (Parts of Quadrangles SD 20-15 and SD 20-11). Santa Cruz de la Sierra: British Geological Survey/Servicio Geológico de Bolivia, 1982. 173 p. (Informe, 10).

LITHERLAND, M.; BLOOMFIELD, K. The Proterozoic history of Eastern Bolivia. Precambrian Research, v. 15. p. 157-179, 1981.

LITHERLAND, M.; KLINCK, B. A. Introducing the terms "Paraguá Craton" and "Pensamiento Granitoid Complex" for use in sheet reports. Santa Cruz de la Sierra: British /Servicio Geológico de Bolivia, 1982. (Informe, ML/37).

LITHERLAND, M.; ANNELLS, R. N.; APPLETON, J. D.; BERRRANGÉ, J. P.; BLOOMFIELD, K.; BURTON, C. C. I.; DARBYSHIRE, D. P. F.; FLETCHER, C. J. N.; HAWKINS. M. P.; KLINCK, B. A.; LLANOS, A.; MITCHELL, W. I.; O'CONNOR. E. A.; PITFIELD. P. E. J.; POWER, G.; WEBB, B. C. The geology and mineral resources of the Bolivian Precambrian Shield. Overseas Memoir/ British Geological Survey, London, v. 9, p. 1-153, 1986.

LITHERLAND. M.; ANNELLS, R. N.; DARBYSHIRE, D. P .F.; FLETCHER, C .J .N.; HAWKINS, M. P.; KLINCK, B. A.; MITCHELL, W. I.; O'CONNOR, E. A.; PITFIELD. P. E. J.; POWER, G.; WEBB, B. C. The Proterozoic of Eastern Bolivia and its relationship to the Andean mobile belt. Precambrian Research, v. 43, p. 157-174, 1989.

MATOS, R.; TEIXEIRA, W.; GERALDES, M. C.; CORDANI, U. G.; BETTENCOURT, J. S. U-Pb and Sm-Nd constraints to the evolution of Bolivian Precambrian terranes. (in preparation).

MANIAR, P. D.; PICOLLI, P. M. Tectonic discrimination of granitoids. Geological Society of America Bulletin, v. 101, p. 635-643, 1989.

MIDDLEMOST, E. A. K. Magmas and magmatic rocks. London: Longman, 1985. 352 p.

NARDI, L. V. S.; BONIN, B. Post-orogenic and nonorogenic alkaline granite associations:the saibro intrusive suite, southern Brazil- A case study. Chemical Geology, v. 92, p. 197-211, 1991.

NAVARRO, M. S. A implantação de rotina, e seu refinamento, para a determinação de elementos terras raras 
em materiais geológicos por ICP-OES e ICP-MS: aplicação ao caso dos granitóides de Piedade-Ibiúna (SP) e Cunhaporanga (PR). SP. 2004. 132 f. Dissertação (Mestrado) - Instituto de Geociências, Universidade de São Paulo, São Paulo.

PAYOLLA, B. L.; BETTENCOURT, J. S.; KOSUCH, M.; LEITE, W. B. JR.; FETTER, A. H.; VAN SCHMUS, W. R. Geological evolution of the basement rocks in the east-central part of the Rondônia Tin province, SW Amazonian craton, Brazil: U-Pb and Sm-Nd isotopic constraints. Precambrian Research, v. 119, p. 141-169. 2002.

PEARCE. J. A. ; HARRIS N. B. W.; TINDLE, A. G. Trace elements discrimination diagrams for the tectonic interpretation of granitic rocks. Journal of Petrology, v. 25 n. 4, p. 956-983, 1984.

PITCHER, W. S. The nature and origin of granite. New York: Blackie Academic and Professional, 1993. 321 p.

PITTFIELD, P. E. J. The geology and mineral potential of the Puerto Villazón area (Quadrangles SD 20-7 and SD 20-3). British Geological Survey/Servicio Geológico de Bolivia. Santa Cruz de la Sierra. 1983. 181 p. (Informe, 15).

RILEY, T. R.; LEAT, P. T.; PANKHURST, R. J.; HARRIS, C. Origin of large volume rhyolitic volcanism in the Antartic Peninsula and Patagonia by crustal melting. Journal of Petrology, v. 42, p. 1043-1065, 2001.

RIZZOTTO, G. J.; BETTENCOURT, J. S.; TEIXEIRA, W.; PACCA, I. I. G.; D'AGRELLA-FILHO, M. S.; VASCONCELOS, P.; BASEI, M. A. S.; ONOE, A.; PASSARELLI, C. R. Geologia e geocronologia da Suíte Metamórfica Colorado e suas encaixantes, SE Rondônia: implicações para a evolução Mesoproterozóica do SW do Craton Amazônico. Geologia USP. Série Científica, v. 2, p. 41-55, 2002.

RIZZOTTO, G. J.; QUADROS, M. L. E. S. Margem Passiva e Granitos Orogênicos do Ectasiano em Rondônia. In: SIMPÓSIO DE GEOLOGIA DA AMAZÔNIA, 10., 2007, Porto Velho. Anais eletrônico... Porto Velho: SBG-Núcleo Norte, 2007. 1 CD-ROM.

ROBERTS, M. P.; CLEMENS, J. D. Origin of high-potassium, calc-alkaline, I-type granitoids. Geology, v. 21, p. 825-828, 1993.

SADOWSKI, G. R.; BETTENCOURT, J. S. Mesoproterozoic tectonic correlations between eastern Laurentia and the western border of the Amazonian Craton. Precambrian Research, v. 76, p. 213-227, 1996.

SANTOS, J. O. S.; MCNAUGHTON, N. J.; MATOS, R.; HARTMANN, L. A.; POTTER, P. E.; FLETCHER, I. R., 2006. The Four Main Orogenies within the Autochthonous Mesoproterozoic Sunsás Province in SW Amazon Craton. In: CONGRESO GEOLÓGICO DE BOLIVIA, 17., 2006, Sucre: Resumenes... Sucre, 2006, p. 1-4.

SANTOS, J. O. S.; MCNAUGHTON, N. J.; HARTMANN, L. A.; FLETCHER, I. R.; MATOS, R. S. The age of deposition of the Aguapeí Group, western Amazonian Craton, based on $\mathrm{U}-\mathrm{Pb}$ study of diagenetic xenotime and detrital zircon. In: CONGRESO LATINOAMERICANO DE GEOLOGÍA, 12., 2005, Quito. Actas... Quito, 2005.

SANTOS, J. O. S.; RIZZOTTO, G. J.; MCNAUGHTON, N. J.; MATOS, R.; HARTMANN, L. A.; CHEMALE Jr., F.; POTTER, P. E.; QUADROS, M. L. E. S. Age and autochthonous evolution of the Sunsás Orogen in West Amazon Craton based on mapping and U-Pb geochronology. Precambrian Research, v. 165, p. 120-152, 2008.

SATO, K.; TASSINARI, C. C. G.; KAWASHITA, K.; PETRONHILO, L. O Método Geocronológico Sm-Nd no IGc/USP e suas aplicações. Anais da Academia Brasileira das Ciências, v. 67, p. 313-336, 1995.

SATO, K.; TASSINARI, C. C. G. Principais eventos de acreção continental no Cráton Amazônico baseados em idade modelo Sm-Nd, calculada em evoluçoes de estágio único e estágio duplo. In: COSTA, M.L.; ANGELICA, R.S., (Eds.). Contribuções à Geologia da Amazônia. Belém: Sociedade Brasileira de Geologia, 1997. p. 91-142.

SPARRENBERGER, I.; BETTENCOURT, J. S.; TOSDAL, R. M.; WOODEN, J. L. Datações U-Pb convencional versus SHRIMP do Maciço Estanifero Santa Bárbara, Suite Granitos Últimos de Rondônia, Brasil. Geologia USP. Série Científica, São Paulo, v. 2, p. 79-94, 2002.

STRECKEISEN, A. To each plutonic rock, its proper name. Earth Science Review, Amsterdam, v. 12, p. 1-33, 1976.

TAYLOR, S. R.; McLENNAN, S. M. The continental crust: its composition and evolution. Oxford: Blackwell Scientific Publications, 1985. 234 p.

TASSINARI, C. C. G.; BETTENCOURT, J. S.; GERALDES, M. C.; MACAMBIRA, M. J. B.; LAFON, J. 
M. The Amazon craton. In: INTERNATIONAL GEOLOGIC CONGRESS, 31., 2000, Rio de Janeiro. Tectonic evolution of South America... Rio de Janeiro, 2000. p. 41-95.

TEIXEIRA, W.; TASSINARI, C. C. G.; CORDANI, U. G.; KAWASHITA, K. A review of the geochronology of the Amazonian Craton: tectonic implications. Precambrian Research, v. 42, p. 213-227. 1989.

TEIXEIRA, W.; BETTENCOURT, J. S.; GIRARDI, V. A. V.; ONOE, A.; SATO, K.; RIZZOTTO, G. J. Mesoproterozoic mantle heterogeneity in the SW Amazonian Craton: ${ }^{40} \mathrm{Ar} /{ }^{39} \mathrm{Ar}$ and $\mathrm{Nd}-\mathrm{Sr}$ isotopic evidence from mafic- felsic rocks. In: HANSKI, E.; MERTANEN, S.; RÄMÖ, T.; VUOLLO, J.(Eds). Dyke swarms - Time Markers of Crustal Evolution. London: Taylor \& Francis, 2006. p. 113-130.

TEIXEIRA, W., CORDANI, U. G. Proterozoic evolution of the Amazonian Craton reviewed. Special volume of the Indian Conference on Global Scenario. World Scientific. 2009 (in press).

TOHVER, E.; VAN DER PLUIJM, B. A.; VAN DER VOO, R.; RIZZOTTO, G.; SCANDOLARA, J. E. Paleogeography of the Amazon Craton at $1.2 \mathrm{Ga}$ : early Grenvillian collision with the Llano segment of Laurentia. Earth Planetary Sciences Letters, v. 199, p. 185-200, 2002.

TOHVER, E.; BETTENCOURT, J. S.; TOSDAL, R.; MEZGER, K.; LEITE. W. B.; PAYOLLA, B. L. Terrane transfer during the Grenville orogeny: tracing the Amazonian ancestry of southern Appalachian basement through $\mathrm{Pb}$ and $\mathrm{Nd}$ isotopes. Earth Planetary Science Letters, v. 228, p. 161-176, 2004a.

TOHVER, E.; VAN DER PLUIJM, B. A.; MEZGER, K.; ESSENE, E.; SCANDOLARA, J. E. Significance of the Nova Brasilândia metasedimentary belt in Western Brazil: redefining the mesoproterozoic boundary of the Amazon Craton. Tectonics, v. 23, TC6004, 2004b. doi: 10.1029/2003TC001563.

TOHVER, E.; VAN DER PLUIJM, B. A.; MEZGER, K.; SCANDOLARA, J. E.; ESSENE, E. Two stage history of the SW Amazon Craton in the late Mesoproterozoic: identifying a cryptic suture zone. Precambrian Research, v. 137 , p. $35-59,2005 a$.

TOHVER, E.; VAN DER PLUIJM, B. A.; SCANDOLARA, J. E.; ESSENE, E. Late Mesoproterozoic deformation of SW Amazonia (Rondônia, Brazil): geochronolog- ical and structural evidence for collision with southem Laurentia. Geology, v. 113, p. 309-324, 2005 b.

TOHVER, E.; TEIXEIRA, W.; VAN DER PLUIJM, B. A.; GERALDES, M. C.; BETTENCOURT, J. S.; RIZZOTTO, G. Restored transect across the exhumed Grenville orogen of Laurentia and Amazonia, with implications for crustal architecture. Geology, v. 34, p. 669-672, 2006. 
Appendix A. Petrographic description of the Pensamiento Granitoids Complex rocks.

\begin{tabular}{|c|c|c|}
\hline Sample & Pluton & Main characteristics \\
\hline PF0501 & Piso Firme & $\begin{array}{l}\text { Medium-fine grained, pinkish brown, massive porphyry quartz syenite. The thin section } \\
\text { shows intergrowth of quartz and alkali feldspar of micrographic type and radiate fabric. } \\
\text { Subordinate anhedral quartz occurs as clusters together with isolated laths of plagioclase } \\
\text { or aggregates. Muscovite appears as scarce secondary mineral. Ferromagnesian } \\
\text { minerals were not observed. }\end{array}$ \\
\hline SC10502 & San Cristobal & $\begin{array}{l}\text { Pink medium-grained, slightly foliated monzogranite gneiss. It shows inequigranular } \\
\text { anhedral texture. It contains clusters of anhedral quartz. The K-feldspar and plagioclase } \\
\text { show variable sizes. The plagioclase (An26) and feldspar crystals form cloudy sericitised } \\
\text { surfaces. }\end{array}$ \\
\hline SC20503 & San Cristobal & $\begin{array}{l}\text { Medium-fine grained, pinkish white, banded monzogranite gneiss with small and } \\
\text { discontinuous streaky biotite. It is common an anhedral inequigranular texture. Clusters } \\
\text { of quartz are of different sizes. The microcline appears in subhedral crystal tablets. } \\
\text { Plagioclase (An27) in small crystals appears between quartz and feldspar. The biotite is } \\
\text { pale straw-yellow to dark olive-green. The spheneis principal accessory mineral. }\end{array}$ \\
\hline PRV0504 & Porvenir & $\begin{array}{l}\text { Medium-fine grained, pinkish massive syenogranite. It has an inequigranular anhedral } \\
\text { seriate texture. A granular mixture of quartz and feldspar appears with few crystals } \\
\text { of hornblende and biotite. The K-feldspar shows microcline-type twinning and forms } \\
\text { anhedral K-microperthite. Plagioclase (An29) shows albite twins, and some clusters } \\
\text { of anhedral quartz are also present. The biotite is straw yellow to pale redish brown. } \\
\text { The hornblende is green and appears as clusters associated with biotite and irregular } \\
\text { masses of opaque minerals. }\end{array}$ \\
\hline СР0505 & Diamantina & $\begin{array}{l}\text { Coarse to medium- grained, pinkish white, massive to slightly porphyritic syenogranite. } \\
\text { It shows equigranular anhedral to subhedral texture. The K-feldspar is microperthite } \\
\text { and shows microcline-type twinning. Some orthoclase crystals show Carlsbad twinning. } \\
\text { Scarce patches of plagioclase are intergrowth with vermicular quartz. Some plagioclase } \\
\text { crystals (An26) contain shreds of muscovite. The biotite is pale straw-yellow to dark } \\
\text { olive-green, and scarcely chloritized. Irregular mass of opaque minerals are also } \\
\text { present. Euhedral zircon and scarce apatite may form biotite inclusions. }\end{array}$ \\
\hline CP20506 & Diamantina & $\begin{array}{l}\text { Medium grained, white, massive to slightly porphyritic syenogranite. It has a consistently } \\
\text { equigranular subhedral to anhedral texture. The plagioclase crystals (An28) contain } \\
\text { a dense mass of very fine grained muscovite and clay minerals of brown pale color } \\
\text { ascribed to alteration. The K-feldspar, a well developed microperthite, shows microcline- } \\
\text { type twinning. The biotite is a pale straw-yellow to dark olive-green, sometimes } \\
\text { chloritized. Secondary epidote occurs in small crystals. Squeletal masses of opaque } \\
\text { minerals contain apatite and epidote. Zircon and apatite in euhedral crystals are the } \\
\text { common accessory minerals. }\end{array}$ \\
\hline CP30507 & Diamantina & $\begin{array}{l}\text { Medium grained, white, massive to slightly porphyritic syenogranite. The thin section } \\
\text { shows an inequigranular anhedral texture. The K-feldspar is a usually a microcline- } \\
\text { microperthite, and the scarce orthoclase-microperthite shows Carlsbad-type twinning. } \\
\text { Patches of plagioclase are seen as intergrowth with vermicular quartz. The biotite is } \\
\text { pale straw-yellow to dark olive-green. Shred muscovite is seen in plagioclase. Irregular } \\
\text { masses of opaque minerals are associated to biotite. The principal accessory mineral } \\
\text { is euhedral apatite. }\end{array}$ \\
\hline
\end{tabular}


Appendix A. (continued)

\begin{tabular}{|c|c|c|}
\hline Sample & Pluton & Main characteristics \\
\hline ME0508 & Diamantina & $\begin{array}{l}\text { Pinkish white, medium-coarse grained quartz monzonite with an equigranular subhedral } \\
\text { to anhedral texture. It contains some phenocrysts of K-feldspar microperthite that show } \\
\text { microcline-type twinning. The plagioclase crystals contain very fine grained muscovite } \\
\text { and clay minerals of brown pale color. Abundant patches of plagioclase are intergrown } \\
\text { with vermicular quartz. Biotite is pale straw-yellow to dark olive-green. Few minute } \\
\text { secondary epidote is also present. Euhedral apatite and zircon inclusions occur as } \\
\text { inclusions in the biotite. }\end{array}$ \\
\hline CA0509 & San Martín & $\begin{array}{l}\text { Medium-fine grained, banded and foliated pink syenogranite gneiss with euhedral } \\
\text { hornblende with inequigranular anhedral texture. Broad sinuous, albite lamellae } \\
\text { traverses the tartan twinning of a microcline crystal. Small plagioclase crystals contain } \\
\text { very fine muscovite and clay minerals. Common clusters of anhedral quartz with wavy } \\
\text { extinction are also present, and secondary quartz in fine aggregates form some mosaics. } \\
\text { Irregular mass of opaque minerals and minute crystals of secondary epidote are also } \\
\text { present. Pale to dark brown allanite appears in aggregates of few crystals. }\end{array}$ \\
\hline FLT0510 & La Junta & $\begin{array}{l}\text { Coarse-grained syenogranite gneiss, pink in color with inequigranular anhedral texture. } \\
\text { Microperthitic intergrowth shows narrow albite lamellae forming a braided pattern in } \\
\text { an orthoclase host. Small plagioclase crystals contain very fine muscovite and clay } \\
\text { minerals of brown pale color in parallel polarized light. Plagioclase occurs as deformed } \\
\text { twins. Streaky banded chloritized biotite is associated with epidote aggregates, sphene } \\
\text { and irregular redish opaque minerals occurs as intergrowths with vermicular quartz. } \\
\text { Sphene shows a micrographic intergrowth. Euhedral apatite is also present. }\end{array}$ \\
\hline LJ10511 & La Junta & $\begin{array}{l}\text { Coarse grained, pinkish white, massive to slightly foliated and porphyritic quartz } \\
\text { monzonite with an inequigranular anhedral texture. Microcline microperthitic intergrowth } \\
\text { is common as well as some clusters of anhedral quartz. Abundant patches of plagioclase } \\
\text { occurs as intergrowths with vermicular quartz. The plagioclase contains very fine } \\
\text { muscovite and brown pale clay minerals in parallel polarized light. The biotite is a pale } \\
\text { straw-yellow to greenish brown mineral and is chloritized. }\end{array}$ \\
\hline LJ20512 & La Junta & $\begin{array}{l}\text { Medium grained, pinkish white, porphyritic monzogranite with an inequigranular } \\
\text { subhedral to anhedral texture. It contains granular cluster of quartz of different size, } \\
\text { with sutured contacts. The K-feldspar shows microcline-type twinning. The anhedral } \\
\text { plagioclase contains very fine muscovite and clay minerals of brown pale color in } \\
\text { parallel polarized light. The plagioclase (An29) slows a pericline twinning, and the biotite } \\
\text { is a pale straw-yellow to dark olive-green poorly chloritized. Irregular masses of opaque } \\
\text { minerals are also present. The principal accessory mineral is the euhedral sphene. }\end{array}$ \\
\hline LJ30513 & La Junta & $\begin{array}{l}\text { Medium grained, gray pinkish monzogranite with an inequigranular anhedral to } \\
\text { subhedral texture. The K-feldspar is microperthite and shows microcline-type twinning. } \\
\text { The plagioclase contains a fine shred of muscovite, and contains patches of vermicular } \\
\text { quartz. The hornblende is pleochroic, and in shades of green. Biotite is pale straw- } \\
\text { yellow to dark olive-green, sometimes with relict aspect between the crystals of quartz } \\
\text { and feldspars. Secondary epidote is rare. Apatite appears as euhedral crystal. }\end{array}$ \\
\hline
\end{tabular}


Appendix B. Summary of megascopic and microscopic petrography for the Pensamiento Granitoids Complex rocks (after Klinck and O'Connor, 1983; Hawkins, 1982; Pitfield, 1983; Litherland, 1982).

\begin{tabular}{|c|c|}
\hline Pluton & Main characteristics \\
\hline $\begin{array}{l}\text { San Martin Granite (Klinck } \\
\text { and O'Connor, 1982). }\end{array}$ & $\begin{array}{l}\text { In the undeformed granite a xenomorphic interlobate equigranular texture is present; the color ranges } \\
\text { from greyish-orange-pink, greyish-pink, yellow-brown to light-olive brown. Modal analysis plot in the } \\
\text { monzogranite field. Equigranular more rarely inequigranular, locally hypidiomorphic texture is observed } \\
\text { with plagioclase forming equant grains. Quartz forms ameboid crystals and sutured interlobate mosaics. } \\
\text { The K-feldspar is usually microcline-microperthite. Tabular plagioclase (An26) insets with a clear rim and } \\
\text { sericitised core are common along with blob-like quartz inclusions. Biotite forms straw or olive brown } \\
\text { colored flakes and is associated with accessory opaque ore, zircon and apatite. Accessory epidote } \\
\text { appears in some samples in association with the biotite. } \\
\text { In the deformed granite three increments of deformation-intensity from quartz textures are seen. The } \\
\text { first comprises intergranular milonitisation between quartz grains with a precursor development of mortar } \\
\text { texture. The biotite fabric is still random. The second increment in intensity of deformation generated } \\
\text { xenoblastic, interlobate elongate textures. The biotite defines a tectonic fabric of variable intensity. The } \\
\text { quartz occurs as elongate lenses and is parallel to the biotite fabric. The quartz ribbon texture appears } \\
\text { and plagioclase twin planes are deformed as intensity of deformation increases. The ribbons define a } \\
\text { preferred orientation. Subsequent metamorphism caused partial polygonisation. } \\
\text { Xenoliths: banded migmatites (e.g., Chiquitania Complex). }\end{array}$ \\
\hline $\begin{array}{l}\text { La Junta Granite } \\
\text { (Hawkins, 1982). }\end{array}$ & $\begin{array}{l}\text { Pinkish-grey in color, medium-to coarse-grained, gneissic monzogranite to syenogranite which grades } \\
\text { into a paler pink variety with a lower biotite content. The rock consists of porphyroblastic alkali feldspar } \\
\text { and string perthitic microcline, aligned parallel to the biotite and associated to quartz and plagioclase } \\
\text { with myrmekitic intergrowth. The biotite appears altered to chlorite. The accessory minerals are: sphene } \\
\text { (locally altering to leucoxene), zircon, apatite, allanite and opaque ores. Some secondary calcite and } \\
\text { epidote may be present locally. } \\
\text { The La Junta Granite exhibits a well-developed migmatitic envelope along its southern margin that } \\
\text { suggests an autochtonous origin. } \\
\text { Xenoliths: partly absorbed rocks (hornblende-biotite gneiss, calc-silicate gneiss, quartzite, amphibolite). }\end{array}$ \\
\hline $\begin{array}{l}\text { Piso Firme Granophyre } \\
\text { (Pitfield, 1983). }\end{array}$ & 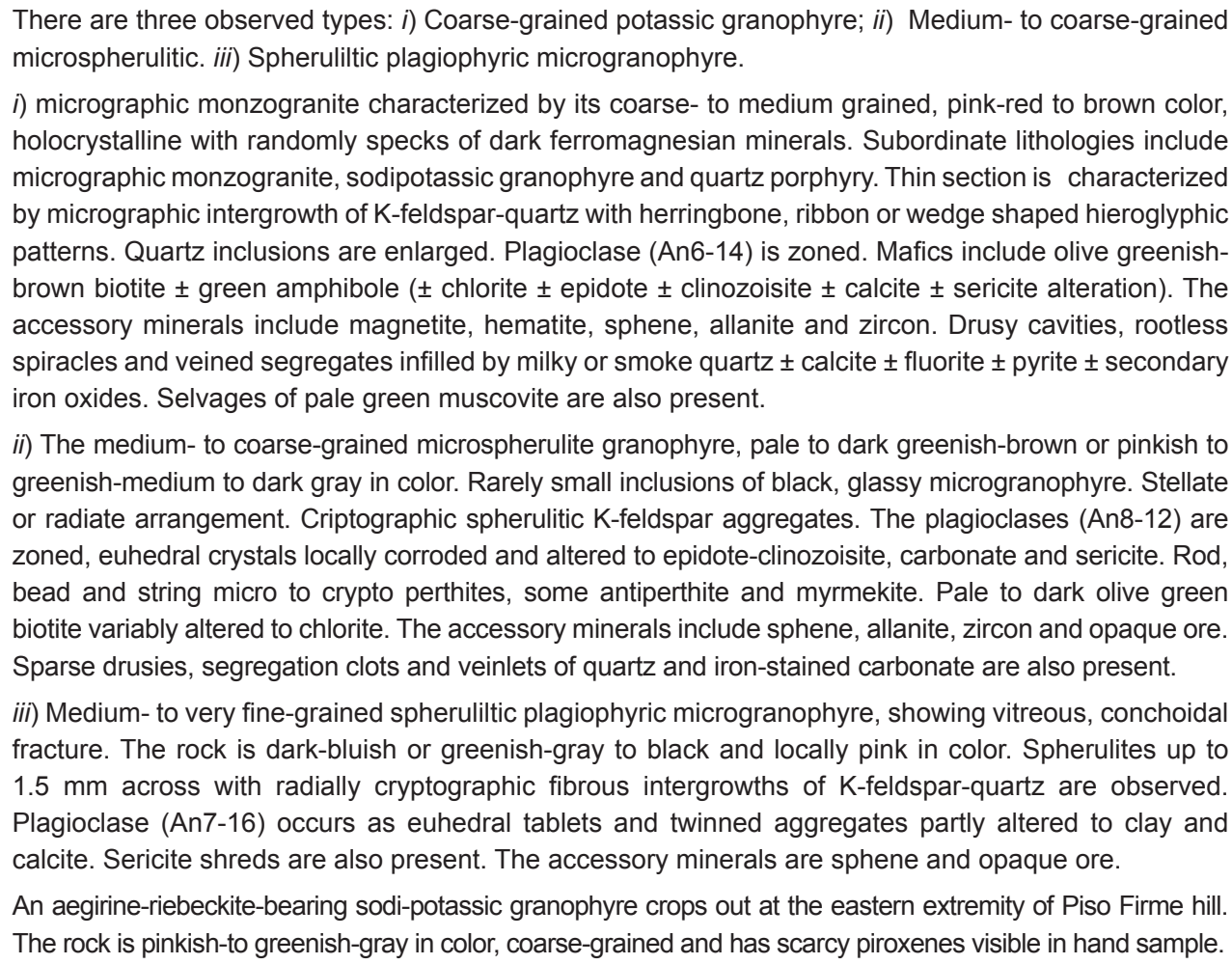 \\
\hline
\end{tabular}


Appendix B. (continued)

\begin{tabular}{|c|c|}
\hline Pluton & Main characteristics \\
\hline $\begin{array}{c}\text { The San Cristobal } \\
\text { Metagranite (Pitfield, } \\
\text { 1983). }\end{array}$ & $\begin{array}{l}\text { It is a medium-to coarse- or very coarse-grained, pink to pale pinkish-grey in color, variably foliated } \\
\text { hornblende-biotite adamellite. The normalised quartz-feldspar modal percentages are consistent with } \\
\text { a monzogranite composition. In thin section the metagranite shows a hypidiomorphic to xenomorphic } \\
\text { granular texture with more or less equal proportions of quartz, plagioclase and variably perthitic microcline. } \\
\text { It rarely forms small augen and lensoid segregates. The quartz is clear to smoky in color and appears } \\
\text { streaked or elongated with the foliation. The K-feldspar forms incipient blastic growths enveloping other } \\
\text { mineral phases and presents an anastomising habit. Plagioclase (An14-26) shows corrosion and } \\
\text { replacement by K-feldspar with local myrmekitic reaction fronts or globular quartz inclusions. Biotite } \\
\text { constitutes up to } 5 \% \text { of the rock, forming pale to dark olive green flakes which define a foliation. Bright } \\
\text { green to dark blue-green, somewhat poikilitic hornblende, no more than } 2 \% \text { of the rock, is associated } \\
\text { with biotite in composite aggregates. Both biotite and hornblende may be altered to chlorite. The main } \\
\text { accessory minerals are sphene, zircon, magnetite and less commonly, metamict allanite. The sphene } \\
\text { occurs as scattered grains and lozenge-shaped sections as well as a mantling to some opaque minerals. } \\
\text { Zircon is typically zoned with idiomorphic overgrowths on rounded detrital grains. } \\
\text { Xenoliths: biotite-hornblende gneisses, biotite amphibolites and epidote calc-silicate rocks. }\end{array}$ \\
\hline $\begin{array}{c}\text { Porvenir Granite } \\
\text { (Klinck and O'Connor, } \\
\text { 1982) }\end{array}$ & $\begin{array}{l}\text { It consists of greyish-orange, pink to pale-red, medium-grained equigranular biotite-hornblende } \\
\text { monzogranite. A weak linear fabric is defined by the streaking of mafics and the preferred orientation } \\
\text { of the quartz-feldspathic groundmass. The texture is xenoblastic-interlobate, inequigranular. K-feldspar } \\
\text { microcline perthite occurs as xenoblastic grains with drop-like quartz inclusions. The plagioclase forms } \\
\text { cloudy sericitised grains in the groundmass and is also recrystallised into the granoblastic polygonal } \\
\text { varieties into the mosaic. The mafics are greenish-straw colored biotite and green hornblende that forms } \\
\text { clots with opaque ore. It can be associated with epidote and sphene. }\end{array}$ \\
\hline $\begin{array}{c}\text { Diamantina Granitoid } \\
\text { (Klinck and O'Connor, } \\
\text { 1982) }\end{array}$ & 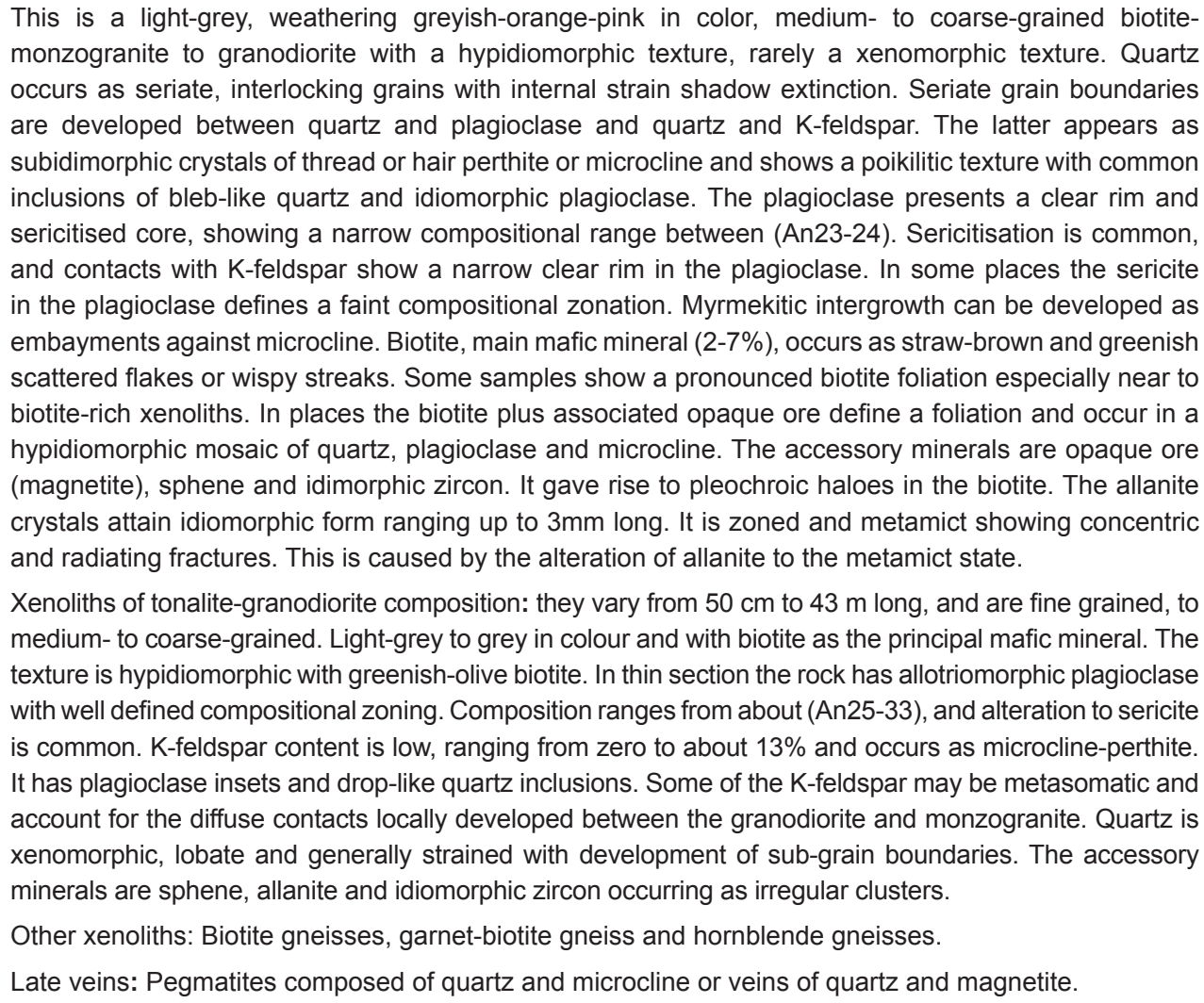 \\
\hline
\end{tabular}


Appendix B. (continued)

\begin{tabular}{|c|l|}
\hline Pluton & \multicolumn{1}{c|}{ Main characteristics } \\
\hline \multirow{5}{*}{$\begin{array}{c}\text { Diamantina Granitoid } \\
\text { (Litherland, 1982), }\end{array}$} & $\begin{array}{l}\text { In the eastern sector of the body occurs a pale pink or pale grey, medium-to medium-coarse-grained rock, } \\
\text { in places containing scattered K-feldspar megacrysts that ranges from } 1 \text { to } 3 \mathrm{~cm} \text { long. The investigated } \\
\text { samples were classified as quartz syenite to quartz-monzonite, and syenogranites and monzogranites } \\
\text { in composition. }\end{array}$ \\
$\begin{array}{l}\text { Microcline or perthite megacrysts enclose smaller crystals of altered plagioclase and quartz. The } \\
\text { plagioclase may be zoned and variable altered to sericite or epidote. The accessory minerals are: } \\
\text { apatite, ore, zircon and allanite whose crystals up may be to } 3 \text { mm long. } \\
\text { The southern part of the body is migmatitic with paleosome (gneiss) and neosome (granitoid) } \\
\text { components mixed on all scales. Small pegmatitic veins and segregations of approximately } 5 \mathrm{~cm} \text { thick } \\
\text { may be present. } \\
\text { Xenoliths: biotite-rich schists or biotite gneisses, that are up to } 5 \mathrm{~m} \text { long. }\end{array}$ \\
\hline
\end{tabular}


Provided for non-commercial research and education use. Not for reproduction, distribution or commercial use.
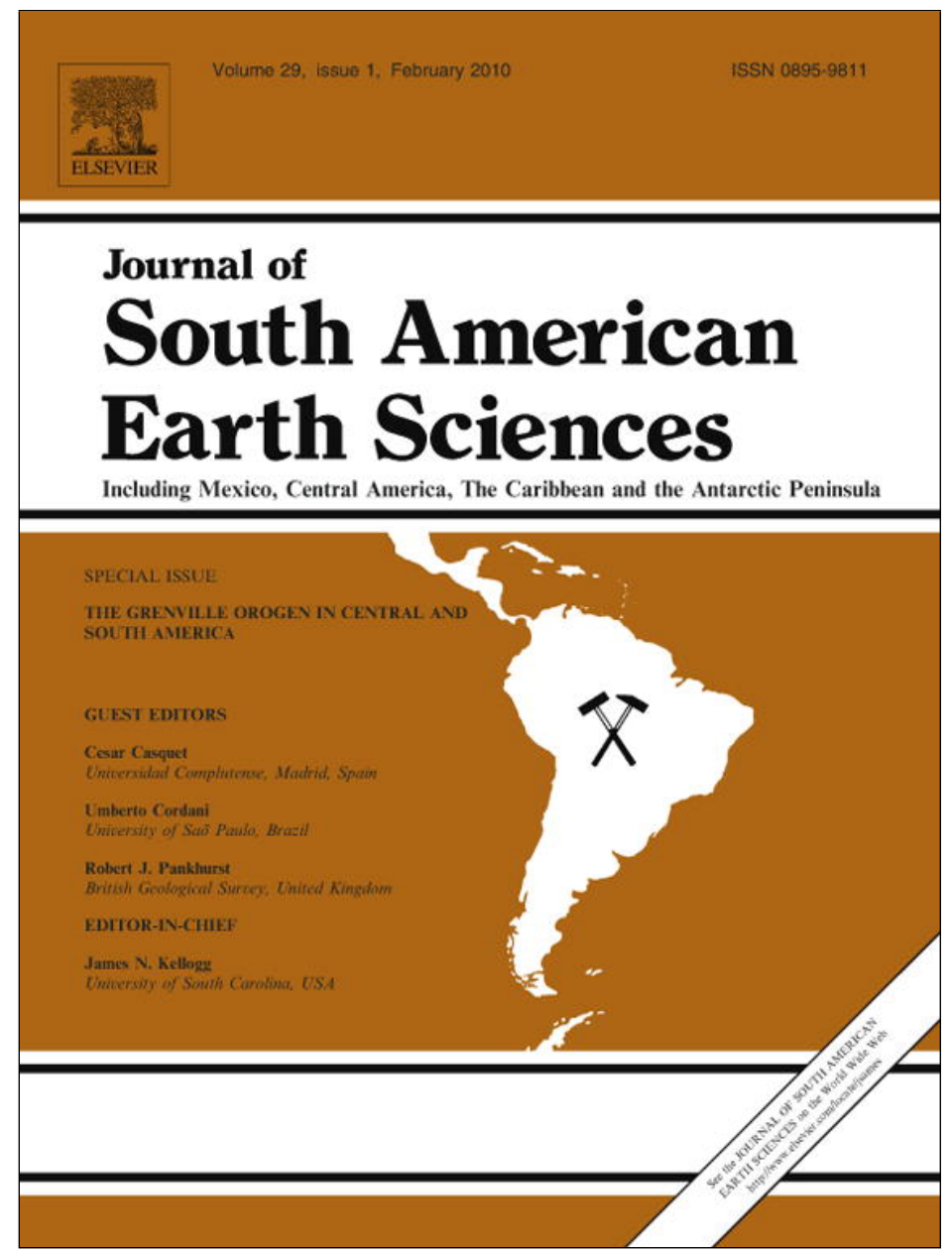

This article appeared in a journal published by Elsevier. The attached copy is furnished to the author for internal non-commercial research and education use, including for instruction at the authors institution and sharing with colleagues.

Other uses, including reproduction and distribution, or selling or licensing copies, or posting to personal, institutional or third party websites are prohibited.

In most cases authors are permitted to post their version of the article (e.g. in Word or Tex form) to their personal website or institutional repository. Authors requiring further information regarding Elsevier's archiving and manuscript policies are encouraged to visit:

http://www.elsevier.com/copyright 


\title{
The Rondonian-San Ignacio Province in the SW Amazonian Craton: An overview
}

\author{
Jorge Silva Bettencourt ${ }^{\mathrm{a}, *}$, Washington Barbosa Leite Jr. ${ }^{\mathrm{b}}$, Amarildo Salina Ruiz ${ }^{\mathrm{c}}$, Ramiro Matos ${ }^{\mathrm{d}, \mathrm{a}}$, \\ Bruno Leonelo Payolla ${ }^{\mathrm{e}}$, Richard M. Tosdal ${ }^{\mathrm{f}}$ \\ ${ }^{a}$ Institute of Geosciences of the University of São Paulo (IGc-USP), São Paulo, Brazil \\ ${ }^{\mathrm{b}}$ Institute of Geosciences and Exact Sciences of the São Paulo State University (IGCE-UNESP), Rio Claro, São Paulo, Brazil \\ ' Institute of Geosciences, Federal University of Mato Grosso, Cuiabá, Brazil \\ ${ }^{\mathrm{d}}$ Institute of Geologic Investigation and Environment, University Mayor de San Andrés, La Paz, Bolivia \\ e Centrais Elétricas do Norte do Brazil SA - Eletronorte, Brazil \\ ${ }^{\mathrm{f}}$ Mineral Deposit Research Unit, Department of Earth and Ocean Sciences, University of British Columbia, 6339 Stores Road, Vancouver, BC, Canada V6T 1Z2
}

\section{A R T I C L E I N F O}

\section{Article history:}

Received 5 May 2009

Accepted 10 August 2009

\section{Keywords:}

SW Amazonian Craton

Rondonian-San Ignacio Province

Mesoproterozoic evolution

Accretionary belts

Collisional orogeny

\begin{abstract}
A B S T R A C T
The Rondonian-San Ignacio Province $(1.56-1.30 \mathrm{Ga})$ is a composite orogen created through successive accretion of arcs, ocean basin closure and final oblique microcontinent-continent collision. The effects of the collision are well preserved mostly in the Paraguá Terrane (Bolivia and Mato Grosso regions) and in the Alto Guaporé Belt and the Rio Negro-Juruena Province (Rondônia region), considering that the province was affected by later collision-related deformation and metamorphism during the Sunsás Orogeny (1.25-1.00 Ga). The Rondonian-San Ignacio Province comprises: (1) the Jauru Terrane (1.78$1.42 \mathrm{Ga}$ ) that hosts Paleoproterozoic basement $(1.78-1.72 \mathrm{Ga})$, and the Cachoeirinha $(1.56-1.52 \mathrm{Ga})$ and the Santa Helena (1.48-1.42 Ga) accretionary orogens, both developed in an Andean-type magmatic arc; $(2)$ the Paraguá Terrane $(1.74-1.32 \mathrm{Ga})$ that hosts pre-San Ignacio units (>1640 Ma: Chiquitania Gneiss Complex, San Ignacio Schist Group and Lomas Manechis Granulitic Complex) and the Pensamiento Granitoid Complex (1.37-1.34 Ga) developed in an Andean-type magmatic arc; (3) the Rio Alegre Terrane $(1.51-1.38 \mathrm{Ga})$ that includes units generated in a mid-ocean ridge and an intra-oceanic magmatic arc environments; and (4) the Alto Guaporé Belt $(<1.42-1.34 \mathrm{Ga})$ that hosts units developed in passive marginal basin and intra-oceanic arc settings. The collisional stage $(1.34-1.32 \mathrm{Ga})$ is characterized by deformation, high-grade metamorphism, and partial melting during the metamorphic peak, which affected primarily the Chiquitania Gneiss Complex and Lomas Manechis Granulitic Complex in the Paraguá Terrane, and the Colorado Complex and the Nova Mamoré Metamorphic Suite in the Alto Guaporé Belt. The Paraguá Block is here considered as a crustal fragment probably displaced from its Rio Negro-Juruena crustal counterpart between 1.50 and $1.40 \mathrm{Ga}$. This period is characterized by extensive A-type and intraplate granite magmatism represented by the Rio Crespo Intrusive Suite (ca. $1.50 \mathrm{Ga}$ ), Santo Antonio Intrusive Suite (1.40-1.36 Ga), and the Teotônio Intrusive Suite (1.38 Ga). Magmatism of these types also occur at the end of the Rondonian-San Ignacio Orogeny, and are represented by the Alto Candeias Intrusive Suite (1.34-1.36 Ga), and the São Lourenço-Caripunas Intrusive Suite $(1.31-1.30 \mathrm{Ga})$. The cratonization of the province occurred between 1.30 and $1.25 \mathrm{Ga}$.
\end{abstract}

(c) 2009 Elsevier Ltd. All rights reserved.

\section{Introduction}

The term Rondonian Province was first introduced by Cordani et al. (1979) for a deformational and metamorphic event in the SW Amazonian Craton, that was constrained by $\mathrm{Rb}-\mathrm{Sr}$ and $\mathrm{K}-\mathrm{Ar}$ geochronology to 1.45-1.25 Ga. Teixeira and Tassinari (1984) and Teixeira et al. (1989) interpreted the province to be a mobile belt extending from northern Rondônia (Brazil) to San Ignacio region (Bolivia) including the rocks attributed to the San Ignacio Orogeny

\footnotetext{
* Corresponding author.

E-mail address: jsbetten@usp.br (J.S. Bettencourt).
}

(1.40-1.28 Ga) of Litherland et al. (1986). Tassinari et al. (1996), based on U-Pb TIMS and SHRIMP ages, proposed the term Rondonian-San Ignacio Province (RSIP: 1.45-1.30 Ga). Subsequently, Tassinari et al. (2000), based on U-Pb data and geological data, subdivided rocks of the RSIP (1.50-1.29 Ga) into the Rio Alegre Terrane (1.50 Ga), Santa Helena Orogen (1.47-1.42 Ga), and Rondonian-San Ignacio Orogen (1.40-1.29 Ga).

Overall, according to Cordani and Teixeira (2007), the RSIP $(1.50-1.30 \mathrm{Ga})$ is an amalgamation of intra-oceanic magmatic arcs and accretionary prisms formed during a continental collision along the SW boundary of the Rio Negro-Juruena Province. It is a collage of medium to high-grade accretionary belts, large shear 
zones, and plutonic complexes that reflect the collisional nature of the boundary. Conversely, Santos et al. (2000) and Santos et al. (2008), based on U-Pb and Sm-Nd, separated the rocks of the RSIP into the Rondônia-Juruena Province (1.84-1.54 Ga) and Sunsás Province $(1.46-1.11 \mathrm{Ga})$. They proposed that the Sunsás Orogen is characterized by an autochthonous evolution and was formed by four orogenies: Santa Helena (1.46-1.42 Ga), Candeias (1.37$1.32 \mathrm{Ga}$ ), San Andres (ca. $1.27 \mathrm{Ga}$ ) and Nova Brasilândia (1.18$1.11 \mathrm{Ga})$.

Currently, the RSIP in the southwestern border of the Amazonian Craton is limited to the north and east by the Rio Negro-Juruena Province. To the south, the RSIP is bounded by the Sunsás Province along the Sunsás tectonic front (Rio Negro Front and Santa Catalina Straight Zone). The western part of the RSIP is covered by Phanerozoic sedimentary sequences. The total area exposed is at least $\sim 2000 \mathrm{~km}$ long and $\sim 800 \mathrm{~km}$ wide. It includes large parts of the Precambrian shield of the Brazilian states of Rondônia and Mato Grosso, as well as a large area of the Santa Cruz and Beni departments in Bolivia. Outcrops of the RSIP in the northwestern corner of the Amazonian Craton are obscured by Phanerozoic sedimentary sequences.

Despite the substantial new geological mapping, and the additional collection of geophysical, geochronological and geochemical data, very little is known about several segments of the RSIP in Rondônia, Mato Grosso and eastern Bolivia regions. This lack of data hampers a better correlation of units. Furthermore, definition of tectonic unit boundaries, age limits, lateral continuation, internal organization, subdivision and varied nomenclature all are controversial, nonetheless leading to several competing chronologic frameworks, and terminology for the tectonic events in the RSIP.

We proposed the RSIP is a composite orogen, consisting of an older complex accretionary orogen (1556-1430 Ma) followed by, the terminal microcontinent-continent collision at 1340-1320 Ma. The major tectonic units are: the Paraguá Terrane, Jauru Terrane, Rio Alegre Terrane and the Alto Guaporé Belt (Fig. 1). We furthermore expand the upper age of RSIP to $1.56 \mathrm{Ga}$ in order to include the Cachoeirinha Orogen (1.56-1.52 Ma). The overall time interval for RSIP is thus considered herein to $1.56-1.30 \mathrm{Ga}$.

We review the presently accepted evolutionary history of the RSIP, including the temporal and spatial distribution, precursors, and tectonic settings. Included are descriptions of the terranes and orogens, and their tectonic limits. These data provide the basis for an overall interpretation and related tectonic model. Post-Rondonian-San Ignacio events (Sunsás Orogeny) that affected the RSIP are described by Teixeira et al. (2010).

\section{The RSIP in the context of the SW Amazonian Craton}

Several recent reviews of the Amazonian Craton (Tassinari and Macambira, 1999; Santos et al., 2000; Tassinari et al., 2000; Cordani and Teixeira, 2007; Cordani et al., 2009) have focused on the correlation of major geologic units and structures. These reviews are substantially enhanced by regional scale work based on U-Pb TIMS and SHRIMP geochronology, Sm-Nd geochemistry, as well as $\mathrm{Pb}-$ $\mathrm{Pb}$ evaporation techniques.

The SW portion of the Amazonian Craton is represented by four Proterozoic sub-parallel provinces (Cordani and Teixeira, 2007; Cordani et al., 2009): Ventuari-Tapajós (2.00-1.80 Ga), Rio NegroJuruena (1.78-1.55 Ga), Rondonian-San Ignacio (1.50-1.30 Ga) and Sunsás-Aguapeí (1.25-1.00 Ga) (Fig. 1). In this context, for Cordani and Teixeira (2007), the RSIP may be interpreted to represent collisional orogeny involving a possible microcontinent combined with domains composed of the Rio Crespo Intrusive Suite (1.50 Ga), Rio Alegre Complex (1.51-1.48 Ga), Santa Helena batholith (1.45-1.42 Ga), Colorado Metamorphic Suite (1.36-1.30 Ga) and the Pensamiento Granitoid Complex (1.36-1.30 Ga). Highgrade metamorphic rocks related to the San Ignacio Orogeny $(1.35 \mathrm{Ga})$ and late- to post-tectonic plutonism: Santo Antônio (1.41 Ga), Teotônio (1.39 Ga), Alto Candeias (1.34 Ga) and São Lourenço-Caripunas intrusive suites are also evident. RSIP cratonization is interpreted to have occurred at $1.30 \mathrm{Ga}$ ( $\mathrm{Ar}-\mathrm{Ar}$ ages) and $1.25 \mathrm{Ga}$ (K-Ar ages).

Cratonization of the RSIP was followed by tectonic reactivation, deformation, thermal overprint, and magmatism related to the Sunsás Orogeny. These effects are manifested by extensive shear zones (e.g. Ji-Paraná Shear Zone, Scandolara et al., 1999; Tohver et al., 2005), mylonitic belts, rifts and sedimentary basins, and post-tectonic and anorogenic intrusions (Cordani and Teixeira, 2007; Cordani et al., 2009; Teixeira et al., 2010).

\section{The Rondonian-San Ignacio Province}

\subsection{The Paraguá Terrane (1.82-1.32 Ga)}

The term Paraguá Craton was introduced by Litherland et al. (1986) in eastern Bolivia Precambrian shield to denote a tectonically stable region during the Meso- to Neoproterozoic deformation of the Sunsás and Aguapeí belts. However, Saes and Fragoso Cesar (1996) subdivided the shield into two terranes, the Paraguá Terrane and the San Pablo Terrane, and Tohver et al. (2004) expanded the limits of the craton to include a large area of the Mato Grosso, and proposed that the E-W trending Nova Brasilândia belt (ca. $2000 \mathrm{~km}$ in extent) marks the limit between the Amazonian and Paraguá cratons, during the late Mesoproterozoic. In this paper, we adopt the term Paraguá Terrane to denote a composite terrane, which comprises Paleoproterozoic basement rocks (Chiquitania Gneissic Complex, San Ignacio Schist Group, Lomas Manechis Granulitic Complex) and Mesoproterozoic granitoids (Pensamiento Granitoid Complex), amalgamated to the protoAmazonian Craton during the Rondonian-San Ignacio Orogeny. To the east a ductile shear zone marks the limit with Rio Alegre Terrane. To the north the limit with the Alto Guapore Belt is hidden by Cenozoic sedimentary sequences. To the south the boundary is hidden by Brasiliano platform sediments (post-Sunsás units), and to the west by Cenozoic sedimentary sequences (Fig. 1).

\subsubsection{Pre-San Ignacio basement rocks (>1640 Ma)}

The pre-San Ignacio crust, based on Rb-Sr whole-rock ages was considered older than $1961 \mathrm{Ma}$ (Litherland et al., 1986). Boger et al. (2005) refined the understanding of these rocks doing precise $\mathrm{U}-\mathrm{Pb}$ SHRIMP zircon ages from two high-metamorphic grade rocks of the Lomas Manechis Granulitic Complex (LMGC), predominantly composed of granites, orthopyroxene bearing granitoids and pinkish granitoids that yielded U-Pb SHRIMP zircon crystallization ages of $1689 \pm 5$ and $1663 \pm 4 \mathrm{Ma}$, and from two high-grade paragneisses from the Chiquitania Gneissic Complex (CGC), represented by biotite-bearing felsic gneisses, and interpreted to be of sedimentary or volcanic origin (detrital zircons). Boger et al. (2005) interpreted the Chiquitania paragneiss protolith to have been derived from a predominantly Paleoproterozoic source formed at about $1765 \mathrm{Ma}$, whereas the paragneiss protolith was deposited after at ca. $1690 \mathrm{Ma}$ (Fig. 2, Table 1).

Additional U-Pb SHRIMP zircon ages from the Lomas Manechis granulitic gneiss, Rio Fortuna orthogneiss, Santa Rita orthogneiss, and Refugio Granite are reported by Santos et al. (2008). The Lomas Manechis granulitic gneiss contains magmatic zircons with ${ }^{207} \mathrm{~Pb} /{ }^{206} \mathrm{~Pb}$ age of $1818 \pm 13 \mathrm{Ma}$; these zircons are the oldest yet identified in Bolivia. The Rio Fortuna and Santa Rita orthogneiss show inherited zircon grains formed between 1772 and 1729 Ma. The Refugio Granite has a ${ }^{207} \mathrm{~Pb} /{ }^{206} \mathrm{~Pb}$ crystallization age of 


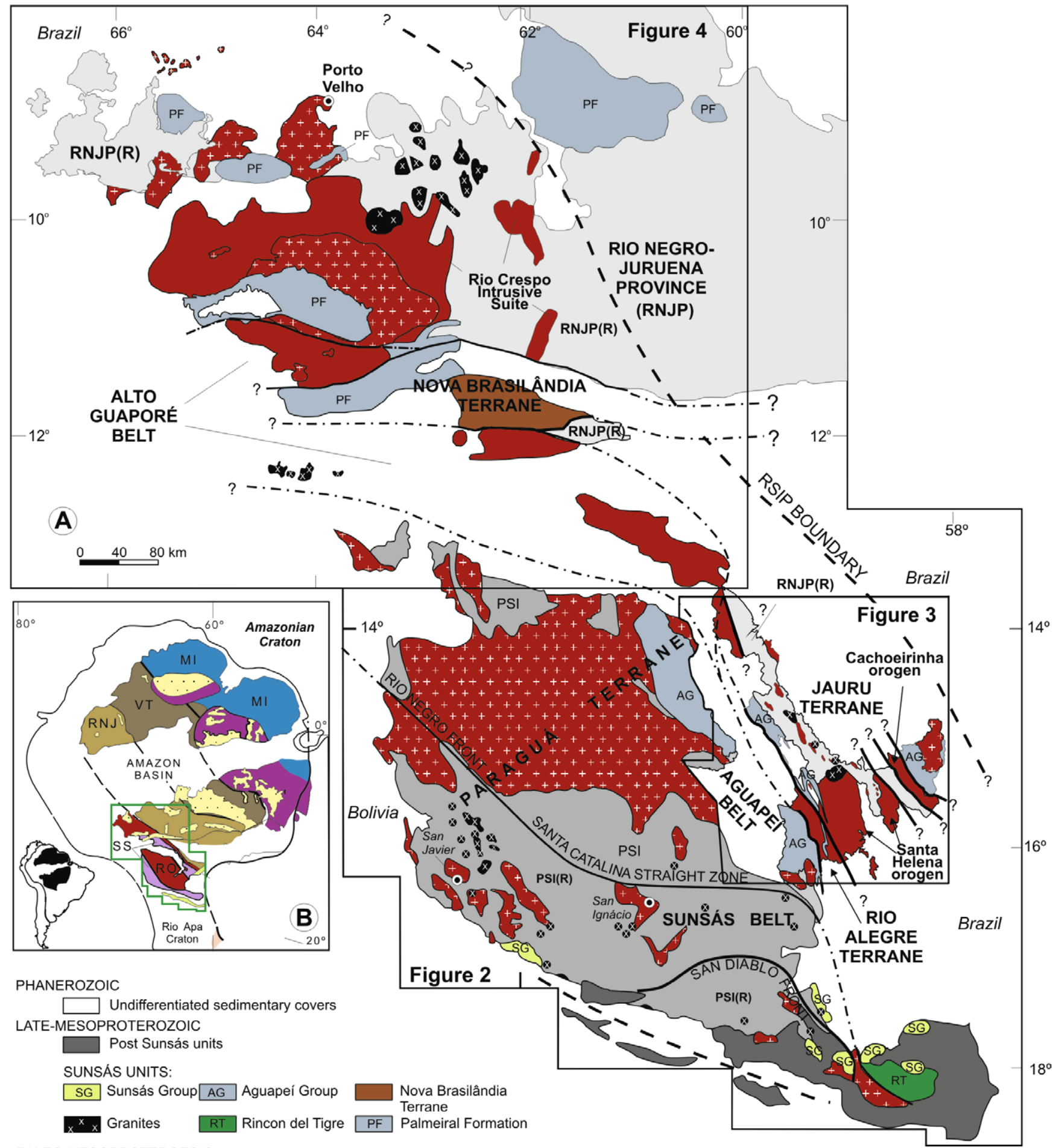

PALEO-MESOPROTEROZOIC

RONDONIAN-SAN IGNÁCIO LITHOLOGIC AND TECTONIC UNITS
++ Granites
Alto Guaporé Belt
Rio Crespo Intrusive Suite
Rio Alegre Terrane
Santa Helena Orogen
Cachoeirinha Orogen
Tectonic boundaries
-.- Inferred tectonic boundaries
- - Rondonian-San Ignacio Province (RSIP) boundary

\section{BASEMENT ROCKS}

$\square$ Pre-San Ignácio basement rocks (PSI),[reworked-PSI(R)]

Rio Negro-Juruena Province (RNJP), [reworked-RNJP(R)]

Fig. 1. (A) Simplified map of the SW Amazonian Craton showing the approximate boundaries of the main provinces, major orogens, terranes and belts, tectonic elements, and lithologic units. (B) Major geochronological provinces of the Amazonian Craton (after Cordani and Teixeira, 2007). MI, Maroni- Itacaiunas Province; VT, Ventuari-Tapajós Province; RNJ, Rio Negro-Juruena Province; RO, Rondonian-San Ignacio Province; SS, Sunsá-Aguapeí Province. Locations of Figs. 2-4 are shown. 


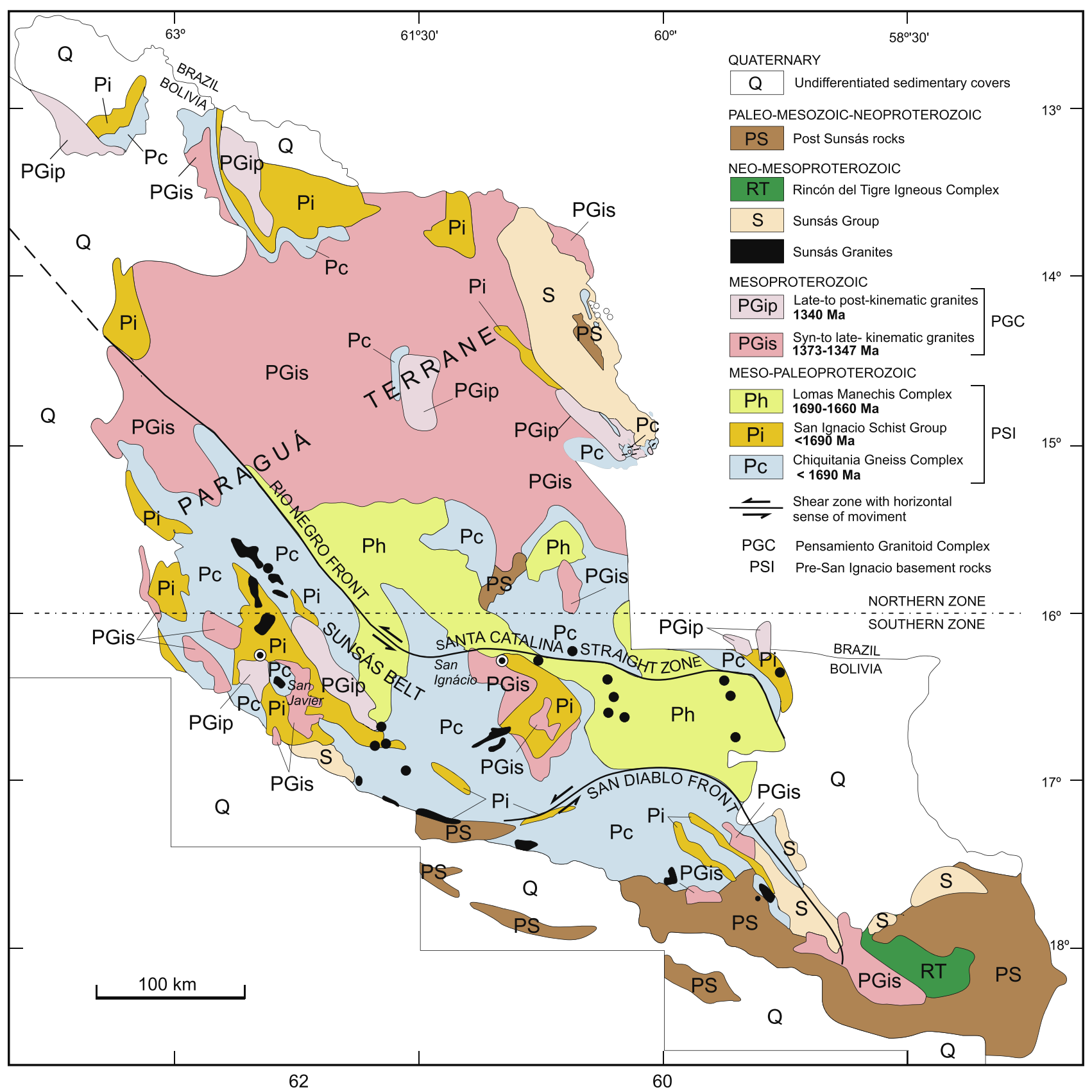

Fig. 2. Major orogens, geological units, and tectonic elements of the Paraguá Terrane (eastern Bolivia) (modified from Litherland et al. (1986), Ruiz (2005), Matos et al. (2009)).

$1641 \pm 4 \mathrm{Ma}$, and $\mathrm{Nd} T_{\mathrm{DM}}$ model age of $1.7 \mathrm{Ga}$ and $\varepsilon_{\mathrm{Nd}(t)}=+4.06$. The La Cruz granite yields ${ }^{207} \mathrm{~Pb} /{ }^{206} \mathrm{~Pb}$ SHRIMP zircon age of $1673 \pm 21 \mathrm{Ma}$, Nd $T_{\mathrm{DM}}$ model age of $1.83 \mathrm{Ga}$ and $\varepsilon_{\mathrm{Nd}(t)}$ of +2.1 .

\subsubsection{Granitoid magmatism}

The Pensamiento Granitoid Complex (PGC) forms much of the Paraguá Terrane, and is related to the San Ignacio Orogeny (Fig. 2). Herein we divided the PGC into two groups of granitoids (Table 1): (1) the syn- to late-kinematic granitoids (U-Pb SHRIMP zircon ages of 1373-1347 Ma) represented by La Junta, Florida, Puerto Alegre, San Martin and Campamento granites, and (2) lateto post-kinematic granitoids comprising the Diamantina (U-Pb SHRIMP zircon age of $1340 \mathrm{Ma}$ ), Porvenir, Padre Eterno, Três Picos, Orobayaya, Discordância, El Tigre, San Cristobal granites and the Piso Firme Granophyre.
The La Junta and San Martin syn- to late-kinematic granites are characterized by $\mathrm{Nd}$ and $\mathrm{Sr}$ isotopic compositions $\left(\varepsilon_{\mathrm{Nd}(t)}\right.$ values of +1.8 to $-3.7 ; \mathrm{Sr}_{i}=0.7052$ ) and negative $\mathrm{Nb}$ and $\mathrm{Ta}$ anomalies indicating that different sources contributed to the granitoid magma genesis in a Mesoproterozoic continental-margin arc system (Matos et al., 2009). Piso Firme and the Diamantina late- to postkinematic granites exhibit ${ }^{87} \mathrm{Sr} /{ }^{86} \mathrm{Sr}$ ratios close to Bulk Earth and Nd $T_{\mathrm{DM}}$ ages $(1.92-1.51 \mathrm{Ga})$, which coupled with the $\varepsilon_{\mathrm{Nd}(t)}$ values $(-1.25$ to +3.90$)$ indicate mixtures among MORB-like magmas and isotopic homogeneous protoliths (Darbyshire, 2000; Matos et al., 2009).

In the Brasilian side of the Paraguá Terrane in Santa Bárbara hill, the PGC is characterized by voluminous crustally derived granitic plutons (Tarumã Granite-Gneiss and Lajes Granite) emplaced along a NNW structural pattern. The strongly foliated syn-kinematic Tarumã Granite-Gneiss shows U-Pb zircon age of $1.38 \mathrm{Ga}$; Nd 
Summary of the main geological and geochronological features in the Paraguá Terrane (RSIP southern sector).

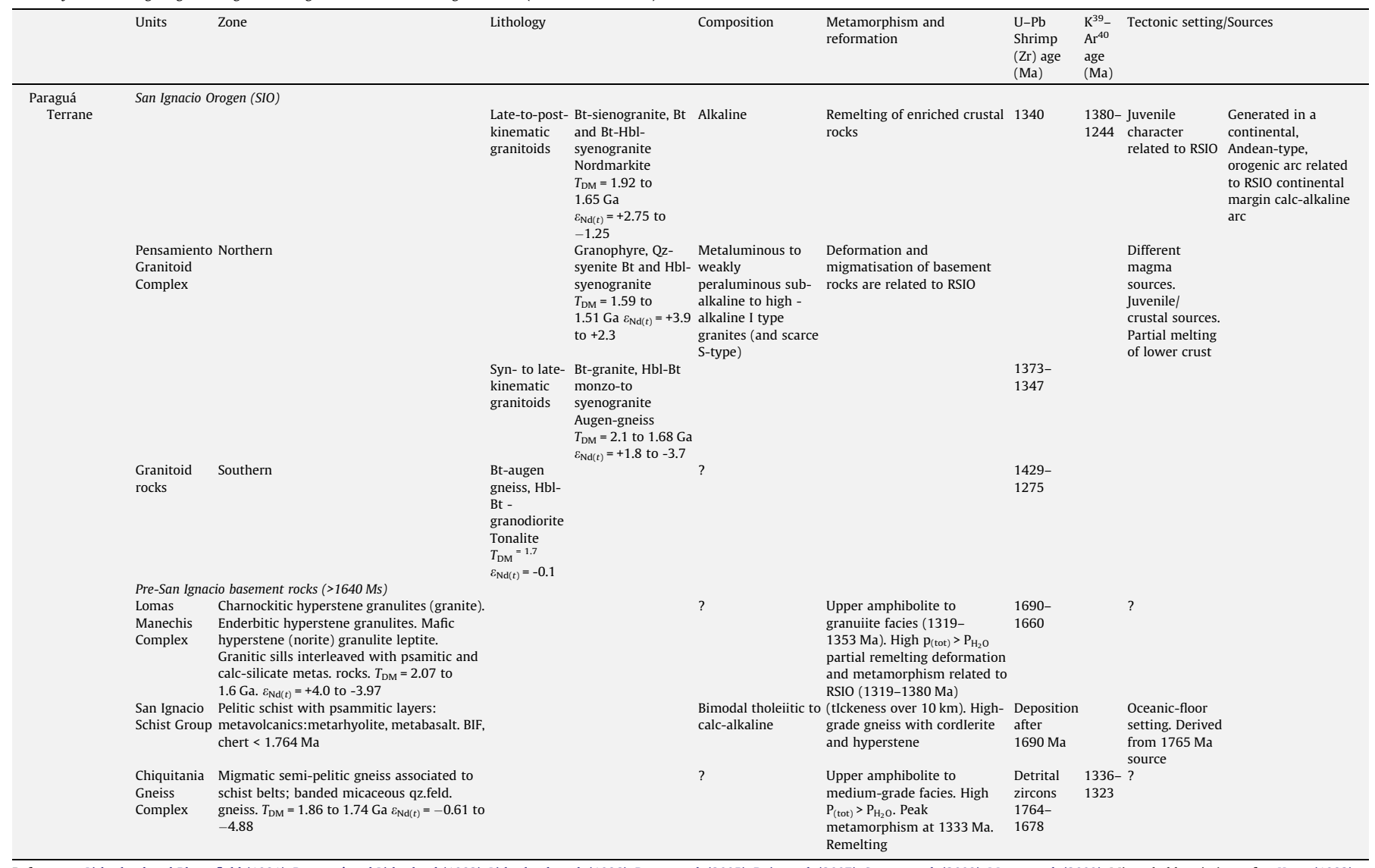


$T_{\mathrm{DM}}=1.9 \mathrm{Ga}$ and $\varepsilon_{\mathrm{Nd}(t)}=-4.11$ and the weakly foliated late-kynematic Lajes Granite exhibits $\mathrm{U}-\mathrm{Pb}$ zircon age of $1.31 \mathrm{Ga}$, Nd $T_{\mathrm{DM}}=1.7 \mathrm{Ga}$ and $\varepsilon_{\mathrm{Nd}(t)}=0.0$ (Geraldes, 2000; Ruiz, 2005).

In the Ricardo Franco or Huanchaca hill the Pensamiento granitoids are not affected by the Sunsás Orogeny, and preserve the San Ignacio metamorphic and deformational characteristics. In the Vila Bela region, the PGC consists of syn-kinematic foliated NNWtrending monzogranite and granodiorite (Guaporeí Granite), and weakly foliated granites such as the Passagem Granite $(1.29 \mathrm{Ga})$. Geochemical and isotopic signatures, and negative $\varepsilon_{\mathrm{Nd}(t)}$ values of the San Ignacio related granitoids in Brazil indicate that they formed in a continental magmatic arc and/or in a collisional continental setting (Ruiz, 2005).

A reappraisal of the San Ignacio granitoids of the Southern Zone as defined by Litherland et al. (1986) is on course, mainly based on precise U-Pb SHRIMP ages and isotopic geochemistry. For example, the San Rafael granite $(1334 \pm 12 \mathrm{Ma})$ was synchronous with the San Ignacio Orogeny, and inherited zircon core age ( $1686 \pm 16 \mathrm{Ma}$ ) indicates that the granite interacted or was melted from a Paleoproterozoic protolith (Boger et al., 2005). The San Ramon granite $\left(1429 \pm 4 \mathrm{Ma}\right.$, Nd $T_{\mathrm{DM}}$ model age of $1.6 \mathrm{Ga}$ and $\left.\varepsilon_{\mathrm{Nd}(t)}=+2.3\right)$ and San Andrés granite $(1275 \pm 7 \mathrm{Ma})$ (Santos et al., 2008 ) indicate the existence of two magmatic events not related to the San Ignacio granitoid magmatism.

Elsewhere, Santos et al. (2008) reported SHRIMP U-Pb zircon ages from Rio Fortuna $1336 \pm 3$ Ma and Santa Rita $1319 \pm 6$ Ma, orthogneisses, both previously considered as part of the Chiquitania Gneiss Complex by Litherland et al. (1986), are related to the San Ignacio Orogeny.

\subsubsection{Deformation and metamorphism}

The San Ignacio Orogeny encompasses three WNW-directed phases of deformation, subscripts Do1, Do2, and Do3 (Litherland et al., 1986). The youngest, Do3, the major penetrative event, was accompanied by voluminous syn-kinematic granite intrusions, and migmatization of the 1690 Ma older sedimentary rocks, but some of the late- to post-kinematic granitoids postdate Do3 phase and were emplaced along a NNW trend (Litherland et al., 1986; Boger et al., 2005). Sunsás-age deformation was confined to Sunsás and Aguapeí belts. In the Sunsás Belt the main shear zones and tectonic front are the Rio Negro Front and Santa Catalina Straight Zone, which define the northern limit of the Sunsás Belt, and San Diablo Front (Litherland et al., 1986). In the Aguapeí Belt the tectonic effects are represented by transpressive shear zones (e.g. Santa Rita Shear Zone), and transposition of older structures parallel to the $\mathrm{N} 20-40^{\circ} \mathrm{W} / 70^{\circ}-80^{\circ} \mathrm{SW}$ orogenic trend (Ruiz, 2005) (Fig. 1).

Upper-amphibolite mineral assemblage characterizes the Chiquitania and Lomas Manechis complexes, whereas the San Ignacio Group is characterized by low- to medium-grade metamorphic minerals. U-Pb SHRIMP zircon rim ages from LMGC (orthopyroxene-bearing granitoid) yield a weighted ${ }^{207} \mathrm{~Pb}-{ }^{206} \mathrm{~Pb}$ age of $1320 \pm 11 \mathrm{Ma}$, and a biotite-bearing felsic gneiss (leucosome) from the CGC has zircon rims with $\mathrm{U}-\mathrm{Pb}$ ages of $1333 \pm 6 \mathrm{Ma}$ (Table 1).These ages are interpreted to reflect the time of partial melting related to the peak metamorphism in the LMGC and CGC during the San Ignacio Orogeny (Boger et al., 2005).

Other U-Pb SHRIMP zircon, monazite and titanite ages from granitoid rocks of the LMGC, Rio Fortuna orthogneiss, Santa Rita orthogneiss suggest that high-grade metamorphism occurred over a long time period between 1353 and $1319 \mathrm{Ma}$ (Santos et al., 2008). Monazite from a Lomas Manechis granulitic rock has a metamorphic age of $1339 \pm 4 \mathrm{Ma}$, which overlaps the ${ }^{207} \mathrm{~Pb} /{ }^{206} \mathrm{~Pb}$ age of metamorphic zircons at $1338 \pm 21$ Ma. The Rio Fortuna orthogneiss has magmatic zircons and rims formed at $1336 \pm 3$ Ma. The Santa Rita orthogneiss has magmatic zircons with ${ }^{207} \mathrm{~Pb} /{ }^{206} \mathrm{~Pb}$ age of $1319 \pm 6$ Ma. These authors concluded that all Lomas Manechis granulite rocks and their counterparts observed in western Rondônia are orogenic rocks formed during the time interval 1353$1319 \mathrm{Ma}$.

\subsection{The Jauru Terrane (1.78-1.42 Ga)}

The Jauru Terrane was defined by Saes and Fragoso Cesar (1996) to include Paleoproterozic metamorphic complexes resulting from accretions of intra-oceanic arcs into the Amazonia Central Province. In this paper, the composite Jauru Terrane consists of Paleoproterozoic basement rocks (Alto Jauru Group, Figueira Branca Intrusive Suite, Alto Guaporé Metamorphic Complex and Cabaçal Tonalite) and the Mesoproterozoic Cachoeirinha and Santa Helena orogens. To the west a ductile shear zone marks the limit with the Rio Alegre Terrane. To the north, east and south the limits are hidden by Phanerozoic sedimentary sequences (Fig. 1).

\subsubsection{Paleoproterozoic basement rocks $(1.78-1.72 \mathrm{Ga})$}

The Paleoproterozoic basement rocks consist of four lithostratigraphic units: The Alto Jauru Group, Figueira Branca Intrusive Suite, Alto Guaporé Metamorphic Complex, and Cabaçal Tonalite (Fig. 3, Table 2).

The Alto Jauru Group (Monteiro et al., 1986) consists of gneisses, migmatites and three metavolcano-sedimentary sequences: Cabaçal, Araputanga, and Jauru. Silicic to intermediate volcanic rocks have $\mathrm{U}-\mathrm{Pb}$ ages of $1.76-1.72 \mathrm{Ga}$, and $\varepsilon_{\mathrm{Nd}(t)}$ values are between +2.6 and +2.2 , allowing a dominantly juvenile mantle derivation for these rocks. Geochemical data from the Cabaçal tholeiitic basalts suggest the incorporation of successive intra-oceanic arcs within the Alto Jauru Group, during the evolution of the continental margin of the Rio Negro-Juruena Province (Pinho et al., 1997; Geraldes et al., 2001). Ar-Ar ages between 1.53 and $1.46 \mathrm{Ga}$ record metamorphic cooling related to the Cachoeirinha Orogeny.

The Figueira Branca Intrusive Suite (unknown age) is composed of numerous meta-basic and meta-ultrabasic plutons that intruded the Alto Jauru Group, are polydeformed and are metamorphosed at high-amphibolite to greenschist facies (Saes et al., 1984; Ruiz, 2005). The close association between the mafic-ultramafic intrusions and the Alto Jauru Group supracrustal rocks indicates that the rock association likely represents relicts of Paleoproterozoic oceanic crust (Ruiz, 2005).

The Alto Guaporé Metamorphic Complex as defined by Menezes et al. (1993) consists of granodioritic to tonalitic orthogneiss, which intruded the volcano-sedimentary supracrustal sequences. The gneisses were metamorphosed at greenschist to amphibolite facies. The oldest dated orthogneisses range in $\mathrm{U}-\mathrm{Pb}$ zircon ages between 1.8 and $1.7 \mathrm{Ga}$. Positive $\varepsilon_{\mathrm{Nd}(t)}$ values varying from +2.4 to -0.8 suggest a crustal contribution to largely mantle derived magma (Pinho, 1996; Geraldes et al., 2001; Ruiz, 2005). Ar-Ar ages indicate that the gneisses were thermally affected during the Cachoeirinha Orogeny at $1.51 \mathrm{Ga}$ or reflect resetting during the Sunsás Orogeny (1.25-1.00 Ma) (Paulo, 2005; Ruiz, 2005).

The Cabaçal Tonalite, first described by Monteiro et al. (1986), is a tonalite batholith metamorphosed at amphibolite facies, which had intruded in the Cabaçal volcanic-sedimentary sequence (Alto Jauru Group). $\mathrm{Pb}$ isotopic data suggest a crystallization age of $1.78 \mathrm{Ga}$ (Pinho, 1996). This segment of the Jauru Terrane was successively reworked during the Cachoeirinha (1.56-1.52 Ga) and Santa Helena orogenies (1.48-1.42 Ga) (Ruiz, 2005).

\subsubsection{The Cachoeirinha Orogen (1.56-1.52 Ga)}

Rocks in the Cachoeirinha Orogen, initially described by Carneiro et al. (1992), evolved during the Cachoeirinha Orogeny (Van Schmus et al., 1998; Geraldes et al.,1999; Geraldes, 2000). The Cachoeirinha Orogen, herein interpreted as an accretionary orogen, 

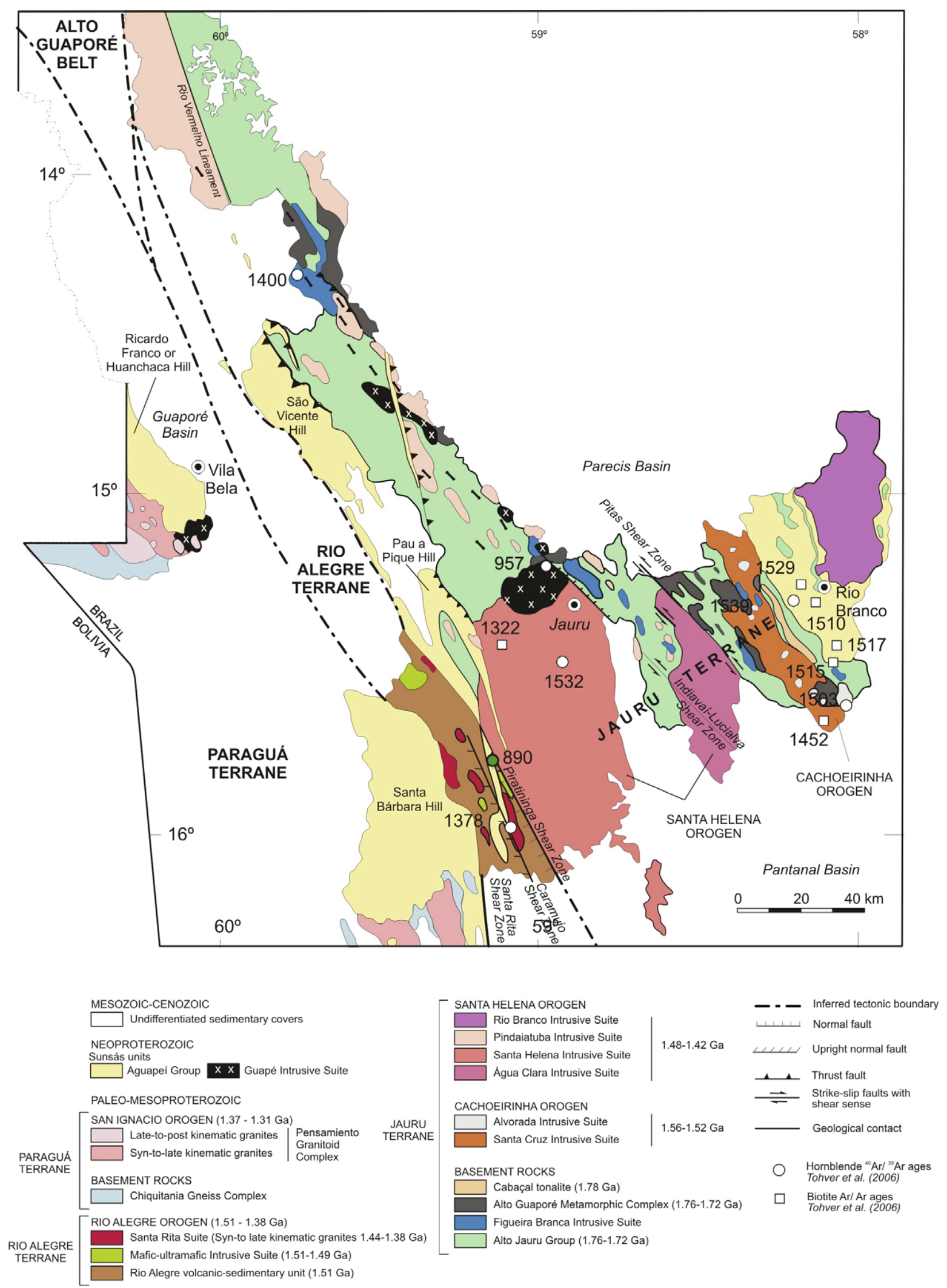

Fig. 3. Simplified geologic-tectonic map of SW Mato Grosso region showing major orogens, terranes and belts, tectonic elements, and lithologic units (modified from Ruiz, 2005). 
Table 2

Summary of the main geological and geochronological features of the Jauru and Rio Alegre terranes (RSIP southern sector).

\begin{tabular}{|c|c|c|c|c|c|c|c|c|}
\hline & Units & Lithology & & Composition & Metamorphism and deformation & $\begin{array}{l}\mathrm{U}-\mathrm{Pb} \\
\text { shrimp } \\
\text { (Zr) age } \\
\text { (Ga) }\end{array}$ & Tectonic setting/sources & \\
\hline & Rio Alegre Orog & en (RAO) & & & & & & \\
\hline \multirow[t]{3}{*}{$\begin{array}{l}\text { Rio } \\
\text { Alegre } \\
\text { Terrane }\end{array}$} & $\begin{array}{l}\text { Santa Rita } \\
\text { Intrusive } \\
\text { Suite }\end{array}$ & $\begin{array}{l}\text { Syn-to- } \\
\text { late- } \\
\text { kinematic } \\
\text { granitoids }\end{array}$ & $\begin{array}{l}\text { Bt-granite, Hbl-Bt } \\
\text { granodiorite, Hbl-Bt tonalite, } \\
\text { Diorite. } T_{\mathrm{DM}}=1.53 \text { to } 1.50 \mathrm{Ga} \\
\varepsilon \mathrm{d}(\mathrm{t})=+4.1 \text { to }+3.7\end{array}$ & $\begin{array}{l}\text { Metaluminous to weakly } \\
\text { peraluminous sub- } \\
\text { alkaline, calc-alkaline } \\
\text { type granites }\end{array}$ & $\begin{array}{l}\text { Deformation and greenschist } \\
\text { metamorphism related to RAO and } \\
\text { reworked Sunsás Orogeny (SO) }\end{array}$ & $\begin{array}{l}1.44- \\
1.38\end{array}$ & $\begin{array}{l}\text { Juvenile character } \\
\text { related to RAO }\end{array}$ & $\begin{array}{l}\text { Generated in volcanic arc type, } \\
\text { orogenic arc related to RAO }\end{array}$ \\
\hline & $\begin{array}{l}\text { Mafic- } \\
\text { ultramafic } \\
\text { Intrusive } \\
\text { Suite }\end{array}$ & \multicolumn{2}{|c|}{$\begin{array}{l}\text { Metaperidotite, metagabbro, serpentinite } \\
T_{\mathrm{DM}}=1.67 \mathrm{Ga} \varepsilon_{\mathrm{Nd}(t)}=+4.5 \text { to }+2.5\end{array}$} & ? & $\begin{array}{l}\text { Greenschist to low-amphibolite facies } \\
\text { metamorphism. Deformation related to } \\
\text { RAO }(1.48-1.46 \mathrm{Ga}) \text { reworked at SO (1.0 } \\
-0.9 \mathrm{Ga})\end{array}$ & $\begin{array}{l}1.51- \\
1.49\end{array}$ & \multicolumn{2}{|c|}{ Generated in Middle Ocean Ridge } \\
\hline & $\begin{array}{l}\text { Rio Alegre } \\
\text { Volcanic- } \\
\text { Sedimentary } \\
\text { Unit }\end{array}$ & \multicolumn{2}{|c|}{$\begin{array}{l}\text { Metavolcanics meta-sedimentary rocks } \\
T_{\mathrm{DM}}=1.54 \mathrm{Ga} \varepsilon_{\mathrm{Nd}(t)}=+4.8 \text { to }+4.3\end{array}$} & ? & $\begin{array}{l}\text { Greenschist to low-amphibolite facies } \\
\text { metamorphism. Deformation related to } \\
\text { RAO (1.48 - } 1.46 \mathrm{Ga}) \text { reworked at SO }(1.0 \\
-0.9 \mathrm{Ga})\end{array}$ & 1.51 & \multicolumn{2}{|c|}{ Generated in Middle Ocean Ridge } \\
\hline \multirow[t]{9}{*}{$\begin{array}{l}\text { Jauru } \\
\text { Terrane }\end{array}$} & $\begin{array}{l}\text { Santa Helena O } \\
\text { Rio Branco } \\
\text { Intrusive } \\
\text { Suite }\end{array}$ & $\begin{array}{l}\text { rogen (SHO) } \\
\text { Anorogenic }\end{array}$ & $\begin{array}{l}\text { Gabbro, diabase, basalts } \\
\text { granites. } T_{\mathrm{DM}}=1.89-1.73 \mathrm{Ga} \\
\varepsilon_{\mathrm{Nd}(t)}=+1.9 \text { to }-1.0\end{array}$ & $\begin{array}{l}\text { A-type syenitic to } \\
\text { granitic }\end{array}$ & Undeformed & $\begin{array}{l}1.47- \\
1.42\end{array}$ & \multicolumn{2}{|c|}{$\begin{array}{l}\text { Intracontinental magmatism. Intra-plate setting, related to } \\
\text { the SHO }\end{array}$} \\
\hline & $\begin{array}{l}\text { Pindaituba } \\
\text { Intrusive } \\
\text { Suite }\end{array}$ & $\begin{array}{l}\text { Late to } \\
\text { post- } \\
\text { kinematic } \\
\text { granitoids }\end{array}$ & $\begin{array}{l}\mathrm{Bt}-\text { monzogranite. } T_{\mathrm{DM}}=\sim 1.8 \\
\text { to } 1.7 \mathrm{Ga} \varepsilon_{\mathrm{Nd}(t)}=+8 \text { to }+0.0\end{array}$ & $\begin{array}{l}\text { Peraluminous to weakly } \\
\text { metaluminous sub- } \\
\text { alkaline, calc-alkaline }\end{array}$ & $\begin{array}{l}\text { Deformation and greenschist-to low- } \\
\text { amphibolite facies metamorphism are } \\
\text { related to SHO }\end{array}$ & $\begin{array}{l}1.48- \\
1.42\end{array}$ & $\begin{array}{l}\text { Juvenile character } \\
\text { related to SHO }\end{array}$ & $\begin{array}{l}\text { Generated in a continental, } \\
\text { Andean-type, orogenic arc } \\
\text { related to SHO. Continental } \\
\text { margin calc-alkaline arc }\end{array}$ \\
\hline & $\begin{array}{l}\text { Santa Helena } \\
\text { and Agua } \\
\text { Clara } \\
\text { intrusive } \\
\text { suites } \\
\text { Cachoeirinha O }\end{array}$ & $\begin{array}{l}\text { Syn- to } \\
\text { late- } \\
\text { kinematic } \\
\text { granitoids } \\
\text { ogen }(\mathrm{CO})\end{array}$ & $\begin{array}{l}\text { Bt-syenogranite Bt- } \\
\text { monzogranite, Hbl-Bt } \\
\text { granodiorite. } T_{\mathrm{DM}}=1.8- \\
1.5 \mathrm{Ga} . \varepsilon_{\mathrm{Nd}(t)}=+4.0 \text { to }+1.7\end{array}$ & & & & \multicolumn{2}{|l|}{$\begin{array}{l}\text { Different magma } \\
\text { sources. Juvenile/ crustal } \\
\text { sources Partial melting of } \\
\text { lower crust }\end{array}$} \\
\hline & $\begin{array}{l}\text { Alvorada } \\
\text { Intrusive } \\
\text { Suite }\end{array}$ & $\begin{array}{l}\text { Late to } \\
\text { post- } \\
\text { kinematic } \\
\text { granitoids }\end{array}$ & $\begin{array}{l}\text { Bt-monzogranite. } T_{\mathrm{DM}}=1.8 \text { to } \\
1.7 \mathrm{Ga} \cdot \varepsilon_{\mathrm{Nd}(t)}=+2.25 \text { to }-1.3\end{array}$ & $\begin{array}{l}\text { Peraluminous to weakly } \\
\text { meta luminous sub- } \\
\text { alkaline, calc-alkaline }\end{array}$ & $\begin{array}{l}\text { Deformation and greenschist-to low- } \\
\text { amphibolite facies metamorphism are } \\
\text { related to CO }\end{array}$ & $\begin{array}{l}1.56- \\
1.52\end{array}$ & $\begin{array}{l}\text { Juvenile character } \\
\text { related to CO }\end{array}$ & $\begin{array}{l}\text { Generated in a continental, } \\
\text { Andean-type, orogenic arc } \\
\text { related to CO. Continental margin } \\
\text { calc-alkaline arc }\end{array}$ \\
\hline & $\begin{array}{l}\text { Santa Cruz } \\
\text { Intrusive } \\
\text { Suite }\end{array}$ & $\begin{array}{l}\text { Syn- to } \\
\text { late- } \\
\text { kinematic } \\
\text { granitoids }\end{array}$ & $\begin{array}{l}\text { Bt-syenogranite, Bt- } \\
\text { monzogranite, Hbl-Bt } \\
\text { granodiorite. } T_{\mathrm{DM}}=1.8- \\
1.9 \mathrm{Ga} \text {. } \varepsilon_{\mathrm{Nd}(t)}=+1.0 \text { to }-0.9\end{array}$ & & & & \multicolumn{2}{|c|}{$\begin{array}{l}\text { Different magma } \\
\text { sources. Juvenile/ crustal } \\
\text { sources. Partial melting } \\
\text { of lower crust }\end{array}$} \\
\hline & $\begin{array}{l}\text { Cabaçal } \\
\text { Tonalite }\end{array}$ & & Tonalitic gneiss & & Amphibolite facies metamorphism & $1.78 ?$ & & \\
\hline & $\begin{array}{l}\text { Alto Guaporé } \\
\text { Metamorphic } \\
\text { Complex }\end{array}$ & \multicolumn{2}{|c|}{$\begin{array}{l}\text { Tonalitic to monzogranite orthogneiss } \\
T_{\mathrm{DM}}=2.0 \text { to } 1.8 \mathrm{Ga} \text {. } \varepsilon_{\mathrm{Nd}(t)}=+2.4 \text { to }-0.8\end{array}$} & $\begin{array}{l}\text { Pera1uminous to } \\
\text { metaluminous sub- } \\
\text { alkaline,calc-alkaline }\end{array}$ & $\begin{array}{l}\text { Upper amphibolite to greenshist facies } \\
(1.7 \mathrm{Ga}) \text {. High } \mathrm{P}_{(\mathrm{TOT})}>\mathrm{PH}_{2} \mathrm{O} \text {. Partial } \\
\text { remelting }\end{array}$ & $\begin{array}{l}1.76- \\
1.72\end{array}$ & \multicolumn{2}{|c|}{ Generated in a oceanic, arc island-type orogen. } \\
\hline & $\begin{array}{l}\text { Figueira } \\
\text { Branca } \\
\text { Intrusive } \\
\text { Suite }\end{array}$ & \multicolumn{2}{|c|}{$\begin{array}{l}\text { Metagabbros, metapyroxenites, } \\
\text { serpentinites. } T_{\mathrm{DM}}=1.78 \mathrm{Ga} . \varepsilon_{\mathrm{Nd}(t)}=+3.68\end{array}$} & & Upper amphibolite & & \multicolumn{2}{|l|}{ ? } \\
\hline & $\begin{array}{l}\text { Alto Jauru } \\
\text { Group }\end{array}$ & \multicolumn{2}{|c|}{$\begin{array}{l}\text { Quartzites, pelitic schist, metavolcanics: } \\
\text { metabasalts, metandesites, acid-tuffsm, BIF } \\
\text { and chert. } T_{\mathrm{DM}}=1.93 \text { to } 1.85 \mathrm{Ga} \text {. } \varepsilon_{\mathrm{Nd}(t)}=+2.6 \\
\text { to }+2.2\end{array}$} & ? & $\begin{array}{l}\text { Upper amphibolite to greenschist } \\
\text { retrogression. Peak- metamorphism at } \\
1.7 \text { Ga. Partial remelting }\end{array}$ & $\begin{array}{l}1.76- \\
1.72\end{array}$ & \multicolumn{2}{|c|}{ Generated in a oceanic, arc island-type orogen. } \\
\hline
\end{tabular}

References: Barros et al. (1982), Carneiro (1985), Matos (1994), Matos et al. (2004), Monteiro et al. (1986), Pinho (1996), Saes (1999), Geraldes (2000), Geraldes et al. (2001), Tassinari et al. (2000), Geraldes et al. (2004a), Ruiz (2005), Araújo (2008) and Sousa et al. (2009). Mineral abbreviations after Kretz (1983). 
is covered on the north and south by Mesozoic-Cenozoic sedimentary sequences and is bounded to the east and west by the Alto Jauru Group (Ruiz, 2005) (Fig. 3). Included in the orogen are tonalite, granodiorite, granite and gneissic migmatite formed during magmatic and metamorphic events between 1.56 and $1.52 \mathrm{Ga}$ (Geraldes et al., 2001; Paulo, 2005; Ruiz, 2005; Araújo, 2008) (Table 2). These events also overprinted precursor lithotectonic units of the Jauru Terrane. Peak metamorphism during the Cachoeirinha Orogeny reached amphibolite facies, but has largely retrogressed to greenschist facies (Ruiz, 1992; Sousa et al., 2009).

According to Geraldes et al. (2001), Ruiz et al. (2004) and Araújo (2008), the Cachoeirinha Orogen evolved through two magmatic stages. A syn-kinematic stage is represented by the Santa Cruz Intrusive Suite and a late-kinematic stage by the Alvorada Intrusive Suite.

3.2.2.1. The Santa Cruz Intrusive Suite. The Santa Cruz Intrusive Suite is a foliated NNW-trending, multiphased batholith (Ruiz et al., 2004; Ruiz, 2005; Araújo, 2008). The batholith has three distinct facies: (1) pink to red medium- to coarse- grained equigranular syenogranite through monzogranite (2) grayish to pink porphyritic monzogranite, and (3) dark to light-gray inequigranular or medium- to coarse-grained porphyritic granodiorite. The geochemical data suggest that the suite is peraluminous and calc-alkaline in character. U-Pb zircon magmatic ages for these granitoids vary from 1.56 to $1.52 \mathrm{Ga}$. Nd $T_{\mathrm{DM}}$ model ages of $1.9-1.8 \mathrm{Ga}$, and $\varepsilon_{\mathrm{Nd}(t)}$ values of +0.9 to +1.0 indicate that the protolith material has both crustal and mantle components (Geraldes et al. 2001; Ruiz, 2005). $\mathrm{Ar}-\mathrm{Ar}$ and $\mathrm{K}-\mathrm{Ar}$ isotopic ages for the same suite varying from 1.53 to $1.52 \mathrm{Ga}$ (Carneiro, 1985; Paulo, 2005), suggest that regional cooling is related to the orogenic metamorphism. The orogen might be considered as the roots of a continental-margin arc built upon the Jauru Terrane (Geraldes et al., 2001; Ruiz et al., 2004; Ruiz, 2005; Araújo, 2008; Sousa et al., 2009).

3.2.2.2. The Alvorada Intrusive Suite. This suite, firstly described by Monteiro et al. (1986) and Ruiz (1992) consists of rounded to elliptical shaped granitic plutons composed of light-gray to pink colored medium- to fine-grained isotropic monzogranitic bodies, which are occasionally foliated. Geraldes et al. (2001), Ruiz et al. (2004) and Araújo (2008) reported U-Pb zircon magmatic ages for these granitoids varying from 1.53 to $1.44 \mathrm{Ga}$, and $\mathrm{Nd}$ isotopic data (Nd $T_{\mathrm{DM}}$ model ages of $1.8-1.7 \mathrm{Ga}$ and $\varepsilon_{\mathrm{Nd}(t)}$ between +0.5 and -1.3 ) suggest a mixing of juvenile mantle derived magmas with recycled older material. The metaluminous to peraluminous, sub-alkaline, calc-alkaline geochemical and isotopic signatures of the suite are typical for volcanic arc granitoids (Ruiz, 2005; Araújo, 2008; Sousa et al., 2009).

\subsubsection{The Santa Helena Orogen (1.48-1.42 Ga)}

Basement rocks mainly of granitic composition were included in the Santa Helena batholith (Saes et al., 1984). Later on Geraldes et al. (1997) and Van Schmus et al. (1998) proposed the term Santa Helena Suite (1.48-1.42 Ga), comprising igneous and meta-igneous rocks, represented by tonalite, orthogneiss, and granite, forming a calc-alkaline arc-related suite. Tassinari et al. (2000) upgraded the Santa Helena Suite to orogen status. The Santa Helena Orogen is bordered to the west by the Rio Alegre Terrane (Piratininga Shear Zone), to the east by Alto Jauru Group, and to the north and south it is covered by Mesozoic-Cenozoic sedimentary sequences (Fig. 3).

The Santa Helena Orogen is herein interpreted as an accretionary orogen, resulted from the development of a continental magmatic arc during the Santa Helena Orogeny. The orogen encompasses the syn-kinematic intrusions of the Santa Helena and Água Clara intrusive suites $(1.48-1.42 \mathrm{Ga})$ and Pindaiatuba Intrusive Suite (1.46-1.42 Ga), as well as the post-kinematic or anorogenic rapakivi granites and associated mafic rocks included in the Rio Branco Intrusive Suite (1.42 Ga) (Geraldes et al., 2001, 2004; Ruiz, 2005; Araújo, 2008) (Table 2).

3.2.3.1. The Água Clara Intrusive Suite. The suite is represented by a batholith (Fig. 3), which comprises two petrographic facies: the dominant one is made up of gray-foliated medium- to coarsegrained equigranular granodiorite and the other subordinated facies comprises gray-foliated porphyritic granodiorite and monzogranites (Ruiz, 2005). Geraldes et al. (2001) provide an estimate for the timing of magmatic activity at $1.48 \mathrm{Ga}$, and $\mathrm{Nd} T_{\mathrm{DM}}$ model age of $1.8 \mathrm{Ga}$ and $\varepsilon_{\mathrm{Nd}(t)}$ of +1.7 suggest an important juvenile source for the batholith. The geochemical data show that the granitoids are sub-alkaline, metaluminous to weakly peraluminous, and plot in the calc-alkaline field, reflecting a magmatic arc setting (Ruiz, 2005).

3.2.3.2. The Santa Helena Intrusive Suite. The Santa Helena Intrusive Suite consists of a batholith, which straddles the NNW trend and encompasses four principal strongly foliated petrographic facies associations, which are syenogranite and monzogranite in composition (Ruiz, 2005) (Fig. 3; Table 2). Geraldes et al. (2001) presented $\mathrm{U}-\mathrm{Pb}$ zircon magmatic ages for the batholith in the range of 1.46$1.42 \mathrm{Ga}$. The Nd $T_{\mathrm{DM}}$ model ages ranging from 1.5 to $1.6 \mathrm{Ga}$ and the $\varepsilon_{\mathrm{Nd}(t)}$ values between +2.7 and +4.0 , indicate a largely juvenile signature (Geraldes et al., 2001). Overall, the magmatism is sub-alkaline and of calc-alkaline chemistry and I-type characteristics. The less evolved Santa Helena granitoid facies is slightly metaluminous and the most fractionated are weakly peraluminous, which indicate crustal contamination (Geraldes et al., 2001). On tectonic classification diagrams, the rocks define distinct fractionation trends and plot from the field of intra-plate granites to the volcanic arc granites (Sousa et al., 2009). Ar-Ar biotite and sericite ages for the Santa Helena granites and schists vary from 0.91 to $0.89 \mathrm{Ga}$ and are interpreted to reflect the regional Sunsás reactivation (Paulo, 2005; Tohver et al., 2006).

3.2.3.3. The Pindaiatuba Intrusive Suite. The suite, consisting of several granitoid batholiths, plutons and stocks, is controlled by first order $\mathrm{N} 30-50^{\circ} \mathrm{W}$ trending regional fault-zones (Fig. 3). The components of the suite are foliated or occasional mylonitic granitoids and compositionally they range from tonalite to syenogranite. U$\mathrm{Pb}$ zircon yielded crystallization ages varying from 1.46 to $1.42 \mathrm{Ga}$ (Table 2). The Nd $T_{\mathrm{DM}}$ model ages are in the range of 1.7 to $1.8 \mathrm{Ga}$, whereas $\varepsilon_{\mathrm{Nd}(t)}$ values vary from +0.03 to +2.33 , indicating that the original magma was derived largely from juvenile sources. Geochemical results indicate that the Pindaiatuba Intrusive Suite is metaluminous to peraluminous, medium to high-K calc-alkaline tonalite and syenogranite, and the tectono-chemical diagrams show that the granitoids plot within the volcanic arc granites field (Ruiz, 2005).

The Ar-Ar ages by Ruiz (2005) suggest four cooling events: (1) $1.45 \mathrm{Ga}$ biotite age from granodiorite; (2) $1.02 \mathrm{Ga}$ biotite ages in mylonites that crosscut granodiorite; (3) 1.02-1.01 Ga biotite ages from foliated granites; and (4) 0.95-0.94 Ga biotite ages for granite bodies exhibiting tectonic foliation and mylonitization. The $1.45 \mathrm{Ga}$ biotite ages record the timing of cooling of the granodiorite body. The $1.02 \mathrm{Ga}$ from mylonites and foliated granites record the timing of regional deformation and regional metamorphic cooling, respectively. The $0.95-0.94 \mathrm{Ga}$ biotite ages from granite record the age of penetrative foliation related to the Sunsás Orogeny, and perhaps from the thermal effects due to younger Sunsás granite intrusions.

3.2.3.4. The Rio Branco Intrusive Suite. Rock units of the Rio Branco Intrusive Suíte intrude volcanic-plutonic rocks of the Alto Jauru 
Terrane (Fig. 3) and are considered as part of a bimodal rapakivi igneous association by Geraldes et al. (1999, 2004a). The mafic member comprises gabbro, tholeiitic diabase dykes and porphyritic basalt, which show U-Pb zircon crystallization age of $1471 \pm 8 \mathrm{Ma}$, Nd $T_{\mathrm{DM}}$ model ages varying from 1.80 to $1.73 \mathrm{Ga}$, and $\varepsilon_{\mathrm{Nd}(t)}$ ranges from +1.9 to +1.2 , suggesting a mantle source and crustal rock contributions (Geraldes et al., 2004a). The felsic members are mostly composed of red to pink granite rocks of syenitic to granitic composition which yielded $\mathrm{U}-\mathrm{Pb}$ zircon age of $1427 \pm 10 \mathrm{Ma}$, Nd $T_{\mathrm{DM}}$ model ages range of $1.89-1.81 \mathrm{Ga}$, and $\varepsilon_{\mathrm{Nd}(t)}$ values varying from +0.2 to -1.0 , indicating an older crustal contribution in their source. The granites exhibit geochemical characteristics of A-type granite and are interpreted to have formed in a intra-plate setting (Geraldes et al., 2004a).

3.2.3.5. Deformation and Metamorphism. The Paleoproterozoic basement exhibits compressive polyphase deformation pattern. The main structural elements comprise of refolded NEE-NWW trending gneissic compositional banding and NNW striking mylonitic zones, which show mass transport from NE towards SW. The metamorphism reached high-amphibole facies, but has retrograssed to greenschist facies conditions. Granitoid rocks from the Cachoeirinha Orogen show a N30-40 $\mathrm{W} / 60-70^{\circ} \mathrm{SE}$ trending penetrative foliation associated with shear zones characterized by a transpressive mass transport towards SW. The Santa Helena Orogen is deeply affected by the Sunsás Orogeny (1.25-1.00 Ga) resulting in a $\mathrm{N} 30-40^{\circ} \mathrm{W}$ trending foliation parallel to the Aguapeí Belt (Indiavaí-Lucialva and Piratininga shear zones), and resetting the Ar-Ar system at $1.0 \mathrm{Ga}$ (Ruiz, 2005).

\subsection{The Rio Alegre Terrane (1.51-1.38 Ga)}

The Rio Alegre Terrane was first defined as a suture zone by Saes and Fragoso Cesar (1996), coined as Rio Alegre Terrane by Saes (1999) or Rio Alegre Orogen by Matos et al. (2004). The terrane is bounded to the east by the Jauru Terrane (Piratininga shear zone) and to the west by the Paraguá Terrane (Santa Rita shear zone) and deformed sediments of the Aguapeí Group (1.17-1.15 Ga). The northern and southern extensions are unknown (Matos et al., 2004), providing that the terrane is covered by Cenozoic sedimentary sequences (Fig. 1). The main geological features and geodynamic significance of the Rio Alegre Terrane are described in detail by Matos et al. (2004) and Ruiz (2005). This accretionary orogen comprises three units: Rio Alegre Volcanic-Sedimentary Unit, Mafic-ultramafic Intrusive Suite, and Santa Rita Intrusive Suite (Fig. 3, Table 2).

\subsubsection{Lithologic units}

The Rio Alegre Volcanic-Sedimentary Unit comprises mafic and ultramafic volcanic rocks, chemical and clastic sedimentary rocks, metamorphosed at greenschist to low-amphibolite facies. It has been subdivided by Matos (1994) and Matos et al. (2004) into three sub-units, as follows:

(a) The Basal Minouro Formation consists of abundant basic to ultrabasic volcanic rocks (basic metavolcanic and subvolcanic rocks, fine-grained metabasalts and diabases), all associated with fine-grained banded iron formations (with magnetite-bearing layers), chemical sediments, chert and clastic rocks. The geochemical data indicate an ocean floor tectonic setting for these rocks (Matos et al., 2004).

(b) The Intermediate Santa Isabel Formation comprises intermediate and acid lavas and pyroclastic rocks, represented by metadacite, metarhyolite and associated meta-pyroclastic rocks. Two samples of metadacite yield $\mathrm{U}-\mathrm{Pb}$ zircon ages of $1509 \pm 10 \mathrm{Ma}$ and $1503 \pm 14 \mathrm{Ma}$, Nd $T_{\mathrm{DM}}$ model ages of ca.
$1.54 \mathrm{Ga}, \varepsilon_{\mathrm{Nd}(t)}$ values of +4.3 and +4.8 , respectively (Geraldes et al., 2000; Matos et al., 2004).

(c) The São Fabiano Formation comprises clastic, chemical and volcaniclastic meta-sedimentary rocks represented by phyllites, quartzites, carbonaceous layers, garnet-kyanitemuscovite-biotite schists, metacherts and banded iron formations.

The Mafic-ultramafic Intrusive Suite crops out for hundreds of kilometers to the NNW, and comprises mesocratic to melanocratic coarse to very coarse-grained cumulate metaperidotite, metaharzburgite, metaleucogabbros, metagabbros and serpentinites, which are derived from metamorphosed dunite, peridotite and harzburgite. In $\mathrm{U}-\mathrm{Pb}$ zircon data, these rocks yield ages ranging from $1509 \pm 10$ to $1494 \pm 11 \mathrm{Ma}$, Nd $T_{\mathrm{DM}}$ model ages of ca. $1.67 \mathrm{Ga}$, and $\varepsilon_{\mathrm{Nd}(t)}$ values of +4.5 to +2.5 (Matos et al., 2004).

The Santa Rita Suite Intrusive Suite comprises tonalite and granites, intruded at the Rio Alegre Volcanic-Sedimentary Unit and Mafic-ultramafic Intrusive Suite, and metamorphosed at greenschist to amphibolite facies. U-Pb zircon ages of these rocks vary from $1444 \pm 15$ to $1384 \pm 40 \mathrm{Ma}$, Nd $T_{\mathrm{DM}}$ model ages values are in the range of $1.52-1.49 \mathrm{Ga}$, and $\varepsilon_{\mathrm{Nd}(t)}$ values vary from +3.7 to +3.6 (Matos et al., 2004; Ruiz, 2005).

The lithologic association, geochemical and isotopic data suggest that the Rio Alegre Volcanic-Sedimentary Unit and Maficultramafic Intrusive Suite (1.51-1.49 Ga) were originated in midoceanic ridge setting, and the Santa Rita Intrusive Suite was formed in an oceanic island arc setting (1.44-1.38 Ga) (Matos et al., 2004; Ruiz, 2005).

\subsubsection{Deformation and metamorphism}

The NNW-trending Piratininga and Santa Rita mylonitic shear zones constitute the main tectonic features observed in the Rio Alegre Terrane, and are related to the Sunsás Orogeny as demonstrated by $\mathrm{Ar}-\mathrm{Ar}$ muscovite age $(0.9 \mathrm{Ga})$. However, the Rio Alegre metavolcanic-sedimentary unit shows a polyphase deformation pattern represented by gneissose banding and/or schistosity $\left(S_{1}\right)$ refolding phases related to Rio Alegre Orogeny. The structural elements indicate a tectonic sense of vergence towards $\mathrm{N} 30-50^{\circ} \mathrm{W}$, under greenschist facies metamorphic conditions (Ruiz, 2005).

The São Fabiano Formation consists of a sequence of low-greenschist metamorphic facies compatible with the chlorite zone. The mafic-ultramafic intrusive rocks underwent low-grade metamorphism, expressed by medium-grade greenschist facies conditions (biotite zone); transition to the high-greenschist facies metamorphic conditions (garnet zone) occur in some area (Matos et al., 2004). The deformation pattern is polyphase and the structural elements indicate a northeastward transport (Matos et al., 2004).

Metamorphism under greenschist to lower-amphibolite facies and deformation are apparently associated with soft-accretion of an oceanic island arc to the proto-Amazonian Craton during the mesoproterozoic (Geraldes et al., 2006). The Ar-Ar amphibole ages of 1.41-1.38 Ga and $\mathrm{Ar}-\mathrm{Ar}$ biotite ages ca. 1.32 Ga (Paulo, 2005; Tohver et al., 2006) are interpreted by Geraldes et al. (2006) as metamorphic cooling of the Rio Alegre Orogen. However, in our opinion, the $\mathrm{Ar}-\mathrm{Ar}$ ages of ca $1.32 \mathrm{Ga}$ are related to the Rondonian-San Ignacio collision orogeny (1.34-1.32 Ga).

\subsection{The RSIP in Rondônia}

The RSIP in the Rondônia region includes geological units with ages varying from 1500 to $1300 \mathrm{Ma}$. Some of them are grouped into a major tectonic unit, the Alto Guaporé Belt (Quadros and Rizzotto, 2007). The spatial and temporal distributions of these units are shown in Fig. 4, and the main geological characteristics are summarized in Table 3. 


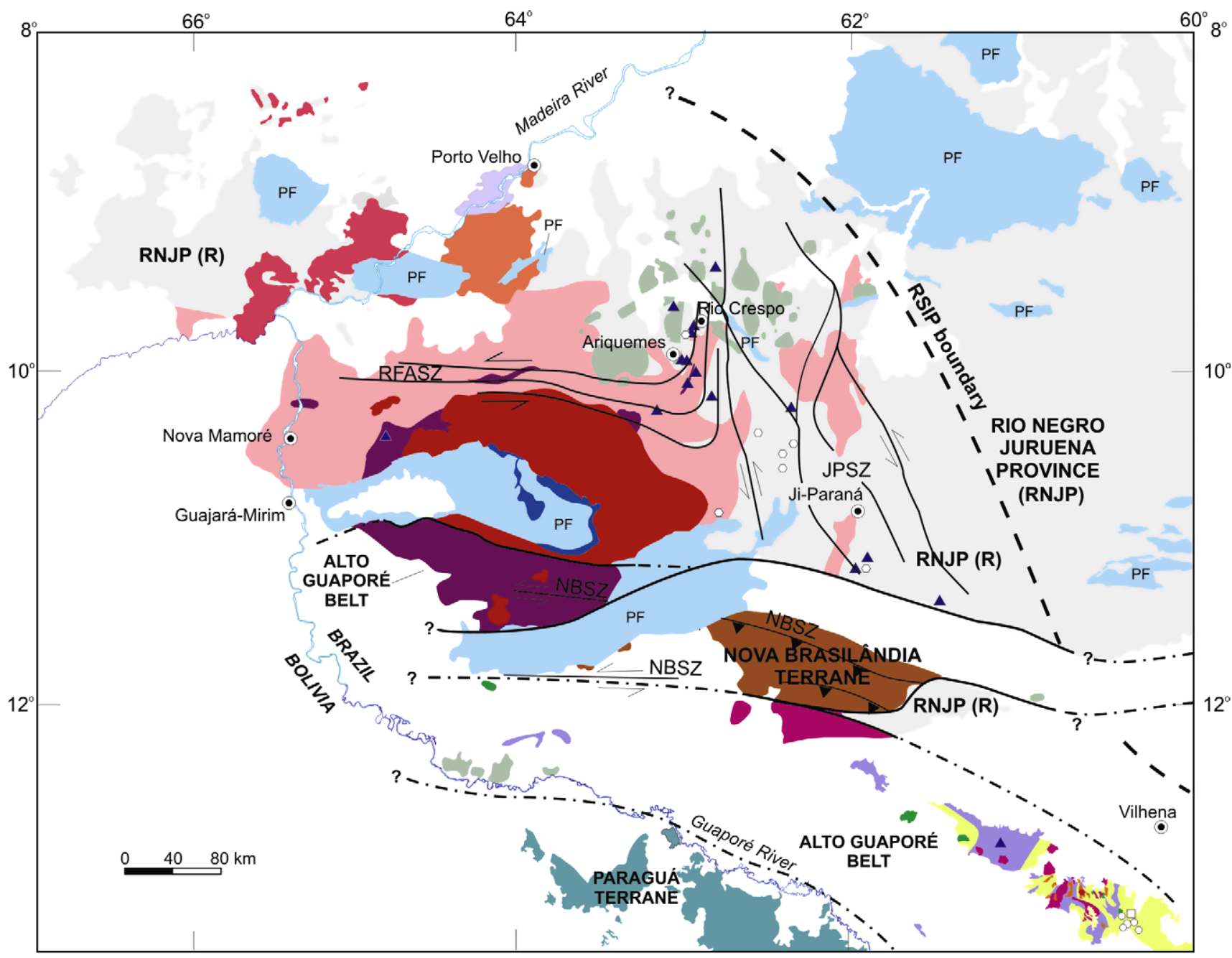

PHANEROZOIC

Undifferentiated sedimentary covers

LATE-MESOPROTEROZOIC

SUNSÁS UNITS (1250-1000 Ma)
$\square$ Nova Brasilândia
Granites
Palmeiral Formation (PF)
Nova Floresta Formation

RONDONIAN-SAN IGNÁCIO PROVINCE

\begin{tabular}{|c|c|c|}
\hline $\begin{array}{l}\text { Anorogenic Suite } \\
\begin{array}{l}\text { Teotônio Intrusive Suite } \\
\text { (1387 Ma) }\end{array}\end{array}$ & $\begin{array}{l}\text { Alto Guaporé Belt } \\
\text { Alto Escondido } \\
\text { Intrusive Suíte (1336 Ma) }\end{array}$ & $\begin{array}{l}\text { Nova Mamoré } \\
\text { Metamorphic Suite } \\
(<1515 \mathrm{Ma})\end{array}$ \\
\hline $\begin{array}{l}\text { Santo Antonio Intrusive } \\
\text { Suite (1400-1358 Ma) }\end{array}$ & $\begin{array}{l}\text { Igarapé Enganado } \\
\text { Intrusive Suite }(1340 \mathrm{Ma})\end{array}$ & $\begin{array}{l}\text { Colorado Complex } \\
\text { (<1420 Ma) }\end{array}$ \\
\hline $\begin{array}{l}\text { Rio Crespo Intrusive } \\
\text { Suite (1500 Ma) }\end{array}$ & $\begin{array}{l}\text { Serra do Colorado } \\
\text { Intrusive Suíte (1352 Ma) }\end{array}$ & $\begin{array}{l}\text { Trincheira Mafic- } \\
\text { Ultramafic Complex }\end{array}$ \\
\hline
\end{tabular}

Late-Post-tectonic suite

$\begin{array}{ll}\text { São Lourenco-Caripunas } & \text { Undifferentiated } \\ \text { Intrusive Sulte (1314-1309 Ma) } & \begin{array}{l}\text { San Ignácio Group and } \\ \text { Pensamiento Granitoid }\end{array}\end{array}$

Alto Candeias Intrusive
Suite (1346-1338 Ma) $0^{\circ}$

PALEOPROTEROZOIC-MESOPROTEROZOIC
Rio Negro-Juruena Province (RNJP) /[ Reworked RNJP(R)]
(1780-1550 Ma)
- Zircon (metamorphic grains and overgrowths), monazite and titanite U-Pb ages
(1350 - 1320 Ma; Payolla et al., 2002; Silva et al., 2002; Scandolara, 2006; Santos et al., 2008)
Hornblende Ar-Ar ages (1.378 to1298 Ma;Tohver et al., 2005; Tohver et al., 2006;
Scandolara, 2006; Quadros e Rizzotto, 2007)
$\square \quad$ Muscovite Ar-Ar ages (1.323 Ma; Tohver et al., 2006)
$\begin{array}{ll} & \text { Tectonic boundaries } \\ -\cdot-\cdot & \text { Inferred tectonic boundaries }\end{array}$
- - Rondonian-San Ignacio Province (RSIP) boundary

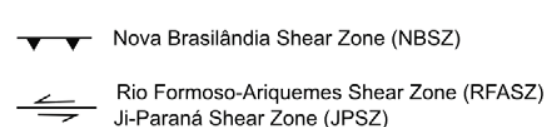

Fig. 4. Simplified geologic-tectonic map of Rondônia region and eastern Bolivia, showing the approximate boundary of the main provinces, major tectonic features, lithologic units, and compiled thermochronologic age data (modified from Litherland et al. (1986), Rizzotto et al. (2004), Quadros and Rizzotto (2007)). 
Table 3

Summary of the main geological and geochronological features of the Rondônia region (RSIP northen sector).

\begin{tabular}{|c|c|c|c|c|c|}
\hline Geological unit & Litholoagical association & $\mathrm{U}-\mathrm{Pb}$ age $(\mathrm{Ma})$ & $\begin{array}{l}{ }^{40} \mathrm{Ar} / 3^{39} \mathrm{Ar} \\
\text { age (Ma) }\end{array}$ & Tectonic settina & Reference \\
\hline \multicolumn{6}{|l|}{ Rondonian-San ignacio Province (1500-1300 Ma) } \\
\hline \multicolumn{6}{|l|}{ Late- to post-tectonic suite } \\
\hline São Lourenco-Caripunas Intrusive Suite & $\begin{array}{l}\text { Alkali-feldspar granite, syenogranite, quartz- syenite, } \\
\text { and rhyolite porphyry. The granites show petrographic } \\
\text { and geochemical characteristics of rapakivi granites }\end{array}$ & 1314-1309 & & $\begin{array}{l}\text { Post-tectonic magmatism } \\
\text { related to the collisional stage of } \\
\text { the Rondonian-San Ignacio } \\
\text { orogeny }\end{array}$ & Bettencourt et al. $(1997,1999)$ \\
\hline Alto Candeias Intrusive Suite & $\begin{array}{l}\text { Monzogranite, syenogranite, charnockite, and syenite. } \\
\text { The granites show petrographic and geochemical } \\
\text { characteristics of rapakivi granites }\end{array}$ & 1346-1338 & & $\begin{array}{l}\text { Late-tectonic magmatism } \\
\text { related to the collisional stage of } \\
\text { the Rondonian-San Ignacio } \\
\text { orogeny }\end{array}$ & Bettencourt et al. $(1997,1999)$ \\
\hline \multicolumn{6}{|l|}{ Alto Guaporé belt } \\
\hline Alto Escondido Intrusive Suite & $\begin{array}{l}\text { Monzogranite and syenogranite. The granites show } \\
\text { petrographic and geochemical characteristics of calc- } \\
\text { alkaline and post-collisional granites. }(\mathrm{T})=+2.0\end{array}$ & 1336 & $\begin{array}{l}(1312- \\
\mathrm{Hbl})\end{array}$ & $\begin{array}{l}\text { Magmatism related to the } \\
\text { collisional stage of the } \\
\text { Rondonian-San Ignacio orogeny. }\end{array}$ & $\begin{array}{l}\text { Quadros and Rizzotto, 2007; Rizzotto and } \\
\text { Quadros, } 2007\end{array}$ \\
\hline Igarapé Enganado Intrusive Suite & $\begin{array}{l}\text { Syenogranite, monzogranite, and granodiorite; rare } \\
\text { tonalite, gabbro and hybrid rocks. The granites exhibit } \\
\text { petrographic and geochemical characteristics of calc-a } \\
\text { lkaline granites. } \varepsilon_{\mathrm{Nd}(t)}=+2.8\end{array}$ & 1340 & & $\begin{array}{l}\text { Syn- to late-tectonic } \\
\text { magmatism related to the } \\
\text { collisional stage of the } \\
\text { Rondonian-San Ignacio orogeny }\end{array}$ & \\
\hline Serra do Colorado Intrusive Suite & $\begin{array}{l}\text { Anorthosite, hornblendite, and serpentinite. The rocks } \\
\text { show geochemical characteristics of N-MORB and OAB. } \\
\varepsilon_{\mathrm{Nd}(t)}=+2.7 . \varepsilon_{\mathrm{S}(t)}=-17.1\end{array}$ & 1352 & & Intra-oceanic arc & $\begin{array}{l}\text { Quadros and Rizzotto (2007), Rizzotto and } \\
\text { Quadros (2007), Rizzotto et al. (2002), Teixeira } \\
\text { et al. (2006) }\end{array}$ \\
\hline Nova Mamoré Metamorphic Suite & $\begin{array}{l}\text { Paragneiss, calc-silicate gneiss, pelitic schist, and } \\
\text { granofels }\end{array}$ & $\begin{array}{l}<1532(1330- \\
1345-\mathrm{Zrn})\end{array}$ & & $\begin{array}{l}\text { Deep oceanic basin (passive } \\
\text { margin) }\end{array}$ & $\begin{array}{l}\text { Quadros and Rizzoto (2007), Rizzotto and } \\
\text { Quadros (2007), Santos et al. (2008), Tassinari } \\
\text { et al. (1999) }\end{array}$ \\
\hline Colorado Complex & $\begin{array}{l}\text { BIF, calc-silicate gneiss, paragneiss, para-amphibolite, } \\
\text { and pelitic schist }\end{array}$ & $\begin{array}{l}<1420(1340- \\
\mathrm{Zrn})\end{array}$ & & & \\
\hline Trincheira Mafic-ultramafic Complex & $\begin{array}{l}\text { Metagabbro, amphibolitic gneiss, metapyroxenite, } \\
\text { metabasalt, and serpentinite. The rocks show } \\
\text { geochemical characteristics of N-MORB basalts }\end{array}$ & (?) & $\begin{array}{l}(1319- \\
\mathrm{Hbl})\end{array}$ & Oceanic crust & $\begin{array}{l}\text { Quadros and Rizzotto (2007), Rizzotto and } \\
\text { Quadros (2007), Santos et al. (2008) }\end{array}$ \\
\hline \multicolumn{6}{|l|}{ Anorogenic Suite } \\
\hline Teotonio Intrusive Suite & $\begin{array}{l}\text { Alkali-feldspar granite, quartz-alkali- feldspar syenite, } \\
\text { and minor syenogranite, quartz-syenite, monzogranite, } \\
\text { diorite, monzodiorite, and monzonite. The granites } \\
\text { show geochemical characteristics of A-type and intra- } \\
\text { plate granites }\end{array}$ & 1387 & & $\begin{array}{l}\text { Anorogenic magmatism in the } \\
\text { Rio Negro-Juruena crust } \\
\text { temporally related to the early } \\
\text { stage of the Rondonian-San } \\
\text { Ignacio orogeny }\end{array}$ & Bettencourt et al. (1999), Payolla (1994) \\
\hline Santo Antonio Intrusive Suite & $\begin{array}{l}\text { Monzonite, syenogranite, quartz monzonite, hybrid } \\
\text { rock, and diabase. The granites show geochemical } \\
\text { characteristics of A type and intra-plate granites }\end{array}$ & $1400-1358$ & & & \\
\hline Rio Crespo Intrusive Suite & $\begin{array}{l}\text { Fine-grained granitic gneiss and charnockitic granulite. } \\
\text { The rocks exhibit geochemical features of A-type and } \\
\text { intra-plate granites. } \varepsilon_{\mathrm{Nd}(t)}=+1.0 \text { to }+1.8\end{array}$ & $\begin{array}{l}1500(1351- \\
1331-Z n n) \\
(1331-M n z)\end{array}$ & & $\begin{array}{l}\text { Anorogenic magmatism in the } \\
\text { Rio Negro-Juruena crust }\end{array}$ & $\begin{array}{l}\text { Bettencourt et al. (2006), Payolla et al. (2001, } \\
\text { 2002), Souza et al. (2006) }\end{array}$ \\
\hline \multicolumn{6}{|l|}{ Rio Negro-Juruena Province (1780-1550 Ma) } \\
\hline $\begin{array}{l}\text { Sao Pedro and Sao Romao intrusive suites, } \\
\text { Jamari Complex, Roosevelt Group, Mutum- } \\
\text { Parana Formation, Igarape Lourdes } \\
\text { Formation, Quatro Cachoeira Suite, Serra da } \\
\text { Providencia Intrusive Suite }\end{array}$ & $\begin{array}{l}\text { Monzogranite and granodiorite, tonalitic and dioritic } \\
\text { gneiss, volcano-sedimentary sequences, sedimentary } \\
\text { sequence, and bimodal plutonism }\end{array}$ & $\begin{array}{l}\text { 1780-1550, } \\
\text { (1348-1321- } \\
\text { Zrn), (1339- } \\
\text { 1334-Mnz), } \\
\text { (1332-1330- } \\
\text { Ttn) }\end{array}$ & $\begin{array}{l}(1367- \\
1309- \\
\mathrm{Hbl})\end{array}$ & $\begin{array}{l}\text { Accretionary belts, volcano- } \\
\text { sedimentary and sedimentary } \\
\text { covers, anorogenic magmatism }\end{array}$ & $\begin{array}{l}\text { Cordani and Teixeira, 2007, Quadros and } \\
\text { Rizzotto (2007), Payolla et al. (2002), Rizzotto } \\
\text { and Quadros (2007), Santos et al. (2008), Silva } \\
\text { et al. (2002), Scandolara (2006), Tohver et al. } \\
\text { (2005) }\end{array}$ \\
\hline
\end{tabular}

Note: Mineral abbreviations after Kretz (1983). 
The controversial boundary between the RSIP and Rio NegroJuruena Province was earlier inferred based on $\mathrm{Rb}-\mathrm{Sr}$ and $\mathrm{K}-\mathrm{Ar}$ ages (Cordani et al., 1979; Teixeira et al., 1989). This, plus further Tassinari et al. (1996) U-Pb zircon ages, and more recently $\mathrm{Ar}-\mathrm{Ar}$ ages, led Cordani and Teixeira (2007) to re-evaluate this contact. It is postulated a new inferred boundary, which is not a structural but rather is based on the spatial distribution of the RSIP geological units, $\mathrm{K}-\mathrm{Ar}, \mathrm{Ar}-\mathrm{Ar}$ and $\mathrm{U}-\mathrm{Pb}$ thermal imprints (Figs. 1 and 4).

\subsubsection{Anorogenic suites}

3.4.1.1. Rio Crespo Intrusive Suite. In the Rondônia region the Rio Crespo Intrusive Suite (ca. 1500 Ma; Bettencourt et al., 2006) is the oldest recognized geologic unit of the RSIP. This unit forms an elongated E-W area across the central Rondônia. The eastern and western extensions of the unit are poorly known (Fig. 4).

The Rio Crespo Intrusive Suite (Payolla et al., 2001) is represented by pink or greenish, fine- to medium-grained, quartz-feldspathic banded gneisses showing medium- to high-grade metamorphic facies. Banding is defined by alternating quartz + plagioclase + K-feldspar layers and hornblende + magnetite + titanite + epidote \pm garnet \pm orthopyroxene \pm clinopyroxene discontinuous layers and enhanced by concordant, locally folded granitic veins. Metacharnockite (ca. $1.56 \mathrm{Ga}$ ) and mafic granulite (ca. $1.73 \mathrm{Ga}$ ) xenoliths support an intrusive origin for the protolith of the fine-grained gneisses and granulites. Preliminary geochemical data indicate that these rocks are characterized by strong iron enrichment, have metaluminous to marginally peraluminous compositions and exhibit a high- to ultra high-K signature (Payolla et al., 2002). Their trace element contents are comparable to the Phanerozoic A-type and intra-plate granites. The positive $\varepsilon_{\mathrm{Nd}(t)}$ $(+1.0$ and +1.8$)$ and the narrow range of $\mathrm{Nd} T_{\mathrm{DM}}$ model ages $(1.73-1.75 \mathrm{Ga})$ of these rocks suggest that they represent juvenile material with minor older crustal source contributions (Bettencourt et al., 2006).

3.4.1.2. Santo Antônio Intrusive Suite. The Santo Antônio Intrusive Suite (1400-1360 Ma; Bettencourt et al. 1999; Quadros and Rizzotto, 2007), along with the Teotônio Intrusive Suite, form the composite Santo Antônio batholith in the northern part of Rondônia (Fig. 4). This batholith covers an area of ca. $2000 \mathrm{~km}^{2}$, but its true dimension is unknown because the northern domain is overlain by Phanerozoic continental sediments of the Amazon basin.

The Santo Antônio Intrusive Suite is composed of two main granitic types. These are seriate to locally porphyritic biotite monzogranite and syenogranite, and equigranular biotite monzogranite. Some distinctive rock types of smaller areal extent include finegrained hornblende-biotite quartz monzonite, dyke-like bodies of hybrid rocks (monzogranite, quartz monzonite, and quartz monzodiorite) and syn-plutonic diabase dykes. The granites are sub-alkaline and slightly peraluminous rocks showing high $\mathrm{Fe} / \mathrm{Mg}, \mathrm{K}, \mathrm{F}, \mathrm{Rb}$, $\mathrm{Ga}, \mathrm{Nb}, \mathrm{Zr}$, and REE, as well as low $\mathrm{Ca}, \mathrm{Mg}$, P, and $\mathrm{Sr}$, being similar to Phanerozoic intra-plate and A-type (A2 group) granites (Payolla, 1994; Bettencourt et al., 1997).

3.4.1.3. Teotônio Intrusive Suite. The Teotônio Intrusive Suite (ca. 1387 Ma; Bettencourt et al. 1999) apparently forms a minor part of the Santo Antônio batholith at the present level of erosion (Fig. 4). The rocks of this suite were described by Payolla (1994) in the Teotônio cataract area. Major units are massive coarsegrained alkali-feldspar granite, banded medium-grained alkalifeldspar granite and pink coarse- to medium-grained quartz alkali-feldspar syenite with less common alkali-feldspar granite and syenogranite. Sparse fayalite-clinopyroxene alkali-feldspar syenite dykes and syn-plutonic diorite, monzodiorite and monzonite dykes cut the granites and syenogranites. Fine-grained syenogranite and monzogranite dykes cut the early rocks. The syenite and granites are metaluminous, and define an alkaline silica-oversaturated series with high $\mathrm{Fe} /(\mathrm{Fe}+\mathrm{Mg})$. The granites show geochemical characteristics of Phanerozoic intra-plate and A-type (A1 group) granites (Payolla, 1994; Bettencourt et al., 1997).

\subsubsection{The Alto Guaporé Belt}

The Alto Guaporé Belt is a WNW-ESE trending area (ca. $500 \times 100 \mathrm{~km}$ ), in the southern and southeastern Rondônia region. The northern boundary is the Pacaás Novos basin, Alto Candeias Intrusive Suite, Nova Brasilândia Terrane and Rio Negro-Juruena Province. To the south and east the boundaries are poorly known, providing that the limits are overlain by Phanerozoic sedimentary sequences (Fig. 1). Herein the belt is characterized as an accretionary orogen comprising at least six units (Fig. 4, Table 3): Trincheira Mafic-ultramafic Complex, Colorado Complex, Nova Mamoré Metamorphic Suite, Serra do Colorado Intrusive Suite, Igarapé Enganado Intrusive Suite and Alto Escondido Intrusive Suite.

3.4.2.1. Trincheira Mafic-ultramafic Complex. The Trincheira Maficultramafic Complex (unknown age) consists mostly of banded amphibolite, metagabbro, amphibolitic gneiss, metapyroxenite, metabasalt, and serpentinite. Preliminary geochemical data suggest that the amphibolites and metagabbros show geochemical characteristics of N-MORB (Rizzotto and Quadros, 2007) although some samples exhibit composition ranges of $\mathrm{Nd}$ and $\mathrm{Sr}$ isotopes $\left(\varepsilon_{\mathrm{Nd}(t)}=+4.1\right.$ and +5.2 ; and $\varepsilon_{\mathrm{Sr}(\mathrm{t})}=-5.0$ and -30.7$)$, and trace element geochemistry of oceanic arc basalts (Girardi et al., 2008).

3.4.2.2. Colorado Complex. The Colorado Complex is a meta-sedimentary sequence, and is composed of paragneiss, pelitic schist, calc-silicate gneiss, para-amphibolite, and BIF. The protolith of paragneiss and pelitic schist is interpreted as a turbiditic sequence deposited in a passive margin basin (Quadros and Rizzotto, 2007). U-Pb zircon ages of $1420 \mathrm{Ma}$ (detrital zircon) and of $1340 \mathrm{Ma}$ (metamorphic zircon) bracket deposition of the original sedimentary protolith of the paragneiss. The main detrital zircon age group (ca. $1508 \pm 13 \mathrm{Ma}$ ) shows that the clastic-wedge sediment was predominantly recycled from the Rio Crespo Intrusive Suite (ca. $1.50 \mathrm{Ma}$ ), and two other subordinate zircon age groups (ca. 1938 and $1645 \mathrm{Ma}$ ) indicate a Paleoproterozoic crust provenance (Rizzotto and Quadros, 2007).

3.4.2.3. Nova Mamoré Metamorphic Suite. The Nova Mamoré Metamorphic Suite was first described in the western side of Rondônia as Nova Mamoré Complex (Quadros and Rizzotto, 2007). However, in our opinion, mainly based on field geological mapping, is that the lithotypes are of restricted occurrence and constitute scattered rock remnants along the Rio Crespo Intrusive Suite. The suite is a meta-sedimentary sequence and shows geological similarities to the Colorado Complex. It is composed of migmatitic paragneiss (pelitic and psamitic gneisses), calc-silicate gneiss and granofels, quartz-fedspasthic granofels, and pelitic schist. The protolith of the paragneiss and pelitic schist is interpreted to be a turbiditic sequence deposited on a passive margin basin (Quadros and Rizzotto, 2007). U-Pb detrital zircon ages vary between 2030 and $1532 \mathrm{Ma}$, and metamorphic zircons yield an age of $1345 \mathrm{Ma}$. The timing of the deposition of the sedimentary protolith is between 1532 and $1345 \mathrm{Ma}$ (Rizzotto and Quadros, 2007).

3.4.2.4. Serra do Colorado Intrusive Suite. The Serra do Colorado Intrusive Suite comprises layered mafic-ultramafic complexes, which are intrusive in the Trincheira and Colorado complexes. The suite is made of metagabbro, metagabbronorite, anorthosite, hornblendite, and serpentinite (Quadros and Rizzotto, 2007; Rizzotto and Quadros, 2007). A sample of metagabbro yields a crystallization age of $1352 \mathrm{Ma}$, and shows geochemical and radiogenic 
isotope $\left(\varepsilon_{\mathrm{Nd}(t)}=+2.1\right.$ and $\left.\varepsilon_{\mathrm{Sr}(\mathrm{t})}=-17.1\right)$ features of $\mathrm{N}-\mathrm{MORB}$ and OAB (Rizzotto et al., 2002; Teixeira et al., 2006; Girardi et al., 2008).

3.4.2.5. Igarapé Enganado Intrusive Suite. The Igarapé Enganado Intrusive Suite includes mainly syenogranite, monzogranite, and granodiorite, together with rare tonalite, gabbro, and hybrid rock. The suite intrudes the supracrustal rocks of the Colorado complex and normally shows magmatic and/or metamorphic foliation (Quadros and Rizzotto, 2007). Foliated monzogranite and syenogranite provide a similar $\mathrm{U}-\mathrm{Pb}$ zircon crystallization age of $1340 \pm 5 \mathrm{Ma}$ (SHRIMP zircon method) and the samples give positive $\varepsilon_{\mathrm{Nd}(t)}$ values of +2.8 and +2.3 , respectively (Rizzotto and Quadros, 2007), suggesting a dominant juvenile character of the magmas. The rocks have metaluminous character with high-K calc-alkaline affinities and the granites show trace elements similarities to collisional granites (Rizzotto and Quadros, 2007).

3.4.2.6. Alto Escondido Intrusive Suite. The Alto Escondido Intrusive Suite is composed of monzogranite and syenogranite and is intrusive in the Trincheira and Colorado Complexes as well as in the Igarapé Enganado Intrusive Suite (Quadros and Rizzotto, 2007). A syenogranite gives a $\mathrm{U}-\mathrm{Pb}$ zircon crystallization age of $1336 \pm 4 \mathrm{Ma}$ (TIMS method), and positive $\varepsilon_{\mathrm{Nd}(t)}$ value of +2.0 (Rizzotto and Quadros, 2007), suggesting a dominant juvenile character of the magmas. The rocks are marginally peraluminous to metaluminous and exhibit high-K calc-alkaline affinities, with trace elements similarities to post-collisional granites (Rizzotto and Quadros, 2007).

\subsubsection{Late- to post-tectonic suites}

3.4.3.1. Alto Candeias Intrusive Suite. The Alto Candeias Intrusive Suite is largely composed of coarse- to medium-grained porphyritic granites and pyterlites, with lesser amounts of porphyritic charnockites, medium- to fine-grained equigranular granite and syenite (Bettencourt et al., 1997). Three samples of the granites provide intrusion ages between 1346 and 1338 Ma (Bettencourt et al., 1999; Santos et al., 2008). The granites are sub-alkaline, metaluminous, and show geochemical characteristic of Phanerozoic intra-plate and A-type granites (Bettencourt et al., 1997).

3.4.3.2. São Lourenço-Caripunas Intrusive Suite. The São LourençoCaripunas Intrusive Suite consists of normal rapakivi granite varieties, such as pyterlite and minor wiborgite, along with associated porphyritic and equigranular granites and subvolcanic and volcanic felsic rocks (Bettencourt et al., 1997). Two granites and one rhyolite porphyry, analysed by Bettencourt et al. (1999), yield intrusion ages between 1314 and 1309 Ma. The rocks are sub-alkaline, metaluminous to marginally peraluminous, and show strong iron enrichment. They have A-type and intra-plate granite trace element signatures (Bettencourt et al., 1997) and are considered to be a late manifestation of the Rondonian-San Ignacio Orogeny.

\subsubsection{Deformation and metamorphism}

The basement rocks of the RSIP in Rondônia region are marked by a wide network of sinistral strike-slip displacement shear zones called Ji-Paraná and Rio Formoso-Ariquemes shear zones (Fig. 4) (Scandolara et al., 1999; Tohver et al., 2004, 2005, 2006; Scandolara, 2006). According to Scandolara (2006) these shear zones are developed within the time interval $1.20-1.15 \mathrm{Ga}$ at lower-amphibolite fácies metamorphism, and all are related either to the late Rondonian-San Ignacio Orogeny stage or to the opening of the Nova Brasilândia basin. Instead Tohver et al. (2006) report that the basement rocks in Rondônia mostly preserve ages older than $1.3 \mathrm{Ga}$ and, localized isotopic Ar-Ar age resetting at 1.18-1.12 Ga is caused by Grenvillian activation of widespread sinistral strikeslip shear zones. Whether the shear zones were generated during the Rondonian-San Ignacio Orogeny and, subsequently reactivated at $1.18-1.12 \mathrm{Ga}$ or created during the Sunsás Orogeny remains an open question.

The Rondonian-San Ignacio event $(1.34-1.32 \mathrm{Ga})$ is characterized by metamorphic mineral assemblages and anatexis, which are suggestive of upper-amphibolite to granulite facies metamorphism, and are widely developed in the supracrustal rocks of the Colorado Complex and Nova Mamoré Metamorphic Suite (Quadros and Rizzotto, 2007; Rizzotto and Quadros, 2007). A tectono-metamorphic imprint over rocks of the Rio Crespo Intrusive Suite and the Rio Negro-Juruena Province is reported in the Ji-Paraná and Ariquemes region, mainly based on $\mathrm{U}-\mathrm{Pb}$ zircon, monazite and titanite ages, as well as $\mathrm{Ar}-\mathrm{Ar}$ in hornblende, biotite and muscovite ages (Fig. 4, Table 3) (Payolla et al., 2002; Silva et al., 2002; Tohver et al., 2005; Bettencourt et al., 2006; Scandolara, 2006; Santos et al., 2008). Hornblende and biotite $\mathrm{Ar}-\mathrm{Ar}$ ages are interpreted to mark cooling as granitic magmatism waned, deformation ceased and stability was achieved. Also the syn- to post-Rondonian-San Ignacio magmatism and regional thermal effects are interpreted to be related to crustal thickening associated with the collision occurred between the Paraguá Block and the Rio Negro-Juruena Province.

\subsection{Regional correlations}

The Rondonian Province (Teixeira and Tassinari, 1984) and San Ignacio Orogen (Litherland et al., 1986, 1989) have been considered to represent coeval segments of Mesoproterozoic crustal growth along the SW margin of the Amazonian Craton (Teixeira et al, 1989; Tassinari et al., 2000; Cordani and Teixeira, 2007). However, this model is controversial (Tohver et al., 2004; Boger et al., 2005). According to Tohver et al. (2004) the E-W trending Nova Brasilândia Belt marks the limit between the Amazonian and Paraguá cratons, and formed during the late Mesoproterozoic. If true, then correlations in the basement province across the belt, including the RISP, are not possible. On the other hand, Boger et al. (2005) proposed that the Proterozoic rocks of eastern Bolivia (the Paraguá Craton) evolved in four geologic distinct stages not present in the Rondônia and Mato Grosso regions of western Brazil. They conclude that the Paraguá Craton was allochthonous with respect to the southwestern margin of the Amazonia. The time-space chart of events in the Rondonian-San Ignacio Province in SW Amazonian Craton is shown in Fig. 5.

According to Boger et al. (2005) the San Ignacio Schist Group (SISG), Chiquitania Gneissic Complex (CGC) and the Lomas Manechis Granulitic Complex (LMGC) have no equivalents in SW Mato Grosso and Rondônia. However, detrital zircons suggest that the SIG and CGC may be the temporal equivalents to the Quatro Cachoeiras Suite (Quadros and Rizzotto, 2007) or to the Machadinho paragneisses (Payolla et al., 2002), in the Rondônia region. Moreover the 1657-1677 Ma magmatic and metamorphic events observed by Santos et al. $(2000,2008)$ and Silva et al. (2002), denote the presence of correlatable LMGC units in Rondônia. Zircon core ages from LMGC (1775-1715 Ma, Boger et al., 2005) and Rio Fortuna orthogneiss (1772-1734 Ma, Santos et al., 2008) are comparable with zircon crystallization ages from rocks of the Jamari Complex (1.76-1.73 Ga) in Rondônia. One magmatic zircon from the LMGC yields an age of $1818 \mathrm{Ma}$, which suggests an older crust in eastern Bolivia, comparable to the basement ages of the Juruena region in northern Mato Grosso (Santos et al., 2008). These facts suggest that the Paraguá Terrane could be a segment of the Rio Negro-Juruena Province detached at ca. $1.50-1.40 \mathrm{Ga}$ time interval, consistent with the model of Sadowski and Bettencourt (1996).

Currently, no correlatable units of the Cachoeirinha accretionary orogen $(1.56-1.52 \mathrm{Ga})$ in the Jauru Terrane are known in 


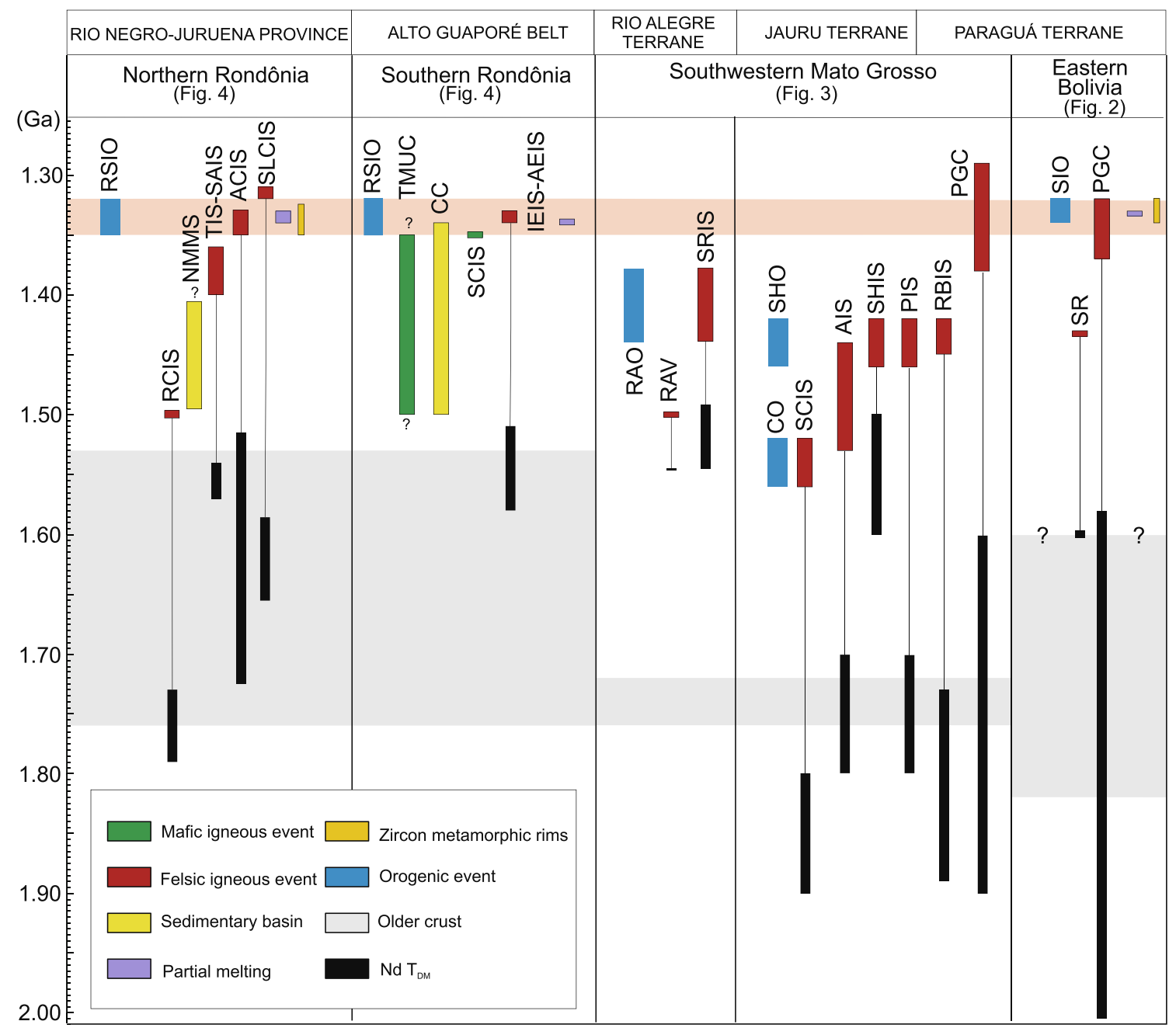

Fig. 5. Tectono-stratigraphic time-space plot showing the timing of major orogenic events, igneous events, depositional packages, and Nd $T_{\mathrm{DM}}$ ranges for the Rondonian-San Ignacio Province. RSIO, Rondonian-San Ignacio Orogeny; RCIS, Rio Crespo Intrusive Suite; NMMS, Nova Mamoré Metamorphic Suite; TIS-SAIS, Teotônio and Santo Antônio intrusive suites; ACIS, Alto Candeias Intrusive Suite; SLCIS, São Lourenço-Caripunas Intrusive Suite; TMUC, Trincheira Mafic-ultramafic Complex; CC, Colorado Complex; SCIS, Serra do Colorado Intrusive Suite; IEIS-AEIS, Igarapé Escondido and Alto Enganado intrusive suites; CO, Cachoeirinha Orogeny; RAO, Rio Alegre Orogeny; SHO, Santa Helena Orogeny; SCIS, Santa Cruz Intrusive Suite; AIS, Alvorada Intrusive Suite; RAV, Rio Alegre Volcanic-Sedimentary Unit; SRIS, Santa Rita Intrusive Suite; SHIS, Santa Helena Intrusive Suite; PIS, Pindaituba Intrusive Suite; RBIS, Rio Branco Intrusive Suite; PGC, Pensamiento Granitoid Complex; SR, San Ramón Granitods; SIO, San Ignacio Orogeny. Data from Litherland et al. (1986), Tassinari et al. (1999), Bettencourt et al. (1999, 2006), Geraldes et al. (2001), Payolla et al. (2001, 2002), Silva et al. (2002), Matos et al. (2004), Boger et al. (2005), Ruiz (2005), Tohver et al. (2005), Tohver et al. (2006), Scandolara (2006), Quadros and Rizzotto (2007), Rizzotto and Quadros (2007), Santos et al. (2008), Matos et al. (2009).

Rondônia region, although the rapakivi granites and related rocks of the Serra da Providência Intrusive Suite $(1.60-1.53 \mathrm{Ga})$ have been interpreted as a probable inboard expression of the subduction-related magmatism of the Cachoeirinha Orogeny (Bettencourt et al. 1999; Tassinari et al., 2000; Payolla et al., 2002; Geraldes et al., 2004b). Conversely, we suggest that the Serra da Providência Intrusive Suite is part of the Rio Negro-Juruena Province (Table 3) and related to a tectono-metamorphic event dated at 1670$1630 \mathrm{Ma}$ (Santos et al., 2008). Both proposals deserve further investigation.

The A-type and intra-plate granites of the Rio Crespo Intrusive Suite in Rondônia region (ca. $1500 \mathrm{Ma}$ ) have no equivalents in the Jauru and Paraguá terranes (Bettencourt et al., 2006). However, these rocks are age-correlative with intermediate volcanic rocks (1510-1500 Ma) of the Rio Alegre Terrane. Based on these observations, we propose that the initial rifting along the flanks of the Rio Negro-Juruena Province was firstly accompanied by the intrusion of the Rio Crespo Intrusive Suite and followed by the Santo Antônio Intrusive Suite (1400-1360 Ma) and Teotônio Intrusive Suite (ca. $1387 \mathrm{Ma})$.
The Santa Helena accretionary orogen (1.48-1.42 Ga) is largely represented by the syn-kinematic Santa Helena and Água Clara intrusive suites $(1.48-1.42 \mathrm{Ga})$, the Pindaiatuba Intrusive Suite $(1.46-1.42 \mathrm{Ga})$, and by the post-kinematic and/or anorogenic, bimodal rapakivi Rio Branco Suite (1.42 Ga) (Geraldes et al., 2001; Geraldes et al., 2004; Ruiz, 2005). San Ramón tonalite (1429 Ma) in the Paraguá Terrane may represent correlative magmatic activity (Santos et al., 2008).

The Pensamiento Granitoid Complex (1373-1340 Ma) is timecorrelated with the Igarapé Enganado Intrusive Suite (1340 Ma), Alto Escondido Intrusive Suite (1336 Ma) (Alto Guaporé Belt), as well as with the Alto Candeias Intrusive Suite (1346-1338 Ma). These granitoid rocks exhibit distinct petrographic and geochemical characteristics, which suggest involvement of different tectonic settings and magmas sources for their formation, during the same period of time (1373-1336 Ma). In this context the Pensamiento Granitoid Complex was generated in an Andean-type magmatic arc, the Igarapé Enganado and Alto Escondido intrusives suites were formed in an intra-oceanic arc and the Alto Candeias Intrusive Suite shows intra-plate and A-type granite affinities. 
Deformation and high-grade metamorphism are recognized along the extent of the RSIP mainly in the Paraguá Terrane and Rondônia region, more frequently between 1340 and 1320 Ma. Peak metamorphism and partial melting are recorded in the Lomas Manechis Granulitic Complex (1339-1320 Ma) and Chiquitania Gneiss Complex (ca. $1333 \mathrm{Ma}$ ) (Paraguá Terrane) (Boger et al., 2005; Santos et al., 2008), and in the Colorado Complex and Nova Mamoré Metamorphic Suite (Alto Guaporé Belt) at ca. $1340 \mathrm{Ma}$ (Tassinari et al., 1999; Payolla et al., 2002; Quadros and Rizzotto, 2007; Rizzotto and Quadros, 2007).

\subsection{Tectonic framework}

The basement rocks (>1560 Ma) which constitute the continental-margin framework to which all the studied Mesoproterozoic orogen where accreted comprise: the Chiquitania Gneiss Complex and San Ignacio Schist Group ( $\geqslant 1.69 \mathrm{Ga}$ ) and the Lomas Manechis Granulitic Complex (1.69-1.66 Ga) in the Paraguá Terrane (Boger et al., 2005); the Alto Jauru Group (1.76-1.72 Ga), Figueira Branca Intrusive Suite, Alto Guaporé Metamorphic Complex (1.8-1.7 Ga) and Cabaçal Tonalite $(1.78 \mathrm{Ga})$ in the Jauru Terrane (Ruiz, 2005) and the Jamari Complex (1.76-1.73 Ga), Mutum Paraná Formation $(1.75 \mathrm{Ga})$, Igarapé Lourdes Formation, Quatro Cachoeiras Suite $(\geqslant 1.60 \mathrm{Ga})$ and Serra da Providência Intrusive Suite (1.60$1.53 \mathrm{Ga}$ ) in the Rio Negro-Juruena Province in Rondônia region (Quadros and Rizzotto, 2007) (Tables 1-3).

The following RSIP tectonic evolution and discussion herein proposed is keyed to Fig. 6 and provide a summary of the chronology of events in the time interval 1.56-1.30 Ga, taking into account the currently geological mapping, petrological and geochemical data, U-Pb TIMS and SHRIMP and Ar-Ar dating. For this purpose we have divided the RSIP into two sectors: northern sector
A

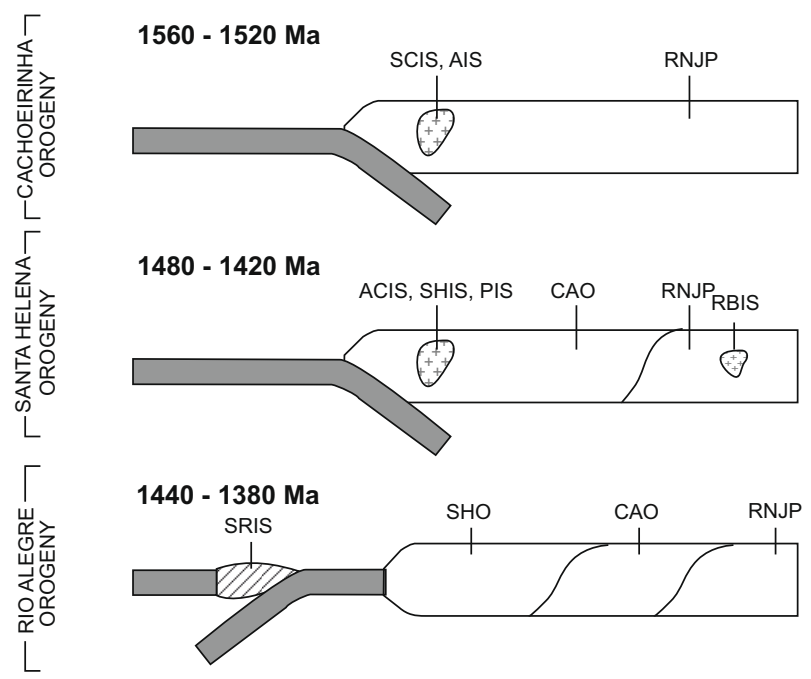

$1370-1340 \mathrm{Ma}$

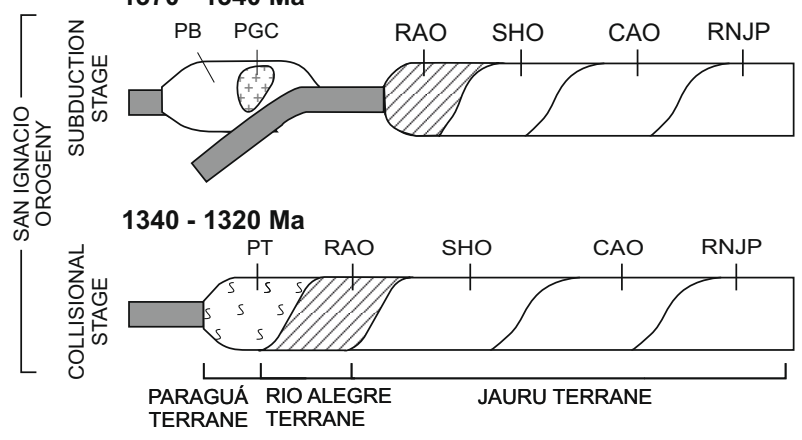

B

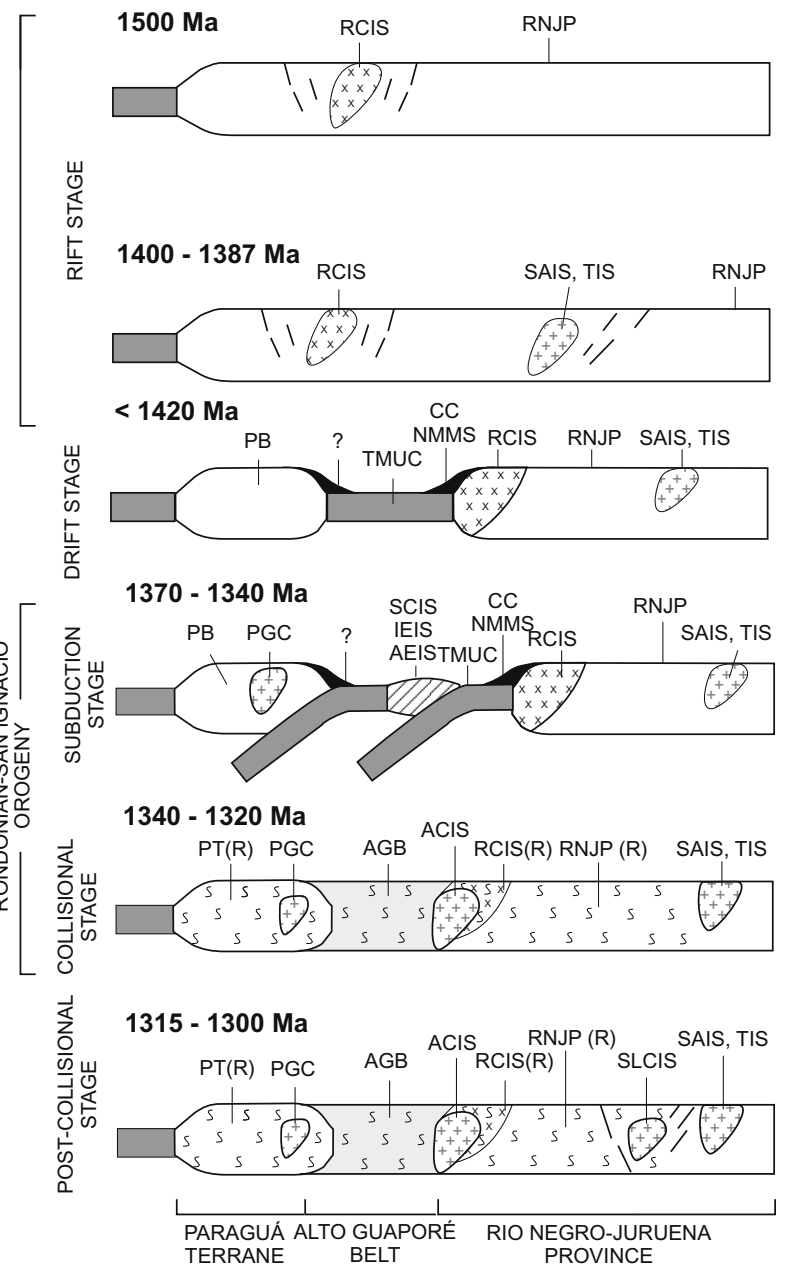

Fig. 6. Hypothetical simplified cartoon version, showing proposed tectonic evolution of the RSIP (see text for explanation). (A) During the time interval 1560-1320 Ma (southern sector). RNJP, Rio Negro-Juruena Province; SCIS, Santa Cruz Intrusive Suite; AIS, Alvorada Intusive Suite; ACIS, Âgua Clara Intrusive Suite; SHIS, Santa Helena Intrusive Suite; PIS, Pindaiatuba Intrusive Suite; CAO, Cachoeirinha Orogen; RBIS, Rio Branco Intrusive Suite; SRIS, Santa Rita Intrusive Suite; SHO, Santa Helena Orogen; PB, Paraguá Block; PGC, Pensamiento Granitoid Complex; RAO, Rio Alegre Orogen; PT, Paraguá Terrane. (B) During the time interval 1500-1300 Ma (northern sector). RNJP(R), Rio Negro-Juruena Province (Reworked); RCIS, Rio Crespo Intrusive Suite; RCIS(R), Rio Crespo Intrusive Suite (reworked); SAIS, Santo Antônio Intrusive Suite; TIS, Teotônio Intrusive Suite; TMUC, Trincheira Mafic-ultramafic Complex; CC, Colorado Complex; NMMS, Nova Mamoré Metamorphic Suíte; SCIS, Serra do Colorado Intrusive Suite; IEIS, Igarapé Enganado Intrusive Suite; AEIS, Alto Escondido Intrusive Suite; ACIS, Alto Candeias Intrusive Suite; SLCIS, São Lourenço-Caripunas Intrusive Suite; AGB, Alto Guaporé Belt. 
(Fig. 4) and southern sector (Figs. 2 and 3). We envisage the evolution of the RSIP into two distinct evolutionary periods: $1560-1370$ and $1370-1300 \mathrm{Ma}$. The older period is marked by diachronous events, leading to the building of the Cachoeirinha, Santa Helena and Rio Alegre accretionary orogens (southern sector), and rifting and oceanic spreading (northern sector), along the flanks of the Rio Negro-Juruena Province. The second period is synchronous along the entire continental margin, and encompasses subduction of oceanic lithosphere and microcontinent (Paraguá Block) - continent (proto-Amazonian Craton) collision. Based on this analysis, the RSIP is interpreted as a composite orogen or an orogenetic system, comprising an older complex accretionary orogen (1556$1340 \mathrm{Ma}$ ), and a terminal microcontinent-continent collision orogen at $1340-1320 \mathrm{Ma}$.

\subsubsection{Cachoeirinha Orogeny (1560-1520 Ma)}

The Cachoeirinha accretionary orogen was formed in a convergent continental margin, resulting in a juvenile magmatic arc. This arc results from calc-alkaline magmatism, which is represented by the syn- to late-kinematic Santa Cruz Intrusive Suite and late- to post-kinematic Alvorada Intrusive Suite (Fig. 6a).

\subsubsection{Santa Helena Orogeny (1480-1420 Ma)}

This orogeny was characterized by the development of the Santa Helena accretionary orogen, considered by Geraldes et al. (2001) and Ruiz (2005), as an Andean-type magmatic arc. This orogen is largely represented by syn-kinematic intrusions, the Santa Helena Intrusive Suite and Água Clara Intrusive Suite (1.44-1.42 Ga), and the Pindaiatuba Intrusive Suite $(1.46-1.42 \mathrm{Ga})$. Post-kinematic and/or anorogenic plutons include the $1.42 \mathrm{Ga}$ rapakivi granites and related mafic rocks of the Rio Branco Intrusive Suite (Geraldes et al., 2001; Geraldes et al., 2004; Ruiz, 2005) (Fig. 6a).

\subsubsection{Rio Alegre Orogeny (1440-1380 Ma)}

The development of the Rio Alegre accretionary orogen (1510 $1380 \mathrm{Ma}$ ) comprises oceanic spreading (1510-1490 Ma), subduction and soft-accretion stages (1440-1380 Ma) (Saes, 1999; Geraldes, 2000; Matos et al., 2004; Ruiz, 2005). The drift stage is characterized by the Rio Alegre Volcano-Sedimentary Unit and the Mafic-ultramafic Intrusive Suite (Matos, 1994; Matos et al., 2004; Ruiz, 2005). The orogenic stage (1480-1380 Ma) is recorded by oceanic lithosphere consumption during convergence in a probable intra-oceanic arc environment, accompanied by extensive tholeiitic and I-type calc-alkaline plutons and batholiths represented by the Santa Rita Intrusive Suite (Fig. 6a). Subsequent soft-collision was accompanied by $\mathrm{N} 30-50^{\circ} \mathrm{W}$ tectonic vergence under greenschist facies conditions (Ruiz, 2005).

\subsubsection{Rondonian-San Ignácio Orogeny (1370-1320 Ma)}

Mesoproterozoic events at the time interval between 1500 and 1300 Ma are best recognized in Rondônia and eastern Bolivia and the proposed time sequence is shown in Fig. 6b. The rift stage (1500-1387 Ma) was mainly characterized in Rondônia region by the emplacement of A-type and intra-plate granites and associated rocks of the Rio Crespo, Santo Antônio and Teotônio intrusive suites. The drift stage ( $<1420 \mathrm{Ma}$ ) was dominated by the development of an oceanic crust represented by the Trincheira Maficultramafic Complex and passive marginal basin sedimentary sequences comprising the Colorado Complex and the Nova Mamoré Metamorphic Suite. It is suggested that at this time the Paraguá Block became detached from its Rio Negro-Juruena crustal counterpart.

Herein the orogeny is divided into two stages: (1) the subduction stage (1370-1340 Ma) was marked by the formation of the Pensamiento Granitoid Complex in a continental magmatic arc (1373-1340 Ma; $\varepsilon_{\mathrm{Nd}(t)}=+3.9$ to -3.7$)$ within the Paraguá Block, and by the formation of the Serra do Colorado Intrusive Suite $\left(1352 \mathrm{Ma} ; \varepsilon_{\mathrm{Nd}(t)}=+2.7 ; \varepsilon_{\mathrm{Sr}(t)}=-17.1\right)$, Igarapé Enganado Intrusive Suite and Alto Escondido Intrusive Suite (1340-1336 Ma; $\varepsilon_{\mathrm{Nd}(t)}=+2.8$ and +2.0$)$, within an intra-oceanic arc, and (2) the collisional stage (1340-1320 Ma) is characterized by deformation, high-grade metamorphism and partial melting (peak metamorphism), which affected primarily the Lomas Manechis Granulitic Complex, Chiquitania Gneiss Complex, Colorado Complex and Nova Mamoré Metamorphic Suite, that represents the culmination stages of the Rondonian-San Ignacio Orogeny. The Alto Candeias Intrusive Suite (1346-1338 Ma) comprises slightly deformed rapakivi granites and associated rocks, closely related to the collisional process. Post-collisional events are represented by extensive bimodal magmatism of the São Lourenço-Caripunas Intrusive Suite (1314-1309 Ma) in Rondônia.

\section{Summary and concluding remarks}

The Rondonian-San Ignácio Province (RSIP) was created through the oblique collision of the Paraguá Block and the proto-Amazonian Craton (including Jauru and Rio Alegre terranes) resulting in the formation of the Rondonian-San Ignacio Orogen (1.56$1.30 \mathrm{Ga}$ ). The record of the collision is preserved mostly in the Paraguá Terrane (Bolivia and Mato Grosso regions), and in the Alto Guaporé Belt and Rio Negro-Juruena Province (Rondônia region), as the orogen has suffered later collision-related deformation and metamorphism during Sunsás Orogeny (1.25-1.00 Ga). The RSIP appears to be a composite orogen, including complex accretionary orogen and collisional orogen developed during the time interval of $1.56-1.34 \mathrm{Ga}$ and $1.34-1.32 \mathrm{Ga}$, respectively. The RondonianSan Ignacio Orogen was formed at the onset of the RondonianSan Ignacio collisional orogeny (1.34-1.32 Ma), and comprises: (1) the Jauru Terrane (1.76-1.72 Ga) hosts of the Cachoeirinha accretionary orogen (1.56-1.52 Ga) and the Santa Helena accretionary orogen (1.48-1.42 Ga), both developed in an Andean-type magmatic arc (2) the Rio Alegre Terrane that comprises the Rio Alegre accretionary orogen (1.51-1.38 Ga), generated in an intra-oceanic environment (3) the Paraguá Terrane $(1.82-1.32 \mathrm{Ga})$ that comprises the San Ignacio accretionary orogen (1.37-1.34 Ga) hosts of the Andean-type Pensamiento Granitoid Complex, and (4) the Alto Guaporé Belt $(<1.42-1.34 \mathrm{Ma})$ that developed in passive marginal basin and intra-oceanic magmatic arc settings. Cratonization of the province is interpreted to have occurred at $1.30 \mathrm{Ga}$ (Ar-Ar ages) and $1.25 \mathrm{Ga}$ (K-Ar ages).

The main orogenies in the tectonic evolution of the RSIP were:

(1) Cachoeirinha Orogeny (1.56-1.52 Ga): development of Andean-type Cachoeirinha accretionary orogen over the Rio Negro-Juruena Province, represented by the Santa Cruz and Alvorada Intrusive suites.

(2) Santa Helena Orogeny (1.48-1.42 Ga): development of Andean-type Santa Helena accretionary orogen, comprising the Santa Helena and Agua Clara intrusive suites.

(3) Rio Alegre Orogeny (1.44-1.38 Ga): generation of the Santa Rita Intrusive Suite.

(4) Rondonian-San Ignacio Orogeny (1.37-1.32 Ga): development of the San Ignacio accretionary orogen, comprising the Pensamiento Granitoid Complex, the intra-oceanic arc comprising the Serra do Colorado, Igarapé Enganado, and Alto Escondido intrusive suites, and collision of the Paraguá Block with the proto-Amazonian Craton.

However, the tectonic framework observed in the RSIP requires a better exercise of understanding, mainly due to the complex geological evolution and overprints related to the Sunsás Orogeny. The 
spatial organization of Sunsás age structures in the SW Amazonian Craton is compatible with a transpressional left-lateral component during collision (Sadowski and Bettencourt, 1996; Teixeira et al., 2010), and extension components responsible for the insertion of the Neoproterozoic basins.

\section{Acknowledgments}

Careful reviews by U.G. Cordani and B. B. de Brito Neves are appreciated. Two other anonymous journal reviewers and Guest Editor Cesar Casquet are thanked for comments that much improve the quality of the manuscript. Also we sincerely thank Thelma Collaço Samara from the the IGc-USP for the drafts.

\section{References}

Araújo, L.M.B., 2008. Evolução do Magmatismo Pós-Cinemático do Domínio Cachoeirinha: Suítes Intrusivas Rio Branco, Alvorada e Santa Cruz, SW do Cráton Amazônico, MT. Ph.D. Thesis, São Paulo State University, Rio Claro, Brazil (in Portuguese).

Barros, A.M., Silva, R.H., Cardoso, O.R.F.A., Freire, F.A., Souza Jr., J.J., da Rivetti, M., Luz, D.S., Palmeira, R.C. Tassinari, C.C.G.1982. Geologia. In: Ministério das Minas e Energia. Projeto RADAMBRASIL, Folha SD 21. Cuiabá. Rio de Janeiro, 544 p. In: Levantamentos de Recursos Naturais, vol. 26, pp. 25-192.

Berrangé, J.P., Litherland, M., 1982. Sinopsís de la geologia y potencial de minerales del area del Proyecto Precambrico. Boletin del Servicio Geológico de Bolivia, Informe 21, 120.

Bettencourt, J.S., Leite, W.B., Payolla, B.L., Scandolara, J.E., Muzzolon, R., Vian, J.A.J. 1997. The rapakivi granites of the Rondônia Tin Province, Northern Brazil. In: 2nd International Symposium on Granites and Associated Mineralizations, Excursion Guide. Salvador, Bahia, Brazil, pp. 3-31

Bettencourt, J.S., Tosdal, R.M., Leite Jr, W.B., Payolla, B.L, 1999. Mesoproterozoic rapakivi granites of the Rondônia Tin Province, southwestern border of the Amazonian Craton, Brazil-I. Reconnaissance U-Pb geochronology and regional implications. Precambrian Research 95, 41-67.

Bettencourt, J.S., Payolla, B.L., Tosdal, R.M.; Wooden, J.L., Leite, W.B., Sparrenberger, I., 2006. SHRIMP-RG U-Pb zircon geochronology of gneiss from the Rio Crespo Intrusive Suite, SW Amazonian Craton, Rondônia, Brazil: new insight about protolith crystallization and metamorphic ages. In: 5th South American Symposium on Isotopic Geology, Short Papers, Punta del Este, Uruguay, pp. 49-52.

Boger, S.D., Raetz, M., Giles, D., Etchart, E., Fanning, M.C., 2005. U-Pb age data from the Sunsas region of Eastern Bolivia, evidence for the allochtonous origin of the Paraguá Block. Precambrian Research 139, 121-146.

Carneiro, M.A., 1985. Contribuição à geologia da região de São José dos Quatro Marcos-MT. M.Sc. Dissertation, University of São Paulo, São Paulo, Brazil (in Portuguese).

Carneiro, M.A., Ulbrich, H.H.G.J., Kawashita, K., 1992. Proterozoic crustal evolution at the southern margin of the Amazonian Craton in the State of Mato Grosso, Brazil: evidence from Rb-Sr and K-Ar data. Precambrian Research 59, 263-282.

Cordani, U.G., Tassinari, C.C.G., Teixeira, W., Basei, M.A.S., Kawashita, K., 1979. Evolução tectônica da Amazônia com base em dados geocronológicos. In: 2nd Congreso Geologico Chileno, Actas, Arica, Chile, pp. 137-148 (in Portuguese).

Cordani, U.G., Teixeira, W., 2007. Proterozoic accretionary belts in the Amazonian Craton. In: Hatcher, R.D., Jr., Carlson, M.P., McBride, J.H., Martínez Catalán, J.R. (Eds.), 4-D Framework of Continental Crust. Geological Society of America Memoir, 200, pp. 297-320.

Cordani, U.G., Teixeira, W., D’Agrella-Filho, M.S., Trindade, R.I., 2009. The position of the Amazonian Craton in supercontinents. Gondwana Research 15, 396-407.

Darbyshire, D.P.F., 2000. The Precambrian of Eastern Bolívia: a Sm-Nd isotope study. In: 31st International Geological Congress, Rio de Janeiro, Brazil, Abstract Vol. Rio de Janeiro, Geological Survey of Brazil, CD-ROM.

Geraldes, M.C., 2000. Geocronologia e geoquímica do plutonismo mesoproterozóico do SW do Estado do Mato Grosso (SW do Cráton Amazônico). Ph.D. Thesis, University of São Paulo, São Paulo, Brazil (in Portuguese).

Geraldes, M.C., Figueiredo, B.R., Tassinari, C.C.G., Ebert, H.D., 1997. Middle Proterozoic vein-hosted gold deposit in the Pontes e Lacerda region, southwestern Amazonian Craton, Brazil. International Geology Review 39, 438-448.

Geraldes, M.C., Matos, J.B., Ruiz, A.S., Fetter, A.H., Kozuch, M., Van Schmus, W.R., Tassinari, C.C.G., Teixeira, W., 1999. U/Pb constraints on Proterozoic magmatic arcs in SW Amazônia Cráton, Brazil. In: 2nd South American Symposium on Isotope Geology, Actas, Córdoba, Argentina, p. 143.

Geraldes, M.C., Teixeira, W., Van Schmus, W.R., 2000. Isotopic and chemical evidence for three accretionary magmatic arcs (1.79-1.42 Ga) in SW Amazon Craton, Mato Grosso State, Brazil. Revista Brasileira de Geociências 30, 99-101.

Geraldes, M.C., Van Schmus, W.R., Condie, K.C., Bell, S., Teixeira, W., Babinski, M., 2001. Proterozoic Geologic Evolution of the SW part of the Amazonian Cráton in Mato Grosso State, Brazil. Precambrian Research 111, 91-128.

Geraldes, M.C., Bettencourt, J.S., Teixeira, W., Matos, J.M., 2004a. Geochemistry and isotopic constraints on the origin of the Mesoproterozoic Rio Branco "anorogenic" plutonic suite, SW of Amazonian Craton, Brazil: high heat flow and crustal extension behind the Santa Helena arc? Journal of South American Earth Science 16, 1-14.

Geraldes, M.C., Teixeira, W., Heilbron, M., 2004b. Lithospheric versus asthonospheric source of the SW Amazonian Craton A-type granites: the role of the Paleo- and Mesoproterozoic accretionary belts for their coeval continental suites. Episodes 27, 185-189.

Geraldes, M.C., Paulo, V.G., Fernandes, C.J., Teixeira, W. 2006. Termocronologia do SW do Cráton Amazônico: a história geológica das acresções dos terrenos Paleo e Mesoproterozóicos do SW do Estado do Mato Grosso. In: Fernandes, C.F., Viana, R.R. (Eds.). Geologia do Cráton Amazônico em Mato Grosso. Cuiabá, EDUFMT, vol. 1, pp. 7-23.

Girardi, V.A.V., Teixeira, W., Bettencourt, J.S., Andrade, S., Navarro, M.S., Sato, K., 2008. Trace elements geochemistry and Sr-Nd characteristics of Mesoproterozoic mafic intrusive rocks from Rondônia, Brazil, SW Amazonian Craton: petrogenetic and tectonic inferences. Episodes 31, 1-9.

Kretz, R., 1983. Symbols for rock-forming minerals. American Mineralogist 68, 277279 .

Litherland, M., Bloomfield, K., 1981. The Proterozoic history of eastern Bolivia. Precambrian Research 15, 157-179.

Litherland, M., Annels, R.N., Appleton, J., Berrange, J., Bloomfield, K., Burton, C., Darbyshire, D.P.F., Fletcher, C.J.N., Hawkins, M.P., Klink, B.A., Llanos, A., Mitchell, W.I., O'Connor, E.A., Pitfield, P.E.J., Power, G., Webb, B.C., 1986. The geology and mineral resources of the Bolivian Precambrian shield. Overseas Memoir, British Geological Survey Paper 9, $154 \mathrm{p}$.

Litherland, M. Annels, R.N., Darbyshire, D.P.F, Fletcher, C.J.N., Hawkins, M.P., Klink, B.A., Mitchell, W.I., O'Connor, E.A., Pitfield, P.E.J., Power, G., Webb, B.C., 1989. The Proterozoic of eastern Bolivia and its relationship to the Andean mobile belt. Precambrian Research 43, 157-174.

Matos, J.B., 1994. Contribuição à geologia da parte da porção meridional do Cráton Amazônico, região do Rio Alegre, MT. M.Sc. Dissertation, University of São Paulo, São Paulo, Brazil (in Portuguese).

Matos, J.B., Schorscher, J.H.D., Geraldes, M.C., Sousa, M.Z.A., Ruiz, A.S., 2004. Petrografia, geoquímica e geocronologia das rochas do Orógeno Rio Alegre, Mato Grosso: um registro de crosta oceânica mesoproterozóica no SW do Cráton Amazônico. Geologia USP, Série Científica 4, 75-90 (in Portuguese).

Matos, R., Teixeira, W., Geraldes, M.C., Bettencourt, J.S., 2009. Geochemistry and Nd-Sr Isotopic Signatures of the Pensamiento Granitoid Complex, RondonianSan Ignacio Province, Eastern Precambrian Shield of Bolivia: Petrogenetic Constraints for a Mesoproterozoic Magmatic Arc Settting, Geologia USP. Série Científica 9, 89-117.

Menezes, R.G., Silva, P.C.S., Silva, L.C., Takahashi, A.K., Lopes, I., Bezerra, J.R.I., 1993. Geologia da Folha Pontes e Lacerda - SD-21-Y-C-II. Levantamentos geológicos Básicos do Brasil, CPRM, Brasília, 126 p. (in Portuguese).

Monteiro, H., Macedo, P.M., Silva, M.D., Moraes, A.A., Marchetto, C.M.L., 1986. O 'Greenstone Belt' do Alto Jauru. In: 34th Congresso Brasileiro de Geologia, Anais, Goiânia, Brasil, SBG, pp. 630-647 (in Portuguese).

Paulo, V.G., 2005. Identificação dos eventos termotectônicos através do método ${ }^{40} \mathrm{Ar} /{ }^{39} \mathrm{Ar}$ nos terrenos Jauru, Pontes e Lacerda e Rio Alegre, SW do Cráton Amazônico. M.Sc. Dissertation. Rio de Janeiro State University, Rio de Janeiro, Brazil, $120 \mathrm{p}$ (in Portuguese).

Payolla, B.L., 1994. As rochas graníticas e sieníticas das cachoeiras Teotônio e Santo Antônio, Rio Madeira, Porto Velho, Rondônia: geologia, petrografia e geoquímica. M.Sc. Dissertation, University of Brasília, Brasília, Brazil (in Portuguese)

Payolla, B.L., Bettencourt, J.S., Leite, W.B., Basei, M.A.S., 2001. The Rio Crespo Intrusive Suite: Geological U-Pb and $\mathrm{Sm}-\mathrm{Nd}$ isotopic evidence for a major $1.43 \mathrm{Ga}$ arc-related magmatism in the Rondônia state, SW Amazonian Craton, Brazil. In: Bettencourt, J.S, Teixeira, W., Pacca, I.G., Geraldes, M.C., Sparrenberger, I. (Eds.), Geology of the SW Amazonian Craton: State-of-theArt. Workshop Extended Abstracts, São Paulo, Brazil, University of São Paulo, pp. 96-99.

Payolla, B.L. Bettencourt, J.S., Kozuch, M. Leite, W.B., Fetter, A.H., Van Schmus, W.R. 2002. Geological evolution of the basement rocks in the east-central part of the Rondônia Tin Province, SW Amazonian Craton, Brazil: U-Pb and Sm-Nd isotopic constraints. Precambrian Research 119, 141-169.

Pinho, F.E.C., 1996. The origin of the Cabaçal Cu-Au deposit, Alto Jauru Greenstone Belt, Brazil. Ph.D. Thesis, University of Western Ontario, London, Canada.

Pinho, F.E.C., Fyfe, W.S., Pinho, M.A.S.B., 1997. Early Proterozoic evolution of the Alto Jauru greenstone belt, southern Amazonian Craton, Brazil. International Geology Review 39, 220-229.

Quadros, M.L.E.S., Rizzotto, G.J., 2007. Geologia e Recursos Minerais do Estado de Rondônia. Texto Explicativo do Mapa Geológico e de Recursos Minerais do Estado de Rondônia, escala 1:1.000.000. Sistema de Informações Geográficas SIG. Serviço Geológico do Brasil - CPRM, Porto Velho, 154 p (in Portuguese).

Rizzotto, G.J., Bettencourt, J.S., Teixeira, W., Pacca, I.I.G., D’Agrella, M.S., Vasconcelos, P., Basei, M.A.S., 2002. Geologia e geocronologia da Suíte Metamórfica Colorado e suas encaixantes, SE de Rondônia: implicações para a evolução mesoproterozóica do SW do Cráton Amazônico. Geologia USP, Série Científica 2, 41-55 (in Portuguese).

Rizzotto, G.J., Quadros, M.L.E.S., Bahia, R.B.C., Dall'igna, L.G., Cordeiro, A.V. 2004. Folha SD.20-Guaporé e Folha SE.20-Lagoa Formosa. In: Schobbenhaus, C., Gonçalves, J.H., Santos, J.O.S., Abram, M.B., Leão Neto, R., Matos, G.M.M., Vidotti, R.M., Ramos, M.A.B., de Jesus, J.D.A. (Eds.). Carta Geológica do Brasil ao Milionésimo, Sistema de Informação Geográfica.CPRM, Brasília, CD-ROM. 
Rizzotto, G.J., Quadros, M.L.E.S., 2007. Margem passiva e granitos orogênicos do Ectasiano em Rondônia. In: 10th Simpósio de Geologia da Amazônia, Resumos Expandidos, Porto Velho, Brasil, SBGN, pp. 245-248 (in Portuguese).

Ruiz, A.S., 1992. Contribuição à Geologia do Distrito de Cachoeirinha, MT. M.Sc. Dissertation, University of São Paulo, São Paulo, Brazil (in Portuguese).

Ruiz, A.S., 2005. Evolução geológica do sudoeste do Cráton Amazônico, região limítrofe Brasil-Bolívia, Mato Grosso. Ph.D. Thesis, São Paulo State University, Rio Claro, São Paulo, Brazil. (in Portuguese).

Ruiz, A.S., Geraldes, M.C., Matos, J.B., Teixeira, W., Van Schmus, W.R., Schmitt, R., 2004. The 1590-1520 Ma Cachoeirinha magmatic arc and its tectonic implications for the Mesoproterozoic. SW Amazonian Craton crustal evolution. Anais da Academia Brasileira de Ciências 76, 807-824.

Ruiz, A.S., Sousa, M.Z.A., Matos, J.B., Lima, G.A., 2007. Geologia do Domínio Tectônico Paraguá, SW do Cráton Amazônico - fronteira Brasil-Bolívia. In: 10th Simpósio de Geologia do Centro-Oeste, Anais, Pirenópolis, Brasil, CD-ROM (in Portuguese).

Sadowski, G.R., Bettencourt, J.S., 1996. Mesoproterozoic tectonic correlations between eastern Laurentia and the western border of the Amazon Craton. Precambrian Research 76, 213-227.

Saes, G.S., 1999. Evolução tectônica e paleogeográfica do Aulacógeno Aguapei (1.2$1.0 \mathrm{Ga}$ ) e dos terrenos do seu embasamento na porção sul do Cráton Amazônico. Ph.D. Thesis, University of São Paulo, São Paulo, Brazil (in Portuguese).

Saes, G.S., Fragoso Cesar, A.R.S., 1996. Acresção de terrenos mesoproterozóicos no SW da Amazônia. In: 39th Congresso Brasileiro de Geologia, Boletim de Resumos Expandidos, Salvador, Brazil, SBG, pp. 124-126 (in Portuguese).

Saes, G.S., Leite, J.A.D., Weska, R.K., 1984. Geologia da Folha Jauru (SD.21.Y.C.III): uma síntese dos conhecimentos. In: 33rd Congresso Brasileiro de Geologia, Anais, vol. 5. Rio de Janeiro, Brasil, pp. 2193-2204 (in Portuguese).

Santos, J.O.S., Hartmann, L.A., Hartmann, L.A., Gaudette, H.E., Groves, D.I., McNaughton, N.J., Fletcher, I.R., 2000. A new understanding of the provinces of Amazon craton based on integration of field mapping and $\mathrm{U}-\mathrm{Pb}$ and $\mathrm{Sm}-\mathrm{Nd}$ geochronology. Gondwana Research 3, 489-506.

Santos, J.O.S., Rizzotto, G.J., Potter, P.E., McNaughton, N.J., Matos, R.S., Hartmann, L.A., Chemale, F., Quadros, M.E.S., 2008. Age and autochthonous evolution of the Sunsás Orogen in West Amazon Craton based on mapping and $\mathrm{U}-\mathrm{Pb}$ geochronology. Precambriam Research 165, 120-152.

Scandolara, J.E., 2006. Geologia e evolução do terreno Jamari, embasamento da faixa Sunsás/Aguapei, centro-leste de Rondônia, sudoeste do Cráton Amazônico. Ph.D. Thesis, University of Brasília, Brasília, Brazil (in Portuguese).

Scandolara, J.E., Rizzotto, G.J., Bahia, R.B.C., Quadros, M.L.E.S., Amorim, J.L., Dall'Igna, L.G., 1999. Geologia e Recursos Minerais do Estado de Rondônia: texto explicativo e mapa geológico na escala 1:1.000.000. Programa Levantamentos Geológicos Básicos do Brasil. CPRM-Serviço Geológicos do Brasil, Brasília, Brasi (in Portuguese).

Silva, L.C., Armstrong, R., Pimentel, M.M., Scandolara, J.E., Ramgrab, G., Wildner, W. Angelim, L.A.A., Vasconcelos, A.M., Rizzotto, G.J., Quadros, M.L.E.S., Sander, A., Rosa, A.L.Z., 2002. Reavaliação da evolução geológica em terrenos précambrianos brasileiros com base em novos dados U-Pb SHRIMP, parte III: províncias Borborema, Mantiqueira Meridional e Rio Negro-Juruena. Revista Brasileira de Geociências 32, 529-544 (in Portuguese).

Sousa, M.Z.A., Batata, M.E.F., Ruiz, A.S., Matos, J.B., Paz, J.D.S., Costa, A.C.D., Silva, C.H., Costa, P.C.C., 2009. Geologia da Folha SD 21-Y-D-I - Rio Branco. Programa
Nacional de Geologia-PRONAGEO. Serviço Geológico do Brasil-CPRM/ Universidade Federal do Mato Grosso, 153 p.

Souza, V.S., Teixeira, L.M., Dantas, E.L., Botelho, N.F., Laux, J.H., 2006. Datação U-Th$\mathrm{Pb}$ e U-Pb em monazita de ortognaisse do Complexo Jamari, área do depósito de estanho de Bom Futuro (RO). Revista Brasileira de Geociências 36, 71-76 (in Portuguese).

Tassinari, C.C.G., Macambira, M.J.B., 1999. Geochronological provinces of the Amazonian Craton. Episodes 22, 174-182.

Tassinari, C.C.G., Cordani, U.G., Nutman, A.P., Van Schmus, W.R., Bettencourt, J.S. Taylor, P.N., 1996. Geochronological systematics on basement rocks from the Rio Negro-Juruena Province (Amazonian Craton) and tectonic implications. International Geology Review 38, 161-175.

Tassinari, C.C.G., Cordani, U.G., Correia, C.T., Nutman, A.P., Kinny, P., Dias Neto, C. 1999. Dating granulites by SHRIMP U-Pb systematics in Brazil: constraints for the age of the metamorphism of Proterozoic orogenies. In: 2nd South American Symposium on Isotope Geology, Actas, Cordoba, Argentina, IGRM-SGMA, pp. 234-238.

Tassinari, C.C.G., Bettencourt, J.S., Geraldes, M.C., Macambira, M.J.B., Lafon. J.M., 2000. The Amazonian Craton. In: Cordani, U.G., Milani, E.J., Thomaz Filho, A., Campos, D.A. (Eds.), Tectonic evolution of South America. 31st International Geological Congress, Rio de Janeiro, Brazil, pp. 41-95.

Teixeira, W. and Tassinari, C.C.G., 1984. Caracterização geocronológica da Província Rondoniana e suas implicações geotectônicas. In: 2nd Symposium Amazônico, Actas, Manaus. Amazonas, Brazil, pp. 75-86 (in Portuguese).

Teixeira, W., Tassinari, C.C.G., Cordani, U.G., Kawashita, K., 1989. A review of the geochronology of the Amazonian Craton: tectonic implications. Precambrian Research 42, 213-227.

Teixeira, W., Bettencourt, J.S., Girardi, V.A.V., Onoe, A., Sato, K., 2006 Mesoproterozoic mantle heterogeneity in the SW Amazonian Craton: ${ }^{40} \mathrm{Ar} /{ }^{39} \mathrm{Ar}$ and $\mathrm{Nd}-\mathrm{Sr}$ isotopic evidence from mafic-felsic rocks. In: Hanski, E. Mertanen, S., Rämö, T., Vuollo, J. (Eds.), Dyke Swarms - Time Markers of Crustal Evolution. Taylor and Francis Group, London, pp. 113-129.

Teixeira, W., Geraldes, M.C., Matos, R., Ruiz, A.S., Saes, G., Vargas-Matos, G., 2010 A review of the tectonic evolution of the Sunsás belt, SW portion of the Amazonian Craton. Journal of South American Earth Science 29, 47-60.

Tohver, E., van der Pluijm, B., Mezger, K., Essene, E.J., Scandolara, J.E., Rizzotto, G.R., 2004. Significance of the Nova Brasilândia metasedimentary belt in western Brazil: redefining the Mesoproterozoic boundary of the Amazon craton. Tectonics 23 TC 6004. doi:10.1028/2003TC001563.

Tohver, E., van der Pluijm, B., Scandolara, J.E., Essene, E.J., 2005. Late Mesoproterozoic deformation of SW Amazonia (Rondônia, Brazil): geochronological and structural evidence for collision with southern Laurentia. Journal of Geology 113, 309-323.

Tohver, E., Teixeira, W., van der Pluijm, B., Geraldes, M.C., Bettencourt, J.S., Rizzotto, G.J., 2006. Restored transect across the exumed Grenville orogen of Laurentia and Amazonia, with implications for crustal architecture. Geology 34, 669672.

Van Schmus, W.R., Geraldes, M.C., Fetter, A.H., Ruiz, A.S., Matos, J.B., Tassinari, C.C.G., Teixeira, W., 1998. U/Pb and $\mathrm{Sm} / \mathrm{Nd}$ constraints on the age and origin of Proterozoic crust in southwestern Mato Grosso, Brazil: evidence for a $1450 \mathrm{Ma}$ magmatic arc in SW Amazonia. In: International Symposium on Tectonics. Abstract Volume, Ouro Preto, Minas Gerais, Brazil, pp. 121-125. 


\title{
A review of the tectonic evolution of the Sunsás belt, SW Amazonian Craton
}

\author{
Wilson Teixeira ${ }^{\mathrm{a}, *}$, Mauro Cesar Geraldes ${ }^{\mathrm{b}}$, Ramiro Matos ${ }^{\mathrm{c}}$, Amarildo Salina Ruiz ${ }^{\mathrm{d}}$, Gerson Saes ${ }^{\mathrm{d}}$, \\ Gabriela Vargas-Mattos ${ }^{\mathrm{e}}$
}

a Instituto de Geociências, Universidade de São Paulo (IGc-USP), São Paulo, Brazil

${ }^{\mathrm{b}}$ Faculdade de Geologia, Universidade do Estado do Rio de Janeiro, Rio de Janeiro, Brazil

' Postgraduate Program, IGc-USP, Instituto de Investigacion Geológica e Ambiental, Universidad Mayor de San Andrés, La Paz, Bolivia

d Instituto de Geociências, Universidade Federal de Mato Grosso, Cuiabá, Brazil

e Postgraduate Program, Faculdade de Geologia, Universidade do Estado do Rio de Janeiro, Rio de Janeiro, Brazil

\section{A R T I C L E I N F O}

\section{Article history:}

Received 8 April 2009

Accepted 22 September 2009

\section{Keywords:}

Amazonian Craton

Mesoproterozoic evolution

Sunsás orogen

Sunsás-Aguapeí province

\begin{abstract}
A B S T R A C T
The Sunsás-Aguapeí province (1.20-0.95 Ga), SW Amazonian Craton, is a key area to study the heterogeneous effects of collisional events with Laurentia, which shows evidence of the Grenvillian and Sunsás orogens. The Sunsás orogen, characterized by an allochthonous collisional-type belt (1.11-1.00 Ga), is the youngest and southwesternmost of the events recorded along the cratonic fringe. Its evolution occurred after a period of long quiescence and erosion of the already cratonized provinces ( $>1.30 \mathrm{Ga})$, that led to sedimentation of the Sunsás and Vibosi groups in a passive margin setting. The passive margin stage was roughly contemporary with intraplate tectonics that produced the Nova Brasilândia proto-oceanic basin $(<1.21 \mathrm{Ga})$, the reactivation of the Ji-Paraná shear zone network $(1.18-1.12 \mathrm{Ga})$ and a system of aborted rifts that evolved to the Huanchaca-Aguapeí basin (1.17-1.15 Ga). The Sunsás belt is comprised by the metamorphosed Sunsás and Vibosi sequences, the Rincón del Tigre mafic-ultramafic sill and granitic intrusive suites. The latter rocks yield $\varepsilon_{\mathrm{Nd}(\mathrm{t})}$ signatures $(-0.5$ to -4.5$)$ and geochemistry (S, I, A-types) suggesting their origin associated with a continental arc setting. The Sunsás belt evolution is marked by "tectonic fronts" with sinistral offsets that was active from c. 1.08 to $1.05 \mathrm{Ga}$, along the southern edge of the Paraguá microcontinent where $\mathrm{K} / \mathrm{Ar}$ ages (1.27-1.34 Ga) and the Huanchaca-Aguapeí flat-lying cover attest to the earliest tectonic stability at the time of the orogen. The Sunsás dynamics is coeval with inboard crustal shortening, transpression and magmatism in the Nova Brasilândia belt (1.13-1.00 Ga). Conversely, the Aguapeí aulacogen (0.96-0.91 Ga) and nearby shear zones $(0.93-0.91 \mathrm{Ga})$ are the late tectonic offshoots over the cratonic margin. The post-tectonic to anorogenic stages took place after ca. $1.00 \mathrm{Ga}$, evidenced by the occurrences of intra-plate A-type granites, pegmatites, mafic dikes and sills, as well as of graben basins. Integrated interpretation of the available data related to the Sunsás orogen supports the idea that the main nucleus of Rodinia incorporated the terrains forming the SW corner of Amazonia and most of the Grenvillian margin, as a result of two independent collisional events, as indicated in the Amazon region by the Ji-Paraná shear zone event and the Sunsás belt, respectively.
\end{abstract}

(c) 2009 Elsevier Ltd. All rights reserved.

\section{Introduction}

The Sunsás-Aguapeí (SA) province at the southwest corner of the Amazonian Craton has been the focus of several geologic works that are part of the reconnaissance mapping of the Bolivian Precambrian shield, first undertaken by the Anglo-Bolivian technical cooperation program known as "Proyecto Precambrico" - GEOBOL (Litherland et al., 1986, 1989). Further efforts have been made towards the better understanding of the Proterozoic evolution of this cratonic segment, which includes more detailed geologic investiga-

\footnotetext{
* Corresponding author. Tel./fax: +55 1130913906

E-mail address: wteixeir@usp.br (W. Teixeira)
}

tions not only in Bolivia but also in the neighboring area in Brazil. Nevertheless, the reader must be aware that the geologic knowledge of the Sunsás-Aguapeí age rocks are far from being well-constrained given the limited number of related publications, in particular, over the remote areas of the Bolivian-Brazilian border.

This paper reassesses the tectonic evolution of the Sunsás orogen $(1.11-1.00 \mathrm{Ga})$, the youngest and southwesternmost of the events in the Amazonian Craton by summarizing the up-to-date geologic knowledge, specially its chronological control in order to better characterize the tectonic province bearing the same name. Taking into account the litho-estratigraphic correlations, the Sunsás evolution can be delineated into three steps: (1) the passive margin formation along the southwestern margin of Amazon 
region; (2) the collisional stage and coeval tectonic events manifested in both plate margin and more distally within its Brazilian counterpart; (3) the post-tectonic and anorogenic events.

In a global context the Sunsás orogen is a key-feature among the collisional processes linked with the agglutination of the Rodinia supercontinent, as suggested by the worldwide correlative orogens particularly with the Grenville province (e.g., Hoffman, 1991; Kröner and Cordani, 2003). In this way, intraplate tectonics through the Amazonian Craton are similarly reflective of such a global phenomenon, given by regional metamorphic overprints, shear zones, thrusts, rift basins and anorogenic magmatism dated between 1.2$1.0 \mathrm{Ga}$ (e.g., Cordani et al., 2010).

Most of the Mesoproterozoic reconstructions place Amazonia against the eastern Laurentia (e.g., Sadowski and Bettencourt, 1996; Rivers, 1997; Boger et al., 2005; Tohver et al., 2002, 2005a, 2006; D'Agrella-Filho et al., 2008; Elming et al., 2009; Cordani et al., 2009). However, alternative positions are envisaged in order to accommodate smaller crustal fragments like the Arequipa-Antofalla (Peru) and Las Matras complexes (Western Sierras Pampeanas in Argentina) that occur in the Andes (e.g., Litherland et al., 1985; Keppie and Ortega-Gutierrez, 1999; Casquet et al., 2006) - see Kröner and Cordani (2003), and Ramos and Aleman (2000) for an outline of Grenvillian-aged reconstructions dealing with Amazônia and the Andes.

\section{Overview of the pre-Sunsás evolution}

Four Proterozoic provinces make up the tectonic scenario of the SW Amazonian Craton (e.g., Teixeira et al., 1989; Cordani and Teixeira, 2007; Bettencourt et al., 2010), as follow: Ventuari-Tapajós (VT; $2.00-1.81 \mathrm{Ga),} \mathrm{Rio} \mathrm{Negro-Juruena} \mathrm{(RNJ;} \mathrm{1.80-1.60} \mathrm{Ga),}$ Rondonian-San Ignacio (RSI; $1.56-1.30 \mathrm{Ga}$ ) and Sunsás-Aguapeí

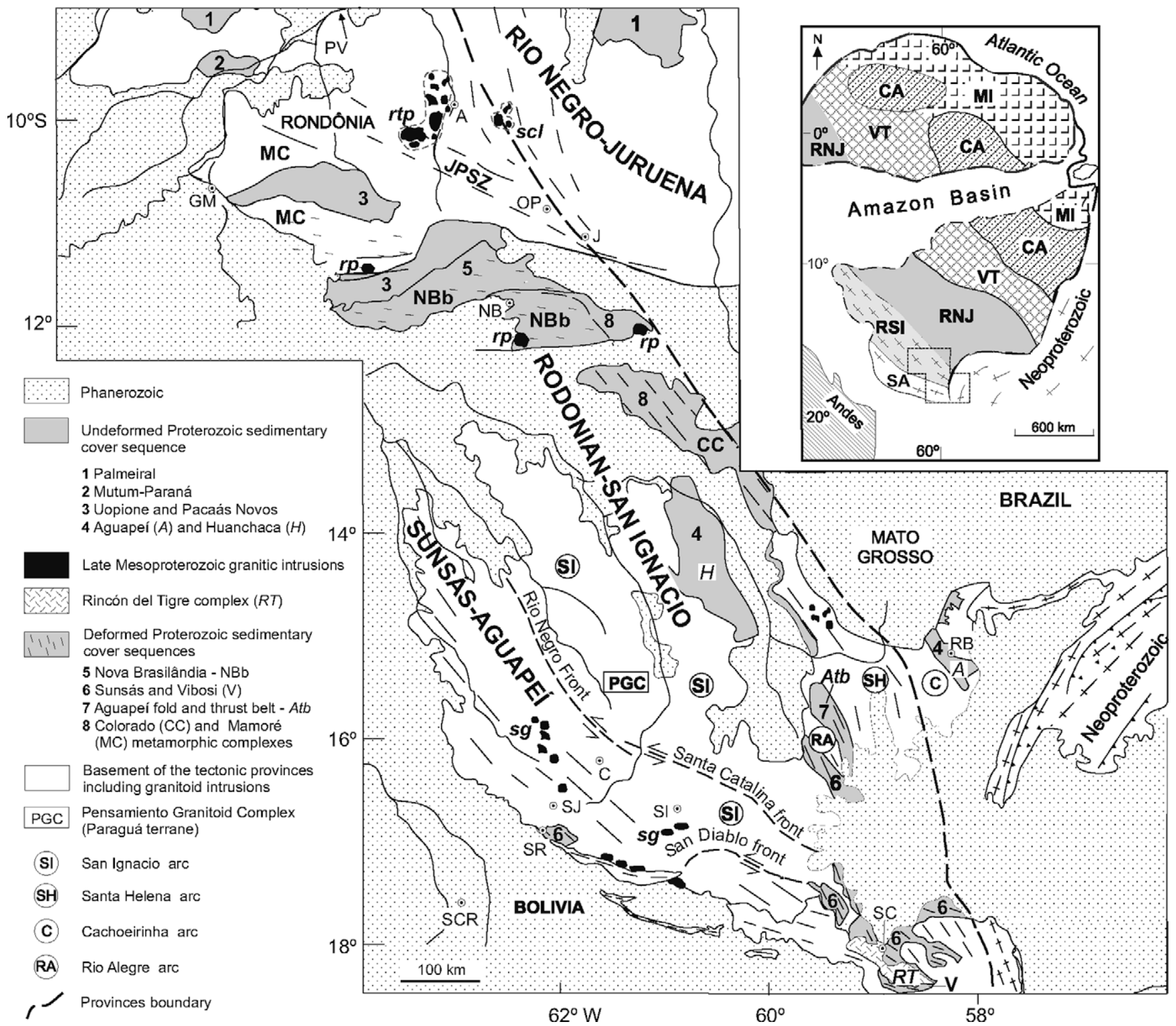

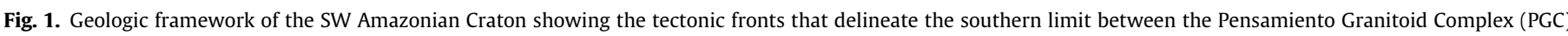

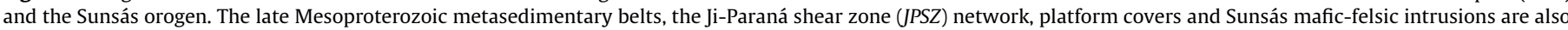

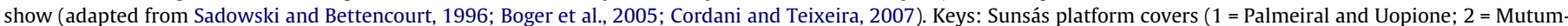

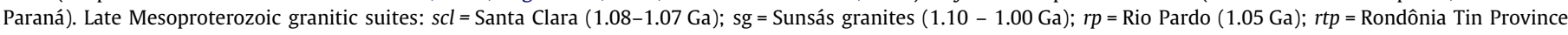

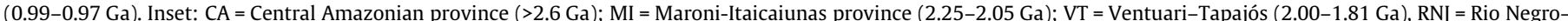

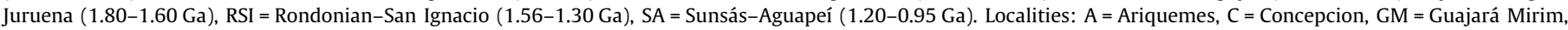
$\mathrm{J}=$ Jiparaná, NB = Nova Brasilândia, OP = Ouro Preto, PV = Porto Velho, RB = Rio Branco, SC = Santo Corazon, SI = San Ignacio, SJ = San Javier, SR = San Ramon. 
(SA; $1.20-0.95 \mathrm{Ga}$ ) (Fig. 1). After cratonization of the SA province, the Amazon region acted as a tectonically stable foreland for the Neoproterozoic belts of Western Gondwanaland (e.g., Cordani et al., 2009).

In short, the Proterozoic dynamics involved a long-term softaccretion/collision regime with concurrent magmatic, sedimentary and metamorphic episodes that resulted into stepwise crustal growth outwards from the core of the proto-craton, as suggested by the tectonic framework and isotopic signatures of the magmatic rocks. As a corollary, the internal cratonic architecture (present position) exhibits linear trending provinces that become relatively young to the SW as reported by Cordani and Teixeira (2007). Noteworthy cratonization of a given province is sustained by the lower age limit of the related basement rocks, shown by regional distribution of the K/Ar and ${ }^{40} \mathrm{Ar} /{ }^{39} \mathrm{Ar}$ ages (e.g., Tassinari et al., 2000; Tohver et al., 2006; Bettencourt et al., 2010).

Other tectonic divisions and boundaries of the Proterozoic provinces have envisaged different configurations on the basis of geologic correlations, $\mathrm{U} / \mathrm{Pb}$ and $\mathrm{Sm} / \mathrm{Nd}$ data, regional structures and metamorphic patterns. A few models argue the Sunsás evolution is autochthonous, belonging to an accretionary orogen evolved from 1.45 to $1.10 \mathrm{Ga}$ (Santos et al., 2000, 2006, 2008; Santos, 2003). However, this idea is not sustained by the general concordance of the geochronologic scenarios of the RNJ, RSI and SA provinces, each one characterized by stepwise crustal growth followed by a given cratonization stage, as described in most of the studies dealing with SW Amazon region (e.g., Sadowski and Bettencourt et al., 1996; Geraldes et al., 2001; Tassinari and Macambira, 2004; Boger et al., 2005; Ruiz, 2005; Tohver et al., 2006; Cordani and Teixeira, 2007). In the same way, the Santos' model is apparently not agreeing with the concept and duration of the Sunsás orogen, which was first postulated by Litherland et al. (1986, 1989). According to these authors the Sunsás orogen is allochthonous, as shown by coherent transport of the folded strata against the structurally-defined Paraguá Craton (Litherland and Bloomfield, 1981; Litherland and Klinck, 1982). In this regard, the Paraguá region, where the Paleoproterozoic nature of the crystalline basement is assigned from the available $T_{\mathrm{DM}}(2.07-1.86 \mathrm{Ga})$ and SHRIMP U/Pb zircon (1.82-1.66 Ga) ages - e.g., Santos et al. (2008), has been interpreted as a terrane or microcontinent based on the significant mismatch of its tectonic history with the geologic framework of the neighboring RSI province (e.g., Sadowski and Bettencourt, 1996; Boger et al., 2005; Ruiz, 2005).
Although there are no doubts that the Paraguá rocks were allochthonous with respect of the SW Amazon margin [see Bettencourt et al. (2010) for a reappraisal of the RSI evolution], its geodynamic behavior during the late Mesoproterozoic is still under debate. Boger et al. (2005) reported some of the alternative tectonic scenarios, which consider either the final docking of the Paraguá microcontinent and the Amazon region during the Sunsás orogen at c. $1.10 \mathrm{Ga}$, as similarly suggested by Tohver et al. $(2004,2006)$. However, these last works also suggested other alternative configurations such as the collision of the Paraguá microcontinent with the southern part of the already cratonized the RNJ province at $\mathrm{c}$. 1.37-1.28 Ga, creating the Rondonian-San Ignacio accretionary belt (see below). We think that the latter hypothesis is more consistent with the available geochronologic background, geologic correlations and regional structure of the SW Amazon region see Betttencourt et al. (2010).

Table 1 portrays the main geologic units and also the metamorphic and tectonic elements of the RNJ and RSI provinces (e.g., Tassinari et al., 2000; Cordani and Teixeira, 2007). In resume, the RNJ framework is a result of stacking and lateral accretion of sucessive intra-oceanic arc complexes and granite-greenstone terrains (e.g., Geraldes et al., 2001). On the other hand, the younger adjacent RSI province records the generation and coalescence of intra-oceanic (e.g., Rio Alegre, Colorado/Mamoré) and continental arcs (e.g., Cachoeirinha, Santa Helena, Pensamiento) as well as the intervening microcontinents (e.g., Paraguá), throughout the Mesoproterozoic (1.56-1.30 Ga) - Geraldes et al., 2004a,b; Bettencourt et al. (2010). Thus, it is implied that the interval over which the preceding RNJ evolution is apparently shorter than previously thought (1.78-1.55 Ga; e.g., Cordani and Teixeira, 2007).

The Rondonian-San Ignacio accretionary belt of the RSI province (Fig. 1) is the youngest and most widespread of the related Mesoproterozoic events, comprising the San Ignacio continental arc (Bolivia) and the coeval Colorado and Mamoré complexes in the Brazilian neighborhoods (Cordani and Teixeira, 2007; Bettencourt et al., 2010). The San Ignacio arc (1.37-1.28 Ga) is represented by voluminous sub-alkaline to high-K calc-alkaline metaigneous suites denominated as Pensamiento Granitoid Complex in the Paraguá region (e.g., Boger et al., 2005; Matos et al., 2009). As a consequence, the Paraguá basement [Lomas Manechis complex (1.68-1.66 Ga), as well as the Chiquitania and San Ignacio metasedimentary units $(<1.79 \mathrm{Ga})$ ] were substantially affected by partial melting and metamorphism at c. $1.34-1.32 \mathrm{Ga}$, which is

Table 1

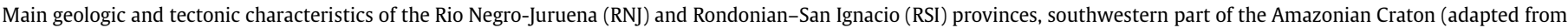
Bettencourt et al., 2006; Tohver et al., 2006; Cordani and Teixeira, 2007). See text and Figs. 1 and 2 for details.

\begin{tabular}{|c|c|c|c|}
\hline Characteristics of the Province & Major metamorphic and tectonic events & $\begin{array}{l}\text { Main regional units, including orogenic } \\
\text { granitoid rocks }\end{array}$ & $\begin{array}{l}\text { Post-tectonic and anorogenic } \\
\text { intrusions }\end{array}$ \\
\hline $\begin{array}{l}\text { Rio Negro-Juruena }(1.80-1.60 \mathrm{Ga}) \text { : } \\
\text { Predominant intra-oceanic arcs } \\
\text { Regional cooling }(1.55-1.50 \mathrm{Ga}) \text { : } \\
\text { cratonic area for the RSI and } \\
\text { Sunsás orogens }\end{array}$ & $\begin{array}{l}\text { Juvenile, recurrent plutonic pulses: } \\
\text { Rondônia }(1.79-1.73 \mathrm{Ga}),(1.57-1.53 \mathrm{Ga}) \text {; } \\
\text { Rio Crespo intrusive suite }(1.49 \mathrm{Ga}) \\
\text { Heterogeneous metamorphic overprint and } \\
\text { tectonic reactivations due to the RSI and } \\
\text { Sunsás orogens southward }\end{array}$ & $\begin{array}{l}\text { Granite-greenstone assemblages, medium- } \\
\text { to high-grade gneissic associations } \\
\text { Syn-tectonic calc-alkaline plutonism } \\
\text { Volcano-sedimentary sequences and } \\
\text { volcanic/plutonic covers } \\
\text { Bimodal anorogenic magmatism (AMCG } \\
\text { suites) }\end{array}$ & $\begin{array}{l}\text { Intrusive suites: Oriente Novo } \\
\text { ( } 1.08 \mathrm{Ga}) \text {; Rondônia Tin Province - } \\
\text { RTP: Santa Bárbara ( } 0.98 \mathrm{Ga}) \text {. Salto } \\
\text { do Céu sills and dikes ( } 1.03- \\
0.98 \mathrm{Ga})\end{array}$ \\
\hline $\begin{array}{l}\text { Rondonian-San Ignacio (RSI; } 1.56- \\
1.30 \mathrm{Ga}) \text { : passive margin setting. } \\
\text { Intra-oceanic and continental } \\
\text { arcs. Collation of the Paraguá } \\
\text { terrane }(\mathrm{c} .1 .32 \mathrm{Ga}) \\
\text { Regional cooling }(1.36-1.28 \mathrm{Ga}) \text { : } \\
\text { cratonic area for the Sunsás belt }\end{array}$ & $\begin{array}{l}\text { Magmatic arcs: Cachoeirinha ( } 1.56- \\
1.54 \mathrm{Ga}) \text {, Rio Alegre }(1.51-1.48 \mathrm{Ga}) \text {, Santa } \\
\text { Helena ( } 1.44-1.42 \mathrm{Ga}) \text {. Colorado/Mamoré/ } \\
\text { San Ignacio ( } 1.37-1.28 \mathrm{Ga}) \text {. Medium- to } \\
\text { high grade metamorphism. Post-tectonic } \\
\text { mafic magmatism }(1.40 \mathrm{Ga}) \\
\text { Orogenic collapse/oceanic rift }(<1.21 \mathrm{Ga}) \text {. } \\
\text { Ji-Paraná shear zone network ( } 1.18- \\
1.12 \mathrm{Ga}) \\
\text { Sunsás inboard effects: intracratonic belts, } \\
\text { shear zones }(1.08-1.05 \mathrm{Ga}), \text { rift structures }\end{array}$ & $\begin{array}{l}\text { Ocean-floor assemblages (Rio Alegre, } \\
\text { Colorado, Mamoré complexes) and calc- } \\
\text { alkaline rocks (Cachoeirinha, Santa Helena } \\
\text { suites). Pensamiento Granitoid Complex } \\
\text { (San Ignacio suite). Nova Brasilândia } \\
\text { metasedimentary belt } \\
\text { Platform covers: Huanchaca/Aguapeí, } \\
\text { Pacaás Novos and Uopione grabens } \\
\text { (Palmeiral formation) } \\
\text { Sunsás inboard effects: Aguapeí fold and } \\
\text { thrust belt }\end{array}$ & $\begin{array}{l}\text { Mafic sills ( } 1.2 \mathrm{Ga} \text {; Pacaás Novos } \\
\text { rift basin). } \\
\text { Santa Clara ( } 1.08-1.07 \mathrm{Ga}) \text { and Rio } \\
\text { Pardo granitic suites }(1.05 \mathrm{Ga}) \\
\text { Hunchaca dolerite suite }(0.98 \mathrm{Ga}) \\
\text { RTP: Maçangana (0.99-0.90 Ga). } \\
\text { Guapé granitic suíte }(0.95- \\
0.92 \mathrm{Ga})\end{array}$ \\
\hline
\end{tabular}


suggested by the SHRIMP $\mathrm{U} / \mathrm{Pb}$ ages of the zircon overgrowths (e.g., Boger et al., Santos et al., 2008).

In contrast to the San Ignacio arc, the contemporary Colorado and Mamoré rocks have their origin associated with a passive margin to ocean floor setting. These units were produced by subsequent shortening and metamorphism of the sedimentary sequences and magmatic rocks that characterizes the Colorado and Mamoré belts in Rondônia state, also named Alto Guaporé accretionary belt by Bettencourt et al. (2010). To the north, the $\mathrm{RNJ}$ rocks record an equivalent age of high-grade metamorphic overprint, given by U/Pb SHRIMP ages $(1.30-1.35 \mathrm{Ga})$ of zircon overgrowths and monazite (Bettencourt et al. 1999a; Payolla et al. 2002, 2003). In addition, slightly foliated intra-plate granitoid intrusions showing a A-type affinity in the RSI province display roughly comparable ages, such as found for the Alto Candeias (1.35-1.34 Ga) and the São Lourenço-Caripunas (1.31 Ga) intrusive suites (Bettencourt et al., 1999a). These magmatic suites can be considered good markers of intraplate activity related with the late tectonic to post-tectonic phases of Rondonian-San Ignacio accretionary belt (Bettencourt et al. 2010).

The timing of cratonization of the RSI province is well recorded over the Paraguá microcontinent, as indicated by preservation of $\mathrm{U} / \mathrm{Pb}$ monazite and ${ }^{40} \mathrm{Ar} /{ }^{39} \mathrm{Ar}$ (Tohver et al., 2006) and $\mathrm{K} / \mathrm{Ar}$ mineral ages (Litherland et al., 1986) between 1.34$1.27 \mathrm{Ga}$. Furthermore, it can also be inferred from the existence of the undeformed Huanchaca Group that unconformably overlies the Paraguá basement rocks. In the same way, the Mamoré and Colorado metamorphic belts, as well as the RSI and RNJ rocks in Mato Grosso preserve ${ }^{40} \mathrm{Ar} /{ }^{39} \mathrm{Ar}$ plateau $(1.34-1.31 \mathrm{Ga})$ and $\mathrm{K} / \mathrm{Ar}$ ages (1.36-1.31 Ga) - Teixeira et al. (1989, 2006), Bettencourt et al. (1996), Rizzotto et al. (2002), Tohver et al. (2006). Hence, all these ages above indicate that the RSI province and the coalesced Paraguá microcontinent attained tectonic stability by $1.3 \mathrm{Ga}$ ago.

As a result from the Mesoproterozoic polycyclic evolution, the region between the RNJ and the RSI provinces is characterized by the occurrence of a complex juxtaposition of distinct geologic units, such as the Nova Brasilândia belt (1.11-1.00 Ga; Tohver et al., 2004) and a great deal of anorogenic, A-type granitic intrusions like the Santa Clara intrusive suite $(1.08-1.07 \mathrm{Ga})$ and the Rondônia Tin Province plutons (0.99-0.97 Ga) - e.g., Bettencourt et al., 1999a; Santos et al., 2001; Leite Jr. et al., 2003). Complementary late-Mesoproterozoic tectonic reactivations are also recognized in the area (e.g., Pacaás Novos e Uopione rift basins; $<1.05 \mathrm{Ga}$ ) - see Fig. 1. In a similar way, a major structure namely Ji-Paraná shear zone network (JPSZ) - extends over hundreds of kilometers (see Fig. 1), crosscuting all the preexisting rock fabrics of the RNJ and RSI provinces (Tohver et al., 2002; Scandolara, 2006). It is marked by NNW, NW and EW transcurrent and transpressive structures developed under low-temperature amphibolite facies conditions at c. $1.34 \mathrm{Ga}$ (Bettencourt et al., 2010) that were further isotopically reset at $1.18-1.12 \mathrm{Ga}$, as shown by the ${ }^{40} \mathrm{Ar} /{ }^{39} \mathrm{Ar}$ age determinations (e.g., Tohver et al., 2004, 2005a,b).

The JPSZ deformation is probably reflective from an early Grenvillian collision of the SW Amazon against the Llano segment $(1.15-1.10 \mathrm{Ga})$ of southern Laurentia (e.g., Tohver et al., 2005a,b,c, 2006). This event contrasts in timing with the slightly younger Grenvillian episodes $(1.05-0.95 \mathrm{Ga})$ from southern Laurentia, which is one the other hand compatible with the timing of the Sunsás orogen from Amazon region - see below.

Roughly contemporary intraplate manifestations, reflected by shear zones and anorogenic magmatism, have been recognized in many places of the Amazonian Craton (e.g., Teixeira et al., 1989; Cordani et al., 2010), which allow us to make a tectonic link with the Grenvillian-aged events.

\section{The Sunsás-Aguapeí province}

The chrono-stratigraphic correlations and structural studies of the key-units in Bolivia and Brazil, inferred from reliable radiometric ages, $\mathrm{Nd}$ isotopic constraints and chemical data are used to highlight the geologic framework of the SA province, in particular to discuss the Sunsás orogen within its southern bounds (e.g., Geraldes et al., 2001; Rizzotto et al., 2002; Santos et al., 2003; Tassinari and Macambira, 2004; Tohver et al., 2006; Boger et al., 2005; Ruiz, 2005; Teixeira et al., 2006; Vargas-Mattos, 2006; Cordani and Teixeira, 2007; Elming et al., 2009).

The late Mesoproterozoic evolution of the Sunsás belt can be distinguished from the passive margin to the post-tectonic stages in both the foreland margin and more distally within the RNJ and RSI provinces. The Sunsás passive margin sequences (Sunsás and Vibosi groups) and the coeval intraplate features over the stable foreland are reassessed highlighted by the Huanchaca-Aguapeí cratonic sedimentation and the Nova Brasilândia proto-oceanic rift basin. The subsequent orogenic processes associated with the Sunsás and the Nova Brasilândia belts are described and time-genetically correlated. The Sunsás late offshoots over the cratonic margin are also summarized (e.g., Aguapeí aulacogen and the revelant shear zones), as well as the post-orogenic magmatism.

\subsection{The Sunsás passive margin stage and coeval pré-orogenic intraplate phenomena}

The evolution of the SA province began after a period of long quiescence and erosion of the western cratonic margin (structurally defined by the Paraguá region), early deposition of the Sunsás and Vibosi Groups (alluvial to deltaic lithologies) in a passive margin environment, subsequently affected by the late Mesoproterozoic orogen (Litherland and Bloomfield, 1981) - see Figs. 1 and 2. Both sedimentary sequences overlie the crystalline basement with a striking planar unconformity (e.g., Litherland et al., 1986, 1989; Boger et al., 2005). A minimum age for the deposition of the Sunsás and Vibosi folded strata comes from the geochronology work done in the intrusive Sunsás granitic suite (1100-1000 Ma) and will be presented here later on.

The Sunsás Group comprises a sequence up to $6500 \mathrm{~m}$ thick, divided into four lithoestratigraphic units with a typical occurrence in the Serrania Sunsás, Bolivia (Litherland and Bloomfield, 1981). It is stratigraphically defined from the base to the top by conglomerates, psammitic units (arkoses, sandstones, quartzites), argillaceous units (mudstones and siltstones), and a combination of arkosic and quartzites lithologies. On other hand, the deposition of the Vibosi Group, a 2000 m thick sequence of mostly sandstones and arkoses that locally overlies unconformably the lithologies of Sunsás Group, took place in the region of maximum subsidence of the basin nowadays located at the southeastern tip of the Sunsás belt.

\subsubsection{The Nova Brasilândia proto-oceanic rift}

The Sunsás passive margin phase developed synchronously with the origin of the Nova Brasilândia Group in the neighboring Brazilian counterpart (RSI province). This group is subdivided into two distinct sedimentary-igneous units subsequently overprinted by a regional and metamorphic-deformational event that gave rise to the homonymous metasedimentary belt (Fig. 1), as described by Rizzotto (1999), Rizzotto et al. (2001) and Tohver et al. (2004). The belt evolution included two granitic pulses - the Rio Branco and Rio Pardo suites - (e.g., Rizzotto et al., 2001) that are contemporary with the timing of the Sunsás magmatism in the Bolivian shield (Boger et al., 2005) - see afterwards. 


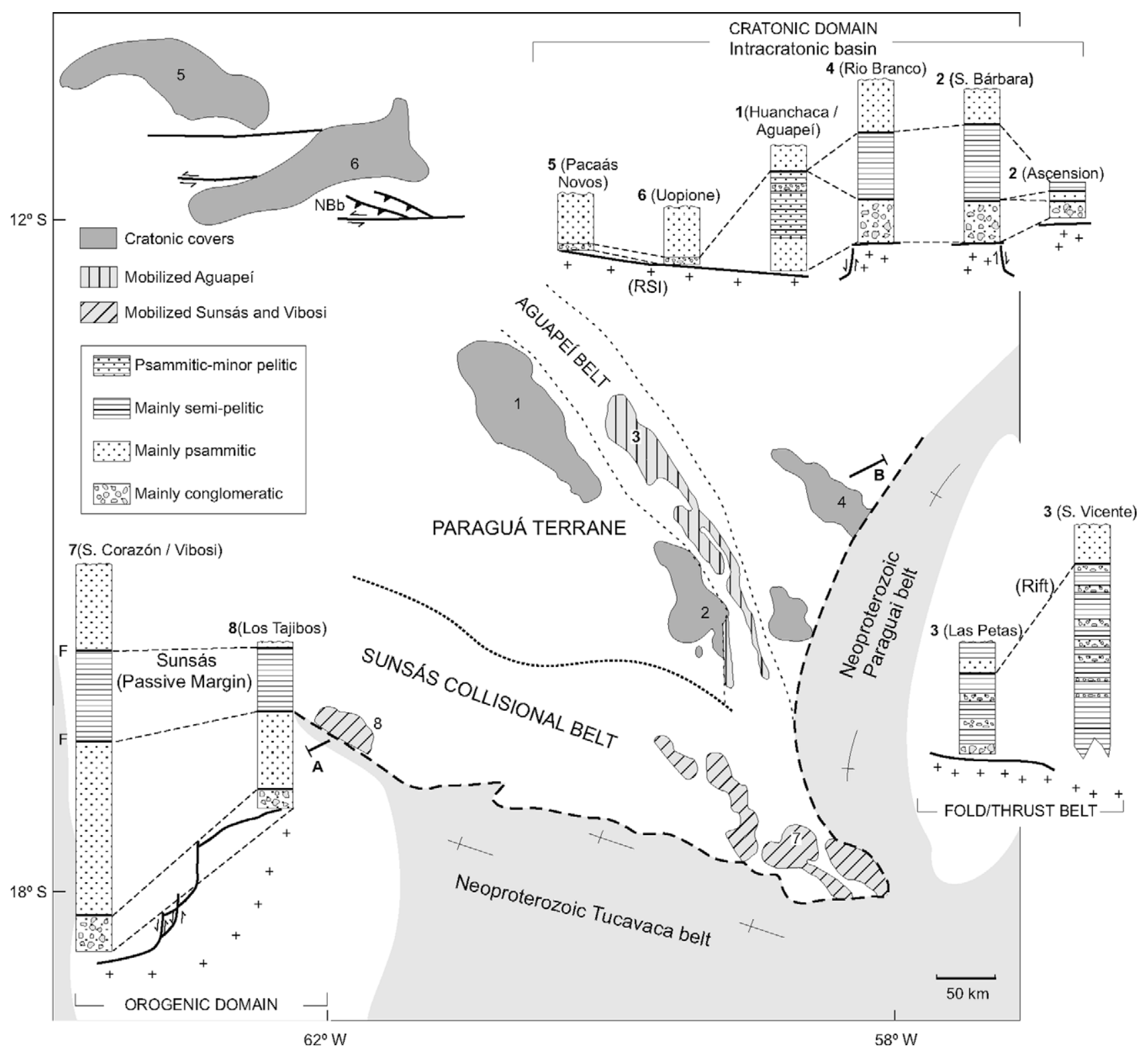

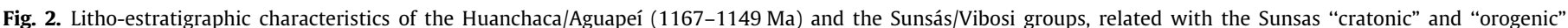

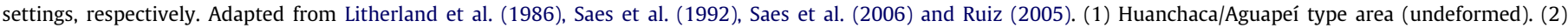

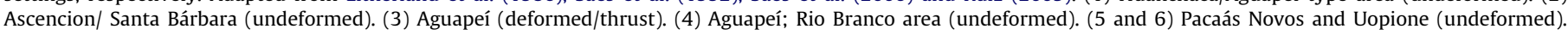
$\mathrm{NBb}=$ Nova Brasilândia belt (1.21-1.05 Ga). F = Fault. See Figs. 1 and 5 (AB section).

The most widespread unit of the Nova Brasilândia Group consisted originally of deep-sea turbidites with siliceous-clastic to carbonatic composition that were metamorphosed to produce calcsilicate gneisses, quartz-feldspar gneisses and mica schists. The metasedimentary package also includes metagabbro sills, amphibolites and minor, metabasalts. The other sedimentary-igneous unit is made up of mafic sills, metadiabases and amphibolites, with subordinate horizons of turbidite.

The Nova Brasilândia Group probably originated in an intracontinental rift setting that was followed by a proto-oceanic opening, further subjected to crustal shortening, deformation and associated magmatism, as suggested by detailed structural studies and metamorphic petrology, coupled with chemical and petrogenetic constraints of the sedimentary and igneous rocks (Rizzotto et al., 2001; Tohver et al., 2004).

The turbidites show compositional and chemical characteristics suggestive of a mixing between distinct continental source materi- als, whereas the maximum sedimentation age is inferred from the youngest, detrital zircon population with U/Pb SHRIMP ages of $1215 \pm 20 \mathrm{Ma}$ (Rizzotto et al., 2001) and $1231 \pm 14 \mathrm{Ma}$ (Santos et al., 2000). On the other hand, the basic rocks display low $\mathrm{K}_{2} \mathrm{O}$, $\mathrm{TiO}_{2}$ and $\mathrm{P}_{2} \mathrm{O}_{5}$ contents associated with high $\mathrm{CaO}, \mathrm{Na} / \mathrm{K}, \mathrm{Zr}, \mathrm{Y}, \mathrm{REE}$ ones, as well as $\mathrm{La} / \mathrm{Sm}>1, \mathrm{La} / \mathrm{Yb}=1.8-3.3$ and $\mathrm{Zr} / \mathrm{Nb}=33$ that show a P-MORB tholeitiic affinity (Rizzotto et al., 2001). In addition, the available isotopic data of the basic rocks exhibit a large variation of the $\varepsilon_{\text {Srt }}$ values $(-2.4 /+34.2)$, with the respective positive $\varepsilon_{\mathrm{Ndt}}$ ones falling on two groups $(+0.1 /+1.6 ;+3.0 /+5.1)$. The highest $\varepsilon_{\mathrm{Nd}(\mathrm{t})}$ values reveal the importance of a juvenile component in the magma source during the proto-oceanic rift opening stage (e.g., Rizzotto et al., 2001; Teixeira et al., 2006). However, the original tholeiitic magma underwent significant contamination as inferred from the large range of the $\varepsilon_{\mathrm{Srt}}$ values and lower positive $\varepsilon_{\mathrm{Ndt}}$ values than expected for these magmas, as well as by positive correlation between the $\mathrm{Sr}$ values and $\mathrm{La} / \mathrm{Yb}$ and $\mathrm{Rb} / \mathrm{Sr}$ ratios (Girardi et al., 2008). 


\subsubsection{The Huanchaca and Aguapeí cover sequences}

These cover sequences are testimony of a complete depositional cycle at the cratonic margin, similarly to the Sunsás and Vibosi sedimentary sequences at their defined orogenic domain (Figs. 1 and 2), (e.g., Saes et al., 1992; Leite and Saes, 2003). Nevertheless, the Huanchaca-Aguapeí cratonic sequence exhibits a significant change in thickness and maturity compared to the sequences in Bolivia, although it can be considered tectonically as platform cover at the time of the Sunsás orogen.

The Huanchaca Group is characteristically flat-lying and nonmetamorphic (Figs. 1 and 2), and includes a volcanic-clastic sequence (Litherland et al., 1986; Boger et al., 2005), while in the neighboring side of Brazil, the correlative Aguapeí Group makes up the Ricardo Franco and Serra do Roncador mesas. Moreover, one remnant of the Aguapeí sequence overlies unconformably the eastern extremity of the RNJ province (Rio Branco area; see Figs. 1 and 2) (e.g., Geraldes et al., 2001; Ruiz, 2005).

The Huanchaca Group (Litherland and Power, 1989) comprises basal sandstones and conglomerates (initial transgressive phase), intermediate psammites (the marine progradation phase) and upper fluvial sandstones (the ultimate marine regression phase). Additional stratigraphic studies in the type-area of the Aguapeí Group (Ricardo Franco escarpment) indicate three formations from the base to the top, whilst overlying the basement rocks with a marked unconformity: the Fortuna, Vale da Promissão and Morro Cristalina formations (e.g., Geraldes et al., 1997; Saes, 1999; Tohver et al., 2004; Ruiz, 2005).

The deposition age of the lower Fortuna Formation is well constrained between $1167 \pm 27 \mathrm{Ma}$ (the youngest detrital zircon age) and $1149 \pm 7 \mathrm{Ma}$ (post-diagenetic event; xenotime age), as determined by SHRIMP U/Pb work in the conglomerates (Santos et al., 2005). Other Aguapeí basal rocks correlative with the Fortuna Formation have complementary SHRIMP U/Pb detrital zircon ages yielding $1231 \mathrm{Ma}$ (e.g., Santos, 2003; Santos et al., 2008; Leite and Saes, 2003) and $1260 \mathrm{Ma}$ (Vargas-Mattos et al., 2007) for the youngest detrital zircon. From the above age data the cratonic sedimentation (Huanchaca-Aguapeí) may be diachronic.

Regional stratigraphic correlations inferred that the Huanchaca-Aguapeí cover sequence evolved through three stages (Saes et al., 1992; Saes, 1999): (i) the initial rift process, marked by conglomerates and accumulation of immature sandstones, with palaeocurrents indicating a longitudinal NW-SE filling pattern; (ii) the flexural subsidence stage that accomodates a thick transgressive section of shallow marine pelites and fine sandstones (tempestites) in the Huanchaca, São Vicente and Rio Branco areas and (iii) a deep marine submarine fan phase located at the central rift zone, which comprises the thickest and most deformed immature sedimentary rocks, whereas (e.g., Huanchaca, Rio Branco areas) the package becomes thinner and non-metamorphic along the outboard zones (see Fig. 2).

The litho-estratigraphic correlation (e.g., facies and palaeocurrents of the Aguapeí Group) coupled with the $\mathrm{U} / \mathrm{Pb}$ ages of detrital zircons of the basal conglomerates are consistent with the idea that late Mesoproterozoic extensional dynamics produced a system of continental, aborted rifts over the cratonized RNJ and RSI provinces, evolving to a wide sag intracratonic basin (e.g., Leite and Saes, 2003). An intraplate setting is similarly envisaged from the available U/Pb ICP-MS-LA work in detrital zircons of the lower Fortuna Formation that yields ${ }^{207} \mathrm{~Pb} /{ }^{206} \mathrm{~Pb}$ peak ages of 1800,1500 and $1350 \mathrm{Ma}$ (Vargas-Mattos et al., 2007). The ages of the most representative zircon populations $(1.5 \mathrm{Ga} ; 1.3 \mathrm{Ga})$ not only signalize the continental sedimentation source (Leite and Saes, 2003), but also the timing of the adjacent magmatic arcs that built up the RSI province in Mato Grosso state, western Brazil (e.g., Geraldes et al., 2001) (see Table 1 and Fig. 1).
The Pacaás Novos graben (see Figs. 1 and 2), the westernmost of the filled rifts of the Huanchaca-Aguapeí sequence, contains a $500 \mathrm{~m}$ thick undeformed pile of coarse siliciclastic deposits, typical of fan braided alluvial system and of dunes, tidalites and proximal storm deposits of coastal-eolian system - namely Palmeiral Formation (Saes et al., 2006). The rift package is floored by gabbroic sills that yield ${ }^{40} \mathrm{Ar} /{ }^{39} \mathrm{Ar}$ plateau crystallization ages of $1198 \pm 3 \mathrm{Ma}$ and $1201 \pm 3 \mathrm{Ma}$ (e.g., Tohver et al., 2002). They are probably related to the timing of an intraplate extension episode, which is age-equivalent of the Sunsás passive margin stage (see above).

\subsection{The Sunsás orogenic phase}

The timing of the Sunsás orogen was first estimated by $\mathrm{Rb} / \mathrm{Sr}$ and $\mathrm{K} / \mathrm{Ar}$ work carried out in the related granitic rocks and pegmatites (1100-900 Ma) confined within the bounds of Sunsás collisional belt, in Bolivia (e.g., Litherland et al., 1986). This belt is structurally marked by extensive mylonitic shear zones (or straightening "tectonic fronts"; e.g., Santa Catalina, Rio Negro and San Diablo: see Fig. 1) that shows preferential sinistral offsets, active at about ca. 1080-1050 Ma along the southern rim of the Paraguá microcontinent. Despite the Sunsás reworking, the internal (pre-Sunsás) non-penetrative deformation is preserved and little or no metamorphic overprint is described (e.g., Litherland et al., 1986; Sadowski and Bettencourt, 1996; Boger et al., 2005), as well as the older San Ignacio structures in the north of Conception (Boger et al., 2005).

The network of shears not only dissects the Sunsás units and the older rocks but also allows the emplacement of syn- to late-tectonic granites (e.g., Sunsás granitic suite - Litherland et al., 1989). Furthermore, these structures control occurrences of gold in the state of Mato Grosso (e.g., Fernandes et al., 2006) and in the Don Mario mineral district in Bolivia (Litherland et al., 1986). The latter district hosts important $\mathrm{Au}-\mathrm{Cu}$ among other metals occurrences produced by hydrothermal mineralization , and is tectonically controlled by shear zones of the San Diablo front (see Fig. 1) and pegmatite injections ( $\mathrm{U} / \mathrm{Pb}$ zircon age of $997 \pm 3 \mathrm{Ma}$ ). In Don Mario mine, the Au-rich zone is dated by Re/Os in molibdenite at $994 \pm 3 \mathrm{Ma}$ (Isla-Moreno, 2009).

The recognized Sunsás and Vibosi metasedimentary sequences of the Sunsás belt (see previous section) exhibit penetrative, upright NW trending folds and regional low-grade metamorphism (Litherland and Bloomfield, 1981) that differs from the staurolite and sillimanite isograds recorded in the schist sequence that occurs in the vicinity of San Ramon (e.g., Adamek et al., 1996) and from the more intense regional deformation developed in the San Diablo, Rio Negro and Santa Catalina fronts (Fig. 1). The latter structure is left lateral in movement, whereas the Rio Negro front has a dextral shift with a normal (brittle) foliation. Such regime resulted from the near frontal, tangential, SW-NE directed collision of the belt under ductile to ductile-brittle conditions against the Paraguá microcontinent. This regime led to the overall movement of Sunsás orogenic compartiments relative to the northward Paraguá stable domain (e.g., Litherland et al., 1986; Boger et al., 2005). As such, the deeper-level rocks of the Paraguá region (e.g., Lomas Manechis and Chiquitania units) are thrust over the higher-level units (San Ignacio and Sunsás rocks), producing the striking open folding and secondary faults and fractures. In this regard, the San Diablo front was tentatively interpreted as a suture zone between the Paraguá and the Sunsás southeast blocks (Saes, 1999). This suggests that the Sunsás and Vibosi metasedimentary rocks may be tectonically related with an arc setting, as envisaged by Litherland et al. (1985).

The Sunsás granitic event encompasses various massives (Litherland et al., 1986; Boger et al., 2005; Vargas-Mattos, 2006; Vargas-Mattos et al., 2009). The older ones (e.g., El Carmen) are 
composed of quartz-monzonites, monzonites and syenogranites and minor pyterlites (a kind of rapakivi granites), while the younger bodies (e.g., Primavera, Señoritas) consist of syenite, trachyte and peraluminous and peralkaline granites (Fig. 3). The syn- to late-tectonic intrusions are genetically related to the main Sunsás shear zones, show blurred contacts with the nebulitic sheared migmatites, and show elongated morphology on aerial images. In contrast, the late to post-tectonic plutons are circular or oval bodies (e.g., Taperas granite). They truncate the Sunsás structures, shears or mineral fabrics of the country rocks, and show little or no signs of foliation and deformation (Litherland et al., 1986; Adamek et al., 1996; Boger et al., 2005; Vargas-Mattos, 2006; Vargas-Mattos et al., 2009).

SHRIMP and TIMS U/Pb zircon ages are available for a limited number of intrusive granites but highlight the timing of the Sunsás plutonic event, previously delineated by a $\mathrm{Rb} / \mathrm{Sr}$ isochron age of $1005 \pm 12 \mathrm{Ma}$ for the Casa de Piedra suite (Fig. 3) and by slightly younger $\mathrm{K} / \mathrm{Ar}$ ages of other intrusions in the range 990-910 Ma (Litherland et al., 1986, 1989). The most reliable U/Pb ages come from the slightly foliated Santa Teresa tonalite that yields $1105 \pm 21 \mathrm{Ma}$ (Matos, pers. comm., 2009), the essentially undeformed Taperas granite (1076 $\pm 18 \mathrm{Ma}$; Boger et al., 2005) and from an orthogneiss in the Don Mario mineral district (1014 $\pm 6 \mathrm{Ma}$; Isla-Moreno, 2009; Table 2 and Fig. 3) . In comparison, the Naranjito, Primavera, Taperas and El Carmen plutons yield roughly comparable U/Pb ICP-MS-LA zircon ages (1092-1047 Ma; VargasMattos et al., 2009). Moreover these plutons display variable negative $\varepsilon_{\mathrm{Nd}(\mathrm{t})}$ values $(-0.5$ to -4.5$)$ and $T_{\mathrm{DM}}$ ages $(1.8-1.6 \mathrm{Ga})$ (Darbyshire, 2000; Vargas-Mattos et al., 2006). When taken collectively into account, the chemical characteristics of the plutons ( $\mathrm{S}, \mathrm{I}, \mathrm{A}-$ types) suggest that the magma sources underwent crustal contamination from protholiths like the Paraguá rocks, given the compatible Nd isotopic constraints (Boger et al., 2005; Santos et al., 2000) - see previous section. From the above, we assume that the Sunsás granites were probably formed in a continental arc environment.

The Rincón del Tigre complex (Prendergast, 2000) was emplaced as a layered, differentiated, mafic/ultramafic sill between the Sunsás and the Vibosi metasedimentary sequences, in the southeast tip of the Sunsás belt (Litherland et al., 1986) - see
Fig. 1. The $\mathrm{Rb} / \mathrm{Sr}(992 \pm 86 \mathrm{Ma})$ and $\mathrm{K} / \mathrm{Ar}(1067 \pm 23 \mathrm{Ma})$ ages (Table 2) obtained from the granophyres (Darbyshire, 1979) are compared within the errors with those reported for the Sunsás granites (see above). Both the Rincón del Tigre Complex and the metasedimentary sequence exhibit gentle NE folds matching well with the lineation trend of the Sunsás shears and with the overprinted deformation in the older rocks (see above). Therefore, the Rincón del Tigre complex was emplaced during the syn to late tectonic phase of the Sunsás orogen.

\subsubsection{The Nova Brasilândia belt}

The Nova Brasilândia belt (Fig. 1) lies in the 1.36 Ga Colorado and Mamoré complexes (see previous section), covered by late Mesoproterozoic flat-lying sequences of the Pacaás Novos and Uopione rift basins (e.g., <1050 Ma Palmeiral Formation; Santos et al., 2001). The aeromagnetic data interpretation suggests a continuity of the Nova Brasilândia belt to the east over at least $1000 \mathrm{~km}$ below the Phanerozoic cover, while the geologic inferences suggests it might be extended to distances up to $2000 \mathrm{~km}$ (Tohver et al., 2004; Rizzotto and Quadros, 2007).

Detailed metamorphic petrology and structural data revealed that the Nova Brasilândia belt is characterized by heterogeneous metamorphic grades that increase from north to south (Luft et al., 2000; Tohver et al., 2004). The northern compartment of the belt preserves vestiges of early phases that reached high P-T conditions (medium- to high-T amphibolite facies) whereas the higher metamorphic facies is restricted to the southern portion. The preserved sequence of metamorphism is a result from crustal thickening and collision-related deformation in a transpressional zone, as also supported from observations of deep-seated thrusting and accompanying sinistral strike-slip motion (Tohver et al., 2004). Regional foliations in the Nova Brasilândia belt are defined by the development of both mylonitic shear zones and metamorphic fabrics, generated by mineral growth and transposition of sedimentary fabrics.

Numerous SHRIMP U/Pb, U/Pb TIMS, ${ }^{40} \mathrm{Ar} /{ }^{39} \mathrm{Ar}$ ages are used in conjunction with $\mathrm{Nd}-\mathrm{Sr}$ isotopic geochemistry to constrain the evolution of the Nova Brasilândia rocks, which includes two episodes of felsic intrusions (Rizzotto, 1999; Rizzotto et al., 2001; Toh-

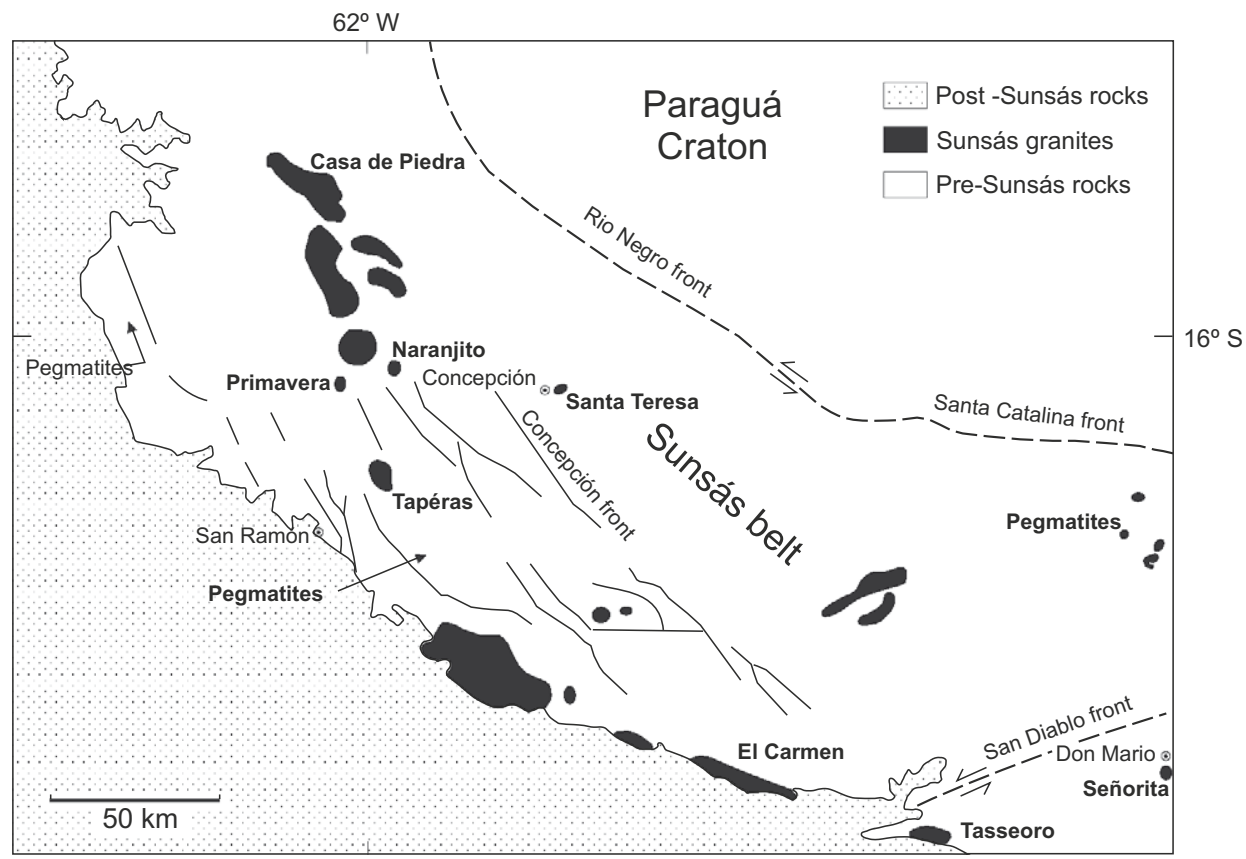

Fig. 3. Main magmatic and tectonic elements of the Sunsás belt, Bolivia. Adapted from Litherland et al. (1986). See text for details. 
Table 2

Summary of age and Nd isotopic data of magmatic rocks tectonically related with the Sunsás- Aguapeí province.

\begin{tabular}{|c|c|c|c|c|c|c|c|}
\hline \multirow[t]{2}{*}{ Unit } & \multirow[t]{2}{*}{ Tectonics/ intrusions } & & \multirow[t]{2}{*}{$\mathrm{Rb} / \mathrm{Sr}$ isochron (Ma) } & \multirow[t]{2}{*}{${ }^{40} \mathrm{Ar} /{ }^{39} \mathrm{Ar} \mathrm{K} / \mathrm{Ar}(\mathrm{Ma})$} & \multirow[t]{2}{*}{$\mathrm{U} / \mathrm{Pb}(\mathrm{Ma})$} & \multicolumn{2}{|l|}{$\mathrm{Sm} / \mathrm{Nd}$} \\
\hline & & & & & & $T_{\mathrm{DM}}(\mathrm{Ga})$ & $\varepsilon_{\mathrm{Ndt}}$ \\
\hline \multirow[t]{15}{*}{ Sunsás belt } & Syn- to late-tectonic & Rincón del Tigre & $993 \pm 139$ & & & & \\
\hline & & El Carmen & & $938 \pm 21$ & $1092 \pm 37$ & 1.80 & $-3.9 /-4.5$ \\
\hline & & & & $907 \pm 20$ & & & \\
\hline & & Santa Teresa & & & $1105 \pm 21$ & & \\
\hline & & Orthogneiss & & & $1014 \pm 6$ & & \\
\hline & Post-tectonic to anorogenic & Casa de Piedra & $1005 \pm 12$ & $958 \pm 27$ & & 1.58 & $-4.0 /-3.1$ \\
\hline & & & & $911 \pm 20$ & & & \\
\hline & & Taperas & & $935 \pm 21$ & $1076 \pm 18$ & $1.71 / 1.66$ & $-3.4 /-4.4$ \\
\hline & & & & & $1047 \pm 24$ & & \\
\hline & & Tasseoro & & $991 \pm 27$ & & & \\
\hline & & Naranjito & & & $1070 \pm 54$ & 1.76 & -2.5 \\
\hline & & Primavera & & & $\sim 1090$ & 1.66 & -0.5 \\
\hline & & & & & & & -0.8 \\
\hline & & Señoritas & & & $1004 \pm 1$ & & \\
\hline & & Pegmatite & & & $997 \pm 3$ & & \\
\hline \multirow[t]{9}{*}{ Nova Brasilândia belt } & Syn-tectonic & Metagabbro & & & $1110 \pm 15$ & & $+4.3 /+2.3$ \\
\hline & & Monzogabbro & & & $1098 \pm 10$ & 1.63 & -0.4 \\
\hline & & & & & $1113 \pm 58$ & & \\
\hline & & Metagabbro & & & & & +5.0 \\
\hline & & Granite & & & & & +3.1 \\
\hline & & Leucogranite & & & $1110 \pm 08$ & 1.66 & -1.5 \\
\hline & & Calc-silicate gneiss & & & & 1.91 & $-4.3 /$ \\
\hline & & Paragneiss & & & & 1.85 & -3.9 \\
\hline & & Monzogranite & & & $995 \pm 15$ & 1.50 & +0.5 \\
\hline \multirow[t]{12}{*}{ Colorado-Mamoré belt } & Santa Clara suite (anorogenic) & Manteiga & $1052 \pm 21$ & $1035 \pm 8$ & $1082 \pm 5$ & & \\
\hline & & Santa Clara & & & $1074 \pm 21$ & & \\
\hline & & Oriente Novo & & & $1080 \pm 27$ & & \\
\hline & ${ }^{\mathrm{a}} \mathrm{RTP}$ (anorogenic) & Rio Pardo & & & $1110 \pm 8$ & & \\
\hline & & & & & $1005 \pm 7$ & & \\
\hline & & Pedra Branca & & $950 \pm 8$ & $995 \pm 05$ & & \\
\hline & & São Carlos & & & $995 \pm 73$ & & \\
\hline & & & & & $974 \pm 06$ & & \\
\hline & & Massangana & & $1000 \pm 7$ & $991 \pm 14$ & & \\
\hline & & Santa Bárbara & & & $993 \pm 5$ & & $-2.9 /$ \\
\hline & & & & & $989 \pm 13$ & & -4.6 \\
\hline & & & & & $978 \pm 13$ & & \\
\hline \multirow[t]{5}{*}{ Aguapeí belt } & Guapé suite (anorogenic) & Guapé & $950 \pm 40$ & & & 1.29 & +1.3 \\
\hline & & São Domingos & & & $939 \pm 19$ & 2.212 .21 & -7.1 \\
\hline & & & & & $914 \pm 14$ & & -7.6 \\
\hline & & Sararé & & $906 \pm 1$ & $917 \pm 18$ & & -5.0 \\
\hline & & & & $905 \pm 8$ & & & \\
\hline
\end{tabular}

a Rondônia Tin Province - RTP. See text for details.

ver et al., 2004; Santos et al., 2008). The oldest intrusive phase (Rio Branco suite) constitutes mega-lenses of A-type monzogranites that yield $1113 \pm 56 \mathrm{Ma}$ (conventional U/Pb zircon age; Rizzotto, $1999)$ and $1098 \pm 10 \mathrm{Ma}$ (U/Pb SHRIMP zircon age; Santos et al., 2000) pointing out to the rock crystallization age. These plutons were emplaced syntectonically with an early-recognized deformational phase of the belt that accompanies sinistral strike-slip zones, thereby exhibiting gneissic foliation with locally developed mylonitic fabrics (Rizzotto et al., 2001; Tohver et al., 2004). The age of the Rio Branco suite agrees well with U-Pb SHRIMP age of $1110 \pm 15$ Ma measured for coeval tholeiitic gabbros (see previous section). Additional $\mathrm{U} / \mathrm{Pb}$ ages in monazite (1096-1082 Ma) and titanite (1070-1020 Ma) evidence the timing of the high-grade metamorphic overprint in the area (Tohver et al., 2004, 2006). The second deformational phase is marked by the Rio Pardo granitic suite $\left(1005 \pm 41 \mathrm{Ma}\right.$; $\varepsilon_{\mathrm{Nd}(\mathrm{t})}=+0.5$; Rizzotto and Quadros, 2007), which exhibits a strong mylonitic foliation with striking E-W trend. In conclusion, both the Nova Brasilândia and the Sunsás belts were involved in an orogenic zone characterized by sinistral strike-slip motion at c. 1.1-1.0 Ga ago.

The regional cooling of the Nova Brasilândia belt took place between $995-910 \mathrm{Ma}$, as shown by the available ${ }^{40} \mathrm{Ar} /{ }^{39} \mathrm{Ar}$ plateau mineral ages (Fig. 4 ), therefore $\sim 100-80$ Myrs after the timing of ultimate deformation recorded along the JPSZ located to the north (e.g., Tohver et al., 2006) - see above. Moreover, the geographic distribution of the cooling ages suggests that this part of the Nova Brasilândia belt was exhumed uniformly, because the apparent lack of correlation with its metamorphic-structural compartments (Tohver et al., 2004). However, these ${ }^{40} \mathrm{Ar} /{ }^{39} \mathrm{Ar}$ ages may be somewhat influenced by nearby emplacement of anorogenic granites (990-970 Ga, Bettencourt et al., 1999a,b), as recognized by related hydrothermalism over the Nova Brasilândia basic rocks (Rizzotto et al., 2001; Tohver et al., 2005b; Teixeira et al., 2006). Tohver et al. (2004, 2005a), on the basis of detailed structural data, combined with thermobarometric calculations and geochronological information, interpreted the Nova Brasilândia metamorphic belt as the result of crustal thickening through an imbrication caused by the transpressive suturing of the Amazon region and Paraguá microcontinent at c. $1.10 \mathrm{Ga}$ ago.

\subsection{Sunsás late to post-orogenic phases}

The strain ellipsoid model for the Sunsás collision (Sadowski and Bettencourt, 1996) illustrates the mechanical compatibility among the observed frontal SW-NE directed strain with left-lateral shearing along the northern bounds of the Sunsás belt (e.g., San 


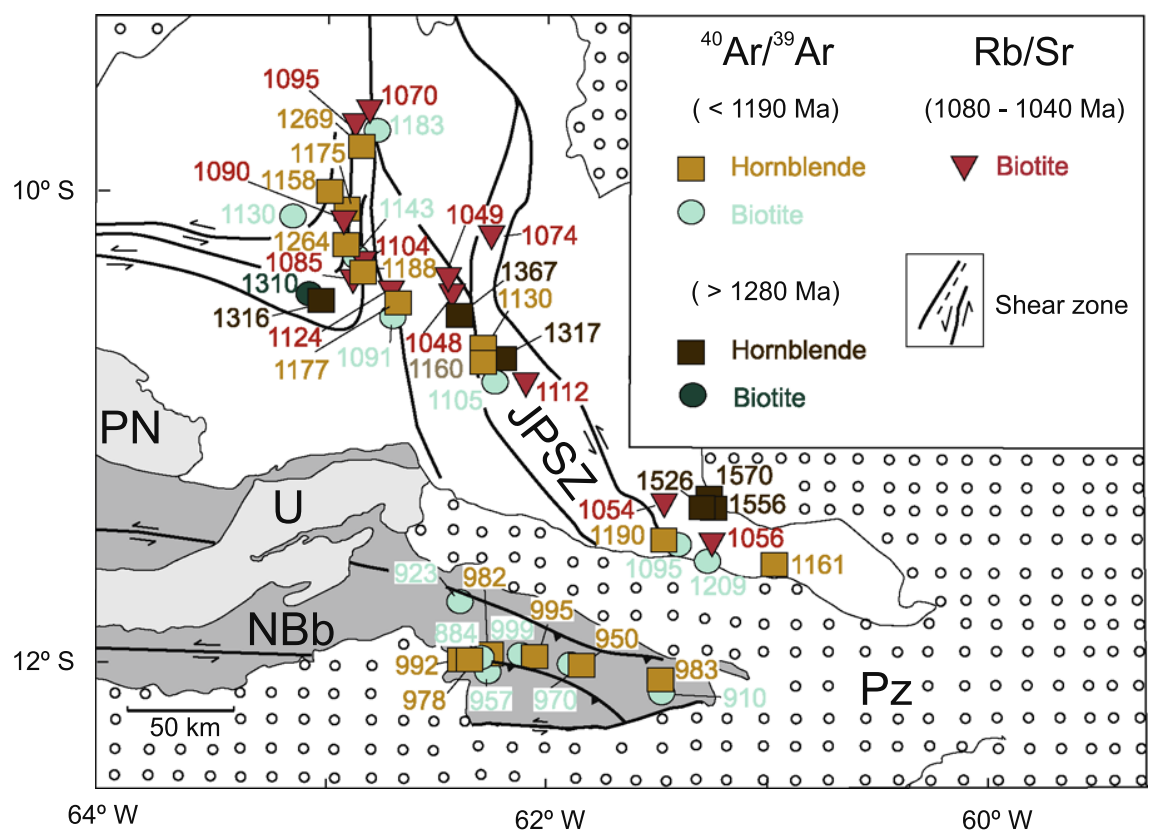

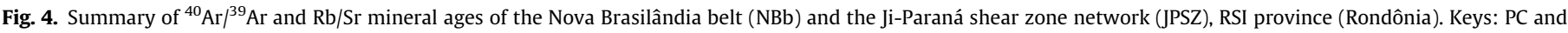
$\mathrm{U}=$ Pacaás Novos and Uopione rift-type sequences. $\mathrm{Pz}=$ Paleozoic. Adapted from Tohver et al. (2006). See text for details.

Diablo front) and the oblique geometry of the Aguapeí fold and thrust belt (see Fig. 1) and other related extension/transpressive components over the cratonic margin. Examples could be the shear zones in Mato Grosso (RNJ and RSI provinces) and the post-tectonic and anorogenic intrusions in Rondônia, Mato Grosso and Bolivia.

\subsubsection{The Sunsás post-tectonic to anorogenic magmatism}

Many felsic and mafic intrusions with ages generally $1000 \mathrm{Ma}$ or less represent the youngest manifestations over the cratonic margin (RNJ, RSI, Paraguá microcontinent), given the significant time hiatus between these igneous phases and the cessation of the Sunsás orogenic processes. These intrusions are well illustrated in the Rondônia Tin Province - RTP on basis of voluminous occurrences of A-type AMCG, anorogenic plutons in the RNJ and RSI provinces (see Fig. 1 and Table 2) (e.g., Priem et al., 1989; Sadowski and Bettencourt, 1996; Bettencourt et al., 1999a,b; Tassinari et al., 2000; Payolla et al., 2002; Santos, 2003).

The RTP encompasses two distinct suites characterized by the presence of rapakivi varieties (e.g., Leite Jr. et al., 2003): (i) metaluminous to subordinately peraluminous subsolvus and (ii) sub-alkaline rocks with minor associated quartz-syenite, quartz-monzonite and monzonite. This last suite consists of at least three distinct intrusive phases: early bodies composed of coarse pyterlite to porphyritic biotite syenogranite, late syenogranites that are succeeded by granites, syenites and related varieties. The later two phases are characterized by associated primary metal deposits (e.g., Sn, Mo, $\mathrm{W})$. The ultimate intrusive phase, which is limited in area, shows a hypersolvus nature and alkaline affinity. It is composed of alkali-feldspar granites and peralkaline granites, alkali-feldspar syenites, trachytes, microsyenites, sub-alkaline quartz-feldspar porphyres and hybrid rocks (quartz microsyenite and quartz syenite). These granites are usually derived from crustal sources, such as the Maçangana pluton (990-980 Ma) and the São Carlos massif (974 $\pm 6 \mathrm{Ma}$; Bettencourt et al., 1999b), the Pedra Branca syenogranite (995 $\pm 5 \mathrm{Ma}$; Tosdal and Bettencourt, 1994), and the Santa Bárbara massif ( $978 \pm 13 \mathrm{Ma}$; Sparrenberger et al., 2002), as suggested by the field relations, chemical signatures and systematic negative $\varepsilon_{\mathrm{Ndt}}$ constraints (Payolla et al., 2002) - see Table 2 .

The Rio Pardo granitic suite ( $905 \pm 7 \mathrm{Ma}$ ) occurs to the south of the RTP (Fig. 1) and shows similar anorogenic behavior of the Gua- pé intrusive suite (Guapé, São Domingos, Sararé plutons), located farther to southeast in the state of Mato Grosso. This latter suite displays U/Pb and ${ }^{40} \mathrm{Ar} /{ }^{39} \mathrm{Ar}$ ages c. 940-905 Ma (e.g., Geraldes et al., 2001; Ruiz et al., 2005) - Table 2. Chemically, the Guapé plutons are mostly sub-alkaline, metaluminous to peraluminous, and likewise the RTP rocks they show affinity with A-type granites, as inferred from the negative Nd signatures (e.g., São Domingos pluton; $\varepsilon_{\mathrm{Nd}(\mathrm{t})}=-7$; Ruiz, 2005).

Anorogenic igneous rocks are similarly recorded within the southeastern bounds of the Sunsás belt, such as the Señoritas granite $(1004 \pm 1 \mathrm{Ma})$ and profuse pegmatites $(997 \pm 3 \mathrm{Ma})$ that host metal deposits ( $\mathrm{Nb}, \mathrm{Mo}, \mathrm{SW}, \mathrm{Sn}, \mathrm{Ta}, \mathrm{Be}$ ), as reported by Isla-Moreno (2009) - see Table 2. Other pegmatites, as well as mafic sills and dikes occur within the belt, showing roughly comparable K/Ar ages (Litherland et al., 1986).

In the Paraguá region, the Huanchaca dolerite suite (Litherland et al., 1986), also named Huanchaca intrusive suite (Ruiz, 2005), comprises unmetamorphosed dikes and sills (not shown) that yield $\mathrm{K} / \mathrm{Ar}$ apparent ages between 936 and $850 \mathrm{Ma}$ in whole rock. The dikes are massive, up to $20 \mathrm{~m}$ thick and crosscut the foliation of the country rocks, whereas the sills generally dip $10-15^{\circ}$ to SW, exhibiting sharp contacts with the Huanchaca sedimentary beds. In the neighboring area of Brazil, the sills similarly interlay concordantly the Vale da Promissão middle formation of Aguapeí Group (Ruiz et al., 2007; Lima et al., 2008), whilst a dike crosscuts a sill at the Ricardo Franco mesa (Sécolo et al., 2008).

To the east, in Mato Grosso state (RNJ province), the Salto do Céu intrusive suite (Araujo, 2008) constitutes massive gabbroic and diabase sills of tholeiitic affinity, interlayed with the Vale da Promissão Formation of the Aguapeí Group (see previous section) that yield $\mathrm{K} / \mathrm{Ar}$ ages in the range 1015-850 Ma (Barros et al., 1982; Ruiz, 2005; Ruiz et al., 2007). Elming et al. (2009) reported a more precise ${ }^{40} \mathrm{Ar} /{ }^{39} \mathrm{Ar}$ plateau age of $981 \pm 2 \mathrm{Ma}$ for one sill, whereas additional studied samples yielded significantly older ages (1035-1025 Ma). This suggests the Salto do Céu suite may have various igneous pulses. To the west in the Rondônia state the mafic dikes and sills yield roughly comparable ${ }^{40} \mathrm{Ar} /{ }^{39} \mathrm{Ar}$ ages between 1030-950 Ma (e.g., Santos, 2003; Teixeira et al., 2006). 


\subsubsection{The Aguapei fold and thrust belt}

The Aguapeí belt or aulacogen (e.g., Souza and Hildred, 1980; Saes et al., 1992) is a narrow NNW-SSE zone of folded sedimentary rocks in Mato Grosso state (Figs. 1 and 2). The belt is structurally confined, lying discontinuously along more than $500 \mathrm{~km}$ in between the northeastern/eastern margins of the Paraguá microcontinent and the reactivated basement of the RSI province in east (Brazil).

There is no apparent structural continuity between the northernmost extent of the Aguapeí belt and the E-W trending Nova Brasilândia metasedimentary-metaplutonic belt, located c. $200 \mathrm{~km}$ to the NNW in the state of Rondônia (see Fig. 2). In spite of both the Aguapeí and the Nova Brasilândia rocks yield roughly comparable detrital zircon ages ( $<1230 \mathrm{Ma}$ and $<1215 \mathrm{Ma}$; see previous sections), the continental source of the Aguapeí Group contrasts with the "oceanic" characteristics of the Nova Brasilândia protholiths. Moreover the rocks of Nova Brasilândia belt exhibit a higher metamorphic grade and are more intensity deformed than those of the Aguapeí aulacogen (Tohver et al., 2004).

The Aguapeí weakness tectonic zone is marked by aeromagnetic anomalies that bound to the southwest the 1.51-1.48 Ga Rio Alegre terrane (e.g., Geraldes et al., 2001; Bettencourt et al., 2010). This suggests that the Aguapeí belt may be one gangway across to which the sinistral shearing and thrusts related to the Sunsás collision late offshoots overprinted the cratonic margin (Litherland et al., 1989). As such the Aguapeí belt, in contrast with Sunsás orogenic framework (in Bolivia), exhibits only localized deformation and low-grade metamorphism (e.g., Geraldes et al., 2001), as given by gentle folds (upright to northeast dipping) and shears of NW trending. The deformation related to this event is characterized by recrystallized mylonites that yielded $\mathrm{K} / \mathrm{Ar}$ and ${ }^{40} \mathrm{Ar} /{ }^{39} \mathrm{Ar}$ mica ages between 960-910 Ma (e.g., Geraldes et al., 1997; Fernandes et al., 2006; Ruiz et al., 2007).

The neighboring country rocks show slightly older, but roughly comparable ${ }^{40} \mathrm{Ar} /{ }^{39} \mathrm{Ar}$ plateau ages in the range $1030-920 \mathrm{Ma}$ (Ruiz, 2005). This indicates that regional cooling of the continental crust shortly followed the SW directed thrusting of the reactived basement over the Aguapeí aulacogen, starting at c. $960 \mathrm{Ma}$. Whereas the ${ }^{40} \mathrm{Ar} /{ }^{39} \mathrm{Ar}$ and $\mathrm{K} / \mathrm{Ar}$ pattern allows constraining a time relationship with the regional cooling of the Sunsás orogen (see previous section), based on the isotopic systems that are susceptible to thermal resetting; the associated compressive phase of the Aguapeí belt postdates the Sunsás magmatism (1100-1000 Ga) and related nappe structures in Bolívia (Litherland et al., 1986; Boger et al., 2005). This reinforces the idea that the Aguapeí aulacogen is a late tectonic element of the SA province, reflective from the Sunsás collision.

\subsubsection{The late tectonic shear zones}

The Piratininga-Corredor and Indavaí-Lucialva zones in the Mato Grosso state (not shown) are major ductile shears that affect both the Aguapeí aulacogen and related country rocks at the southeast part of the RNJ and RSI provinces, as described by Ruiz (2005).

The Piratininga-Corredor shears constitute a highly stress zone that juxtaposes the Rio Alegre terrane and the reactivated basement to the east, while confining the NNW-SSE Aguapeí aulacogen. The protomylonites yield ${ }^{40} \mathrm{Ar} /{ }^{39} \mathrm{Ar}$ plateau muscovite ages between 930 and $920 \mathrm{Ma}$ (Ruiz et al., 2007), which agree well with the age pattern of the Aguapeí belt own (see above). The NW-SE trending Indavaí-Lucialva shears occur along the northeast bounds of the 1.44-1.42 Ga Santa Helena rocks, and exhibit general, upper transport to northeast (see Table 1). The recrystallized mylonites yield ${ }^{40} \mathrm{Ar} /{ }^{39} \mathrm{Ar}$ plateau ages of c. $915 \mathrm{Ma}$ (Ruiz, 2005) that are comparable to that of the Guapé intrusive suite (see above).

\section{Summary and late Mesoproterozoic evolution}

Geologic correlations coupled with interpretation of $\mathrm{U} / \mathrm{Pb}$ ages and petrogenetic constraints provide a clear-cut picture of the Sunsás-Aguapeí evolution (1200-950 Ma), the youngest of the tectonic provinces in SW Amazonian Craton. The early evolution stage (passive margin; <1200 Ma) developed along the southern edge of the already cratonized RNJ and RSI provinces, as given by deposition of the Sunsás and Vibosi groups. This stage was roughly contemporary with extensional and compressional intraplate processes, such as the Nova Brasilândia proto-oceanic opening (<1215 Ma), a wide-sag platform-like sedimentation (HuanchacaAguapeí basin; 1167-1149 Ma), as well as deformation and metamorphism along the JPSZ network (1180-1120 Ma). Subsequently, the Sunsás orogen created an allochthonous collisional belt, characterized by mafic-ultramafic and granitic suites (1105$1004 \mathrm{Ma}$ ) that truncated both the folded Sunsás/Vibosi strata and the major related tectonic structures. In comparison, the coeval Nova Brasilândia belt (1113-1005 Ma) results from the orogenic shortening and transtension inboard, while the flat-lying Huanchaca-Aguapeí cover represents the associated intracratonic basin. In contrast, the Aguapeí aulacogen (960-910 Ma) and the IndavaíLucialva-Piratininga-Corredor mylonitic shear zones (930$910 \mathrm{Ma}$ ) may be interpreted as regional late offshoots of Sunsás belt that was developed under transpressive conditions over the plate margin.

So far, the evolution of the SA province can be characterized by two major timing-independent events separated by 100-80 Myrs: (i) the first one overprints the basement rock fabrics (RNJ and RSI provinces) and is highlighted by the Ji-Paraná shearing and deformation features. Its tectonic reactivation allowed the emplacement of the undeformed A-type Santa Clara suite (1082-1074 Ma), which supposedly is associated with the timing of an early cratonization phase in the area. (ii) The second event, namely Sunsás orogen, is the youngest of the orogenic events recorded in the SW cratonic fringe. It is coeval with the Nova Brasilândia belt but they are clearly distinguished whichever because the later exhibits higher metamorphic grade and minor volume of felsic rocks.

The broad distribution of rocks with nearly similar $\mathrm{K} / \mathrm{Ar}$ and ${ }^{40} \mathrm{Ar} /{ }^{39} \mathrm{Ar}$ ages over the SW Amazon region points out to a timing of the regional uplift and cooling of the Sunsás orogen, and thereby the final tectonic stability of the SA province occurring at about c. 1000-950 Ma (Litherland et al., 1986; Teixeira et al., 1989, 2006; Tohver et al., 2006). In this regard, post-tectonic events of the Sunsás orogen are marked by voluminous A-type granites, pegmatites and mafic dikes and sills (980-940 Ma), as well as by reactived rift basins (e.g., <1050 Ma; Palmeiral formation). Fig. 5 and Table 3 present a SW-NE tectonic sketch of the Sunsás belt and a tentative time-outline of the late Mesoproterozoic evolution of the SW Amazonian Craton, respectively.

The late Mesoproterozoic orogenic history summarized here prevents the recognition of clear boundaries of the SA province with the RNJ and RSI ones by considering the tectonic juxtaposition of distinct geologic units. For example, the referred JPSZ network, the Nova Brasilândia and Aguapeí belts, the Huanchaca-Aguapeí and other cover sequences described here (see Fig. 1). When taken into account, these features suggest that the SA province overprints much of the RNJ and RSI provinces.

On the other hand, the paleotectonic association of the above geologic units and related structures with the Paraguá microcontinent are still a matter of debate. For example, Boger et al. (2005) argued that the Nova Brasilândia, Aguapeí and Sunsás belts would represent the Sunsás orogen properly on the basis of geologic correlations, in contrast with the model above proposed. Other alter- 


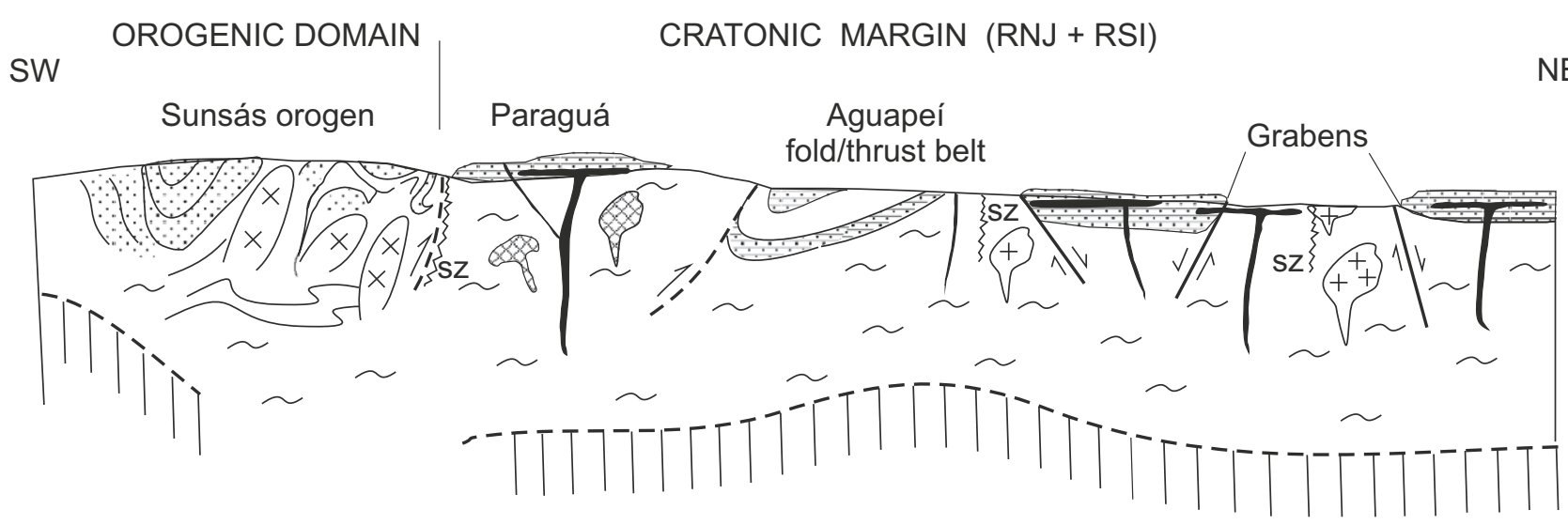

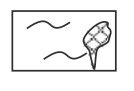

Pre-Sunsás basement, including San Ignacio granitoid rocks

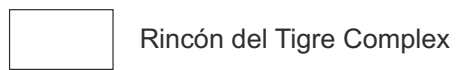

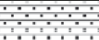

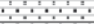

Folded Sunsás-Aguapei strata 
event is age-equivalent with the extensional tectonics occurred in the eastern Grenville province, characterized by the presence of marine sedimentary sequences, the AMGC magmatism (1130 \pm $50 \mathrm{Ma}$ ), the Abitibi dike swarm (1140 Ma), among other features (e.g., Sadowski and Bettencourt, 1996; Windley, 1989; Rivers, 1997). Putting it all together, the extensional and compressive events in the SA province provide good evidence of the early phases of geologic evolution of Amazônia and Laurentia.

The Sunsás belt (1100-1000 Ma) apparently overlaps within age errors with some of the major geologic episodes such as the major Grenvillian deformation in Eastern Laurentia, also known as Ottawan pulse of the Grenville orogen (Rivers, 1997). This episode is known for signaling the terminal continent-continent suturing of the Rodinia supercontinent (e.g., Sadowski and Bettencourt, 1996; Tohver et al., 2006; Cordani et al., 2009).

The tectonic significance and kinematics of the inferred Amazônia-Laurentia collation are largely unresolved, given the differences recognized among the orogenic and post-orogenic rocks in both plates, allowing various Rodinia reconstructions - as discussed by Tohver et al. (2006), Cordani and Teixeira (2007) and Santos et al. (2008). The age limits of the Ottawan pulse may vary along the Grenville province in North America but probably started c. 1100 Ma (e.g., Rivers, 1997; Carr et al., 2000; Gower and Krogh, 2002),

\section{Acknowledgements}

The authors acknowledge the Brazilian National Research Council (CNPq) for its continued supports through Grants 471585/20076 (to W. Teixeira) and 301539/2005-7 (to M.C. Geraldes). This work benefited from discussions with U. Cordani, J. Bettencourt and M. D'Agrella-Filho and English edition by Francisco da Cruz. The criticism by the reviewers was gratefully appreciated, and considered very important for shaping the final version of this paper.

\section{References}

Adamek, P.M., Troeng, B., Landivar, G., Llanos, A., Matos, R., 1996. Evaluación del los recursos minerales del Distrito San Ramón. Boletín del Servicio Geológico de Bolivia 10, 77

Araujo, L.M.B., 2008. Evolução do Magmatismo do Domínio Cachoeirinha: Suítes Intrusivas Santa Cruz, Alvorada, Rio Branco e Salto do Céu, SW do Cráton Amazônico MT. Doctoral Thesis. Instituto de Geociências e Ciências Exatas, State University of São Paulo, Rio Claro, Brazil, p. 165.

Barros, A.M., Silva, R.H. da, Cardoso, O.R.F.A., Freire, F.A., Souza Jr., J.J., Rivetti, M., Luz, D.S., Palmeira, R.C., Tassinari, C.C.G., 1982. Geologia. In: Ministério das Minas e Energia. Projecto RADAMBRASIL, Folha SD. 21, Cuiabá, p. 544.

Bettencourt, J.S., Onstott, T.C., De Jesus, T., Teixeira, W., 1996. Tectonic interpretation of ${ }^{40} \mathrm{Ar} /{ }^{39} \mathrm{Ar}$ ages on country rocks from the Central Sector of the Rio Negro-Juruena Province, Southwestern Amazonian Craton. International Geology Review 38, 42-56.

Bettencourt, J.S., Tosdal, R.M., Leite Jr., W.B., Payolla, B.L., 1999a. Mesoproterozoic rapakivi granites of Rondonia Tin Province, southwestern border of the Amazonian Craton, Brazil-I. Reconnaissance U-Pb geochronology and regional implications. Precambrian Research 95, 41-67.

Bettencourt, J.S., Payolla, B.L., Leite Jr., W.B., Tosdal, R.M., Spiro, B., 1999b. Mesoproterozoic Rapakivi granites of Rondonia tin province, SW border of Amazonian Craton, Brazil. III-Reconnaissance $\mathrm{Nd}, \mathrm{Sr}, \mathrm{O}, \mathrm{Pb}$ isotopic geochemistry and regional implications. In: Barbaran, B. (Ed.), Fourth Hutton Symposium Clermont Ferrand, France. Abstracts, BRGM 290, p. 132.

Bettencourt, J.S., Payolla, B.L., Tosdal, R.M., Wooden, J.L., Leite Jr., W.B., Sparrenberger, I., 2006. SHRIMP-RG U/Pb zircon geochronology of gneiss from the Rio Crespo Intrusive Suite, SW Amazonian Craton, Rondônia, Brazil: New insight about protolith crystallization and metamorphic ages. In: V South American Symposium on Isotopic Geology. Punta del Este, Uruguay. Short Papers, pp. 49-52.

Bettencourt, J.S., Leite Jr., W., Payolla, B., Ruiz, A.S., Matos, R.S., Tosdal, R.M., 2010. The Rondonian-San Ignacio Province in the SW Amazonian Craton: an overview. Journal of South American Earth Sciences 29, 28-46.

Boger, S.D., Raetz, M., Giles, D., Etchart, E., Fanning, C.M., 2005. U-Pb age from the Sunsás region of eastern Bolivia, evidence for allochtonous origin of the Paragua Block. Precambrian Research 139, 121-146.

Carr, S.D., Easton, R.M., Jamieson, R.A., Culshaw, N.G., 2000. Geologic transect across the Grenville orogen of Ontario and New York. Canadian Journal of Earth Sciences 37, 193-216.
Casquet, C., Pankhurst, R.J., Fanning, M., Baldo, E., Galindo, C., Rapela, C.W., Casado, J.M.G., Dahlquist, J.A., 2006. U-Pb SHRIMP zircon dating of Grenvillian metamorphism in Western Sierras Pampeanas (Argentina): correlation with the Arequipa-Antofalla Craton and constraints on the extent of the Precordillera Terrane. Gondwana Research 9 (4), 524-529.

Cordani, U.G., Teixeira, W., 2007. Proterozoic accretionary belts in the Amazonian Craton. In: Hatcher Jr., R.D., Carlson, M.P., McBride, J.H., Martinez Catalán, J.R. (Org.), The 4D Framework of Continental Crust. GSA Memoir. Boulder, Colorado: Geological Society of America Book Editors 200, 297-320.

Cordani, U.G., Teixeira, W., D́Agrella-Filho, M.S., Trindade, R.I., 2009. The position of the Amazonian Craton in supercontinents. Gondwana Research 15, 396-407. 10.10.16/j.gr.2008.12.005.

Cordani, U.G., Fraga, L.M., Reis, N., Tassinari, C.C.G., Brito-Neves, B.B., 2010. On the origin and tectonic significance of the intra-plate events of the Grenvillian-type age in South America: a discussion. Journal of South American Earth Sciences 29, 143-159.

D’Agrella-Filho, M.S., Tohver, E., Santos, J.O.S., Elming, S.A., Trindade, R.I.F., Pacca I.G., Geraldes, M.C., 2008. Direct dating of paleomagnetic results from Precambrian sediments in the Amazon Craton: evidence for Grenvillian emplacement of exotic crust in SE Appalachians of North America. Earth and Planetary Science Letters 267, 188-199. doi:10.1016/j.epsl.2007.11.030.

Darbyshire, D.P.F., 1979. Results of the age determination programme. Report Eastern Bolivia Mineral Exploration Project, phase I, p. 9 (unpublished report available on openfile in Bolivia (Geobol) and the United Kingdom (BGS)).

Darbyshire, D.P.F., 2000. The Precambrian of Eastern Bolivia-a Sm-Nd Isotope Study. In: 31st International Geological Congress, Rio de Janeiro, CD-ROM (abstracts volume).

Elming, S.A., D’Agrella-Filho, M.S., Page, L.M., Tohver, E., Trindade, R.I.F., Pacca, I.I.G. Geraldes, M.C., Teixeira, W., 2009. A paleomagnetic and ${ }^{40} \mathrm{Ar} /{ }^{39} \mathrm{Ar}$ study of Late Precambrian sills in the SW part of the Amazonian Craton. Geophysical Journal International (1), 106-122. doi:10.1111/j.1365-246X.2009.04149.

Fernandes, C.J., Kuyumjian, R.M., Pulz, G.M., Geraldes, M.C., Pinho, F.E.C., 2006 Geologia estrutural e idade ${ }^{40} \mathrm{Ar} /{ }^{39} \mathrm{Ar}$ do depósito de ouro Pau-a-Pique, Faixa Móvel Aguapeí, sudoeste do Estado do Mato Grosso. Revista Brasileira de Geociências 36, 3-15.

Geraldes, M.C., Figueiredo, B.R., Tassinari, C.C.G., Ebert, H.D., 1997. Middle Proterozoic vein-hosted gold deposits in the Pontes e Lacerda region, southwestern Amazonian Craton, Brazil. International Geology Review 39, 438-448.

Geraldes, M.C., Van Schmus, W.R., Condie, K.C., Bell, S., Teixeira, W., Babinski, M. 2001. Proterozoic geologic evolution of the SW part of the Amazonian Craton in Mato Grosso state. Brazil: Precambrian Research 111, 91-128.

Geraldes, M.C., Teixeira, W., Heilbron, M., 2004a. Lithospheric versus asthenospheric source of the SW Amazonian Craton A-type granites: the role of the Paleo- and Mesoproterozoic accretionary belts for their coeval continental suite. Episodes 27 (3), 185-189.

Geraldes, M.C., Bettencourt, J.S., Teixeira, W., Matos, J., 2004b. Geochemistry and isotopic constrains on the origin of the mesoproterozoic Rio Branco "Anorogenic" Plutonic Suite, SW of Amazonian Craton, Brazil: high heat flow and crustal extension behind the Santa Helena Arc. Journal of South American Earth Sciences 16, 1-14.

Girardi, V.A.V., Teixeira, W., Bettencourt, J.S., Andrade, S., Navarro, M.S., Sato, K., 2008. Trace element geochemistry and Sr-Nd characteristics of Mesoproterozoic mafic intrusive rocks from Rondônia, SW Amazonian Craton: petrogenetic and tectonic inferences. Episodes 31 (4), 392-400.

Gower, C.F., Krogh, T.E., 2002. A U-Pb geochronological review of the Proterozoic history of the eastern Grenville Province. Canadian Journal of Earth Sciences 39, 795-829.

Hoffman, P.F., 1991. Did the breakout of Laurentia turn Gondwanaland inside out? Science 252, 1409-1411.

Isla-Moreno, L., 2009. Distrito Don Mario, un deposito de Au-Cu hidrotermal asociado a zonas de cizalla. XVIII Congreso Geológico de Bolivia, Potosi, Bolívia. Memorias del Colegio de Geólogos, 85-92.

Keppie, J.D., Ortega-Gutierrez, F.O., 1999. Middle American Precambrian basement: a missing piece of the reconstructed $1 \mathrm{Ga}$ orogen. Geological Society of America, Special Paper 336, 199-210.

Kröner, A., Cordani, U.G., 2003. African, southern Indian and South American cratons were not part of the Rodinia supercontinent: evidence from field relationships and geochronology. Tectonophysics 375, 225-352.

Leite, A.D.J., Saes, G.S., 2003. Geocronologia $\mathrm{Pb} / \mathrm{Pb}$ de zircões detríticos and análise estratigráfica das coberturas sedimentares proterozóicas do sudoeste do Cráton Amazonas. Revista Geologia USP Série Científica 3, 113-127.

Leite Jr., W.B, Bettencourt, J.S., Payolla, B.L., 2003. Evidence for multiple sources inferred from $\mathrm{Sr}$ and $\mathrm{Nd}$ isotopic data from felsic rocks in the Santa Clara Intrusive Suite, Rondonia, Brazil. In: IV South American Symposium on Isotope Geology, Short Papers. Salvador, Brazil, pp. 583-585.

Lima, G.A., Souza, M.Z.A., Ruiz, A.S., Batata, M.E.F., Campos, M.S., 2008. Geologia e Petrografia das Soleiras Máficas-Ultramáficas da Suíte Intrusiva Huanchaca Serra Ricardo Franco (MT) - SW do Cráton Amazônico. Anais do IV Simpósio de Vulcanismo e Ambientes Associados. Foz do Iguaçu, Brazil. Coluna do Saber, 2008, pp. 1-5.

Litherland, M., Bloomfield, K., 1981. The Proterozoic history of eastern Bolivia. Precambrian Research 15, 157-179.

Litherland, M., Klinck, B.A., 1982. Introducing the terms: "Paraguá Craton" and "Pensamiento Granitoid Complex" for use in sheet reports. Report Eastern Bolivia Mineral Exploration Project, Santa Cruz, Bolivia (ML/37 unpublished). 
Litherland, M., Power, P.E.J., 1989. The geologic and geomorphologic evolution of Serrania Huanchaca, eastern Bolivia: the legendary "Lost World". Journal of South American Earth Sciences 2 (1), 1-17.

Litherland, M., Klinck, B.A., O'Connor, E.A., Pitfield, P.E.J., 1985. Andean-trending mobile belts in the Brazilian shield. Nature 314 (6009), 345-348.

Litherland, M., Annels, R.N., Appleton, J.D., Berrange, J.P., Boomfield, K., Darbyshire, D.P.F., Fletcher, C.J.N., Hawkins, M.P., Klinck, B.A., Mitchell, W.I., O'Connor, E.A., Pitfield, P.E.J., Power, G., Webb, B.C., 1986. The geology and mineral resources of the Bolivian Precambrian Shield. Overseas Memoir. British Geological Survey, vol. 9, p. 153

Litherland, M., Annels, R.N., Hawkins, M.P., Klinck, B.A., O’Connor, E.A., Pitfield, P.E.J., Power, G., Darbyshire, D.P.F., Fletcher, C.N.J., Mitchell, W.I., Webb, B.C., 1989. The Proterozoic of eastern Bolivia and its relationships to the Andean mobile belt. Precambrian Research 43, 157-174.

Luft, J.L.J., Rizzotto, G., Chemale Jr., F., Lima, E.F., 2000. Análise geológica-estrutura do Cinturão Sunsás na Região de Nova Brasilândia, Sudeste de Rondônia. Revista Pesquisas Geociências 2, 65-78.

Matos, R., Teixeira, W., Geraldes, M.C., Bettencourt, J.S., 2009. Geochemistry and isotopic evidence of the Pensamiento Granitoid Complex, Rondonian-San Ignacio province, eastern Precambrian Shield of Bolivia: petrogenetic constraints for a Mesoproterozoic magmatic arc setting. Revista Geologia USP série científica 9 (2), 89-117.

Payolla, B.L., Bettencourt, J.S., Kozuch, M., Leite Jr., W.B., Fetter, A.H., Van Schmus, W.R., 2002. Geological evolution of the basement rocks in the east-central part of the Rondônia Tin Province, SW Amazonian Craton, Brazil: U-Pb and Sm-Nd isotopic constraints. Precambrian Research 119, 141-169.

Payolla, B.L., Bettencourt, J.S., Tosdal, R.M., Wooden, J.L., Leite Jr., W.B., 2003. SHRIMP-RG, U-Pb geochronology of high grade paragneisses from NE Rondônia SW Amazonian Craton, Brazil: constraints on provenance and metamorphism. In: IV South American Symposium on Isotope Geology, Salvador, Brasil, Short papers, vol. 1, pp. 248-251.

Prendergast, M.D., 2000. Layering and precious metals mineralization in the Rincón del Tigre Complex, Eastern Bolivia. Economic Geology 95, 113-130.

Priem, H.N.A., Bon, E.H., Verdumen, E.A.Th., Bettencourt, J.S., 1989. Rb-S chronology of Precambrian crustal evolution in Rondonia (western margin Brazilian Craton). Journal of South American Earth Sciences 2, 163-170.

Ramos, V.A., Aleman, A., 2000. Tectonic evolution of the Andes. In: Cordani, U.G. Miliani, E.J., Thomaz-Filho, A., Campos, D.A. (Eds.), Tectonic Evolution of South America. 31st International Geological Congress, Rio de Janeiro, Brazil, pp. 635685 (special volume of selected papers).

Rivers, T., 1997. Lithotectonic elements of the Grenville Province: review and tectonic implications. Precambrian Research 86, 117-154

Rizzotto, G.J., 1999. Petrologia e geotectônica do Grupo Nova Brasilândia, Rondônia. MSc. Dissertation. Federal University of Rio Grande do Rio Grande do Sul. Porto Alegre, Brazil, p. 131

Rizzotto, G.J., Quadros, L.Q., 2007. Margem Passiva e granitos Orogênicos do Ectasiano em Rondônia. In: X Simpósio de Geologia da Amazônia. Porto Velho CDROM, 2007.

Rizzotto, G.J., Lima, E.F., Chemale Jr., F., 2001. Geologia do Grupo Nova Brasilândia sudeste de Rondônia, acresção continental e implicações geotectônicas. In: Reis, N.J., Monteiro, M.A.S. (Coords.), Contribuiç̃̃es à Geologia da Amazônia, SBG 2 , pp. 342-442.

Rizzotto, G.J., Bettencourt, J.S., Teixeira, W., D’Agrella Filho, M.S., Vasconcelos, P. Basei, M.A.S., Onoe, A., Passarelli, C.R., 2002. Geologia e Geocronologia da Suíte Metamórfica Colorado e suas encaixantes, SE de Rondônia; implicações para evolução mesoproterozóica do Craton Amazônico. Geologia USP série científica $2,41-56$.

Ruiz, A.R., 2005. Evolução geológica do sudoeste do Craton Amazônico, região limítrofe Brasil-Bolívia-Mato Grosso. Doctoral Thesis, State University of São Paulo, UNESP-Rio Claro, SP, Brazil, p. 260

Ruiz, A.S., Simões, L.S.A. Costa, P.C.C., Matos, J.B., Araújo, L.M.B., Godoy, A.M., Souza, M.Z.A., 2005. Enxame de Diques Máficos (Suíte Intrusiva Rancho de Prata) no SW do Cráton Amazônico: Indícios de Colapso Extensional no Orógeno Sunsás? III Simpósio de Vulcanismo e Ambientes Associados, Cabo Frio, vol. 1, pp. 1-5.

Ruiz, A.S., Simões, L.S.A., Araujo, L.M.B., Godoy, A.M., Matos, J.B., Souza, M.Z.A., 2007 Cinturão Orogênico Aguapeí (1025-900 Ma): Um exemplo de Faixa Móvel Intracontinental no SW do Cráton Amazônico. In: XI Simpósio Nacional de Estudos Tectônicos, 2007, Natal. Anais do XI SNET, pp. 116-118.

Sadowski, G.R., Bettencourt, J.S., 1996. Mesoproterozoic tectonic correlations between eastern Laurentia and the western border of the Amazonian Craton. Precambrian Research 76, 213-227.

Saes, G.S., 1999. Evolução tectônica e paleogeográfica do Aulacógeno Aguapeí (1.2$1.0 \mathrm{Ga}$ ) e dos terrenos do seu embasamento na porção sul do Craton Amazônico. Doctoral thesis, Institute of Geociences, University of São Paulo, São Paulo Brazil, p. 135.

Saes, G.S., Leite, J.A.D., Alvarenga, C.J.S., 1992. Evolução tectono-sedimentar do Grupo Aguapeí, Proterozóico Médio na porção meridional do Cráton Amazônico: Mato Grosso e Oriente Boliviano. Revista Brasileira de Geociências 23 (1), 31-37.

Saes, G.S., Leite, J.A.D., Fragoso Cesar, A.R.S., 2006. Seqüências deposicionais mesoproterozóicas do sudoeste do Cráton Amazônico. In: Fernandes, C.J. Ribeiro, R.V. (Eds.), Coletânea geológica de Mato Grosso, EDUFMT, pp. 149-164.

Santos, J.O.S., 2003. Geotectônica dos Escudos das Guianas e Brasil Central. In: Bizzi, L.A., Schobbenhaus, C., Vidotti, R.M., Gonçalves, J.H. (Orgs.), Geologia, Tectônica e Recursos Minerais do Brasil - CPRM, Brasilia IV (II), pp. 169-226.
Santos, J.O.S., Hartmann, L.A., Gaudette, H.E., Groves, D.I., McNaughton, N.J., Fletcher, I.R., 2000. A new understanding of the provinces of the Amazon Craton based integration of field mapping and U-Pb and Sm-Nd geochronology. Gondwana Research 3 (4), 453-488.

Santos, J.O.S., Rizzotto, G.J., Hartmann, L.A., McNaughton, N.J. and Fletcher, I.R. (2001). Ages of sedimentary basins related to the Sunsás and Juruena Orogenic cycles, southwestern Amazon Craton, established by zircon U-Pb geochronology. In: South American Symposium on Isotope Geology, 2001, Pucón, Chile. Comunicaciones, p. 81.

Santos, J.O.S., Rizzotto, G.J., Chemale Jr., F., Hartmann, L.A., Quadros, M.L.E.S., McNaughton, N.J., 2003. Three distinctive collisional orogenies in the southwestern Amazon Craton: constraints from U-Pb geochronology. In: IV South American Symposium on Isotope Geology, short papers. Salvador, Brazil, vol. 1, 282-285.

Santos, J.O.S., McNaughton, N.J., Hatmann, L.A., Fletcher, I.R., Salinas, R.M., 2005. The age of the deposition of the Aguapeí Group, Western Amazon Craton, based on $\mathrm{U}-\mathrm{Pb}$ study on diagenetic xenotime and detrital zircon. In: Latin American Congress, Quito, Equador, extended abstracts, pp. 1-4.

Santos, J.O.S., Rizzotto, G.J., McNaughton, N.J., Matos, R., Hartmann, L.A., Potter, P.E., Fletcher, I.R., 2006. The four main Orogenies within the Autochthonous Mesoproterozoic Sunsás Province in SW Amazon Craton. In: XVII Congreso Geológico de Bolivia, 2006. Sucre, Bolívia, resumenes, pp. 1-4.

Santos, J.O.S., Rizzotto, G.J., McNaughton, N.J., Matos, R., Hartmann, L.A., Chemale Jr. F., Potter, P.E., Quadros, M.L.E.S., 2008. The age and autochthonous evolution of Sunsás Orogen in West Amazon Craton. Precambrian Research 165, 120152

Scandolara, J.E., 2006. Geologia e evolução do terreno Jamari, embasamento da faixa centro-leste de Rondônia, sudoeste do Craton Amazônico. Doctoral Thesis, University of Brasília. Brasília, Brazil, p 384.

Sécolo, D.B., Ruiz, A.S., Souza, M.Z.A., Lima, G.A., Batata, M.E.F., 2008. Caracterização Geológica e Petrográfica do Enxame de Diques Máficos (Suíte Intrusiva Huanchaca) no Domínio Tectônico Paraguá - SW do Cráton Amazônico - MT. In: $44^{\circ}$ Congresso Brasileiro de Geologia, 2008, Curitiba, Brazil. Anais do $44^{\circ}$ Congresso Brasileiro de Geologia, p. 545.

Souza, A.E.P., Hildred, P.R., 1980. Contribuição ao estudo da geologia do Grupo Aguapeí, Mato Grosso. 31 Congresso Brasileiro de Geologia 2, 587-598.

Sparrenberger, I., Bettencourt, J.S., Tosdal, R.M., Wooden, J.L., 2002. Datações U-Pb convencional versus SHRIMP do Maciço Estanífero Santa Bárbara; Suite Granitos Últimos de Rondônia, Brasil. Revista Geologia USP série científica 2, 79-94.

Tassinari, C.C.G., Macambira, M.J.B., 2004. A evolução tectônica do Craton Amazônico. In: Mantesso-Neto, V., Bartorelli, A., Carneiro, C.R., Brito-Neves, B.B. (Eds.), Geologia do Continente Sul-Americano, vol. XXVIII, Beca, São Paulo, Brazil, pp. 471-485

Tassinari, C.C.G., Bettencourt, J.S., Geraldes, M.C., Macambira, M.J.B., Lafon, J.M., 2000. The Amazonian Craton. In: Cordani, U.G., Miliani, E.J., Thomaz-Filho, A., Campos, D.A. (Coord.), Tectonic Evolution of South America. 31st International Geological Congress, Rio de Janeiro, Brazil, pp. 41-95 (special volume of selected papers).

Teixeira, W., Tassinari, C.C.G., Cordani, U.G., Kawashita, K., 1989. A review of the geochronology of the Amazonian Craton: tectonic implications. Precambrian Research 42, 213-227.

Teixeira, W., Bettencourt, J.S., Girardi, V.A.V., Onoe, A.T., Sato, K., 2006 Mesoproterozoic mantle heterogeneity in SW Amazonian Craton: ${ }^{40} \mathrm{Ar} /{ }^{39} \mathrm{Ar}$ and $\mathrm{Nd}-\mathrm{Sr}$ evidence from mafic-felsic rocks. In: Hansji, E., Mertanen, S., Rämö, T., Vuollo, J. (Orgs.), Dyke Swarms - Time Markers of Crustal Evolution. Proceedings of the V International Dyke Conference, 2005, vol. 1, Taylor and Francis Group, London, pp. 113-129.

Tohver, E., Van der Pluijm, B.A., Van der Voo, R., Rizzotto, G.J., Scandolara, J.E., 2002. Paleogeography of the Amazon Craton at 1.2 Ga: early Grenvillian collision with the Llano segment of Laurentia. Earth and Planetary Science Letters 199, 185200.

Tohver, E., Van der Pluijm, B.A., Mezger, K., Essene, E., Scandorala, J.E., Rizzotto, G.J., 2004. Significance of the Nova Brasilândia metasedimentary belt in western Brazil: redefining the mesoproterozoic boundary of the Amazon Craton. Tectonics. doi:10.1029/2003TC001563 (TC6004)

Tohver, E., Van der Pluijm, B.A., Scandolara, J.E., Essene, E., 2005a. Late mesoproterozoic deformation of SW Amazonia (Rondonia, Brazil): geochronological and structural evidence for collision with Southern Laurentia. Journal of Geology 113, 309-323. doi:10.1086/428807.

Tohver, E., Van der Pluijm, B.A., Mezger, K., Scandolara, J.E., Essene, E.J., 2005b. Two stage tectonic history of the SW Amazon Craton in the late Mesoproterozoic: identifying a cryptic suture zone. Precambrian Research 137, 35-39. doi:10.1016/j.precamres.2005.01.002.

Tohver, E., Van der Pluijm, B.A., Scandolara, J.E., Essene, E.J., 2005c. Grenville-aged deformation of Amazônia (Rondônia, Brazil): evidence for collision with southern Laurentia. Journal Geology 113, 309-323.

Tohver, E., Teixeira, W., Van der Pluijm, B.A., Geraldes, M.C., Bettencourt, J.S., Rizzotto, G., 2006. A restored transect across the exhumed Grenville orogen of Laurentia and Amazonia, with implications for crustal architecture. Geology 34, 669-672.

Tosdal, R.M., Bettencourt, J.S., 1994. U-Pb zircon ages and Pb isotopic compositions of Middle Proterozoic Rondonian massifs, southwestern margin of the Amazon Craton, Brazil. Actas del 7 Congreso Geologico Chileno, Concepcion, vol. 2, Chile, pp. $1538-1541$ 
Vargas-Mattos, G.L., 2006. Geocronologia U/Pb en granitos post y sin-tectónicos de la Orogenia Sunsás en el Cratón Amazonico de Bolivia. Msc Dissertation, Universidade do Estado do Rio de Janeiro, Rio de Janeiro, Brazil, p. 107.

Vargas-Mattos, G.L., Geraldes, M.C., Teixeira, W., Salinas, R.M., 2006. Geochronologic correlations between Paleo and Mesoproterozoic orogens in Brazil and Bolívia, SW Amazonian Craton. In: V South American Symposium on Isotope Geology, 2006, Punta Del Este, Uruguay, short papers, pp. 207-209.

Vargas-Mattos, G.L., Geraldes, M.C., Schmitt, R.S., Matos, R., Teixeira, W., Valencia, V., Ruiz, J., 2007. Geocronologia U-Pb de zircões detríticos do Grupo Aguapeí
(Serras Ricardo Franco, Santa Bárbara e Salto do Céu): Implicações na evolução geológica do SW do Cráton Amazônico. XI Congresso Brasileiro de Geoquímica. Atibaia, Brazil. CD-ROM.

Vargas-Mattos, G.L., Geraldes, M.C., Matos, R., Teixeira, W., 2009. Resultados parciais U-Pb de alguns corpos intrusivos gerados na orogênese Sunsás, SW do Craton Amazônico na Bolivia. Anais do XI Simpósio de Geologia do Centro-Oeste. Cuiabá, Brazil, 62.

Windley, B.F., 1989. Anorogenic magmatism and the Grenvillian Orogeny. Canadian Journal of Earth Sciences 26, 479-489. 
An overview of the Proterozoic evolution of the Eastern Bolivian shield: SHRIMP, TIMS and LA-MC-ICP-MS U-Pb zircon geochronology and $\mathrm{Nd} / \mathrm{Sr}$ evidence from the Lomas Manechis and Pensamiento complexes

Ramiro Matos ${ }^{1,3}$, Wilson Teixeira ${ }^{1}$, Mauro C. Geraldes ${ }^{2}$, Jorge S. Bettencourt ${ }^{1}$, Umberto G. Cordani ${ }^{1}$.

1 Instituto de Geociências, Universidade de São Paulo, Rua do Lago 562, Cidade Universitária. 05508-080 São Paulo, SP, Brasil. E-mail: rmatoss@igc.usp.br; wteixeir@usp.br; ucordani@usp.br; jsbetten@usp.br; ucordani@usp.br

2 Faculdade de Geologia, Universidade do Estado do Rio de Janeiro, Rua São Francisco Xavier 524, 20559-900 Rio de Janeiro, RJ, Brasil. E-mail: geraldes@uerj.br;

3 Instituto de Investigaciones Geológicas y del Medio Ambiente, Universidad Mayor de San Andrés, Calle 27, Pabellón Geologia, Campus Universitario Cota Cota. La Paz, Bolivia. Email: rmatoss@yahoo.com

Keywords: Bolivia, Pensamiento Granitoid Complex, San Ignacio Orogeny, SHRIMP U-Pb Ages, Amazonian Craton.

Abstract

Contents

1. Introduction and tectonic framework

2. Precambrian geology and previous geochronology

2.1 The Lomas Manechis Granulite Complex

2.2 Chiquitania Gneiss Complex

2.3 The San Ignacio Schist Group

2.4 The Lomas Manechis Suite

2.5 The San Ramón granite 
2.6 The San Ignacio Granitoid Complex

2.6.1 The La Junta and San Martín granites

2.6.2 The Porvenir and San Cristobal granites and the Piso Firme granophyre

2.6.3 The Diamantina granite

2.6.4 The San Rafael granite

2.6.5 The Santa Rita and Rio Fortuna orthogneiss

2.6.6 Talcoso granite

2.6.7 Limonal granite.

2.6.8 Cachuela granite

2.6.9 San Andrés granite

3. Analytical methods

4. Results

4.1 Yarituses suite

4.1.1 La Cruz granite.

4.1.2 Refugio granite

4.1.3 San Pablo granite

4.2 San Ramón granite

4.3 San Ignacio Granitoid rocks (SIG)

4.3.1 San Martín granite

4.3.2 La Junta granite

4.3.3 Diamantina granite

4.3.4 Las Maras granite

4.3.5 Talcoso granite

4.3.6 Limonal granite

4.3.7 San Andrés granite

4.4 Sm-Nd results

5. Discussion and tectonic implications

5.1 Proterozoic tectonic history

5.2 Tectonic extrapolations

References

Abstract

\section{Introduction and tectonic framework}

The Precambrian terrains of eastern Bolivia, as part of the Amazonian craton, have been studied during the last 5 years thanks to an international cooperative scientific program, sponsored by the Brazilian Council of Technological and Scientific Research. This effort has 
provided a significant set of radiometric ages coupled with $\mathrm{Nd} / \mathrm{Sr}$ isotopic and geochemical data for the most relevant lithoestratigraphic units of the Precambrian shield, therefore allowing a better understanding of the Proterozoic polycyclic evolution. Nevertheless, many geological aspects are still unclear due to the lack of a systematic mapping project with the aid of geochronological and geophysical control, subsequent to the reconnaissance mapping undertaken by the Anglo-Bolivian cooperation program known as "Proyecto Precambrico"GEOBOL (Litherland et al., 1986, 1989). In a similar way the extensive rain forest cover with low exposure of outcrops, and particularly the limited access to extreme north of the area, along the border with Brazil are difficult task for any further geologic work.

This paper reports SHRIMP, TIMS U-Pb and Laser Ablation zircon ages for the metamorphic basement and granitoid rocks (Pensamiento Complex), coupled with new Sm$\mathrm{Nd} \mathrm{T}_{\mathrm{DM}}$ ages. These data are interpreted together with the available geochronological background of Precambrian shield of Bolivia. As such, the age, origin and tectonic significance of these units are addressed, allowing correlations with the recognized igneous and tectonic events in the Brazilian counterpart of the SW Amazonian craton (Fig. 1).

Insert the Fig. 1 here

Further the continental substratum constituting the Paragua block in the extreme NE sector where the SISG is represented by San Simón, Dalriada and El Cielo were deformed during the San Ignacio orogeny (Fig 9). Arguably the anorogenic intrusives Remancito granitoid and Discordancia rapakivi granites (recognized in the Dalriada belt underlying Huanchaca according to Litherland, 1982) could represent the inboard manifestation of the San Ignacio collision of the Paragua Block against the RNJP, implying a within-plate origin for the Sunsás, Nova Brasilandia, and Aguapeí groups (Teixeira et al., 2010). Finally the Suite. Ion microprobe geochronology shows that zircons in granitic gneiss of the Rio Crespo Intrusive Suite are composed of 1,50 Ga igneous cores (Payolla et al., 2002; Bettencourt et al., 2006).

Recent field mapping and geochronological studies carried out on the Paragua block of the Mato Grosso state identified several intrusive bodies. The oldest one is the Agua Branca monzogranite gneiss that was analized by LA-ICP-MS in zircon grain yielding $1711 \pm 13 \mathrm{Ma}$ (Faria, Ruiz and Matos, 2009). Another pluton is the Turvo orthogneiss reported by Lisboa et al. (2009) where using $\mathrm{Pb}-\mathrm{Pb}$ systematics in zircon grain obtained an age of $1651 \pm 4 \mathrm{Ma}$. Geraldes et al. (2004) in the Mato Grosso state described the Santa Helena orogen composed by three syn-kinematic intrusions: the Santa Helena Intrusive Suite, Agua Clara Intrusive Suite and Pindaituba Intrusive Suite. These rocks present U-Pb zircon magmatic 
ages ranging between 1,48 to $1,42 \mathrm{Ga}$, the $\mathrm{Nd} \mathrm{T}_{\mathrm{DM}}$ model ages between $1,5-1,8$ and the $\varepsilon \mathrm{Nd}$ between 0,03 to +4 . Similarly the Rio Branco Intrusive Suite considered as a bimodal rapakivi igneous association yielded U-Pb zircon crystallization age of $1471 \pm 8 \mathrm{Ma}$. In like manner o coeval body has been reported on the Paragua block of Brazilian-Bolivia boundary; the Cascata granite analyzed by $\mathrm{Pb}-\mathrm{Pb}$ evaporation in zircon grain yielded $1412 \pm 5 \mathrm{Ma}$ (Cabrera et al., 2009).

The RSIP in Rondônia (Fig.2) consists predominantly of amphibolite grade granitegneiss, tonalites and granitoids rocks genetically related to distinct magmatic arcs (e.g., Payolla et al., 2002), partly covered by Late-Mesoproterozoic sedimentary basins. Several AMCG-like intrusive suites are also present. The Sm-Nd studies of the RSIP granitoid rocks yielded positive to slightly negative $\varepsilon_{\mathrm{Nd}(\mathrm{t})}$ signatures roughly between +5.0 and -2.0 (Payolla et al., 2002; Tassinari et al., 2000), reinforcing the idea that juvenile events combined with reworking of the pre-existent crust played a major role during the plate convergence dynamics and further collision of the Paraguá block with the RNJP (Cordani and Teixeira, 2007). The collision features are envisaged by occurrence of shear zones and fold-and-thrust belts (Tassinari et al., 2000), as well as suggested by the 1.35 - 1.32 Ga granulitic metamorphism (SHRIMP U/Pb ages of zircon overgrowths) that overprints the country rocks of the RNJP.

The basement rock in the western side of Rondonia constitutes several complexes and suites represented by metavolvcano-sedimentary sequences and mafic to felsic intrusive rocks. The Trincheira mafic- ultamafic complex comprises subvertical bands of anphibolites and metagabbros of N-MORB signature. The Colorado Complex (Rizzotto et al., 2002; Rizzotto and Quadros, 2007) probably represents the major, ultimate magmatic-metamorphic episode that built up the RSIP. This complex consists of amphibolites, serpentinites, metabasalts, interlayered BIF, para- and orthogneisses, schists and bimodal magmatism originated in a passive margin setting associated to an intra-oceanic arc amalgamated against the already cratonized rocks of the RNJP. In consequence the country rocks were deformed by compression tectonics associated to the collision whilst further intruded by syn and post-tectonic granites. The detailed geochronological data for the Colorado Complex allow the following inferences about the tectonic evolution (Rizzoto et al., 2002; Teixeira et al., 2006; Rizzotto and Quadros, 2007; Bettencourt et al., 2009): i) the detrital zircons ages in the paragneisses yield ages from 1938 to 1508; on the other hand the metamprphic zircons yield $1352 \pm 4 \mathrm{Ma}$. The Nova Mamoré Metamorphic Suite is a meta-sedimentary sequence of migmatitic paragneiss, calc-silicate gneiss and granofels metamorphosed to the amphibolite facies. U-Pb detrital zircon age range between 2030 to $1532 \mathrm{Ma}$ and metamorphic zircons yielded $1345 \mathrm{Ma}$ age, this last one coeval with the PGC. Further the 
Serra do Colorado Intrusive suite consists of layered mafic to ultramafic complexes; a metagabbro yields an age of $1352 \pm 4 \mathrm{Ma}$ considered the crystallization age. These basement rocks above described has been intruded by the Igarapé Enganado Intrusive Suite and the Alto Escondido Intrusive Suite both are composed by syenogranite and monzogranite and are intruded into the Colorado Complex. U-Pb SHRIMP in zircon grains of the Igarapé Enganado Intrusive Suite yield a crystallization age of $1340 \pm 5 \mathrm{Ma}$ and $\varepsilon \mathrm{Nd}+$ 2,3. The Alto Escondido Intrusive Suite produced a U-Pb Zircon (TIMS method) age of 1332 $\pm 3 \mathrm{Ma}$ and a $\varepsilon \mathrm{Nd}$ of +1.5 (Rizzotto and Quadros, 2007). On the other hand, on the Paragua block of the Mato Grosso state two plutons related to the PGC have been recently reported. The Guaporeí granite has been dated by $\mathrm{Pb}-\mathrm{Pb}$ evaporation in zircon grain yielding $1314 \pm 2$ Ma (Nalon et al., 2009); whereas the Passagem granite (Jesus et al., 2010) yielded by LAICP-MS in zircon grain $1291 \pm 2 \mathrm{Ma}$. Both of them could be considered late- to post- kinematic granites related to the PGC of the San Ignacio orogeny.

Obs. Além do Colorado existe mais outra unidade geológica descrita pelo Rizzoto e Quadros. Incluir também nesta sua síntese

The orogenic magmatism and deformation of the Colorado Complex is coeval with the Pensamiento Granitoid Complex in the Bolivian counterpart which is interpreted as the major product of the San Ignacio (SI) orogeny affecting voluminous parts of the Paraguá block.

The San Ignacio orogeny is the most important geochronological event in the Precambrian shield of Bolivia. This is manifested by the PGC that consists of voluminous, intrusive plutonic and subvolcanic granitoid rocks, with subordinate syenites, granodiorites, tonalites, trondhjemites and diorites and dispersed tonalites and granodiorites to the southwest of the Paragua block. This magmatism has been divided into two intrusive events on the basis of the structural work: i) the syn- to late kinematic granitoid rocks. ii) the late- to post- kinematic granitoid rocks. Regarding the metamorphism, the area north of the PGC have undergone the superposition of Mo2 and Mo3 events (Litherland et al., 1986) and possesses a very low grade metasedimentary core bordered by prograde metamorphism passing to a medium grade composed by gneisses and granofelses. To the east of PGC, near to the Brazilian border (Huanchaca) an apparent telescoping occured between low grade chlorite sericite fabric to higher grade of sillimanite and perthite. More sharp changes show the metamorphic grade in the San Ramón area from low grade (chlorite) to medium grade (garnet and kianite) and high grade with sillimanite attributed to the imprint of Sunsás orogeny. The area of san Ignacio and San Antonio de Lomerío is characterized by the record of staurolite and garnet. The gneisses of the Chiquitania Complex that crops out between San Ignacio and San Ramón are of high grade and show complex metamorphic and tectonic history without 
regional metamorphic hypersthene and cordierite that characterize the Lomas Manechis Complex.

In Bolivia, the southwestern limit of the of the SI orogeny (RSIP) is assigned to the mylonitic shear zone of the Rio Negro Front and along the south to the Santa Catalina Straight Zone (Fig.2). The latter structure also marks the limit of the RSIP with the Sunsás collisional belt (e.g, Litherland et al., 1986), as indicated in the San Ramon district (SW fringe of the Paraguá block) where the metamorphic basement is deformed by an important oblique tectonic style, with sinistral shear sense, as suggested by geophysical interpretation (Matos, 2009). One the other hand, the east-west San Diablo Shear Front cross-cuts the structures of San Ignacio orogeny outcrops whilst showing a transcurrent motion (Landivar and Gonzalez, 1997).

The metasedimentary and bimodal metaplutonic Nova Brasilandia belt has a heterogeneous metamorphic grade that increases from $\mathrm{N}$ to $\mathrm{S}$. Two episodes of felsic magmatism were recognized, the syn-kinematic Rio Branco suíte $(1.13$ to $1.0 \mathrm{Ga})$ and the post-kinematic Rio Pardo suíte (1.0 Ga). The Rio Branco suite shows derivation from magma source mixed with crustal material. The Rio Pardo suite records a juvenile component. The Ji-Paraná Shear Zone of amphibolite-grade is a large scale lineament of hundreds of kilometers long, that cut the Amazonian basement. It consists of subvertical milonitic zones with horizontal L-fabric that record a sinistral shear sense. The timing of this deformation ranges between $\mathrm{Ca} 1.18$ Ga to $1.15 \mathrm{Ga}$.

Insert here Fig. 2

\section{Precambrian geology of Bolivia and previous geochronology}

Early views of the geological framework of the Bolivian Precambrian shield considered that three major lithostratigraphic units made up the crystalline basement, on the basis of geologic mapping, metamorphic and structural studies, as well as reconnaissance scale Rb-Sr and K-Ar geochronology (e.g., Litherland et al., 1986): i) the Lomas Maneches Granulite Complex, ii) the Chiquitania Gneiss Complex, and iii) the San Ignacio Schist Group. These basement rocks were intruded by the Pensamiento Granitoid Complex (PGC) of widespread occurrence in the Paraguá block, considered as the most representative geologic unit of the so-called San Ignacio orogen (Table 1). Concerning the tectonic framework of the Precambrian shield of Bolivia two regional metamorphic episodes, Mo2 and Mo3 have been attributed to the Do1/Do2 and Do3 deformation phases respectively. The Do3 is considered the last phase of penetrative deformation related to the San Ignacio orogeny that yielded the So3 planar mica fabric and K-feldspar megacrysts evidenced principally in the gneisses. Furthermore, tectonic events that postdate Do3 have been 
labelled Do4 and Do5 characterized by non penetrative phases. Nevertheless, subsequent studies supported by SHRIMP U-Pb and Sm-Nd data allowed a more realistic tectonic framework (e.g., Boger et al., 2005; Santos et al., 2008; Matos et al., 2009) of the Precambrian shield of Bolivia (Table 2). Then, the complex framework that characterized the San Ignacio orogen is followed to the southwestern side of the Bolivian Precambrian shield by the younger Sunsás orogen formed by the collision against the RSIP yielding folded and metamorphosed rocks over the orogen and is flat lying over the Paragua block this last one represented by the Huanchaca sedimentary cover (Teixeira et al., 2009).

Insert Table 1 here

Insert the Table 2

\subsection{The Lomas Manechis Granulite Complex}

This unit comprises granulites massifs passing upwards to biotite (+ garnet) gneisses. The granulites consist of bands of charnockitic, enderbitic and basic hypersthene granulites (Litherland et al., 1986). Santos et al. (2008) dated the Lomas Manechis granulitic gneiss on the way of Ascensión - Las Rengas, with the magmatic zircons yielding a ${ }^{207} \mathrm{~Pb} /{ }^{206} \mathrm{~Pb}$ age of $1818 \pm 13$ which is the older age identified in the Complex up to the present. The Sm-Nd $T_{D M}$ age is $2.07 \mathrm{Ga}$ and the $\varepsilon N d$ of +0.53 . The additional monazite analysis provided a metamorphic age of $1339 \pm 4 \mathrm{Ma}$. In the same sector another sample has metamorphic zircons with a precise and concordant ${ }^{207} \mathrm{~Pb} /{ }^{206} \mathrm{~Pb}$ age of $1334 \pm 2.4 \mathrm{Ma}$.

Finally, K-Ar data reported by Litherland et al. (1986) on hornblende and biotite (samples 23 and 24), to the northeastern of San Ignacio, yielded apparent ages of $1336 \pm 33$ Ma and $1323 \pm 33$ Ma respectively (Darbyshire, 1979), pointing to the regional cooling of the San Ignacio tectonic event, to be presented below.

\subsection{The Chiquitania Gneiss Complex}

This is the most widespread unit of the Bolivian Precambrian shield. It consists mainly of amphibolite facies, partly migmatized rocks that, exhibit complex structural evolution such as interference folding features. The transitional contacts with the San Ignacio schists (Litherland et al., (1986) suggest that they represent a single unit with barrovian metamorphic zoning, instead of different ones. The bulk of the Chiquitania complex is composed of pale pink to gray, biotite gneiss (medium- to coarse- grained) and banded, micaceous quartzfeldspathic gneisses, without hypersthene and cordierite (Litherland et al., 1986). They may be intercalated with granite gneisses (Boger et al., 2005), interpreted to be either of volcanic or sedimentary origins such as in the San Ignacio area. These authors sampled rocks $20 \mathrm{~km}$ east of San Rafael (Fig. 3), where the zircon cores yielded ages between $1830 \mathrm{Ma}$ and 1690 
$\mathrm{Ma}$, whereas less discordant zircon grains yielded a mean ${ }^{207} \mathrm{~Pb} /{ }^{206} \mathrm{~Pb}$ age of $1333 \pm 6 \mathrm{Ma}$ interpreted as due to a partial melt episode related to the so-called San Ignacio orogeny.

According to Boger et al. (2005) the Chiquitania Gneiss Complex derives from sources of about $1765 \mathrm{Ma}$ and contains detritic zircons as young as $1690 \mathrm{Ma}$. Santos et al. (2008) reported for another outcrop that the main population of detritic zircons yields ${ }^{207} \mathrm{~Pb} /{ }^{206} \mathrm{~Pb}$ ages in the $1690-1630 \mathrm{Ma}$ range, whereas the $\mathrm{T}_{\mathrm{DM}}$ crustal residence ages are of 1.86 .

\subsection{The San Ignacio Schist Group}

The San Ignacio Schist Group (SISG) crops out as discrete belts composed of metapsamites, schists, phyllites, slates, mafic metatuffs, BIF, metachert, metalavas of tholeiitic and felsic composition (e.g., Litherland et al., 1986), intruded by granitic rocks such as the La Cruz and Refugio ones (see discussion afterward). In the northeastern sector of the SISG the recognized San Simón, El Cielo and Dalriada structures are crosscut by the Remancito augen gneiss and Discordancia rapakivi granite (no geochronological data). In the extreme northeast (Paraguá block), the SISG is unconformably overlaid by the flat-lying Huanchaca Formation, while in the southern area the Sunsás folded strata (Sunsás belt) overlies the San Ignacio rocks. Boger et al. (2005) reported a U-Pb age for a San Ignacio paragneiss between San Rafael and San Ignacio village. The largest population (29 zircons) yielded a concordant ${ }^{207} \mathrm{~Pb} /{ }^{206} \mathrm{~Pb}$ age of $1764 \pm 6 \mathrm{Ma}$ indicating that the protolith derived from a major Paleoproterozoic source, in roughly agreement with the $\mathrm{T}_{\mathrm{DM}}$ ages available for the Chiquitania rocks (see above). For these authors the San Ignacio Schist Group derived from Paleoproterozoic sources and was not deposited before $1690 \mathrm{Ma}$.

The San Ignacio Group has been better studied than the other Precambrian units due to its metallogenetic potential. The Puquio Norte gold mine, for example, has been described as an exhalative-sedimentary (SEDEX) deposit associated with gold-chert in BIFs of oxides, sulfides and carbonates phases assigned to the local Naranjal Group, metamorphosed at the greenschist to amphibolite facies. Chert, serpentinite and amphibolites also occur $30 \mathrm{~km}$ southeastern of San Ramón (R. Matos; GEOBOL, open file report 1995), and may be therefore assigned to the Naranjal unit as well. At regional scale, the recognized gold mineralizations have been interpreted as genetically related with oceanic volcanism accompanying deposition of the San Ignacio Group (Pinto-Vasquez, 2001).

Metavolcanic rocks were also described by Biste and Gourlay (2000) at the Ascensión de Guarayos, at the western border of the Precambrian shield of Bolivia (Fig. 3), where amphibolite grade volcanogenic massive sulfide body occurs. Discontinuous outcrops of serpertinites indicate that the metavolcanic sequence probably extends $40 \mathrm{~km}$ south of Guarayos (Fletcher, 1979). In sum, these occurrences of metavolcanic rocks, interlayered 
$\mathrm{BIF}$, and schists may represent a single unit at least 250 to $300 \mathrm{~km}$ long and 60 to $85 \mathrm{~km}$ wide (from the north of Ascensión de Guarayos to Lomerío), genetically related to a magmatic arc (Fig. 3).

\subsection{The Lomas Manechis Suite}

Granitoid sills were called by Boger et al. (2005) Lomas Manechis suite. One of these sills at the east of San Rafael (an orthopyroxene bearing granitoid rock), contains zircon cores that yielded a weighted mean ${ }^{207} \mathrm{~Pb} /{ }^{206} \mathrm{~Pb}$ SHRIMP zircon age of $1663 \pm 13 \mathrm{Ma}$, inferred as the rock emplacement age. Additional analyses of the zircon rims yielded an age of $1320 \pm 11 \mathrm{Ma}$, interpreted as the time of partial melting, and reinforcing the important role of the San Ignacio overprinting event (see above). South from San Rafael, a hornblendebiotite granitoid rock yielded a concordant ${ }^{207} \mathrm{~Pb} /{ }^{206} \mathrm{~Pb}$ zircon SHRIMP zircon age of $1689 \pm 5$ Ma (Table 2).

Santos et al. (2006; 2008) reported additional SHRIMP U-Pb ages in zircon, monazite and titanite from granitoid rocks near San Javier (Table 1): one of these, the Refugio granite, has zircons with no metamorphic rim, and yielded $a^{207} \mathrm{~Pb} /{ }^{206} \mathrm{~Pb}$ age of $1641 \pm 4 \mathrm{Ma}$ and $\mathrm{Sm}$ $\mathrm{Nd} \mathrm{T}_{\mathrm{DM}}$ model age of $1.66 \mathrm{Ga}\left(\varepsilon_{\mathrm{Nd}(\mathrm{t})}=+4.06\right)$. On the other hand the Refugio granite (according to Fletcher, 1979) exhibits tectonic contacts along the eastern and western sides, while on its northern border it is intrusive into the San Ignacio Schist Group. Similar crosscutting relationships with these schists are reported for the La Cruz granite in the San Ramón area (see discussion afterwards; Table 2). From the above, the Lomas Manechis suite is significantly younger than Chiquitania and San Ignacio Group, as well as some of the granulites assigned as the proper Lomas Manechis Complex.

\subsection{The San Ramon granite}

This granite represents an important rock generation event about $1430 \mathrm{Ma}$ in the Precámbrian shield of Bolivia that could be confirmed in the future associated to others plutons in the area. The San Ramón granite is an intrusive body of ca. $35 \mathrm{~km} 2$, and host shear zones following NNW direction. This pluton (Santos et al., 2008) (Table 1), yielded similar zircon and titanite SHRIMP U/Pb age of $1429 \pm 4 \mathrm{Ma}$ and TDM age of $1.6 \mathrm{Ga}\left(\varepsilon_{\mathrm{Nd}(\mathrm{t})}=\right.$ +2.3 ), establishing therefore a distinct igneous episode within the PGC. O. Santos (verbal communication) obteined $\mathrm{Hf}$ isotope analysis from this granite yielding a model age of $1.7 \mathrm{Ga}$ and a $\varepsilon \mathrm{Hf}$ between +3.49 and +5.47 . This implies that the juvenile accretion event was mainly from a Mesoproterozoic mantle source, as similar as several recognized arc magmatic pulses in the Brazilian counterpart, such as the Santa Helena, Rio Branco and Rio Crespo suites (Payolla et al., 2002; Geraldes et al., 2001; Cordani and Teixeira, 2007). 


\subsection{The San Ignacio Granitoid Complex}

Much of the San Ignacio granitoid rocks make up the bulk of the Pensamiento Granitoid Complex (PGC) at the Paragua block (Litherland et al., 1986), while to the south and southwest part of the Bolivian shield, coeval granitic bodies are intrusive into the Chiquitania Complex, the San Ignacio Schist Group and the Lomas Manechis Complex (see above). The PGC and the coeval plutons are composed of two major regional units tectonically related with the so-called San Ignacio orogeny: syn- to late-kinematic and late- to post-kinematic granitoid rocks Litherland et al. (1986); Matos et al. (2009). Preliminary Rb/Sr whole rock isochrones for these intrusive plutons yielded ages between 1391 to $1244 \mathrm{Ma}$ (e.g., Florida, San Cristobal, and Padre Eterno granites), as reported by Litherland et al. (1986) and confirmed by K/Ar geochronology referred to the uplift and regional cooling of the Paraguá craton. The Do3, the major penetrative event in the area related to the San Ignacio orogeny, accompanies generation of the bulk syn-kinematic granitoid plutons. Some of the late- to post-kinematic granitoid plutons postdate Do3 phase and were emplaced following a markedly NNW trend. Darbyshire (2000) first reported the Sm-Nd characteristics for PGC rocks. The syn- to late- kinematic Puerto Alegre/La Junta granites display roughly comparable $\mathrm{T}_{\mathrm{DM}}$ model ages of 1.99 and $2.09 \mathrm{Ga}$ and $\varepsilon_{\mathrm{Nd}(\mathrm{T})}$ values of -1.5 and -2.8 respectively (personal communication) . In contrast, the Piso Firme Granophyre (Rb/Sr whole rock isochron age of $\sim 1325 \mathrm{Ma}$;Litherland et al.,1986), yields significant younger $\mathrm{T}_{\mathrm{DM}}$ model ages $(1.51$ and $1.57 \mathrm{Ga})$, and positive $\varepsilon_{\mathrm{Nd}(\mathrm{T})}$ values $(+3.3$ to +3.9$)$. In a similar way the contemporary late- to post-kinematic Diamantina and Orobayaya granites yielded positive $\varepsilon_{\mathrm{Nd}(\mathrm{T})}$ values $(+1.0$ to +1.4$)$ and $\mathrm{T}_{\mathrm{DM}}$ model ages of 1.69 and $1.73 \mathrm{Ga}$.

\subsubsection{The La Junta and San Martín granites}

According to Matos et al. (2009) the syn- to late-kinematic La Junta pluton, crops out on the southern part of PGC and is constituted by gneisses of monzogranite to syenogranite composition with biotite as the principal and subordinate hornblende mafic minerals, with titanite as the characteristic accessory phase. Its texture is porphyritic and is medium to coarse grained. The San Martín pluton occupy the western part of the PGC; this body has a syenogranite composition, exhibits a granular texture with biotite and hornblende defining a weak foliation. The San Martín and La Junta granites show SiO2 contents from 69 to 77 wt\%. The major oxides display decreasing $\mathrm{Al} 2 \mathrm{O} 3, \mathrm{MgO}, \mathrm{CaO}$ and $\mathrm{Fe} 2 \mathrm{O} 3 \mathrm{~T}$ ot with increasing $\mathrm{SiO} 2$. They are high- $\mathrm{K}$ and calc-alkaline, moderately fractioned in terms of LREE/HREE with a slightly negative Eu anomaly. They show negative peaks of $\mathrm{Sr}, \mathrm{P}$ and $\mathrm{Ti}$ with the typical pattern of Andean-type igneous rock. The San Martin and La Junta samples yield calculated ${ }^{87} \mathrm{Sr}^{86} \mathrm{Sr}_{i}$ ratios from 0.7039 to 0.7061 ; these plutons yielded "normal" crustal differentiation $f_{\mathrm{Sm} / \mathrm{Nd}}$ ratios of -0.28 to -0.50 . The $\mathrm{T}_{\mathrm{DM}}$ model ages is of 1.7 and $2.0 \mathrm{Ga}$, respectively (Table 
2). The $\varepsilon_{\mathrm{Nd}(1.33 \mathrm{Ga})}$ value for the San Martin Granite is +1.8 whereas the La Junta Granite shows a contrasting source given by the negative values between -2.9 to -4.3 .

\subsubsection{The Porvenir and San Cristobal granites and the Piso Firme granophyre}

These late- to post- kinematic bodies crop out in the northern part of the PGC. The Porvenir is a hornblende syenogranite to monzogranite. The San Cristobal pluton corresponds to a biotitic monzogranite. These three plutons display negative correlations for $\mathrm{Al} 2 \mathrm{O} 3, \mathrm{MgO}, \mathrm{CaO}$ and $\mathrm{Fe} 2 \mathrm{O} 3 \mathrm{~T}$ ot with increasing $\mathrm{SiO} 2$ contents and a positive correlation to the Na2O. They have narrow range in $\mathrm{SiO} 2$ contents (74 to $76 \%$ ) and plot in the high-K field. The Piso Firme granophyre and San Cristobal have metaluminous composition and the Porvenir shows a peraluminous composition. All three bodies show low REE fractionation and a subhorizontal tendency of HREE with negative Eu anomaly and show deeper negative peaks of Sr, P and Ti (Matos et al., 2009). The San Cristobal, Porvenir and Piso Firme plutons show a larger variation in ${ }^{87} \mathrm{Sr}^{86} \mathrm{Sr}_{\mathrm{t}}$ ratios from 0.7017 to 0.7066 . The $f_{\mathrm{Sm} / \mathrm{Nd}}$ ratios between -0.31 and-0.25, $\mathrm{T}_{\mathrm{DM}}$ model ages from 1.58 to $1.74 \mathrm{Ga}$, and positive $\varepsilon_{\mathrm{Nd}(1.33 \mathrm{Ga})}$ values of +2.7 to +1.5 (Table 2). This reinforces the important role of Mesoproterozoic mantle source in the magma genesis of these rocks.

\subsubsection{The Diamantina granite}

This intrusive body has a subcircular or elongate shape of $53 \mathrm{~km}$ long (Klinck and O'Connor, 1982), and crops out on the middle of the PGC, close to the road to Piso Firme village. This rock is a biotite syenogranite massive to moderately foliated with equigranular anhedral to subhedral texture. In thin section the K-feldspar is microperthite and contains patches of plagioclase intergrowth with vermicular quartz. This body shows $\mathrm{SiO}_{2}$ content that ranges from 72 to $75 \mathrm{wt} \%$, and is placed on the peraluminous composition. In the REE patterns two different signatures can be distinguished: $l$ ) show steep patterns of LREE and depletion in HREE, probably reflecting amphibole fractionation and/or allanite. ii) shows "gull wingshaped" REE patterns with moderate negative Eu anomaly, typical of differentiated granites. In the multielement diagrams, the negative peaks of $\mathrm{Sr}, \mathrm{P}$, and $\mathrm{Ti}$ can be interpreted as fractionation of mica, feldspar, apatite, and Ti phases. The Sm-Nd data of Diamantina Granite displays $\mathrm{T}_{\mathrm{DM}}$ model ages between 1.65 and $1.92 \mathrm{Ga}\left(f_{\mathrm{Sm} / \mathrm{Nd}}\right.$ ratios between -0.50 and -0.25), and $\varepsilon_{\mathrm{Nd}(1.33 \mathrm{Ga})}$ values from +0.4 to -1.2 ; the Diamantina granite displays a characteristic crustal mixing nature (Matos et al., 2009).

\subsubsection{The San Rafael granite}

This pluton occur between the road of San Rafael and San Miguel and it is characterized by pavement outcrops. The rock is a biotite-muscovite metagranite, medium 
grained and moderately foliated orthogneiss; in places it is a feldspar augen gneiss. Under the microscope this body shows a hypidiomorphic texture. The principal accessories are the zircon sphene and Fe-opaques (Litherland, 1979). Boger et al. (2005) reported a SHRIMP $\mathrm{U} / \mathrm{Pb}$ age of $1334 \pm 12 \mathrm{Ma}$ for the syn-kinematic San Rafael granite, interpreted as the emplacement age. In addition, five zircon cores from this granite yielded an upper intercept age of $1686 \pm 16 \mathrm{Ma}$, suggesting the derivation from a Paleo-Mesoproterozoic protolith likewise suggested by the Nd signatures reported for some PGC rocks by Darbyshire (2000).

\subsubsection{The Santa Rita and Rio Fortuna orthogneiss}

Santos et al. (2008) sampled the Santa Rita orthogneiss of granodioritic composition $34 \mathrm{~km}$ northeastern of San Ignacio. This rock probably correspond to the Espíritu metagranite that occur in this part as small out crops of homogeneous, medium-grained composed by quartz, microcline perthite, oligoclase and straw-coloured biotite (Litherland, 1979). Following Santos et al. (2008) this rock has magmatic zircons with SHRIMP U/Pb age of $1319 \pm 6 \mathrm{Ma}$, whereas one inherited grain gives $1674 \pm 21 \mathrm{Ma}$ (see Table 2). In addition, the Rio Fortuna orthogneiss, eastern of San Ignacio. It is a dark gray, granodioritic to tonalitic composition and has two zircon populations. The first one, magmatic zircon and rim formed at $1336 \pm 3 \mathrm{Ma}$, and the second one, inherited grains and cores at $1753 \pm 10 \mathrm{Ma}$.

\subsubsection{Talcoso granite}

This pluton is exposed $18 \mathrm{~km}$ north of San Javier, it is characterized by the rounded form with its diameter of $13 \mathrm{~km}$ long. On colour composite imagery the granitoid show clear contacts with the host rock. Fletcher (1976) considered this body composed of quartz monzonite to granite and distinguished two phases, the first one occupy a band at the eastern side of the pluton and two portions in the western side. The second phase is more developed in the central part. There is not evidence of hydrothermal activity around the body and no metamorphic aureole have been observed. Litherland et al. (1986) reported a sample of pegmatite cutting the Talcoso granite yielding $\mathrm{K}-\mathrm{Ar}$ age of $986 \pm 27 \mathrm{Ma}$.

\subsubsection{Limonal granite}

The San Antonio de Lomerío area, localized to the southeastern of San Ramón, is characterized by two types of granites: Santa Rosario and Limonal (Fletcher, 1979), both groups hosted by the La Bella Group (a local name of the SISG). Whereas the first one resulted by interference model the second forms irregular bodies. Seven bodies form the Limonal granitoids, they are porfiroblastic leucosyenogranites, medium to coarse-grained. The K-feldspar is a microcline-perthite that forms scattered porphyroblast to subporphyroblast of about $2-3 \mathrm{~cm}$. The biotite is the principal mafic mineral $(3 \%)$, 
accompanied by muscovite (3\%). A foliation is commonly developed around the bodies containing ovoid patches of weakly deformed material. Some exposures of garnet bearing pegmatoids have been noted in a phase of this granite (Fletcher, 1979).

\subsubsection{Cachuela granite}

This intrusive body outcrops $22 \mathrm{~km}$ east of San Ramón, is a subcircular unit of $7 \mathrm{~km}$ long and it forms extensive rounded blocks and pavements. On the color composite image of airborne radiometric and magnetic data of the San Ramón area (Adamek et al., 1996) shows clear expression contacts, hosted by the San Ignacio Schist Group. The rock is pale pink medium to coarse-grained containing scattered K-feldspar megacrysts around 1 to $2 \mathrm{~cm}$ long. Under the microscope, this intrusive shows two generation of quartz, K-feldspar and plagioclase: major and minor components, both of them show an anhedral granular texture. The mafic scarce mineral is the green biotite with chlorite growing from biotite. TIMS analysis of multigrain fraction zircons from six points ploted in the Concordia diagram yielded upper intercept age of $1307.3 \pm 6.6 \mathrm{Ma}$. Two concordant points yielded $207 \mathrm{~Pb} / 206 \mathrm{~Pb}$ age of 1309.5 Ma $(0.52 \%$ of discordance) and $1310.9 \mathrm{Ma}(-0.76 \%$ of discordance) Vargas-Mattos et al., 2008.

\subsubsection{San Andrés granite}

Santos et al. (2008), sampled the San Andrés granite west of Concepción on the road to San Javier. This body is one of the most developed in the area and follow an NNW trend; the rock is pale gray, coarse- grained leucocratic biotite granite with an inequigranular anhedral to subhedral texture. The outcrops form big exposures of rounded blocks; in places contains scattered K-feldspar megacrysts. Typically this body has a massive appearance forming an ovoid patch of weakly deformed material surrounded by strongly deformed rock due to Sunsás deformation and constituting a K- feldspar augen gneiss ( $R$. Matos, verbal communication). This post-kinematic body could be considered the last pulse of the San Ignacio orogeny and yielded a SHRIMP U/Pb age of $1275 \pm 7$ Ma (Table 1), coeval with the Passagem granite of 1291 \pm 2 Ma in Mato Grosso (Jesus et al., 2010).

\section{Analytical methods}

Zircon crystals were dated by U-Pb SHRIMP, TIMS and LA-MC-ICP-MS methods; the zircon grains were separated using conventional heavy liquid and magnetic techniques. The La Junta (sample LJ20512) and San Martín (CA0509), Diamantina (CP30507), La Cruz (LC0558) and San Andrés (SA0404) granites were dated by U-Pb SHRIMP. Representative 
zircon grains were handpicked under binocular microscope and mounted in epoxy resin disc, and then polished and coated with gold film. Zircons were documented with transmitted and reflected light images as well as cathodoluminescence $(C L)$ images to reveal their external and internal structures. The U-Pb isotopic analyses were performed using the Sensitive High-Resolution Ion Microprobe (SHRIMP-II) at the Chinese Academy of Geological Sciences (Beijing). Data were plotted on Concordia diagram using isoplot excel software (Ludwig, 2003). Details of the analytical procedures of zircons using SHRIMP were described by Compston et al. (1992). Inter-element fractionation ion emission of zircon was corrected relative to the RSES reference TEMORA 1 (417 Ma; Black et al., 2003). The uncertainties in ages are cited as $1 \sigma$ and the weighted mean ages are quoted at the $95 \%$ confidence level $(2 \sigma)$. All ages described on the text are weighted mean 207Pb/206Pb ages (Table 3).

The Refugio (sample SR83) and Las Maras (sample LM81) granites were analyzed by U-Pb TIMS methodology following procedures outlined in Parrish et al. (1987). Prior to dissolution zircon fractions were strongly abraded to remove outer rims and minimize the effects of peripheral lead loss and individual grains carefully selected. Zircons were dissolved and $\mathrm{Pb}$ and $U$ were separated using procedures following Basei et al. (1995) adapted of Krogh (1982). All samples were total- spiked with a mixed $205 \mathrm{~Pb} / 235 \mathrm{U}$ tracer solution. The U/Pb isotopic analyses were done in a multi-collector ion counting Finnigan MAT-262 mass spectrometer at the Geochronological Research Center (CPGeo) of the Instituto de Geociências at the University of Sao Paulo. The isotopic data are presented in Table 3. Zircon data were calculated using the Microsoft Excel version of Isoplot (Ludwig, 2003). Age uncertainties in the table, Concordia plots and text are presented at the $95 \%$ confidence level.

U-Pb LA-MC-ICP-MS were performed for the San Pablo (sample SP0601), Talcoso (sample BO418) and Limonal (sample MT544) granites. Selected grains were placed on epoxy mounts, polished and cleaned with $3 \%$ nitric acid before analysis. Backscattering electrons (BSE) images were used for spot targeting. BSE images were acquired with a JEOL 5510 scanning electron microscope at the Department of Geology of the Federal University of Ouro Preto, Brazil. The U-Pb analyses were performed on zircon grains using a Neptune MC-ICP-MS coupled with a Nd:YAG UP213 New Wave laser ablation system, installed in the Laboratory of Geochronology of the University of Brasilia. The U-Pb analyses on zircon grains were carried out using the standard-sample bracketing method using the GJ-1 standard zircon in order to control the ICP-MS fractionation. Two to four samples have been analyzed between GJ-1 standard analysis and ${ }^{206} \mathrm{~Pb} /{ }^{207} \mathrm{~Pb}$ and ${ }^{206} \mathrm{~Pb} /{ }^{238} \mathrm{U}$ ratio have been time corrected. When possible, on larger zircon grains, laser induced $\mathrm{U}$ and $\mathrm{Pb}$ fractionation 
was minimized using raster laser ablation with a spot size of $30 \mu \mathrm{m}$. On smaller zircon grains single spot laser induced fractionation the ${ }^{206} \mathrm{~Pb} /{ }^{238} \mathrm{U}$ ratio was recalculated using the linear regression method (Kosler et al., 2001). The raw data processed off-line and reduced using an Excel worksheet (Buhn et al., 2008).During analytical session zircon standard Temora-2 has been analyzed as an unknown sample. Common lead $\left({ }^{204} \mathrm{~Pb}\right)$ interference- and background correction is normally carried out monitoring the ${ }^{202} \mathrm{Hg}$ and $\left({ }^{204} \mathrm{Hg}+{ }^{204} \mathrm{~Pb}\right)$ masses during analytical sessions and using a model Pb composition (Stacey and Kramer, 1975).

The Table 4 shows the samples that were analyzed by Sm-Nd whole-rock technique at the Geochronological Research Center (CPGeo) of the IGc-USP. Approximately $0.1 \mathrm{mg}$ of powdered rock sample was dissolved in concentrated $\mathrm{HNO}_{3}, \mathrm{HF}$ and $\mathrm{HCl}$. The $\mathrm{Sm}$ and $\mathrm{Nd}$ concentrations were determined by isotope dilution with a combined spike tracer, using the two-column technique, as described by Sato et al. (1995). The isotope ratios were measured on VG-354 multi-collector mass spectrometer. Laboratory blanks for the chemical procedure, during the period of analyses, yielded maximum values of $0.4 \mathrm{ng}$ for $\mathrm{Nd}$ and $0.7 \mathrm{ng}$ for Sm. The average ${ }^{143} \mathrm{Nd} /{ }^{144} \mathrm{Nd}$ for La Jolla standard was 0.511857 (46 analyses), with $2 \sigma$ standard deviations reported in parentheses. The $\mathrm{Sm}-\mathrm{Nd} \mathrm{T}_{\mathrm{DM}}$ model ages were calculated using DePaolo (1981) model parameters: $a=0.25, b=3, c=8.5$ as well as ${ }^{143} \mathrm{Nd} /{ }^{144} \mathrm{Nd}=0.7219$ to normalize the isotope ratios $\left[{ }^{143} \mathrm{Nd} /{ }^{144} \mathrm{Nd}(\mathrm{CHUR})_{0}=0.512638\right.$ and ${ }^{147} \mathrm{Sm} /{ }^{144} \mathrm{Nd}(\mathrm{CHUR})_{0}=$ $0.1967]$. The $\varepsilon_{N d}$ values were calculated using the simplified equation $\varepsilon_{N d(T)}=\varepsilon_{N d(0)}-Q_{N d} f_{S m / N d}$ $T$, with the $(\mathrm{CHUR})_{0}$ values above and $Q_{N d}=25.09$. The $\varepsilon_{N d}$ values for the $P G C$ samples were recalculated for the SHRIMP U-Pb age of $1.33 \mathrm{Ga}$, reported by Boger et al (2005). Table 4 presents the analytical data.

\section{Results}

\subsection{Yarituses suite}

The U-Pb geochronological SHRIMP, TIMS and laser ablation-ICP-MS from this study document Paleoproterozoic crust formation in the form of $1673 \mathrm{Ma}$ to $1621 \mathrm{Ma}$ of this granitic suite (after the Yarituses tribe that occupies the San Javier area where this suite crop out). The data shows that these granites not only are granitic sills as mencioned by Boger et al (2005), instead they represent a large portion of plutons in the Precambrian shield of Bolivia. This fact induce as to introduce the Yarituses suite as a new discovery instead of the Lomas Manechis suite of Boger et al. (2005), and maintain the Lomas Manechis Granulite Complex of Litherland as structurally the lowest and older unit as determined by Santos et al. (2008) for the granulite gneiss of $1818 \pm 13 \mathrm{Ma}$ in the area of San Matías. The Yarituses suite just to now comprises the La Cruz granite, Refugio granite and San Pablo Granite. 


\subsubsection{La Cruz granite.}

This pluton crops out $15 \mathrm{~km}$ to the northeast of San Ramón, and constitutes two individual bodies hosted by the San Ignacio Schist Group (Fig. 3). As a whole it shows clearly contacts with the hosted San Ignacio Schist Group as can be seen in color composite satellite imagery and presents a roughly sigmoidal-shape showing the typical deformation trend of the Sunsás orogeny. The La Cruz intrusion (sample LC0558) is a pale pink leucocratic syenogranite with scarce biotite as the mafic mineral. The dominant texture is allotriomorphic granular. From the principal minerals the K-feldspar is characterized by a abundant flamelike or braided pattern perthite.

Zircons from the La Cruz granite are between 100-220 $\mu \mathrm{m}$ long and generally have ratios close to $2: 1$. The $U$ content of zircon is variable from 138 to $932 \mathrm{ppm}$, only one grain contains $3134 \mathrm{ppm}$. The Th/U ratios vary between 0.27 and 0.92 (Table 3), suggesting a magmatic origin. The cathodoluminescent images show that most of the crystals are euhedral and have both parallel-faces zoning and distinct concentric growth. SHRIMP analysis of eight zircon grains (Table 3), and five cores lie on the Concordia with a weighted mean 207Pb/206Pb age of $1673 \pm 21 \mathrm{Ma}(\mathrm{MSWD}=1.6$ ) (Fig. 4a and 4b), considered as the emplacement. This age compares within error with two ages obtained by Boger et al. (2005) and one by Santos et al. (2008) for the Lomas Manechis rocks in the range of 1689 to1663 Ma. The Sm-Nd whole rock analyses for the La Cruz granite yielded crustal differentiation $f_{\mathrm{Sm} / \mathrm{Nd}}$ ratio of -0.42 . Their $\mathrm{T}_{\mathrm{DM}}$ model ages are $1.83 \mathrm{Ga}$ (Table 4). The $\varepsilon_{\mathrm{Nd}(1.67 \mathrm{Ga})}$ value for this body is +2.1 .

\subsubsection{Refugio granite}

The Refugio granite is a large body that crops out on the northern side of the road San Javier - Concepción (Fig. 3). We have sampled this granite in two places: sample RF0408 and SR83. The first one was sampled $17 \mathrm{~km}$. eastern of San Javier on the road to Concepción. It was sampled by $\mathrm{Sm}-\mathrm{Nd}$ that will be discussed later. The rock is a syenogranite, weakly foliated, with hipidiomorfic-granular texture; the plagioclase tend to be euhedral, while the alkali feldspar is subhedral and quartz occupies irregular interspaces. Locally is observed a fine grained matrix of irregular patches of granulated quartz-feldspar material. The mafic mineral is the green biotite seldom cloritized. The SR83 was sampled at $8 \mathrm{~km}$ eastern of San Javier on the road to Talcoso hill. This rock is a leucogranite, white in color, masive to weakly foliated. The K-feldspar is the microcline and subordinately appears the orthoclase, the plagioclase tend to be euhedral. Both of them contain disseminated sericite-epidote alteration. The mafic mineral is the biotite scarcely distributed in the rock $(<2 \%)$; the principal accessory is the brown granular sphene. Zircon mostly occurs as colourless elongate prisms, light brown stubby grains are also present. Core and oscillatory were observed in a number of grains by transmitted - light microscopy. TIMS analyses of four multigrain fractions yield 
three concordant points and one discordant point (Fig 4c) with $207 \mathrm{~Pb} / 206 \mathrm{~Pb}$ age of $1673 \pm$ $25 \mathrm{Ma}$, a MSWD of 36 taken as the best estimate for the time of crystallization of the pluton.

\subsubsection{San Pablo granite}

This body has $11 \mathrm{~km}$ long by $4 \mathrm{~km}$ wide and is exposed $25 \mathrm{~km}$ southern of San Antonio de Lomerío (Fig. 3). It is oriented WNW parallel to the San Diablo lineament and consequently the granite has been sheared; the rock is pink in color, fine to medium-grained and composed by a biotite quartz monzonite. In thin section the rock has an anhedral-granular texture. The plagioclase shows curved twins. Both K-feldspar and plagioclase show altered surfaces. The quartz is anhedral, occupying irregular spaces between the other constituents. The mafic mineral is the biotite, straw to green in color and often it carries dusty inclusions of iron ore. The rock has been crushed and it contains bands of finely comminuted material around the felsic grains. Zircons from the San Pablo quartz monzonite (sample SP0601) appear to be colorless, transparent, with well crystallized prismatic form. Rhyme zoning, manifested by the CL images, indicates their magmatic origin. The analytical results are listed in Table 3. The all data combined yield an average age of $1621 \pm 80 \mathrm{Ma}(2 \sigma)$ (Fig. $4 \mathrm{~d}$ ).

Insert the Fig. 4 here

\subsection{San Ramón granite}

This pluton crop out at San Ramón town (Fig.3). Contact relations with the Chiquitania Gneiss Complex are largely masked by Cenozoic sediments; it probably extends farther west, but the limits are still unknown. The sample SR0401 of this body is gray in color, composed of biotite gronodiorite with anhedral granular texture, where the mafic minerals in aggregates show an irregular distribution; the characteristic accesory minerals are titanite, allanite and zircon. The San Ramón granite has been sampled by Sm-Nd ( see below).

\subsection{San Ignacio granitoid rocks (SIG)}

The SHRIMP U-Pb age determinations in zircon grains were performed in the San Martín, La Junta, Diamantina and San Andrés granites.

\subsubsection{San Martín granite}

This pluton is one of largest syn- to late-kinematic intrusions of the PGC and it crops out on the western side of PGC (Fig. 3). This weakly foliated granite has a granular appearance with biotite flakes and prismatic hornblende. The K- feldspar forms scattered phenocrysts from 1.5 to $3 \mathrm{~cm}$ long. In places a lens or augen-texture is developed. On the western side of the batholiths the mineral assemblage reached the medium metamorphic 
grade conditions (Klinck and O'Connor, 1982). The analyzed zircon grains are commonly between 150 to $275 \mu \mathrm{m}$ and mostly euhedral with ratios of 3-4:1. The $U$ content is variable, from 160 to $2700 \mathrm{ppm}$. The Th/U ratios are between $0.24-0.47$, but three of the analyses showed $\mathrm{Th} / \mathrm{U}$ ratios as low as $0.02-0.04$. The most common zircon morphology shows oscillatory zoning in the cathodoluminescent $(\mathrm{CL})$ imagery. However, some grains present a moderately gray-CL core (Table 3).

Ten analyses from various sites within different zircon grains from the two main populations were obtained (Table 3). Six magmatic cores yielded a ${ }^{207} \mathrm{~Pb} /{ }^{206} \mathrm{~Pb}$ age of $1373 \pm 20 \mathrm{Ma}(\mathrm{MSWD}=0.83$ ) whereas three metamorphic rims yielded $1318 \pm 14 \mathrm{Ma}$ (MSWD =1.4) (Fig. 5a). Fig. 5b Given the concentrically zoned structure of the zircons of the first population, we interpret the upper intercept age obtained from the core analyses as the emplacement age of the San Martin granite, in agreement therefore with the the synkinematic phase of the San Ignacio Orogeny. The metamorphic rims are interpreted as highgrade metamorphism formed during the collision of San Ignacio orogeny against the Rio Negro-Juruena Province, as an extrapolation with comparable U/Pb data available for the Colorado Complex in Rondonia.

\subsubsection{La Junta granite}

This is one of the syn- to late-kinematic granitoids of the San Ignacio Orogeny. The body is exposed as sprinkled outcrops on the southern part of PGC (Fig. 3), and may become gneissic with a well developed planar tectonic fabric (Hawkins, 1982). However, the La Junta granite, for the most part shows a transition from saturated monzogranites to more differentiated syenogranites (Matos et al., 2009). The rocks are pinkish-grey in color, medium to coarse-grained, and show inequigranular subhedral to anhedral texture. The main mineral constituents are a porphyroblastic alkali feldspar and string perthitic microcline.aligned with the the biotite foliation. Prismatic hornblende is associated to quartz and plagioclase with myrmekitic intergrowth.

$\mathrm{U}-\mathrm{Pb}$ data from the La Junta Granite (sample LJ0512) was collected following the road to Campamento (Fig. 3). Zircons from this sample are from 165 to $235 \mu \mathrm{m}$ and commonly show well-formed euhedral terminations. The cathodoluminescent images the crystals generally have cores with gray light oscillatory zoning, surrounded by thin mantles of low-CL zircon. The low-CL rims show subtle concentric zoning, not developed in the cores. Some grains are gray dark due the high $U$ content. Seven analyses of zircon grains performed in this sample. The zircon cores are characterized by $U$ concentrations of 168 to 542 but one grain exceptionally has $3154 \mathrm{ppm}$. The Th/U ratios vary between 0.18 and 0.77 , only one grain has 
a value of 0.06 (Table 3). From five core analyses, an upper intercept $207 \mathrm{~Pb} / 206 \mathrm{~Pb}$ age of $1347 \pm 21 \mathrm{Ma}(\mathrm{MSWD}=4.5$ ) was obtained (Fig. 5c) and constrains the age of emplacement. Grain 512.3 (Fig. 5.d) shows an inherited minimum age of $1486 \pm 18 \mathrm{Ma}$.

\subsubsection{Diamantina granite}

This intrusion in contrast to the two bodies described above, represents the late- to postkinematic granites of the San Ignacio Orogeny. This pluton makes up a north trending hill, forming an elliptical body about $53 \mathrm{~km}$ long (Klinck and O'Connor, 1982) and crops out as an "island" in the forest. The subcircular or elongate shape of the granitoid body is based on field relationship and it can not be seen on the color satellite imagery. The dominant rock type is a pale pink and non foliated biotitic syenogranite. This rock is a light-grey, weathering greyish-orange-pink in color, medium- to coarse-grained. Chemically the western side of the Diamantine granite is composed of tonalite and syenogranites but all bulk of the samples are monzogranites (Matos et al., 2009). One syenogranite sample (CP0507) was sampled at Cerro Pelado Hill. The zircons are between 160-270 $\mu \mathrm{m}$ long and some grains have ratios about $4: 1$. In this sample, the $U$ content is variable, from 140 to $683 \mathrm{ppm}$, while $\mathrm{Th} / \mathrm{U}$ ratios vary between 0.07 and 1.07 suggesting a magmatic origin. Two grains are metamorphic, containing $U$ content of 2377 and 2753 ppm (Table 3). Cathodoluminescent images of these zircons show that all grains have distinct concentric growth zoning which is often truncated by the margins of the zircon grains. The concentric growth is interpreted to represent zircon growth at the time of emplacement of the granite. From six analyses on five zircons an upper intercept yield a weighted mean 207Pb/206Pb age of 1340 $220 \mathrm{Ma}(\mathrm{MSWD}=4.1)(\mathrm{Fig} .5 \mathrm{e})$.

\subsubsection{Las Maras granite}

The granitoid forms a near rectangular body exposed $9 \mathrm{~km}$ NW of San Javier, with its long axis of $5 \mathrm{~km}$ oriented $\mathrm{N}$. The wide in an $\mathrm{E}-\mathrm{W}$ direction is of $2,5 \mathrm{~km}$. On the color composite image of airborne radiometric and magnetic data of the San Ramón area (Adamek et al., 1996) has a marked expression hosted in the SISG. The characteristic rock is a light pink, weathering orange, coarse grained monzogranite. Pinkish gray- feldspar locally forms phenocryst up to $1,5 \mathrm{~cm}$. long and the biotite occurs as scarce flakes. To the $\mathrm{S}$, the Las Maras granite is hosted by a turbidity metasedimentary rock characterized by the graded beds, but the contacts are not exposed. To the $\mathrm{N}$ of the body the hosted rock is a crenulated muscovite schist. Petrographic analyses show a hipidiomorphic texture, The K-feldspar forms large anhedral crystals, the plagioclase is subhedral; both of them contain rectangular flakes of muscovite and the quartz in minor size occupies irregular interspaces. The mafic mineral is the straw green biotite scarcely distributed in the rock $(<2 \%)$. Zircon shows prismatic elongate morphology. Some Core - overgrowth relationships have been observed by 
transmitted - light microscopy. U -Pb TIMS analysis (Table 3 ) of four multigram fractions yield four concordant points (Fig. 5f), with 207Pb/206Pb of 1346.8 $\pm 9.3 \mathrm{Ma}$ with a MSWD of 8.3. Taking into account field relationships with de SISG (ca $1.7 \mathrm{Ga}$ ) and an age comparable to the Diamantina granite $(1340+-21 \mathrm{Ma}$ by U-Pb SHRIMP) this granite is post-kinematic to the SIO.

\subsubsection{Talcoso granite}

This rounded body has a massive and coarse- grained character. The foliation in the host rock follow a NW trend as is seen on the satelite imagery at the northeastern side of the pluton. On the composite colour image of the airborne radiometric and magnetic data (Adamek et al., 1996) this pluton show S-C sinistral structure produced by the Sunsas orogeny that reimprinted the San Ignacio orogeny. In thin section the intrusive shows two generation of quartz microcline perthite and plagioclase: major and minor components. The major crystals consist of subhedral granular texture and the minor crystals form mosaic of anhedral fine grained texture between the grains boundaries. This second generation can be attributed to the granulation of the rock due to the Sunsas orogeny. The k-feldespar appears as perthite microcline with grain boundary embayed by mirmequite intergrowth, the quartz show fractured grains. The mafic mineral consists of strew - green biotite accompanied by scarce muscovite, with epidote as the principal secondary mineral. On the basis of its intrusive contacts respect the hosted Naranjal Group (a local name for the San Ignacio Schist Group), that follow a NW trend of foliation, and the isotropic character of the granite in hand sample the age of this rock can be considered post -kinematic with respect to the San Ignacio orogeny. Zircons from the Talcoso granite (TL0402) appear to be colorless, transparent, well crystallized with prismatic form. The analytical results are listed in Table 3. The weighted average 207Pb/ 206Pb age yielded $1333 \pm 68$ Ma for a MSWD=75) (Fig. 5g).

\subsubsection{Limonal granite}

This pluton forms a group of bodies that crops out along a sheared narrow zone following a WNW trend formed during the Sunsas orogeny. This ductile shear zone record displacement between blocks where recognizable markers such as grain tail (we use grain in a general sense, in this case referred to large granitic body), that acted as rigid bodies. The tail of $\sigma$ type lets us determine the sinistral shear sense as is shown in Fig 6. We have sampled one body (MT0544) of the Limonal granitoids. Zircon grains are mostly colorless, transparent, well crystallized with prismatic habit. The CL images show magmatic zoning. 30 um spot sizes applied for this sample are listed in Table 3 . The weighted average 207Pb/206Pb age yielded1330 $\pm 36 \mathrm{Ma}($ MSWD $=81)$ (Fig. $5 \mathrm{i})$. 


\subsubsection{San Andrés granite}

This pluton is exposed to the western side of Concepcion (Fig. 3). The granite for the most part is heterogeneous varying from sheared feldspar-augen gneiss, migmatitic schlieren type with biotite defining short strings to a medium to coarse-grained massive rock. The color composite satellite imagery do not show contacts of this unit with other lithologies, however the composite radiometric and magnetometric image (Adamek et al 1996) shows a fish-like form (Fig. 3). Zircon grains are clear and euhedral prismatic. The crystals range from 50 to $120 \mu \mathrm{m}$ in length, with ratios of $2: 1$ to $4: 1$. The $C L$ images reveal that most grains have oscillatory zoning, indicating magmatic origin. A total of 15 analyses were performed on 14 zircons from sample SA0404. They have $U$ contents ranging from 79 to $434 \mathrm{ppm}$ and Th/Ucontents of 0.24 to 0.85 (Table 3). The data define an upper intercept 207Pb/206Pb age of $1289 \pm 19$ interpreted as a magmatic age (Fig. 5j). Furthermore, one analysis of an inherited age (grain 1.13) yield a 207Pb/206Pb age of $1616 \pm 18$ (Fig. 5k).

Fig. 5: insert here

Fig. 6: insert here

\subsection{Sm-Nd results}

. Fifty five samples of the Bolivian Precambrian shield were investigated (Table 4) following De Paolo (1981); the Nd isotopic parameter were calculated according as reference SHRIMP $\mathrm{U} / \mathrm{Pb}$ age of $1.8 \mathrm{Ga}$ for the Lomas Maneches Complex; 1.67 to 1.62 for samples of the Chiquitania Complex and Yarituses suite; the San Ramón granite was modeled according to 1.4 Ga and the San Ignacio granites following $1.33 \mathrm{Ga}$ and 1.27 for the San Andrés granite all these ages interpreted as the emplacement age respectively. The $\varepsilon_{N d}$ versus $T$ diagram is shown in Fig. 7 and Fig. 8 represents the isotopic boundaries based on the $T_{D M}$ values. One sample of the Lomas Manechis Granulite Complex yield the oldest crystallization age of 1.8 $\mathrm{Ga}$ and another sample yields the oldest model age value of $2.2 \mathrm{Ga}$. The $\varepsilon_{\mathrm{Nd}}$ range from 3.32 to -1.44 indicating mantle- derived magmas variably contaminated with

Paleoproterozoic crust in the evolution of the Lomas Maneches Complex.

The Chiquitania Gneiss Complex presents $\mathrm{T}_{\mathrm{DM}}$ model ages values of 1.6 to $1.9 \mathrm{Ga}$ and $\varepsilon_{\mathrm{Nd}}$ values from +4.2 to -0.61 ; the $f_{\mathrm{Sm} / \mathrm{Nd}}$ ratio is of -0.3 to -0.56 . The $\varepsilon_{\mathrm{Nd}}$ values represent juvenile accretion and limited contamination of the parental magma with the country rocks. The Yarituses suite contains $f_{\mathrm{Sm} / \mathrm{Nd}}$ ratio of -0.38 to $-0.56, \mathrm{~T}_{\mathrm{DM}}$ model ages of 1.7 to $1.9 \mathrm{Ga}$, and 
Further the continental substratum constituting the Paragua block in the extreme NE sector where the SISG is represented by San Simón, Dalriada and El Cielo were deformed during the San Ignacio orogeny (Fig 9). Arguably the anorogenic intrusives Remancito granitoid and Discordancia rapakivi granites (recognized in the Dalriada belt underlying Huanchaca according to Litherland, 1982) could represent the inboard manifestation of the San Ignacio collision of the Paragua Block against the RNJP, implying a within-plate origin for the Sunsás, Nova Brasilandia, and Aguapeí groups (Teixeira et al., 2010). Finally the the Rio Negro Juruena province.

Fig. 7: insert here

Fig.8: insert here

\section{Discussion and tectonic implications}

\subsection{Proterozoic tectonic history}

The Lomas Manechis and the Chiquitania complexes and the San Ignacio Schist Group constitute the Paleoproterozoic polimetamorphic basement (Fig. 9), as supported by the available U-Pb evidence shown on Fig. 3 (Boger et al., 2005; Santos et al., 2008; Matos et al., 2009). The Lomas Manechis is comparable in age and Nd signature to the Alto Guaporé Metamorphic Complex of Brazil (Bettencourt et al., 2010), although they differ in the metamorphic grade corresponding to granulites and green schist-amphibolite respectively. The western side of Paragua block, the San Ramón District preserves an island- arc tectonic setting comprising mafic ultramafic bodies, BIF and chert that are similar in the lithologies and age to the Alto Jauru Group in Mato Grosso state (Geraldes et al., 2001; Teixeira et al., 2010). This lithological association was progressively amalgamated to the evolving continental margin, revealing a large oceanic domain in this area of Bolivia at the Paleoproterozoic time.

Supported by the U-Pb and $\mathrm{Sm}-\mathrm{Nd}$ results three magmatic events mark the evolution of the Precambrian shield of Bolivia: The Yarituses suite, The San Ramón granite and the San Ignacio granites (Table 4). The San Ramón granite produced a crystallization age $1.43 \mathrm{Ga}$, $\mathrm{T}_{\mathrm{DM}}$ model ages of 1.6-1.7 and positive $\varepsilon_{\mathrm{Nd}}$ values. This granite is comparable in age to the Santa Helena orogen (1.48-1.42 Ga). In the San Ignacio granites zircon geochronology has made it possible to identify magmatic and metamorphic events and interpret inherited grains in the eastern Precambrian rocks of Bolivia. These rocks represented by syn-to latekinematic and late-to post-kinematic granitoids have magmatic age between 1.37 to 1.34 and metamorphic zircon ages from 1.32 to $1.3 \mathrm{Ga}$, therefore it is the major accretionary event in Bolivia. The protracted history of those rocks is envisaged for inherited zircon from 1.62 to $1.77 \mathrm{Ga}$, allowing to propose a crustal derivation from the Paraguá rocks (the Lomas 
Manechis and the Chiquitania complexes) as well as a tectonic correlation with the Rio Negro-Juruena and Ventuari-Tapajos province. In the southeastern of Rondônia. Contemporary orogenic and post-orogenic granites make up the bulk of the 1.36-1.30 Ga Colorado Complex (Rizzotto and Quadros 2007). San Ramón area is characterized by an oblique tectonic style produced during the Sunsás orogeny over pre-San Ignacio rocks (Fig.6), with structures similar to the Nova Brasilândia and Ji-Parana shear zones (Tohver et al., 2002; Tohver et al., 2004; Tohver et al., 2005) with sinistral shear sense (Adamek et al., 1996; Matos, 2009). Such features are collectively related to the collision between Amazonia and Laurentia during Sunsás orogeny (Teixeira et al., 2010), and implying therefore to a continuity of structures from Rondônia to Bolivia. This scenario let us to conclude that the Paraguá Block was allochthonous with respect to the Rio Negro-Juruena and it moved to the ENE and accreted during the San Ignacio orogeny.

Fig. 9: insert here

\subsection{Tectonic extrapolations:}

\subsubsection{The Cerro Uyarani}

This unit in the Western Cordillera (Volcanic arc) of Bolivia (Fig. 1) represents one of the Paleoproterozoic inliers in the Andean chain. It shows a rounded shape of $4 \mathrm{~km}$ of diameter with exposures rising up $4500 \mathrm{~m}$ above the sea level, in some places covered by tertiary tuffs. In the outcrops a medium-fine grained gneissic leptite, mafic granulites, charnockites and amphibolites predominate (Worner et al., 2000) with the foliation following the NW direction. Additionally, $150 \mathrm{~km}$ north of Uyarani a metaconglomerate was described in the Azurite Formation (Tosdal 1996) and at the Cerro Chilla (R. Matos, personal communication). All these exposures are part of the Arequipa Antofalla Block, (AAB), a Proterozoic crustal block along the Central Andean margin. Wasteneys et al. (1995) considered the $A A B$ a rifted margin of eastern Laurentia. According Tosdal (1996), the $\mathrm{Pb}$ isotopic composition of $A A B$ overlaps those of the $A C$, supporting a link between them. Loewy et al. (2004) conclude that the AAB was accreted to AC during Sunsás orogeny. Based in geotermobarometry, geochemical and petrological studies at Cerro Uyarani, Worner et al. (2000) consider it as part as of the AAB; the zircon TIMS analysis from a charnockite of Cerro Uyarani defined a discordia with an upper intercept of $2024 \pm 133 \mathrm{Ma}$ and a lower intercept of $1157 \pm 62 \mathrm{Ma}$; the ${ }^{40} \mathrm{Ar} /{ }^{39} \mathrm{Ar}$ spectrum age from amphiboles separated from an amphibolite of Cerro Uyarani defined a plateau age of $982.5 \pm 1.7 \mathrm{Ma}$ by $77.1 \%$ of the total ${ }^{39} \mathrm{Ar}$ released. A Sm-Nd isochron has been improved to get of the time of near-peak of high grade metamorphism giving an age of $1008 \pm 16 \mathrm{Ma}$ (Worner et al., 2000). 
On the basis of our new data and geologic correlations we envisage the following evolution for the Precambrian shield of Bolivia (Fig 10) on the basis of the available $\mathrm{Pb}$ isotope composition regional study (Tosdal, 1996; Worner et al., 2000) of the AAB and accepting that this Proterozoic terrane was part of the Amazonian craton (Fig 10a).

1. Rifting during break up of Amazonian Craton in the late Paleoproterozoic led to separation of $A A B$ from the AC (Paraguá Block) (Fig 10b). The boundary between the two crustal blocks constitute an ocean (here called Guarayos ocean).

2. Andean- type subduction between these two blocks originated the Yarituses suite at late Paleoproterozoic (1.7-1.6 Ga) (Fig 10c). The paleosuture of the ocean crust could be the San Ignacio Group of San Ramón area.

3. Later subduction led to the collision of the Paragua Block against RNJP during San Ignacio orogeny (1340-1320 Ma) (Fig 10d).

4. Eventually,during Sunsás orogeny occurred the collision of Laurentia against the $A C$ and the accretion of $A A B$ and the Sunsás belt against the Rondonian San Ignacio Province (Fig 10e).

Fig. 10: insert here

\section{References}

Adamek, P. M., Troeng, B., Landivar, G, Llanos, A., Matos, R., 1996. Evaluación de los recursos minerales del Distrito San Ramón. Boletín del Servicio Geológico de Bolivia No.10, 77 p., La Paz.

Bettencourt, J. S., Tosdal, R. M., Leite, W. B. JR., Payolla, B. L., 1999. Mesoproterozoic rapakivi granites of the Rondônia Tin Province, southwestern border of the Amazonian craton, Brazil-I. Reconnaisance U-Pb geochronology and regional implications. Precamb. Res., 95 (1-2), 41-67.

Bettencourt, J. S., Leite, W. B. JR., Ruiz, A. S., Matos, R.,Payolla, B. L., Tosdal, R. M., 2010. The Rondonian san Ignacio province in the SW Amazonian Craton: an overview. J. South Am Earth Sci., 29, 28-46.

Biste, M.H., Gourley, A.W., 2000. Geology and Setting of the Miguela A-Zone, Guarayos Greenstone Belt, Eastern Bolivia. In: VMS Deposits of Latin America, Geol. Assoc. of Canada, Min. Dep. Div., Spec. Pub. №.2, pp. 359-374.

Black, L.P., Kamo, S.L., Allen,C.M., Aleinkoff,J.N., Davis,D.W., Korsch, R.J., Foudoulis, C., 2003. TEMORA 1: a new zircon standard for Fanerozoic U-Pb geochronology. Chem. Geol. 200, 155-170. 
Boger, S.D., Raetz, M., Giles, D., Etchart, E., Fanning, M.C., 2005. U-Pb age data from the Sunsas region of Eastern Bolivia, evidence for the allochtonous origin of the Paragua Block. Precamb. Res. 139, 121-146.

Cabrera, R. F., Nogueira, S. F., Ruiz, A. S., Souza, M. Z. A., Macambira, M. J. B., Figueiredo, F. L. P., Lima, G. A., 2009. Caracterizaçao geológica e geocronológica (Pb$\mathrm{Pb}$ ) do Granito Cascata - Terreno Paraguá - SW do Cráton Amazônico (MT). Boletim de Resumos Expandidos, Simpósio 45 Anos de Geocronología no Brasil, 15-17 de dezembro, 2009, São Paulo, Brasil, pp. 159-161.

Compston, W., Williams, I. S., Kirschvink, J. L., Zhang, Z., Ma, G., 1992. Zircon U-Pb age from the Early Cambrian time-scale. J. Geol. Soc. Lond. 149, 171-184.

Cordani, U. G., Teixeira, W., 2007. Proterozoic accretionary belts of the Amazonian Craton. In: Hatcher, R.D. Jr., Carlson, M. P., McBride, J. H., and Martinez Catalán, J. R. (Org.). The 4D Framework of Continental Crust. GSA Memoir. Boulder, Colorado: Geol. Soc. Am Memoir 200, p. 297-320.

Cordani, U.G., Sato, K., Teixeira, W., Tassinari, C. C. G., Basei, M. A. S., 2000. Crustal evolution of the South American Platform. In: $31^{\text {ST }}$ International Geologic Congress, Rio de Janeiro, Brazil, p. 19-40.

Darbyshire, D. P. F., 1979. Results of the age determination programme. Rep. E. Bolivia Miner. Explor. Proj. (Proyecto Precámbrico), Phase I, 9 (unpublished interim report).

Darbyshire, D. P. F., 2000. The Precambrian of Eastern Bolivia - a Sm-Nd isotope study In: $31^{\text {st }}$ International Geologic Congress, Rio de Janeiro, Brazil. Abstract Volume (CD-Rom).

DePaolo, D. J., 1981. A neodymium and strontium isotopic study of Mesozoic calc-alkaline granitic batholiths of of the Sierra Nevada and Peninsular Ranges, California. J. Geophys. Res. 86, No B11, 10470-10488.

Figueiredo, F. L. P., Ruiz, A. S., Souza, M. Z. A., Macambira, M. J. B., 2009. Dados Isotópicos $\mathrm{Pb}-\mathrm{Pb}$ em Zircão do Ortognaisse Turvo (Terreno Paraguá - SW do Cráton Amazônico). Boletim de Resumos Expandidos, Simpósio 45 Anos de Geocronología no Brasil, 15-17 de dezembro, 2009, São Paulo, Brasil, pp. 177-179.

Fletcher, C. J. N., 1979. La geología y potencial de minerales del área de Concepción (Cuadrante SE 20-3 con parte de SE 20 - 2). British Geological Survey - Servicio Geológico de Bolivia. (1 mapa escala 1:250.000). Santa Cruz, Bolívia. 73 p. (Open-file Report).

Geraldes, M. C., Teixeira, W., Van Schmus, W. R., 2000. Isotopic and chemical evidence for three accretionary magmatic arcs (1.79- $1.42 \mathrm{Ga})$ in SW Amazon craton, Mato Grosso State, Brazil, Revista Brasileira de Geociências 30, 99-101. 
Geraldes, M.C., Teixeira, W., Heilbron, M., 2004. Lithospheric versus asthenospheric source of the SW Amazonian craton A-types granites: the role of the Paleo and Mesoproterozoic accretionary belts for their coeval continental suites, Episodes, 25, 3, 185-189.

Geraldes, M. C., Van Schmus, W. R., Condie, K. C., Bell, S., Teixeira, W., Babinski, M., 2001. Proterozoic geologic evolution of SW part of the Amazonian craton in Mato Grosso State, Brazil. Precamb. Res. 111, 91-128.

Girardi, V.A.V., Teixeira, W., Bettencourt, J.S., Andrade, S., Navarro, M.S., Sato,K., 2008. Trace element geochemistry and Sr-Nd characteristics of Mesoproterozoic mafic intrusive rocks from Rondonias, Brazil, SW Amazonian Craton: petrogenetic and tectonic inferences. Episodes 31 (4), 392-400.

Hawkins, M. P. The geology and mineral potential of the Manomó area (Part of quadrangle SD 20-16). Santa Cruz de la Sierra: British Geological Survey/Servicio Geológico de Bolivia, 1982. 105 p. (Open -file Report).

Klinck, B. A., O'connor, E. A., 1983. The geology and mineral potential of the Perseverancia and Monte Verde areas (Quadrangles SD 20-15 and SD 20-11).. Institute of Geological Sciences-Servicio Geológico de Bolivia. Santa Cruz. 178 p. (1 mapa escala 1:250.000) (Open -file Report).

Isla-Moreno, L., 2009. Distrito Don Mario, un depósito de Au-Cu tipo hidrotermal asociado a zonas de cizalla. Memorias del XVIII Congreso Geológico Boliviano, Potosi, Bolivia, p. 8587.

Landivar, G., Gonzalez, R., 1997. Mapa Geológico del Area Serranías San José - San Diablo. Servicio Nacional de Geología y Minería, escala 1:100.000.

Litherland, M., 1982. The geology and mineral potential of the Huanchaca area (Parts of Quadrangles SD 20-15 and SD 20-11). Institute of Geological Sciences-Servicio Geológico de Bolivia. Santa Cruz. 173 p. (1 map scale 1:250,000) (Open -file Report).

Litherland, M., Bloomfield, K., 1981. The Proterozoic history of Eastern Bolivia. Precamb. Res. $15,157-179$.

Litherland, M., Klinck, B. A. 1982. Introducing the terms "Paragua Craton" and "The Pensamiento Granitoid Complex" for use in sheet reports. Rep. East. Bolivia Miner. Expl. Proj., Santa Cruz (Unpublished).

Litherland, M., Klinck, B. A., O'connor. E.A., Pitfield. P.E.J., 1985. Andean-trending mobile belts in the Brazilian Shield. Nature 314: 345-348

Litherland, M., Annells, R. N., Appleton, J. D., Berrange, J.P., Blommfield, K., Burton, C. C. I.; Darbyshire, D. P. F., Fletcher, C. J. N., Hawkins. M.P., Klinck, B.A., Llanos, A., Mitchell, W. I., O'connor. E.A., Pitfield. P.E.J., Power, G., Webb, B.C., 1986. The geology and 
mineral resources of the Bolivian Precambrian Shield, British Geological Survey, Overseas Memoir 9. London. 153 p.

Litherland M., Annells, R. N., Darbyshire, D. P. F., Fletcher, C .J .N., Hawkins, M. P., Klinck, B. A., Mitchell, W. I., O'connor, E. A., Pitfield. P. E .J., Power, G., Webb. C., 1989. The Proterozoic of Eastern Bolivia and its relationship to the Andean mobile belt. Precamb. Res. 43, 157-174.

Loewy, S.L., Connelly, I.N., Dalziel. I.W.D., 2004. An orphaned basement block: the Arequipa-Antofalla Basement of the central Andean margin of South America. Geol. Soc. Am. Bull. 116. 171-187.

Ludwig, K. R., 2003. User's manual for ISOPLOT 3.0: a geochronological toolkit for Microsoft Excel. Berkeley Geochronology Center, Special Publication, vol 4, 71 p.

Matos, R., 1995. Geología del área de San Ramón, Precámbrico, Hoja 4437 Palmarito. Proyecto 6 Recursos Minerales del Precámbrico, Servicio Geológico de Bolivia-SGAB de Suecia, Santa Cruz, Bolivia (Informe interno).

Matos, R., 2009. Estilos tectónicos frontal y oblícuo en la evolución del MesoNeoproterozoico de la Provincia Sunsás del Precámbrico Boliviano. XVIII Congreso Geológico Boliviano, Potosi, Bolivia, 2009 (Memorias), p. 120-123.

Matos, R., Landivar, G., Curro, G., 1996. Mapa geológico Hoja 7642 - Cerro El Encanto. Servicio Geológico de Bolivia, La Paz, Escala 1:100.000.

Matos, R., Teixeira, W., Geraldes, M. C., Bettencourt, J. S., 2009. Geochemistry and Nd-Sr Isotopic Signatures of the Pensamiento Granitoid Complex, Rondonian-San Ignacio Province, Eastern Precambrian Shield of Bolivia: Petrogenetic Constraints for a Mesoproterozoic Magmatic Arc Setting. Geologia USP. Série Científica, 9, 2, 89-117.

Matos, R., Teixeira, W., Geraldes, M. C., Bettencourt, J. S. Oblique tectonic in the Sunsás Province, constraints to the evolution of Bolivian Precambrian terranes (In preparation).

Payolla, B. L., Bettencourt, J. S., Kosuch, M., Leite, W. B. JR., Fetter, A. H., Van Schmus, W. R., 2002. Geological evolution of the basement rocks in the east-central part of the Rondônia Tin province, SW Amazonian craton, Brazil: U-Pb and $\mathrm{Sm}-\mathrm{Nd}$ isotopic constraints. Precamb. Res. 119, 141-169.

Pinto-Vasquez, J., 2001. Potencial de yacimientos de gran volumen de CU-Zn-Pb en el Escudo Precámbrico Boliviano. Estilos de mineralización en Bolivia. Publicación del Colegio de Geólogos de Bolivia, 29 de noviembre, 2001, La Paz, p. 13-18.

Pitifield, P. E. J., 1982. The geology and mineral potential of the Puerto Villazón area (Quadrangles SD 20-7 and SD 20-3). Institute of Geological Sciences - Servicio Geológico de Bolivia. Santa Cruz. 181 p. (1 map scale 1:250,000) (Open -file Report). 
Rizzotto, G.J., Quadros, M.L.E.S., 2007. Margem Passiva e granitos Orogênicos do Ectasiano em Rondônia, X Simpósio de Geologia da Amazônia, Porto Velho, Rondônia, (CD Room).

Santos, J. O. S., Rizotto, G.J., Mcnaughton, N. J., Matos, R., Hartmann, L. A., Potter, P. E., Fletcher, I. R., 2006. The Four Main Orogenies within the Autochthonous Mesoproterozoic Sunsas Province in SW Amazon Craton, XVII Congreso Geológico de Bolivia. Sucre, Bolívia, p. 1-4.

Santos, J. O. S., Rizzotto, G.J., Mcnaughton, N. J., Matos, R., Hartmann, L. A., Chemale Jr., F., Potter, P. E., Quadros, M.L.E.S., 2008. Age and autochthonous evolution of Sunsás Orogen in West Amazon Craton based on mapping and U-Pb geochronology. Precamb. Res. 165, 120-152.

Sato, K., Tassinari, C. C. G., 1997. Principais eventos de acreçao continental no Cráton Amazonico baseados em idade modelo $\mathrm{Sm}-\mathrm{Nd}$, calculada em evoluçoes de estágio único e estágio duplo. In: Costa, M.L., Angelica, R.S., (Eds.), Contribuçoes à Geologia da Amazonia, Belém, Sociedade Brasileira de Geologia, p. 91-142.

Tassinari, C.C.G., Bettencourt, J. S., Geraldes, M. C., Macambira, M. J. B., Lafon, J.M., 2000. The Amazon craton. In: Cordani, U.; Milani, E.J.; Thomaz Filho, A., and Campos, D.A., (Eds.), Tectonic evolution of South America, $31^{\text {st }}$ International Geologic Congress, Rio de Janeiro, Brazil, p. 41-95.

Teixeira, W., Cordani, U. G., 2009. Proterozoic evolution of the Amazonian Craton reviewed. Special volume of the Indian Conference on Global Scenario. World Scientific. (in press). Teixeira, W., Tassinari, C. C. G., Cordani, U. G., Kawashita, K. 1989. A review of the geochronology of the Amazonian Craton: Tectonic implications. Precamb. Res. 42, 213227.

Teixeira, W., Bettencourt, J. S., Girardi, V. A. V., Onoe, A., Sato, K., Rizzotto, G. J., 2006. Mesoproterozoic mantle heterogeneity in the SW Amazonian Craton: ${ }^{40} \mathrm{Ar} /{ }^{39} \mathrm{Ar}$ and $\mathrm{Nd}-\mathrm{Sr}$ isotopic evidence from mafic- felsic rocks. In: Hanski, E., Mertanen, S., Ramo, T, Vuollo, J. (eds) Dyke swarms - Time Markers of Crustal Evolution. London, Taylor \& Francis Group, p. 113-130.

Teixeira, W., Geraldes, M. C., Matos, R., Ruiz, A. S., Saes, G., Vargas-Mattos, G. A review of the tectonic evolution of the Sunsás belt, SW portion of the Amazonian Craton. J. South Am Earth Sci., 29, 47-60.

Tohver, E., van der Pluijm, B.A., van der Voo, R., Rizzotto, G., Scandolara, J.E., 2002. Paleogeography of the Amazon Craton at $1.2 \mathrm{Ga}$ : early Grenvillian collision with the Llano segment of Laurentia. Earth Planet. Sci. Lett. 199, 185-200.

Tohver, E., van der Pluijm, B.A., Mezger, K., Essene, E., Scandolara, J.E., 2004. Significance of the Nova Brasilândia metasedimentary belt in Western Brazil: Redefining 
the Mesoproterozoic boundary of the Amazon Craton. Tectonics, TC6004, doi: 10.1029/2003TCool563.

Tohver, E., van der Pluijm, B.A., Mezger, K., Scandolara, J.E., Essene, E., 2005. Two stage tectonic history of the SW Amazon craton in the late Mesoproterozoic: identifying a cryptic suture zone. Precamb. Res. 137, 35-59.

Tosdal, R. M., 1996. The Amazon-Laurentian connection as viewed from the Middle Proterozoic rocks in the Central Andes, western Bolivia and northern Chile. Tectonics 15, 827-842.

Wasteneys, H.A., Clark, A.H., Farrar, E., Langridge, R.J., 1995. Grenvillian granulite facies metamorphism in the Arequipa Massif, Peru: a Laurentia-Gondwana link. Earth Planet. Sci. Lett. 132, 63-73.

Wömer, O., Lezaun, J., Beck, A., Heber, V., Lucassen, F., Zinngrebe, E., Rössling, R, Wilke, H.G., 2000. Preeambrian and Early Palaeozoic evolution of the Andean basement at Belen (northern Chile) and Cerro Uyarani (western Bolivia Altiplano).

J. South Am. Earth Sci. 13,717-737. 


\title{
SM - ND CHARACTERISTICS OF THE DIAMANTINA GRANITOID, RONDONIAN- SAN IGNACIO PROVINCE - BOLIVIAN EASTERN PRECAMBRIAN SHIELD
}

\author{
Matos, R. ${ }^{1,3}$, Teixeira, W. ${ }^{1}$, Sato, K. ${ }^{1}$, \& Geraldes, M.C. ${ }^{2}$ \\ 1 Instituto de Geociências, Universidade de São Paulo, Rua do Lago 562, Cidade Universitária. 05508-080 Sao \\ Paulo, SP, Brasil. E-mail: rmatoss@igc.usp.br; wteixeir@usp.br; keisato@usp.br \\ 2 Faculdade de Geologia, Universidade do Estado do Rio de Janeiro, Rua São Francisco Xavier 524, 20559-900 Rio \\ de Janeiro, RJ, Brasil. E-mail: geraldes@uerj.br \\ 3 Instituto de Geología Económica y del Medio Ambiente, Universidad Mayor de San Andrés, Calle 27, Pabellón \\ Geologia, Campus Universitario Cota Cota. La Paz, Bolivia. E-mail: rmatoss@ yahoo.com
}

Keywords: Bolivia, Pensamiento Granitoid Complex, San Ignacio Orogeny, Sm-Nd isotopic, Amazonian Craton.

\section{INTRODUCTION}

The recognized framework of the Amazonian craton comprises the Maroni-Itacaiunas (2.25-1.95 Ga), Ventuari-Tapajós (2.0-1.8 Ga), Rio NegroJuruena (1.8-1.55 Ga), Rondonian-San Ignacio $(1.55-1.30 \mathrm{Ga})$, and Sunsas (1.30-1.0 Ga) geochronological provinces (e.g., Teixeira et al., 1989; Tassinari et al., 2000). Sm-Nd studies (Cordani and Sato, 1999) have confirmed this general crustal architecture, supported by a large set of $\mathrm{U}-\mathrm{Pb}$ and $\mathrm{Rb}-\mathrm{Sr}$ data in granitoid rocks. The Rondonian- San Ignacio Province (RSIP) of widespread occurrence in the SW part of the Amazonian craton (Brazil and Bolívia) has been studied by several authors (Sato and Tassinari, 1997; Van Schmus et al., 1998; Bettencourt et al., 1999; Geraldes et al., 2000, 2001; Leite and Saes, 2000; Payola et al. 2002, Santos et al., 2000; Santos et al., 2005), but ages, structures, and composition of rocks units and orogenic events within the Bolivian territory are still poorly known.

The Diamantina, La Junta and San Martin granitoids of the Pensamiento Granitoid Complex are part of the San Ignacio Province in Eastern Precambrian shield of Bolivia (Litherland et al., 1986; Boger et al., 2005) in which granulites and gneisses of the Lomas Maneches Complex are similarly widespread. The Diamantina granitoid makes up a north trending hill, forming an elliptical body about $53 \mathrm{~km}$ long (Klinck and O'Connor, 1982), and crops out as a "island" in the forest, close to the road that joints Santa Rosa de la Roca and Piso Firme localities, Santa Cruz department, in Eastern Bolivia; approximately 110 $\mathrm{km}$ north from Santa Rosa de la Roca (Figure 1). The dominant rock type is a pale pink and non foliated biotite monzogranite. The host rocks to the Diamantina granite are the syn-to late kinematic San Martin and La Junta granites which are moderately foliated accordingly to the regional structure of the Complex.
This work, carried out at the Centro de Pesquisas Geocronologicas, in Sao Paulo, Brazil, presents preliminary Sm-Nd data of the Diamantina, San Martin, and La Junta granitoids, that place important isotopic constraints on rock protholiths of the RSIP, in the Bolivian territory. This is part of a project that aims to determine the Precambrian tectonic evolution of Eastern Bolivia and its relationship to Mesoproterozoic evolution of SW Amazonian craton.

\section{PREVIOUS ISOTOPIC DATA}

Previous $\mathrm{Rb}-\mathrm{Sr}$ whole rock isochron for the Diamantina granitoid (Table 1) yielded an age of $1391 \pm 70 \mathrm{Ma}$ and ${ }^{87} \mathrm{Sr} /{ }^{86} \mathrm{Sr}$ initial ratio from 0.75949 to 0.77617 (Litherland et al., 1986). After Darbyshire (2000), Nd isotopic compositions of granulites and gneisses from the Lomas Maneches Complex, and the San Ignacio Supergroup demonstrate the important role of the Transamazonian orogeny for the protoliths, displaying $\varepsilon \mathrm{Nd}(\mathrm{t})$ values of 1.0 to 1.4 and $\mathrm{T}_{\mathrm{DM}}$ between 1.69 and 1.73 (Two stage model) for Diamantina and Orobayaya granites.

\section{RESULTS AND CONCLUSIONS}

For four samples of the Diamantina granite yield $\varepsilon_{\mathrm{Nd}(1.4)}$ values between -0.52 to +1.23 and $\mathrm{T}_{\mathrm{DM}}$ ranging from 1.80 to $1.93 \mathrm{Ga}$ (Two stage model; Table 2). This indicates that the original magma of this post-tectonic granite resulted predominantly from Proterozoic juvenile sources. One sample from San Martin granite have $\varepsilon_{\mathrm{Nd}(1.4)}$ value of +2.26, and $\mathrm{T}_{\mathrm{DM}}$ age of $1.71 \mathrm{Ga}$; therefore indicating that the host rock of the Diamantina granite derived mostly from juvenile sources as well. In contrast, two samples from La Junta granite yield $\varepsilon_{\mathrm{Nd}(1.4)}$ values of -2.07 and -3.54 and $\mathrm{T}_{\mathrm{DM}}$ ages of 2.05 and $2.16 \mathrm{Ga}$; the negative $\varepsilon_{\mathrm{Nd}}$ values show that the original magma was derived from a significant crustal component compared to the Diamantina and San Martin granitoids.

The above preliminary results from the Pensamiento Complex reveal distinct isotopic characteristics for three granitoids, although the 
obtained signatures are consistent with the idea that the Rondonian-San Ignacio orogeny makes up a major differentiation/accretion event in SW Amazonian craton.

Table 1. Rb-Sr whole rock data of Diamantina Granitoid (After Litherland et al.,1986)

\begin{tabular}{|c|c|c|c|c|c|c|}
\hline $\begin{array}{c}\text { BOL/AD } \\
\text { Number }\end{array}$ & Rock type & Unit & Ppm Rb & Ppm Sr & $87 \mathrm{Rb} / 86 \mathrm{Sr}$ & $87 \mathrm{Sr} / 86 \mathrm{Sr}$ \\
\hline 158 & Granite & $\begin{array}{c}\text { Diamantina } \\
\text { Granite }\end{array}$ & 186 & 176 & 3.068 & 0.76206 \\
\hline 159 & Granite & $\begin{array}{c}\text { Diamantina } \\
\text { Granite }\end{array}$ & 226 & 183 & 3.602 & 0.77197 \\
\hline 160 & Granite & $\begin{array}{c}\text { Diamantina } \\
\text { Granite }\end{array}$ & 191 & 186 & 2.981 & 0.75949 \\
\hline 161 & Granite & $\begin{array}{c}\text { Diamantina } \\
\text { Granite }\end{array}$ & 236 & 181 & 3.795 & 0.77617 \\
\hline
\end{tabular}

Table 2. Sm-Nd analytical data of Diamantina, San Martin, and La Junta granites.

\begin{tabular}{|c|c|c|c|c|c|c|c|}
\hline Granite & Sample) & ${ }^{147} \mathrm{Sm} /{ }^{144} \mathrm{Nd}$ & ${ }^{143} \mathrm{Nd} /{ }^{144} \mathrm{Nd}$ & $\mathrm{F}_{\mathrm{Sm} / \mathrm{Nd}}$ & $\mathrm{T}_{\mathrm{DM}}(\mathrm{Ga})$ & $\varepsilon_{(0)}$ & $\varepsilon_{\mathrm{Nd}(1.4)}$ \\
\hline Diamantina & PECP0505 & 0.1019 & 0.511834 & -0.48 & 1.80 & -15.69 & 1.23 \\
\hline Diamantina & PECP20506 & 0.0989 & 0.511789 & -0.50 & 1.82 & -16.56 & 0.90 \\
\hline Diamantina & PECP30507 & 0.1145 & 0.511859 & -0.42 & 1.93 & -15.20 & -0.52 \\
\hline Diamantina & PEME0508 & 0.1469 & 0.512202 & -0.25 & 1.86 & -8.51 & 0.38 \\
\hline San Martin & PECA0509 & 0.1424 & 0.512257 & -0.28 & 1.71 & -7.43 & 2.26 \\
\hline La Junta & PELJ20512 & 0.0988 & 0.511636 & -0.50 & 2.05 & -19.55 & -2.07 \\
\hline La Junta & PELJ30513 & 0.1124 & 0.511685 & -0.43 & 2.16 & -18.59 & -3.54 \\
\hline
\end{tabular}

\section{AKNOWLEDGEMENTS}

This work forms a part of a doctoral study at the Universidade de São Paulo, supported by CAPES (Coordenação de Aperfeiçoamento de Pessoal de Nível Superior), Brazil. The study is supported by CNPq (Conselho Nacional de Pesquisa Científica e Tecnológica, Brazil); \# 470373/2004-0.

\section{REFERENCES}

Bettencourt, J.S., Tosdal, R.M., Leite, W.B. Jr., and Payolla, B.L., 1999. Mesoproterozoic rapakivi granites of the Rondônia Tin Province, southwestern border of the Amazonian craton, Brazil-I. Reconnaisance U-Pb geochronology and regional implications. Precambrian Research 95, 1-2, pp. 41-67.

Boger, S.D., Raetz, M., Giles, D., Etchart, E., and Fanning, M.C., 2005. U-Pb age data from the Sunsas region of Eastern Bolivia, evidence for the allochtonous origin of the Paragua Block. Precambrian Research, 139, 121-146.

Cordani, U.G., and Sato, K., 1999 Crustal evolution of the South American Platform, based on $\mathrm{Nd}$ isotopic systematics on granitoid rocks. Episodes, Vol. 22, no. $3,167-173$

Darbyshire, D.P.F., 2000. The Precambrian of Eastern Bolivia - a Sm-Nd isotope study in: 31 International Geologic Congress, Rio de Janeiro, Brazil. Abstract Volume (CD-Room).

Geraldes, M.C., Teixeira, W., and Van Schmus, W.R., 2000. Isotopic and chemical evidence for three accretionary magmatic arcs $(1.79-1.42 \mathrm{Ga})$ in $\mathrm{SW}$ Amazon craton, Mato Grosso State, Brazil, Revista Brasileira de Geociências 30, 99-101.

Geraldes, M.C., Van Schmus, W.R., Condie, K.C., Bell, S., Teixeira, W., and Babinski, M., 2001. Proterozoic geologic evolution of SW part of the Amazonian craton in Mato Grosso State, Brazil. Precambrian Research $111,91-128$.

Klinck, B. A., and O'connor, E.A., 1983. The geology and mineral potential of the Perseverancia and Monte Verde areas (Quadrangles SD 20-15 and SD 20-11).Informe interno Institute of Geological Sciences-Servicio Geológico de Bolivia. La Paz.

Leite, J.A.D., and Saes, G.S., 2000. Geology of the southern Amazon craton in southwestern Mato Grosso, Brazil: a review. Revista Brasileira de Geociências 30, 91-94.

Litherland, M., R. N. Annels, J. D. Appleton, J. P. Berrange, K. Bloomfield, C. C. J. Burton, etc., 1986. The geology and mineral resouces of the Bolivian Precambrian Shield, British Geological Survey, Overseas Memoir 9 : 1-153, London.

Payolla, B.L., Bettencourt, J.S., Kosuch, M., Leite, W.B. Jr., Fetter, A.H., and Van Schmus, W.R., 2002. Geological evolution of the basement rocks in the eastcentral part of the Rondônia Tin province, SW Amazonian craton, Brazil: $\mathrm{U}-\mathrm{Pb}$ and $\mathrm{Sm}-\mathrm{Nd}$ isotopic constraints. Precambrian Research 119, 141-169.

Santos, J.O.S., Hartmann, L.A., Gaudette, H.E., Groves, D.I., McNaughton, N.J., and Fletcher, I.R., 2000. A new understanding of the provinces of Amazon craton based on integration of field mapping and $\mathrm{U}-\mathrm{Pb}$ and $\mathrm{Sm}-\mathrm{Nd}$ geochronology. Gondwana Res. 3, 489-506.

Santos, J.O.S., McNaughton, N.J., Hartmann, L.A., Fletcher, I.R., and Matos, R. 2005. The age of the deposition of the Aguapeí Group, Western Amazon craton, based on U-Pb study on diagenetic xenotime and 
detrital zircon. In Congreso Latinoamericano de Geologia, Quito, Ecuador, Geologia, CD-ROM.

Sato, K., and Tassinari, C.C.G., 1997. Principais eventos de acreçao continental no Cráton Amazonico baseados em idade modelo Sm-Nd, calculada em evoluçoes de estágio único e estágio duplo. In: Costa , M.L., Angelica, R.S., (Eds.), Contribuçoes á Geologia da Amazonia, Belém, Sociedade Brasileira de Geociencias, pp. 91-142.

Tassinari, C.G., Bettencourt, J.S., Geraldes, M.C., Macambira, M.J.B., and Lafon, J.M., 2000. The Amazon craton. In: Cordani, U., Milani, E.J., Thomaz Filho, A., and Campos, D.A., (Eds.), Tectonic evolution of South America, 31st International Geological Congress, Rio de Janeiro, Brazil, pp. 41-95.

Teixeira W., Tassinari, C.C.G., Cordani, U.G., and Kawashita, K., 1989, A review of the geochronology of the Amazonian Craton: Tectonic implications. Precamb. Res., v. 42, p.213-227.

Van Schmus, W.R.., Geraldes, M.C., Kozuch, M., Fetter, A.H., Tassinari, C.C.G., and Teixeira, W., 1998. $\mathrm{U} / \mathrm{Pb}$ and $\mathrm{Sm} / \mathrm{Nd}$ constraints on the age and origin of Proterozoic crust in southwestern Mato Grosso, Brazil: evidence for a 1450 Ma magmatic arc in Sw Amazonia. International Symposium on Tectonics, Ouro PretoMG, Brazil, Abstract Volume, pp. 121-125.
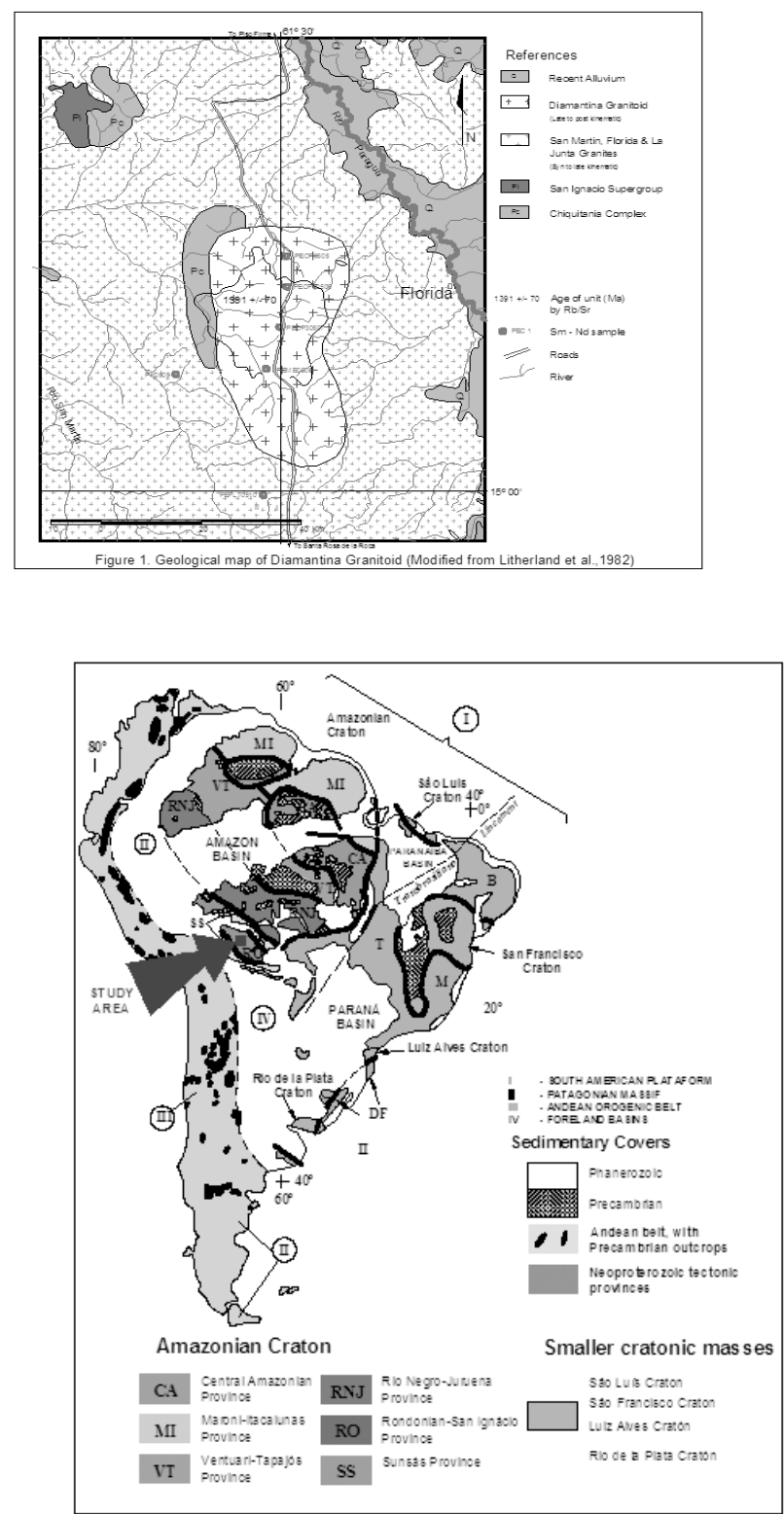
International Geologiical Congress - Oslo 2008

鹿

Home

Search Abstracts

Author Index

Symposia Programmes

Sponsors

Help
AMS-06 Neoproterozoic to early Paleozoic orogenic belts of South America

\section{Geochemistry and nd isotopic evidence of the pensamiento granitoid complex, rondonian san} ignacio province, eastern bolivia: Petrogenetic constraints for a plutonicarc model

Ramiro Matos, University of San Andrés, La Paz (Bolivia)

Wilson Teixeira, University of Sao Paulo (Brazil)

Mauro Geraldes, State University of Rio de Janeiro (Brazil)

Umberto Cordani, University of Sao Paulo (Brazil)

Kei Sato, University of Sao Paulo (Brazil)

The Pensamiento Granitoid Complex (PGC), forms part of the Rondonian- San Ignacio Province (RSIP; $1.55-1.30 \mathrm{Ga}$ ) in the SW Amazonian craton. The PGC crops out almost entirely within the Paragua craton, and is overprinted in places by low grade metamorphism and shearing tectonically linked with the Sunsas Orogeny. The PGC comprises plutonic granites and subvolcanic terms, and subordinately syenites, granodiorites, tonalites, trondhjemites and diorites. Tectonically these rocks have been distinguished as syn- to late-kinematic and late- to post- kinematic granitoids correlated to the RSI orogeny. Thirteen whole rock analysis for major, trace and REE in selected samples of the Pensamiento Granitoid Complex indicate that these rocks belong to the subalkaline series, whereas in the AFM diagram they plot in the calc-alkaline field. The syn- to late- kinematics La Junta and San Martin granites show wide range of $\mathrm{SiO} 2$ contents and suggests an origin by fractional crystallization from mafic and intermediate terms. The REE patterns are moderately fractioned in terms of LREE/HREE with a slightly negative Eu anomaly. One sample shows no negative Eu anomaly. The spider diagram presents steep patterns because the high LILE contents of these rocks. Negative peaks of $\mathrm{Sr}$, $\mathrm{P}$, and Ti suggest fractionation of feldspar, apatite, and titano-magnetite and sphene, respectively. New SHRIMP U-Pb yielded ages of $1373 \pm 20 \mathrm{Ma}$ and $1347 \pm 21 \mathrm{Ma}$ respectively. Sm- Nd yielded TDM model ages between 1.7 to $2.0 \mathrm{Ga}$, and $\mathrm{Nd}(1330)$ values ranging from +1.8 to -4.3 . The late- to post-kinematic Porvenir, 
San Cristobal, Diamantina and Piso Firme calc-alkaline granitoids display SiO2 content that ranges from 72 to $76 \mathrm{wt} \%$. They plot on the boundary between metaluminous to peraluminous composition. The Piso firme Granophyre, San Cristobal and Porvenir granites show low LREE fractionation, and subhorizontal tendency of HREE with negative Eu anomaly. They have deeper negative peaks of $\mathrm{Sr}$, $\mathrm{P}$ and $\mathrm{Ti}$. The Diamantina Granite displays REE patterns with two different signatures: first, steep patterns due to high contents of LREE and depletion in HREE with negative europium anomaly. Second, "gull wing" pattern with enriched HREE. In the multielement diagrams show negative peaks of $\mathrm{Sr}$, $\mathrm{P}$, and $\mathrm{Ti}$. The Diamantina Granite yielded SHRIMP U-Pb ages of $1340 \pm 20 \mathrm{Ma}$. Sm-Nd data displays TDM model ages of 1.6 to 1.9 and $\mathrm{Nd}(1330)$ values from -1.25 to +0.39 . The late- to post-kinematic granites yield $\mathrm{Sm}-\mathrm{Nd}$ TDM model ages are of 1.6 to $1.7 \mathrm{Ga}$, and the $\mathrm{Nd}(1330)$ values of +1.5 to +2.7 . Coupled

litogeochemistry and Sm- Nd isotopic data indicate that the PGCrocks exhibit plutonic arc setting comprising mostly juvenile derived granitoids (Porvenir, San Cristobal, Diamantine and Piso Firme). However the La Junta and San Martin granitoids may be interpreted as fractionated or crustal contaminated magmas, as evidenced by their Nd signature intruded in a pre- San Ignacio Basement.

CD-ROM Produced by $\underline{X-C D}$ Technologies 


\title{
GEOCHEMISTRY AND ISOTOPIC SIGNATURES OF THE PENSAMIENTO GRANITOID COMPLEX, RONDONIAN-SAN IGNACIO PROVINCE, EASTERN PRECAMBRIAN SHIELD OF BOLIVIA: PETROGENETIC CONSTRAINTS FOR A MESOPROTEROZOIC MAGMATIC ARC SETTING
}

\author{
Ramiro Matos $^{1,3}$; Wilson Teixeira ${ }^{1}$; Mauro C. Geraldes ${ }^{2}$; Jorge S. Bettencourt ${ }^{1}$, \\ 1 Instituto de Geociências, Universidade de São Paulo; 2. Faculdade de Geologia, Universidade do Estado do Rio de Janeiro, 3. Instituto de \\ Geología Económica y del Medio Ambiente, Universidad Mayor de San Andrés
}

The Pensamiento Granitoid Complex (PGC), in Eastern Precambrian of Bolivia, is assigned to the evolution of the Rondonian- San Ignacio Province (1.55-1.30 Ga) of the SW Amazonian Craton. The Proterozoic evolution of the Craton results from development of NW-SE mobile belts that became successively younger to the southwest, as exemplified by the Rondonian/San Ignacio (1.36-1.30 $\mathrm{Ga}$ ) and the Sunsas orogenies (1.20-1.00 Ga) in Bolivian and Brazilian territories. The PGC, as part of the Rondonian/San Ignacio Orogeny, crop outs almost entirely within the Paragua Craton and is partly overprinted by Sunsas low grade metamorphism and shearing episodes. The PGC comprises granites and subvolcanic terms, and subordinately syenites, granodiorites, tonalites, trondhjemites and diorites, tectonically characterized as syn- to late-kinematic and late-to post-kinematic granitoids. Thirteen whole rock chemical analysis for major, trace and REE in PGC plutonic rocks indicate subalkaline character. The syn- to late- kinematics La Junta and San Martin granites are peraluminous in composition, and show wide range of $\mathrm{SiO}_{2}$ contents (69 to $\left.77 \mathrm{wt} \%\right)$ suggesting an origin by fractional crystallization from mafic and intermediate terms. Both plutons show moderately fractioned LREE/HREE patterns with a slightly negative Eu anomaly, and one sample has any negative Eu anomaly. The spider diagram presents steep patterns due to the high LILE contents of these rocks. Negative peaks of Sr, P, and Ti suggest fractionation of feldspar, apatite, and titano-magnetite and sphene, respectively. SHRIMP U-Pb zircon ages of the San Martin and La Junta plutons are comparable within error $(1373 \pm 20 \mathrm{Ma}$ and $1347 \pm 21 \mathrm{Ma})$, whereas they yield $\mathrm{Sm}-\mathrm{Nd} \mathrm{T}_{\mathrm{DM}}$ model ages between 1.9 to $2.0 \mathrm{Ga}$ and $\varepsilon_{\mathrm{Nd}(1330)}$ values ranging from +1.8 to -4.3 , respectively. The late- to post-kinematic Porvenir, San Cristobal, Diamantina and Piso Firme calc-alkaline granitoid rocks display $\mathrm{SiO}_{2}$ contents from 72 to $76 \mathrm{wt} \%$, and are metaluminous to peraluminous in composition. Regarding the REE patterns the Piso Firme Granophyre and San Cristobal and Porvenir granites show low LREE fractionation, and subhorizontal tendency of HREE with negative Eu anomaly. They have deeper negative peaks of Sr, P and Ti when compared with the La Junta and San Martin granites. These three plutons yielded $\mathrm{Sm}-\mathrm{Nd} \mathrm{T}_{\mathrm{DM}}$ model ages between 1.6 to $1.7 \mathrm{Ga}$, and the positive $\varepsilon_{\mathrm{Nd}(1330)} \mathrm{values}$ from +2.7 to +1.5 . In contrast, the Diamantina Granite displays REE patterns with two different signatures: $i$ ) steep patterns due to the high contents of LREE and depletion in HREE with negative Eu anomaly; ii) "gull wing" pattern with enriched HREE contents. In the multi-element diagrams the samples show negative peaks of $\mathrm{Sr}, \mathrm{P}$, and Ti. Moreover, Diamantina Granite (SHRIMP U-Pb age of $1340 \pm 20 \mathrm{Ma}$ ) yields more variable $\mathrm{Sm}-\mathrm{Nd} \mathrm{T} \mathrm{T}_{\mathrm{DM}}$ model ages $(1.6$ to $1.9 \mathrm{Ga})$ and $\varepsilon_{\mathrm{Nd}(1330)}$ values $(+0.4$ to -1.2$)$ when compared with the other late- to post-kinematic plutons. Coupled litogeochemistry and Sm-Nd isotopic signatures of the Porvenir, San Cristobal, Diamantina and Piso Firme plutons are consistent with a plutonic arc setting thereby comprising mostly juvenile-derived granitoids. Meanwhile some of the studied syn- to late kinematic granitoid rocks may also be interpreted as subordinately derived from fractionated or crustal contaminated magmas, as suggested by the negative $\varepsilon_{\mathrm{Nd}(t)}$ parameters. 


\title{
GEOLOGÍA ESTRUCTURAL TECTÓNICA
}

\section{ESTILOS TECTÓNICOS FRONTAL Y OBLÍCUO EN LA EVOLUCIÓN DEL MESO- NEOPROTEROZOICO DE LA PROVINCIA SUNSÁS DEL PRECÁMBRICO BOLIVIANO}

\author{
Ramiro Matos \\ Instituto de Investigaciones Geológicas y del Medio Ambiente, Universidad Mayor de San Andrés, Calle27, Pabellón Geología, \\ Campus Universitario Cota Cota. La Paz, Bolivia. E-mail: rmatoss@yahoo.com
}

Palabras claves: Bolivia, Sunsás, Orogenia San Ignacio, Cratón Amazónico.

\section{INTRODUCCIÓN}

Tectónica vertical versus tectónica horizontal ha sido un debate común en años recientes al discutir el crecimiento cortical durante el Proterozoico. Uno de los criterios de discriminación más común para uno u otro de estos estilos es el modelo de "strain" registrado en un segmento cortical considerado. El estilo tectónico horizontal se considera un proceso de la tectónica de placas de estilo moderno, responsable para el desarrollo de una foliación horizontal o de bajo ángulo. Contrariamente la tectónica vertical resulta del desarrollo de amplios dominios formados por la sobreposición de estructuras domo y cuenca. Por otro lado, la tectónica recumbente o nappe relacionada con la orogenia San Ignacio fue propuesta por Litherland et al. (1986, pag. 56), para San Joaquín, San Simón, El Cielo, Dalriada y el Esquisto Ascensión en las rocas del Precámbrico de la Chiquitanía Boliviana.

Este estudio presenta un ejemplo de una zona de deformación retrabajada por cizallamiento de deslizamiento de rumbo, dominantemente siniestra y otra zona de plegamiento horizontal normal. Ambos estilos de deformación reflejan dos sectores tectónicos distintos para un mismo lapso de tiempo. Los ejemplos provienen de la Provincia Sunsás del Precámbrico Boliviano localizada en la región sudoeste del Cratón Amazónico (Figura 1), formada durante la amalgamación final de esta provincia al citado cratón durante el Neoproterozoico Superior (1250- $1000 \mathrm{Ma}$ ) (Cordani y Teixeira 2007). Nuestros resultados arguyen dos estilos de deformación dentro de hasta ahora la misma provincia para un mismo lapso de tiempo 1,2 a 0,95 Ga, probablemente un estilo corresponde a una etapa temprana y el otro estilo formado en una etapa tardía.

La primera zona estudiada comprende desde Guarayos a San Antonio de Lomerío totalizando no menos de 300 kilómetros, incluyendo parte de las hojas geológicas Concepción, la parte sur de Ascensión de Guarayos y el sector noroeste de San José de Chiquitos. Esta zona se denomina Distrito San Ramón (Figura 2). La segunda, dentro de la misma provincia geológica, involucró pliegues normales horizontales vinculados a la intrusión del Complejo Ígneo del Rincón del Tigre datada en $992 \pm 86 \mathrm{Ma}$, dentro de la Hoja Roboré- Santo Corazón (no mostrada en este trabajo).

Este trabajo, efectuado en el Instituto de Investigaciones Geológicas y del Medio Ambiente (IGEMA) de la UMSA y en el Instituto de Geociencias de la Universidad de Sao Paulo, Brasil es parte de un proyecto de doctorado que el autor, docente e investigador de la UMSA realiza en la USP de Sao
Paulo, Brasil. El propósito del estudio es determinar la evolución tectónica del Precámbrico del oriente de Bolivia y su relación a la evolución de la región sudoeste del Cratón Amazónico durante el Mesoproterozoico.

\section{AREAS CON TÍPICA TECTÓNICA OBLÍCUA}

Varios ejemplos de la Tectónica vertical versus tectónica horizontal pueden citarse dentro del Cratón Amazónico. Este cratón comprende las provincias geocronológicas MaroniItacaiunas (2.25-1.95 Ga), Ventuari-Tapajós (2.0-1.8 Ga), Rio Negro-Juruena (1.8-1.55 Ga), Rondoniana-San Ignacio (1.55-1.30 Ga), y Sunsás (1.30-1.0 Ga) (Cordani etal., 2000; Cordani y Teixeira, 2007). Las provincias Rondoniana-San Ignacio (PRSI) y Sunsás (PS), tienen amplia distribución en la región sudoeste del Cratón Amazónico, en particular en Bolivia (Figura 1). Esta área fue estudiada por varios autores (Litherland et al., 1986), sin embargo la edad, estructura, composición de las unidades rocosas y eventos orogénicos dentro del territorio boliviano aun son poco conocidos.

Dos ejemplos al suroeste del Cratón Amazónico, en el estado de Rondonia de edad Sunsás constituyen la Zona de Cizalla Ji-Paraná, caracterizada por una tectónica de transcurrencia siniestra y la Faja Metasedimentaria Nova Brasilandia, con un evento compresional inicial que desarrolló una fabrica al noreste y fue seguido por el desarrollo de zonas de cizalla de deslizamiento de rumbo siniestro. Ambos ejemplos se sitúan en el estado de Rondonia, Brasil.

Las regiones con típica tectónica oblicua se caracterizan por los siguientes factores (Figura 2, zona 6 y 9 ).

1. Zonas de cizalla de deslizamiento de rumbo paralelo a la faja móvil, con patrón de foliación $\mathrm{S} / \mathrm{C}$ en los bloques intervinientes y una red interna de cizalla lenticular sigmoidal en todas las escalas de observación (Figura 2, zona 9).

2. Organización interna de ramificación compleja con diferentes bloques, mostrando diferentes edades, patrones estructurales sedimentarios y metamórficos unidos por zonas de cizalla transcurrente.

3. Pliegues en "echelon" oblicuos a la faja móvil, rotados a la dirección de cizalla de rumbo principal.

4. Lineación de estiramiento horizontal paralela u oblicua a la faja móvil.

5. Intrusiones graníticas siguiendo esa fábrica. 
En el Distrito San Ramón las rocas del ciclo San Ignacio y protolitos más antiguos forman el basamento. Las rocas comprenden gneisses, una asociación volcano-sedimentaria de ambiente oceánico a transicional compuesto por esquistos, filitas, metabasalto, metariolitas, intrusivos ultramáficos y máficos y granitoides; el grado metamórfico es de bajo a alto (Litherland et al., 1986, Adamek et al., 1996, Witschard et al., 1993). Estas rocas sufrieron un pronunciado retrabajamiento durante la Orogenia Sunsás provocando la destrucción de las estructuras antiguas y sobreimprimiendo el actual patrón de afloramientos (Figura 2). Esta orogenia estuvo acompañada por la intrusión de granitos sin a tardicinemáticos y tardi a post cinemáticos por ejemplo Casa de Piedra, Talcoso y Taperas. Evidencias de campo de imágenes satelitales, geofísica y petrografía respaldan un estilo tectónico de estructuras $\mathrm{s}-\mathrm{c}$, granos fracturados colas de granos tipo $\sigma 1$ (sigma) y venas sigmoidales resultante de la cizalla de deslizamiento de rumbo siniestro (Figura 2).

\section{ÁREAS TÍPICAS CON TECTÓNICA FRONTAL}

Estas regiones poseen las siguientes características:

1. Fajas plegadas y corridas de rumbo paralelo a los bordes del antepaís con una clara vergencia al cratón.

2. Foliación inclinándose a la faja móvil, con grandes zonas con foliación suave asociados con nappes o mantos de traslape desarrollados en las áreas marginales.

Los sinclinales y anticlinales observados en el área de Rincón del Tigre (Mitchell, 1979), son pliegues normales horizontales desarrollados en los grupos Sunsás y Vibosi, incluyendo el sill estratificado del Complejo Igneo de Rincón del Tigre intruido entre ambos grupos. Los ejes de pliegue se hunden al sureste con un ángulo bajo $\left(\sim 10^{\circ}\right)$. El área contiene diversas fallas de orientación noroeste con un paralelismo a la faja y perpendiculares a $\sigma 1$. Este $\sigma 1$ es responsable de la deformación de la Serranía Las Conchas, Santo Corazón y Bella Boca, siguiendo una orientación NWSE.

Los lineamientos orientados con dirección noreste podrían considerarse fracturas de tensión por compresión axial, bajo condiciones de baja presión de confinamiento. Estas fracturas son paralelas a $\sigma 1$, un proceso conocido como partición longitudinal (Van der Pluijm y Marshak, 2005, pag. 121). La presión de confinamiento baja en la zona está respaldada por el grado de metamorfismo equivalente a la facies de los esquistos verdes.

\section{CONCLUSIONES}

En zonas de cizalla dúctil como el Distrito San Ramón, es razonable asumir un esfuerzo principal compresivo $\sigma 1$ haciendo un ángulo de aproximadamente $45^{\circ}$ con la dirección $\mathrm{C}$ y perpendicular con la dirección externa S. La fábrica sigmoidal de las foliaciones se debe a la deformación de rotación acumulada. Desde el marco general de las fajas móviles frontales y oblicuas del Cratón Amazónico, es posible proponer un modelo de esfuerzos principales de compresión WNW-ESE a SSW-NNE para el Distrito San Ramón. Sugerimos que esto representa los vectores de desplazamiento principal, de acuerdo con el cuadro coherente de la cinemática para la amalgamación del oeste del Cratón Amazónico, durante las etapas finales de la orogenia Sunsás.

Las estructuras desarrolladas en la zona Rincón del Tigre y el Distrito San Ramón (Mitchell, 1979; Fletcher, 1979), están relacionadas con la colisión del orogeno Sunsás. Las fases tardías de la deformación en el ciclo Sunsás, que causaron la colisión fueron citados por Adamek et al. (1996).

\section{REFERENCIAS}

Adamek, P. M., Troeng, B., Landívar, G., Llanos, A. y Matos, R., 1996. Evaluación del los recursos minerales del Distrito San Ramón. - Boletín del Servicio Geológico de Bolivia, n.10, 77 p., La Paz.

Cordani, U.G.; Sato, K.; Teixeira, W.; Tassinari, C. C. G.; Basei, M. A. S. Crustal evolution of the South American Platform. In: $31^{\mathrm{ST}}$ International Geologic Congress, Rio de Janeiro, Brazil, p. 19-40. 2000.

Cordani, U. G., Teixeira, W., 2007. Proterozoic accretionary belts of the Amazonian Craton. In: Hatcher, R.D. Jr., Carlson, M. P., McBride, J. H., and Martinez Catalán, J. R. (Org.). The 4D Framework of Continental Crust. GSA Memoir. Boulder, Colorado: Geological Society of America Book Editors, 200, p. 297-320.

Fletcher, C. J. N., 1979. La geología y potencial de minerales del área de Concepción (Cuadrante SE 20-3 con parte de SE 20 - 2).- Informe inédito British Geological Survey - Servicio Geológico de Bolivia. (1 mapa). Santa Cruz, 73 p.

Litherland, M., Annells, R. N., Appleton, J. D., Berrange, J.P., Blommfield, K., Burton, C. C. I.; Darbyshire, D. P. F., Fletcher, C. J. N., Hawkins. M.P., Klinck, B.A., Llanos, A., Mitchell, W. I., O'connor. E.A., Pitfield. P.E.J., Power, G.; Webb, B.C., 1986. The geology and mineral resources of the Bolivian Precambrian Shield, British Geological Survey, Overseas Memoir 9. London. 153 p.

Mitchell, W. I., 1979. La geología y potencial de minerales del área de Santo Corazón - Rincón del Tigre (Cuadrantes SE 21-5, con parte de SE 21-9 y SE 21-6 con parte de SE 2110). Informe inédito British Geological Survey - Servicio Geológico de Bolivia. (1 mapa). Santa Cruz de la Sierra, 131 p.

Van der Pluijm, B.A. y Marshak, S., 2005. Earth Structures: An Introduction to Structural Geology and Tectonics. New York. W. W. Norton, 656 p.

Witschard, F., Matos, R. y Nilsson, L., 1993. Estudio de geofísica aerotransportada e interpretaciones de sensores remotos en el área de San Ramón. Boletín del Servicio Geológico de Bolivia, No.2 (Especial), 55 p., La Paz. 
Figura 1. Provincias geotectónicas de Sudamérica (según Cordani et al., 2000).

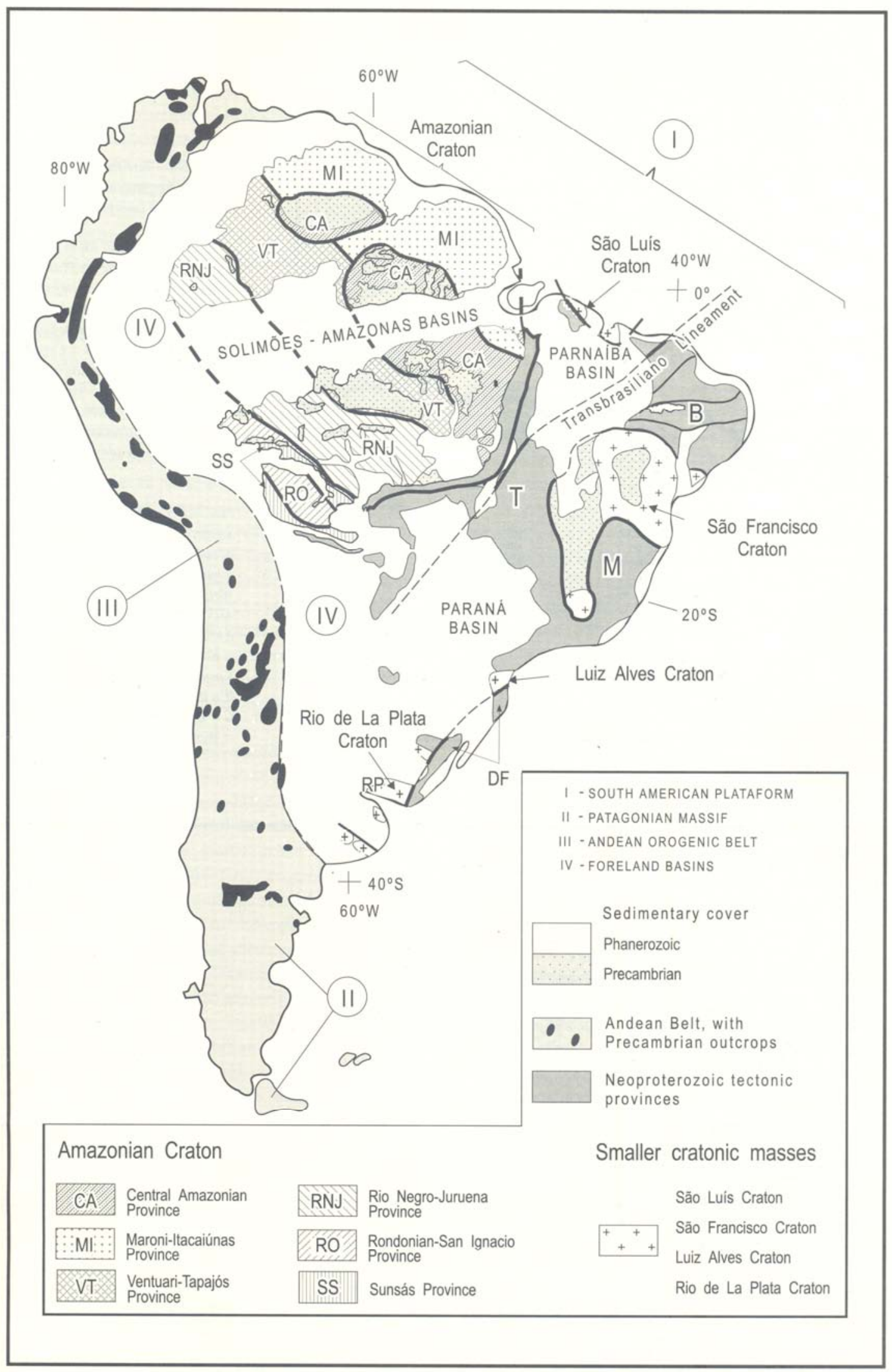


Figura 2. Subdivisión estructural del Distrito San Ramón. R: San Ramón, A: Ascensión de Guarayos, C: Concepción, T: Cerro Talcoso, F: Cerro San Francisco o Taperas. 1: Gneisses y granitos porfíricos, 2: Probablemente intrusivos básicos a ultrabásicos, 3: Migmatitas y gneisses, 4: Gneiss y granitoides, 5: Granitos porfiroides y gneisses indiferenciados, 6: Zona de rift, 7: Grupo Sunsás, 8: Terreno granito -gneiss, 9: Granitos y gneisses deformados (según Witschard et al., 1993).

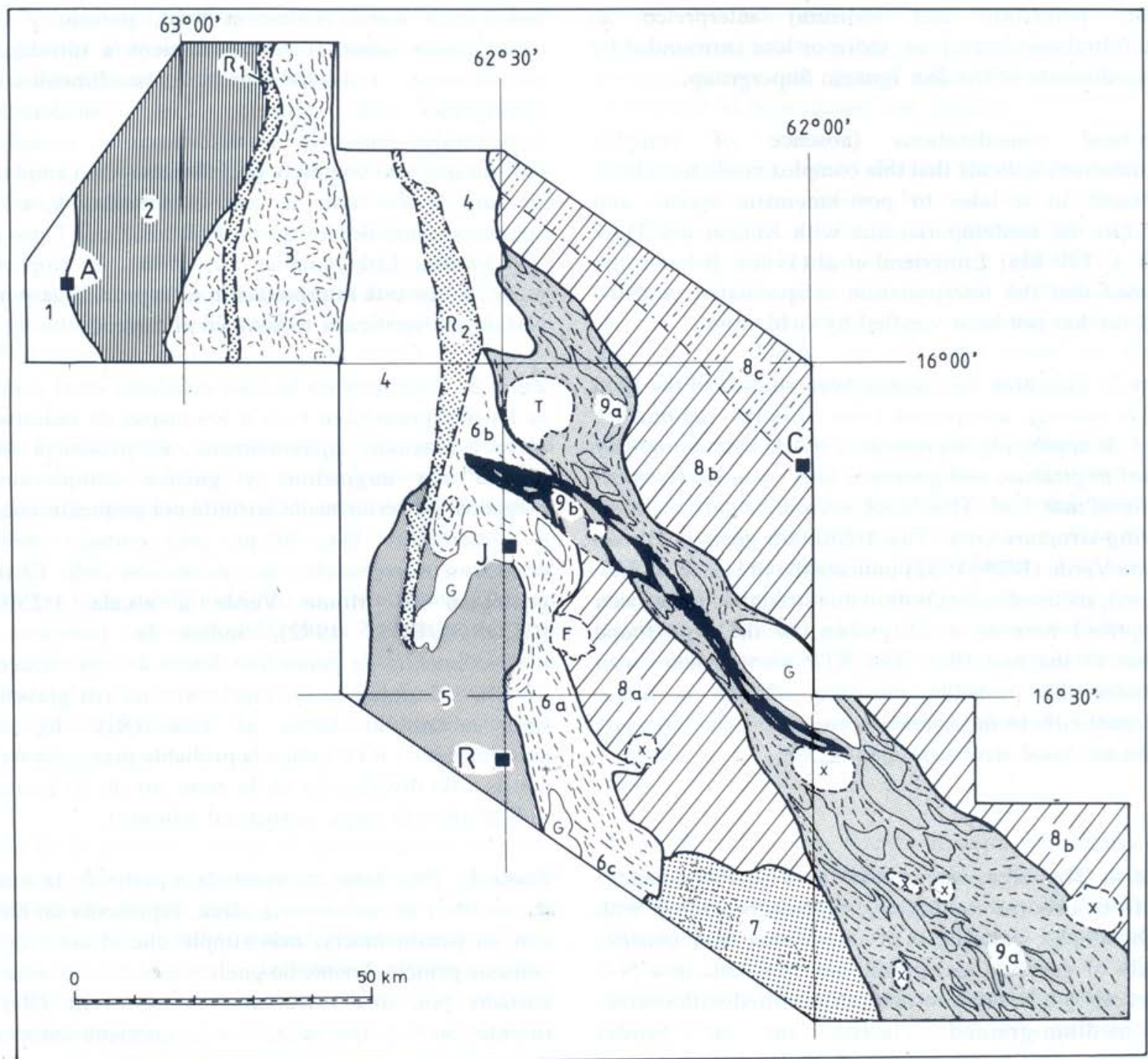




\title{
U-Pb and Sm-Nd geochronology from Yarituses suite and San Ramón
}

\section{granite, SW Amazonian craton: implications for the crustal evolution of the}

\section{Eastern Precambrian shield of Bolivia}

\author{
Ramiro Matos $^{1,3}$, Wilson Teixeira ${ }^{1}$, Mauro C. Geraldes ${ }^{2}$, Jorge S. Bettencourt ${ }^{1}$. \\ 1 Instituto de Geociências, Universidade de São Paulo, Rua do Lago 562, Cidade Universitária. 05508- \\ 080 São Paulo, SP, Brasil. E-mail: rmatoss@igc.usp.br; wteixeir@usp.br; jsbetten@usp.br; \\ 2 Faculdade de Geologia, Universidade do Estado do Rio de Janeiro, Rua São Francisco Xavier 524, \\ 20559-900 Rio de Janeiro, RJ, Brasil. E-mail: geraldes@uerj.br; \\ 3 Instituto de Investigaciones Geológicas y del Medio Ambiente, Universidad Mayor de San Andrés, \\ Calle 27, Pabellón Geología, Campus Universitario Cota Cota. La Paz, Bolivia. E-mail: \\ rmatoss@yahoo.com
}

Keywords: U-Pb and Sm-Nd data, Paleo- to Mesoproterozoic magmatism, San Ignacio Orogeny, Amazonian Craton. Eastern Bolivia

\section{INTRODUCTION}

Three dominant periods of granitic magmatism mark the evolution of the Paraguá terrane (Bettencourt et al., 2010), as supported by field geology, petrology and U-Pb (SHRIMP, TIMS and laser ablation-ICP-MS) and Sm-Nd results: the Yarituses suite, the San Ramón granite and the San Ignacio granites. The new U-Pb zircon ages document crust formation events during the time interval of $1673 \mathrm{Ma}$ to $1621 \mathrm{Ma}$. Our data show that these granitoid rocks are not only the granitic sills, as reported by Boger et al. (2005) for the so-called Lomas Maneches suite, instead they represent several, large contemporary plutons, in the San Javier and San Ramón areas such as the La Cruz, Refugio and San Pablo granites. This fact allows us to propose the Yarituses suite for such a widespread plutonic event over the Paraguá Craton. Meanwhile, we maintain the Lomas Manechis Granulite Complex (Litherland et al., 1986) as the oldest chrono-stratigraphic unit of the Bolivian Precambrian shield, as supported by the $1818 \pm 13 \mathrm{Ma}$ SHRIMP zircon age of granulite gneiss in the Las Rengas area, to the eastern of San Ignacio town (Santos et al., 2008). The other basement units of the Paraguá terrane are the Chiquitania Complex and San Ignacio Schist Group, as supported by radiometric data in the range between 1690 and 1830 (Boger et al.,2005; Santos et al., 2008). This paper reports and integrates SHRIMP, TIMS U-Pb and Laser Ablation zircon ages for the Yarituses suite and the San Ramón granite coupled with new Sm-Nd $\mathrm{T}_{\mathrm{DM}}$ ages. The data show that two granitic pulses, preceded the 1.37-1.34 Ga San Ignacio orogeny (Pensamiento Granitoid Complex), developed in an Andean-type magmatic arc.

The La Cruz granite crops out $15 \mathrm{~km}$ northeast from San Ramón, and constitutes two individual bodies hosted by the San Ignacio Schist Group. It shows clear contacts with the hosted San Ignacio Schist Group and presents a roughly sigmoidal-shape showing the typical deformation trend related to the 1.11.0 Ga Sunsás orogeny. This body (sample 558) is a pale pink leucocratic syenogranite with K-feldspar (perthite) and scarce biotite as the mafic mineral. The dominant texture is allotriomorphic granular. The Refugio granite is a large body that crops out along the road San Javier - Concepción. We have sampled this granite in two places: sample RF408 and SR83. The first one was collected $17 \mathrm{~km}$ eastern of San Javier, along the road to Concepción. The rock is a weakly foliated syenogranite, with hipidiomorficgranular texture; the alkali feldspar is subhedral, the plagioclase tends to be euhedral and the quartz occupies irregular intergranular interspaces. The mafic mineral is green biotite seldom chloritized. SR83 was sampled $8 \mathrm{~km}$ eastern of San Javier on the road to Talcoso hill. This is a white, massive to weakly 
foliated leucogranite. The K-feldspar is the microcline and orthoclase is subordinate. Plagioclase tends to be euhedral. The mafic mineral is biotite $(<2 \%)$; the principal accessory mineral is brown granular sphene. Santos et al. (2008) reported SHRIMP U-Pb zircon, monazite and titanite ages from the Refugio granite, which has zircons with no metamorphic rim, and yields a ${ }^{207} \mathrm{~Pb} /{ }^{206} \mathrm{~Pb}$ age of $1641 \pm 4 \mathrm{Ma}$ and $\mathrm{T}_{\mathrm{DM}}$ age of $1.66 \mathrm{Ga}\left(\varepsilon_{\mathrm{Nd}(\mathrm{t})}=+4.06\right)$. Finally the San Pablo granite, exposed $25 \mathrm{~km}$ southern of San Antonio de Lomerío, comprises an oriented batholith (11 km long by $4 \mathrm{~km}$ wide). The rock is a pink, fine to mediumgrained biotite-quartz-monzonite with an anhedral-granular texture. The plagioclase shows curved twins and quartz is anhedral, occupying irregular inergranular spaces. Biotite is the mafic mineral, straw to green in color.

The San Ramón granite represents a distinct igneous episode dated at $1429 \pm 4$ Ma (Santos et al., 2008) which invaded the metamorphic basement (Paraguá terrane), and still to be confirmed in the near future as an important rock generation event associated to others plutons in the area. The San Ramón granite is an intrusive body of ca. $35 \mathrm{~km}^{2}$ that hosts NNW shear zones, and probably extends farther west, but the contact relationships with the Chiquitania Gneiss Complex are largely hidden by Cenozoic sediments. The representative sample SR0401 is a gray, biotite granodiorite which has anhedral granular texture. Aggregates of mafic minerals show an irregular distribution. The main accessory minerals are: titanite, allanite and zircon. This pluton yields similar SHRIMP U/Pb zircon and titanite ages of $1429 \pm 4$ $\mathrm{Ma}$ (Santos et al., 2008). One coeval body has been recently reported on the Paragua terrane, close to the Brazilian-Bolivian boundary; zircons from the Cascata granite yields a $207 \mathrm{~Pb} / 206 \mathrm{~Pb}$ zircon evaporation age of $1412 \pm 5 \mathrm{Ma}$ (Cabrera et al., 2009). On the other hand, J. O. Santos (oral comm., 2009) obtained Hf isotope analysis from the San Ramón granite yielding a $\mathrm{T}_{\mathrm{DM}}$ model age of $1.7 \mathrm{Ga}$ and a $\varepsilon_{\mathrm{Hf}}$ between +3.5 and +5.5 . As such this suggests a juvenile accretion event of mainly Mesoproterozoic mantle source in Bolivia, as similar as recognized in the Brazilian counterpart, such as the Santa Helena and Rio Branco suites (Geraldes et al., 2001; Cordani and Teixeira, 2007; Bettencourt et al., 2010).

\section{RESULTS AND DISCUSSION}

Zircons from the La Cruz granite are between 100-220 $\mu \mathrm{m}$ long and generally have elongation ratios close to $2: 1$. The $U$ content of zircon is variable from 138 to $932 \mathrm{ppm}$, only one grain (4.1) contains $1413 \mathrm{ppm}$. The $\mathrm{Th} / \mathrm{U}$ ratios vary between 0.27 and 0.92 , denoting magmatic origin. The cathodoluminescent images show that most of the crystals are euhedral and have both parallel-zoning faces and distinct oscillatory zoning. SHRIMP analysis were carried out on eight zircon spots; five cores lie on the Concordia, three are discordant and using all result with a weighted mean $207 \mathrm{~Pb} / 206 \mathrm{~Pb}$ age of $1673 \pm 21 \mathrm{Ma}(\mathrm{MSWD}=0.67$ ), considered as the crystallization age (Fig 1). This age compares, within error, with two ages obtained by Boger et al. (2005) and Santos et al. (2008) for the Lomas Manechis suite, ranging from 1689 to $1663 \mathrm{Ma}$.

Zircons from Refugio granite (sample SR83) mostly occur as colourless elongated prisms; light brown stubby grains are also present. Cores and oscillatory zoning were observed in a number of zircon grains by transmitted-light microscopy. U-Pb TIMS analyses among four multigrain zircon fractions yield three concordant points with a $207 \mathrm{~Pb} / 206 \mathrm{~Pb}$ age of $1673 \pm 25 \mathrm{Ma}(\mathrm{MSWD}=36$ ), taken as the best estimate for the time of crystallization of the pluton.

Zircons from the San Pablo quartz-monzonite (SP601) appear to be colorless, transparent, with well crystallized prismatic form. Oscillatory zoning, observed in CL images, indicates their magmatic origin of the zircons, as also suggested by $\mathrm{Th} / \mathrm{U}$ ratios from 0.17 to 0.54 . From the eigth analyses an upper intercept $207 \mathrm{~Pb} / 206 \mathrm{~Pb}$ age of $1621 \pm 80 \mathrm{Ma}(\mathrm{MSWD}=134$ was obtained $(2 \sigma)$. 
These La Cruz, Refúgio and San Pablo granites (Yarituses suite) show $f_{\mathrm{Sm} / \mathrm{Nd}}$ ratios from - 0.38 to $-0.56, \mathrm{~T}_{\mathrm{DM}}$ model ages of $1.7-1.9 \mathrm{Ga}$, and calculated $\varepsilon \mathrm{Nd}(\mathrm{t})$ values from +0.2 to +4.0 . This suggests a significant contribution of a juvenile component in the petrogenetic process.

The 1.42 Ga San Ramón granite represents juvenile material accreted to the the metamorphic basement (Paraguá terrane) as is suggested by the $\varepsilon_{\mathrm{Hf}}$ between +3.5 and +5.5 and the $\mathrm{T}_{\mathrm{DM}}$ model age of $1.7 \mathrm{Ga}$. This pluton is coeval with the Cascata granite of $1.41 \mathrm{Ga}$ (Cabrera et al., 2009) and the Santa Helena and Rio Branco suites (Geraldes et al., 2001).

\section{CONCLUSIONS}

The Lomas Manechis complex, Chiquitania complex and San Ignacio Schist Group constitute the Paleoproterozoic polymetamorphic basement formed during the 1.82-1.69 Ga time interval. U-Pb SHRIMP zircon and Sm-Nd isotopic data have identified three dominant periods of granitic magmatism in the Precambrian framework. These are the Yarituses suite, The San Ramón granite and the San Ignacio granites. The Yarituses suite represents a juvenile accretion event during the time interval $1.67-1.62 \mathrm{Ga}$. Figueiredo et al. (2009) reported a coeval pluton in the Mato Grosso state (Turvo orthogneiss) which yields a $207 \mathrm{~Pb}-206 \mathrm{~Pb}$ zircon age of $1651 \pm 4 \mathrm{Ma}$, indicating a more regional scale for such event. U-Pb zircon data from the San Ramón granite yield $207 \mathrm{~Pb} / 206 \mathrm{~Pb}$ age of $1.43 \mathrm{Ga}, \mathrm{T}_{\mathrm{DM}}$ model ages of 1.6-1.7 and positive $\varepsilon_{\mathrm{Nd}}$ values. This granite is time correlated to the Santa Helena orogeny (1.48-1.42 Ga) and the Cascata granite (1.41 Ga).

The San Ignacio orogenic plutonism named the Pensamiento Granitoid Complex comprises synto late and late- to post-tectonic plutons that took place between 1370 and $1320 \mathrm{Ma}$, as constrained by the SHRIMP U/Pb ages and a $\mathrm{T}_{\mathrm{DM}}$ ages of $2.04-1.87 \mathrm{Ga}$ and $1.74-1.58 \mathrm{Ga}$ respectively. The syn-tectonic plutons have $\mathrm{Nd}$ signatures consistent with derivation from mixing of juvenile material with older crust, possibly within a continental margin setting; conversely, the late- to post-tectonic granitic pulses were largely originated in an intra-oceanic arc setting (Matos et al, 2009). This multiple tectonic and magmatic evolution of the Paragua terrane is comparable to the events in the RNJP and the RSIP of the SW Amazonian craton.

\section{REFERENCES}

Bettencourt, J. S., Leite, W. B. JR., Ruiz, A. S., Matos, R.,Payolla, B. L., Tosdal, R. M., 2010. The Rondonian san Ignacio province in the SW Amazonian Craton: an overview. J. South Am Earth Sci., $29,28-46$.

Boger, S.D., Raetz, M., Giles, D., Etchart, E., Fanning, M.C., 2005. U-Pb age data from the Sunsas region of Eastern Bolivia, evidence for the allochtonous origin of the Paragua Block. Precamb. Res. 139, 121-146.

Cabrera, R. F., Nogueira, S. F., Ruiz, A. S., Souza, M. Z. A., Macambira, M. J. B., Figueiredo, F. L. P., Lima, G. A., 2009. Caracterizaçao geológica e geocronológica $(\mathrm{Pb}-\mathrm{Pb})$ do Granito Cascata Terreno Paraguá - SW do Cráton Amazônico (MT). Boletim de Resumos Expandidos, Simpósio 45 Anos de Geocronología no Brasil, 15-17 de dezembro, 2009, São Paulo, Brasil, pp. 159-161.

Cordani, U. G., Teixeira, W., 2007. Proterozoic accretionary belts of the Amazonian Craton. In: Hatcher, R.D. Jr., Carlson, M. P., McBride, J. H., and Martinez Catalán, J. R. (Org.). The 4D Framework of Continental Crust. GSA Memoir. Boulder, Colorado: Geol. Soc. Am Memoir 200, p. 297-320.

Figueiredo, F. L. P., Ruiz, A. S., Souza, M. Z. A., Macambira, M. J. B., 2009. Dados Isotópicos $\mathrm{Pb}-\mathrm{Pb}$ em Zircão do Ortognaisse Turvo (Terreno Paraguá - SW do Cráton Amazônico). Boletim de 
Resumos Expandidos, Simpósio 45 Anos de Geocronología no Brasil, 15-17 de dezembro, 2009, São Paulo, Brasil, pp. 177-179.

Geraldes, M. C., Van Schmus, W. R., Condie, K. C., Bell, S., Teixeira, W., Babinski, M., 2001. Proterozoic geologic evolution of SW part of the Amazonian craton in Mato Grosso State, Brazil. Precamb. Res. 111, 91-128.

Litherland, M., Annells, R. N., Appleton, J. D., Berrange, J.P., Blommfield, K., Burton, C. C. I.; Darbyshire, D. P. F., Fletcher, C. J. N., Hawkins. M.P., Klinck, B.A., Llanos, A., Mitchell, W. I., O'connor. E.A., Pitfield. P.E.J., Power, G., Webb, B.C., 1986. The geology and mineral resources of the Bolivian Precambrian Shield, British Geological Survey, Overseas Memoir 9. London. 153 p.

Matos, R., Teixeira, W., Geraldes, M. C., Bettencourt, J. S., 2009. Geochemistry and Nd-Sr Isotopic Signatures of the Pensamiento Granitoid Complex, Rondonian-San Ignacio Province, Eastern Precambrian Shield of Bolivia: Petrogenetic Constraints for a Mesoproterozoic Magmatic Arc Setting. Geologia USP. Série Científica, 9, 2, 89-117.

Santos, J. O. S., Rizzotto, G.J., Mcnaughton, N. J., Matos, R., Hartmann, L. A., Chemale Jr., F., Potter, P. E., Quadros, M.L.E.S., 2008. Age and autochthonous evolution of Sunsás Orogen in West Amazon Craton based on mapping and U-Pb geochronology. Precamb. Res. 165, 120-152.

Teixeira, W., Geraldes, M. C., Matos, R., Ruiz, A. S., Saes, G., Vargas-Mattos, G., 2010. A review of the tectonic evolution of the Sunsás belt, SW portion of the Amazonian Craton. J. South Am Earth Sci., 29, 47-60.

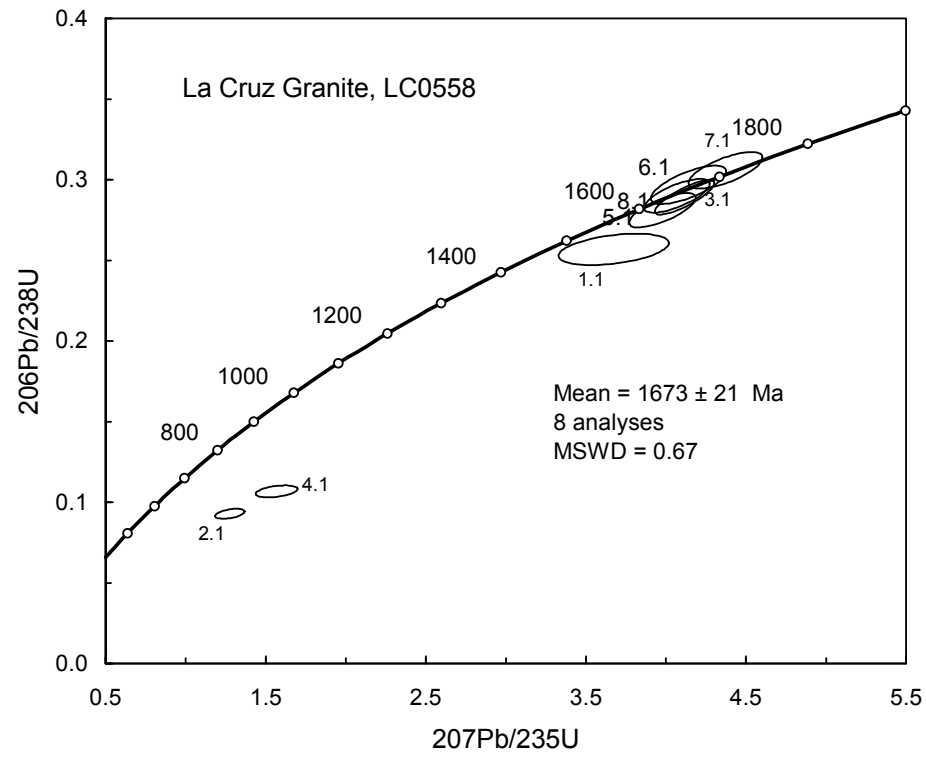

Figure 1. SHRIMP zircon U-Pb concordia diagram of the sample LC0558, La Cruz granite. 
Apêndice A- Descrição sintética dos afloramentos visitados (continua)

No Local

2004

2 San Ramón

10B Talcoso

San Javier

Candelaria

Suponema

Santa Ana

Pachorrí

San Silvestre

San Silvestre

San Javier

El Cusi

San Pedro

San Luis

Puquio Norte

Pejich

Pejichi

Santa Rosa

6 Fazen. Jalisco

47 Fazen. La Cruz

2005

Piso Firme

Cerro El Puente

Cerro Leyton

Porvenir

Cerro Pelado

Cerro Pelado

Cerro Pelado

La Mechita

9 Co. La Trampa

Florestal

Santa Rosa

Florest-Camp

Guadalupe

San Martín

San Martin

Don Mario

Makanaté

2 Río Negro

Río Negro
Unidade

Granod. S. Ramón

Suite S. Ignacio

Suite S. Ignacio

Granito San Andrés

Suite S. Ignacio

Granito San Rafael

Suite S. Ignacio

Granito Refugio

Granito Pobrecito

GranitoPrimavera

Granito Taperas

Granito San Pedro

Granito Cachuela

G.X. San Ignacio

G.X. San Ignacio

G.X. San Ignacio

G.X. San Ignacio

G.X. San Ignacio

Granito La Cruz

Granófiro P. Firme

Granito S.Cristobal

Granito S.Cristobal

Granito Porvenir

Gran. Diamantina

Gran. Diamantina

Gran. Diamantina

Gran. Diamantina

Gran. San Martín

Granito La Junta

GranitoLa Junta

Granito La Junta

Granito La Junta

C. L. Manechis

C. L. Manechis

Gran. Señoritas

C. L. Manechis

C. L. Manechis

C. L. Manechis

Amostre $X$ (utm) Y (utm)

401

402

40

405

406

407

408

409

410

411

412

414

415

4

418

419

420

501

502

503

504

505

506

507

508

510

511

512

513

514

515

$516 \quad 21445$

$518 \quad 574318$

$519 \quad 574318$
8263237 Rocha de cor cinza escuro, inequigranular, biotítica com foliação vertical fraca

5599298221891 Rocha porfirítica de coloração cinza esbranquiçada a rosa, de granulação grossa

5542368100752 Rocha de cor rosa, granulação média, biotítica com ligeira orientação preferencial

5917408203230 Gnaisse milonítico cinza claro, com porfiroclastos de feldspato potássico de 2 a $4 \mathrm{~cm}$

8173146 Rocha básica foliada de cor esverdeado, contendo anfibólio e plagioclásio.

8152671 Rocha de granulação média de coloração cinza claro a rosa, biotítica

8149359 Gabro de granulação fina, coloração preta e estrutura maciça compacta.

8201088 Rocha de cor rosada, maciça e levemente porfirítica, granulação média

5696408203646 Rocha de granulação grossa e cor castanho claro, biotítico

8201135 Rocha de cor branca a cinza, granulação média, friável caraterizada pela muscovita.

649158189752 Rocha de cor castanho claro, maciça, granulação grossa e porfirítica em cristais de $4 \mathrm{~cm}$

5803168157132 Rocha de granulação grossa, coloração rosada e porfirítica, com biotita em agregados

87661686071 Rocha de granulação grossa, coloração rosada, porfirítica inequigranular e biotítica

8167249 BIF composto pela alternância de bandas centimétricas de chert e hematita

07398165707 Grauvaca quartzosa, cor ocre e estrutura foliada, metamorfisada na fácies xisto verde

5602938171681 Filito sericítico com foliação e lineação de crenulação. Fácies xisto verde

6353768493848 Rocha de granulação fina, cor rosa pálido e estrutura maciça, rica em feldspato

6237638479614 Rocha de cor rosa, foliação fraca com biotita em linhas irregulares.

6253028474694 Rocha de cor rosa pálido, granulação fina a média e estrutura gnáissica

8406505 Rocha maciça de granulação fina a média e coloração rosada, contém hornblenda.

6616188392877 Rocha de cor rosa claro, estrutura maciça e inequigranular, porfirítica, com biotita dispersa

6624598385600 Rocha de granulação média a grossa e coloração esbranquiçada, biotita dispersa

608358376150 Rocha de granulação média a grossa (cristais de $1 \mathrm{~cm}$ ) e cor branca, biotita dispersa

6593358367510 Granito de granulação média a grossa, maciço e cor rosa esbranquiçado com biotita

6426538367578 Gnaisse bandado e foliado, cor rosa com cristais prismáticos de hornblenda de $5 \mathrm{~mm}$

621548342436 Gnaisse de granulação grossa, coloração rosa, com bandas de clorita.

626018324646 Rocha branca rosada de granulação grossa, maciça, inequigranular; contém biotita

8313212 Rocha de cor branca rosada, maciça e porfirítica, cristais de 2 a $3 \mathrm{~cm}$.

22938309407 Rocha cor cinza rosada, foliada, granulação média, fenocristais de $2 \mathrm{~cm}$

8298287 Gnaisse com porfiroclastos de feldspato potássico de 2-3 cm, rico em biotita.

8294599 Ganaisse leucocrático de granulação fina com hornblenda em bandas finas

080658 Rocha com assinatura pegmatítica com feldspato potássico, quartzo e muscovita.

8289767 Gnaisse bem foliado, com coloração cinza escuro e cisalhado. 
Río Negro

Monte Verde

San Pedro

Faz. Las Lajas

Faz. Las Lajas

Fazenda 26

Faz. Tacucito

Faz Tacucito

San Antonio

Sta. Catalina

San Silvestre

San Pablo

Fazenda Vibosi

Fazenda Vibosi

Calama

Santa Teresa

Noviquia

Panorama

Cruce

Santa Rosario

Surusubi

Río Tobosí

S.A. Lomerío

Motacusal

Motacusal

Motacusa

Monterito

San Rafaelito

Faz. Sujalito

Faz. Naranjal

Faz. Limones

El Puente

El Cerrito

Guarayos

Puesto Nuevo

Puesto Nuevo

Sta. Rosa Mina

Sta. Rosa Mina

Faz. La Honda

Faz. Jalisco

Faz. La Cruz 2007
Pegmatita

C. L. Manechis

C. L. Manechis

C. L. Manechis

C. L. Manechis

C. L. Manechis

C. L. Manechis

C. L. Manechis

C. L. Manechis

C. L. Manechis

C. L. Manechis

C. L. Manechis

C.G. Chiquitania

C.G. Chiquitania

Suite Sunsás

Suite Sunsás

C.G. Chiquitania

El Cármen

G.X. San Ignacio

Suite S. Ignacio

Suite S. Ignacio

Suite S. Ignacio

Série Sunsás

G.X. San Ignacio

Suite S. Ignacio

Suite S. Ignacio

Suite S. Ignacio

Suite S. Ignacio

G.X. San Ignacio

G.X. San Ignacio

C.G. Chiquitania

Suite S. Ignacio

C.G. Chiquitania

Suite S. Ignacio

Suite S. Ignacio

Gran. Marimonos

Suite S. Ignacio

G.X. San Ignacio

G.X. San Ignacio

G.X. San Ignacio

Granito La Cruz
5743188299328 Rocha de cor castanho, granulação grossa cortando um tonalito

5742198298175 Tonalito de coloração cinza esverdiado, com fenocristais fortemente cisalhados

5751888290147 Rocha de granulação fina, coloração cinza escuro rica em quartzo e biotita.

5807808283204 Augen gnaisse com grãos de feldspato potássico de $4 \mathrm{~cm}$, sentido sinistral

5810868282637 Milonito gerado em uma zona de cisalhamento de $90 \mathrm{~cm}$ de largura

5819518280039 Gnaisse tonalítico bandado, com pequenas dobras e foliação transposta.

5851658276681 Gnaisse de granulação fina com quartzo, feldspato potássico e biotita.

5880158276212 Gnaisse de granulação fina com quartzo, feldspato potássico e biotita.

5885768275523 Aplito de granulação fina, sacaroide cortando um gnaisse de granito biotítico

5972328262192 Gnaisse de granulação fina com biotita e veios de granito grosso.

5972398261268 Augen gnaisse com porfiroblastos de $3 \mathrm{~cm}$ diâmetro, cisalhamento sinistral

5995468255538 Gnaisse de granulação fina, cor castanho, com granada de até $2 \mathrm{~mm}$

5985098248041 Gnaisse com faixas de biotita parcialmente contínuas; bandamento de 1 a $5 \mathrm{~cm}$

5982138245104 Anfibolito de granulação fina e coloração esverdeada com estrutura foliada

6085128222073 Tonalito biotítico de cor cinza, granulação média e estrutura maciça

8216499 Granito biotítico porfirítico com cristais de feldspato potássico de 2 a $4 \mathrm{~cm}$

6083458187286 Granito gnáissico biotítico, cor cinza, granulação média a grossa, porfirítico

6110948169631 Gnaisse biotítico, coloração rosada, granulação média e fenocristais de $2 \mathrm{~cm}$

6117438166226 Xisto quartzo micáceo, friável, estrutura foliada e coloração cinza clara

6117478162032 Granito gnáissico rosa, granulação média, faixas discontinuas de biotita

6121078150827 Gnaisse foliado de granulação média e dobras menores centimétricas

6191618151488 Gnaisse de cor rosa, granulação média com faixas de biotita em "Z" .

6299738148317 Arenito de grão fino a médio, cor amarelo com camadas cruzadas

8139170 Rocha meta-sedimentar de granulação grossa e coloração castanha clara.

6313608142183 Gnaisse cor rosa claro, granulação média, com presença de biotita e muscovita

6296328142407 Lajes cor cinza esbranquiçada, granulação média e com biotita e muscovita

6096828153006 Gnaisse de cor rosa, com granulação média e faixas de biotita de traço irregular

5921778160963 Granito de granulação grossa, róseo, biotita em agregados de 1 centímetro

5686358161055 Riolito cinza escuro de granulação muito fina, compacto com textura porfírica

5646118160509 Metabasalto foliado de cor cinza esverdeada em afloramentos de lajes

5355518180534 Gnaisse biotítico, cor acinzentado, fortemente foliado, granulação média

5089168194888 Gnaisse granítico com biotita, foliado a maciço, de granulação grossa

4928098223593 Gnaisse de granulação média, faixas de biotita, dobras decimétricas

4785478243487 Gnaisse de granulação média com faixas de biotita e magnetita dispersa

8158302 Gnaisse granítico de granulação grossa, cor rosa, fenocristais de feldspato

8198302 Granito maciço de granulação grossa, fenocristais de feldspato

5559048170806 Gabro de cor esverdeada com manchas brancas e granulação grossa.

5593278171677 Filito sericítico de coloração verde acinzentada, brilho sedoso

5601108171312 Filito de coloração esbranquiçada a castanho claro, friável.

631968173324 Metabasalto cinza esverdeado, contendo magnetita de 1-2 mm.

5650178173086 Rocha de cor avermelhada e granulação fina média, estrutura maciça 
1 Huanchaca

Huanchaca

Vera Cruz

EI Retiro

Papayo

2008

Las Maras

2 Faz. Las Maras

Santa Rosa

4 Fazenda Suarez

5 Aguas Frías

Turunapé
Dique Huanchaca PNK71 747988

Granito Discordancia PNK72 739867

Gran.Campamento PNK73 725851

Gran.Campamento PNK74 717774

C. L. Manechis PNK75 688339

Granito Las Maras

G.X. San Ignacio

Granito Refugio

Casa de Piedra

Casa de Piedra

Casa de Piedra

LM81 544000

LM82 545054

SR83 560392

CS84 554580

AF85 554946

CT86 555275
8381290 Diabásio cinza escuro esverdeado, granulação fina a média

8389035 Rocha de textura rapakivi en cristais de 2 a $4 \mathrm{~cm}$, com biotita

8326753 Gnaisse cinza claro, granulação grossa, friável, escasa biotita.

8263573 Rocha maciça, granulação média, porfirítica, com quartzo defumado

8232314 Gnaisse foliado, cor cinza, com faixas de biotita ate 2 centímetros
8204744 Rocha maciça de granulação grossa, cor rosa esbranquiçada

8202521 Metaturbidita de cor cinza com estratificação gradada e cruzada

8202484 Granito maciço, granulação grossa, cor esbranquiçada

8242059 Granito gnáissico com estrutura foliada, biotítico e cor esbranquiçada.

8239138 Granito gnáissico de cor rósea e biotita como mineral ferromagnesiano.

8236662 Granito de cor rosa, biotítico e com foliação pouco expressiva. 
13 Chaquipoc

14 San Juan

15 San Juan

16 San Juan

17 San Silvestre

18 Murciélago

19 Boquí

21 Totomaca

22 Correreca

23 Correreca

24 Verano

25 Santo Corazón

26 Santo Corazón

27 Santo Corazón

Casa de Piedra

G.X. San Ignacio

C.G. Chiquitania

G.X. San Ignacio

GranitoTasseoro

GranitoTasseoro

GranitoTasseoro

Formação Piococa

Serie Sunsás

Serie Sunsás

Serie Sunsás

Granito Tarechi

C.G. Chiquitania

Suite S. Ignacio

C.G. Chiquitania

Suite S. Ignacio

Suite S. Ignacio

Granito Tauca

Granito Tauca

Granito Tauca

Grupo El Portón

Grupo Murciélago

Grupo Boquí

Granito Correreca

Granito Correreca

Granito Correreca

Granito S. Corazón

Granito S. Corazón

Granito S. Corazón

Fazenda Isabel Rincón del Tigre

29 Qda Fortuna Rincón del Tigre

30 Rincón d Tigre Rincón del Tigre

Rincón d Tigre Rincón del Tigre

31 Rincón d Tigre Rincón del Tigre

32 Portería Rincón del Tigre

33 Portería Rincón del Tigre

34 Vibosi

Grupo Vibosi

35 Don Mario

2009
CT87 555275

GG88 552938

AT89 538390

EP10 539791

TS81 731409

TS82 729847

TS83 731409

PC84 733868

SD85 754636

SD86 754593

SD87 769051

TA88 776526

SP89 192612

SP810 193647

SP811 194160

8053057 Anfibolito bandado, cor cinza claro a escuro e de origem sedimentar.

TU814 2224148043149 Rocha de granulação fina a média, de cor cinza a rosa, pegmatítico

TU815 2224148043149 Gnaisse de granulação grossa, tonalítico, com biotita e magnetita

TU816 2169798041137 Gnaisse de granulação grossa, tonalítico, com biotita e magnetita

SS817f 2216157976810 Arenito de granulação media a grossa,avermelhado e friável.

MU817 2823267099881 Calcário laminar cruzado, de cor cinza claro com partes avermelhadas

BO818 2857128002551 Diamictito com clastos angulosos de até $3 \mathrm{~cm}$ e cor vermelha.

CO820 2888838002057 Rocha de granulação grossa, cor rosa, estrutura foliada

CO821 2934678002840 Rocha de granulação grossa, estrutura foliada, matriz de clorita e biotita

C0822 2951098002987 Rocha de granulação média, cor rosa, biotítica, estrutura maciça

CO823 3052388009432 Rocha de granulação grossa, cor esbranquiçada e cisalhada

SC824 $305238 \quad 8010134$ Granito cinza esverdeado, quartzo translúcido e defumado e hornblenda

SC825 3052388010134 Granito cinza esverdeado, quartzo translúcido e defumado e hornblenda

SC826 3090818012348 Granito maciço, rosa, granulação fina a média, com quartzo translúcido

RT827 3353728012420 Rocha máfica de cor cinza, estrutura foliada com veios de serpentina

RT828 3353728012420 Rocha da unidade ultramáfica, maciça de cor cinza.

RT829 3353728012420 Rocha de cor cinza esverdeada, maciça com piroxênio e olivino

RT830 3482428002160 Rocha de cor cinza esverdeada, maciça com piroxênio e olivino

RT831 3482428002160 Rocha afanítica, foliada, com plagioclásio e vesículas estiradas.

RT832 3675727988594 Rocha maciça, leve, cor cinza claro e intemperizada.

RT833 3760737987032 Norito de granuloação média, cor cinza escuro, com olivina e piroxênio

RT834 3706967984011 Norito de granulação fina a média e cor cinza escuro.

RT835 3706267981312 Diamictito pardo avermelhado, clastos angulosos a subarredondados

RT836 2059628075794 Gnaisse porfiroblástico bandado com K feldspato e faixas de biotita.

CA101 5554828210498 Rocha volcanosedimentar de cor cinza, porfirítica; tem foliaçã transposta

1 Cachuela Sunsás 
2 Moscú

3 Totaitú

4 La Estrella

5 San Andrés

6 San Pablo

7 Concepción

8 Villa Nueva

9 San Rafae

10 San Rafael

$11 \mathrm{~L}$. Manechis

12 Sta Rosa Mina

13 Sta Rosa Mina
G.X. San Ignacio

Sunsás

San Andrés

San Andrés

Sunsás

C.G Chiquitania

C.G.L. Manechis

G.X. San Ignacio

C.G Chiquitania

C.G.L. Manechis

G.X. San Ignacio

G.X. San Ignacio
MO102 5561498216244 Xisto actinolítico con granada dispersa de 2 a $3 \mathrm{~mm}$. Granulação grossa a fina

T0103 5508798202887 Gabro de granuloação fina a média, de cor cinza esverdiado, masivo, pirita dispersa

5751308202196 Augen gnaisse milonítico, contém xenolitos de granodiorito; está migmatizado

SA104 5901688189040 Augen gnaisse milonítico cor cinza con fenoblastos de FK de 2 a $3 \mathrm{~cm}$.

SP105 $591928 \quad 8193416$ Fm. Zapocoz da série Sunsás. Cisalhamento S-C predominantemente dextral

C0106 6044758212958 Migmatitos flebíticos y gnaissicos com biotita como mineral máfico formando dobras

VN107 6822008236660 Mataçoes arredondados de uma rocha compacta, cor cinza de granulação fina.

7292728154942 Xisto muscovítico alterado, friavel, com granada de 3-5 mm de diámetro

SRF10 $754517 \quad 8127406$ Migmatito gnaissico, flebítico; contem granada, biotita, plalgioclásio e horblenda

LM109 8000638156066 Gnaisse leucocrático foliado com faixas claras e escuras, cor acinzentado

SM101( 5560838171188 Metagabro de granuloação media, cor cinza esverdiado, masivo.

LH1011 5609378171818 Filito sericítico cinza esverdiado cisalhado com foliação de crenulação 


\section{Apêndice B- Dados experimentais}

Neste Apêndice apresentam-se as metodologias correspondentes a geoquímica e geocronologia no IGc-USP. Os dados estão subdivididos nas tabelas abaixo:

B1.Geoquímica

B2.Resultados analíticos U-Pb SHRIMP

B3.Resultados analíticos U-Pb TIMS

B4.Resultados analíticos U-Pb LA-ICP-MS

B5.Resultados analíticos $\mathrm{Sm}-\mathrm{Nd}$ e $\mathrm{Rb}-\mathrm{Sr}$

\section{Apêndice B1, Geoquímica}

As análises de óxidos $\left(\mathrm{SIO}_{2}, \mathrm{TIO}_{2}, \mathrm{Al}_{2} \mathrm{O}_{3}, \mathrm{Fe}_{2} \mathrm{O}_{3(\mathrm{~T})}, \mathrm{MnO}, \mathrm{MgO}, \mathrm{CaO}, \mathrm{Na} 2 \mathrm{O}, \mathrm{K}_{2} \mathrm{O}\right.$ e $\left.\mathrm{P}_{2} \mathrm{O}_{5}\right)$ e elementos traços (Ba, Ce, Cl,Co, Cr, Cu, F, Ga, La, Nb, Nd, Ni, Pb, Rb, S, Sc, Sr, Th, U, V, Y, Zn, e $\mathrm{Zr}$ ), para as amostras de Pré-cambriano Boliviano, foram realizadas no Laboratório de Fluorescência de Raios-X (F-RX) do Departamento de Mineralogia e Geotectônica do Instituto de Geociências USP, com o equipamento instrumental automático da marca Philips, modelo PW2400. As pastilhas prensadas fornecem os dados dos elementos traços, enquanto a concentração dos maiores é dada pela amostra das pastilhas fundidas. O procedimento é analisar essas pastilhas, através da fluorescência de Raios-X (F-RX), cujo espectro faz a excitação das amostras, que fornecerão uma resposta de acordo com sua composição.

As análises de terras raras foram realizadas no Laboratório de Química e ICP-AES do Departamento de Mineralogia e Geotectônica, Instituto de Geociências da USP. O equipamento utilizado é o ICP-AES, um nebulizador ultrassônico acoplado ao espectrômetro de emissão atômica com plasma induzido

\section{Apêndice B2 Métodos isotópicos e procedimentos analíticos}

As análises geocronológicas foram realizadas no centro de Pesquisas Geocronológicas (CPGEO) do Instituto de Geociências (IGc) da Universidadde de São Paulo (USP), tendo sido empregados tres métodos nos estudos das rochas do Pré-cambriano boliviano: U-Pb, Sm-Nd e Rb-Sr. Para a sistemática U-Pb os cristais de zircão foram datados por SHRIMP, TIMS e LA-MCICP-MS. Os estudos geocronológicos por SHRIMP foram realizados na Academia Chinesa de 
Ciências Geológicas (Pequim) e os LA-ICPMS no laboratório geocronológico do Instituto de Geociências da UnB, em Brasilia.

\section{Análises U-Pb SHRIMP}

As datações U-Pb (zircoes) SHRIMP (Sensitive High Resolution lon Microprobe) foram executadas através de cooperação científica com a Academia de Ciencias da China. Os grãos de zircão foram escolhidos por catação manual sob lupa binocular e montados em discos de resina epóxi com 2,54 cm de diámetro e $6 \mathrm{~mm}$ d espessura, em seguida, polido e revestido com película de ouro. Os zircões foram documentados com imagens de luz transmitida e refletida, bem como por catodoluminescência (CL) com o intuito de revelar as suas estruturas internas e externas. As análises isotópicas U-Pb foram realizadas utilizando o SHRIMP-II, operado remotamente desde do CPGeo. Detalhes dos procedimentos analíticos dos zircões usando SHRIMP foram descritos por Compston et al. (1984) e Williams (1997). Os padrões utilizados para medição das concentrações e das razoes isotópicas foram o SL-13e AS-57. Os erros das contagens são absolutos e referemse a $1 \sigma$, em quanto das idades são apresentadas com $2 \sigma$. Os resultados foram calculados em programa ISOPLOT/Ex, versão 2,10, de Ludwig (2003), observando-se as constantes recomendadas pela IUGS (Steiger e Jager, 1977).

\section{Análises U-Pb TIMS}

As amostras do estudo foram trituradas em britador, moídas em moinho de disco e posteriormente, peneirada em diferentes intervalos de granulometria para obtenção de concentrado de minerais. Este concentrado é separado numa mesa de Wiffley para a separação dos minerais pesados como o zircão que foi utilizado no presente caso.

Este novo concentrado e então levado a um separador magnético do tipo Frantz, cujo objetivo e separar a fração não magnetita (zircão) para posterior processamento em líquidos densos (Bromoformio $d=2,6$ e lodeto de Metileno d=3,2). O concentrado de zircão e então lavado e secado em seguida, submetido ao separador magnético (Frantz), onde varias frações de zircão são obtidas em função da susceptibilidade magnética. A fração não magnética foi então processada em líquidos densos (bromoformio e iodeto de metileno) de onde resultou o concentrado com zircões. Os zircões produziram frações que variaram entre $M(6)$ (fração mais magnética) a $M(-2)$ (fração menos magnética). A seleção fina (multi-graos) foi realizada por catação manual sob lupa binocular, utilizando-se para pesagem a relação densidade versus volume media dos cristais. 
Os grãos foram dissolvidos em micro-bombas de teflon sob placa aquecedora, sendo que o $\mathrm{Pb}$ e $\mathrm{U}$ foram separados através de colunas de resina aniônica, segundo procedimentos descritos em Basei et al (1995) e Passarelli et al 2008. O traçador (Spike) utilizado no laboratório U-Pb foi o ${ }^{205} \mathrm{~Pb}$, e o branco total obtido foi da ordem de 10pg durante o período das analises.

As razoes isotópicas foram medidas em um espectrômetro de massa multicolector Finnigan MAT262. Os valores médios medidos para os padrões NBS-981 e NBS-983 são respectivamente de: ${ }^{204} \mathrm{~Pb} /{ }^{206} \mathrm{~Pb}=0,05903 \pm 0,02 \%$ e $0,000368 \pm 3 \% ;{ }^{207} \mathrm{~Pb} /{ }^{206}=0,9147 \pm 0,01 \%$ e $0,071212 \pm 0,05 \%$; $\mathrm{Pb}{ }^{208} \mathrm{~Pb} /{ }^{206} \mathrm{~Pb}=2,1675 \pm 0,01 \%$ e $0,013617 \pm 0,06 \%$ com variação de $1 \sigma$. O fator de correção de fracionamento utilizado para normalização é de 0,095 u.m.a. (unidade de massa atómica). Os resultados foram calculados no programa Isoplot 2003 (Ludwig, 2003) e apresentados com desvios de $2 \sigma$. As constantes utilizadas são as recomendadas por Steiger e Jager (1977).

\section{$U-P b$ LA-MC-ICP-MS}

De maneira geral, este método proporciona resultados comparáveis aos obtidos pelo SHRIMP, muito embora o diametro da analise pontual seja maior, o que limita de certo modo a sua aplicação para cristais relativamente de maior granulação.

Os grãos de zircão selecionados foram montados em disco de resina epóxi, em seguida, polido e limpos com uma solução de ácido nítrico 3\%. As análises espectrométricas foram realizadas em um espectrômetro Thermo Neptune MC-ICP-MS acoplado com um sistema de ablação por laser NewWave Nd: YAG UP213. Detalhes sobre o laboratório da UnB estão descritos em Buhn et al., (2009).

As análises espectrométricas foram realizadas utilizando os padroes GJ-1 e Temora-2, a fim de controlar o fracionamento das medidas pelo LA-ICP-MS. Para posterior normalizacao e/ou correção dos desvios ("bias") nas medidas de razões isotópicasOs dados brutos foram processados off-line e reduzidos utilizando uma planilha do Excel (Buhn et al., 2009), fazendo uso do modelo de composição de Pb de Stacey e Kramer, 1975.

\section{Método Sm-Nd}

As análises $\mathrm{Sm}-\mathrm{Nd}$ foram realizadas em rocha total e os procedimentos utilizados seguiram os descritos em Sato (1998). No CPGeo os valores médios medidos para os padrões La Jolla e BCR-1, são ${ }^{143} \mathrm{Nd} /{ }^{144} \mathrm{Nd} 0.511849 \pm 0,000025$ e $0.512662 \pm 0,000027$ respectivamente com variação de $1 \sigma$. Os erros máximos medidos das razoes ${ }^{143} \mathrm{Nd} /{ }^{144} \mathrm{Nd}$ e ${ }^{147} \mathrm{Sm} /{ }^{144} \mathrm{Nd}$ em amostras foram 
menores que $0,004 \%$ e $0,01 \%$ respectivamente, com nível de precisão de $2 \sigma$. As razoes isotópicas de Nd foram obtidas em espectrômetro de massa multi-coletor Finnigan MAT-262, enquanto as de Sm em espectrômetro mono-coletor VG-354 do laboratorio. O branco total foi baseado em valores publicados em DePaolo et al. (1991): ${ }^{143} \mathrm{Nd} /{ }^{144} \mathrm{Nd}=0.7219$ e ${ }^{143} \mathrm{Nd} /{ }^{144} \mathrm{Nd}(\mathrm{CHUR})_{0}=0.512638$, ${ }^{147} \mathrm{Sm} /{ }^{144} \mathrm{Nd}(\mathrm{CHUR})_{0}=0.1967$ e $\lambda_{147} \quad=6,54 \times 10^{-12}$ anos ${ }^{-1}$. Para as interpretações foram utilizadas idades modelo $\mathrm{T}_{\mathrm{DM}}$ (representando eventos de diferenciação crosta-manto), bem como os valores de $\varepsilon_{(\mathrm{T})}$, modelados para a idade obtida pelo método $\mathrm{U}-\mathrm{Pb}$, quando pertinente. Os cálculos estes parâmetros estão sumarizados abaixo (DePaolo, 1981)

O Sm e o Nd são elementos terras raras leves (LREEs), do grupo 3B da tabela periódica; formam íons de forte carga (+3) e têm número atômico elevado. Isso faz com que eles não se difundam facilmente no estado sólido e forneçam um sistema mais estável, do que das outras metodologias. Além da idade isocrônica, que tem interpretação similar a metodologia Rb-Sr e por isso não é o alvo desse trabalho, o sistema Sm-Nd oferece a Idade Modelo e a notação $\varepsilon N d$, como instrumentos de estudo, amplamente utilizados nessa metodologia.

O parâmetro petrogenêtico $\varepsilon_{\mathrm{Nd}}$, como o de Sr, compara a razão inicial $\left({ }^{143} \mathrm{Nd} /{ }^{144} \mathrm{Nd}\right) \mathrm{da}$ amostra com a do CHUR (reservatório condrítico uniforme), para indicar a fonte que gerou a rocha. O $\mathrm{Nd}$ é um pouco mais incompatível do que o $\mathrm{Sm}$, fazendo com que haja maior concentração de $\mathrm{Nd}$ em relação ao $\mathrm{Sm}$, em rochas mais evoluídas, ou seja na crosta. Isso implica em razões $\mathrm{Sm} / \mathrm{Nd}$ menores na crosta do que no manto, e conseqüentemente, menores razões ${ }^{143} \mathrm{Nd} /{ }^{144} \mathrm{Nd}$, já que o ${ }^{143} \mathrm{Nd}$ é fruto do decaimento radioativo do ${ }^{147} \mathrm{Sm}$. Se a razão da amostra, na época de cristalização da rocha, for maior do que a do manto, o valor de $\varepsilon_{\mathrm{Nd}}$ será positivo, com enriquecimento relativo em ${ }^{147} \mathrm{Sm}$, indicando que a fonte dessa rocha seria o manto, rico nos compatíveis. Se a razão for menor, o valor de $\varepsilon_{\text {Nd }}$ será negativo, com empobrecimento em ${ }^{147} \mathrm{Sm}$, indicando fonte rica em incompatíveis, a crosta. Todas as amostras com $\mathrm{Nd}$ coletado, também tiveram o $\mathrm{Sr}$, para que possa ser feito o cálculo de $\varepsilon_{\mathrm{Sr}}$ e $\varepsilon_{\mathrm{Nd}}$, para uma mesma amostra.

O comportamento geoquímico do $\mathrm{Sm}$ e do $\mathrm{Nd}$ é semelhante, sendo que o evento capaz de fracionar significativamente a razão Sm-Nd, é o processo de diferenciação manto-crosta (Sato et al., 1995). É esse fato, aliado à baixa difusão desses elementos no estado sólido, que permite o cálculo da Idade Modelo, ou seja, da época aproximada em que o magma parental da rocha estudada diferenciou-se do manto, qualquer que tenha sido a história geológica posterior. A Idade Modelo consiste na época em que a razão ${ }^{143} \mathrm{Nd} /{ }^{144} \mathrm{Nd}$ da amostra é igual a do manto. Os cálculos são baseados em valores para um manto empobrecido em incompatíveis (DM. "depleted mantle") e não terão valor algum se o manto que gerou a rocha for diferente. Alguns autores 
como Zindler e Hart (1986) propõe vários tipos de manto, o que contesta os valores de Idade Modelo.

Apesar do comportamento geoquímico similar do $\mathrm{Sm}$ e do $\mathrm{Nd}$, às vezes, durante alguns processos, pode haver fracionamento entre esses dois elementos, inviabilizando o cálculo da Idade Modelo em único estágio (Sato, 1998). Rochas enriquecidas em minerais que concentram seletivamente os terras-raras, ou fruto da mistura entre duas fontes distintas, ou ainda fruto da fusão parcial de sedimentos heterogêneos, podem dar idades-modelo sem significado geológico. Para resolver tal problema DePaolo et al. (1991) desenvolveu uma formula para calcular a Idade Modelo em estágio duplo. A necessidade de se realizar o cálculo em estágio duplo é indicado pelo fator de fracionamento, $f_{\mathrm{Sm} / \mathrm{Nd}}$ que mede o grau de fracionamento de uma amostra. O valor de $f_{\mathrm{Sm} / \mathrm{Nd}}$ deve estar por volta de $-0,44$, ou de uma razão $\mathrm{Sm} / \mathrm{Nd}$ de $0,11 \pm 0,02$, que corresponde a valores de $f_{\mathrm{Sm} / \mathrm{Nd}}$ entre -0.54 e $-0,34$, para rochas granitóides acrescidas em arcos magmáticos. Esse valor foi estimado empiricamente, avaliando-se a distribuição dos dados existentes em histograma. Desta forma, para amostras com valores de $f_{\mathrm{Sm} / \mathrm{Nd}}$ fora desse intervalo, é necessário o cálculo da idade Modelo em dois estágios.

\section{Cálculos e constantes envolvidas}

DePaolo (1981) modelou uma evolução isotópica de Nd não linear para o manto superior fracionado, e neste caso a idade modelo é obtida resolvendo-se a seguinte equação:

$\varepsilon_{\mathrm{Na}}(T)=0,25 T^{2}-3 T+8,5$ curva do manto empobrecido (DM)

$\varepsilon_{N d}(T)=\varepsilon_{N d}(0)-Q_{(S m / N d)}\left\{=0.512638 /\left({ }^{143} N d /{ }^{144} N d\right){ }_{C H U R}(T)\right\}\left[e^{\lambda T}-1\right]$

considerando $\mathrm{e}^{\lambda T}-1 \cong \lambda \mathrm{T}$ e $0.512638 /\left({ }^{143} \mathrm{Nd} /{ }^{144} \mathrm{Nd}\right)_{\mathrm{CHUR}}(\mathrm{T}) \cong 1$

$\varepsilon_{\mathrm{Nd}}(T) \cong \varepsilon_{\mathrm{Nd}}(0)-\mathrm{Qf}{ }_{(\mathrm{Sm} / \mathrm{Nd})} T$ evolução da rocha crustal

eq.(3)

onde o parâmetro $Q_{N d}$ é uma constante que insere o valor da constante de desintegração $\lambda_{S m}$,

$$
\begin{aligned}
Q_{N d} & =\left[10^{4} \lambda_{N d}\left({ }^{147} \mathrm{Sm} /{ }^{144} \mathrm{Nd}\right)_{C H U R}(0)\right] /\left({ }^{143} \mathrm{Nd} /{ }^{144} \mathrm{Nd}\right)_{C H U R}(0) \\
& =\left[10^{4} \times 0.00654 \times 0.1967\right] / 0.512638=25.09 \text { b.a }^{-1}
\end{aligned}
$$


O parâmetro $\varepsilon_{\mathrm{Nd}}(0)$ é definido como a razão atual ${ }^{143} \mathrm{Nd} /{ }^{144} \mathrm{Nd}$ da amostra sobre a razão ${ }^{143} \mathrm{Nd} /{ }^{144} \mathrm{Nd}$ do manto CHUR, subtraído de 1 e multiplicado por um fator 10000 :

$$
\varepsilon_{\mathrm{Nd}}(0)=\left\{{\overline{\left({ }^{143} \mathrm{Nd} /{ }^{144} \mathrm{Nd}\right)(0) \mathrm{am}}}^{-1}\right\} 10000 \quad \text { equação } 4
$$

Por outro lado, o parametro $\mathrm{f}_{\mathrm{Sm} / \mathrm{Nd}}$ indica o grau de fracionamento da razão ${ }^{147} \mathrm{Sm} /{ }^{144} \mathrm{Nd}$ da amostra em relação ao manto CHUR e em geral e da ordem de -0.5 a -0.4 em rochas ditas "crustais":

$$
\left.f_{(\mathrm{Sm} / \mathrm{Nd})}={ }^{147} \mathrm{Sm} /{ }^{144} \mathrm{Nd}\right)_{\mathrm{am}}-\left({ }^{147} \mathrm{Sm} /{ }^{144} \mathrm{Nd}\right)_{\mathrm{CHUR}}
$$

Onde:

$\mathrm{Sm} / \mathrm{Nd}_{\text {CHUR (hoje) }}=0,1967$

${ }^{143} \mathrm{Nd} /{ }^{144} \mathrm{Nd}(0) \mathrm{CHUR}=0,512638$

$Q=25,09$ ba'- (parâmetro que insere a constante de desintegração)

$(0)=0$ tempo atual

am = amostra

$\mathrm{T}=$ qualquer tempo

A equação que define o parâmetro $\varepsilon_{N d}$, para qualquer idade, é uma reta do gráfico de $\varepsilon_{N d}$ pelo tempo. O $f_{\mathrm{Sm} / \mathrm{Nd}}$ é o grau de fracionamento de $\mathrm{Sm} / \mathrm{Nd}$ da amostra em relação ao manto CHUR e pode ser entendido graficamente como a inclinação dessa reta, já que é a constante que acompanha a variável x (T) (DePaolo et al., 1991). Matematicamente pode ser escrito como a derivada de $\varepsilon_{\mathrm{Nd}}$ em função do tempo.

$\underline{\partial \varepsilon}_{\underline{N d}}=Q_{N d} f_{S m / N d} T$

$\partial$ 
A idade modelo $T_{D M}$ é representada graficamente pelo ponto de intersecção da reta, que define a variação de $\varepsilon_{N d}$ no tempo, com a parábola que representa a evolução da razão ${ }^{143} \mathrm{Nd} /{ }^{144} \mathrm{Nd}$ do manto empobrecido, definida por DePaolo (1981). Matematicamente é obtida igualando-se a equação de $\varepsilon_{\mathrm{Nd}}$, com a de evolução do manto:

$\varepsilon_{\mathrm{Nd}(\mathrm{T})}=0,25 \mathrm{~T}^{2}-3 \mathrm{~T}+8,5$ (equação de DePaolo, para evolução isotópica de $\mathrm{Nd}$ no manto empobrecido)

Esta é uma maneira simplificada de se calcular a idade modelo. Segundo Sato (1998), a diferença entre os resultados obtidos pela formula simplificada e a sem aproximação é pequena, não passando de aproximadamente 10 Ma para o Neoproterozóico, 15 Ma para o Paleoproterozóico e 35 Ma para o Arqueano.

O cálculo da Idade Modelo $\mathrm{T}_{\mathrm{DM}}$ em dois estágios está definido por Sato (1998) e difere um pouco da proposta por DePaolo et al. (1991):

$$
\begin{aligned}
& \mathrm{T}_{\mathrm{DM}}=\frac{1}{\lambda} \ln \left\{1+\frac{\left\{{ }^{143} \mathrm{Nd} /{ }^{144} \mathrm{Nd}\right.}{\mathrm{DM}}-\frac{\left[{ }^{143} \mathrm{Nd} /{ }^{144} \mathrm{Nd}\right.}{\mathrm{am}}\right. \\
& \left. \pm \frac{\left({ }^{147} \mathrm{Sm} /{ }^{143} \mathrm{Nd}\right.}{\mathrm{e}} \frac{-{ }^{147} \mathrm{Sm} /{ }^{143} \mathrm{Nd}}{\mathrm{am}}\right)\left(\mathrm{e}^{\lambda \mathrm{T}} \underline{\underline{2}} \frac{-1)]\}\}}{{ }^{147} /{ }^{143} \mathrm{Nd} \mathrm{DM}-{ }^{147} \mathrm{Sm} /{ }^{143} \mathrm{Nd}}\right.
\end{aligned}
$$

Onde

$\lambda=$ constante de decaimento

$\mathrm{DM}=$ valores de manto empobrecido

$\mathrm{am}=$ valores da amostra (hoje)

$\mathrm{e}=$ valores estimados, no caso 0,11

${ }^{147} \mathrm{Sm} /{ }^{144} \mathrm{Nd} \mathrm{DM}=0,219$

${ }^{143} \mathrm{Nd} /{ }^{144} \mathrm{Nd} \mathrm{DM}_{\mathrm{DM}}=0,51315$

$\mathrm{T} 2=$ idade de um evento secundario, que possa ter fracionado a amostra

A idade de um evento secundario pode ser obtida por uma isócrona $\mathrm{Rb} / \mathrm{Sr}$ ou $\mathrm{Sm} / \mathrm{Nd}$ ou outros métodos. 


\section{Método Rb-Sr}

A preparação das amostras de rocha foi similar àquela das amostras analisadas pelo método $\mathrm{Sm} / \mathrm{Nd}$. O procedimento químico foi de acordo com as rotinas do laboratório do CPGeo, onde branco laboratorial médio e da ordem de $4 \mathrm{ng}$ de Sr. A quantificação de $\mathrm{Rb}$ e $\mathrm{Sr}$ foi obtida por fluorescência de RX. Os teores de Rb-Sr das amostras Gr-15ª , V-314, V-332, Gr-15, D-982, V198, D-806-a,b foram determinadas por fluorescência de RX, com uma precisão de $\leq 1.4 \%$ para $\mathrm{Rb}$ e $\leq 1.0$ \% para Sr. Já as concentrações Rb-Sr das amostras Gr-29. Gr-29 a,b,d,e,f,h,i, V-290 e D-806-c foram obtidas por diluição isotópica, com precisão superior. As razoes ${ }^{87} \mathrm{Sr} /{ }^{86} \mathrm{Sr}$ foram determinadas em espectrômetro mono-coletor VG-354, tendo sido corrigidas para o valor médio do padrão NBS-987 (0,710254+- 0.000022 , nivel 2 б) e normalizadas a ${ }^{86} \mathrm{Sr} /{ }^{88} \mathrm{Sr}=01194$. A proporção ${ }^{87} \mathrm{Rb} /{ }^{86} \mathrm{Sr}$ foi obtida através de cálculos, a partir dos valores de $\mathrm{Rb}$ total e $\mathrm{Sr}$ total. Os teores de Rb-Sr das amostras Gr-15a determinadas por fluorescência de Raio-X, com uma precisão de $\leq 1.4 \%$ para $\mathrm{Rb}$ e $\leq 1.0 \%$ para Sr. Já as concentrações Rb-Sr das amostras Gr-29. Gr-29 a,b,d,e,f,h,i, V-290 e D-806-c foram obtidas por diluição isotópica. Os dados $\mathrm{Rb}$-Sr foram interpretados em diagramas binários $\mathrm{Nd}$-Sr e também para fins da modelagem petrogenetica das rochas granitoides.

\section{Referencias metodológicas citadas}

Basei, M.A.S.; Siga Jr., O.; Sato, K.; Sproesser, W.M. 1995. A metodologia U-Pb na Universidade de São Paulo. Princípios metodológicos, aplicações e resultados obtidos. CPGeo-USP. Anais da Academia Brasileira de Ciéncias, 67 (2): 221-237.

Buhn, B.; Pimentel, M.M.; Matteini, M.; Dantas, E.L. 2009. High spatial resolution analysis of Pb and $U$ isotopes by laser ablation multi-collector inductively coupled plasma mass spectrometry (LA-MC-ICP-MS). Anais da Academia Brasileira de Ciencias, 81 (1): 99-114.

Compston, W.; Williams, I. S.; Myer, C. 1984 U-Pb geochronology in zircons from Lunar Breccia 73217 using a sensitive high mass-resolution ion microprobe. Journal of Geophysical Research, 89, 525-534.

DePaolo, D. J. 1981. A neodymium and strontium isotopic study of Mesozoic calc-alkaline granitic batholiths of of the Sierra Nevada and Peninsular Ranges, California. Journal Geophysical Research, 86, No B11, 10470-10488. 
DePaolo, D. J.; Linn, A.M.; Schubert, G. 1991. The continental age distribution: methods of determining mantle separation ages fro $\mathrm{Sm}-\mathrm{Nd}$ isotopic data and application to the Southwestern United states. Journal Geophysical Research, 96, 2071-2078.

Ludwig, K. R. 2003.User's Manual for Isoplot/Ex-version 3.0 A geochronological toolkit for Microsoft excel. Berkeley geochronology Center. Special Publication 4. 71 p.

Passarelli, C.R.; Basei, M.A.S.; Siga Jr., O.; Sato, K.; Sproesser, W.M.; Loios, V.A.P. 2009. Dating minerals by ID-TIMS geochronology at times of in situ analysis: selected kay studies from the CPGeo-IGc-USP laboratory. Anais da Academia Brasileira de Ciencias, 81 (1): 73-97.

Sato, K. 1998. Evolução crustal da plataforma sulamericana com base na geoquímica isotópica Sm-Nd. Tese de Doutoramento, Universidade de São Paulo, 297 p.

Sato, K.; Tassinari, C.C.G.; Kawashita, K.; Petronhilo, L. 1995. O Método Geocronológico Sm-Nd no IGc/USP e suas aplicações. Anais da Academia Brasileira das Ciências, 67, 313-336.

Stacey, J.S.; Kramer, J.D. 1975. Approximation of terrestrial lead isotope evolution by a two-stage model. Earth Planet. SC. Lett. 26, 207-221.

Steiger, R.H.; Jäger, E. 1977. Subcomission on Geochronology: Convention on the use of Decay Constants in Geochronology. Contribution to the geologic time scale, Studies in geology, 6 , 67-72.

Williams, I.S.1997. U-Th-Pb geochronology by ion microprobe: not just ages but histories. Reviews in Economic Geology, 7, 1-35.

Zindler, A.; Hart, S. 1986. Chemical geodynamics. Ann. Rev. Earth Planet. Sci. 14, 493-571. 
Apêndice B1. Análises de óxidos, traços e terras raras em rocha total dos granitoides da Zona Sul (continua).

\begin{tabular}{|c|c|c|c|c|c|c|c|c|c|c|c|c|}
\hline $\begin{array}{l}\text { Amostra } \\
\text { Unidade }\end{array}$ & $\begin{array}{c}401 \\
\text { SRamon }\end{array}$ & $\begin{array}{c}403 \\
\text { SJavier }\end{array}$ & $\begin{array}{c}404 \\
\text { SAndrés }\end{array}$ & $\begin{array}{c}406 \\
\text { SRafael }\end{array}$ & $\begin{array}{c}408 \\
\text { Refugio }\end{array}$ & $\begin{array}{c}412 \\
\text { SPedro }\end{array}$ & $\begin{array}{c}514 \\
\text { LManech }\end{array}$ & $\begin{array}{c}515 \\
\text { LManech }\end{array}$ & $\begin{array}{c}516 \\
\text { DonMario }\end{array}$ & $\begin{array}{c}518 \\
\text { RNegro }\end{array}$ & $\begin{array}{c}528 \\
\text { Silvestre }\end{array}$ & $\begin{array}{c}531 \\
\text { Spablo }\end{array}$ \\
\hline $\mathrm{SiO} 2$ & 64,16 & 74,05 & 72,75 & 73,07 & 74,74 & 74,57 & 69,17 & 74,33 & 63,72 & 53,72 & 72,59 & 73,57 \\
\hline Al2O3 & 15,93 & 13,68 & 12,89 & 13,37 & 13,46 & 13,12 & 13,72 & 13,19 & 20,73 & 14,32 & 15,67 & 14,67 \\
\hline MnO & 0,063 & 0,043 & 0,060 & 0,052 & 0,053 & 0,055 & 0,080 & 0,076 & 0,024 & 0,146 & 0,022 & 0,017 \\
\hline $\mathrm{MgO}$ & 1,15 & 0,21 & 0,29 & 0,23 & 0,28 & 0,28 & 0,88 & 0,28 & 0,10 & 7,26 & 0,07 & 0,23 \\
\hline $\mathrm{CaO}$ & 3,55 & 1,27 & 1,23 & 0,92 & 1,29 & 0,13 & 2,58 & 2,88 & 1,23 & 5,76 & 1,73 & 1,53 \\
\hline $\mathrm{Na2O}$ & 4,24 & 3,73 & 2,79 & 2,88 & 3,93 & 0,56 & 2,72 & 5,01 & 5,55 & 2,10 & 3,85 & 3,56 \\
\hline K2O & 2,74 & 4,52 & 5,24 & 5,35 & 4,00 & 2,76 & 3,66 & 0,57 & 6,58 & 4,98 & 5,37 & 5,03 \\
\hline TiO2 & 0,79 & 0,171 & 0,383 & 0,245 & 0,173 & 5,790 & 0,699 & 0,257 & 0,075 & 1,047 & 0,044 & 0,149 \\
\hline P2O5 & 0,254 & 0,051 & 0,087 & 0,078 & 0,043 & 0,154 & 0,200 & 0,068 & 0,133 & 0,627 & 0,023 & 0,039 \\
\hline $\mathrm{Fe} 2 \mathrm{O} 3$ & 5,02 & 1,30 & 3,12 & 2,01 & 1,35 & 0,06 & 4,38 & 2,51 & 0,66 & 7,91 & 0,36 & 1,13 \\
\hline Loi & 0,65 & 0,37 & 0,44 & 0,94 & 0,44 & 1,83 & 0,65 & 0,20 & 0,73 & 1,00 & 0,32 & 0,36 \\
\hline Total & 98,55 & 99,40 & 99,28 & 99,15 & 99,76 & 99,31 & 98,74 & 99,37 & 99,53 & 98,87 & 100,05 & 100,29 \\
\hline $\mathrm{Ba}$ & 1180 & 594 & 556 & 363 & 562 & 370 & 798 & 117 & 480 & 2471 & 1749 & 480 \\
\hline $\mathrm{Nb}$ & 9 & 8 & 19 & 26 & 11 & 11 & 12 & 8 & 24 & 12 & 1 & 5 \\
\hline $\mathrm{Pb}$ & 18 & 31 & 28 & 36 & 18 & 29 & 23 & 8 & 58 & 20 & 68 & 48 \\
\hline Rb & 95 & 177 & 275 & 413 & 120 & 267 & 121 & 5 & 552 & 190 & 142 & 220 \\
\hline $\mathrm{Sr}$ & 688 & 215 & 60 & 74 & 206 & 39 & 227 & 210 & 138 & 757 & 877 & 169 \\
\hline Th & 16 & 14 & 32 & 35 & 13 & 13 & 46 & 8 & 30 & 14 & 1 & 18 \\
\hline U & 11 & 3 & 5 & 6 & 3 & 5 & 2 & 1 & 5 & 1 & 1 & 25 \\
\hline V & 70 & 10 & 22 & 14 & 9 & 9 & 45 & 16 & 9 & 112 & 9 & 9 \\
\hline $\mathbf{Y}$ & 15 & 4 & 140 & 58 & 12 & 69 & 25 & 33 & 9 & 23 & 1 & 9 \\
\hline $\mathrm{Zr}$ & 275 & 95 & 340 & 229 & 90 & 116 & 368 & 150 & 101 & 303 & 30 & 105 \\
\hline La & 65,6 & 30,20 & 191,67 & 64,50 & 24,94 & 30,41 & 158,43 & 42,39 & 39,67 & 92,4 & 8,50 & 22,5 \\
\hline $\mathrm{Ce}$ & 126 & 44,64 & 211,06 & 137,67 & 43,54 & 60,04 & 278,84 & 63,24 & 66,64 & 182 & 12,9 & 44,3 \\
\hline Pr & 14,1 & 5,00 & 40,62 & 17,40 & 4,86 & 8,72 & 32,40 & 9,84 & 6,96 & 23,4 & 1,23 & 4,97 \\
\hline Nd & 47,7 & 14,56 & 144,59 & 59,20 & 15,40 & 31,59 & 113,25 & 35,28 & 20,91 & 89,2 & 3,72 & 17,5 \\
\hline Sm & 7,09 & 1,76 & 26,49 & 11,46 & 2,51 & 8,02 & 16,84 & 6,61 & 3,42 & 15,2 & 0,51 & 3,38 \\
\hline Eu & 1,69 & 0,49 & 2,70 & 0,94 & 0,55 & 0,68 & 2,17 & 1,07 & 0,54 & 3,92 & 1,30 & 0,78 \\
\hline Gd & 6,53 & 1,51 & 26,21 & 10,38 & 2,59 & 8,35 & 15,28 & 6,28 & 3,15 & 11,2 & 0,41 & 2,81 \\
\hline Tb & 0,63 & 0,14 & 3,87 & 1,57 & 0,32 & 1,66 & 1,36 & 0,93 & 0,35 & 1,26 & 0,04 & 0,37 \\
\hline Dy & 3,17 & 0,73 & 22,12 & 9,19 & 1,80 & 10,74 & 6,49 & 5,54 & 1,67 & 5,70 & 0,22 & 1,79 \\
\hline Ho & 0,57 & 0,14 & 4,59 & 1,96 & 0,39 & 2,56 & 1,05 & 1,25 & 0,28 & 0,98 & 0,04 & 0,33 \\
\hline Er & 1,50 & 0,44 & 12,59 & 5,87 & 1,14 & 7,24 & 2,74 & 3,52 & 0,72 & 2,39 & 0,11 & 0,85 \\
\hline Tm & 0,21 & 0,06 & 1,82 & 1,03 & 0,18 & 1,15 & 0,31 & 0,55 & 0,09 & 0,30 & 0,01 & 0,11 \\
\hline $\mathrm{Yb}$ & 1,26 & 0,49 & 12,31 & 7,98 & 1,29 & 7,74 & 1,71 & 3,82 & 0,58 & 1,79 & 0,12 & 0,69 \\
\hline Lu & 0,19 & 0,09 & 1,74 & 1,23 & 0,20 & 1,11 & 0,25 & 0,57 & 0,08 & 0,26 & 0,01 & 0,10 \\
\hline
\end{tabular}


Apêndice B1. Análises de óxidos, traços e terras raras em rocha total dos granitoides da Zona Sul (conclusão).

\begin{tabular}{|c|c|c|c|c|c|c|c|c|c|c|c|c|c|c|}
\hline $\begin{array}{l}\text { Amostra } \\
\text { Unidade }\end{array}$ & $\begin{array}{c}532 \\
\text { Vibosi }\end{array}$ & $\begin{array}{c}533 \\
\text { Calama }\end{array}$ & $\begin{array}{c}534 \\
\text { STeresa }\end{array}$ & $\begin{array}{c}535 \\
\text { EICarmen }\end{array}$ & $\begin{array}{c}538 \\
\text { SRosario }\end{array}$ & $\begin{array}{c}546 \\
\text { Rafaelito }\end{array}$ & $\begin{array}{c}547 \\
\text { Sujalito }\end{array}$ & $\begin{array}{c}549 \\
\text { Limones }\end{array}$ & $\begin{array}{c}550 \\
\text { EIPuente }\end{array}$ & $\begin{array}{c}551 \\
\text { Momené }\end{array}$ & $\begin{array}{c}552 \\
\text { Guarayos }\end{array}$ & $\begin{array}{c}\text { 553A } \\
\text { PNuevo }\end{array}$ & $\begin{array}{c}\text { 553B } \\
\text { PNuevo }\end{array}$ & $\begin{array}{c}558 \\
\text { LaCruz }\end{array}$ \\
\hline $\mathrm{SiO} 2$ & 71,31 & 62,02 & 63,18 & 63,90 & 76,57 & 75,09 & 75,45 & 61,41 & 72,68 & 80,04 & 76,49 & 72,61 & 72,74 & 76,78 \\
\hline Al2O3 & 13,46 & 14,45 & 14,79 & 15,30 & 11,98 & 13,01 & 11,94 & 16,90 & 14,10 & 10,12 & 11,68 & 14,01 & 14,40 & 12,33 \\
\hline MnO & 0,064 & 0,099 & 0,087 & 0,074 & 0,028 & 0,032 & 0,053 & 0,070 & 0,027 & 0,032 & 0,038 & 0,028 & 0,027 & 0,021 \\
\hline $\mathrm{MgO}$ & 0,38 & 1,72 & 1,66 & 1,64 & 0,01 & 0,19 & 0,08 & 1,61 & 0,44 & $<0.01$ & 0,08 & 0,53 & 0,32 & 0,16 \\
\hline $\mathrm{CaO}$ & 1,66 & 3,63 & 3,38 & 2,78 & 0,58 & 0,75 & 0,26 & 4,20 & 1,66 & 0,53 & 0,70 & 1,76 & 1,28 & 0,20 \\
\hline $\mathrm{Na2O}$ & 2,67 & 3,12 & 3,18 & 3,70 & 3,14 & 2,91 & 3,73 & 4,46 & 3,42 & 2,40 & 2,35 & 3,15 & 3,37 & 3,26 \\
\hline K2O & 5,44 & 4,26 & 3,97 & 4,59 & 5,24 & 5,68 & 4,53 & 2,61 & 4,71 & 5,06 & 6,01 & 4,57 & 5,43 & 5,24 \\
\hline TiO2 & 0,503 & 1,360 & 1,235 & 1,011 & 0,167 & 0,249 & 0,297 & 0,908 & 0,277 & 0,175 & 0,200 & 0,345 & 0,269 & 0,158 \\
\hline P2O5 & 0,157 & 0,533 & 0,477 & 0,357 & 0,008 & 0,049 & 0,025 & 0,325 & 0,089 & 0,005 & 0,022 & 0,131 & 0,066 & 0,012 \\
\hline $\mathrm{Fe} 2 \mathrm{O} 3$ & 3,39 & 7,19 & 6,45 & 5,34 & 1,68 & 1,81 & 3,35 & 5,37 & 1,94 & 1,71 & 1,94 & 2,17 & 1,78 & 1,38 \\
\hline Loi & 0,70 & 0,76 & 0,86 & 0,60 & 0,46 & 0,50 & 0,04 & 1,18 & 1,00 & 0,40 & 0,34 & 0,47 & 0,48 & 0,62 \\
\hline Total & 99,73 & 99,14 & 99,27 & 99,29 & 99,86 & 100,27 & 99,76 & 99,04 & 100,34 & 100,47 & 99,85 & 99,77 & 100,16 & 100,16 \\
\hline $\mathrm{Ba}$ & 729 & 1245 & 1243 & 1313 & 225 & 765 & 1381 & 3503 & 908 & 132 & 914 & 1123 & 746 & 740 \\
\hline $\mathrm{Nb}$ & 26 & 32 & 30 & 30 & 27 & 15 & 20 & 9 & 10 & 24 & 17 & 9 & 11 & 20 \\
\hline $\mathrm{Pb}$ & 30 & 25 & 23 & 35 & 29 & 25 & 22 & 10 & 43 & 36 & 33 & 34 & 65 & 21 \\
\hline Rb & 270 & 186 & 171 & 243 & 302 & 227 & 87 & 43 & 197 & 2132 & 218 & 179 & 209 & 174 \\
\hline $\mathrm{Sr}$ & 142 & 338 & 355 & 447 & 16 & 67 & 70 & 1093 & 310 & 15 & 75 & 367 & 187 & 56 \\
\hline Th & 34 & 23 & 31 & 40 & 29 & 15 & 14 & 9 & 37 & 31 & 24 & 26 & 52 & 21 \\
\hline U & 4 & 2 & 2 & 6 & 4 & 3 & 3 & 1 & 2 & 6 & 3 & 2 & 11 & 4 \\
\hline V & 16 & 88 & 83 & 72 & 11 & 20 & 9 & 73 & 32 & 9 & 8 & 26 & 18 & 10 \\
\hline $\mathbf{Y}$ & 89 & 80 & 85 & 66 & 113 & 47 & 75 & 9 & 30 & 160 & 91 & 17 & 11 & 70 \\
\hline $\mathrm{Zr}$ & 333 & 946 & 813 & 502 & 288 & 190 & 434 & 357 & 207 & 237 & 305 & 240 & 209 & 174 \\
\hline La & 95,2 & 148 & 162 & 157 & 78,4 & 36,0 & 102 & 141 & 75,4 & 82,0 & 84,6 & 55,2 & 59,4 & 68,4 \\
\hline $\mathrm{Ce}$ & 244 & 323 & 338 & 295 & 151 & 111 & 133 & 224 & 151 & 182 & 195 & 99,6 & 122 & 129 \\
\hline $\mathrm{Pr}$ & 25,1 & 43,0 & 44,5 & 33,9 & 19,1 & 10,3 & 25,2 & 22,8 & 17,0 & 24,0 & 20,7 & 11,1 & 12,6 & 16,1 \\
\hline Nd & 89,8 & 153 & 154 & 115 & 70,2 & 37,0 & 94,8 & 71,0 & 59,1 & 93,5 & 74,6 & 37,7 & 42,0 & 58,3 \\
\hline $\mathrm{Sm}$ & 17,3 & 25,6 & 26,3 & 18,0 & 14,6 & 7,31 & 17,3 & 7,58 & 10,2 & 22,8 & 14,6 & 5,98 & 6,56 & 11,1 \\
\hline Eu & 2,08 & 3,46 & 3,45 & 2,75 & 1,07 & 0,99 & 3,09 & 3,18 & 1,60 & 0,99 & 1,60 & 1,62 & 1,19 & 1,19 \\
\hline Gd & 16,3 & 21,4 & 22,0 & 15,7 & 15,4 & 6,94 & 15,3 & 5,92 & 8,53 & 25,4 & 14,4 & 5,25 & 4,87 & 10,7 \\
\hline Tb & 2,68 & 2,97 & 3,10 & 2,18 & 2,74 & 1,20 & 2,29 & 0,52 & 1,24 & 4,71 & 2,43 & 0,70 & 0,53 & 1,75 \\
\hline Dy & 16,0 & 15,8 & 16,6 & 11,8 & 17,1 & 7,38 & 12,8 & 2,27 & 6,47 & 28,8 & 14,6 & 3,47 & 2,31 & 10,3 \\
\hline Ho & 3,57 & 3,21 & 3,34 & 2,44 & 3,96 & 1,69 & 2,77 & 0,37 & 1,26 & 6,58 & 3,29 & 0,64 & 0,40 & 2,36 \\
\hline Er & 10,2 & 8,56 & 8,85 & 6,63 & 11,1 & 4,73 & 7,72 & 1,00 & 3,09 & 17,4 & 9,02 & 1,58 & 1,08 & 6,61 \\
\hline $\mathrm{Tm}$ & 1,59 & 1,17 & 1,22 & 0,94 & 1,68 & 0,73 & 1,15 & 0,13 & 0,41 & 2,46 & 1,36 & 0,19 & 0,15 & 1,02 \\
\hline Yb & 10,8 & 7,53 & 7,72 & 5,93 & 11,3 & 4,83 & 7,78 & 0,74 & 2,35 & 15,0 & 8,74 & 1,16 & 1,14 & 6,93 \\
\hline Lu & 1,52 & 1,10 & 1,09 & 0,83 & 1,62 & 0,71 & 1,18 & 0,12 & 0,33 & 2,00 & 1,22 & 0,17 & 0,18 & 1,04 \\
\hline
\end{tabular}




\begin{tabular}{|c|c|c|c|c|c|c|c|c|c|}
\hline $\begin{array}{l}\text { Amostra } \\
\text { Unidade }\end{array}$ & $\begin{array}{c}501 \\
\text { PisoFirme }\end{array}$ & $\begin{array}{c}502 \\
\text { S.Cristobal }\end{array}$ & $\begin{array}{c}503 \\
\text { S.Cristobal }\end{array}$ & $\begin{array}{c}504 \\
\text { Porvenir }\end{array}$ & $\begin{array}{c}505 \\
\text { Diamant }\end{array}$ & $\begin{array}{c}506 \\
\text { Diamant }\end{array}$ & $\begin{array}{c}507 \\
\text { Diamant }\end{array}$ & $\begin{array}{c}508 \\
\text { Diamant }\end{array}$ & $\begin{array}{c}509 \\
\text { S Martír }\end{array}$ \\
\hline $\mathrm{SiO} 2$ & 76,07 & 76,08 & 74,12 & 74,26 & 72,33 & 72,14 & 73,53 & 74,84 & 76,76 \\
\hline Al2O3 & 12,44 & 12,46 & 13,02 & 13,75 & 14,39 & 14,47 & 13,49 & 13,43 & 11,51 \\
\hline $\mathrm{MnO}$ & 0,025 & 0,030 & 0,054 & 0,043 & 0,035 & 0,034 & 0,034 & 0,033 & 0,044 \\
\hline $\mathrm{MgO}$ & 0,06 & 0,08 & 0,22 & 0,22 & 0,30 & 0,29 & 0,28 & 0,19 & 0,09 \\
\hline $\mathrm{CaO}$ & 0,56 & 0,56 & 1,07 & 1,27 & 1,33 & 1,28 & 1,15 & 1,00 & 0,62 \\
\hline $\mathrm{Na2O}$ & 4,47 & 3,73 & 3,49 & 3,74 & 3,19 & 3,21 & 2,96 & 3,36 & 2,41 \\
\hline K2O & 4,07 & 4,88 & 4,86 & 4,53 & 5,52 & 5,94 & 5,44 & 5,07 & 5,63 \\
\hline TiO2 & 0,123 & 0,117 & 0,242 & 0,173 & 0,255 & 0,243 & 0,241 & 0,140 & 0,188 \\
\hline P2O5 & 0,017 & 0,017 & 0,048 & 0,047 & 0,068 & 0,062 & 0,067 & 0,051 & 0,025 \\
\hline $\mathrm{Fe} 2 \mathrm{O} 3$ & 1,50 & 1,42 & 2,24 & 1,31 & 1,68 & 1,65 & 2,03 & 1,35 & 2,20 \\
\hline Loi & 0,67 & 0,38 & 0,21 & 0,39 & 0,38 & 0,20 & 0,34 & 0,40 & $<0.01$ \\
\hline Total & 100,01 & 99,75 & 99,57 & 99,73 & 99,48 & 99,52 & 99,56 & 99,86 & 99,48 \\
\hline Ba & 811 & 336 & 614 & 822 & 902 & 776 & 690 & 429 & 721 \\
\hline $\mathrm{Nb}$ & 11 & 10 & 8 & 22 & 9 & 7 & 12 & 8 & 7 \\
\hline $\mathrm{Pb}$ & 6 & 13 & 12 & 21 & 44 & 39 & 44 & 55 & 22 \\
\hline $\mathbf{R b}$ & 100 & 157 & 158 & 179 & 245 & 212 & 249 & 251 & 144 \\
\hline $\mathrm{Sr}$ & 24 & 24 & 59 & 21 & 215 & 201 & 153 & 176 & 69 \\
\hline Th & 8 & 7 & 6 & 14 & 20 & 39 & 55 & 32 & 17 \\
\hline $\mathbf{U}$ & 3 & 3 & 2 & 5 & 5 & 7 & 8 & 16 & 1 \\
\hline V & $<9$ & $<9$ & $<9$ & $<9$ & $<9$ & 18 & 14 & $<9$ & $<9$ \\
\hline $\mathbf{Y}$ & 45 & 66 & 54 & 148 & 23 & 18 & 18 & 122 & 95 \\
\hline $\mathrm{Zr}$ & 215 & 142 & 197 & 360 & 178 & 197 & 185 & 118 & 292 \\
\hline La & 31,4 & 33,0 & 34,8 & 65,1 & 69,7 & 99,5 & 70,0 & 24,2 & 91,6 \\
\hline $\mathrm{Ce}$ & 60,1 & 61,7 & 55,9 & 179 & 128 & 128 & 182 & 56,9 & 212 \\
\hline Pr & 7,83 & 8,97 & 9,45 & 19,3 & 15,2 & 21,3 & 17,8 & 6,49 & 26,8 \\
\hline Nd & 29,2 & 35,1 & 36,4 & 76,0 & 52,4 & 71,1 & 61,2 & 23,5 & 106 \\
\hline $\mathrm{Sm}$ & 6,44 & 8,13 & 8,33 & 17,9 & 8,55 & 11,0 & 11,2 & 5,95 & 24,1 \\
\hline $\mathrm{Eu}$ & 0,64 & 0,44 & 1,12 & 1,88 & 1,20 & 1,27 & 1,24 & 0,79 & 2,70 \\
\hline Gd & 6,61 & 8,59 & 8,30 & 20,1 & 7,34 & 9,21 & 9,28 & 7,96 & 24,3 \\
\hline $\mathrm{Tb}$ & 1,13 & 1,52 & 1,48 & 3,57 & 0,77 & 0,90 & 1,00 & 1,92 & 3,88 \\
\hline Dy & 7,10 & 9,36 & 8,98 & 22,3 & 3,75 & 4,06 & 4,45 & 14,1 & 21,0 \\
\hline Ho & 1,69 & 2,23 & 2,07 & 5,26 & 0,72 & 0,66 & 0,72 & 3,82 & 4,16 \\
\hline $\mathrm{Er}$ & 4,80 & 6,24 & 5,86 & 14,9 & 2,00 & 1,65 & 1,72 & 11,3 & 10,1 \\
\hline $\mathrm{Tm}$ & 0,77 & 0,98 & 0,94 & 2,30 & 0,29 & 0,20 & 0,22 & 1,75 & 1,24 \\
\hline $\mathrm{Yb}$ & 5,33 & 6,67 & 6,41 & 15,4 & 1,92 & 1,21 & 1,33 & 11,3 & 7,03 \\
\hline Lu & 0,80 & 0,99 & 0,94 & 2,27 & 0,29 & 0,19 & 0,21 & 1,65 & 0,85 \\
\hline Hf & 7,00 & 6,13 & 6,15 & 12,6 & 5,51 & 6,43 & 6,45 & 4,93 & 11,0 \\
\hline $\mathrm{Ta}$ & 0,77 & 0,75 & 0,76 & 1,38 & 0,68 & 0,28 & 0,25 & 0,49 & 0,53 \\
\hline
\end{tabular}




\begin{tabular}{|c|c|c|c|c|c|c|}
\hline Amostra & 510 & 511 & 512 & 513 & 514 & 515 \\
\hline Unidade & La Junta & La Junta & La Junta & La Junta & L.Manechis & L.Manechis \\
\hline $\mathrm{SiO} 2$ & 69,27 & 71,26 & 74,19 & 68,63 & 69,17 & 74,33 \\
\hline $\mathrm{Al} 2 \mathrm{O} 3$ & 14,83 & 14,48 & 14,16 & 15,46 & 13,72 & 13,19 \\
\hline MnO & 0,034 & 0,032 & 0,022 & 0,030 & 0,080 & 0,076 \\
\hline $\mathrm{MgO}$ & 0,75 & 0,43 & 0,24 & 0,59 & 0,88 & 0,28 \\
\hline $\mathrm{CaO}$ & 1,24 & 1,33 & 2,04 & 1,80 & 2,58 & 2,88 \\
\hline $\mathrm{Na2O}$ & 2,55 & 2,80 & 3,63 & 3,49 & 2,72 & 5,01 \\
\hline K2O & 6,52 & 6,30 & 3,96 & 4,98 & 3,66 & 0,57 \\
\hline TiO2 & 0,477 & 0,330 & 0,106 & 0,442 & 0,699 & 0,257 \\
\hline P2O5 & 0,148 & 0,120 & 0,044 & 0,156 & 0,200 & 0,068 \\
\hline $\mathrm{Fe} 2 \mathrm{O} 3$ & 2,79 & 2,05 & 1,33 & 3,24 & 4,38 & 2,51 \\
\hline Loi & 0,82 & 0,40 & 0,19 & 0,67 & 0,65 & 0,20 \\
\hline Total & 99,43 & 99,53 & 99,91 & 99,49 & 98,74 & 99,37 \\
\hline $\mathrm{Ba}$ & 1515 & 776 & 805 & 525 & 798 & 117 \\
\hline $\mathrm{Nb}$ & 13 & 12 & 4 & 20 & 12 & 8 \\
\hline $\mathrm{Pb}$ & 26 & 40 & 20 & 36 & 23 & 8 \\
\hline $\mathbf{R b}$ & 165 & 224 & 141 & 223 & 121 & 5 \\
\hline $\mathrm{Sr}$ & 287 & 168 & 296 & 109 & 227 & 210 \\
\hline Th & 20 & 33 & 5 & 67 & 46 & 8 \\
\hline U & 2 & 3 & 2 & 5 & 2 & 1 \\
\hline v & 26 & 14 & 16 & 37 & 45 & 16 \\
\hline $\mathbf{Y}$ & 54 & 23 & 7 & 43 & 25 & 33 \\
\hline $\mathrm{Zr}$ & 206 & 216 & 110 & 314 & 368 & 150 \\
\hline La & 64,0 & 70,5 & 17,2 & 110 & 158 & 42,4 \\
\hline $\mathrm{Ce}$ & 130 & 148 & 31,8 & 220 & 279 & 63,2 \\
\hline $\mathrm{Pr}$ & 20,2 & 17,3 & 3,55 & 25,9 & 32,4 & 9,84 \\
\hline $\mathbf{N d}$ & 76,1 & 60,5 & 11,6 & 91,0 & 113 & 35,3 \\
\hline Sm & 14,0 & 10,8 & 1,77 & 16,3 & 16,8 & 6,61 \\
\hline Eu & 1,95 & 1,10 & 0,59 & 1,15 & 2,17 & 1,07 \\
\hline Gd & 12,5 & 9,81 & 1,75 & 15,6 & 15,3 & 6,28 \\
\hline $\mathrm{Tb}$ & 1,71 & 1,08 & 0,21 & 1,86 & 1,36 & 0,93 \\
\hline Dy & 9,39 & 4,99 & 1,15 & 9,11 & 6,49 & 5,54 \\
\hline Ho & 1,90 & 0,85 & 0,25 & 1,56 & 1,05 & 1,25 \\
\hline Er & 5,00 & 1,99 & 0,75 & 3,39 & 2,74 & 3,52 \\
\hline $\mathrm{Tm}$ & 0,68 & 0,24 & 0,12 & 0,34 & 0,31 & 0,55 \\
\hline $\mathrm{Yb}$ & 3,98 & 1,31 & 0,89 & 1,69 & 1,71 & 3,82 \\
\hline Lu & 0,51 & 0,20 & 0,14 & 0,25 & 0,25 & 0,57 \\
\hline $\mathrm{Hf}$ & 5,86 & 7,33 & 4,45 & 10,0 & 9,75 & 4,73 \\
\hline $\mathrm{Ta}$ & 1,22 & 0,26 & 0,46 & 0,96 & 0,47 & 0,55 \\
\hline
\end{tabular}


Apêndice B2, Tabela1. Resultados analíticos das datações U-Pb en zircão por SHRIMP (continua).

\begin{tabular}{|c|c|c|c|c|c|c|c|c|c|c|c|c|c|c|c|c|c|}
\hline \multirow[t]{2}{*}{ No ponto } & \multirow[t]{2}{*}{$\mathrm{U}(\mathrm{ppm})$} & \multirow{2}{*}{\multicolumn{2}{|c|}{ Th(ppm) Th/U }} & \multirow{2}{*}{\multicolumn{2}{|c|}{$\mathrm{Pb}^{*}\left(\mathrm{ppm}^{204} \mathrm{~Pb}\right)^{206} \mathrm{~Pb}$}} & \multirow[t]{2}{*}{$\int_{206 \%}$} & \multicolumn{10}{|c|}{ Idade (Ma) } & \multirow[t]{2}{*}{$\%$ Disc } \\
\hline & & & & & & & ${ }^{206} \mathrm{~Pb} /{ }^{238} \mathrm{U}$ & \pm & ${ }^{207} \mathrm{~Pb} /{ }^{235} \mathrm{U}$ & \pm & ${ }^{207} \mathrm{~Pb} /{ }^{206} \mathrm{~Pb}$ & \pm & ${ }^{206} \mathrm{~Pb} /{ }^{238} \mathrm{U}$ & \pm & ${ }^{207} \mathrm{~Pb} /{ }^{206} \mathrm{~Pb}$ & \pm & \\
\hline \multicolumn{18}{|c|}{ Amostra CA0509, granito San Martín } \\
\hline 509.1 & 976 & 41 & 0,04 & 202 & 0,00010 & 0,16 & 0,240 & 0,48 & 2,841 & 0,93 & 0,085 & 0,68 & 1387 & 5,9 & 1334 & 16 & -4 \\
\hline 509.2 & 2782 & 61 & 0,02 & 502 & 0,00010 & 0,16 & 0,210 & 0,45 & 2,519 & 0,70 & 0,086 & 0,48 & 1228 & 5,0 & 1363 & 10 & 10 \\
\hline 509.3 & 247 & 100 & 0,42 & 53 & 0,00000 & 0,00 & 0,250 & 0,77 & 3,052 & 1,50 & 0,085 & 1,40 & 1436 & 9,9 & 1398 & 25 & -3 \\
\hline 509.4 & 260 & 94 & 0,37 & 57 & 0,00000 & 0,00 & 0,253 & 0,75 & 3,156 & 1,50 & 0,087 & 1,30 & 1455 & 9,8 & 1433 & 24 & -2 \\
\hline 509.5 & 1008 & 276 & 0,28 & 215 & 0,00011 & 0,18 & 0,248 & 0,47 & 3,027 & 0,89 & 0,087 & 0,64 & 1428 & 6,0 & 1395 & 14 & -2 \\
\hline 509.6 & 1464 & 49 & 0,03 & 280 & 0,00011 & 0,19 & 0,222 & 1,10 & 2,583 & 1,50 & 0,084 & 0,88 & 1293 & 13,0 & 1301 & 19 & 1 \\
\hline 509.7 & 163 & 54 & 0,34 & 39 & 0,00030 & 0,49 & 0,279 & 0,87 & 3,343 & 2,30 & 0,083 & 1,60 & 1587 & 12,0 & 1358 & 41 & -17 \\
\hline 509.8 & 271 & 93 & 0,35 & 59 & 0,00005 & 0,09 & 0,255 & 0,73 & 3,119 & 1,50 & 0,088 & 1,30 & 1463 & 9,5 & 1399 & 25 & -5 \\
\hline 509.9 & 259 & 117 & 0,47 & 60 & 0,00000 & 0,00 & 0,270 & 0,82 & 3,376 & 1,40 & 0,086 & 1,30 & 1540 & 11,0 & 1442 & 22 & -7 \\
\hline 509.1 & 218 & 51 & 0,24 & 42 & 0,00000 & 0,00 & 0,223 & 0,87 & 2,765 & 1,80 & 0,088 & 1,60 & 1295 & 10,0 & 1428 & 30 & 9 \\
\hline \multicolumn{18}{|c|}{ Amostra SA0404 granito San Andrés } \\
\hline 404.1 & 149 & . & & 7 & 14 & 0,24 & 0,207 & & 2,361 & &, 077 & & & & & 9 & 4 \\
\hline 404.2 & 98 & 60 & 0,63 & 17 & 0,00045 & 0,76 & 0,204 & 2,5 & 2,224 & 3,8 & 0,082 & 2,3 & 1196 & 27 & 1175 & 57 & -2 \\
\hline 404.3 & 434 & 101 & & 76 & 0,00065 & 1,08 & 0,201 & 2,3 & 2,217 & & 81 & 1,2 & & & 4 & 7 & 1 \\
\hline 404.4 & 79 & 45 & 0,59 & 13 & 0,00009 & 0,16 & 0,190 & 2,7 & 2,275 & 3,9 & 0,081 & 2,8 & 1121 & 27 & 1357 & 54 & 17 \\
\hline 404.5 & 413 & 240 & 0,60 & 73 & 0,0 & 0,00 & 0,205 & 2,3 & 2,382 & 2,5 & 0,078 & 1,2 & 3 & 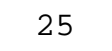 & 1298 & 2 & 7 \\
\hline 404.6 & 130 & 54 & 0,42 & 24 & 0,00000 & 0,00 & 0,216 & 2,4 & 2,578 & 3 & 0,08 & 1,9 & 1262 & 28 & 1348 & 34 & 6 \\
\hline 404.7 & 192 & 158 & 0,85 & 36 & 0,00000 & 0,00 & 0,220 & 2,3 & 2,539 & 2,8 & 0,074 & 1,8 & 1282 & 27 & 1286 & 30 & 0 \\
\hline 404.8 & 92 & 57 & 0,64 & 17 & 0,00000 & 0,00 & 0,214 & 2,6 & 2,448 & 3,4 & 0,070 & 2,8 & 1250 & 29 & 1269 & 45 & 2 \\
\hline 404.9 & 110 & 75 & 0,70 & 19 & 0,00016 & 0,27 & 0,202 & 2,5 & 2,322 & 3,4 & 0,078 & 2,4 & 1185 & 27 & 1279 & 45 & 7 \\
\hline 404.1 & 293 & 126 & 0,44 & 56 & 0,00005 & 0,08 & 0,223 & 2,3 & 2,597 & 2,7 & 0,082 & 1,3 & 1295 & 27 & 1308 & 26 & 1 \\
\hline 404.11 & 144 & 73 & 0,53 & 27 & 0,00013 & 0,21 & 0,214 & 2,4 & 2,441 & 3,2 & 0,078 & 2 & 1251 & 27 & 1261 & 41 & 1 \\
\hline 404.12 & 175 & 143 & 0,85 & 31 & 0,00012 & 0,19 & 0,207 & 2,4 & 2,39 & 3,1 & 0,082 & 1,7 & 1211 & 26 & 1289 & 38 & 6 \\
\hline 404.13 & 318 & 205 & 0,67 & 74 & 0,00007 & 0,12 & 0,270 & 2,3 & 3,705 & 2,5 & 0,094 & 1 & 1540 & 31 & 1616 & 18 & 5 \\
\hline 404.14 & 312 & 153 & 0,51 & 49 & 0,00012 & 0,20 & 0,181 & 2,3 & 2,09 & 2,8 & 0,071 & 1,7 & 1073 & 23 & 1285 & 29 & 16 \\
\hline
\end{tabular}


Apêndice B2, Tabela1. Resultados analíticos das datações U-Pb en zircão por SHRIMP (conclusão).

\begin{tabular}{|c|c|c|c|c|c|c|c|c|c|c|c|c|c|c|c|c|}
\hline \multirow[t]{2}{*}{ No ponto } & \multirow[t]{2}{*}{$\mathrm{U}(\mathrm{ppm})$} & \multirow{2}{*}{\multicolumn{2}{|c|}{$\mathrm{Th}(\mathrm{ppm} \mathrm{Th} / \mathrm{U}$}} & \multirow[t]{2}{*}{$\mathrm{Pb}^{*}(\mathrm{ppm})$} & \multirow[t]{2}{*}{${ }^{204} \mathrm{~Pb} /{ }^{206} \mathrm{~Pb}$} & \multirow[t]{2}{*}{$\int_{206 \%}$} & \multicolumn{9}{|c|}{ Idade $(\mathrm{Ma})$} & \multirow[t]{2}{*}{$\%$ Disc } \\
\hline & & & & & & & ${ }^{206} \mathrm{~Pb} /{ }^{238} \mathrm{U}$ & \pm & ${ }^{207} \mathrm{~Pb} /{ }^{235} \mathrm{U}$ & \pm & ${ }^{207} \mathrm{~Pb} /{ }^{206} \mathrm{~Pb}$ & \pm & ${ }^{206} \mathrm{~Pb} /{ }^{238} \mathrm{U}$ & \pm & ${ }^{207} \mathrm{~Pb} /{ }^{206} \mathrm{~Pb} \pm$ & \\
\hline \multicolumn{17}{|c|}{ Amostra LC0558 granito La Cruz } \\
\hline $558-1.1$ & 244 & 160 & 0,68 & 56 & 0,00191 & 3,02 & 0,257 & 1,5 & 3,670 & 3,8 & 0,1083 & 1,4 & 1473 & 20 & 169265 & 13 \\
\hline $558-1.2$ & 932 & 240 & 0,27 & 76 & 0,00136 & 2,16 & 0,093 & 1,4 & 1,276 & 3,0 & 0,0836 & 1,8 & 572 & 8 & 161849 & 65 \\
\hline $558-1.3$ & 257 & 136 & 0,55 & 64 & 0,00021 & 0,34 & 0,290 & 1,5 & 4,068 & 2,1 & 0,1037 & 1,1 & 1642 & 21 & 165627 & 1 \\
\hline $558-1.4$ & 1413 & 586 & 0,43 & 135 & 0,00266 & 4,16 & 0,107 & 1,4 & 1,568 & 3,4 & 0,1085 & 1,0 & 654 & 9 & 174157 & 62 \\
\hline $558-1.5$ & 186 & 122 & 0,68 & 45 & 0,00023 & 0,37 & 0,281 & 1,5 & 3,978 & 2,1 & 0,1273 & 1,0 & 1597 & 22 & 167327 & 5 \\
\hline $558-1.6$ & 138 & 123 & 0,92 & 35 & 0,00019 & 0,30 & 0,297 & 1,6 & 4,141 & 2,3 & 0,1014 & 1,5 & 1676 & 24 & 164630 & -2 \\
\hline $558-1.7$ & 279 & 120 & 0,44 & 74 & 0,00017 & 0,27 & 0,306 & 1,5 & 4,372 & 2,2 & 0,1055 & 1,1 & 1720 & 23 & 169129 & -2 \\
\hline $558-1.8$ & 317 & 192 & 0,62 & 79 & 0,00007 & 0,11 & 0,289 & 1,5 & 4,117 & 1,8 & 0,1054 & 1,0 & 1637 & 22 & 168419 & 3 \\
\hline \multicolumn{17}{|c|}{ Amostra LJ20512, granito La Junta } \\
\hline 512.2 & 168 & 117 & 0 & 1 & 0, & 0,06 &, 217 & 2,4 & 2,639 & 2,8 & 44 & 1,6 & 65 & 27 & 38930 & 9 \\
\hline 512.3 & 452 & 106 & 0,24 & 97 & 0,00002 & 0,03 & 0,249 & 2,3 & 3,195 & 2,5 & 0,08869 & 0,9 & 1435 & 29 & 148618 & 3 \\
\hline 5 & 3134 & 190 & 0,06 & 18 & 017 & & 03 & 2,2 & 2,468 & 2,3 & 0,0 & 0,4 & 1 & 24 & 138710 & 14 \\
\hline 512.5 & 259 & 127 & 0,51 & 52 & 0,00002 & 0,04 & 0,233 & 2,3 & 2,801 & 2,6 & 0,0831 & 1,3 & 1348 & 28 & 136825 & 1 \\
\hline 512.6 & 542 & 101 & 0,19 & 79 & 0,00248 & 4 & 0,163 & 2,3 & 1,930 & 6,4 & 0,082 & 4,8 & 73 & 21 & 1339120 & 27 \\
\hline 512.7 & 442 & 78 & 0,18 & 84 & 0,00017 & 0,28 & 0,220 & 2,3 & 2,598 & 2,7 & 0,0857 & 1,2 & 1280 & 27 & 133227 & 4 \\
\hline 512.8 & 176 & 131 & 0,77 & 34 & 0,00039 & 0,63 & 0,226 & 2,4 & 2,759 & 3,3 & 0,0795 & 1,8 & 1311 & 28 & 139845 & 6 \\
\hline \multicolumn{17}{|c|}{ Amostra CP0507, granito Diamantina } \\
\hline 507.1 & 332 & 136 & 0,42 & 10 & 0,00003 & 0,05 & 0,245 & 0,7 & 2,955 & 1,3 & 0,0855 & 1,2 & 1413 & 8 & 137022 & -3 \\
\hline 507.2 & 2377 & 2452 & 1,07 & 400 & 0,00014 & 0,24 & 0,195 & 0,4 & 2,285 & 0,8 & 0,05988 & 1,0 & 1149 & 4 & 131412 & 13 \\
\hline $507-3.1$ & 683 & 47 & 0,07 & 125 & 0,00013 & 0,22 & 0,212 & 0,5 & 2,496 & 1,1 & 0,08657 & 0,8 & 1241 & 6 & 132119 & 6 \\
\hline $507-3.2$ & 2753 & 212 & 0,08 & 548 & 0,00038 & 0,62 & 0,230 & 0,4 & 2,764 & 0,8 & 0,08648 & 0,5 & 1334 & 5 & 136414 & 2 \\
\hline 507.5 & 274 & 104 & 0,39 & 55 & 0,00019 & 0,31 & 0,231 & 0,8 & 2,849 & 2,0 & 0,0859 & 1,5 & 1339 & 10 & 141435 & 5 \\
\hline 507.6 & 140 & 65 & 0,48 & 28 & 0,00042 & 0,70 & 0,229 & 1,1 & 2,656 & 3,3 & 0,0786 & 2,2 & 1330 & 14 & 129361 & -3 \\
\hline
\end{tabular}


Apêndice B3, Resultados analíticos U-Pb TIMS

\begin{tabular}{|c|c|c|c|c|c|c|c|c|c|}
\hline \multicolumn{10}{|c|}{ Amostra: Syenogranito Refugio, SR83 } \\
\hline Fração & SPU & Peso & $\mathrm{U}$ & $\mathrm{Pb}$ & $206 / 204^{*}$ & 207/235\# & $206 / 238 \#$ & $207 / 206 \#$ & $207 / 206$ \\
\hline & & (ug) & (ppm) & (ppm) & & & & & Age (Ma) \\
\hline$A(z r)$ & 4064 & 5,4 & 388 & 227 & 52 & $3,001 \pm 0,89$ & $0,2080 \pm 0,72$ & $0,11046 \pm 0,50$ & 1708 \\
\hline$B(z r)$ & 4065 & 5,0 & 441 & 114 & 363 & $2,896 \pm 0,81$ & $0,2049 \pm 0,80$ & $0,10251 \pm 0,15$ & 1670 \\
\hline$C(z r)$ & 4066 & 9,0 & 240 & 64 & 311 & $2,743 \pm 0,80$ & $0,2079 \pm 0,79$ & $0,09567 \pm 0,16$ & 1542 \\
\hline$D(z r)$ & 4067 & 4,3 & 286 & 97 & 183 & $3,435 \pm 1,07$ & $0,2426 \pm 1,06$ & $0,10268 \pm 0,19$ & 1673 \\
\hline \multirow{2}{*}{\multicolumn{10}{|c|}{ Amostra: Monzogranito Las Maras , LM81 }} \\
\hline & & & & & & & & & \\
\hline Fração & & $\begin{array}{c}\text { Peso } \\
\text { (ug) }\end{array}$ & $\begin{array}{c}\text { U } \\
(\mathrm{ppm})\end{array}$ & $\begin{array}{c}\mathrm{Pb} \\
(\mathrm{ppm})\end{array}$ & $206 / 204^{*}$ & 207/235\# & 206/238\# & 207/206\# & $\begin{array}{c}\text { 207/206 } \\
\text { Age (Ma) }\end{array}$ \\
\hline$A(z r)$ & 4680 & 21,8 & 70 & 18 & 94 & $1,936 \pm 5,45$ & $0,1617 \pm 5,42$ & $0,08682 \pm 0,63$ & 1357 \\
\hline$C(z r)$ & 4070 & 20,8 & 116 & 30 & 174 & $2,253 \pm 3,17$ & $0,1897 \pm 3,14$ & $0,08615 \pm 0,40$ & 1342 \\
\hline$D(z r)$ & 4071 & 11,9 & 107 & 35 & 81 & $2,275 \pm 5,48$ & $0,1892 \pm 5,44$ & $0,08720 \pm 0,69$ & 1365 \\
\hline$E(z r)$ & 4072 & 22,4 & 136 & 33 & 445 & $2,368 \pm 1,32$ & $0,1989 \pm 1,31$ & $0,08633 \pm 0,17$ & 1346 \\
\hline
\end{tabular}

SPU: número de laboratório

\# Razões corrigidas pelo branco analítico e pelo chumbo inicial

* Nao corrigidas pelo branco e pelo chumbo inicial

Concentrações de $\mathrm{U}$ and $\mathrm{Pb}$ total corrigidas para o branco analítico

Idades: em Ma calculadas com base nas constantes de decaimento recomendadas por Steiger e Jäger(1977) 
Apêndice B4. Resultados analíticos das datações U-Pb en zircão por abrasão laser (continua).

Apêndice B4. Resultados analíticos das datações U-Pb en zircão por abrasão laser.

\begin{tabular}{|c|c|c|c|c|c|c|c|c|c|c|c|c|c|c|}
\hline $\begin{array}{l}\text { Anali- } \\
\text { ses }\end{array}$ & $\mathrm{Th} / \mathrm{U}$ & $\begin{array}{l}{ }^{200} \mathrm{~Pb} / \\
{ }^{206} \mathrm{~Pb}\end{array}$ & $\begin{array}{l}\sigma \sigma \\
\text { erro } \\
(\%)\end{array}$ & $\begin{array}{l}{ }^{20 /} \mathrm{Pb} / \\
{ }^{235} \mathrm{~Pb}\end{array}$ & $\begin{array}{l}\sigma \\
\text { erro } \\
(\%)\end{array}$ & $\begin{array}{l}{ }^{206} \mathrm{~Pb} / \\
{ }^{23} \mathrm{~Pb}\end{array}$ & $\begin{array}{l}1 \sigma \\
\text { erro } \\
(\%)\end{array}$ & $\rho$ & $\begin{array}{l}{ }^{20 /} \mathrm{Pb} / \\
{ }^{206} \mathrm{~Pb} \\
\text { idade }\end{array}$ & $\begin{array}{l}\sigma \sigma \\
\text { erro } \\
(\%)\end{array}$ & $\begin{array}{l}{ }^{20 /} \mathrm{Pb} / \\
{ }^{235} \mathrm{~Pb} \\
\text { idade }\end{array}$ & $\begin{array}{l}\sigma \sigma \\
\text { erro } \\
(\%)\end{array}$ & $\begin{array}{l}{ }^{206} \mathrm{~Pb} / \\
{ }^{238} \mathrm{~Pb} \\
\text { idade }\end{array}$ & $\begin{array}{l}\sigma \\
\text { erro } \\
(\%)\end{array}$ \\
\hline $3 z 1$ & 0,30 & 0,08329 & 1,0 & 2,8836 & 2,0 & 0,25111 & 1,8 & 0,84 & 1275,9 & 18,8 & 1377,6 & 15,3 & 1444,2 & 23,3 \\
\hline 10Z4B & 0,09 & 0,08408 & 0,5 & 1,3957 & 1,5 & 39 & 1,4 & 0 , & 1294,4 & 10,0 & 887,1 & 8,7 & 732,8 & 9,5 \\
\hline $11 Z 05$ & 0,30 & 0,08731 & 0,5 & 2,9316 & 1,3 & 0,24352 & 1,1 & 0,85 & 1367,4 & 10,2 & 1390,1 & 9,4 & 1405,0 & 14,3 \\
\hline $12 \mathrm{z} 06$ & 0,13 & 0,08803 & 1,0 & 1,3956 & 2,1 & 0,11497 & 1,9 & 0,96 & 1383,2 & 18,3 & 887,1 & 12,5 & 701,6 & 12,6 \\
\hline $16 Z 8$ & 0,12 & 0,08634 & 0,6 & 2,4605 & 2,1 & 20668 & 2,0 & 0,9 & 1345,9 & 11,1 & 1260,5 & 15,0 & 1211,1 & 22,2 \\
\hline $17 Z 9 N$ & 0,23 & 0,08822 & 0,4 & 3,0844 & 1,6 & 25356 & 1,6 & 0,9 & 1387,4 & 8,0 & 1428,8 & 12,4 & 1456,8 & 20,5 \\
\hline $22 Z 10$ & 0,21 & 0,08486 & 0,5 & 2,9784 & 1,9 & 0,25456 & 1,8 & 0,95 & 1312,3 & 10,1 & 1402,1 & 14,1 & 1462,0 & 23,5 \\
\hline $23 Z 011$ & 0,03 & 0,09173 & 1,6 & 0,3800 & 22,0 & 3004 & 21,9 & 1, & 1461,9 & 30 , & 327,0 & 59,6 & 190,8 & 41,1 \\
\hline $24 \mathrm{z} 011 \mathrm{~N}$ & 0,08 & 0,10890 & 5,4 & 1,9118 & 7,7 & 12732 & 5,5 & 0,8 & 1781,1 & 95,7 & 1085,2 & 50,1 & 772,6 & 39,8 \\
\hline $33 z 15$ & 0,23 & 0,08497 & 0,6 & 2,9890 & 2,0 & 0,25513 & 1,9 & 0,94 & 1314,9 & 11,5 & 1404,8 & 15,1 & 1464,9 & 25,0 \\
\hline $39 z 16$ & 0,14 & 0,08404 & 0,5 & 2,8142 & 1,5 & 0,24288 & 1,5 & 0,87 & 1293,4 & 9,7 & 1359,3 & 11,5 & 1401,6 & 18,4 \\
\hline $40 \mathrm{z} 17$ & 0,64 & 0 & 1 & 2,3390 & 2,1 & 22400 & 1,8 & 0,8 & 1088,0 & 21,5 & 1224,2 & 15,0 & 1303,0 & 21,6 \\
\hline $41 \mathrm{Z01 \varepsilon}$ & 0,28 & 0,08115 & 0,5 & 2,6530 & 1,7 & 0,23709 & 1,7 & 0,9 & 1225,2 & 8,9 & 1315,5 & 12,8 & 1371,6 & 20,7 \\
\hline $42 z 019$ & 0,04 & 0,06870 & 0,9 & 1,5531 & 2,1 & 0,16396 & 1,9 & 0,95 & 889,8 & 18,8 & 951,7 & 12,8 & 978,7 & 17,0 \\
\hline
\end{tabular}


Apêndice B4. Resultados analíticos das datações U-Pb en zircão por abrasão laser (conclusão).

Amostra 418, Granito Talcoso
\begin{tabular}{|l|l|l|l|l|l|l|l|l|l|l|l|l|l|l|}
\hline $\begin{array}{l}\text { Anali- } \\
\text { ses }\end{array}$ & Th/U & $\begin{array}{l}{ }^{207} \mathrm{~Pb} / \\
{ }^{206} \mathrm{~Pb}\end{array}$ & $\begin{array}{l}1 \sigma \\
\text { erro } \\
(\%)\end{array}$ & $\begin{array}{l}{ }^{207} \mathrm{~Pb} / \\
{ }^{235} \mathrm{~Pb}\end{array}$ & $\begin{array}{l}1 \sigma \\
\text { err } \\
0 \\
(\%)\end{array}$ & $\begin{array}{l}{ }^{206} \mathrm{~Pb} / \\
{ }^{238} \mathrm{~Pb}\end{array}$ & $\begin{array}{l}1 \sigma \\
\text { erro } \\
(\%)\end{array}$ & $\rho$ & $\begin{array}{l}{ }^{207} \mathrm{~Pb} / \\
{ }^{206} \mathrm{~Pb} \\
\text { idade }\end{array}$ & $\begin{array}{l}1 \sigma \\
\text { erro } \\
(\%)\end{array}$ & $\begin{array}{l}{ }^{207} \mathrm{~Pb} / \\
{ }^{235} \mathrm{~Pb} \\
\text { idade }\end{array}$ & $\begin{array}{l}1 \sigma \\
\text { erro } \\
(\%)\end{array}$ & $\begin{array}{l}{ }^{206} \mathrm{~Pb} / \\
238 \mathrm{~Pb} \\
\text { idade }\end{array}$ & $\begin{array}{l}1 \sigma \\
\text { erro } \\
(\%)\end{array}$ \\
\hline $05 Z 03$ & 0,18 & 0,08944 & 0,5 & 2,8934 & 1,5 & 0,23463 & 1,4 & 0,90 & 1413,6 & 9,9 & 1380,2 & 11,0 & 1358,7 & 16,8 \\
\hline $015 Z 8$ & 0,27 & 0,08591 & 0,8 & 2,5352 & 1,8 & 0,21402 & 1,6 & 0,86 & 1336,2 & 14,5 & 1282,2 & 13,0 & 1250,2 & 18,5 \\
\hline $027 Z 14$ & 0,21 & 0,08219 & 2,5 & 2,4528 & 2,9 & 0,21644 & 1,5 & 0,47 & 1250,1 & 48,4 & 1258,3 & 20,8 & 1263,1 & 17,0 \\
\hline $029 Z 15$ & 0,26 & 0,08688 & 0,7 & 2,6289 & 1,3 & 0,21947 & 1,2 & 0,82 & 1357,8 & 12,6 & 1308,8 & 9,8 & 1279,1 & 13,5 \\
\hline $037 Z 18$ & 0,11 & 0,09066 & 1,4 & 2,0528 & 2,0 & 0,16421 & 1,5 & 0,66 & 1439,5 & 26,1 & 1133,2 & 13,9 & 980,2 & 13,7 \\
\hline $038 z 19$ & 0,34 & 0,08068 & 0,9 & 1,9915 & 1,5 & 0,17902 & 1,2 & 0,84 & 1213,7 & 17,0 & 1112,6 & 10,1 & 1061,6 & 12,0 \\
\hline $043 Z 22$ & 0,22 & 0,08329 & 0,9 & 2,1369 & 1,6 & 0,18607 & 1,4 & 0,81 & 1276,1 & 16,6 & 1160,8 & 11,3 & 1100,1 & 14,2 \\
\hline $044 z 23$ & 0,18 & 0,08281 & 3,8 & 1,5939 & 4,2 & 0,13960 & 1,9 & 0,65 & 1264,8 & 72,3 & 967,8 & 26,0 & 842,4 & 14,6 \\
\hline
\end{tabular}


Apêndice B5. Resultados analíticos Sm- Nd (continua). San Ignacio Suite

\begin{tabular}{|c|c|c|c|c|c|c|c|c|c|c|}
\hline Amostra & SPS & Unidade & Sm (ppm) & Nd (ppm) & ${ }^{147} \mathrm{Sm} /{ }^{144} \mathrm{Nd}$ & ${ }^{143} \mathrm{Nd} /{ }^{144} \mathrm{Nd}$ & $\varepsilon_{(0)}$ & $\mathbf{f}_{\mathrm{Sm} / \mathrm{Nd}}$ & $\begin{array}{c}T_{\mathrm{DM}} \\
(\mathrm{Ga})\end{array}$ & $\varepsilon_{(\mathrm{T} 1)}$ \\
\hline 404 & 4396 & San Andrés & 30,760 & 161,515 & 0,1152 & 0,51188 & $-14,86$ & $-0,41$ & 1,8 & $-1,60$ \\
\hline 535 & 4983 & San Andrés & 19,105 & 126,586 & 0,0913 & 0,512027 & $-11,92$ & $-0,54$ & 1,3 & $+5,22$ \\
\hline 538 & 4984 & El Carmen & 14,564 & 73,080 & 0,1205 & 0,512177 & $-8,99$ & $-0,39$ & 1,4 & $+3,40$ \\
\hline $543^{*}$ & 5614 & Limonal & 10,511 & 49,300 & 0,1289 & 0,511978 & $-12,87$ & $-1,34$ & 1,9 & $-1,64$ \\
\hline 403 & 4395 & San Javier & 1,988 & 15,764 & 0,0763 & 0,51152 & $-21,79$ & $-0,61$ & 1,7 & $-1,31$ \\
\hline 406 & 4397 & San Rafael & 12,772 & 63,763 & 0,1211 & 0,51179 & $-16,57$ & $-1,38$ & 2,1 & $-3,72$ \\
\hline 501 & 4400 & Piso Firme & 6,830 & 30,375 & 0,1360 & 0,512229 & $-7,99$ & $-0,31$ & 1,7 & $+2,32$ \\
\hline 502 & 4401 & San Cristóbal & 7,826 & 32,431 & 0,1459 & 0,512337 & $-5,87$ & -- & 2,2 & $+2,75$ \\
\hline 503 & 4402 & San Cristóbal & 9,647 & 40,460 & 0,1442 & 0,512316 & $-6,28$ & -- & 1,7 & $+2,63$ \\
\hline 504 & 4234 & Porvenir & 19,278 & 79,089 & 0,1474 & 0,512285 & $-6,89$ & -- & 1,7 & $+1,48$ \\
\hline 505 & 4225 & Diamantina & 10,664 & $63, .260$ & $0, .1019$ & 0,511834 & $-15,69$ & $-0,48$ & 1,7 & $+0,39$ \\
\hline 506 & 4226 & Diamantina & 12,872 & $78, .696$ & 0,0989 & 0,511789 & $-16,56$ & $-0,50$ & 1,7 & +0.03 \\
\hline 507 & 4227 & Diamantina & 13,279 & 70,132 & 0,1145 & 0,511859 & $-15,20$ & $-0,42$ & 1,4 & $-1,25$ \\
\hline 508 & 4228 & Diamantina & 5,738 & 23,615 & 0,1469 & 0,512202 & $-8,51$ & -- & 1,7 & $-0,06$ \\
\hline 509 & 4229 & San Martín & 25,353 & 107,634 & 0,1424 & 0,512257 & $-7,43$ & -- & 1,6 & $+1,78$ \\
\hline 510 & 4230 & La Junta & 18,727 & 99,733 & 0,1135 & 0,511727 & $-17,77$ & $-0,42$ & 1,4 & $-3,66$ \\
\hline 511 & 4231 & La Junta & 14,692 & 80,734 & 0,1100 & 0,511720 & $-17,91$ & $-0,44$ & 1,6 & $-3,21$ \\
\hline 512 & 4232 & La Junta & 3,599 & 22,018 & 0,0988 & 0,511636 & $-19,55$ & $-0,50$ & 1,6 & $-2,94$ \\
\hline 513 & 4233 & La Junta & 18,697 & 100,573 & 0,1124 & 0,511685 & $-18,59$ & $-0,43$ & 1,6 & $-4,29$ \\
\hline 528 & 4978 & San Luis & 0,541 & 4,087 & $0, .0801$ & 0,511523 & $-21,75$ & $-0,59$ & 1,7 & $+2,99$ \\
\hline 546 & 4985 & San Pedro & 7,661 & 39,523 & 0,1172 & 0,511926 & $-13,88$ & $-0,40$ & 1,7 & $-0,37$ \\
\hline 547 & 4986 & Sujalito & 15,695 & 86,354 & 0,1099 & 0,511839 & $-15,59$ & $-0,44$ & 1,7 & $-0,83$ \\
\hline 549 & 4987 & Limones & 7,874 & 74,163 & 0,0642 & 0,511420 & $-23,75$ & $-0,67$ & 1,6 & $-1,23$ \\
\hline 552 & 4990 & Guarayos & $12, .330$ & 63,241 & 0,1179 & 0,511954 & $-13,35$ & $-0,40$ & 1,7 & $+0,05$ \\
\hline $553 \mathrm{~A}$ & 4991 & Marimonos & 6,245 & 38,574 & 0,0979 & $0, .511803$ & $-16,29$ & $-0,50$ & 1,6 & $+0,51$ \\
\hline 553B & 4992 & Marimonos & 8,242 & 53,990 & 0,0923 & 0,511740 & $-17,51$ & $-0,53$ & 1,6 & $+0,24$ \\
\hline
\end{tabular}

$\mathrm{T}(\mathrm{Ma})=1,33 \mathrm{Ga}$ calculado segundo a idade SHRIMP U-Pb (Boger et al., 2005). ${ }^{*}$ Dado Obtido de Vargas Mattos, 2010 
Apêndice B5. Resultados analíticos Sm- Nd (conclusão)

Granodiorito San Ramón

\begin{tabular}{|c|c|c|c|c|c|c|c|c|c|c|}
\hline Amostra & SPS & Unidade & Sm (ppm) & Nd (ppm) & ${ }^{147} \mathrm{Sm} /{ }^{144} \mathrm{Nd}$ & ${ }^{143} \mathrm{Nd} /{ }^{144} \mathrm{Nd}$ & $\varepsilon_{(0)}$ & $\mathbf{f}_{\mathrm{Sm} / \mathrm{Nd}}$ & $\mathrm{T}_{\mathrm{DM}}(\mathrm{Ga})$ & $\varepsilon_{(\mathrm{T} 1)}$ \\
\hline 401 & 4394 & San Ramón & 7,653 & 53,742 & 0,0861 & 0,51159 & $-20,45$ & $-0,56$ & 1,7 & $-0,29$ \\
\hline
\end{tabular}

$\mathrm{T}(\mathrm{Ma})=1,4 \mathrm{Ga}$ calculado segundo a idade SHRIMP U-Pb (Santos et al., 2008).

\section{Suite Yarituses}

\begin{tabular}{|c|c|c|c|c|c|c|c|c|c|c|}
\hline Amostra & SPS & Unidade & Sm (ppm) & Nd (ppm) & ${ }^{147} \mathrm{Sm} /{ }^{144} \mathrm{Nd}$ & ${ }^{143} \mathrm{Nd} /{ }^{144} \mathrm{Nd}$ & $\varepsilon_{(0)}$ & $\mathbf{f}_{\mathrm{Sm} / \mathrm{Nd}}$ & $\mathrm{T}_{\mathrm{DM}}(\mathrm{Ga})$ & $\varepsilon_{(\mathrm{T} 1)}$ \\
\hline 558 & 4994 & La Cruz & 11,391 & 60,583 & 0,1137 & 0,51183 & $-11,59$ & $-0,42$ & 1,8 & $+2,12$ \\
\hline $601^{*}$ & 5615 & San Pablo & 1,541 & 7,583 & 0,1229 & 0,51203 & $-11,76$ & $-0,38$ & 1,7 & $+3,50$ \\
\hline 408 & 4398 & Refugio & 2,815 & 17,014 & 0,1000 & 0,51161 & $-20,04$ & $-0,49$ & 1,9 & $+0,18$ \\
\hline
\end{tabular}

$\mathrm{T}(\mathrm{Ma})=1,6 \mathrm{Ga}$ calculado segundo a idade SHRIMP U-Pb (Santos et al., 2008) para as amostras 601 e 408. Amostra 558, T(Ma)=1,7 Ga

nesse trabalho. * Dado Obtido de Vargas-Mattos, 2010

\section{Complexo Lomas Manechis}

\begin{tabular}{|c|c|c|c|c|c|c|c|c|c|c|}
\hline Amostra & SPS & Unidade & Sm (ppm) & Nd (ppm) & ${ }^{147} \mathrm{Sm} /{ }^{144} \mathrm{Nd}$ & ${ }^{143} \mathrm{Nd} /{ }^{144} \mathrm{Nd}$ & $\varepsilon_{(0)}$ & $\mathbf{f}_{\mathrm{Sm} / \mathrm{Nd}}$ & $\mathrm{T}_{\mathrm{DM}}(\mathrm{Ga})$ & $\varepsilon_{(\mathrm{T} 1)}$ \\
\hline 514 & 4235 & L.Manechis & 17,132 & 0,092 & 0,1137 & 0,51158 & $-20,5$ & $-0,53$ & 1,8 & $-2,87$ \\
\hline 515 & 4236 & L.Manechis & 7,035 & 36,480 & 0,1166 & 0,51162 & $-19,83$ & $-0,41$ & 2,2 & $-2,84$ \\
\hline 518 & 4977 & L.Manechis & 17,152 & 100,626 & 0,1031 & 0,51180 & $-16,29$ & $-0,48$ & 1,7 & $-0,37$ \\
\hline
\end{tabular}

$\mathrm{T}(\mathrm{Ma})=1,7 \mathrm{Ga}$ calculado segundo a idade SHRIMP U-Pb (Boger et al., 2005). 
Apêndice B5. Resultados analíticos Rb- $\mathrm{Sr}$ (continua) San Ignacio Suite

\begin{tabular}{|c|c|c|c|c|c|c|c|c|}
\hline Amostra & SPR & Unidade & Rb (ppm) & Sr (ppm) & $1 / \mathrm{Sr}$ & ${ }^{87} \mathrm{Sr} /{ }^{86} \mathrm{Sr}$ & ${ }^{87} \mathrm{Rb} /{ }^{86} \mathrm{Sr}$ & $\begin{array}{c}\left({ }^{87} \mathrm{Sr} /{ }^{86} \mathrm{Sr}\right) \mathrm{t} \\
\mathrm{p} / \mathrm{T}(\mathrm{Ma})\end{array}$ \\
\hline 404 & 4396 & San Andrés & 299,10 & 79,60 & 0,0125 & 0,90317 & 11,089 & - \\
\hline 535 & 4983 & San Andrés & 285,10 & 519,40 & 0,0019 & 0,73149 & 1,592 & 0,70114 \\
\hline 538 & 4984 & El Carmen & 151,48 & 14,58 & 0,0686 & 0,63174 & 32,796 & - \\
\hline $543^{*}$ & 5614 & Limonal & 488,20 & 63,30 & 0,0158 & 1,05431 & 23,070 & - \\
\hline 403 & 4395 & San Javier & 176,10 & 233,00 & 0,0042 & 0,74494 & 2,196 & 0,70309 \\
\hline 406 & 4397 & San Rafael & 450,30 & 95,20 & 0,0105 & 0,95290 & 14,015 & - \\
\hline 501 & 4400 & Piso Firme & 111,59 & 27,68 & 0,0361 & 0,72473 & 11,687 & - \\
\hline 502 & 4401 & San Cristóbal & 157,45 & 27,69 & 0,0361 & 1,03027 & 16,974 & 0,70664 \\
\hline 503 & 4402 & San Cristóbal & 170,70 & 72,00 & 0,0139 & 0,83417 & 6,949 & 0,70169 \\
\hline 504 & 4234 & Porvenir & 183,36 & 21,98 & 0,0455 & 1,18192 & 25,269 & 0,70015 \\
\hline 505 & 4225 & Diamantina & 271,20 & 224,80 & 0,0044 & 0,76888 & 3,512 & 0,70193 \\
\hline 506 & 4226 & Diamantina & 228,70 & 208,00 & 0,0048 & 0,76477 & 3,201 & 0,70374 \\
\hline 507 & 4227 & Diamantina & 301,00 & 167,90 & 0,0060 & 0,79669 & 5,235 & - \\
\hline 508 & 4228 & Diamantina & 232,90 & 166,10 & 0,0060 & 0,78021 & 4,086 & 0,70230 \\
\hline 509 & 4229 & San Martín & 158,80 & 72,90 & 0,0137 & 0,82563 & 6,376 & 0,70407 \\
\hline 510 & 4230 & La Junta & 169,30 & 287,40 & 0,0035 & 0,73644 & 1,710 & 0,70385 \\
\hline 511 & 4231 & La Junta & 242,10 & 187,30 & 0,0053 & 0,77712 & 3,768 & 0,70529 \\
\hline 512 & 4232 & La Junta & 140,10 & 323,00 & 0,0031 & 0,73006 & 1,258 & 0,70608 \\
\hline 513 & 4233 & La Junta & 245,60 & 119,90 & 0,0083 & 0,81792 & 5,994 & 0,70364 \\
\hline 528 & 4978 & San Luis & 69,66 & 675,82 & 0,0014 & 0,71467 & 0,298 & 0,70898 \\
\hline 546 & 4985 & San Pedro & 241,10 & 67,40 & 0,0148 & 0,82125 & 10,464 & - \\
\hline 547 & 4986 & Sujalito & 89,70 & 71,20 & 0,0140 & 0,78001 & 3,672 & - \\
\hline 549 & 4987 & Limones & 48,44 & 878,65 & 0,0011 & 0,70530 & 0,159 & 0,70226 \\
\hline 552 & 4990 & Guarayos & 227,40 & 74,90 & 0,0133 & 0,86200 & 8,922 & \\
\hline $553 \mathrm{~A}$ & 4991 & Marimonos & 191,30 & 389,80 & 0,0025 & 0,72895 & 1,423 & 0,70182 \\
\hline 553B & 4992 & Marimonos & 281,70 & 194,80 & 0,0051 & 0,76944 & 4,211 & - \\
\hline
\end{tabular}

$\mathrm{T}(\mathrm{Ma})=1,33 \mathrm{Ga}$ calculado segundo a idade SHRIMP U-Pb (Boger et al., 2005). *Dado Obtido de Vargas Mattos, 2010 
Apêndice B5. Resultados analíticos Rb- $\mathrm{Sr}$ (conclusão) Granodiorito San Ramón

\begin{tabular}{|l|l|l|l|l|l|l|l|l|}
\hline Amostra & SPS & Unidade & $\mathbf{R b}(\mathbf{p p m})$ & $\mathbf{S r}(\mathbf{p p m})$ & $\mathbf{1 / S r}$ & ${ }^{87} \mathbf{S r} /{ }^{86} \mathbf{S r}$ & ${ }^{87} \mathbf{R b} /{ }^{86} \mathbf{S r}$ & $\begin{array}{c}\left.{ }^{87} \mathbf{S r} /{ }^{86} \mathbf{S r}\right) \mathbf{t} \\
\mathbf{p} / \mathbf{T}(\mathbf{M a})\end{array}$ \\
\hline 401 & 4394 & San Ramón & 88,96 & 726,52 & 0,0014 & 0,71046 & 0,354 & 0,70324 \\
\hline
\end{tabular}

$\mathrm{T}(\mathrm{Ma})=1,4 \mathrm{Ga}$ calculado segundo a idade SHRIMP U-Pb (Santos et al., 2008).

\section{Suite Yarituses}

\begin{tabular}{|c|c|c|c|c|c|c|c|c|}
\hline Amostra & SPS & Unidade & $\mathrm{Rb}$ (ppm) & Sr (ppm) & $1 / \mathrm{Sr}$ & ${ }^{87} \mathrm{Sr} /{ }^{86} \mathrm{Sr}$ & ${ }^{87} \mathrm{Rb} /{ }^{86} \mathrm{Sr}$ & $\begin{array}{c}\left({ }^{87} \mathrm{Sr} /{ }^{86} \mathrm{Sr}\right) \mathrm{t} \\
\mathrm{p} / \mathrm{T}(\mathrm{Ma})\end{array}$ \\
\hline 558 & 4994 & La Cruz & 216,80 & 66,40 & 0,0150 & 0,90869 & 9,637 & - \\
\hline $601^{*}$ & 5615 & San Pablo & 397,10 & 96,60 & 0,0103 & 0,89919 & 12,117 & - \\
\hline 408 & 4398 & Refugio & 133,20 & 191,70 & 0,0075 & 0,74553 & 2,019 & - \\
\hline
\end{tabular}

$\mathrm{T}(\mathrm{Ma})=1,6 \mathrm{Ga}$ calculado segundo a idade SHRIMP U-Pb (Santos et al., 2008) para as amostras 601 e 408. Amostra 558, T(Ma)=

1,7 nesse trabalho. * Dado Obtido de Vargas Mattos, 2010

\section{Complexo Lomas Manechis}

\begin{tabular}{|l|l|l|l|l|l|l|l|l|}
\hline Amostra & SPS & Unidade & $\mathbf{R b}(\mathbf{p p m})$ & $\mathbf{S r}(\mathbf{p p m})$ & $\mathbf{1 / S r}$ & ${ }^{87} \mathbf{S r} /{ }^{86} \mathbf{S r}$ & ${ }^{87} \mathbf{R b} /{ }^{86} \mathbf{S r}$ & $\begin{array}{l}\left.\mathbf{(}^{87} \mathbf{S r} /{ }^{86} \mathbf{S r}\right) \mathbf{t} \\
\mathbf{p} / \mathbf{T}(\mathbf{M a})\end{array}$ \\
\hline 514 & 4235 & L.Manechis & 140,00 & 254,20 & 0,0071 & 0,73841 & 1,599 & - \\
\hline 515 & 4236 & L.Manechis & 5,44 & 223,79 & 0,1838 & 0,70607 & 0,070 & 0,70435 \\
\hline 518 & 4977 & L.Manechis & 103,54 & 614,42 & 0,0096 & 0,71894 & 0,488 & 0,70700 \\
\hline
\end{tabular}

$\mathrm{T}(\mathrm{Ma})=1,7 \mathrm{Ga}$ calculado segundo a idade SHRIMP U-Pb (Boger et al., 2005). 


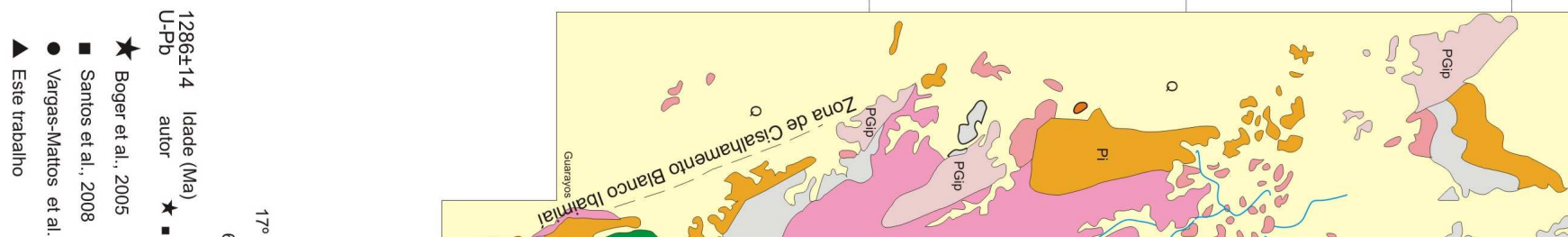

$\left[\begin{array}{l}0 \\ 0 \\ 0 \\ 0 \\ \text { 중 }\end{array}\right.$

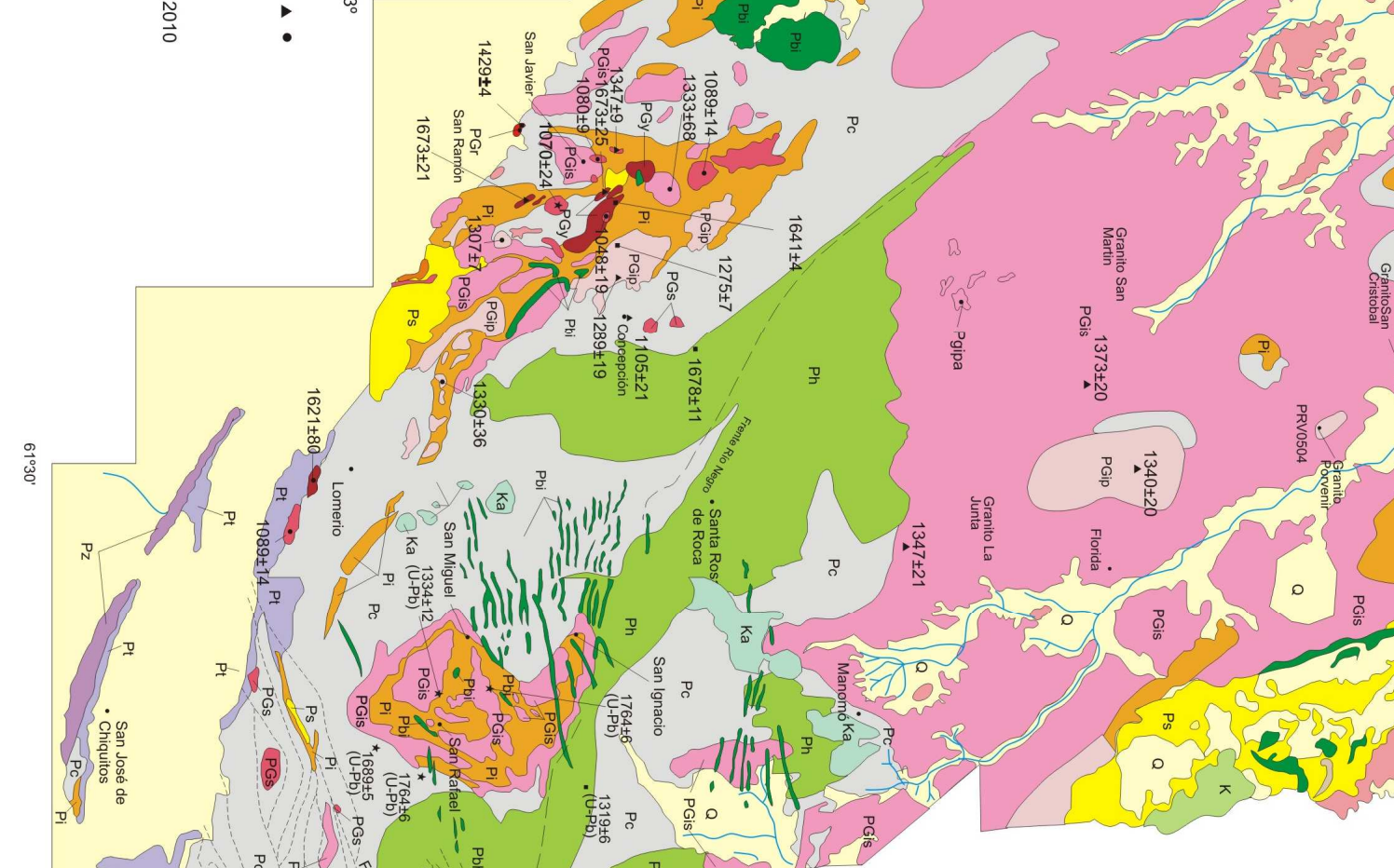

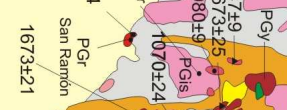
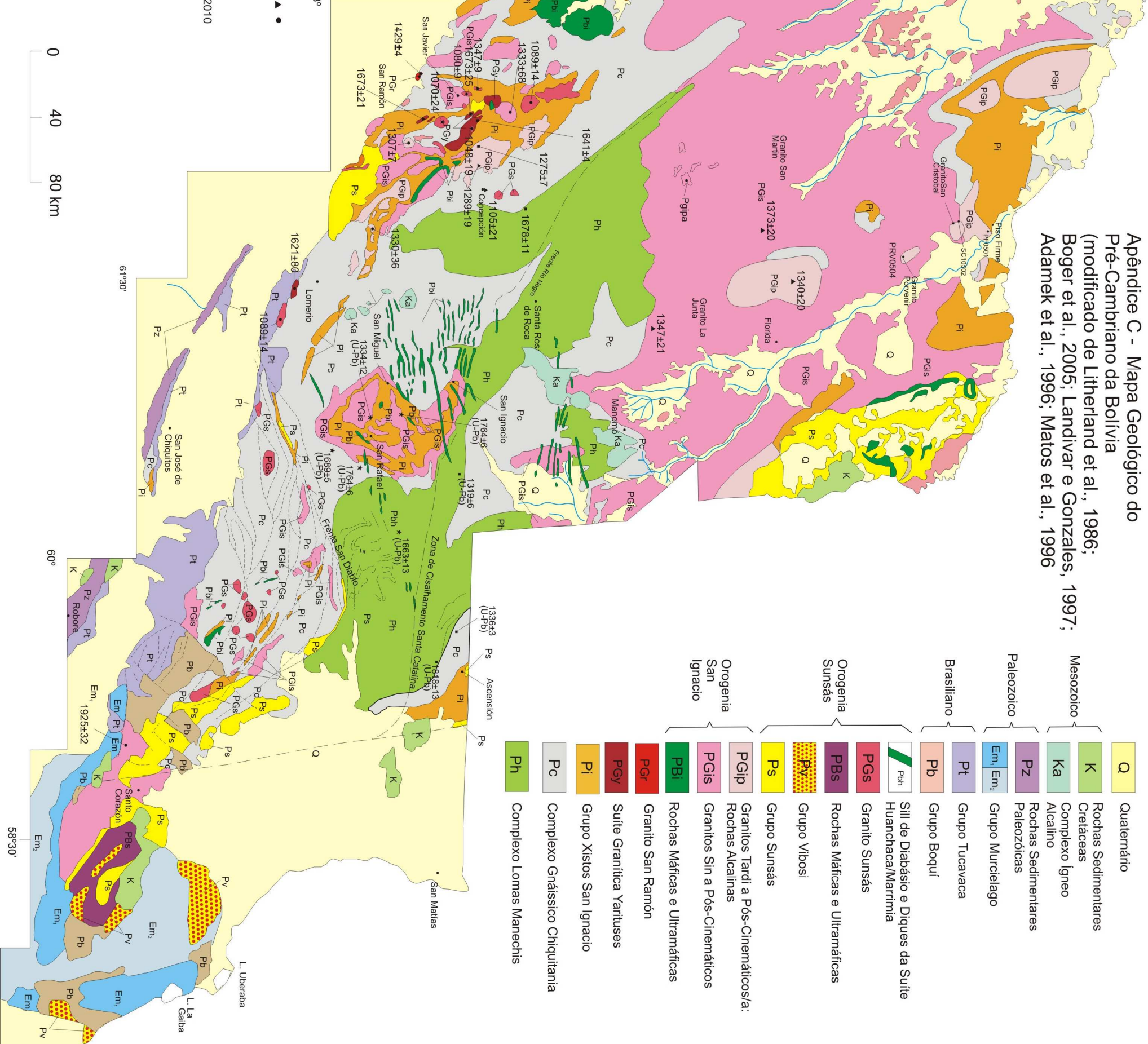